







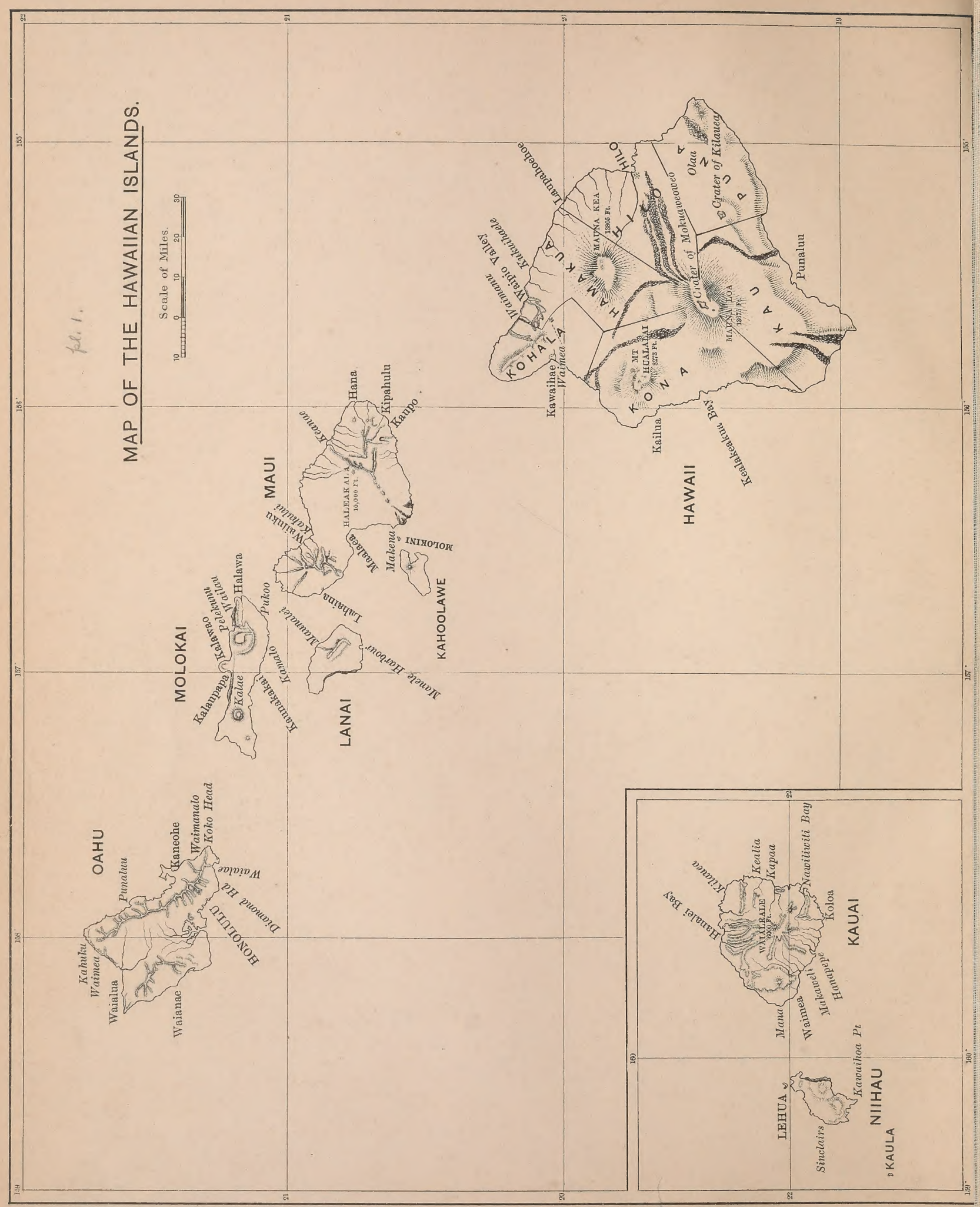




\section{AVES HAWAIIENSES:}

\section{THE BIRDS}

OF THE

\section{SANDWICH ISLANDS.}

$\mathrm{BY}$

SCOTT B. WILSON, F.Z.S., F.R.G.S., ASSISTED BY

A. H. EVANS, M.A., F.Z.S.

LON DON :

R. H. PORTER, 7 PRINCES STREET, CAVENDISH SQUARE, W. 1890-99. 


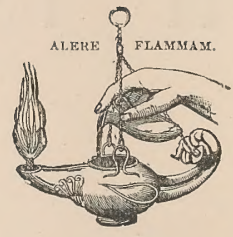

PRINTED BY TAYLOR AND FRANCIS,

RED LION COURT, FLEET STREET. 


\section{PROFESSOR NEWTON,}

WHO FIRST SUGGESTED MY EXPEDITION TO THE ISLANDS,

AND SUBSEQUENTLY ASSISTED ME IN THE KINDEST POSSIBLE WAY

TO LAY THE RESULTS BEFORE MY READERS

IN THEIR PRESENT FORM. 



\section{CONTENTS.}

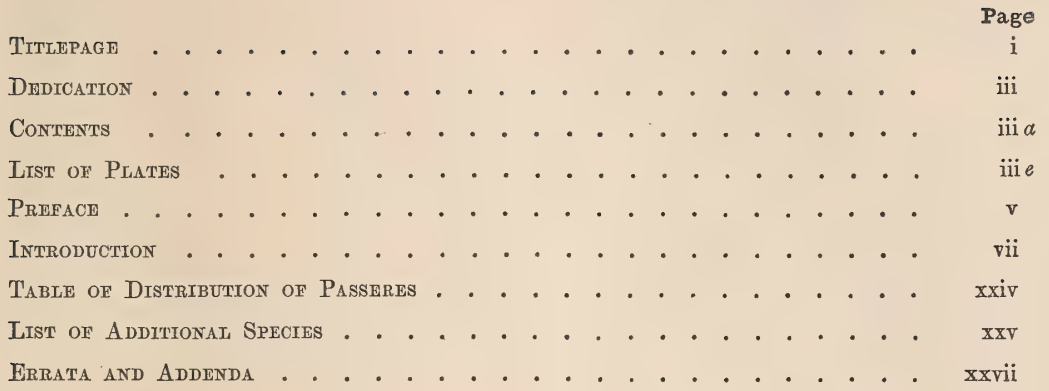

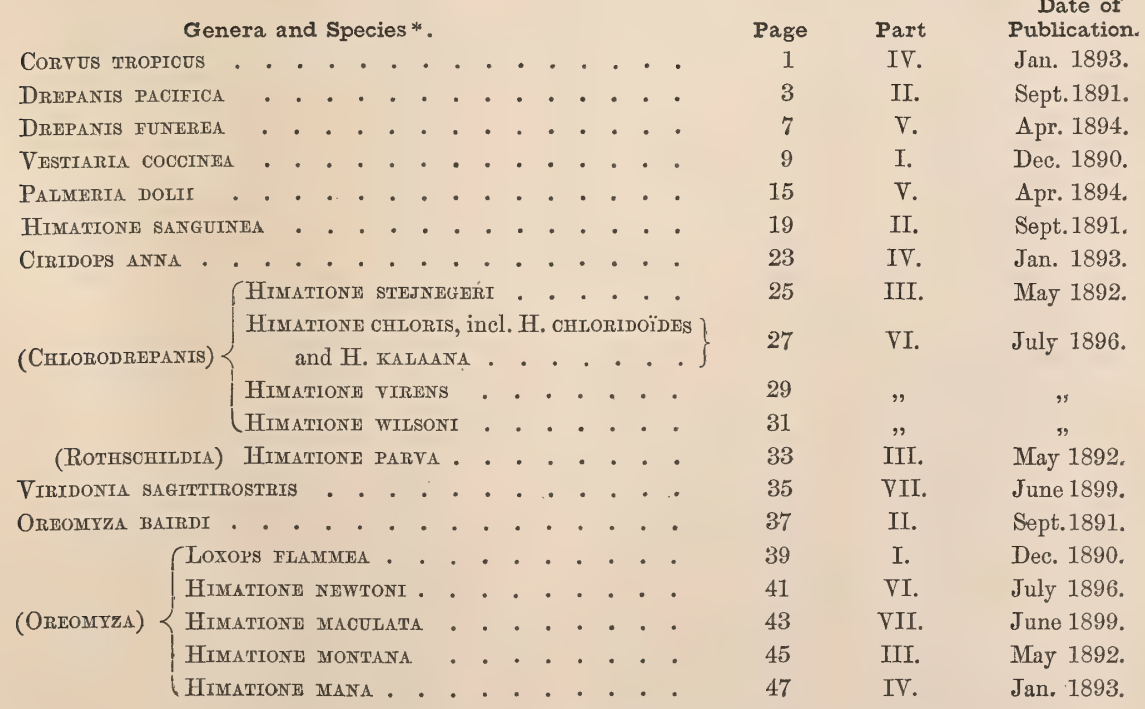

* For changes of nomenclature see Introduetion. 


\begin{tabular}{|c|c|c|c|c|c|c|c|c|c|c|c|c|c|c|}
\hline \multicolumn{12}{|c|}{ Genera and Species*. } & Page & Part & Publication \\
\hline LOXORS COCCINEA . . & & & 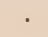 & • & . & • & . & & . & - & . & 49 & I. & Dec. 1890. \\
\hline LOXOPS RUFA. . . . & . . & . . & . & . & $\cdot$ & · & . $\cdot$ & - & - & - & - & 53 & VI. & July 1896. \\
\hline Loxops AUREA, vice HIMAT & ITIO & DNE & $A \cup R$ & & & ancell & lled & & . & . & . & 55 & $"$ & $"$ \\
\hline CHRYSOMITRIDOPS CARULEI & Iro & DSTR I & Is . & • & - & .. & - & & . & · & . & 59 & I. & Dec. 1890 . \\
\hline HeMranathus pRocerus. & - . & .. & . & - & . & · $\cdot$ & . . & - & . & . & . & 61 & III. & May 1892. \\
\hline HeMtgNatHUS ITCHTENSTEI & INI & I. & . & . & - & . $\cdot$ & . . & - & - & . & . & 65 & V. & Apr. 1894. \\
\hline HEMTGNATHUS OBSCURUS . & . & . . & . & . & . & $\cdot \cdot$ & .. & - & - & $\cdot$ & $\cdot$ & 67 & III. & May 1892. \\
\hline Hemignathus lanatensts & . & . . & . & - & $\cdot$ & . $\cdot$ & . . & - & . & . & . & 71 & VII. & June 1899. \\
\hline \multirow{4}{*}{\multicolumn{4}{|c|}{ (Heterorhynchus) $\left\{\begin{array}{l}\text { Hemignathus } \\
\text { Hemignatios } \\
\text { Hemignathos } \\
\text { Hemignathus }\end{array}\right.$}} & & $\mathrm{UCI}$ & Des . & . & . & . & . & . & 73 & V. & Apr. 1894. \\
\hline & & & & & & ACEU & US . & & . & . & . & 75 & III. & May 1892. \\
\hline & & & & & FEII & NIS . & - . & - & . & . & . & 77 & VI. & July 1896. \\
\hline & & & & & & APEPE & PE . & - & . & . & . & 81 & III. & May 1892. \\
\hline Pseddonestor XaNTHOPHRI & & . & $\cdot$ & - & . & . $\cdot$ & .. & • & . & . & - & 83 & VI. & July 1896. \\
\hline Psittactrostra PSITtacea & . & . . & - & . & . & . $\cdot$ & . & - & . & . & . & 85 & II. & Sept.1891. \\
\hline LoxtoÏDES BaULLEUT . . & . . & . . & . & . & . & . . & . . & . & . & . & . & 89 & I. & Dec. 1890. \\
\hline RHODACAN'CHIS PALMERI . & . . & . . & . & - & $\cdot$ & . . & $\therefore \quad$. & - & - & - & . & 93 & V. & Apr. 1894. \\
\hline RHODAOANTHIS FLAVICEPS & & . . & . & . & . & . . & . . & - & . & $\therefore$ & . & 95 & VII. & June 1899. \\
\hline CHLORIDOPS KONA . . & - . & . . & . & . & . & .. & . . & . & . & . & . & 97 & IV. & Jan. 1893. \\
\hline ACRULOCERCUS BRACCATUS & & . . & . & . & - & .. & . . & . & . & . & . & 99 & I. & Dec. 1890. \\
\hline ACRULOCERCUS APICALIS . & . . & . . & . & - & . & . . & . . & . & . & . & . & 103 & $\nabla$. & Apr. \\
\hline ACRULOCEROUS NOBILIS . & . . & . . & . & . & . & . . & . . & . & . & . & . & 105 & I. & Dec. 1890. \\
\hline ACRULOCERCUS BISHOPI - & . . & . . & . & . & . & . $\cdot$ & . . & & . & . & . & 111 & $\nabla$. & Apr. 1894. \\
\hline СНÆTOPTIIA ANGUSTIPLUMA & & - $\cdot$ & - & - & · & · $\cdot$ & · $\cdot$ & & - & $\cdot$ & $\cdot$ & 113 & II. & Sept. 1891. \\
\hline Pheoris myiadestina . & . . & . . & . & . & . & .. & . . & . & . & - & . & 117 & $"$ & $"$ \\
\hline Phæornis tanatensis & - . & .. & - & - & - & . $\cdot$ & . . & & . & - & - & 119 & $"$ & $"$ \\
\hline РHÆORNIS OBSCURA & - . & . $\cdot$ & . & . & . & . $\cdot$ & . $\cdot$ & & . & . & · & 121 & I. & Dec. 1890. \\
\hline Phæornis palmeri . . & - . & . . & . & . & - & . . & . . & & . & - & $\cdot$ & 123 & VI. & July 1896. \\
\hline CHASIEMPIS SANDVICENSIS & • & .. & . & . & . & . . & . . & & . & . & . & 125 & $"$ & $"$ \\
\hline CHASIEMPIS GAYI . . & . $\cdot$ & - $\cdot$ & . & . & . & . $\cdot$ & . $\cdot$ & - & - & . & . & 129 & " & $"$ \\
\hline CHASTEMIPIS SOLATERI . • & · $\cdot$ & - $\cdot$ & . & . & $\cdot$ & $\cdot \cdot$ & · $\cdot$ & • & - & - & $\cdot$ & 131 & $"$ & $"$ \\
\hline Asto ACOIPITRINUS . . & . . & . . & . & . & . & . . & . . & . & . & . & . & 133 & II. & Sept. 1891. \\
\hline STERRA FULIGINOSA - & $\cdot \cdot$ & - $\cdot$ & . & . & $\cdot$ & $\cdot \cdot$ & - & • & . & - & - & 137 & VII. & June 1899. \\
\hline Sterna lunata . . . & & - $\cdot$ & $\cdot$ & . & . & - $\cdot$ & · $\cdot$ & • & . & - & . & 139 & $"$ & $"$ \\
\hline Anous stomides $\cdot \cdot \cdot$ & · · & - $\cdot$ & . & ${ }^{\circ}$ & $\cdot$ & . $\cdot$ & . $\cdot$ & & · & - & $\cdot$ & 141 & $"$ & , \\
\hline ANoUS HAWAMENSIS $\cdot$ & · . & - $\cdot$ & $\cdot$ & . & - & . $\cdot$ & - . & - & - & - & . & 143 & $"$ & " \\
\hline GYGIS ALBA $\cdot \cdot \cdot \cdot \cdot$ & & - $\cdot$ & $\cdot$ & - & $\cdot$ & . $\cdot$ & · $\cdot$ & • & - & - & . & 145 & , & $"$ \\
\hline NUMENIUS TAHITIENSIS & · $\cdot$ & . . & - & $\cdot$ & - & .. & . . & · & 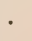 & . & . & 147 & III. & May 1892. \\
\hline Totands incands . & · $\cdot$ & . $\cdot$ & . & • & . & . $\cdot$ & . . & - & . & · & · & 151 & " & $"$ \\
\hline CALIDRIS ARENARIA. . & - . & - $\cdot$ & $\cdot$ & · & $\cdot$ & · & · & - & - & - & - & 153 & , & $"$ \\
\hline HTMANTOPUS KNUDSENI & - $\cdot$ & . $\cdot$ & . & $\cdot$ & - & . & . & • & - & - & . & 155 & IV. & Jan. 1893. \\
\hline STREPSILAS INTERPRES . - & - . & - $\quad$. & - & • & - & · & - . & - & . & - & - & 159 & III. & May 1892. \\
\hline CHARADRIUS FULVUS & · $\cdot$ & - . & . & - & $\cdot$ & $\cdot$. & - $\cdot$ & & 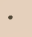 & . & . & 161 & , & $"$ \\
\hline FULICA ALAI . . . . & - $\cdot$ & $\cdot$. & - & - & - & . $\cdot$ & - . & - & . & . & - & 163 & IV. & Jan. 1893. \\
\hline GALLINULA SANDVIOENSIS & • & - $\cdot$ & - & - & · & · $\cdot$ & - $\cdot$ & - & - & - & - & 165 & " & $"$ \\
\hline Pennula ecaudata $\cdot$ & · $\cdot$ & - $\cdot$ & . & . & . & . . & - . & & - & - & • & 171 & $\mathrm{~V}$ & Apr. 1894. \\
\hline Penndla sandvidensis & · . & - $\cdot$ & - & ${ }^{\bullet}$ & . & - : & : . & • & - & - & - & 175 & VII. & June 1899. \\
\hline
\end{tabular}

* For changes of nomenclature see Introduction. 


\begin{tabular}{|c|c|c|c|c|c|c|c|c|c|c|c|c|c|c|c|c|}
\hline Genera & and & & ec & es & & & & & & & & & & Page & Part & $\begin{array}{c}\text { Date of } \\
\text { Publication. }\end{array}$ \\
\hline Pexnula wilsoni & . . & . & . & . & . & . & . & . & . & · & . & . & . & 176 & VII. & June 1899. \\
\hline Buteo solitamius . & . . & . & . & . & . & . & . & . & . & . & . & . & . & 179 & II. & Sept. 1891. \\
\hline CrRCUS HUDSONIUS . & . . & . & . & . & . & . & . & . & . & . & . & . & . & 185 & $"$ & 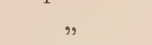 \\
\hline BERNICLA SANDTICENSIS & s. & . & . & . & . & . & . & . & . & . & . & - & - & 187 & IV. & Jan. 1893. \\
\hline Anas wyviLLIANa . & . . & . & . & . & . & . & . & - & - & - & - & - & . & 191 & ", & $"$ \\
\hline Dafila acuta . . & . . & . & . & . & . & . & . & . & - & . & . & . & - & 193 & , & $"$ \\
\hline Spatula clipeata. . & .. & . & . & . & . & . & . & . & - & • & · & . & . & 195 & , &, \\
\hline Plegadis guarauna . & . . & . & . & . & . & . & . & . & . & . & . & . & . & 197 & VII. & June 1899. \\
\hline ARDEA SACRA. . . & . . & . & . & . & . & . & . & . & . & . & . & . & - & 199 & " & , \\
\hline NyCticorax GRISEUS. & .. & . & . & . & . & . & . & - & . & . & . & . & . & 201 & $"$ & $"$ \\
\hline Fregata aquila . & . . & . & . & . & . & . & . & . & - & . & - & . & - & 203 & " & ", \\
\hline Phaethon xthereus . & . . & . & . & . & . & • & . & . & . & . & . & . & . & 205 & " & ", \\
\hline Phatimon rubricauda & . & . & . & . & . & . & . & . & . & . & . & . & . & 207 & $"$ & $\eta$ \\
\hline OCEANODROMA CRYPTOLF & EUCU & URA & . & . & . & 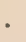 & . & . & . & . & . & . & . & 209 & IV. & Jan. 1893. \\
\hline BULWERIA ANJINHO & - . & . & . & . & . & - & . & . & . & . & . & - & . & 211 & VII. & June 1899. \\
\hline CEsTRELATA PHAOPXGIA & . & . & . & . & . & • & . & . & . & . & . & . & . & 213 & V. & A.pr. 1894. \\
\hline Puffinus cuneatus . & . & . & . & - & . & • & . & - & - & · & . & . & . & 215 & IV. & Jan. 1893. \\
\hline DIOMEDEA IMMUTABILIS & . & . & . & . & - & • & . & . & . & - & - & . & . & 217 & VII. & June 1899. \\
\hline
\end{tabular}

* For changes of nomenclature see Introduction.

Remarks on the Structure of certatn Hawaitan Birds, with Reference to their Systematio Position, By Hans Gadow, M.A., Ph.D.

Page

PART I. . . . . . . . . . . . . . . . . . . .

PART II. . . . . . . . . . . . . . . . . 



\section{LIST OF PLATES.}

- Map of the Hatrattax Istands.

: Corvus tropicus.

Drepanis pacticica.

DREPANIS FUNEREA.

Vestrarta coccinea. (Two Plates.)

7 Nest of Vesitiaria cocorimea.

Patmerta dolit.

Himatione sanguinia.

is Nests of Himationg sangutnea and H. virens.

Eggs of Himatione, sp., and Chasiempis, sp.

Ciridops anya.

*. Himatione stejaegreri.

Himatione OHLORIS.

Humatione virens.

ic. Himatione wilsoni.

HTMATTONG PARTA.

VIRIDONIA SAgITTIROSTRIS.

Oremomza batrdi.

2. LoXOPS COCCINEA and L. FLAMMEA.

21 Himatione newtoni.

$\therefore$ Himatione mactlata.

Himatione montana.

Himatione mana.

26, 26. Loxops AURea and L. rufa. (Two Plates.)

2: Chrysomitridops C.ERULEIROSTRIS.

$\therefore$ Hemignathos procertus.

: Homignathos LICHTENSTHINI.

Hemignathus obscurus.

$\therefore$ Hemignathus huotidus.

HEMIGNATHUS OLIVACEUS.

$\therefore$ Hemignathus affinis.

$\because$ HEMIGNATHUS IIANAPEPE.

Pendionestor xaNthophrys.
Psitthadrostra pitutacea, 36

Loxiö̈DES BaILLeUt. 37

RhodaCanthis Palmeri. 38

Chtortdops Kona. 3 ?

ACRULOCERCUS BracCatus. $Y$ :

ACrUlocercus aptCalis. "

ACRULOCERCUS NOBILIS.

ACRULOCERCUS BISHOPI. 43

Chæторqila angustipludra. 4 .

Pheornis myiadestina and P. Lanaiensis. 45

PHAORNIS OBSCURA.

Phemornis palmeri.

Chasiempis Sandvicensis.

Nest of CHASIEMPIS SANDVICUNSTS.

Chasiempis gati. is

Chastempis sclateri. 3

ANous HaWAIIENSIS.

NUMENiUs TAHITIENSIs. 5

Totanus incands.

HIMANTOPOS KNUDSEN, \&

Fultoa ALAI. $\quad 56$

Gallinula sandvicensis. 5:

Penndla ecaudata. 5 ?

Pennula sandvicensis.

Pennula milsont. by

Buteo solitarius. (Threo Plates.) 6!, 62, 63

BerNICLA SANDVICENSIS. 6

Anas wyvidiliana.

OCEANODROMA ORYPTOLEUCURA. 66

Estretata PHeopygia, 6 ร

Puffinds cuneatus. $\quad 6 \varepsilon$

Anatomical Structure of oertain Hawaitan $/ 0$ : 0 Binds. (Three Plates.) 



\section{P R E F C E.}

Now that this difficult and prolonged task has come to an end, I am glad to have the opportunity of putting on record my-sincere thanks to all my kind friends in the Hawaiian Islands for the assistance that they have given me in various ways during my collecting-trips in the different island districts. Unfortunately, since the occasion of my first visit in 1887-88, some of them have died. His Majesty King Kalakana is no more-a talented man and the author of several valuable works, who took the greatest interest in my researches and gave me (through his Chamberlain, the Hon. C. P. Jankea) letters to several prominent natives in Hawaii. Mr. H. N. Greenwell and Mr. Frank Spencer, of the same island, have also died, both of whom were residents of over 40 years' standing and rendered me most valuable aid. As regards Oahu, a most valued friend has been lost to Honolulu in the person of the late Judge R. F. Bickerton, a son-in-law of Mr. Spencer's; while Mr. Jesse Morehead is no more to be seen on Lanai, and the news has just reached me of the sudden death on Maui of Mr. Randal von Tempsky, by whom I was entertained not only on that island but also on the adjacent and seldom visited one of Kahoolawe.

To the Hon. C. R. Bishop, who has, since the occasion of my first visit, taken up his residence in San Francisco, but whose princely gifts to Honolulu are to be seen in the Bishop Museum and Schools, and who has taken the greatest interest in the researches of my friend Mr. R. C. L. Perkins, I must express my gratitude for many acts of kindness. To Mrs. Francis Sinclair-a member of the family of that name in Niihau and Kauai, who have been kindness itself to me-herself well known by reason of her beautifully illustrated book 'The Flora of the Hawaiian Islands'-I must tender my 
sincerest thanks for having allowed my artist, Mr. Frohawk, in many instances to make use of portions of the plates in that work as backgrounds, thereby enabling me to reproduce the indigenous trees and plants at the same time as the birds.

To enumerate by name all those from whom I met with kindness in the islands would be a well-nigh endless task; but I must refer, in conclusion, to a few friends in England whose untiring assistance has been of the most valuable description: to Professor Newton (to whom I have the very great pleasure of dedicating this work), to the Hon. Walter Rothschild, to Dr. Hans Gadow, to the late Mr. Osbert Salvin, and to Mr. R. C. L. Perkins.

S. B. WILSON.

Heatherbank, Weybridge,

May 19th, 1899. 


\section{INTRODUCTION.}

So long as the English tongue is spoken by Britons, and so long as they hold in honour the deeds by which the maritime glory of this country was established, so long will the name of the SANDWICH ISLANDS, almost the last discovery of the great English navigator, remain a household word. The story of the death of Captain JAMES Cookthe discoverer whose character secured for him during a fierce war immunity from the "ancient enemy" of England-has been for more than a century part of the history of this country, and thousands of English boys and girls have heard with the deepest emotion how that great chief was stricken down in a miserable quarrel on the shore of the "Island of Owhyhee"-one of the group which he had sighted but little more than a twelvemonth before, and appropriately named after the English statesman to whose influence and encouragement the undertaking of this last and fatal voyage was due. For many years past this name has been set aside by their inhabitants, and the designation of the "Hawaiian Islands" has been substituted; but that bestowed by Cook-the Sandwich Islands-can never be erased from English memories.

The group lies in the North Pacific, extending approximately from the 155th to the 161st degree of W. longitude and from the 19th to the 23rd degree of $\mathrm{N}$. latitude, and the several islands, reckoning from the north-west, are Niihau (Oneehow), Kauai (Atooi), Oahu, Molokai, Lanai, Maui, Kahoolawe, and Hawaii. The last-named is divided into eight districts, namely, North Kohala, South Kohala, Hamakua, North Kona, South Kona, Hilo, Kau, and Puna; Oahu contains five-Honolulu, Ewa (with Waianao), Waialua, Koolauloa, and Koolaupoko; Maui four-Lahaina, Wailuku, Hana, and Makawao; Kauai four-Waimea, Lihue and Koloa, Kawaihau, and Hanalei. With the exception of Kahoolawe, which is almost entirely flat, all of the above are more or less mountainous, though in parts at least of every member of the group stretches of level beach lie around the elevated central area. Lehua, Kaula, and Molokini are adjacent rocky islets, bare and uninteresting, while there are a few others that are still smaller. On the east of Hawaii the cliffs attain a height of some 1600 feet, on the north-east of Oahu they rise to about 2000, while in some parts of Windward Molokai they are said to be as much as 4000 , and descend as sheer precipices to the ocean.

The mountains were in olden times densely clothed with tropical vegetation and trees of various kinds, and such is still the case to a considerable extent in most of the 
islands; though in certain districts, especially of Lanai and Oahu, the primeval woods have been completely destroyed by the agency of animals or man. Goats are the chief offenders in Lanai, deer (introduced of course) in Molokai, and cattle in Hawaii, while in the last-named the ground is being extensively cleared to make room for coffeeplantations. At the present day there is no forest on Niihau or Kahoolawe, nor are there any resident land-birds on either; but that the former was at one time covered with trees, or at least bush, is indubitable, since the large land-mollusks of the genus Carelia, which are found there in a sub-fossil condition, can only exist in damp woodlands.

Besides the lowland zones, well-defined upper and lower forest-zones ${ }^{1}$ may be distinguished, which are characterized by the presence or comparative abundance of special kinds of trees: the former, which includes all the heights from 3000 feet upwards, being the chief natural habitat of the Koa (Acacia koa), the Mamáne (Sophora chrysophylla), the Sandalnwood (Santalum album), the Naio or Bastard Sandal-wood (Myoporum santalinum), and the Lobeliacece generally; the lower, which extends from about 1100 to 3000 feet, furnishing Pandanus odoratissimus, the Kukui (Aleurites triloba), the parasitic Ieie (Freycinetia arborea), and above all the Ohia (Metrosideros polymorpha), though the two last-named are also met with on the higher slopes in a dwarfish form. 'The summit of Kauai consists of an extensive plateau, boggy and thickly wooded; a like state of things occurs on the mountains of western Maui and on the Kohala range in northern Hawaii; while Molokai and Lanai shew signs of having formerly been similar in this respect, though in these two cases the ground has now become comparatively dry. Towards the coast the trees ordinarily diminish in size, while nearer to the actual beach the prickly pear now covers considerable areas in several districts. The heights of the zones, of course, vary somewhat in different places.

As will be seen in the description of the various species of birds, many of them are more or less restricted to the forests at particular altitudes; but no safe deductions

I A more precise account of tho zones may be found in the 'Flora of Hawaii' of Hillebrand. That, author distinguishes :-

1. A Lowland Zone, exhibiting Pandanus, Gossypium, and other plants in abundance.

2. A Lower Forest Zone, extending up to 1000 or 2000 feet. This is of a tropical nature, with rather open woods. Aleurites is the characteristio tree, and Zingiber zerumbet covers the ground. Pandanus odoratissimus reaches it, but goes no higher; Freycinetia occurs here and upwards.

3. A Middle Forest Zone, attaining a height of 5000 or 6000 feet, and possessing many trees and shrubs common to the regions above and below it. It lios within the region of clouds, and is especially luxuriant in vegetation both as regards trees and jungle. The most representative forms are Dodoncea viscosa (the Alii), Pelea sp. (the Alani), Cheirodendron gaudichaudii (the Olapa), Acacia koa, and Metrosideros polymorpha. The arborescent Lobeliacece are there very fine, but solitary.

4. An Upper Forest Zone, extending up to 8000 or 9000 feet, with moderately heavy soil, covered with liverworts, mosses, and sedges. It is characterized by stunted trees of Sophora, Myoporum, and so forth, with shrubby Compositce and the Ohelo (Taccinium reticulatum).

5. Above the forests are found ereeping forms of Metrosideros, Cyathodes, and the like. 
can be made from observations of this description, since a large number of forms follow their food, as the fruits ripen successively from the lower to the higher elevations. Nor must it be assumed as certain that the regrettable extinction of certain of the rarer woodland birds is due to the absence of the trees which supply a large part of their diet; for other causes have undoubtedly contributed to their loss, and it has been well remarked that, for all we know to the contrary, the destruction of some particular insect might result in the simultaneous disappearance of one or more members of the avifauna. Nevertheless to many species forests would seem to be a necessity, for though Vestiaria coccinea and Himatione sanguinea are found on Niihau, when blown across by strong winds from Kauai, they perish there in a very short time.

A characteristic feature of the scenery of the islands is the constant occurrence of deep wooded valleys or gorges, descending from the knife-edged ridges above to the comparatively level districts below, these glens branching again laterally into other subordinate ravines: and herein to the ornithological collector lies one of his chief difficulties; for many specimens, when shot, fall among the dense scrub or fern with which the banks are clothed, and are then, as will easily be understood by those conversant with such localities, practically irretrievable, unless by foresight or an unusual stroke of luck a good dog is at hand to secure them.

The trees in these islands average from 60 to 100 feet at most, and do not attain to that stupendous height of which we read in still more tropical climates, where the feathered tribes occupy, as it were, a level of their own far above that of man; nevertheless the nests, save of a few of the commoner species, are exceptionally difficult to procure, owing to the fact of their being usually built at the very extremity of the slenderest branches, whether they be horizontal or vertical. Strange though it may seem after the efforts of so many collectors, the only eggs absolutely identified at present are those of Chasiempis sandvicensis and Himatione virens. The favourite sites for nidification are the Koa and the Ohia trees.

The equable climate and convenient geographical position of the islands lend themselves naturally to facilities for trade and commerce. The average temperature at the sea-level is $75^{\circ} \mathrm{F}$, and there is no rainy season, though snow lies for at least two months on all the higher peaks. Roughly speaking, the group lies about 2100 miles from San Francisco, 3810 miles from Auckland in New Zealand, and 3440 miles from Yokohama; so that its central position bestows upon it a great advantage as compared with many other countries.

The visible mountain-peaks, moreover, being but the projecting summits of a vast and lofty submarine chain, the ocean surrounding them is as a matter of course of great depth, and consequently little difficulty is experienced in landing at any sheltered spot; indeed from the Sandwich Islands to Japan the soundings only vary from 2500 to 3100 fathoms. As might be expected, however, disembarkation is often dangerous on the windward coasts, where the trade-wind blows for some nine months in the year; but this state of things is to a considerable extent remedied by the proximity of the islands to one another, as they are in certain cases only separated by comparatively 
narrow channels. In ascending the hills, the trade-wind is said to be no longer felt when an altitude of from 8000 to 10,000 feet is reached, a fact particularly observable in the uplands of Kona; but it causes almost perpetual wet weather at the higher elevations on the windward sides.

The whole archipelago consists of volcanic rocks of a basaltic nature ${ }^{1}$, with a few remnants of raised sea-beaches composed of consolidated coral sands of a white colour, especially noticeable on Hawaii ; in consequence of this the traveller finds, along with the thin layer of cultivated soil in various parts, large "flows" or stretches of hard bare lava, not uncommonly extending to the shore, though more frequently in evidence at the higher levels. Deep rich soils adapted to the growth of the sugar-cane form some fortieth part of the whole area, and occur chiefly where there is dense forest, or where such has been the case in former times; while the valleys provide a heavy clay, suitable for the cultivation of rice and taro (Arum esculentum). Coral-reefs environ the islands to a great extent, and narrow strips of coral limestone are to be met with along: some parts of the coasts; the craters of Mauna Loa and Kilauea, in Hawaii, are still the outlets of active volcanoes, and others, such as Haleakala in Maui, or Hualalai in Hawaii, are but recently extinct.

Taro is the staple food of the natives; but the chief industry is the cultivation of the sugar-cane, which is usually raised on the windward side of the mountains, in spots remarkable for their general humidity, and, at the greater elevations, for their heavy rainfall. On the leeward side this plant can only be grown by the aid of irrigation, for which the water is obtained from the hills or from wells sunk for the purpose. The practice has been greatly extended of late years in Oahu and Kanai. Coffee, the introduction of which has failed in Kauai, has, on the contrary, succeeded in Hawaii, and may be considered to occupy the second place among the exports. Oranges, lemons, limes, pine-apples, bananas, peaches, and other tropical or subtropical fruits are chiefly used for home consumption; a few cocoanuts are to be found in places; sweet potatoes are a well-known product; while cotton, which has never been largely grown, is now wholly abandoned. Many districts lend themselves naturally to the cultivation of rice, that necessity of life to the Chinese and Japanese, of whom there are vast numbers in the archipelago.

These islands, deeply interesting as they always must be to those engaged in the study of "Geographical Distribution," have unfortunately only been appraised at their true worth from a comparatively recent period. This is the more remarkable since not only does their avifauna contain many forms as extraordinary and highly specialized as are to be found in any quarter of the globe, but, unlike other more isolated and inaccessible regions, their shores have from time to time been visited by travellers who should have served to keep alive the expectation of new discoveries. It must, however, be admitted that the record was for long but a series of disappointments due to neglected opportunities, while the meagreness of the information obtained and the

\footnotetext{
1 The assistance afforded to the authors in this connexion by Capt. C. E. Dutton's work on 'Hawaiian Volcanoes' (Washington, :884) must be gratefully acknowledged.
} 
entire absence of any correct list of species in the accounts of the older writers are much to be deplored. By the early voyagers the importance of exact information was unfortunately little appreciated.

The following account of the discovery of the islands, and of their visitors down to the year 1891, is from the pen of Professor Newton, who wrote in 'Nature'1 after the appearance of the second part of the present work, and has now most kindly allowed the authors not only to utilize the greater part as originally published, but has, moreover, furnished several further particulars, where information of a later date made modifications or additions desirable :-

"The Sandwich Isles have not been fortunate in their Natural Historians, though perhaps no worse off in this respect than many another group 'lying in dark purple spheres of sea.' Discovered in 1778 by Cook, during the last of his celebrated voyages, his ships communicated with one of the more western islands-Atooi, as its name sounded to him and his companions, but since, and doubtless more correctly, written, Kauai. The admiration of the visitors was excited by the cloaks and helmets of the natives, beautifully bedecked with feathers, the more or less moth-eaten remains of which may yet be seen in many a museum; and the scarlet birds which furnished the most brilliant adornment of these ingenious works of art were duly mentioned by Cook in his journal as published. After less than a fortnight's stay, in the course of which the existence of five islands was made out, his ships stood off to the northward to prosecute their voyage of discovery. Towards the end of the year they returned, and Cook, having had experience of the hospitable treatment of the islanders, designed to make bis winter-quarters in the Sandwich Isles, as he had named them, after the then First Lord of the Admiralty; but, keeping more to windward, the first land he made was the most eastern of the group, one that he had not even seen on his first visit. This was the historic Owhyhee-nowadays written Hawaii-which, being the largest of them, and that which eventually produced the warrior-king and statesman who eventually subdued all the rest, has given its official name to the Archipelago.

"Though Owhyhee was sighted on November 29, Cook's course along its eastern and southern coast was so deliberate that it was not till January 17,1779 , that he found a safe anchorage, and that in Kealeakakua Bay, on its western side. What passed there during the next three weeks need not be here recorded; but those who know how to read his narrative and the accounts since divulged from native sources will admit that it throws an important and yet most lurid light on the history of superstition. To the unprejudiced it must be doubtful whether even now the whole truth is, or ever can be, known. The ships sailed on February 4 ; but in making her way to the northward the 'Resolution' sprung her mainmast, and within a week returned to her old anchorage. Three days later occurred the terrible tragedy which deprived the world of one of its greatest seamen.

"A week after Cook's death the ships sailed to the westward, touching at some of.

'Vol. xiv. pp. 465 et seqq. (March 17th, 1892). 
the intermediate islands-Mowee (Maui), Lanai, and Morotai (Molokai)-making once more for Atooi (Kauai) and Oneehow (Niihau), the last famous for its yams. Then, on March 15, they bore away again to the northward and did not return.

"Now the object of giving here these details is to shew that the natural-history specimens obtained by Cook's ships were procured only on the islands of Hawaii, Kauai, and Niihau. This is the more needful because the first descriptions of any of the birds of the Sandwich Isles were given, with two exceptions, by Latham in his 'General Synopsis of Birds,' published in 1781-85, and most of the specimens so described no longer exist. Some were in the British Museum or the collection of Sir Joseph Banks, afterwards transferred thereto; the rest were in the Leverian Museum. In the former, as is well known, not one remains; but fortunately, at the breaking up of the last in 1806, a few were bought by the then Lord Stanley, who (dying in 1851, as thirteenth Earl of Derby and President of the Zoological Society) bequeathed his collection to the town of Liverpool, and there, thanks to the care that has been taken of them, they still exist in fair condition. - A few more were bought for the private collection of the then Emperor of Austria, and are still carefully preserved in the Museum of Vienna ${ }^{1}$. Of several of the species it is not known that any other specimens were brought to Europe until some three years ago. On both of Cook's previous voyages qualified naturalists had been sent; but the arrangements for publishing their discoveries were so imperfect that little credit followed to anyone concerned. On this, his third and last voyage, there was no expert, though Mr. William Ellis, who in an irregularly published narrative calls himself 'Assistant Surgeon to both vessels,' was somewhat of a draughtsman, and made a series of sketches, which, becoming the property of Banks, subsequently passed to the British Museum. The commoner species of Sandwich-Island birds are generally recognizable, but others are so unhappily limned that even the word caricature (which always implies some likeness) seems too strong to apply to them. Nevertheless Mr. G. R. Gray adventured to determine all of them.

"More than a quarter of a century passed before any further progress was made in the knowledge of the zoology of the Sandwich Isles, though they were visited by numerous ships, and in 1794 were ceded to Britain under Vancouver. In 1814 an attempt was made to seize them for Russia; and Kotzebue, whose voyage has so much scientific interest, was there in 1816-17, but the accomplished naturalists, Chamisso and Eschscholtz, who were with him, took little heed of the fauna of the islands ${ }^{2}$.

"The year 1822 saw the arrival of the more celebrated William Ellis, whose missionary labours throughout the Pacific and in Madagascar are so widely known. The Sandwich Isles had by this time fallen under the sway of the conquering Kamehameha I., whose son and successor, desirous of seeing European civilization, arrived in Enyland in 1824 with his wife-both to die of measles within a few weeks. The British Government determined to send their remains for interment in Honolulu, by that time become the

\footnotetext{
1 See Von Pelzeln, 'Ibis,' 1873, pp. 14-54; 1874, p. 462.

2 "The same nogative results attended his secoud risit in 1824-25."
} 
capital of the islands ; and accordingly H.M.S. 'Blonde,' commanded by George Anson seventh Lord Byron (first cousin and successor to the poet), was commissioned to convey the dismal freight. The duty was performed, and the islands again were ceded to the British Crown, but again declined. On board the 'Blonde' sailed as chaplain Mr. Rowland Bloxam, together with his brother Andrew, who was somewhat of a naturalist; and it was intended that the published account of her voyage should contain a proper appendix on the natural history of the islands. An 'Appendix" there indeed is, but one utterly unworthy of its reputed author, for the book was edited by a lady ${ }^{1}$ who had nothing but a few of his notes to guide her, and though assisted, as it is stated, by 'the gentlemen connected with that department in the British Museum,' the Appendix is a disgrace to all concerned, since, so far from advancing the knowledge of the subject, it introduced so much confusion as to mislead many subsequent writers."

Professor Newton, as above stated, wrote in 1892; but since that date, thanks to Mr. A. Roby Bloxam, of Christchurch, New Zealand, son of the naturalist on the 'Blonde,' the authors have been allowed access to his father's original notes, and find from them that he obtained in the Islands 25 specimens of 9 species of Landbirds-one of them bearing the MS. name 'Turdus woahensis.' This is just mentioned in the 'Appendix' to the 'Voyage' (p. 250) as a variety of 'Turdus sandwichensis' (by which name Bloxam erroneously designated Phoeornis obscurc ${ }^{2}$ ) found on Oahu, where no species of the genus has been before or since known to exist, and it has doubtless been long extinct. Bloxam's description of it is:- 'Length $7 \frac{1}{2}$ inch. Upper parts olive-brown, extremities of the feathers much lighter color; tail and wings brown; bill bristled at the base'; while the corresponding description of the species from Hawaii, $P$. obscura, is:- 'Length 8 inches. Belly light ash ; back, tail, and wings an ash-brown; bill slender, $\frac{3}{4}$ inch long, bristled at the base. A beautiful songster.'

All the specimens obtained by Mr. Andrew Bloxam, properly prepared and labelled, were placed at the disposal of the Lords of the Admiralty, as shewn by a copy of the letter he wrote to their Secretary, and probably all were sent, as some certainly were, to the British Museum; but no other trace of this unique specimen of a vanished species, which may be properly called Phoornis oahensis, is now forthcoming.

1. "Mrs. Maria Graham, as we learn from Dr. Smiles's "Memoir and Correspondence of the late John Murray' (London: 1891), vol. i. pp. 319-321, and vol. ii. p. 293. She was the daughter of Rear-Admiral Dundas, and married, first, Captain Graham, R.N., nephew of James Graham, who wrote the 'Birds of Scotland,' and, secondly, Mrr. (afterwards Sir) Angustus Callcott, R.A., and was the author of sereral works."

2 It is not possible to say with certainty what the 'Sandwich Thrush' of Latham (Gen. Syn, ii. p. 39), on which was founded the Turdus sandwichensis of Gmelin (Syst. Nat. i. p. 313), may have been; but its length, ' $5 \frac{1}{2}$ inches' according to Latham's description, and its white forehead preclude its being Phocornis obscura, though Ellis's unpublished figure (no. 77), on which 'Turdus sandwichensis' is written, can hardly represent anything else. It seems just possible that the bird described by Latham may have been Oreomyza bairdi; but the name Turdus sanduichensis has been purposely excluded from our synonymy. 
Professor Newton continues:- "Some years later another great opportunity was missed, and this time by the American traveller Townsend, who, after crossing the Rocky Mountains to the Columbia River, sailed, in company with Nuttall, the wellknown naturalist, for the Sandwich Islands, where they arrived in January 1835, and stayed nearly three months, visiting Oahu and Kauai. Returning at the end of the year, Townsend found the Prussian naturalist Deppe at Honolulu, and with him passed some time in the pursuit of natural history, visiting most of the windward islands before he left in March 1837'. Among the specimens obtained by Deppe for the Berlin Museum were some of two species for which Lichtenstein rightly established a new genus - the singular form Hemignathus - and, as it has since proved, both these species were new, though he had not unnaturally identified one of them with a species described by Latham.

"Of Townsend's collection a considerable part was given to the Academy of Natural Sciences at Philadelphia ${ }^{2}$, where it still remains; but he sent several specimens to Audubon, at that time, I believe, in Edinburgh, and he parted with them to Carfrae, a dealer there, who sold them to the late Sir William Jardine, at the dispersal of whose collection I was so fortunate as to secure them-some of them bearing Townsend's label-for the Museum of the University. If Tornsend had but published a list of his captures, he would indeed have rendered a very good service; but of course the value of island-forms, to say nothing of the fact that many of them were threatened with extirpation by colonization and civilization, had not then been appreciated, if even entertained, by naturalists.

"In the year of 'Townsend's departure the French frigate 'Vénus,' in the course of her troublous career under Du Petit-Thouars, arrived in the Sandwich Islands, with two

2 As Townsend's work is not commonly to be met with, the following extracts may be acceptable to the reader. The first (pp. 207-208) refers to the island of Kauai and to the month of February 1835; the second (p. 269) to Oahu and to the date of January 15th, 1836 :-

"We made here several long excursions orer the hills and through the deep valleys, without much success. The birds are the same as those we found and collected at Oahu, but are not so numerous. They are principally creepers (Certhia) and honey-suckers (Nectarinia); feed chiefly upon flowers, and the sweet juice of the banana, and some species are very abundant. The native boys here have adopted a singular mode of catching the honey sucking birds. They lay themselves flat upon their backs on the ground, and cover their whole bodies with bushes, and the campanulate flowers of which the birds are in search. One of these flowers is then held by the lower portion of the tube hetween the fingers and the thumb; the little bird inserts his long, curved bill to the base of the flower, when it is immediately seized by the fingers of the boy, and the little flutterer disappears beneath the mass of bushes. In this way dozens of beautiful birds are taken, and they aro brought to us living and uninjured."

"Several days ago Mr. Deppe and myself visited Nuano valley, where we hired a native house, in which we are now living. Our object has been to procure birds, plants, \&e., and we have so far been very successful. I have already prepared about eighty birds which I procured here."

2 "In mentioning these facts, I desire to record my deep gratitude to the authorities of both these museums-Berlin and Philadelphia-for their obliging readiness in allowing me to have some of these valuable specimens, one of them unique, for examination." 
naturalists, Léclancher and Néboux, on board; and some years later the atlas of plates illustrating the zoology of her voyage appeared, but the text was deferred for a long while, and, indeed, was not completed till 1856. Herein was figured and described, though not for the first time, a species of the curious Hemignathus.

"In the meanwhile the celebrated expedition of Commodore Wilkes took place, and he, with some of his ships, wintered there. In the course of their six months' stay, the naturalists attached, Pickering and Peale, seem to have made large collections; but nearly all was lost in the wreck of the 'Peacock,' one of the ships of the squadron. By 1848 Peale had completed his report on the specimens of mammals and birds collected, and it was printed off. A few copies only had been distributed, when the rest were destroyed by fire. It was by no means a bad performance; and I cannot understand why the late Mr. Cassin made so many changes in it when he, ten years later, brought out a new edition of it. Some of them (I speak only of those relating to the Sandwich Island fauna) were certainly not improvements. However, a distinctly forward step was made by the Peale-Cassin labours; and since few can obtain access to the original work, I may mention that Dr. Hartlaub considerately published an abstract of it ${ }^{1}$, just as two years later he did ${ }^{2}$ of the French 'Voyage au Pôle Sud,' wherein, having sorted out the different species observed by various voyagers on the several Pacific groups, he gave a useful list of those found on each, and thus he assigned to the Sandwich Isles thirty species of birds, marking two of them as doubtful. One of them is now known to be rightly included, but the other must be struck out, as well as, for one reason or another, four more-leaving a total of twenty-five, only sixteen of which are Land-birds and only fourteen Passeres.

"Hitherto no list of the birds of the Sandwich Isles had been published, so that Dr. Hartlaub's met a great want, though it had of course been possible, since 1814, for anyone to pick out for himself the species assigned to that group from the general list compiled by Tiedemann ('Anatomie und Naturgeschichte der Vögel,' ii.' pp. 426-436), and in like manner, since 1859, from Mr. G. R. Gray's useful 'Catalogue of the Birds of the Tropical Islands of the Pacific Ocean;' printed by order of the Trustees of the British Museum; but the former was obsolete, and the latter, as we now know, very erroneous ${ }^{3}$. Mr. Gray's references shew him to have been as usual a model of accuracy, but his judgment as an ornithologist was frequently at fault.

"It was therefore with great pleasure that, some time in the winter of 1870-71, I received a copy of a 'Synopsis of the Birds hitherto described from the Hawaiian Islands,' which had been communicated in February 1869 to the Boston Society of Natural History by Mr. Dole, a resident in those islands, and had been published in the 'Society's 'Proceedings' (xii. pp. 294-309); and Mr. Sclater, who I knew

1 "Archiv für Naturgeschichte, 1852, Heft i. pp. 93-138."

2 "Journal für Ornithologie, 1854, pp. 160-171."

3 "Many of its worst errors are doubtless due to the loss, before mentioned, of the type specimens, which had been suffered by the Museum long before Mr. G. R. Gray was connected with it. Latham, in 1821, had already lamented their decay." 
had long taken an interest in the ornithology of the group, lost no time in noticing this very important publication (Ibis, 1871, pp. 356-362), adding thereto some valuable observations. This list has naturally proved a serviceable foundation for future work. Forty-eight species were included, the author stating that this number 'probably comprises but little more than half the avifauna of the group.' That the list should be free from error was not to be expected, and a revised version of it, published in the 'Hawaiian Almanac and Annual for 1879' (pp. 41-58), corrected some of the mistakes; but it was an honest piece of work, doing credit to its compiler.

"In the meanwhile, however, the historic voyage of H.M.S. 'Challenger' had commenced, and one of the places at which she was to call was the Sandwich Islands. Of course the main object of her voyage was the exploration of the depths of the sea ; nevertheless, the terrestrial zoology of the countries visited, though forming a very subordinate part of the original plan, was not to be wholly neglected-nor was it in this case, for during the three weeks she stayed in Hawaiian waters (July 27th to August 19th, 1875) her officers aviiled themselves to some extent of the opportunity of studying the ornitholngy of the islands, though it does not appear that they had received any special instruction in regard to our imperfect knowledge of it. Here, then, was another great chance lost; for had those who drew up the directions for the scientific members of the Expedition taken the trouble to acquaint themselves with the particular points on which investigation was needed, so as to indicate the lines on which further research was desirable, no doubt some one of the 'Challenger's' staff would have supplied, even in the short time of her stay, some of the missing facts, or at least would have thrown some light on the subject. As it was, the collection was reported as 'small' (twenty-four bird-skins and no specimen in spirit), and 'containing nothing absolutely new except a single species of Anas,' afterwards named A. wyvilliana (Proc. Zool. Soc. 1878, p. 350). 'The late Prof. Moseley, in his 'Notes of a Naturalist on the "Challenger," stated (p. 514) that the last excursion on shore of his colleague, Von Willemös-Suhm, was at Hilo in Hawaii with a native guide, 'in pursuit of the interesting endemic birds,' and that 'almost the last notes he wrote were some on the Sandwich Islands, relating especially to the birds,' but these notes, which have been kindly entrusted to me by Sir John Murray, F.R.S., unfortunately prove to contain no information of aly interest-for the writer had evidently never been informed as to the many points to which lis attention might have been profitably directed."

What next followed may also best be recorded in Prof. Newton's words :-

"Having myself felt a good deal of interest in the avifauna of the Sandwich Isleswhich, like that of many other islands throughout the world, was, as I had learnt, threatened with extirpation, chiefly in consequence of the destruction of the forestsI could not fail to be disappointed at the meagre results obtained by our people on this celebrated cruise, when it would have been so easy for them to have done better had their attention been duly called, and I cast about in several directions to find some 
suitable person to visil the islands with the view of investigating their ornithology in a thorough way. My young friend Mr. Scott Barchard Wilson (son of the well-known Mr. George Wilson, F.R.S.) - of whose taste for natural history I was well assured by his residence in my own College, by his journey to Portugal with Dr. Gadow, and by his subsequent sojourn in Switzerland (Ibis, 1887, pp. 130-150)-willingly took up the enterprise, and left Liverpool on February 24th, 1887, for Honolulu, where he arrived on April 8th, having on his way paid a visit to Washington to confer with Dr. Stejneger, whose name had already appeared in connexion with the birds of the Sandwich Isles. Mr. Wilson stayed in the islands until towards the close of the following year. He brought back such a collection as had never before been made there; but, rich as it was in some respects, defects became apparent as it was gradually worked out, anil some of these defects were so grave that, until they were remedied, no complete list of the avifauna could be formed. However, he had done a great deal more than anybody before him ${ }^{1}$ : he had ascertained the precise localities of nearly all the birds hitherto known, and added to them not inconsiderably-fourteen new species or local forms of Passeres, two of which required generic acknowledgment-all, it needs not to say, being peculiar to the islands, and mostly to one particular island only.

"But Mr. Wilson was not content, as so many collectors in foreign countries are, with preserving only the skins of the birds he procured. He was careful to obtain specimens in spirit of all the important existing types; and these, when properly subjected to examination by Dr. Gadow, led to some remarkable results. They are contained in a dissertation 'On the Structure of certain Hawaiian Birds, with reference to their Systematic Position,' contributed by Dr. Gadow to Mr. Wilson's work (Part II.). Most of the land-birds of the Sandwich Islands had been, at one time, thought to belong to the Meliphagido, or Honey-suckers-a family very characteristic of the Australian region, and known to be very polymorphic. It was thought to be still more so; and the surmise had been acted upon, so that some Finch-looking birds, Psittacirostra and Loxioides, had been supposed to be Honey-suckers in disguise, and classed accordingly. Dr. Gadow shewed that this supposition was wholly erroneous, and at the date of his article considered, from the material in his hands, that these last, together with another form, Chloridops-one of Mr. Wilson's discoveries-were true Fringillida; while, out of the whole Hawaiian avifauna, only two genera could be referred to the Meliphagida, namely, Acrulocercus (Moho of some writers) and Chcetoptila, the last being presumably

1 "I havo no desire to overlook the services of Mr. Valdemar Knudsen, of Kauai, who sent thence to the United States National Museum several collections, the most important of which was described by Dr. Stejneger in the 'Proceedings' of that institution for 1887 (pp.75-102), the year of Mr. Wilson's arrival in the islands. The Doctor's paper is of the exhaustive character to which one is accustomed in all his productions, and has been of considerable use in working out Mrr. Wilson's collections, while these have enabled the latter to correct several mistakes - under the circumstances quite pardonable-made by the former, who subsequently described in the same "Proceedings' (xii. pp. 377-386) another collection from the same quarter." 
extinct. All the other forms which had been-accounted Meliphagine presented a peculiar structure of tongue forbidding that alliance, or any affinity to the Prionopida, Dicceidae, or Nectariniida, but revealing a distinct relationship to the Coerebida-now known as a family characteristic of the Neotropical Region! Hereby a beam of light was thrown on the origin and derivation of the ornithic population of the Sandwich Islands. The distinct inference was that the first stock of their existing avifauna was received from America, in days when the range of the Coerebidee extended further to the northward than it does at present, and that certain cognates or ancestors of the present Coerebidoc colonized the islands, there differentiating into the modern Drepanididce. The importance of this inference on views that are held as to the geographical distribution of birds in North America is a subject into which there is no need here to enter, for that would be a subject foreign to my present remarks; but I doubt not it will receive due attention from American ornithologists, whom it most nearly concerns.

"That these colonists, from what I have elsewhere ventured to term a 'Columbian" fauna-since it cannot literally be called a Neotropical one, and is certainly not 'Nearctic' -were the earliest settlers which have left descendants one can hardly doubt, for they have existed in the Sandwich Islands long enough to undergo a great amount of change. Subsequently there has been a small infusion of blood from the 'Australian Region.' I say subsequently, because Dr. Gadow has shewn that this immigration has undergone comparatively little modification. We have (or had) the two Meliphagine genera Acrulocercus and Chcetoptila - the latter, indeed, beyond anatomical examination, but shewing no very great external deviation from well-known Australian types; while the former undoubtedly retains the normal Meliphagine tongue. To these may be added Chasiempis, a well-marked genus; but, without question, very nearly allied to the genus Rhipidura, so widely spread over the Australian Region, and found also in New Zealand. 'Thus three genera constitute, so far as I am able to see, the 'Australian' element in the avifauna of the Sandwich Islands-and what are they among so many others? 1

"More recently than this Australian infusion has supervened an influx of Holarctic types, and especially of the Fringitlidce. Whether these have arrived from America or Asia, I do not pretend to say; but the long chain of islets running to the westwardone of which produces a remarkable form (Telespiza cantans), the knowledge of which we also owe to Mr. Wilson (Ibis, 1890, pp. 339-341, pl. ix.) -suggests the possibility of an Asiatic origin, a possibility confirmed by the consideration that his fine Chloridops kona may be the magnified descendant of the long-known Chloris kawarahiba, which has already an enterprising relative, C. kittlitzi (Ibis, 1890, p. 101), established in the Bonin Islands. Still later must have been the appearance on the scene of members of the genera Corvus and Buteo, both of which are, so far as is yet known, confined to

1 "In connexion herewith may be noticed the absence of Parrots, Kingfishers, and Dores-all families that are very characteristic of an "Australian' fauna." 
Hawaii, the most eastern of the islands, and therefore suggest an emigration from the Nearctic area. These have been settled long enough to assume recognizable specific characters; but an apparently more modern colonist exists in Asio accipitrinus, the common Short-eared Owl of Asia, Europe, and North America, which extends its range over many islands in the Pacific Ocean, so far at least as the Galapagos, and has found a permanent home in the Sandwich Isles, breeding there, as it would seem, regularly - as it does in England, when permitted by the gamekeepers. More than this, there is an indication that the tendency to colonization from the Holarctic region still continues. Within an hour or two of his leaving the islands, there was sent to Mr. Wilson a freshly-killed example of Circus hudsonius-the American Hen-Harrier-a species which he had already ascertained to have before occurred in the group; but, not being recognized by Judge Dole, it had been endowed with a new name, and figures in his second list as Accipiter hawaii. The existence in considerable numbers of a Californian species of Carpodacus is thought, and no doubt rightly, by $\mathrm{Mr}$. Wilson to be due to human agency, and accordingly I do not attach any importance to that fact; but there is one very puzzling species, of which only a few specimens seem to have been preserved, that needs particular attention. This was described by Judge Dole under the name of 'Fringilla anna,' but, of course, is no true Fringilla. Mr. Wilson brought home but a single specimen, which he owed to the kindness of the Hon. C. R. Bishop, it having been formerly in the Mills Collection, and subsequently established for it a new genus, Ciridops-so named because its bright coloration recalls the well-known Emberiza ciris of Linnæus, the Painted Bunting of authors, or 'Nonpareil' of bird-dealers. It is supposed to be now almost if not quite extinct, but it was truly a native species. It probably belongs to the fauna which I have above called 'Columbian'; but I cannot suppose it to have been so early a settler as the Drepanididce, since it has changed so little.

"There remains of land-birds the genus Phoornis, which earlier systematists were inclined to put among the Flycatchers (Muscicapido). The examples in spirit, placed by Mr. Wilson at Dr. Gadow's disposal, have enabled the latter to set aside that view, and to show that, of all the families to which this genus has been supposed to be allied, 'it differs least from the Turdidae, and he would regard it 'as a generalized or rather primitive Thrush" "1.

From the summer of 1889 Professor Newton had been urging Mr. Wilson to return to the Islands and complete their ornithological exploration; for it was obvious that much remained to do, and what he had done gave promise of still more important results. Mr. Wilson being then unable to arrange for a second visit, Prof. Newton brought the subject before the British Association at the Leeds Meeting in September 1890, and obtained the appointment of a Committee, with Prof. (now Sir William)

' "A minute anatomical comparison with the New Zealand Turnagra would be desirable." 
Flower as Chairman and Dr. David Sharp as Secretary, to investigate the Fauna of the Islands, the sum of $£ 100$ being voted to assist their labours. On this slender benefaction a gentleman offered his services to proceed immediately to the Islands as an ornithological collector, and Prof. Newton was very anxious that they should be accepted $^{1}$; but the Committee thought it advisable to obtain further pecuniary help, especially from the Hawaiian Government, and through the delay entailed in negotiations to this end the grant was allowed to lapse, and thus a whole year was lost, though meanwhile, in 1891, the Government Grant Committee of the Royal Society had voted $£ 200$ for the same purpose. In August of that year the British Association re-appointed the Sandwich Islands Committee, renewing the grant and empowering it to co-operate with the Committee appointed by the Royal Society. The Joint Committee thus formed met and, from several candidates, selected Mr. R. C. L. Perkins, B.A., of Jesus College, Oxford, as their collector, and that gentleman accordingly left England for Honolulu, where he arrived in March 1892, and remained diligently exploring the various islands until the end of the summer of 1894 , when he returned to England; but, at the request of the Joint Committee, again departed early in the following year, reaching Honolnlu in March 1895, and stayed in the Islands for two years longer, the expenses incurred during the later portion of his time being defrayed almost wholly by the Trustees of the Bernice Pauahi Bishop Museum. His collections in all branches of zoology are very large, and the results are being by degrees published; but here it is only necessary to mention his ornithological achievements. The loss of the season of 1891 was unfortunate for the credit of the Joint Committee; for many discoveries which its collector, had one been sent out in that year, could not have failed making fell to the lot of the persons employed by Mr. Rothschild in 1890-92, and the only new species of bird discovered by Mr. Perkins was the Drepanis funerea, which, thanks to the Joint Committee, was first figured in the present work; but that gentleman brought back a very fine series of almost every other species now existing in the Islands, of which the first set has been deposited in the British Museum, the second and third in the Museums of Cambridge and Honolulu respectively. The specimens obtained by Mr. Rothschild's collectors are, naturally, at Tring. Mr. Perkins was most successful on his second visit in obtaining specimens of several species not found on his first expedition, owing to want of time.

The "Further Remarks on the Relationships of the Drepanididæ" with which Dr. Gadow has favoured this work contribute not a little to the difficulty of the Authors in determining the systematic position of many of the forms of Passeres described in the following pages. That these "Remarks" contain valuable considerations is obvious; but it will be observed that the Doctor, in arriving at his latest conclusions, expresses himself with some caution, and the Authors would exercise a

1 When it is mentioned that this gentleman was Mr. Lionel W. Wiglesworth, who subsequently compiled the 'Aves Polynesiæ,' and has been, with Dr. A. B. Meyer of Dresden, joint author of 'The Birds of Celebes,' the wish to accept his offer may be thought justified. 
similar becoming reserve in accepting those conclusions as final. Still it seems on the whole best to follow them, based as they are on Mr. Perkins's experience in the field. It is a very old supposition that some of the Finch-like forms were Meliphagine, and though that is now proved to be erroneous, those who accepted that view may well be content to regard those forms as Drepanid; while Mr. Sclater will be pleased to find his conclusions (Ibis, 1879, p. 91) as to their relationships to Drepanis and Hemignathus corroborated. On the other hand, looking to the unsatisfactory way in which the Passeres are unavoidably grouped at present, some systematists may demur to the removal of such a genus as Chloridops from the Finches, until a far more exhaustive study of the Fringillidoe and their presumed allies shall have been made.

Leaving this question for future solution, it must here be remarked that of the species attributed in the present work to the genus Himatione, H. sanguinea, which is the type of that genus, should in Mr. Perkins's opinion alone remain in it ${ }^{1}$, while those with straight bill ( $H$. maculata, H. montana, H. mana, and $H$. newtoni)-though not H. parva-together with Loxops Aammea, should be referred to Oreomyza ${ }^{2}$, and those with a curved bill should be placed in a new genus Chlorodrepanis, which he thus characterizes :-

"Primaries pointed and not truncate at the apex; nasal opercula with bristles at the base and not overhung by antrorse feathers; brush tongue thin and tubular; second primary a little shorter than the third ; bill curved."

Hence we have:-Chlorodrepanis stejnegeri, C. chloris, C. chloridoïdes, C. kalaana, C. virens, C. wilsoni; Oreomyza bairdi, O. Aammea, O. maculata, O. montana, O. mana, O. newtoni.

Himatione parva, though having a straight bill, Mr. Perkins now wishes to keep apart from Oreomyza, and to place it in a genus by itself as Rothschildia parva, while he would also recognize Heterorhynchus as a genus distinct from Hemignathus. On the other hand he would include Chrysomitridops with Loxops, as would Mr. Rothschild, and his idea of a natural arrangement of the Drepanidida is in two groups as follows:-

1. Drepanis, Vestiaria, Palmeria, Himatione, Ciridops.

2. Chlorodrepanis, Rothschildia, Viridonia, Oreomyza, Loxops, Hemignathus, Heterorhynchus, Pseudonestor, Psittacirostra, Loxioüdes, Telespiza, Rhodacanthis, Chloridops;

for reasons which he thus assigns:-

"Chlorodrepanis in reality is much more closely allied to Viridonia and Hemignathus than to Himatione, the feathers of which, it may be observed, are in certain parts of very different structure. Oreomyzc is at once

\footnotetext{
$1 H$. freethi of the island of Laysan forming a second species.

2 Mr. Rothschild, writing in 1893 ("Avifauna of Laysan '), and Mr. Perkins in 1895 ('Ibis '), for the most part agree as to the species to be placed in this genus; so that although most of the experience of the latter dates from 1892, Mr. Rothschild was first to publish the facts.
} 
distinguished by the very different form of tongue, as well as external characters; Hemignathus by the long beak, and absence of bristles at the base of the nasal opercula; Loxops by the short thick beak and long forked tail. Viridonia is hardly more than a large stoutly built species of the genus, slightly more aberrant in one

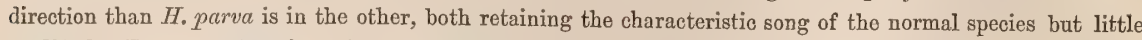
modified. The truncate apices of the primaries throw together the genera Himatione, Vestiaria, Drepanis, and probably Ciridops - the latter not being available for examination; and it is noteworthy that the young of all these birds are wholly or in part of black plumage, as also in Palmeria, which on that account, and for its evident relationship to Himatione, must be referred to the same section, although differing in the form of the primaries. All the other Drepanididoe are green or greyish-green in the immature condition, and all have pointed primaries."

A few words may here be added as to the progress of our knowledge of the Avifauna, and in particular of the Passerine Fauna, of the islands. When Mr. Wilson first visited them in 1887, the species of Passeres known to exist, or to have existed, were those marked in the Table on p. xxii by a cross prefixed to them-Himantopus knudseni, Chasiempis sclateri, Phoornis myiadestina, Oreomyza bairdi, and O. (Rothschildia) parva having been recently described by Mr. Ridgway and Dr. Stejneger. To these Mr. Wilson was enabled to add the following:-Chloridops kona, Chrysomitridops caruleirostris, Chasiempis gayi, Oreomyza mana, O. montana, Chlorodrepanis kalaana, C. chloridö̈des, C. stejnegeri (= Himatione chloris, Stejneger, from Kauai), Hemignathus procerus, H. lichtensteini, Heterorhynchus wilsoni ${ }^{1}, H$. hanapepe, Oreomyza Alammea, Phaornis lanaiensis. Two Petrels mentioned by Mr. Dole have proved to be Oceanodroma castro of Harcourt, and Estrelata phoopygia of Salvin, and a Shearwater described by Dr. Stejneger to be Puffinus cuneatus of Salvin.

Besides the above, Mr. Wilson had procured a specimen of another fine form (his Telespiza cantans) which had been captured in Laysan, whence T. Alavissima was subsequently brought by Palmer; and had shot in Maui a young example of a. bird, which he named at the time Himatione dolii, but which proved to be so distinct, when the adult was secured by Palmer, that Mr. Rothschild created for it the genus Palmeria. Chcetoptila angustipluma and Acrulocercus apicalis were not obtained by any of the explorers mentioned.

Mr. Perkins, as already stated, was fortunate enough to discover another member of the genus Drepanis ( $D$. funerea), and to procure many of the new species that Mr. Rothschild's collectors, Palmer and Munro, between them brought to light, namely, the marvellous Pseudonestor xanthophrys, Rhodacanthis palmeri, R. Alaviceps, Oreomyza newtoni, Chlorodrepanis wilsoni, Hemignathus lanaiensis, Heterorhynchus affinis, Phoornis palmeri, Acrulocercus bishopi, and Viridonia sagittirostris.

\footnotetext{
${ }^{1}$ Described and figured in the present work as $H$. olivaceus, in the belief that it was the species so named by Lafresnaye; but subsequently shewn by Mr. Rothschild to be distinct, and called by him H. witsoni. Since the publication of Part V. (where, under the heading of $H$. lucidus, this matter is mentioned) Lafresnaye's type, which for a time was misplaced in the Boston Museum, has been discovered there with the rest of his collection, and in December 1896 was kindly submitted to our inspexion by Professor Hyatt.
} 
The appended Table, shewing the Distribution in the principal Islands of the species of the Order Passeres, tells its own story ; but the fact must be emphasized that every one of them is peculiar to the group-that is to say, not found elsewhere. In addition to these (fifty-three in number), there is one peculiar species of Accipitres, two of Anseres, one of Limicolo, and apparently there were four of Rallida-two being now extinct,-making the whole number of peculiar species of Birds amount to sixty. Indeed, setting aside the sea-birds, there seem to be but two breeding species-the Short-eared Owl (Asio accipitrinus) and the Night-Heron (Nycticorax griseus) - which are also inhabitants of other lands, and these two have possibly the widest range of their respective Families. This remarkable amount of peculiarity well deserves the attention of all interested in the problems of Geographical Distribution, and especially of those who study that subject in the light it casts on the history of the globe. Those students must also be reminded, as already briefly stated by Prof. Newton, that of the resident land-forms of the Sandwich Islands there is only one genus, Chasiempis, which is allied to any that are characteristic of the Islands of the Pacific Ocean in general, though there are two, Acrulocercus and Chotoptila, not far removed from forms peculiar to the continent of Australia. These facts, combined with the absence of Parrots, Kingfishers, and Doves-all so characteristic of the South Sea Islands,-are very significant, and seem to indicate that the Hawaiian Archipelago should be no longer included in what most authors have called the "Australian Region."

It remains to be stated that, as before announced to the Subscribers of this work, Mr. Wilson made a second visit to the Islands in 1896, but no new species were then discovered. 


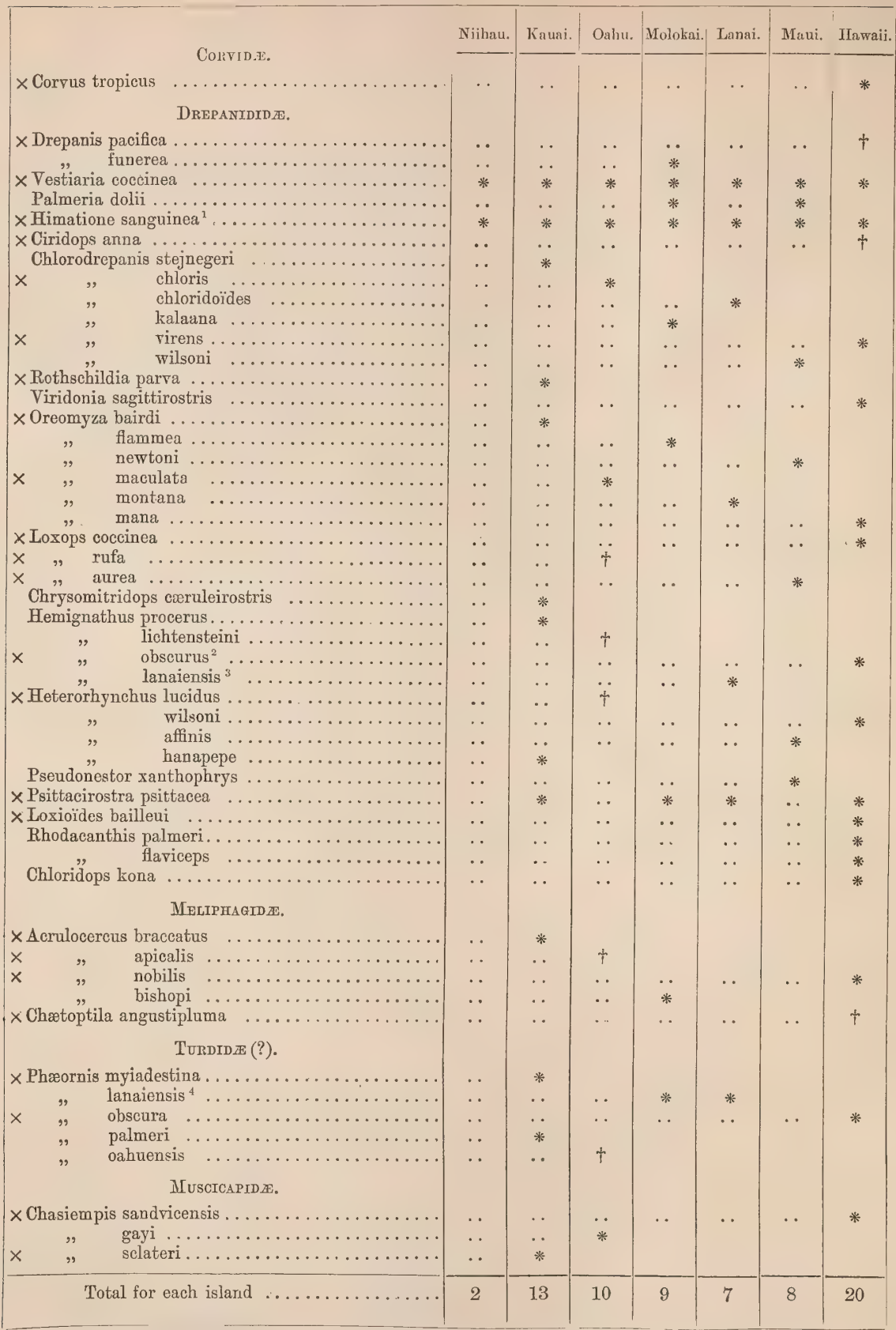

All the species above-named are peculiar to the group, i.e. not found clsewhere. A * indicates that the species inhabits the island whose name heads the column. A + shews that the species is believed to be extinct; a $\times$ that the species was known before Mr. Wilson's visit in 1887.

${ }^{1}$ See text for Himatione freethi, Telespiza cantans, and T. flavissima of Laysan.

${ }^{2}$ Mr. Dole, doubtless in error, adds Maui to the habitat.

$3 \mathrm{Mr}$. Rothschild states that he has strong presumptive evidence of the former occurrence of a species of Heterorhynchus on Lanai.

${ }^{4}$ A species which formerly abounded in Maui was probably identical with this. 


\section{SPECIES OF BIRDS.}

A. Obtained accidentally on the Sandwich Islands ; or found in the immediate neighbourhood, and especially on the Laysan group.

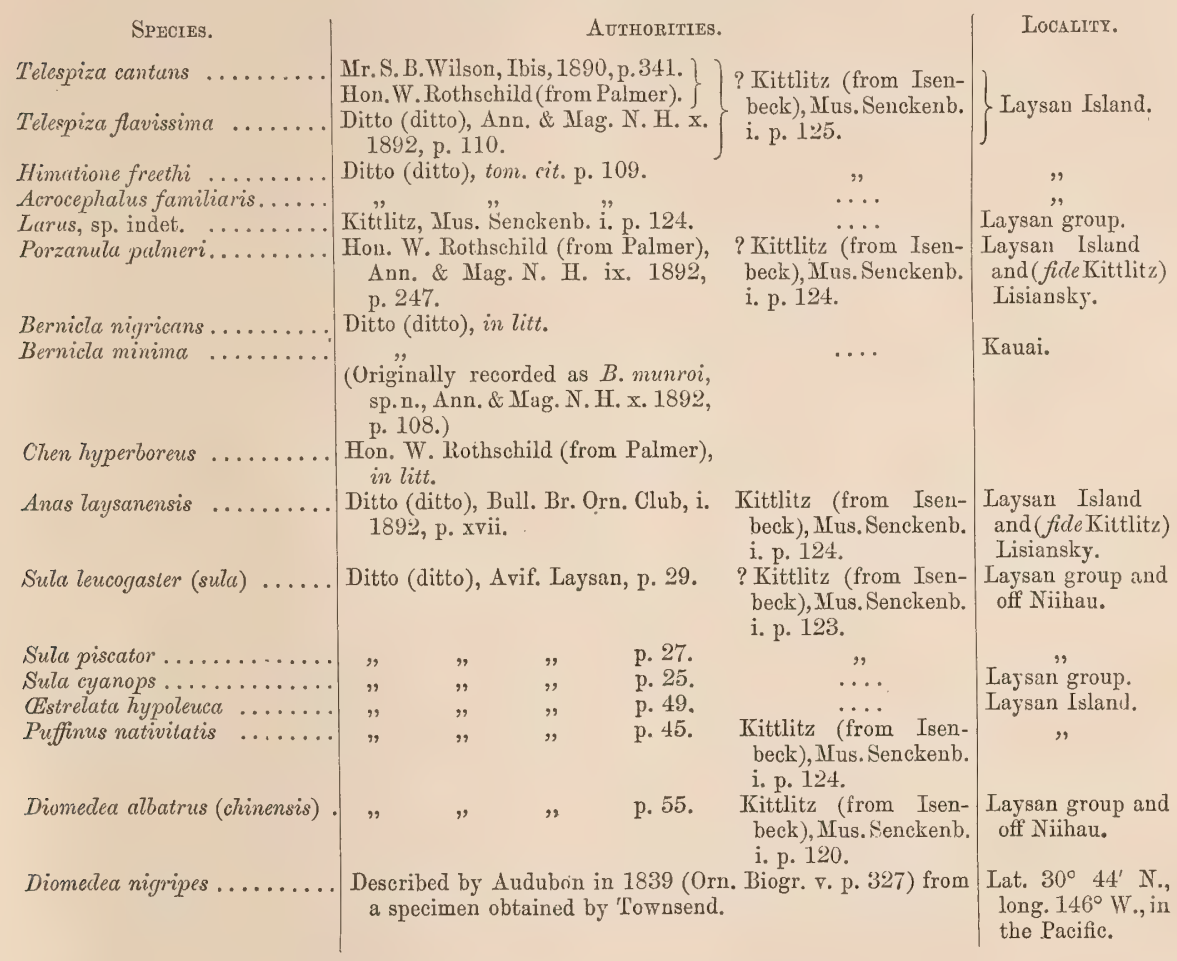

B. Recorded, but not yet corroborated.

Sterna bergii ........... Mr. Dole, Pr. Bost. Soc. N. H. 1869, p. 306.

| Sandwich Islands.

C. Apparently occurring, but of which the identity cannot be at present determined.

Charadrius "like C. hiaticula." Dr. Finsch, Ibis, 1880, p. 79.

Gallinago"like G. scolopacina."

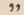

Maui, Sandwich Islands.

\section{Imported from other Countries.}

Passer domesticus.

Carpodacus frontalis.

Acridotheres tristis?

T'urtur chinensis.

Tame Pigeons.

Fowls, \&c., \&c. 



\section{ERRATA AND ADDENDA.}

AcrdLOCERcus Nobilis, p. $6,1.2$, add " under tail-coverts yellow."

Phжornis obscura, p. 1, 1. 14, add "Specimens were obtained by the 'Challenger' Expedition."

For Chrysomitridops cezruleorostris (on Plate) read "Chrysomitridops czreleirostris."

Psittactrostra Psittacea, p. 2, 1. 15, after "Verzeichniss" add " der Doublctten."

[The deduction is therefore erroneous.]

Acrolockrcus ApICALIs, p. 2, 9 lines from bottom : "The striated appearance..... noticeahle."

This should be transferred to A. BISHOPI. 




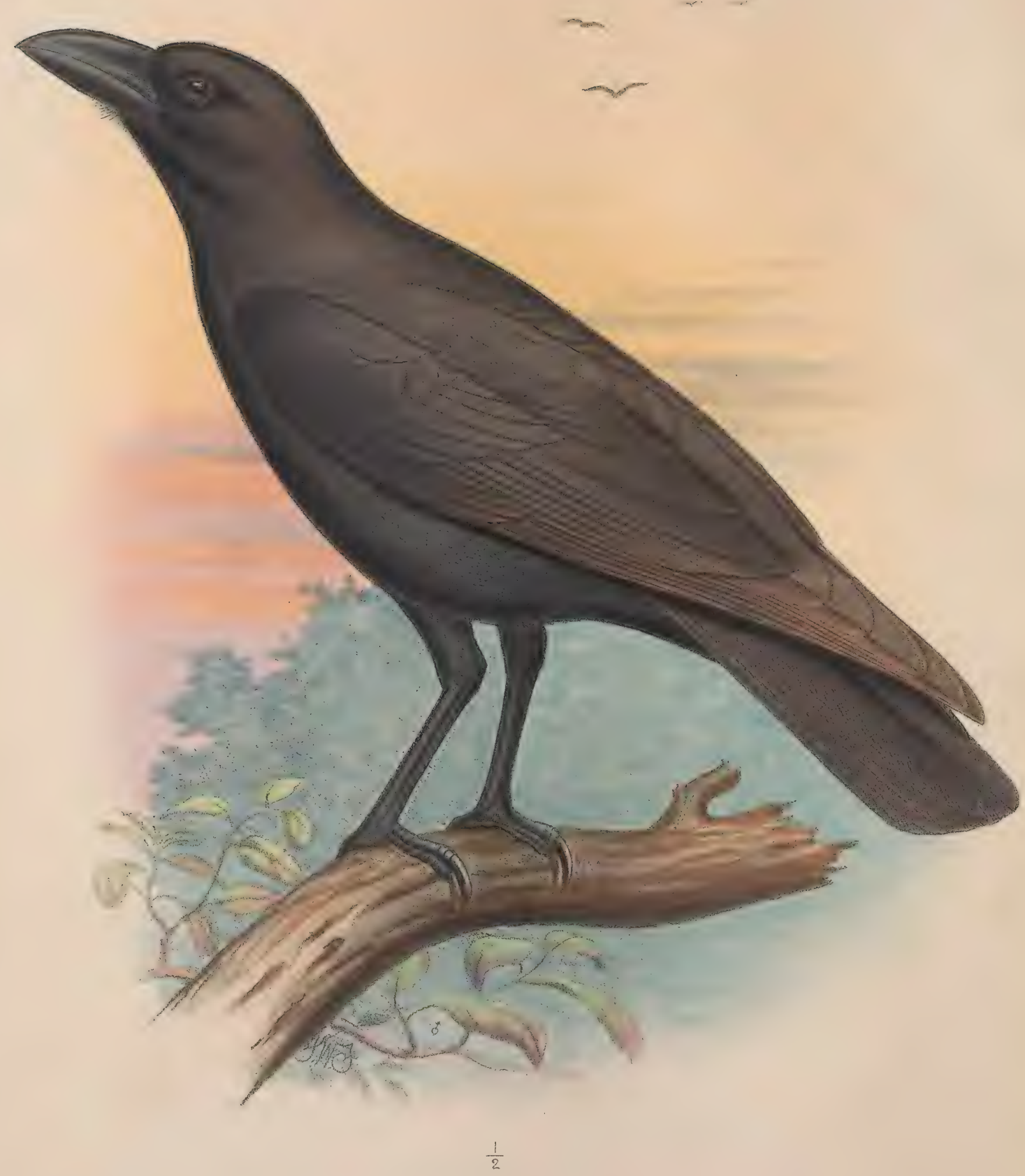

FW.Frohavis del etlith. 


\section{CORVUS TROPICUS.}

ALALA.

“Tropic Crow," Lath. Gen. Synops. i. p. 384 (1781).

"Raven," King, Voy. Pacif. Ocean, iii. pp. 119, 161 (1784).

Corvus tropicus, Gmelin, Syst. Nat. i. p. 372 (1788) ; Latham, Ind. Orn. i. p. 157 (1790); Donndorff, Orn. Beytr. i. p. 372 (1794) ; Shaw, Zool. vii. p. 355 (1809) ; Tiedemann, Anઘt. Naturgesch. Vög. ii. p. 432 (1814); Bloxam, Voy. 'Blonde,' p. 250 (1826) ; Hartlaub, Arch. f. Naturgesch. 1852, i. p. 133 ; G. R. Gray, Cat. B. Trop. Isl. p. 25 (1859).

? Cracticus ater, Vieill. N. Dict. d'Hist. Nat. v. p. 356 (1816).

Corvus hawaiiensis, Peale, U.S. Expl. Exped., Birds, p. 106, pl. xxviii.* (1848) ; Hartlaub, ut suprà, pp. 102, 133; Cassin, U.S. Expl. Exped., Mamm. \& Orn. p. 119, pl. vi.* (1858) ; G. R. Gray, Cat. B. Trop. Isl. p. 24 (1859) ; Dole, Proc. Bost. Soc. N. H. xii. p. 300 (1869) ; id. Hawaiian Alman. p. 48 (1879); Sclater, Ibis, 1871, pp. 359, 360; id. op. cit. 1879, p. 92 ; Sharpe, Cat. B. Br. Mus. iii. p. 13, note (1877).

Corvus (Physocorax) hawaiiensis et tropicus, G. R. Gray, Hand-l. B. ii. p. 14 (1870).

* Figurce notabiles.

THere can be no doubt that the "Ravens" mentioned by King in his account of Cook's last voyage as having been met with at Kakooa in Hawaii are to be referred to this bird, specimens of which must have reached England about that period, for Latham described his Tropic Crow in 1781 from an example brought from Hawaii in the collection of Sir Joseph Banks, which from the details appears to have been a pied specimen. Peale's Corvus hawairiensis is of course identical, since this is the only species in the island.

Bloxam noticed this species in his account of the voyage of the 'Blonde,' and Peale procured several examples during the United States Exploring Expedition; but as these were lost in the wreck of the 'Peacock,' the latter must be considered fortunate to have so readily obtained the loan of two others from Dr. J. K. Townsend, which were sent from Kaawaloa by Mr. Forbes, a missionary at Karakakoa Bay, and were afterwards deposited in the collection of the Philadelphia Academy. Cassin, however, while remarking upon the uniform cinereous tinge visible in Peale's examples, and upon their small dimensions, did not consider them to belong to Corvus tropicus of Gmelin, which is founded on Latham's Tropic Crow, but surmised that they might be the $C$. australis of the former author.

This interesting bird; well known to the natives by its name of Alala-the strict signification of which is the cry made by any young animal-is fairly common in the 
district of Kona on Hawaii, where it ranges from 1100 to 6000 feet and probably higher. As Peale observes, in his excellent account, "They frequent the woody district of the interior, seldom, if ever, visiting the coast."

In the ohia forests, a few miles above Kaawaloa (celebrated as being the spot where Captain Cook fell), I found this bird numerous in the month of June, by which time the brood had already left the nest. A friend, extremely clever at imitating sounds, was able, by carefully concealing himself and then mimicking the cry of the young Alala, to collect round him in a short time many of the old birds; he had found a nest at the end of April, which he informed me was a large loosely-fashioned structure of dead sticks, resembling that of a Pigeon, placed in a Pandanus. The Alala seems to feed principally on the fruit of the Iéié (Freycinetia arborea), but no doubt, when occasion serves, takes the young of the various forest birds. Peale remarks in this connection :- "We noticed that the smaller species of birds were kept in great terror by the presence of the Alala; from this we infer that, like other crows, they will rob nests of their eggs, and when an opportunity offers eat the old birds also: such was their character given to us by the natives."

I was assured by the islanders that they collect in large numbers and feed on the sheep occasionally found dead from natural causes or killed by wild dogs, which animals are said only to suck the blood, leaving the carcass otherwise intact.

The Alala is a noisy species, and Peale remarks that "its voice closely resembles that of the North-American Fish-Crow, C. ossifragus." It is far from wild; and I secured a specimen by a shot from my 28-bore when on the back of a steady-going mule, as we were riding through the forests. It seems to be restricted to two districts of Hawaii-Kona and Kau; personally I only observed it in the former, but was assured, on the authority of a friend who resided in Kau, of its presence there as well. At Puuanahulu - a veritable oasis surrounded by lava-flows-I shot several examples; but this spot, though many miles distant from Kaawaloa, is still in the district of Kona.

Description.-Adult male. Entire plumage dusky brown, almost black on the head and neck, somewhat lighter on the tail and wings, the quills of the latter being of a rusty brown, with the shafts of the feathers white. Irides dark hazel; bill bluish black, lighter at the tip; nostrils covered with glossy black bristle-like feathers; feet black, yellowish underneath.

Dimensions.-Adult male. Total length 19 inches, wing from carpal joint 13.50 , culmen $2 \cdot 50$, tarsus $2 \cdot 50$, tail $8 \cdot 50$.

The total length of an adult female is 17.25 inches, while the other parts are proportionately smaller than in the male. In plumage the sexes do not differ.

Immature specimens have the whole plumage of a more rusty shade, and the primaries light ochreous. 



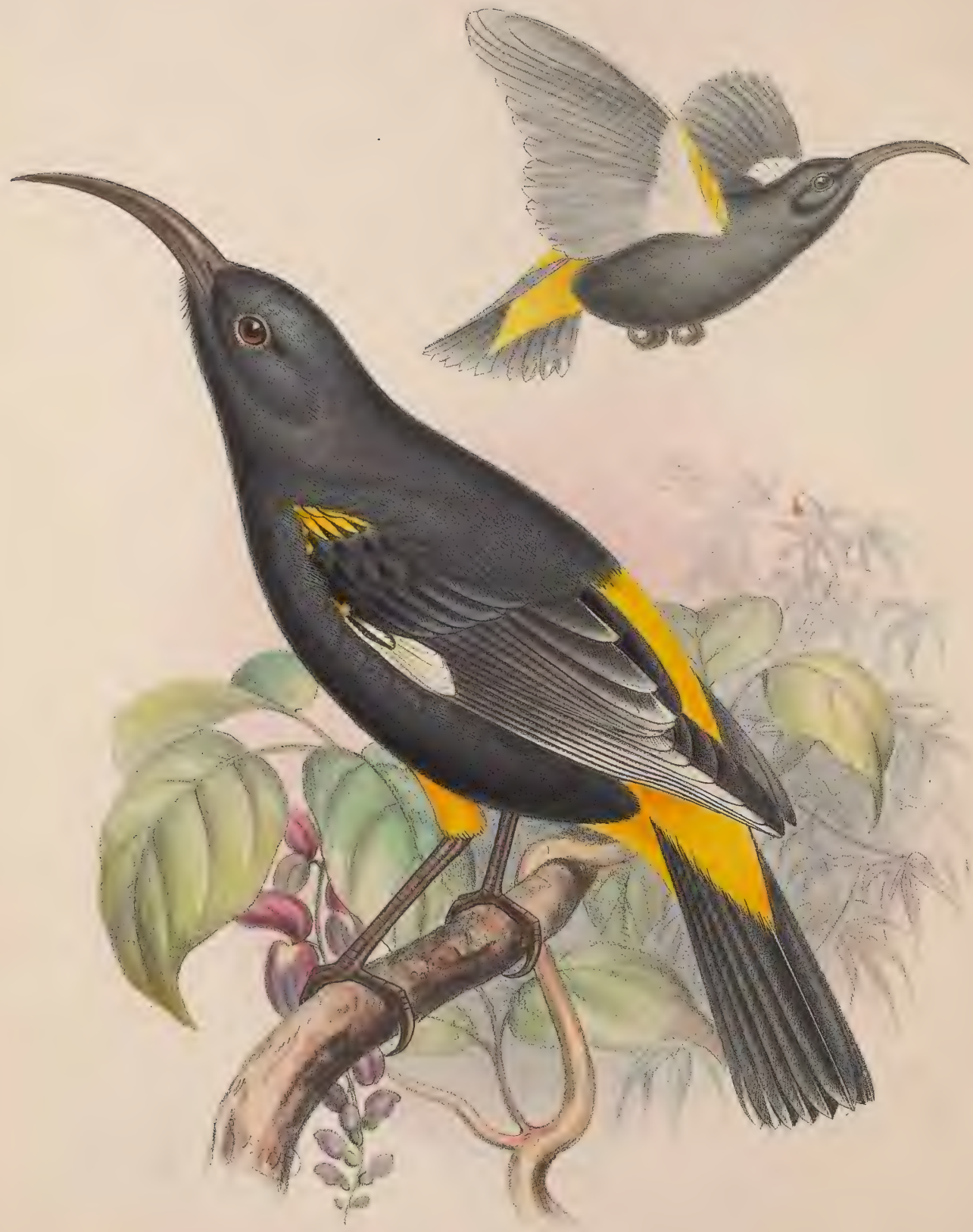




\title{
DREPANIS PACIFICA.
}

\author{
MAMO.
}

"Great Hook-billed Creeper," Latham, Gen. Synops. i. p. 703 (1782); id. Suppl. p. 126 (1787).

"? Hoohoo," King, Voy. Pacif. Ocean, iii. p. 119, partim (1784).

Certhia pacifica, Gmelin, Syst. Nat. i. p. 470 (1788); Latham, Ind. Orn. i. p. 281 (1790) ; Donndorff, Orn. Beytr. i. p. 621 (1794); Shaw, Zool. viii. p. 227 (1812) ; Tiedemann, Anat. Naturgesch. Vög. iv. p. 431 (1814) ; Peale, U.S. Expl. Exped., Birds, p. 149 (1848); Hartlaub, Arch. f. Naturgesch. 1852, i. p. 109; Cassin, U.S. Expl. Exped., Mamm. \& Orn. p. 171 (1858).

"Le Hoho," Vieillot, Ois. Dorés, ii, p. 124, pl. lxiii.* (1802) ; Lesson, Compl. Buffon, ix. p. 156 (1837).

"Grimpereau à long bec des îles Sandwich," partim, Virey (Sonnini), Hist. Nat. Buffon, Ois. xvii. p. $97(1804,5)$.

"Le Mérops jaunoir," Levaillant, Hist. des Promérops et des Guêpiers, p. 45, pl. xix.* (1807).

Melithreptus pacificus, Vieillot, N. Dict. d'Hist. Nat. xiv. p. 323 (1817); id. Encycl. Méth., Ornithol. p. 602 (1823) ; Cuvier, Règne Anim. éd. 2, i. p. 433 (1829); J. E. Gray (Griffith), Anim. Kingd. vii. p. 358 (1829).

Drepanis pacifica, Temminck, Man. d’Orn. i. p. Ixxxvi (1820) ; G. R. Gray, Gen. B. i. p. 96 (1847); id. Cat. B. Trop. Isl. p. 7 (1859) ; id. Hand-list, i. p. 113 (1869) ["Friendly Islands"!]; Bonaparte, Consp. Av. i. p. 403 (1850) ; Hartlaub, Arch. f. Naturgesch. 1852, i. p. 131 ; Reichenbach, Handb. sp. Orn. p. 253, pl. 611. figs. 3828, $3829 *$ (1853) ; Dole, Proc. Bost. Soc. N: H. xii. p. 297 (1869) ; id. Hawaiian Alman. 1879, p. 45 ; Sclater, Ibis, 1871, p. 368; id. op. cit. 1879, p. 92 ; Sundevall, Tentam. p. 48 (1872); Von Pelzeln, Journ. f. Orn. 1872, p. 26 ; id. Ibis, 1873, p. 21 ; Sharpe, Cat. B. Br. Mus. x. p. 5 (1885); S. B. Wilson, Ibis, 1890, p. 178.

Vestiaria hoho, Lesson, Rev. Zool. 1840, p. 269.

* Figurae notabiles.

'THIs species, the Great Hook-billed Creeper of Latham, was first described in the 'General Synopsis' from two examples in the Leverian Museum, said to be male and female, which are now, according to Herr von Pelzeln, in the Imperial Museum at Vienna. In the main text of Latham's work the bird is erroneously stated to inhabit the "Friendly Islands, in the South Seas," though this slip is rectified in the "Supplement,' where it is said to be "common at Owhyhee and called by the natives Hoohoo." Vieillot, nevertheless, in the 'Oiseaux Dorés' makes a fresh blunder by giving the habitat as 'Owhihee, Iles des Amis," and G. R. Gray in his 'Hand-list' repeats the mistake as far as the islands are concerned. The specimens thus brought to notice were no doubt derived from the spoils of the early explorers of the Pacific, and King mentions the "Hoohoo" in his account of Cook's last voyage; but as this name appears 
to have been used for Acmulocerous nobilis also, the yellow feathers of which were applied to the same purposes of cloak manufacture, it cannot be confidently averred which of the two was intended by the author; yet, if it be true that Drepanis was common at Hawaii at that period, the voyagers can hardly have failed to meet with it there during their seven weeks' stay.

The first scientific appellation was that of Certhia pacifica, bestowed by Gmelin in 1788; while it is somewhat remarkable that no figure of so fine a bird should have been published before the time of Vieillot, who took his illustration from one of the examples described by Latham, a drawing of which, by Sydenham Edwards, was lent to him by Parkinson, then owner of the Leverian Museum. An earlier drawing by Ellis (No. 27) is, however, still to be found at the British Museum inscribed "W. W. Ellis vivum delin ${ }^{t}$ et pinx $^{t}$ 1779." Temminck, thirty-eight years after the date of the 'General Synopsis,' separated the present species from Certhia under the new generic name of Drepanis, which is now generally recognized.

Peale, in his account of the ornithology of the.U.S. Exploring Expedition, asserts that it was found at Hanalei in Kauai, and mentions the yellow feathers and their use : but Cassin, in his later edition of the same work, considers that he confounded it with Acrulocercus braccatus; and this is probably the case, as there are no tufts on the thighs in Drepanis, nor have we any other proof of its occurrence on the island. of Kauai. Bloxam gives us no information in his account of the voyage of the 'Blonde,' though the bird does not appear, as will be seen below, to have been extinct in 1859. A single example was purchased by 'Temminck at the dispersal of the Bullock Museum, when it was described in the catalogue of the 17th day of the sale as "Great Hook-billed Creeper, C. pacifica"; while another is stated by Herr von Pelzeln (Ibis, 1873, p. 21) to have been in Levaillant's cabinet.

Of this extremely rare and apparently extinct species I obtained two specimens from a collection which was formed by the late Mr. Mills ${ }^{1}$ of Hilo in Hawaii, some thirty years or more ago. The fact of its native name "Mamo" being the same as that used for the war-cloaks mentioned below seems to imply that they received it from this bird, and that they were originally chiefly wrought of the beautiful golden yellow feathers from its back and vent, which are much deeper in colour, as they are larger and longer, than the axillary tufts of Acrulocercus nobilis.

I could obtain no certain information of examples having been observed since those in the Mills collection were procured-about 1859, though while staying at Olaa in the district of Puna in Hawaii, where Mr. Mills secured them, I was assured by the natives that the bird still existed, and at the time of my visit (October) had, together with the $\mathrm{O}-\mathrm{O}$, migrated to the mountains, which is barely possible. I saw

\footnotetext{
3 To the late Mr. J. Mills of Hilo, Hawaii, science is indebted for the preservation not only of several specimens of Drepanis pacifica, but also of several more species now extinct. Mr. Mills died, I regret to say, some two months after I landed on the Islands. He was an ardent naturalist, and would shut up his store and disappear in the forest for weeks together, accompanied only by natives who aided him in collecting specimens. Mr. Mrills was also an accomplished artist, some of his paintings possessing great merit.
} 
several fine wreaths, "leis," composed of its plumes in the possession of the Hon. C. R. Bishop, while since my return I have carefully examined the feather-robes in the Ethnological Collection in the British Museum, and find that in the three large warcloaks it contains, chiefly made of the yellow feathers of Acrulocercus nobilis, are interspersed here and there, usually in diamond-shaped patterns, the deeper yellow feathers of the present species.

One cape only in this collection is made entirely of the plumage of the Mamo, and in that the upper margin, about one inch in width, is formed of its black feathers; the dimensions are as follows:-

$$
\begin{array}{cc}
\text { feet } & \text { in. } \\
3 & 6 \text { following lower margin. } \\
1 & \frac{1}{2} \text { at middle. } \\
0 & 9 \text { following top margin. }
\end{array}
$$

Another cape, in which the plumes of this bird occur, may also be worth describing :-It has the ground-colour red (Vestiaria coccinea), the upper edge made of the black and gold feathers of Drepanis pacifica and red feathers of V. coccinea intermingled; at the bottom is a broad band of the yellow feathers of Acrulocercus nobilis, while on the red ground of the cape are three angular patches of the same. Among the wreaths, "leis," in the collection, there is but one in which the golden plumage of Drepanis occurs. This "lei" is 15 inches in length, and the yellow feathers, of which there are six bunches, each one inch in length, are arranged alternately with bunches of red feathers of $V$. coccinea. The length and beauty of the former are very striking in this wreath, and I have only seen one other which perhaps surpasses it in beauty; this is made entirely of Mamo feathers, and has been quite recently brought to this country by Mr. Herbert Purvis-the value it is impossible to estimate, nor can its beauty, at least in the eyes of an Hawaiian, be outshone.

Sir Walter Buller, in his 'History of the Birds of New Zealand,' 2nd ed. p. 104, tells us of a gorgeous feather-robe which was largely ornamented with the canaryyellow feathers of the wing of the Hihi (Pogonornis cincta), and goes on to say: "one can only compare it in imagination with that gorgeous coronation-robe of costly yellow plumes worn by the kings and queens of Hawaii, of which mention is made by the early writers on Polynesia." As Sir Walter Buller speaks of the New Zealand featherrobe as "largely ornamented," we may conclude that the feathers of other species were intermingled with those of the Hihi, and on this account I think it could not have equalled the unbroken sheet of gold presented by the war-cloak of Kamehameha I. described in my article on Acrulocercus nobilis. The yellow feathers of Pogonornis are, however, of a richer tint than those of Acrulocercus, and more nearly approach those of Drepanis.

One of the specimens which I brought home has been beautifully remounted by Mr. Cullingford, of Durham, and is now in the Museum of the University of Camb̌ridge, 
the second is in the fine collection of the Hon. Walter Rothschild. I am not aware of the existence of other examples in this country.

Description.-Glossy black, with the exception of the lower part of the body, the rump, the tail-coverts both above and below, the feathers of the tibia and those of the anterior margin of the wing, which are of a fine crocus-yellow; the larger primary wing-coverts and under wing-coverts white, the former mottled with blackish grey, and the latter tinged with yellow. Remiges brownish black, tipped with dull white on the external vane of the five outer primaries, and both vanes of the next four, as well as those proceeding from the olecranon. Four middle rectrices glossy black, the rest more or less brown, and showing a patch of dull white near the tip, which though indistinct on the inner feathers becomes very distinct on the extreme pair. Bill and legs apparently deep brown.

Dimensions.-Total length about 8 inches, wing from the bend $4 \cdot 12$, tail $2 \cdot 5$, bill from forehead along the culmen $1 \cdot 75$, from gape in a straight line $1 \cdot 5$, tarsus $1 \cdot 31$, middle toe without claw $\cdot 56$, hind toe $\cdot 43$. 



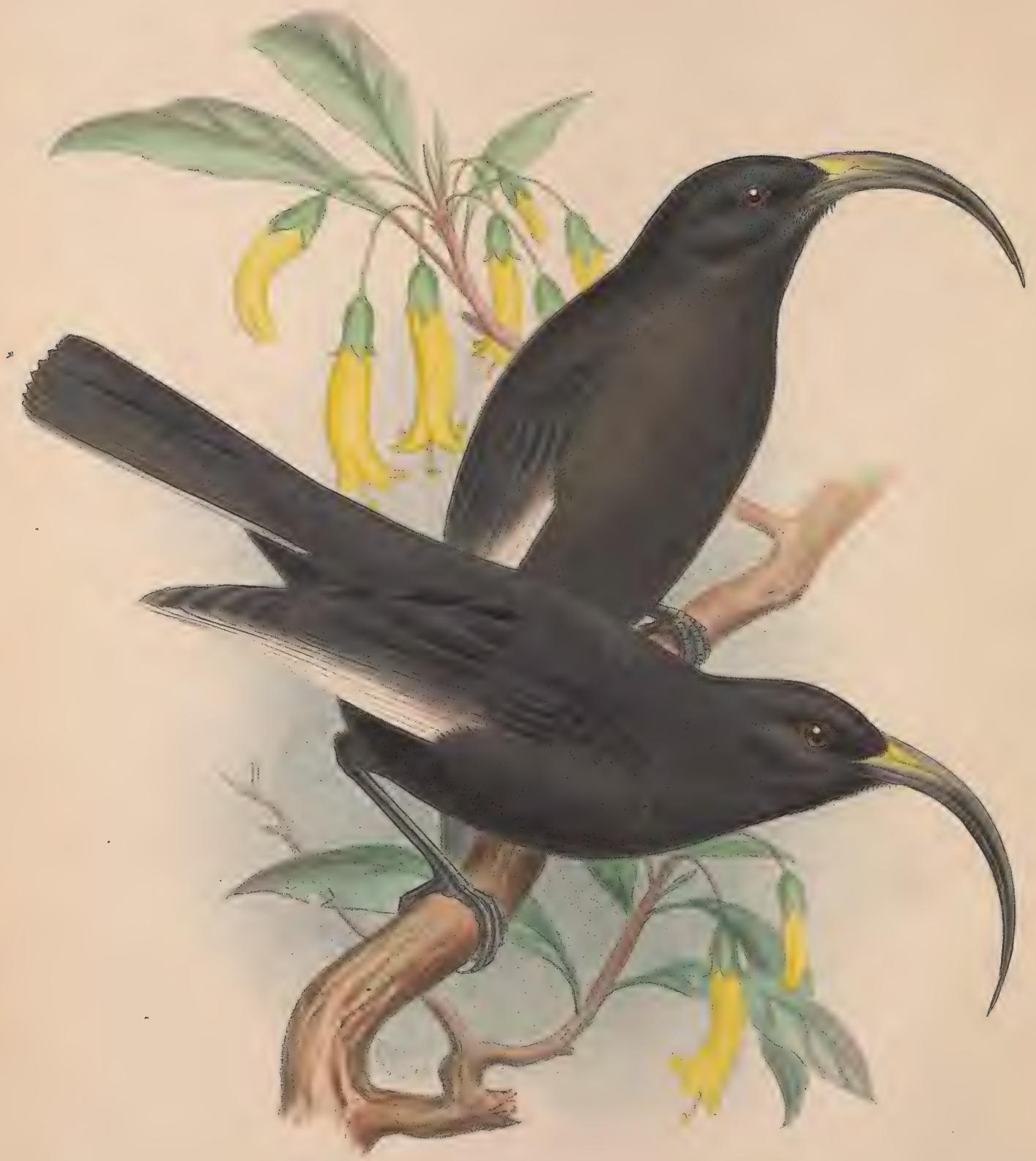

F.W.Frohawk del.et lith. 


\section{DREPANIS FUNEREA.}

Drepanis funerea, A. Newton, Proc. Zool. Soc. 1893, p. 690.

To the Joint Committee appointed by the Royal Society and by the British Association for the Advancement of Science to carry on a Zoological Exploration of the Sandwich Islands, my sincere thanks are due for the privilege of including in this work, and of figuring for the first time, the remarkable and in many respects very interesting new species of Drepanis (as the genus is now limited) discovered by their agent, Mr. Robert C. L. Perkins, B.A., of Jesus College in the University of Oxford, who is to be congratulated on this ornithological reward of his arduous labours - a reward that was wholly unexpected, since the island of Molokai, on which, by dint of perseverance, he found it, had been already and very recently ransacked by a collector who wanted neither skill nor experience. I have only to add my regrets to those expressed by the describer of Drepanis funerea that Mr. Perkins's modesty has hindered him from introducing his discovery to the scientific world.

Of this species, which is somewhat smaller than D. pacifica, Mr. Perkins obtained several examples in Molokai, at an altitude of about 5000 feet, in June 1893. He marks the long-billed specimens as males, the short-billed as females.

The following is from Prof. Newton's paper (loc. cit.) describing the species:-

"Diagn.-Atra, remigibus manualibus externè grisei-limbatis, rostro valdè decurvato, maxillâ mandibulam multò transeunte.

"Long. tot. 8 ; alæ 4 ; caud. 2.75 ; rostri culminis 2.5 ; tarsi 1.25 uncc.

" $\mathrm{Hab}$. in montibus sylvestribus insulæ Molokai.

"The sexes are outwardly alike. Mr. Perkins states that the nasal opercula and the base of the bill between the nostrils are yellow, especially in the young; the irides 'pale yellowish-brown.'

"It would be easy to point out characters that in the eyes of some writers would justify the foundation of a new genus for this bird. At first sight the configuration of its bill naturally suggests the genus Hemignathus; but closer inspection shows that in its breadth and height at the base it wholly agrees with Drepanis, as restricted by modern authors, only differing therefrom in its exaggerated maxilla. Some inequality in the length of the mandibles is, however, exhibited by $D$. pacifica, and the examples of the new species sent by Mr. Perkins show no little variability in this respect. For the rest it is distinct enough, its almost lustreless black plumage not being relieved by any 
yellow feathers, though the patch of that colour at the base of the maxilla must be a conspicuous feature in life."

He adds that "Its sombre plumage and the sad fate that too probably awaits the species" induce him to propose the trivial name that he has bestowed upon it.

Since the article on Drepanis pacifica was written, Mr. Rothschild's collectors have obtained an example in Hawaii, showing that the species was not entirely extinct at the time of my visit. 



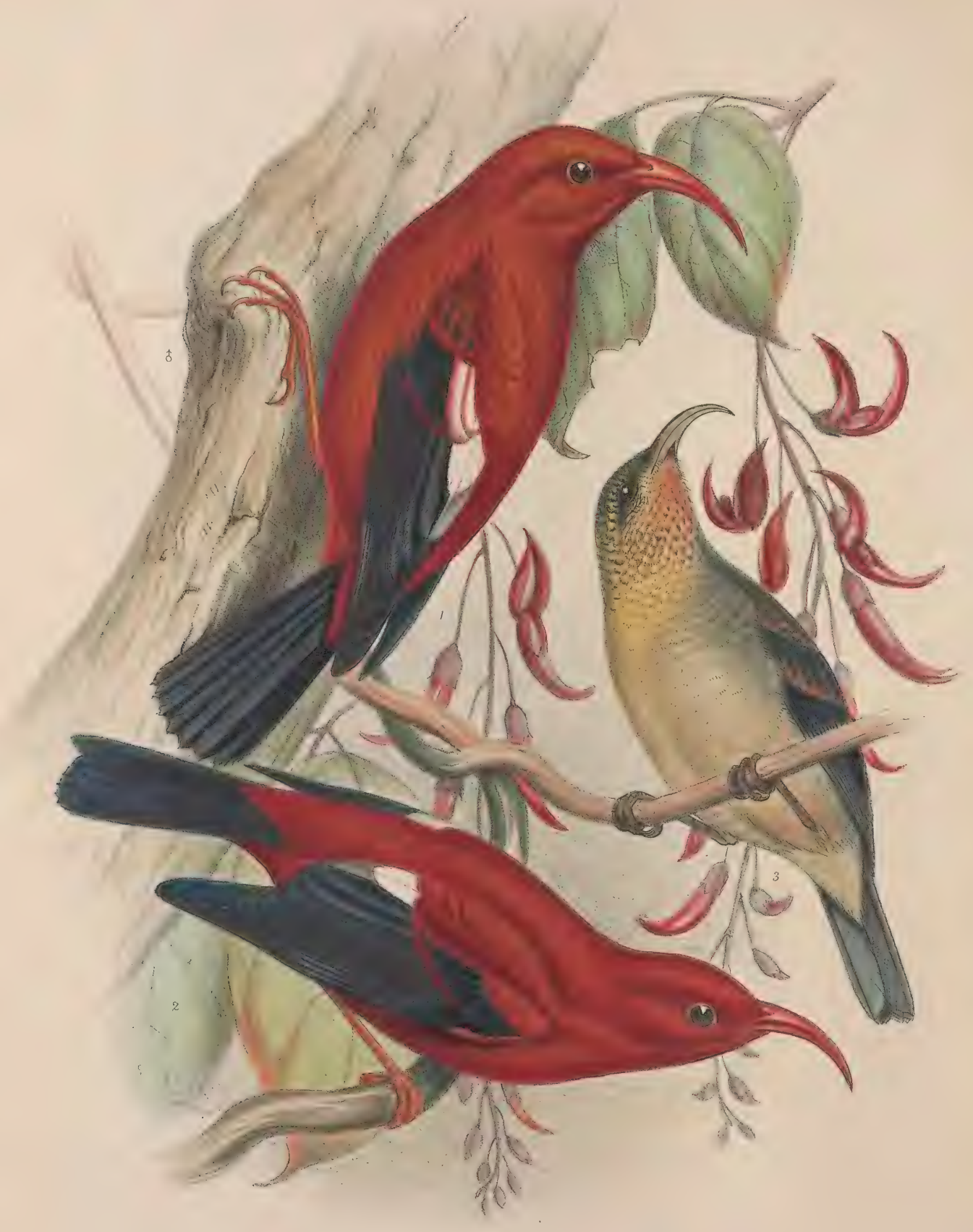





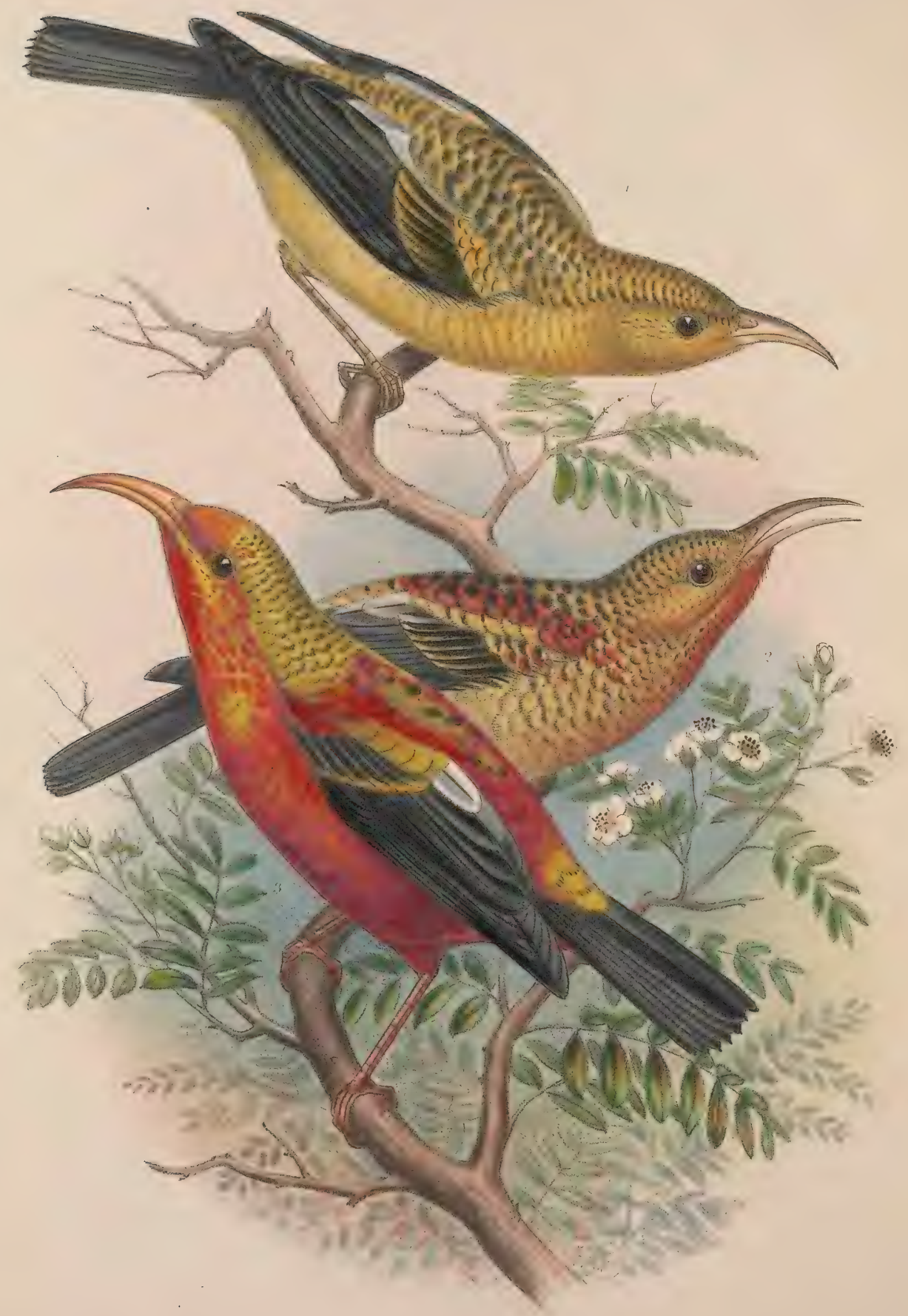





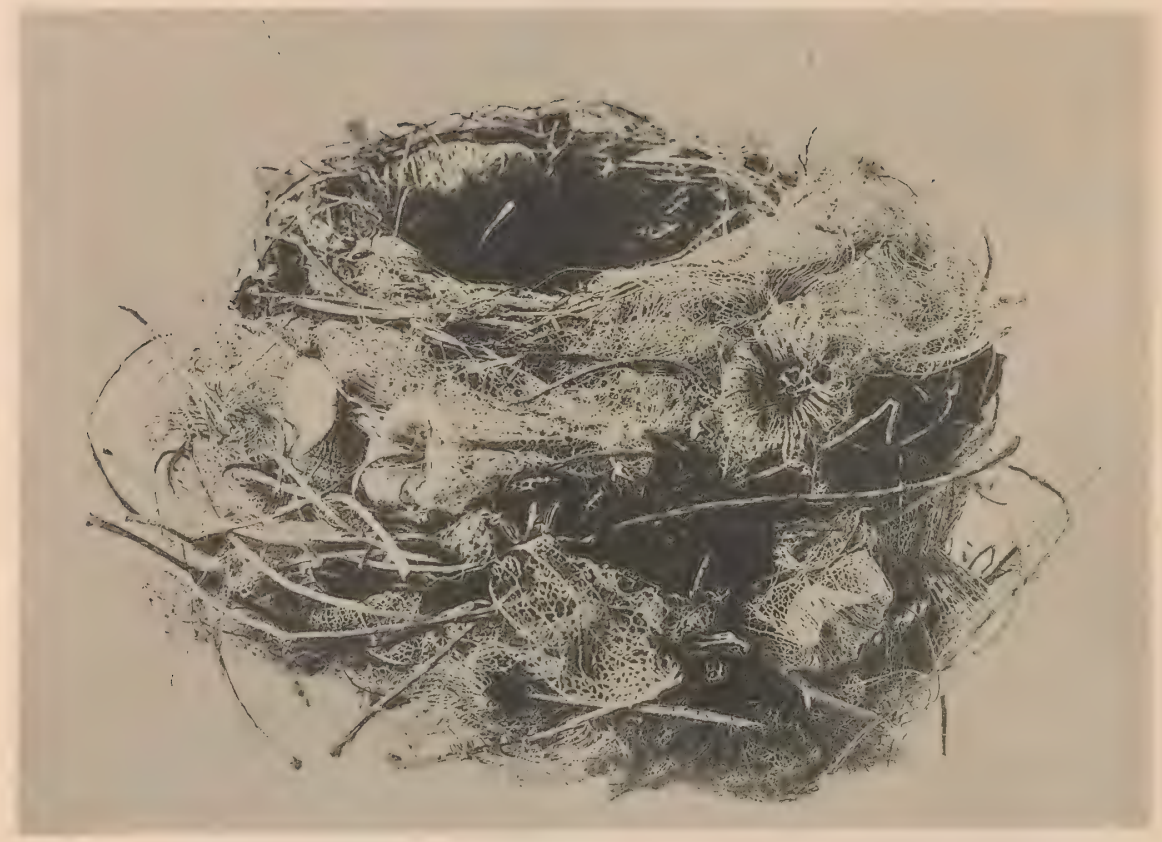

VESTIARIA COCCINEA. 


\title{
VESTIARIA COCCINEA.
}

\author{
OLOKELE ${ }^{1}$ OR IIWI.
}

TMNATURE: OLOKELE POPOLO, OLOKELE HOKII, IIWI POPOLO, IIWI POLENA.

Certhia coccinea, G. Forster, Götting. Mag. Wissensch. i. 6, p. 346 ("1780") [1781 ?]; Gmelin, Syst. Nat. i. p. 470 (1788); Blumenbach, Naturgesch. ed.2, p. 190 (1782); id. Abbild. naturhist. Gegenst. Heft ii. tab. $16 *$ (1797) ; Shaw, Nat. Miscell. pl. $75 *$ (1791) ; Donndorff, Handb. Thiergesch. p. 251 (1793); id. Orn. Beytr. i. p. 621 (1794); Tiedemann, Anat. Naturgesch. Vög. ii. p. 430 (1814).

"Hook-billed Red Creeper," Latham, Gen. Synops, i. p. 704 (1782); id. Suppl. p. 127 (1787).

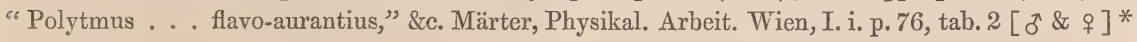
(1788).

Mellisuga coccinea, Merrem, Beytr. besond. Gesch. Vögel, Heft i. p. 16, tab. iv.* (1784).

Merops sp.?, Cook, [Last] Voy. Pacif. Ocean, ii. p. 207 (1784).

"Scarlet bird," id. $t . c$. p. 227 (1784).

"Eee-eve," King, Voy. Pacif; Ocean, iii. p. 119 (1784).

Certhia vestiaria, Latham, Ind. Orn. i. p. 282 (1790); Shaw, Zool. viii. p. 229 (1812).

"L'Héoro-taire," Vieillot, Ois. Dorés, ii. p. 109, pl. lii.* (1802).

"Le Soui-manga Cardinal à queue et ailes noires," Virey (Sonnini), Hist. Nat. Buffon, Ois. xvii. p. $90(1804-5)$.

Nectarinia coccinea, Tiedemann, ut suprò, p. 431 (1814); Bloxam, Voy. 'Blonde,' p. 247 (1826), "Hehivi."

Melithreptus vestiarius, Vieillot, N. Dict. d’Hist. Nat. xiv. p. 322 (1817) ; id. Encycl. Méth., Ornithol. p. 601 (1823) ; id. Galérie, pl. 181* (1825); Lesson, Tr. d’Orn. p. 300 (1831).

Drepanis vestiaria, Temminck, Man. d’Orn. i. p. lxxxvi (1820); Hartlaub, Syst. Verz. Mus. [Bremen], p. 16 (1844) [ex "Otaheite"!].

"L'ei-evi," Lesson, Compl. Buffon, ix. p. 155 (1837).

Vestiaria evi, id. Rev. Zool. 1840, p. 268.

"Le vestiaire," Léchlancher, t. c. p. 322.

Drepanis coccinea, G. R. Gray, Gen. B. i. p. 96, partim, pl. 33. fig. I* (1847); Bonaparte, Consp. Av. i. p. 404 (1850); Cabanis, Mus. Hein. i. p. 99 (1850-51) ; Hartlaub, Arch. f. Naturgesch. 1852, i. p. 131 ; id. Journ.f. Orn. 1854, p. 170; Lichtenstein, Nomencl. p. 55 (1854); Cassin, U.S. Expl. Exped., Mamm. \& Orn. p. 177 (1858) ; Dole, Proc. Bost. Soc. N. H. xii. p. 297 (1869) ; id. Hawaiian Alman. 1879, p. 44; Sclater, Ibis, 1871, p. 360 ; id. Proc. Zool. Soc. 1878, p. 347 ; Sundevall, Tentam. p. 48 (1872) ; Von Pelzeln, Journ. f. Orn. 1872, p. 26; Finsch, Ibis, 1880, p. 79.

Melithreptes vestiaria, Peale, U.S. Expl. Exped., Birds, p. 152 (1848).

Vestiaria coccinea, Reichenbach, Handb. sp. Orn. p. 254 (1853), tab. 562. figg. 3820-3832*; Sharpe, Cat. B. Br. Mus. x. p. 6 (1885); Scott Wilson, Ibis, 1890, p. 181.

1 The only name by which it is known on Kauai, as I am informed by Mr. Francis Gay. 
Drepanis (Vestiaria) coccinea, G. R. Gray, Cat. B. Trop. Isl. p. 8, partim (18559); id. Hand-list, i. p. 113 (1869).

"rosea, Dole, Hawaiian Alman. 1879, p. 44.

Loxops rosea, Sharpe, Cat. B, Br. Mus. x. p. 509 (1885).

(In the above list of references, obrious misprints have been disregarded.)

* Figurce notabiles.

THIS species, like many others from the Sandwich Islands, was first obtained by Cook and his fellow-voyagers; but, unlike them, did not come into Latham's hands before being made known elsewhere. The fortunate person in this case was Georg Forster, at the time Professor of Natural History at Cassel, who, with his father, had accompanied the great navigator on a former voyage, and naturally took great interest in the further results of his explorations; while he was also, possibly, not averse from stealing a march on other competitors, which was rendered possible by Barthold Lohman ${ }^{1}$, a man from the same town, who had sailed with Cook's last expedition, and immediately on its return brought Forster four examples of the present species, a description of which he promptly published in the Göttingen Magazine for 1780 , under the title of Certhia coccinea. Latham, however, was not far behind, as in 1782 he named it the "Hook-billed Red Creeper"-no doubt in ignorance of having been forestalled-while for the first figures of male and female we are indebted to Märter, who was quickly succeeded by Merrem and later by Blumenbach.

It is not a matter of surprise that many naturalists should have hastened to describe and figure so remarkable and brilliant a bird directly it became known in civilized countries, while their independent action had the effect, as will be seen above, of complicating the synonymy; but though it has been included in a vast number of works, we hear nothing absolutely fresh until the time of Peale, who, during the United States Exploring Expedition in the 'Vincennes' and 'Peacock,' found it not at all uncommon on most of the Hawaiian group of islands, and mentions, as former authors had done, the use of its feathers for capes and robes of chiefs, and especially for the ornamental figures thereon; noticing also its habit of feeding on the honey of the gigantic lobelias. Cassin, in his account of the same expedition, merely quotes from Peale with a summary of the information he gives, and other writers have added little or nothing to our knowledge of the bird's habits, though many more examples must have been received by various museums and private collections, in which while by no means uncommon, they are yet more plentiful than_any other of the Sandwich-Island species. The generic name of Certhia being discarded as inapplicable, many substitutes have been proposed; but the majority of writers on the subject

\footnotetext{
1 This was probably the man spoken of by the anonymous author of the Journal of Captain Cook's last voyage, published in 1781 (pp. 197-208), under the name of Bartholomew Lorimer or Loreman, who in an extraordinary way was nearly lost on Christmas Island.
} 
have accepted Fleming's Vestiaria, taken from the specific name applied by Latham, and derived from the use of the feathers in forming the ornamental garments.

This beautiful species, generally distributed throughout the entire Sandwich archipelago, is by far the most conspicuous of its birds, on account of the gorgeous scarlet of the plumage, which is greatly heightened in brilliancy by contrast with the deep black of the wings and tail. It is especially well known to every Hawaiian, less from the attractiveness of its colours than from the fact that its breast-feathers were largely used in the fabrication of the famous feather-robes ${ }^{1}$ of ancient times-worn by the priesthood and chiefs alone; and thus its various names occur in many an ancient tale of chivalry, and in the "mélés" or songs, which every native loves so well to chant.

The immature birds are not so familiar to the islanders as the adults and are often regarded by them as belonging to a distinct species, called in the Hawaiian tongue "Iiwi Popolo" or "Iiwi Polena,"- an error which Judge Dole shares in his wellknown "Catalogue of Hawaiian Birds," where he describes a specimen in the earlier state of plumage under the name of Drepanis rosea; nor is it a matter of astonishment that he has gone astray, seeing that the spotted yellowish plumage of the young shown in the upper figure of the second Plate is so very unlike that of the older bird.

The call-note of the "Iiwi" is peculiar, and is very powerful for so small a songster -ta-weet, ta-weet, ta-wee-ah, its flute-like clearness being unsurpassed by that of any other Sandwich-Island species. The bird has, in addition, a somewhat sweet and plaintive song, which I heard on a few occasions, usually soon after sunrise; the note first mentioned is, however, by far the most characteristic, and is that most frequently heard. I regret to say that I did not succeed in obtaining the eggs, but I found a nest about which there appears to be little doubt. Perhaps it will be well to quote from my notes made at the time:-

"There are a number of stunted ohia trees (Metrosideros) growing right among" the clinker-beds of a comparatively recent lava-flow, which is as yet destitute of any herbaceous vegetation, save for a few ferns growing here and there in the crevices of

\footnotetext{
${ }^{1}$ In the ethnological collection of the British MIuseum are three large mantles, two of which are mainly composed of the red feathers of the Iiwi and the yellow feathers of the 0-O (Acrulocercus nobitis), while the third, of which the bulk is made of the black tail-feathers of the domestic cock, has a narrow margin of the plumage of the two above-named species interwoven in an angular pattern; these mantles are each about 5 feet long and 8 feet across the bottom. There is a fourth, somewhat shorter, though of the same wiath, made likewise of red and yellow feathers; this is in by far the best state of preservation, the colours being of nearly as bright a tint as in freshly-killed birds. Besides these robes there are in the collection several "leis" or feather-wreaths, some fabricated entirely of the red feathers of the present species, others of red, green, yellow, and black feathers arranged in rings in varying order, which are accompanied by three gigantic masks formerly worn by the priesthood at their ceremonies, and also, I believe, by chiefs in time of war. These truly monstrous-looking objects consist of a framework of fibre, covered entirely with the red feathers of the Iiwi; the mouth is set with fish-teeth, and for eyes they have a fragment of pearl-shell with a round knob of black wood in the centre. I noticed at the same time several smaller capes, in which the feathers of Vesticuria are used.
} 
the lava-blocks. These trees are a mass of crimson blossom, and among their branches the Iiwi was in great numbers, busily engaged in probing the flowers in search of nectar. We found a nest in one of the small trees, which probably belonged to this bird, as it was the only species observed in this vicinity, and this supposition is strengthened by the fact of our shooting two quite young birds soon afterwards"1. I may briefly describe the nest as a round and shallow cup, 4 inches in diameter, composed of mosses and dry bents, the inside being composed of slender rootlets.

The food of the Iiwi consists chiefly of honey, which it finds in the blossoms of the ohia and of the arborescent Lobeliaceæ ${ }^{2}$; no doubt it also preys on the small insects found in the flowers ; but as honey will often drip from the bill of this bird, when shot, it probably constitutes its sustenance to a greater extent than that of other species, where such is not the case.

I have met with the subject of this article at an elevation of 6000 feet in the district of Kona, in Hawaii, and I am informed that it is abundant at certain seasons of the year above Kalaieha-a sheep-station on the same island at a still higher level. This shows that it follows its food, and that when the ohia is over at 2000 feet, but in full flower at 5000 , it migrates to a greater elevation. In the first Plate a flowering branch of a tall woody climber (Strongylodon lucidum) is shown, from a sketch from nature by myself, which festoons the forest-trees, and of which the scarlet sickleshaped flowers mimic in a most perfect manner, both in colour and shape, the bill of the Iiwi; it is therefore known to the natives by the name of "Nukuiiwi" (bill of Iiwi) or "Kaiiwi" (the Iiwi).

I must also note, with regard to its vertical range, that this bird is frequently to be observed on the sea-beach, to which uncongenial region it is driven by the high winds from its forest home, as is the case with the "Apapane" (Himatione sanguinea). I quote the following from a letter of my friend Randal von Tempsky, of Kula, Maui, received in March 1890, as interesting in this connection:- "This winter has killed off an extraordinary number of native birds in Kula, I am sorry to say; there has been an exceptionally long spell of dry weather accompanied by a gale of wind. I found several mountain birds on the sand at the 'beach,' a place the most unpropitious you

1 Bloxam, Voy. 'Blonde,' App. p. 249, states that this species builds on the tops of trees.

${ }^{2}$ Cassin, U. S. Expl. Exped. p. 178, merely remarks about this species "that several specimens in excellent plumage were obtained by the naturalists of the expedition," but he quotes some interesting details of Peale's which I think worth transcribing here:- "This curiously and highly coloured bird is found inhabiting most of the Hawaiian group of islands, where it is one of the most common species. At Oahu, we found them generally about the gigantic Lobelias which characterize the botany of that island. They extract their food from the flower of the Lobelia, for which the singularly formed bill is admirably adapted. The red feathers of this species were usually selected for the ornamental figures on the capes and robes of the ancient Howaiians, but by reason of their abundance were not so highly valued as those of the 0-0."

Dr. Finsch (Ibis, 1880, pp. 79, 80) says that he observed many examples of Drepanis coccinea and $D$. sanguinea while collecting at Olinda on the island of Maui, at 5400 feet altitude, but that the stomach contained nothing more than small seeds; I can only say that my observations, extending over a much longer period, lead to a different conclusion. 
could imagine for a mountain bird ; natives canght plenty and so did cats. If we have another such winter I doubt whether we will have any native birds left in the Kula district."

Mrs. Francis Sinclair informs me that after stormy weather she has seen numbers of these birds on the island of Niihau (where no forest now remains), to the uncongenial shores of which they had been driven by gales from the adjacent island of Kauai, separated by a channel 18 miles in width.

The upper figure in my second Plate, in which no trace of scarlet is seen, and of which the plumage is bright yellow-buff, I obtained on the island of Maui; other examples procured in the same locality seem to show a clearer tint of buff than those from the remaining islands; the bills in those from Maui are also slightly shorter and stouter. Dr. Stejneger, however, states that a careful comparison of Mr. Knudsen's four birds with three in the museum of the Smithsonian Institution, probably not from Kauai, shows no tangible difference in colour or dimensions; and with the exception of these immature birds, I find this to be the case with my series, in which the islands of Kauai, Oahu, Molokai, Lanai, and Hawaii are represented ${ }^{1}$.

A flowering branch of the uulei (Osteomeles anthyllidifolia) is shown in my second Plate-a low shrub with hawthorn-like flowers, among the branches of which I have often seen the Iiwi disporting itself; the wood of this shrub is used by the natives in the manufacture of pipes.

Description.-Adult male. General colour above and beneath vermilion; wing-quills and tail black; innermost secondaries white or ashy brown on the inner web; wingcoverts black, edged outwardly with crimson; wing-lining and edge of the wing of a whitish hue tinged with pinkish scarlet; irides dark hazel; bill clear vermilion, darker on maxilla; feet vermilion.

Adult female. May always be distinguished from the male by her deeper colour, especially below, where she is almost crimson.

Immature bird. General colour greenish yellow, mottled with blackish spots at the tips of the feathers ; wing-quills and tail black; irides dark hazel ; bill light brownish grey, maxilla yellow at margin.

The colour of the feet and bill in a very young bird was brown-pink, the scales on the tarsi darker; the soles of the feet yellow.

\footnotetext{
${ }^{1}$ Reichenbach (loc. cit.) seems to have clearly understood the changes of plumage in this species, which he fully describes; while he figures, grouped together, an adult female, a young bird with no trace of scarlet, and a second with a few buff feathers about the head and neck. These drawings are accurato enough, but, from an artistic point of view, are caricatures of a most beautiful and elegant bird; nor is the transition state so completely illustrated as to make a new figure superfluous. Dr. Finsch alone gives correctly the colour of the bill of the adult of this species, Latham and Merrem describing it as whitish : in Merrem's figure accordingly the bill is almost colourless; this is probably due to the fact that in slins the colour of both bill and legs soon fades.
} 
Dimensions.-Adult male. Total length 5.75 inches, wing from carpal joint 3.45 , culmen 1 , tarsus $\cdot 95$, tail $2 \cdot 40$.

Obs.-Four specimens in transition plumage are figured, showing more or less scarlet according to age. 



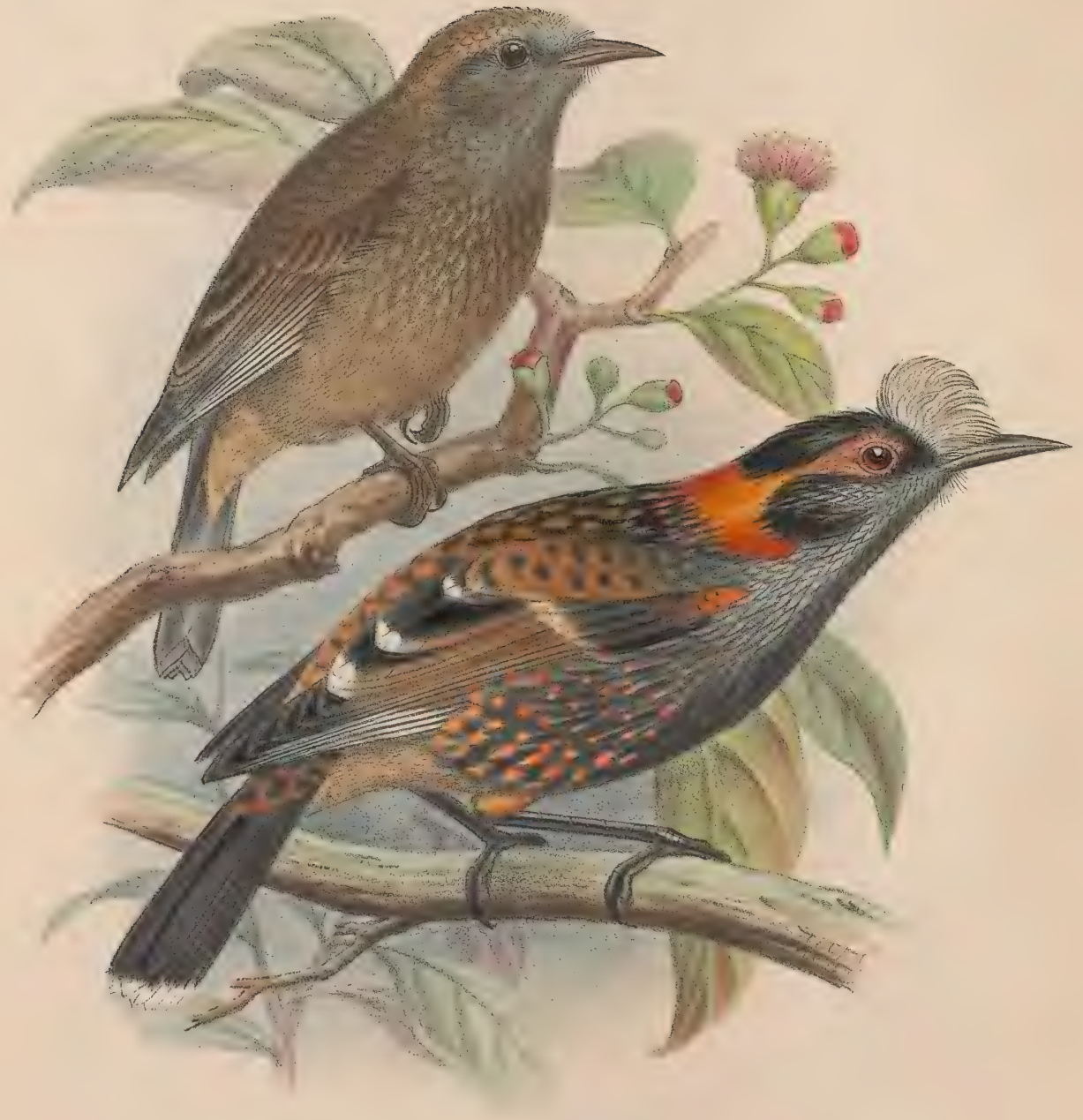

F.W.Frohawk delet lith. 


\section{PALMERIA DOLII.}

Himatione dolei (err. typogr.), S. B. Wilson, Proc. Zool. Soc. 1891, p. 166.

Palmeria mirabilis, Rothschild, Ibis, 1893, p. 113; Bull. Br. Orn. Club, i. p. xvi (1893).

Palmeria dolei, Rothschild, Bull. Br. Orn. Club, ii. p. ix (15 Nov., 1893).

IN the month of July 1888, while exploring the district of Kula in Maui, I shot, in company with an example of Himatione sanguinea, a bird-apparently of the same family-which was similar in its habits, but was much darker in plumage. It was obviously young, and for a long while I hesitated to describe it, hoping to get another and more mature specimen. As time, however, went on and none appeared, I ventured to specify it as Himatione dolii and so left it. But when, on visiting Cambridge on October 26th, 1893, I saw the series of specimens of Palmeria recently obtained in Molokai by Mr. Perkins, I at once recognized that the younger examples, though considerably larger, agreed essentially with my bird; the absence of the crest, which is so remarkable a feature in the adult, and the fact that $\mathrm{Mr}$. Rothschild referred his Palmeria to the family Meliphagida, having combined to prevent my discovering the identity of the two birds sooner. That gentleman, I believe, made the discovery previously, when he obtained the loan of my specimen for comparison, but he did not inform me of the fact, leaving me to infer it from his note in the 'Bulletin' of the British Ornithologists' Club, as follows:-

"Mr. Scott Wilson, in the 'Proceedings of the Zoological Society' for 1891 (p. 166), described, under the name of Himatione dolei a bird from Mauai [sic] which has not since been identified ${ }^{1}$. Through the kindness of Mr. Wilson I have been enabled to examine his type; and I found, to my astonishment, that it was a very young specimen of the bird which I had named Palmeria mirabilis, although no one could possibly have made this out from the description. As the type, therefore, proves beyond doubt that Wilson's bird is merely the young of my Palmeria, and as the latter genus is very distinct and has nothing to do with Himatione, being a genus of the Meliphagidce near Chatoptila and not one of the Drepanididce, the name of this peculiar bird must stand henceforth as Palmeria dolei (Wils.)."

In this note Mr. Rothschild lays great stress, as he had done in his original description, upon his new genus belonging to the Meliphagidos; but herein I believe him to be wholly mistaken, for Dr. Gadow has favoured me with the following remarks :-

\footnotetext{
${ }^{1}$ I am unable to understand the meaning of this remark, unless. Mr. Rothschild wished to suggest that I had described a species which did not exist.
} 
"The Hon. Walter Rothschild ('Ibis,' 1893, p. 113) remarks: 'This genus is nearest to Acrulocercus, but differs from it in the three following points :-

" "(1) The tail is square and has no elongated central tail-feathers.

" '(2) There is a heavy crest of long curled feathers on the forehead, much like the crest of certain species of Sturnopastor.

" (3) The beak is straighter, much shorter, and more pointed than in Acrulocercus, and in this respect Palmeria more nearly approaches my genus Viridonia (Ann. N. H. ser. 6, vol. x. p. 112, 1892).'

"Why Palmeria 'is nearest to Acrulocercus' we are not told. From examination of a spirit-specimen, obtained by Mr. Perkins, I am enabled to state that Palmeria differs from the Meliphagida, and agrees with the Drepanidide in at least the following points, which, so far as these families are concerned, are of decisive importance:-

"(1) Tongue, typically Drepanine, like that of Hemignathus, Drepanis, Himatione, not brush-like or multifid.

"(2) Crop present.

"(3) Tenth or terminal primary obsolete, not long and functional as in Acrulocercus.

"(4) Edges of bill smooth, not serrated.

"(5) The pattern of colour closely resembles that of Himatione sanguinea.

"Although the formation of the œsophagus and of the tongue $(1,2)$ were possibly not available, and are, moreover, 'anatomical' features, the other characters (3-5) at least would, I should have thought, obtained such consideration as to have enabled the new genus to be correctly referred from skins only."

Description.-Adult male. Crown covered by a flat crest of linear lanceolate feathers, which are blackish with distinct light shaft-streaks; those nearer the nape are slightly tipped with brilliant orange-scarlet, while those of the nape itself have long tips of that colour and join a line of the same which extends across the neck on each side. A tuft of dirty white feathers springs from the forehead and bends forward so as to cover about half the culmen. The back, lesser wing- and tail-coverts are blackish, with duller orange-scarlet tips and slighter shaft-streaks; the wings and tail are still darker, the secondaries and greater wing-coverts having greyish-white tips, and most of the primaries white margins. Scarlet is also present to some extent at the bend of the wing, the under surface of which is rather light grey. The throat, sides of head, and neck are silvery grey, the feathers being more or less lanceolate. An orange ring surrounds the eye. The underparts are similar to the back, the thighs reddish orange. The bill and feet are black.

Dimensions. - Total length 7 inches, wing $3 \cdot 75$, tail 3 , tarsus $1 \cdot 12$, culmen $\cdot 75$.

Very young.-Crown of the head grey, shading into dull brown-pink, which is tinged on the sides with dull red; rest of the upper parts dusky brown mottled with greenish buff; beneath, the throat and breast grey, the tips of the feathers brown; 
belly greenish buff, shading off into white on the under tail-coverts; wing-quills and tail black, the former edged outwardly with a narrow line of white; wing-coverts and secondaries black, edged with brown-pink; irides dark hazel; bill and feet horncolour.

Dimensions. -Total length $5 \cdot 20$ inches, wing $3 \cdot 10$, tail $2 \cdot 20$, culmen $\cdot 55$, tarsus $1 \cdot 5$.

The figures are from an adult example obtained by Mr. Perkins and from my immature type specimen respectively. 



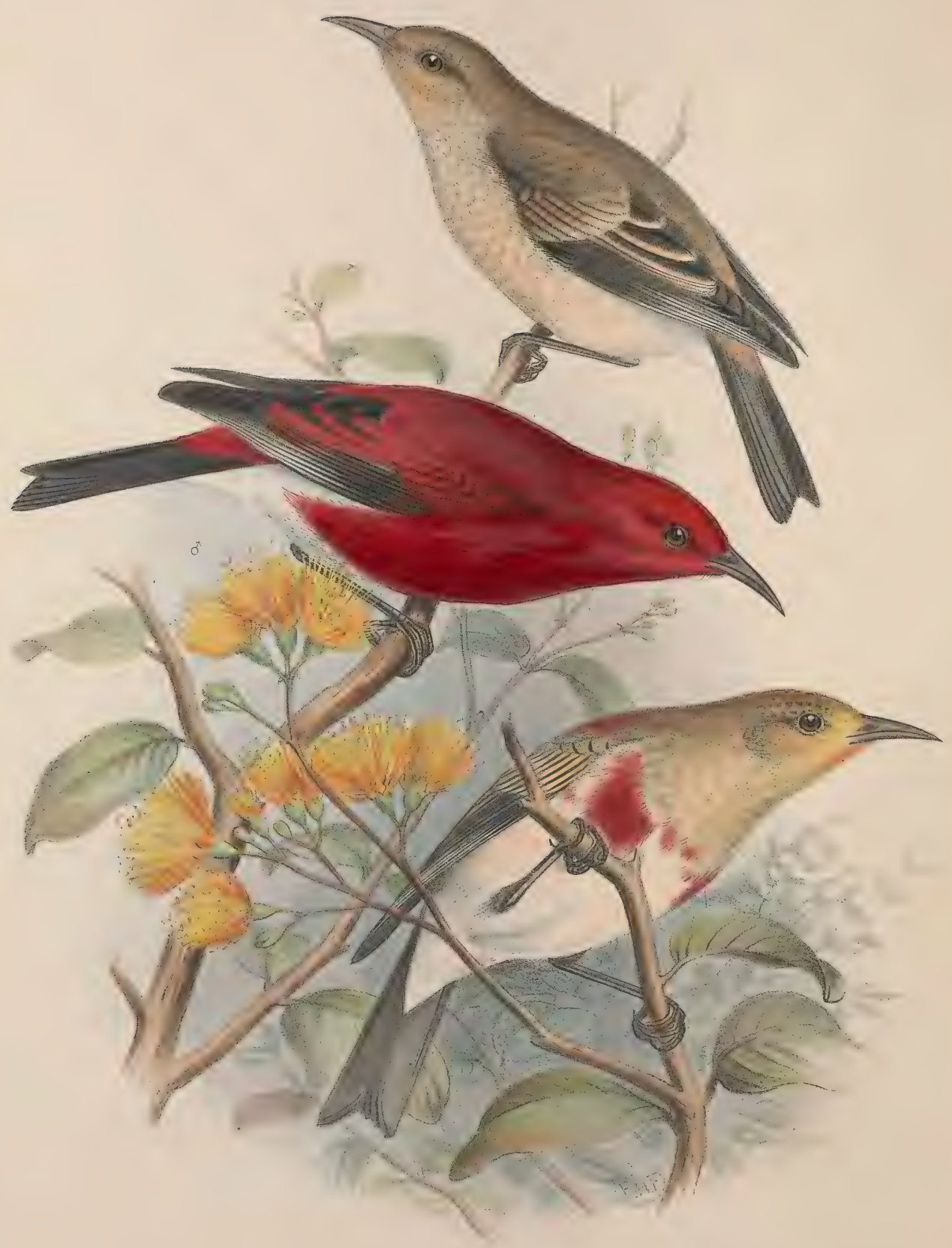




\title{
HIMATIONE SANGUINEA.
}

\author{
APAPANE.
}

"Crimson Creeper," Latham, Gen. Synops. i. p. 739 (1782).

"Bird of a deep crimson colour," Cook, [Last] Voy. Pacif. Ocean, ii. p. 227 (1784).

Certhia sanguinea, Gmelin, Syst. Nat. i. p. 479 (1788); Latham, Ind. Orn. i. p. 290 (1790); Donndorff, Orn. Beytr. i. p. 643 (1794); Shaw, Zool. viii. p. 231 (1812) ; Tiedemann, Anat. Naturgesch. Vög. ii. p. 431 (1814).

“L'Héoro-taire cramoisi," Vieillot, Ois. Dorés, ii. p. 128, pl. lxvi.* (1802).

"Le Soui-manga sanguinolent," Virey (Sonnini), Hist. Nat. Buffon, Ois. xvii. p. 107 (1804-5).

Nectarinia sanguinea, Cuvier, Règne Anim. i. p. 410 (1817).

Petrodroma sanguinea, Vieillot, N. Dict. d’Hist. Nat. xxvi. p. 108 (1818) ["Tanna" !]; id. Encycl. Méth., Ornithol. p. 621 (1823) ; J. E. Gray (Griffith), Anim. Kingd. vii. p. 353 (1829).

Nectarinia byronensis, Bloxam, Voy. 'Blonde,' p. 249 (1826).

Drepanis byronensis, J. E. Gray, ut suprà, pl. opp. p. 390 (1829) ; id. Zool. Miscell. p. 12 (1831).

Myzomela? sanguinea, G. R. Gray, Gen. B. i. p. 118 (1846).

Drepanis sanguinea, Hartlaub, Syst. Verz. Mus. [Bremen], p. 16 (1844); id. Arch. f. Naturgesch. 1852, i. p. 131 ; G. R. Gray, ut suprà, p. 96, partim (1847); Bonaparte, Consp. Av. i. p. 404, partim (1850); Lichtenstein, Nomencl. p. 55 (1854); Cassin, U.S. Expl. Exped., Mamm. \& Orn. p. 439 (1858); Dole, Proc. Bost. Soc. N. H. xii. p. 297 (1869) ; id. Hawaiian Alman. 1879, p. 44; Sclater, Proc. Zool. Șoc. 1878, p. 347; id. Ibis, 1879, p. 92.

Himatione sanguinea, Cabanis, Mus. Hein. i. p. 99 (1850-51) ; Reichenbach, Handb. sp. Orn. p. 255, partim, pl. 612. fig. 3834* (1853) ; Sclater, Ibis, 1871, p. 360 ; Von Pelzeln, Journ. f. Orn. 1872, p. 27, partim; Sundevall, Tentam. p. 48 (1872); Sharpe, Cat. B. Br. Mus: x. p. 8 (1885); Stejneger, Proc. U.S. Nat. Mus. 1887, p. 95 ; S. B. Wilson, Ibis, 1890, p. 183.

Drepanis (Himatione) sanguinen, G. R. Gray, Cat. B. Trop. Isl. p. 8, partim (1859); id. Hand-list, i. p. 113, partim (1869).

\footnotetext{
* Figurce notabiles.
}

THe circumstances attending the discovery and description of this bird are almost identical with those in the case of several other Sandwich Island species: for in the account of Cook's last voyage it is mentioned as the "Bird of a deep crimson colour ;" Latham, in the 'General Synopsis,' gives it the English name of "Crimson Creeper ;" and Gmelin, whose only acquaintance with it was from Latham's work, bestowed upon it, in his 'Systema Naturæ,' the Latin title of Certhix sanguinea; while Peale does not mention it at all in the history of the U.S. Exploring Expedition, though Cassin gives it a place in the Catalogue at the end of his edition of the same. Latham, however, did not figure this species in his book, though Vieillot subsequently did so in his 'Oiseaux Dorés,' and still earlier W. W. Ellis, in 1779, had made a drawing of it 
(No. 30) which is still preserved in the British Museum. Later, Bloxam introduced a possible source of error by calling the bird Nectarinia byronensis, after the commander of H.M.S. 'Blonde,' under the impression that it was unknown; but, although J. E. Gray followed Bloxam in recognizing a second species, the misapprehension was soon rectified and the specific name sanguinea finally approved. The type was very fortunately kept, and was identified by G. R. Gray and later by Dr. Sharpe. With regard to the generic appellation, however, Professor Cabanis in 1850 rightly separated the subject of our notice from the genus Drepanis, making it the type of his Himatione, so called from the use of the feathers in the robes of chieftains. Helmets covered with its feathers may still be seen in some museums.

This species, with Vestiaria, in company with which it is commonly seen, is distributed throughout the whole group, and its vertical range is practically identical. Its principal food is honey, obtained from the flowers of the ohia (Metrosideros polymorpha), while I have seen it in numbers among the mamáne trees (Sophora chrysophylla) in the flowering season; and though I am uncertain whether their golden-yellow racemes or the small insects among their foliage were the attraction, still I have no doubt that it feeds partially on the latter, which abound in all the flowers visited, since I have often found insects in the stomach when dissecting specimens. Dr. Finsch, on the other hand (Ibis, 1880, p. 80), states that he only found small seeds; but Mr. Knudsen, whose field-knowledge of Hawaiian birds places him on an equality with Dr. Finsch, expresses his belief (Proc. U.S. Nat. Mus. 1887, p. 96) "that the Apapane feeds exclusively on flower honey." I am, on the whole, of opinion that were Mr. Knudsen to have added "and on insects," his would be the right view of the matter. Although I did not find a nest of the Apapane, I shot a female on the 24th of May, 1887, at Kaáwaloa in the district of Kona, in the ovary of which was an egg almost ready for exclusion, a circumstance which enables me to fix approximately its breedingtime, which seems to be later than that of the Iiwi, for I had shot several of the young of the latter before the above date. I never, however, obtained specimens of the Apapane so young as those of the Iiwi, although I have many immature examples in which not a trace of the crimson plumage is to be seen : in this stage, as will be seen by my Plate, they differ so much from the adult (as is also the case with Vestiaria) that it is not easy at first to believe that they are of the same species, and my natives were quite sure that I was wrong when I told them of it. The note of the Apapane is a feeble though clear tweet twice repeated, but it also has a pretty simple song generally heard soon after sunrise or towards sunset. In its flight the white under tail-coverts are very conspicuous and serve to easily determine it on the wing. The crimson feathers were not used to any great extent in the fabrication of the wellknown native robes of olden times; but there is in the Ethnological Collection in the British Museum a kind of waist-covering of the black tail-plumes of the domestic cock, of which the upper border-four inches in width-is composed of the crimson feathers of this bird, the dimensions of this very war-like and savage-looking oinament being-length 41 inches, width at the middle 18 inches. In the account of 
Captain Cook's last voyage, cited above, we find $H$. sanguinea referred to as follows:"The scarlet birds already described [Vestiaria coccinea] which were brought for sale, were never met with alive; but we saw a single small one, about the size of a canary bird, of a deep crimson colour." These observations were made on the first visit to the island of Kauai-or Atooi, as it was termed by the early explorers.

The Hawaiians in their old mythology frequently make mention of the Apapane and of its sweet song, and the following extract from the romantic story of Laieikawai ('Legends and Myths of Hawaii,' pp. 459, 460) may be of interest:-

"The kahu [servant] of the king first met the princess and her companion, and, when requested by him to favour his royal master with a visit, the princess informed him that she might possibly comply with his request the night following. ' If I come,' she said, 'I will give you warning.' 'Now, listen and heed,' she continued. 'If you hear the voice of the Ao [Procellaria alba?] I am not in its notes, and when you hear the caw of the Alala [Corvus hawaiiensis] I am not in its voice. When the notes of the Elepaio [Chasiempis sandvicensis] are heard, I am getting ready to descend. When you hear the song of the Apapane [Himatione sanguinea] I shall have come out of my house. Listen, then, and if you hear the Iiwipolena [Vestiaria coccinea] singing, I am outside of your house. Come forth and meet me.' And so it came to pass. In the kihi, or first watch of the evening, resounded the cry of the $A 0$, in the second watch the caw of the Alala, at midnight the chirruping of the Elepaio, in the pili of the morning the song of the Apapane, and at daybreak the voice of the Iiwipolena. Then a shadow fell on the door, 'and we were enveloped,' said the king, 'in a thick fog, and when it cleared away the princess was seen in her glorious beauty, borne on the wings of birds.' The name of the divine being, he said, was Laieikawai."

Of this species I obtained examples on all the islands, which I am quite unable to distinguish one from another. Dr. Stejneger (Proc. U.S. Nat. Mus. 1887, p. 95) states that he carefully compared five specimens procured by the U.S. Exploring Expedition and one by Dr. 'Townsend ${ }^{1}$ with three sent by Mr. Knudsen, and goes on to say that neither in colour nor in dimensions can he discover any difference between them. It was formerly a pretty general belief that the red plumage of this species was peculiar to the male, and that the female was greenish. Thus Reichenbach, as above cited, described and figured (fig. 3833) one of the green species of Himatione as the female of this one, stating that it is "Above olive-green, shading into grass-green, below greenish yellow, wings and tail blackish brown, bill and feet brown." Herr von Pelzeln also, in his paper on the sexual difference of the Honey-suckers of the Sandwich Islands, to which reference is made in the synonymy above given, thought that Himatione virens was the young of this species, and sought to distinguish between the male and female as follows:- "In the female the under mandible with the exception of the point whitish,

1 Thanks to the kindness of the authorities of the Museum of the Academy of Sciences of Philadelphia in forwarding many specimens of the birds collected by Dr. Townsend, I have been enabled to compare three of his examples of the present species with mine. Most of those from that excellent collector are in a capital state of preservation, though now over 50 years old. 
which is not the case with the others; the bill also appears somewhat smaller and more slender; the tip of the bill, however, in both the male and female is somewhat damaged, so that this cannot with certainty be decided." Dr. Stejneger does not appear to have known whether the sexes differed, but he was right in concluding that the bird described by Dr. Sharpe as an adult female is really only in transition plumage: I am glad, therefore, to have been able to settle this point by saying that a careful comparison of males and females in my collection shows that the females can only be distinguished as stated below.

Description.-Adult male. Entire upper surface of body crimson, brightest on the head; underparts crimson as far as the abdomen, where it shades into white; under tail-coverts white; remiges and rectrices black, the former with a very narrow outer edge of crimson; secondaries black, edged broadly with scarlet; wing-lining and under wing-coverts ashy; irides dark hazel; bill and feet black.

Adult female. Differs from the male in having the general crimson of the plumage of a distinctly lighter shade, while the crimson on the outer edge of the secondaries is of the same shade as the rest of the plumage, whereas in the male it is of a much lighter tint.

Immature. General colour above ashy brown; orange-buff on head and neck; beneath white tinged with buff, wing-coverts and secondaries broadly margined with buff; crimson feathers absent or interspersed among the plumage according to age.

Dimensions.-Male. Total length 5.25 inches, wing from carpal joint $2 \cdot 95$, culmen $\cdot 70$, tarsus $\cdot 95$, tail $2 \cdot 90$.

Female. Total length 4.85 inches, wing from carpal joint $2 \cdot 85$, culmen $\cdot 60$, tarsus $\cdot 95$, tail $1 \cdot 85$. 



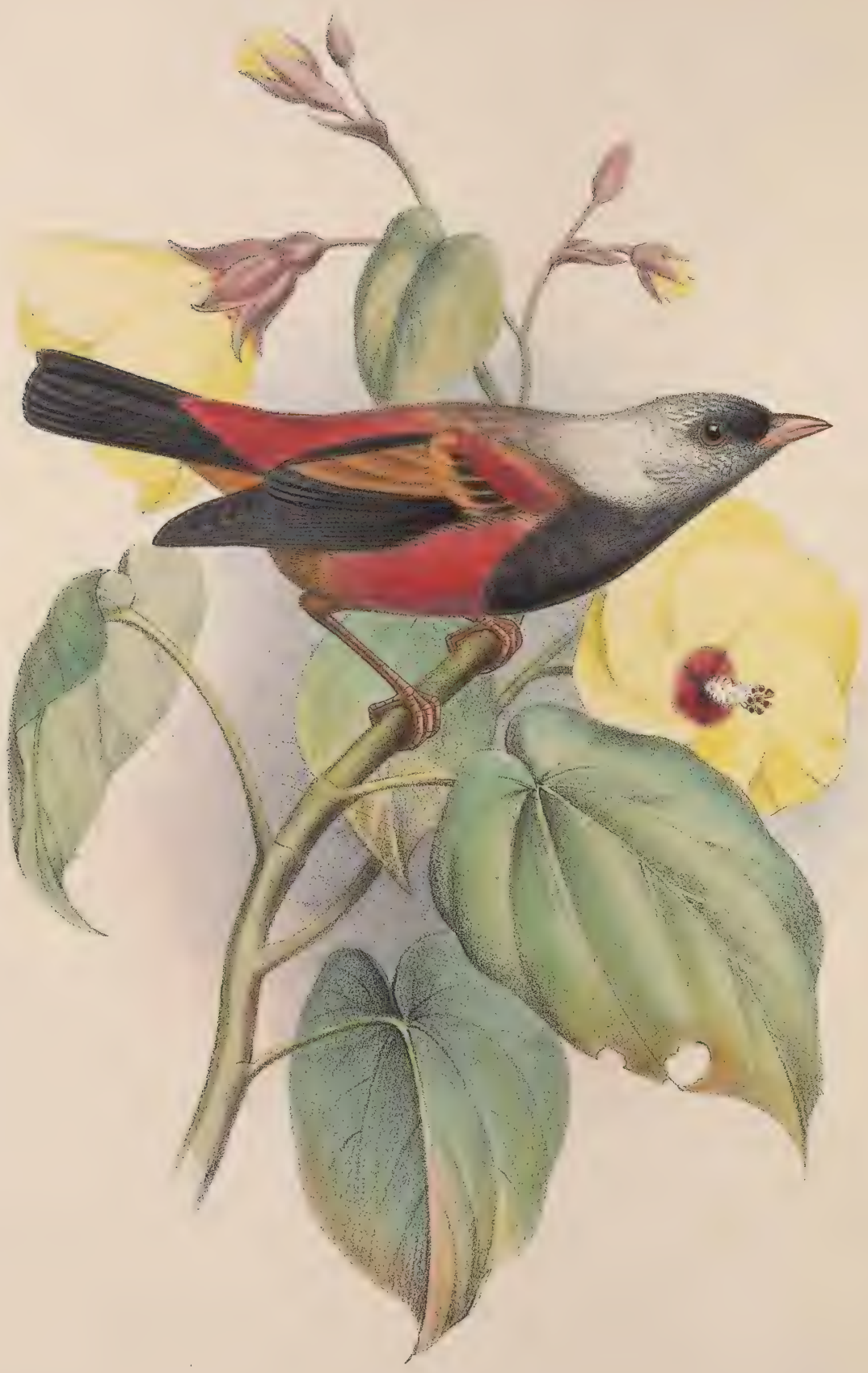

FW Frohawik del et lith

\author{
CIRIDOPS ANNA
}




\title{
CIRIDOPS ANNA.
}

\author{
ULAAIHAWANE.
}

Fringilla anna, Dole, Hawaiian Alman. 1879, p. 49, (reprinted) Ibis, 1880, p. 241.

"Ciridops —-, Wilson," Nature, xlv. p. 469 (17 March, 1892).

JUDGE DOLE'S original account of this species is as follows :- "Not previously described. $5 \frac{1}{2}$ in. long. Bill short, straight. Toes 3 front, 1 back. Wing-coverts and breast red; throat, primaries and tail black; secondaries white; head grey, merging into white on the upper part of the neck, and grey again on the back. Habitat Hawaii. Probably belongs to the genus Fringilla. This is a bird of remarkable beauty, its peculiar combination of colours producing a most harmonious and elegant effect."

I procured a stuffed specimen from the Hon. C. R. Bishop, which had been obtained by the late Mr. Mills of Hilo. Mr. Bishop has a very much finer example remaining, with more grey about the head and neck, taken by the same gentleman. I used to hear repeatedly of the "Ulaaihawane," by which name it is well known to the natives, who told me that it feeds on the fruit of the Hawane palm, whence its name-Ula (red), ai (to eat), Hawane (the Hawane palm); and therefore I have little doubt that it will be found, perhaps in some numbers, in the upland region of the interior, which I was unable to explore. The present specimen-now in the collection of the Hon. Walter Rothschild-has not the sex marked; so it is impossible to say whether the male differs from the female or not. My friend Mr. Francis Spencer, writing to me quite recently, says that his natives had seen the bird in the swampy forest-region above Ookala on Hawaii, and his description leaves no doubt of its identity.

\section{CIRIDOPS ${ }^{1}$.}

Bill moderate, culmen slightly arched, mandible almost straight, gape deflected.

Nostrits covered by a membrane, no rictal bristles, but a few bristly feathers on the chin.

Wings with first primary shortest, second, third, and fourth nearly equal.

Tail moderate, rectrices nearly equal.

Feet fairly strong.

Feathers of crown short and, with those of the throat, acuminate. Webs of all the feathers, especially on the belly, decomposed.

Description.-Crown in front black, gradually shading into silvery grey and white on

${ }^{1}$ Emberizæ Ciridis, Linnaei, faciem habens. 
the nape, becoming tinged with brown on the back; rump, upper tail-coverts, lower breast, median and part of lesser coverts bright glossy scarlet; sides of face grey, deepening into smoky black on the throat and breast, where it forms a distinct gorget; vent, under tail-coverts, outer webs of last three secondaries, secondary and lesser coverts ochreous buff; primaries and greater part of secondaries and tail black. Irides dark hazel ; bill and feet pinkish brown.

Dimensions.-Total length $4 \cdot 25$ inches, wing 3 , bill $\cdot 45$, tarsus $\cdot 85$, tail $1 \cdot 80$. 



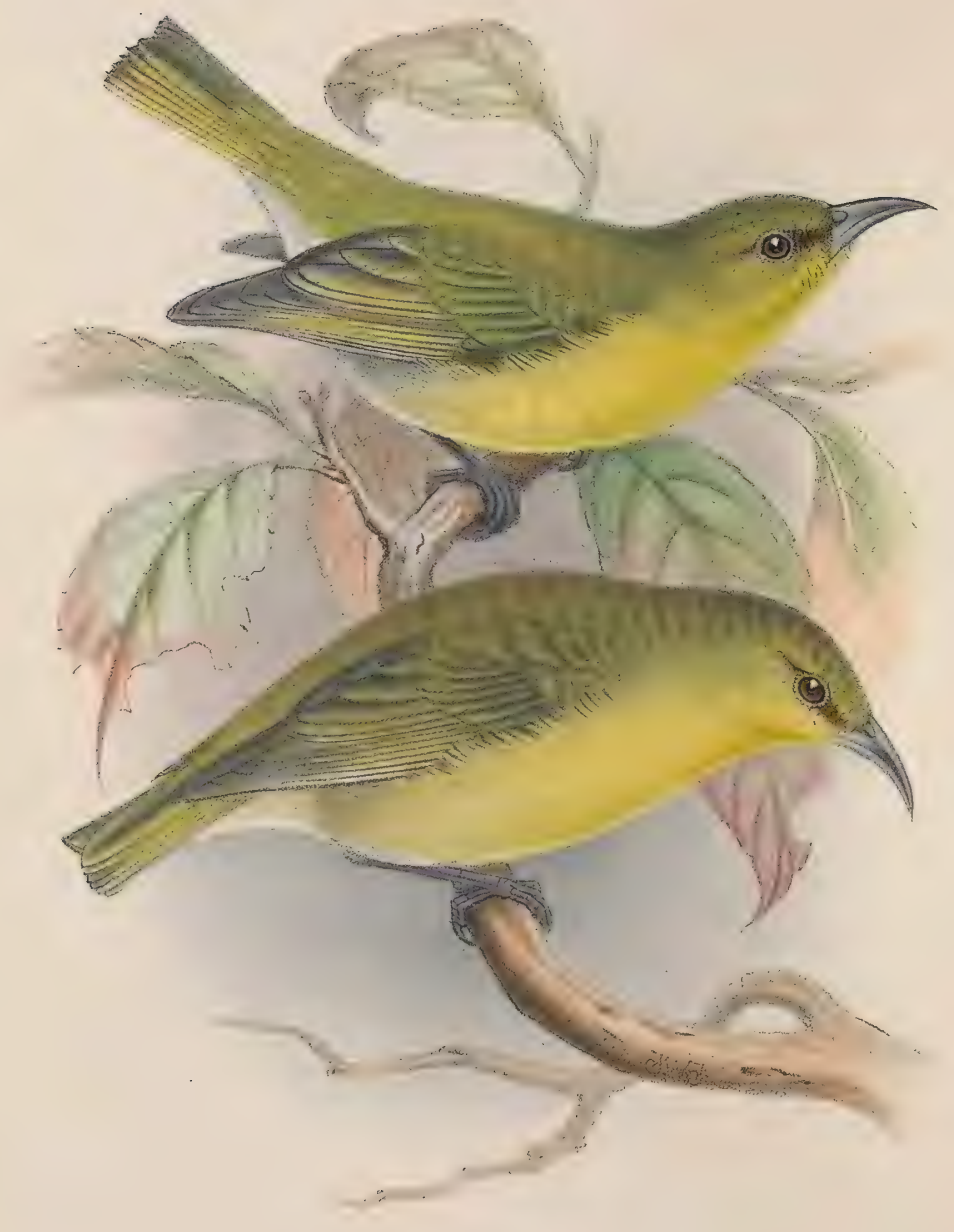

FWFrohavile del et lith. 


\title{
HIM A TIONE STEJNEGERI.
}

\author{
AMAKIHI.
}

Himatione chloris, Stejneger, Proc. U.S. Nat. Mus. 1887, p. 96 (nec Cabanis).

Himatione stejnegeri, S. B. Wilson, Proc. Zool. Soc. 1889, p. 446.

Tris species, first obtained by Mr. V. Knudsen in Kauai, I met with shortly afterwards in the forests of the district of Kaholuamano-the mountain-ridge adjacent to that of Halemanu, where the original examples were procured. Dr. Stejneger, to whom they were sent, noticed them under the head of Himatione chloris in his account of Mr. Knudsen's collection, but it will be observed that he did not feel certain as to the identity of the form from Kauai with that from Oahu, whence came Professor Cabanis's types of $H$. chloris, and where I obtained others agreeing with them. I named it in the 'Proceedings of the Zoological Society, as above, after my friend Dr. Stejneger, to whom, for his advice on several points, I am greatly indebted. It seems to be rather scarce, or at any rate was so at the time of my visit, and I shot but few specimens; but I was able to observe that it showed a decided preference for the short underwood, and searched for its insect-food on the trunks and limbs of the small ohias and other low trees, to which its strong claws enabled it to cling with ease. It is at once distinguishable by its short stout build from any other member of the genus, while the curve of its powerful bill more nearly approaches that of $V$. coccined than that of any other Sandwich Island species.

Description.-Adult male. Upper surface, head, nape, mantle, and rump olive-green with a greyish tinge, shading into yellowish green on the tail-coverts; forehead slightly brighter than the crown; lores brownish black; primaries, secondaries, and coverts smoky black, with the edges of outer webs bright olive-green; throat and breast lemon-yellow, with a golden-green hue, blending into a whitish tint on the abdomen and under tail-coverts; tail short, colouring same as wing; bill strong and deep at the base and decurved.

Dimensions. - Adult male. Total length $4 \cdot 45$ inches, wing $2 \cdot 60$, culmen $\cdot 55$, tarsus $\cdot 70$, tail $1 \cdot 60$.

Female. Similar to the male.

Obs.-Closely resembling H. chloris, but having the bill much higher at the base, more decurved, and with the maxilla perceptibly exceeding the mandible in length. 




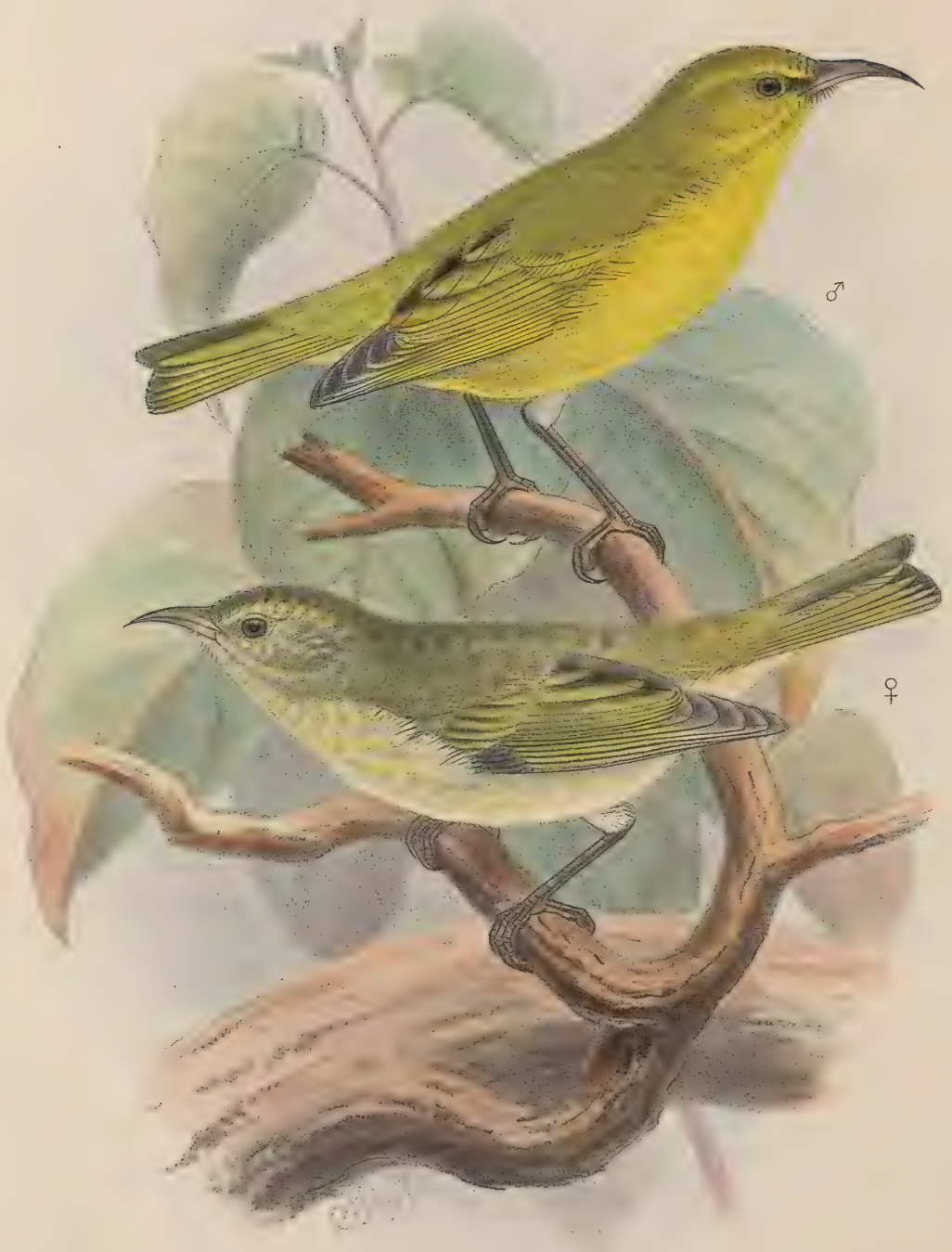

E.W. Frohawk del. et lith. 


\title{
HIM ATIONE CHLORIS.
}

\author{
AMAKIHI.
}

Himatione chloris, Cabanis, Mus. Hein. i. p. 99, note (1850-51) ; Bonaparte, Comptes Rendus, xxxviii. p. 264 (1854); S. B. Wilson, Proc. Zool. Soc. 1889, p. 447; id. Ibis, 1890, p. 185.

Drepanis (Himatione) sanguinea, G. R. Gray, Cat. B. Trop. Isl. p. 9, partim (1859) ; id. Hand-list B. i. p. 113, partim (1869) (nec Gmelin).

Himatione virens, Sharpe, Cat. B. Br. Mus.x. p. 9, partim (1885) (nec Gmelin).

The synonymy of this species presenting few complications, and its habits being, so far as they are known, so similar to those of its congener, Himatione virens, little remains to be said beyond that it was originally described by Professor Cabanis from specimens obtained by Deppe in Oahu, to which island H. chloris is confined. I have been able to compare my specimens with one in the Museum of the University of Cambridge, procured by 'Townsend (Deppe's companion), which was submitted for determination to the Professor, and was marked by him as agreeiug with his type in the Museum of Berlin.

On Oahu, in the district of Halemanu (house of the birds), this species seems to frequent more especially the depths of the steep and densely wooded ravines, and loves, above all trees, the gigantic Lobeliaceæ-the strange foliage and great heads of the purple flowers of which plants are so striking a feature of a Sandwich Island forest, and one, I believe, only to be met with in these Pacific Isles.

Description.-Adult male. Above uniform bright yellowish green, with very narrow black forehead and lores, and brownish-grey wings and tail, margined with the same colour as the remaining upper parts; below golden yellow; bill and feet blackish brown.

Dimensions. - Total length 4.5 inches, wing $2 \cdot 6$, tail $1 \cdot 9$, tarsus $\cdot 75$, culmen $\cdot 4$.

As I have elsewhere remarked (Proc. Zool. Soc. 1889, pp. 446, 447; Ibis, 1890, pp. 185, 186) the representative forms of Himatione chloris in the islands of Molokai and Lanai are easily distinguishable from each other and also from the type, and it had been my original intention to describe them as distinct species, the form from the 
latter as $H$. chloridoides, and that from the former as H. kalaana. It then appeared to me that some ornithologists would consider the differences too slight to be accounted specific, and I accordingly refrained from doing more than indicating their existence. I have since found that Mr. Perkins, who obtained a good series of examples of each, has in his manuscript lists kept them apart (though I am not aware of his having published his views on the subject), and I therefore consider it advisable to follow his example, without pledging myself to the opinion that they are more than local forms. I here repeat the characters which I then thought would serve to distinguish them:-

Oahu. - A trace only of a yellow mark from the bill to the eye. Upper parts of a dark greyish buff tinged with a faint shade of olive. Underparts whitish buff tinged with yellow. Bill and legs dark brown.-True H. chloris.

Lanai.-A distinct yellow mark from the base of the bill to the eye. Upper parts light greyish buff, distinctly tinged with olive. Beneath on the breast and throat light lemon-yellow, shading into buff on the flanks. Bill and legs lighter brown. The bill is more slender.- $H$. chloridoides.

On the island of Lanai all the specimens which I obtained were shot in some fine guavas, quite 30 feet in height, which fringed the edge of the streamlet of the deeplywooded Waiapaa ravine. The birds were so busily engaged in hunting for insects, which abounded in the guavas, that I had an excellent opportunity of observing their graceful movements; here I saw the old birds feeding the young with small flies, larvæ, and other insects.

Molokai.-A distinct yellow mark from the bill to the eye, as in the Lanai form. Upper parts darker than in the Lanai form, but not so dark as in the type from Oahu. Underparts yellow, but not so bright as in the Lanai form. Bill and legs considerably stouter than in the preceding form.-H. kalaana.

On Molokai I have often with delight watched this bird searching for its insect-food among the low shrubs of ohia which cover the sunny slopes of the ravines on that island, in my opinion the most lovely of the group, visited, however, but seldom by travellers, on account of the Leper settlement being situated on its shores. 


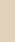




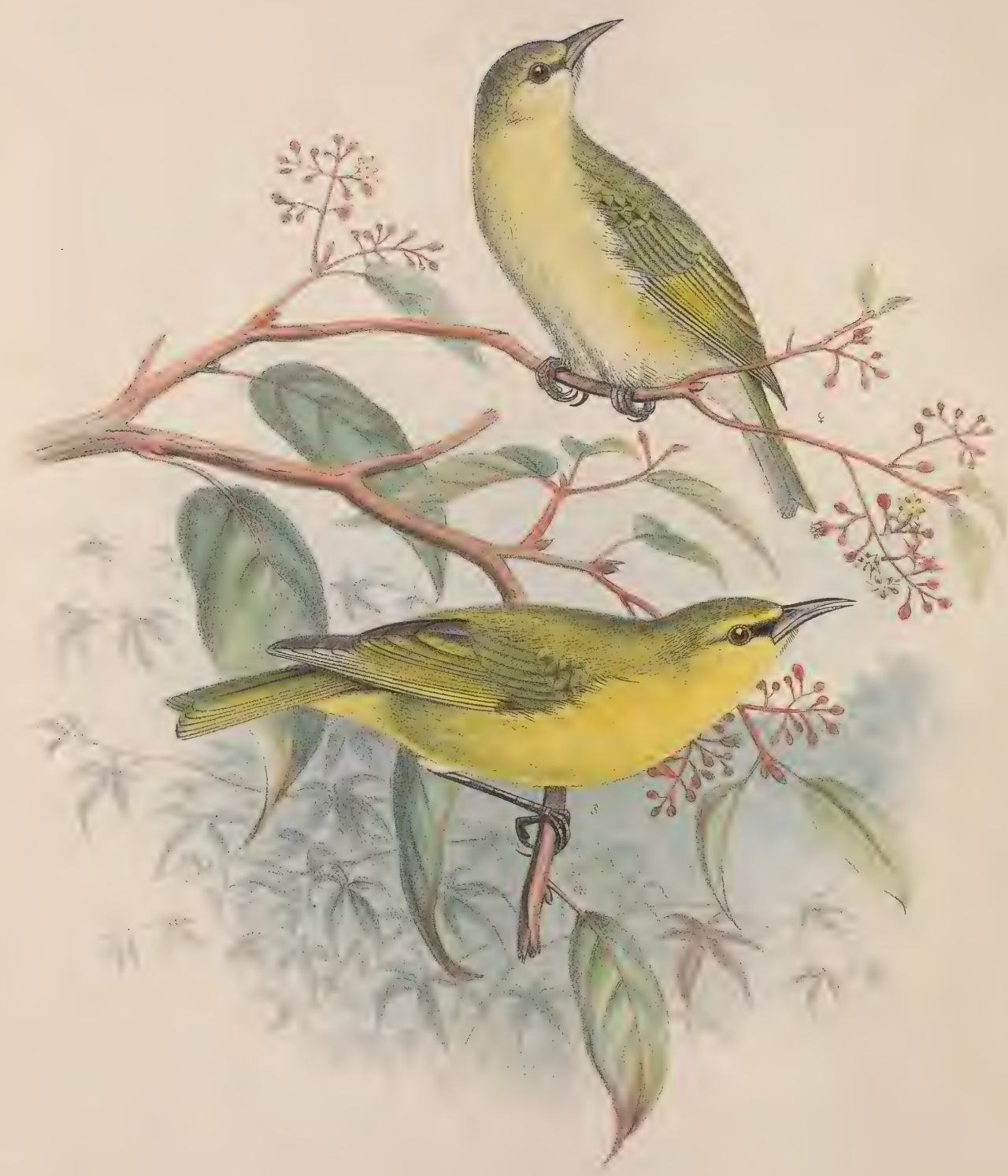




\title{
HIMATIONE VIRENS.
}

\author{
AMAKIHI ${ }^{2}$.
}

"Olive-green Creeper," Latham, Gen, Synops. i. p. 740 (1782).

Certhia virens, Gmelin, Syst. Nat. i. p. 475 (1788) ; Latham, Ind. Orn. p. 290 (1787); Donndorff, Orn. Beytr. i. p. 644 (1794); Shaw, Gen. Zool. viii. p 232 (1812) ; Tiedemann, Anat. und Naturgesch. Vög. ii. p. 431 (ex Insulis Amicis !) (1814).

? "L’Héoro-taire vert-olive," mâle, Vieillot, Ois. Dorés, ii. p. 129, pl. Ixvii. (1802) "

"Le Soui-manga verdâtre," Virey (Sonnini), Hist. Nat. Buffon, Ois. xvii. p. 107 (1804-5).

Melithreptus virens (partim?), Vieillot, N. Dict. d’Hist. Nat. xiv. p. 330 (1817); id. Encycl. Méthod. p. 607 (1823).

"Crimson Honey-eater" o , Latham, Gen. Hist. B. iv. p. 200 (1822).

? Nectarinia flava, Bloxam, Voy. 'Blonde,' p. 249 (1826), "Amakee."

? Drepanis flava, J. E. Gray, Zool. Miscell. p. 12 (1831); Hartlaub, Arch. I. Naturgesch. 1852, i. p. 110 (partim) ; id. Journ. f. Orn. 1854, p. 170 ; Dole, Proc. Bost. Soc. N. H. 1869, p. 298; id. Hawaiian Alman. 1879, p. 45.

Phyllornis tonganensis, Lesson, Rev. Zool. 1840, p. 165 !

Phyllornis virens (Vieill.), G. R. Gray, Gen. B. p. 124 (1846)-erased id. op. cit. App. p. 6.

Drepanis sanguinea (partim), G. R. Gray, Gen. B. p. 96 (1847).

Drepanis (Himatione) sanguinea, \&, G. R. Gray, Cat, B. Trop. Isl. p. 8, partim (1859) ; id. Hand-l. B. i. p. 113, partim (1869).

Himatione sanguinea, Reichenbach, Handb. sp. Orn. p. 255 (partim), pl. 562. fig. 3833 (1853).

? Himatione flava, Reichenbach, ut suprà, p. 255, partim (1853).

Drepanis flava, Sclater, Proc. Zool. Soc. 1878, p. 34.8 (qu. Bloxam ?); id. Voy. 'Challenger,' p. 95 (1881) (qu. Bloxam ?).

Himatione virens, Sharpe, Cat. B. Br. Mus. x. p. 9, partim (1885) ; Wilson, Ibis, 1890, p. 184; Perkins, Ibis, 1893, p. 105.

THrs curve-billed species from the Island of Hawaii has, as may be seen from the above, a long list of synonyms; but little information was until lately forthicoming concerning it, as the majority of writers who mentioned it in their works took their facts from the original description of Latham, in which it was named the "Olive-green Creeper." Gmelin's Certhia virens is, of course, but the same in Latinized form, while the two specimens figured by Vieillot must be referred here with some hesitation. Forty years after he first described it, Latham in the 'General History of Birds' gave it as the female of the Crimson Honey-eater; G. R. Gray subscribing to the same error by placing it under Drepanis (Himatione) sanguineu at a still later date. There remains to be considered Bloxam's example, procured during the voyage of the 'Blonde.' What is said to be the type of Nectarinia flava of that writer, and of Drepanis flava of J. E. Gray, still exists at the British Museum, and

1 The name applied to several other of the yellow-green species of Himatione.

" A rery bad figure, questionable whether it refers to this species; also whether the "femelle" described and figured, p. 130, pl. Ixviii., is of the same species; but the latter is most like H. virens. 
certainly appears to be the form found in Hawaii and not that of Oahu; otherwise the presumption would be that Bloxam's specimens were obtained in Oahu, in which case most of the references to Nectarinia, Drepanis, or Himatione flava would be more properly entered under $H$. chloris. Two specimens in the Liverpool Museum were obtained from Townsend through Audubon, and a third is in the Museum of the Academy of Philadelphia, among the collections made by the United States Exploring Expedition, though Peale does not mention it in his work; while Mr. Sclater records it in the 'Proceedings of the Zoological Society' for 1878, as brought home by the naturalists of the 'Challenger' Expedition.

This little bird is peculiar to the Island of Hawaii, and ranges from the lowest forest zone to 5000 feet or higher. Very unobtrusive in its movements, it may constantly be seen among the undergrowth of the forest, diligently searching every limb and slender branch and tapping the bark for its prey; and at Mana, in Hawaii (3500 feet), I found it in great numbers in January on the mamáne trees, which abound in that district, and are at that season in full bloom. As far as I have observed, this species lives almost entirely on insects and larvæ, and finds its favourite huntinggrounds on the aaka or Bastard Sandalwood (Myoporum santalinum), the koa (Acacia koa), and the mamáne (Sophora chrysophylla), though it also frequents the ohia. It may occasionally feed on honey, but I never observed it to do so, and at any rate it cannot be the case with it to such an extent as with its ally $H$. sangiinea. Moreover, it hunts rather among the lower foliage of a tree than in the flowering branches. The commonest note is a low "tweet," which is something like that of the European Goldcrest; but it has, besides this, a sweet though short song. The birds are depicted on a branch of kauila (Alphitonia excelsa), of which I obtained specimens on Hawaii, where it is now extremely scarce. In olden times the war-spears of the islanders were made of the wood of this tree, which is extremely hard and of a very handsome dark reddish colour.

Mr. Perkins says (Ibis, 1893, pp. 105, 106) that this species is very partial to the lehua flowers, and that he has seen the nest at different heights in various trees. It is lined with roots, and has many fruit-capsules of the poka, dry and more or less skeletonized, woven in the exterior.

Description.-Adult male. Above yellowish orange, somewhat brighter on the rump, the forehead and sides of the head being yellow with an inclination to orange; lores black and well defined; beneath, the entire surface of the body of a bright greenish yellow, inclining to lemon-yellow on the abdomen; wing and tail-quills blackish brown, edged with olive-green; under tail-coverts and wing-lining whitish; irides dark hazel: bill and feet black.

Adult female. Much duller than the male, the abdomen being almost primroseyellow, while the greenish yellow of the upper parts in the male is replaced by ashy olive. Apparently the forehead is not yellow.

Dimensions - Total length 4.5 inches, wing from carpal joint 2.63 , culmen 65 , tarsus 80 , tail $1 \cdot 85$. 


$$
\text { - }
$$




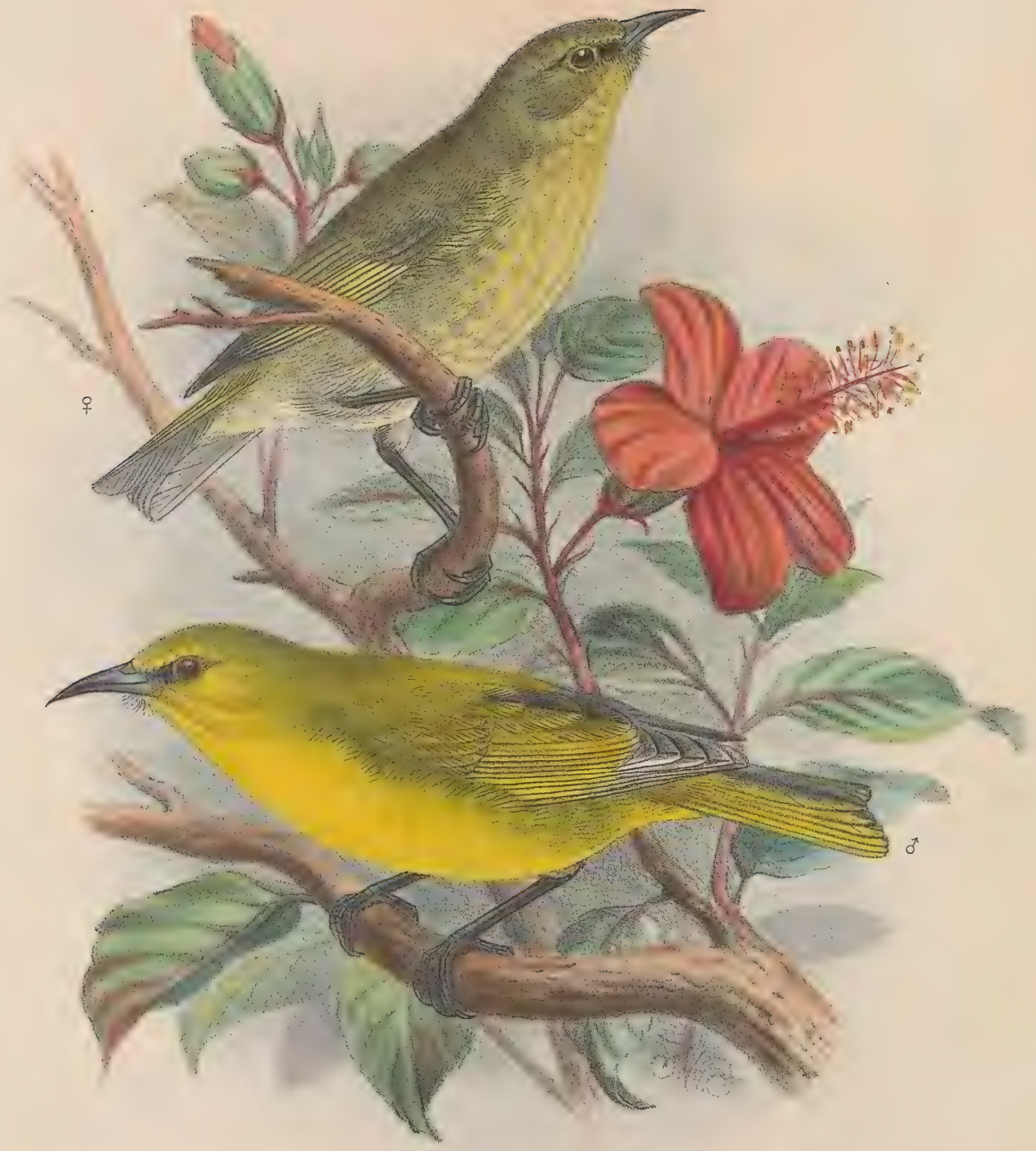

F.W. Frohawle del, et lith 


\section{HIMATIONE WILSONI。}

Himatione chloris, S. B. Wilson, Proc. Zool. Soc. 1889, p. 447 ; id. Ibis, 1890, p. 185 (partim). Himatione wilsoni, Rothschild, Bull. Brit. Orn. Club, i. p. xlii (1893).

OF this species, peculiar to Maui, the habits are at present undescribed, though they are doubtless similar to those of its congeners, for which special reference may be made to $H$. virens.

Description.-Above yellowish green, below bright yellow with an inclination to orange; the superciliary streak is of the same yellow tint, the lores and a very narrow frontal line being black.

Dimensions. -Total length $4 \cdot 6$ inches, wing $2 \cdot 45$, tail $1 \cdot 65$, tarsus $\cdot 8$, culmen $\cdot 55$.

The female is greyer above, and paler in the yellow portions.

Mr. Rothschild says :- "Similar to $H$. stejnegeri of Kauai, but smaller, the beak considerably less and straighter, in this respect resembling $H$. virens of Hawaii." For my own part I have considered this bird indistinguishable from $H$. chloris. 



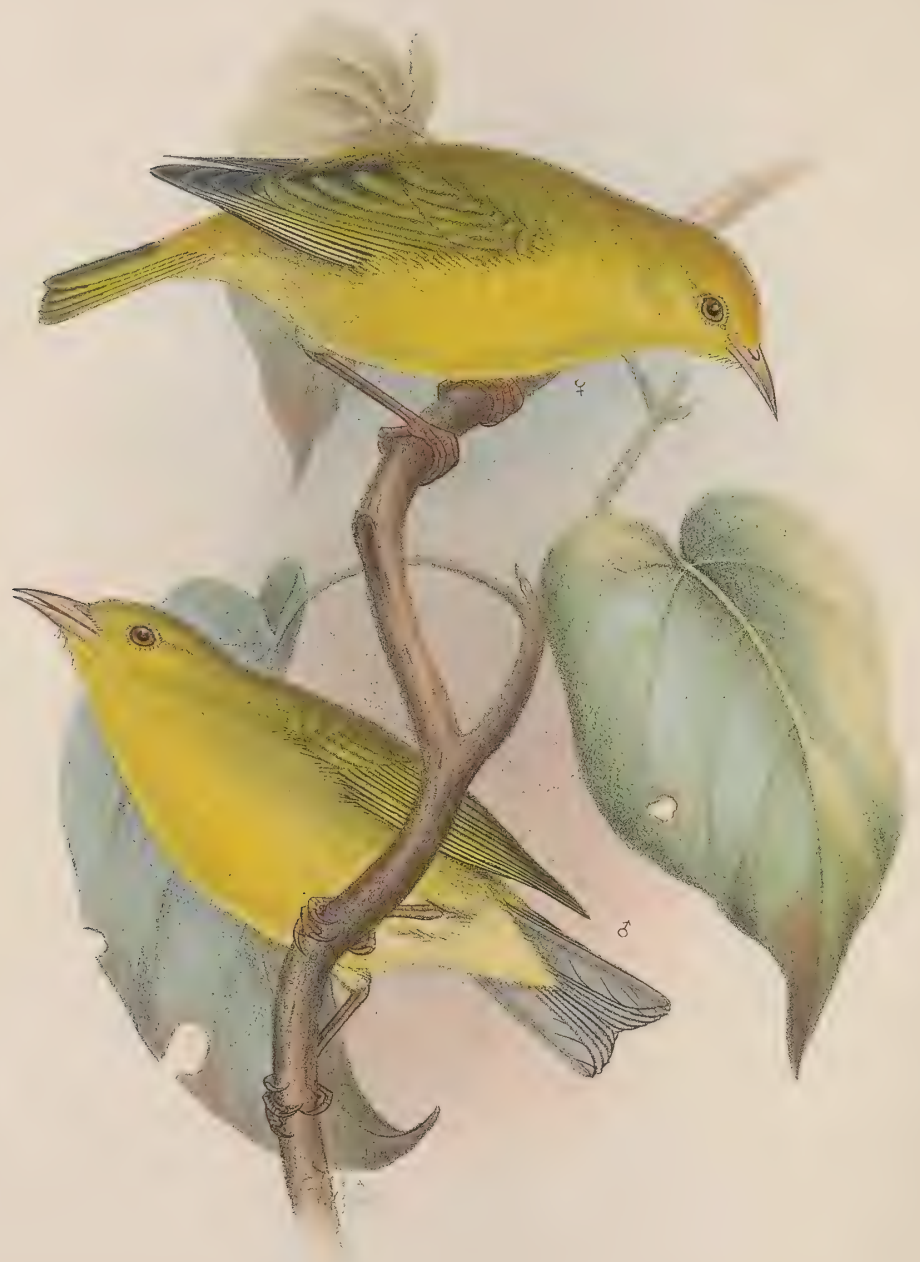

FW. Frohawk deletlith.

West, Newnan imp

HIMATIONE PARVA. 


\title{
HIM A TIONE PARTA.
}

\author{
ALAWI OR ANAUANII.
}

Himatione parva, Stejncger, Proc. U.S. Nat. Mus. 1887, p. 94.

'THIs species was first obtained in Kauai, to which island it is peculiar, while a good description of it was given by Dr. Stejneger as above cited. It is met with in small flocks, usually in company with Oreomyza bairdi, and at times also with Chrysomitridops caruleirostris, from which it is hardly distinguishable at a short distance; it has a low chirp, but no song that I heard. The range seems to extend throughout the forestregion, as it was found by Mr. Francis Gay towards the summit of Waialeale (4000 feet), the highest point on the island of Kauai. It feeds principally on insects ${ }^{1}$, as does Himatione virens, but no doubt also occasionally on honey.

Dr. Stejneger, in his remarks on this bird, says :-

"In general proportions the present species, which is the smallest of the slenderbilled Hawaiian Dicceida, agrees very well with Himatione sanguinea, except in its proportionately somewhat shorter bill, and cannot be separated from it generically, although in shape and size of bill somewhat intermediate between the latter species and Loxops. It is of about the same size as $L$. coccinea, consequently much smaller than $H$. sanguinea, and easily separable from both by its coloration, except perhaps from the female Loxops coccinea, which, according to v. Pelzeln (Journ. f. Orn. 1872, p. 29), is green above and yellow below. The bare nasal fossæ and longer bill of $H$. parva will prevent its being confounded with Loxops, however. In regard to colour it approaches more closely Himatione chloris, but H. parva is brighter yellow both above and below, and has the under tail-coverts yellow, strongly contrasting with the white of the abdomen, while in $H$. chloris they are whitish washed with dull buff. They are very easily told apart by the quite different dimensions and proportions, $H$. chloris being much larger, with a much longer and more curved bill and a proportionately much shorter tail than $H$. parva.

"From H. virens (Gm.) (which I take to be the same as Sharpe's and Sclater's bird of the same name and also the same as Bloxam's H. Alava, Mr. Sharpe having the type of the latter in the British Museum) our $H$. parva may be distinguished principally by its smaller size, and especially by its much shorter bill.

${ }^{2}$ Dr. Stejneger, on the authority of Mr. Knudsen, gives its native name as Kamao, which is incorrect; but that gentleman is doubtless right in stating that it "feeds on bugs, but also on the juices of flowers." 
"H. maculata, Cabanis, which is evidently quite distinct from both $H$. virens and H. chloris, is at once excluded from comparison with $H$. parva on account of the dimensions, and especially as having an entirely different wing-formula."

Dr. Stejneger's description is as follows :-

Description.-Adult male. Entire upper surface and sides of body, as well as the outer edges of quills and tail-feathers, bright yellowish olive-green, inclining to oliveyellow on forehead, region above the lores, supercilia, and rump; trace of a dusky line between bill and eye; under surface, including under tail-coverts, bright oliveyellow; middle of abdomen, tibiæ, axillaries, and under wing-coverts white, except those of the latter nearest to the edge of the wing, which are bright yellow; quills blackish, edged in the outer web with yellowish olive, in the inner one with white. Bill horny, brownish grey; pale at base below the nostrils; feet horny, brownish grey.

The female is similar to the male.

Dimensions (taken from a specimen in my collection).-Total length 4.30 inches, wing from carpal joint $2 \cdot 40$, culmen $\cdot 40$, tarsus $\cdot 70$, tail $1 \cdot 40$. 



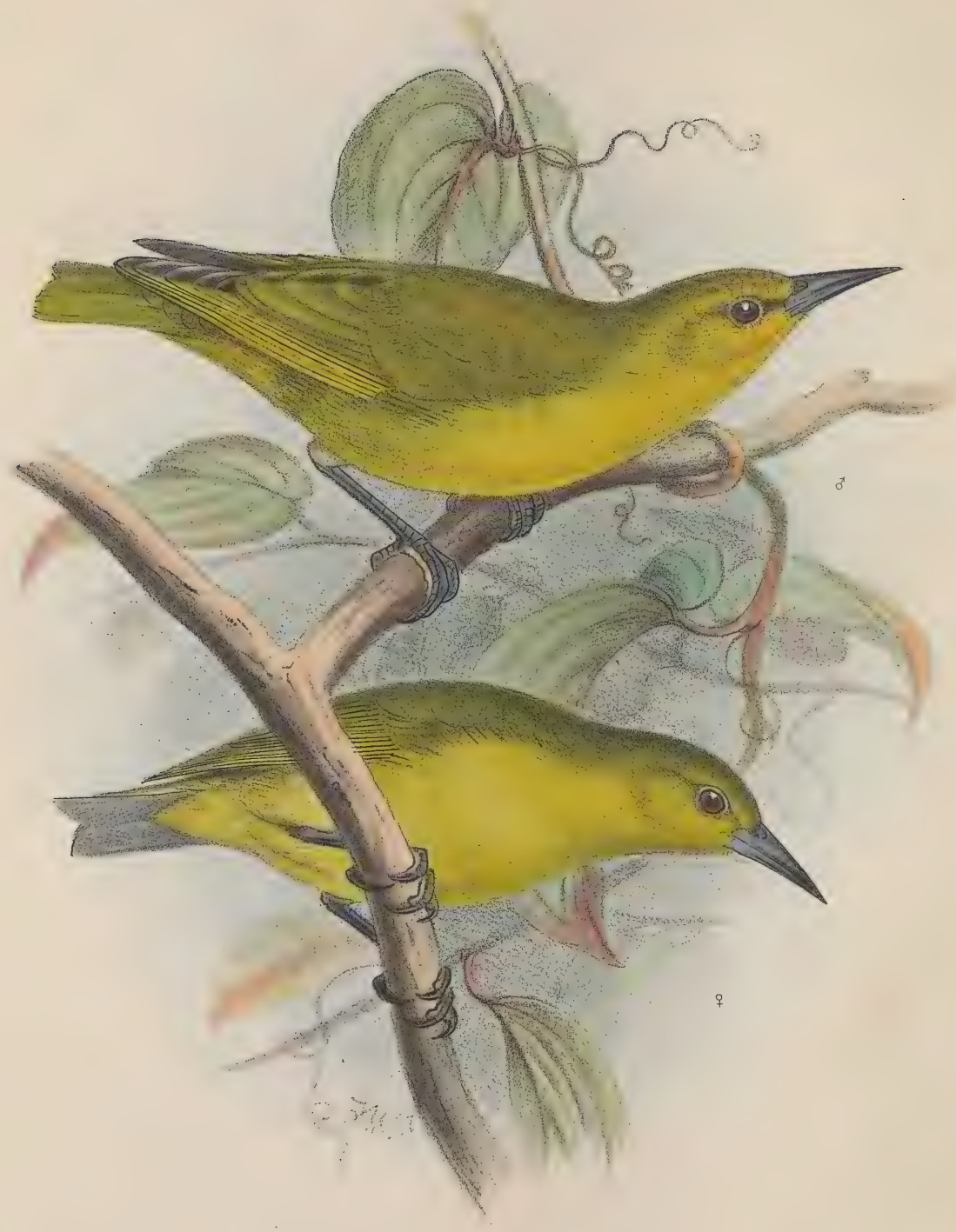

F. W.Frahewix del, ef lith. 


\title{
VIRIDONIA SAGITTIROSTRIS.
}

Viridonia sagittirostris, Rothschild, Ann. \& Mag. Nat. Hist. ser. 6, x. p. 112 (July 1892); id. Avif. Laysan, p. 109, pl. (1893).

Mr. Rотнschild described this new species in the "Annals and Magazine of Natural History' for 1892, in the following words :-

\author{
" Fam. Meliphagidæ. \\ "VIRIDONIA, gen. nov.
}

"Bill slightly curved, stout at the base, attenuating towards the tip, which is sharply pointed; wing rather broad, the first quill slightly shorter than the sixth; no bastard primary; tail rather short, nearly even at the tip; legs and feet stout; culmen about equal in length to the tarsus.

"Viridonia sagittirostris, sp. $\mathrm{n}$.

"Adult male. Upper parts bright olive-green, rather paler and brighter on the sides of the head and upper tail-coverts. Underparts bright yellowish green; wings blackish brown, the primaries narrowly and the secondaries more broadly margined with yellowish green; tail blackish brown, with yellowish-green margins; under surface of the wings dark ashy, the quills margined with dull white on the basal half; margin of the wing tinged with yellow. Bill black; legs black; iris brownish grey.

"Total length about 6.5 inches, culmen $0 \cdot 9$, wing $3 \cdot 3$, tail $2 \cdot 1$, tarsus 0.91 .

"Adult female. Resembles the male, but is rather duller in tinge of colour both on the upper and underparts.

"Hab. Mauna Kea, Hawai, Sandwich group."

This bird was discovered in 1892 by Palmer, when collecting for Mr. Rothschild, on the slopes of Mauna Kea, above Hilo; it frequents high trees and masses of creepers in the densest forest, generally at an altitude of from 500 to 1500 feet, is shy and fairly active, and utters a high clear call-note, rather like that of the Mamo, varied by a regular whistling trill. The song is not unlike that of Chlorodrepanis, but has two or three loud notes at the end. Only four specimens were obtained in the first instance, but Mr. Perkins secured several on his visit to the islands in 1896, one of them at an altitude of 2000 feet. The stomachs of those he shot were filled with crickets of the genus Paratrigonidium. 
It will be seen that Mr. Rothschild originally referred this species to the family Meliphagidæ; but that he subsequently modified his opinion is clear from his statement, in the 'Avifauna of Laysan,' to the effect that the genus comes "nearest to Oreomyza." It undoubtedly belongs to the Drepanididæ, as that group is now understood. In the work just mentioned a new rersion of the generic characters is given, which runs as follows :-

"Bill straight or very slightly curved, high and stout at base, attenuating towards the tip, which is sharply pointed. Nostrils protected by an upper operculum, only at base a little overhung by short feathers. Wing rather broad; first primary entirely rudimentary; fourth and fifth about equal and longest, gradually becoming shorter towards both sides; second slightly shorter than the seventh, and about equal to the eighth. Tail somewhat short, nearly even at tip. Legs and feet strong. Plumage rich and soft.

"Sexes similar." 


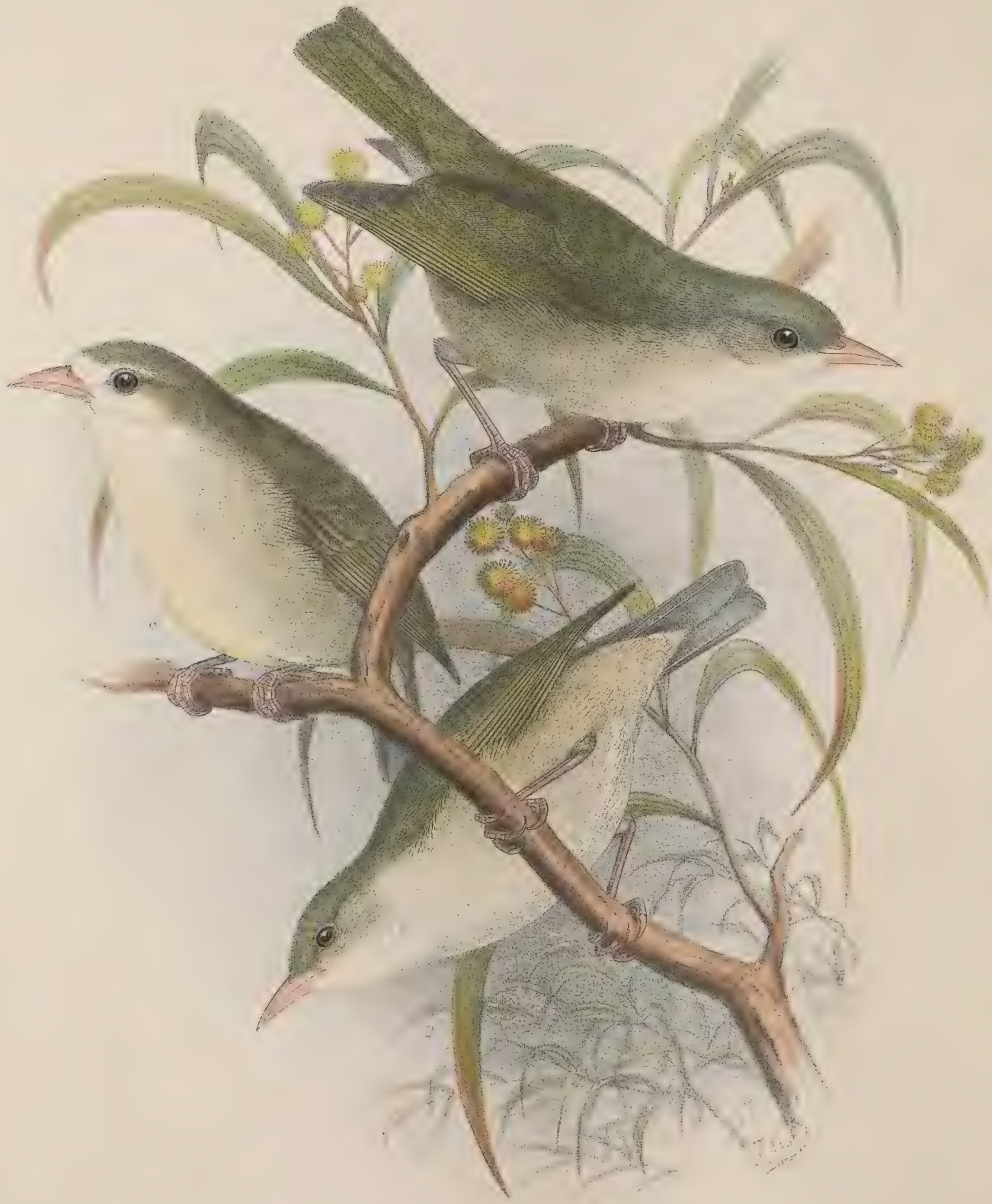




\title{
OREOMYZA BAIRDI.
}

\section{AKIKIKI.}

\author{
Oreomyza bairdi, Stejneger, Proc. U.S. Nat. Mus. 1887, p. 99 ; id. op. cit. 1889, p. 385 ; S. B. \\ Wilson, Ibis, 1890, p. 193. \\ Oreomyza wilsoni, Stejneger, Proc. U.S. Nat. Mus. 1889, p. 386.
}

THIS species was first obtained by Mr. Knudsen in Kauai, to which island it is peculiar, while an excellent description of it was given by Dr. Stejneger as above cited. It is usually met with in small flocks of from eight to twelve, and is a particularly active bird, continually running up and down the limbs and trunks of the high trees in search of insects; it is, in fact, the most energetic bird of the Hawaiian forests. Its short tail, in Dr. Stejneger's opinion, indicates terrestrial habits, but I only observed it at some considerable height from the ground, in the lofty ohia and koa trees, for the dead branches of which it evinces a decided preference; a flowering branch of the narrow-leaved variety of the latter, taken from a dried specimen, is well depicted in the Plate by Mr. Frohawk. The note is a simple twit, twit, twit, repeated constantly. Its range seems to reach an elevation of 3000 feet. Occasionally examples of this bird have the forehead white, and Dr. Stejneger upon them has founded a second species which he has done me the honour of distinguishing by my name. I do not think, however, that it is valid, as my examples were all obtained in one locality; but at the same time the variation in plumage does not seem to be due to sex.

Dr. Stejneger, in establishing a new genus for this bird says :- "This genus may be characterized as one of the nine-primaried Dicaidae (as defined by R. B. Sharpe, Cat. B. Brit. Mus. x. p. 2) distinguished (1) by having the nasal fossæ partly hidden by antrorse feathers; (2) by the absence of rictal bristles; $(3)$ by the elongated, but otherwise Loxops-like bill; (4) by the shortness of the first (ninth) primary, which is but slightly longer than the secondaries; (5) by the shortness and stoutness of the feet, the tarsus being not more than twice the hind toe without claw.

"In some respects the present form seems to agree with Pinaroloxias, Sharpe, especially in the profile of the bill. I can find no other structural character of consequence assigned to the latter species than 'the culmen flattened in front of the nostrils' (Sharpe, Cat. B. Brit. Mus. x. p. 3), a peculiarity not at all shared by Oreomyza.

"The most noteworthy peculiarity of the present genus is expressed by the wingformula, which seems to be unique among the Hawaiian members of the Dicaida, for all the other forms which I have been able to examine, viz. Hemignathus, Vestiaria, Himatione, Heterorhynchus (lucidus), Loxops (coccinea), and Psittirostra, have the first (ninth) primary never shorter than the fifth, while in Oreomyza it is shorter than the 
seventh, and only slightly longer than the secondaries, which in the other genera fall short of the tips of the exterior primary by more than the length of the hind toe without claw. I have examined carefully both specimens of Oreomyza bairdi and find they agree completely; I also find the quills are fully grown, so that there is no chance of their being undeveloped.

"Another important feature is the partial covering of the nasal fossæ by overhanging feathers, and the absence of real bristles. In the specimens of Loxops and Psittirostra before me, the nasal fossæ are likewise covered by antrorse feathers (in the cuts of the bills of these genera in the tenth volume of Cat. B. Brit. Mus. pp. 49, 51, the nasal fossæ are represented as entirely bare), and the bristles, if present, are slightly developed, while in the other genera strong and black bristles are seen guarding the base of the upper mandible.

"The hind toe is better developed, and the tarsus comparatively shorter than in the allied genera. Taken in connection with the rounded shape of the wing and the comparative shortness of the tail, it seems likely that the habits of the present form are more terrestrial than those of the other Hawaiian Dicoida."

To Dr. Stejneger's account, part of which is here transcribed, I can add that in freshly-killed specimens the bill is light brown, tinged with pink, the feet light pink, the irides dark hazel, and that the female is similar to the male; while the native name "Akakane" is incorrect, "Akikiki" being right.

Description.-Adult male. Above clear olive-grey, tinged with pale olive-green on rump and margins of tail-feathers and secondaries; beneath pale olive-buff, nearly white on chin, throat, and under wing-coverts, tinged with pale primrose-yellow on the fore neck, and suffused with olive-grey on the flanks; lores whitish; ear-coverts like the upper parts.

Dimensions (taken from a specimen in my collection).-Total length $4 \cdot 45$ inches, wing from carpal joint $2 \cdot 80$, culmen $\cdot 45$, tarsus $\cdot 65$, tail $1 \cdot 85$. 



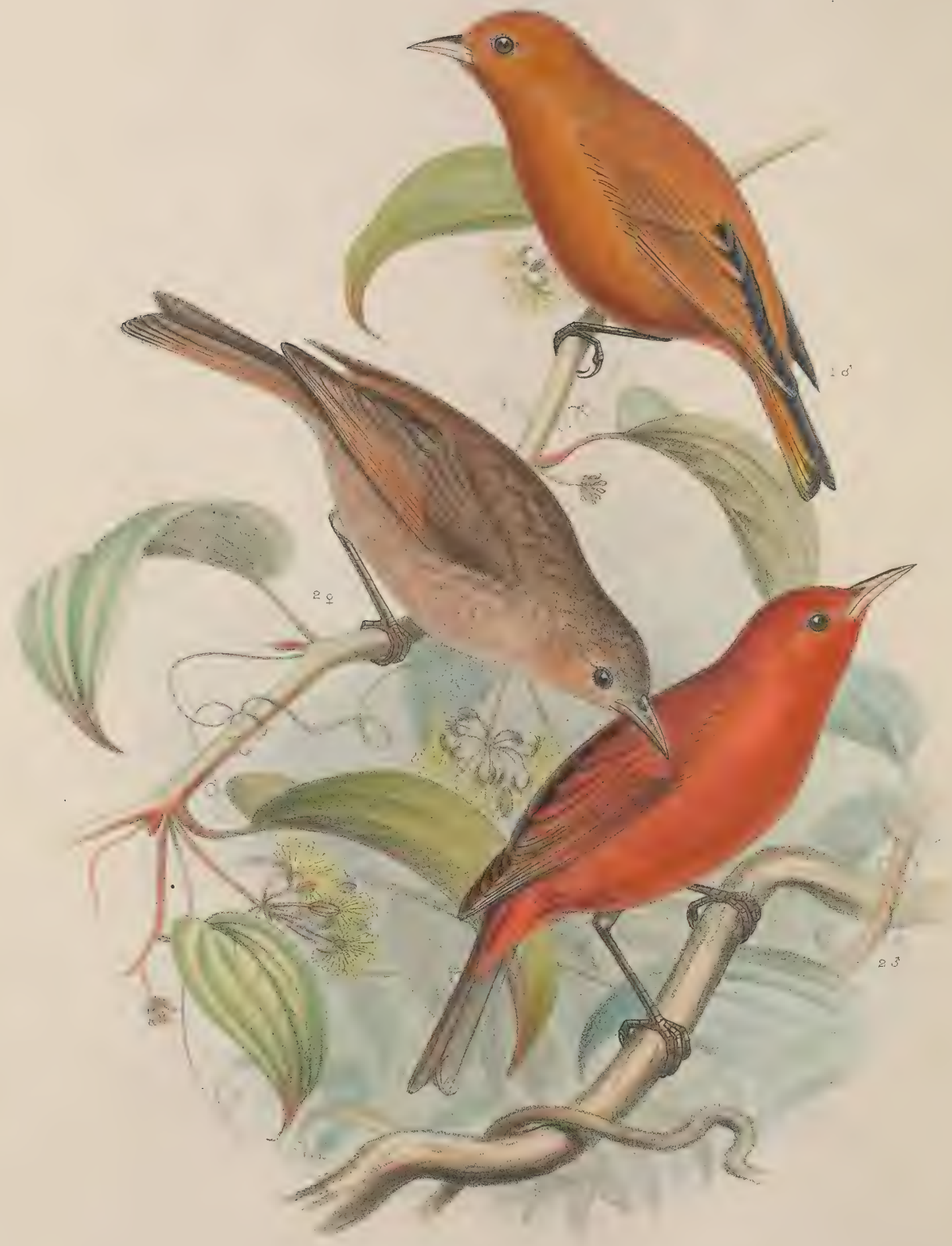




\title{
LOXOPS FLA MMEA.
}

\author{
KAKAWAHIE.
}

Loxops flammea, Scott Wilson, Proc. Zool. Soc. 1889, p. 445.

The new species of Loxops, of which the discovery is related here, was originally described in the 'Proceedings of the Zoological Society,' as above.

It is peculiar, as far as I can judge, to the island of Molokai, and I only procured three specimens during my stay, all at Kalae; it may not, however, be safe to consider it rare, as my host easily obtained the native name for me, thus showing the bird to be known to the aborigines. I met with all three examples on the same day, killing a male and female at the same shot. It was in one of those penetrating mists, which fortunately we did not often experience in the Sandwich Islands, that I had started early in the morning from Mr. Meyer's residence, accompanied only by a native boy, and till noon the day was clear; in the afternoon, however, the mist gathered and a cold rain began to fall; soon we were completely enveloped, and my native, well acquainted with the forest as he was, lost the way. While we were wandering about and searching for the trail, I heard a curious sound,- - continued chip, chip, chip, not unlike the sound of chopping wood when heard at a distance-which at first I did not think could belong to a bird; soon, however, I was undeceived, as a flash of brilliant orange colour passed us in the fog; when, on trying to follow it up, the continuous metallic note enabled me to get within range and I fired, bringing down two birds, which proved to be male and female. Soon afterwards I shot another of the bright-coloured males. We had by this time hopelessly lost our way, and the consequences might have been serious; so we were extremely glad to hear revolver shots at no great distance, which proved to be fired by Mr. Meyer's sons, who had come out in search of us. The name applied to this bird in the Hawaiian language means firewood; but whether this is given to it from the note, which, as remarked above, resembles the sound of chopping wood, or from the brilliant flame-colour of its plumage, I am unable to say.

Description.-Adult male. Front and sides of the head pure scarlet; top of the head and back brownish scarlet, brightening into nearly pure scarlet on the rump; chin, throat, and lower surface generally pure scarlet, but paler in hue, brightening, however, on the flanks; remiges and rectrices blackish brown edged with brownish scarlet; winglining pale scarlet. Bill and legs light pinkish brown.

Adult female. Top of the head hair-brown, but each feather brownish scarlet at the base, and the shafts of those towards the back of the head grey; back hair-brown 
tinged with red; rump distinctly russet; upper tail-coverts brownish scarlet; remiges and rectrices blackish brown edged with brownish scarlet, as also are the upper wing-coverts. Beneath, dull white tinged with pale scarlet; sides of the body reddish brown, and wing-lining white tinged with scarlet.

Dimensions. - Total length 5 inches, wing from carpal joint $2 \cdot 5$, culmen $\cdot 5$, tarsus $\cdot 75$, tail 2.

Obs.-Differs from $L$. coccinea not only in its much larger size, but in the intense purity of its scarlet, which replaces the scarlet-orange of that bird. 



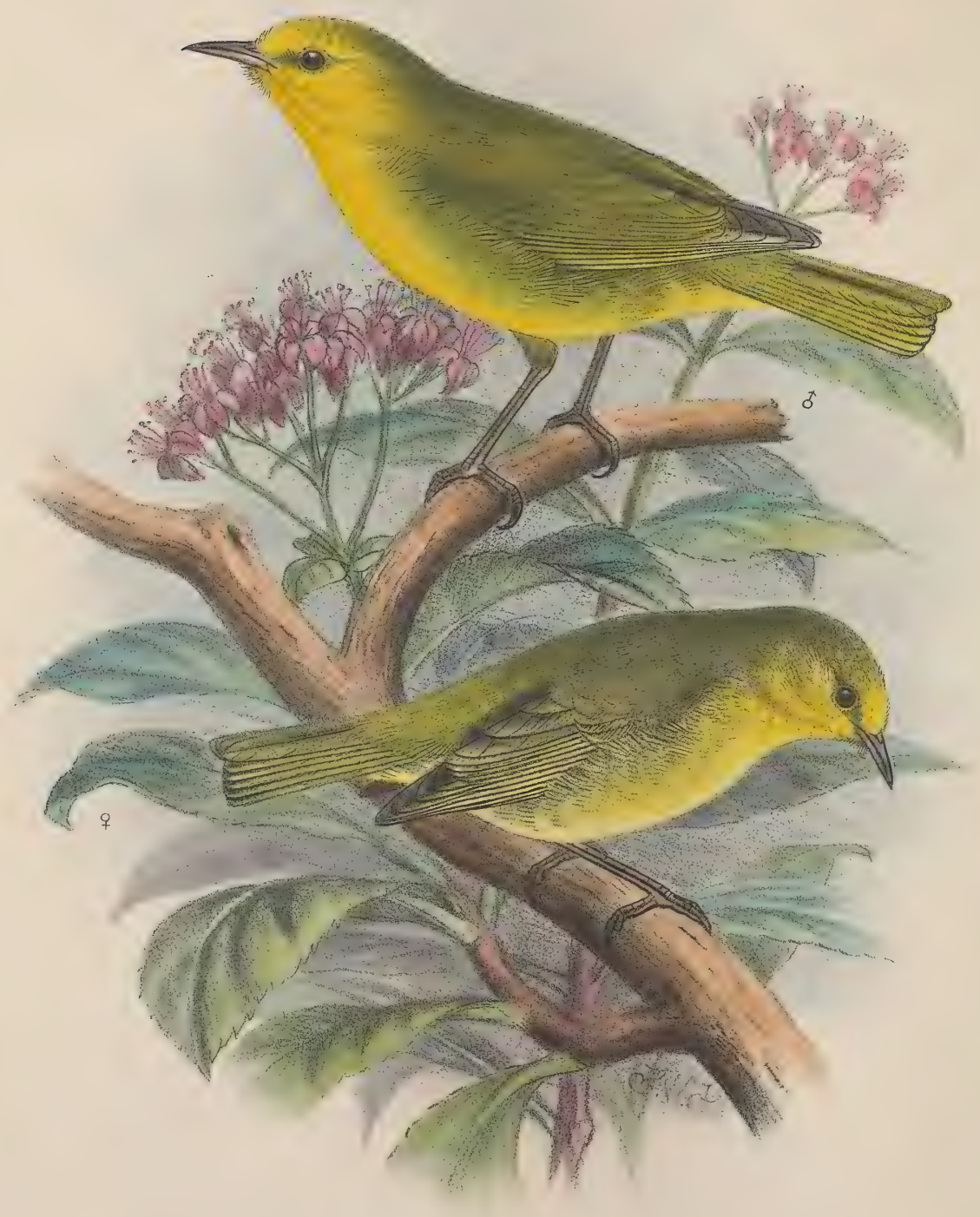

F.W.Frohawk del et Tith.

West, Newman imp.

HIMATIONE NEWTONI 


\section{HIMATIONE NEWTONI.}

Himatione newtoni, Rothschild, Bull. Brit. Orn. Club, i. p. xlii (1893).

Oreomyza newtoni, Rothschild, Avif. Laysan, p. 115 ; Perkins, Ibis, 1895, p. 122.

As will be seen from the above, this straight-billed form was discovered in Maui by the collectors of Mr. Rothschild, who accordingly described it in 1893 and considered it to be closely allied to $H$. montana of Lanai.

Mr. Perkins's remarks on the habits of the birds of this genus are of such interest that I think it advisable to reproduce them here, some of the species having already been treated in former parts of the present work. He says :-

"They are pre-eminently insect-eaters, hunting for these on the trunks and branches of the trees. Their cry is a monotonous 'chip, chip,' which they utter very vociferously when their haunts are intruded upon. It is a little different-rather less sharp-in the species found on Hawaii and Kauai (O. mana and O. bairdi).

"The two Oreomyzoe peculiar to Maui and Lanai (O. newtoni and O. montana) have a distinct song, short, rather vigorous, but very rarely heard. Apparently they sing only when intensely excited, as, for instance, when one male has been successful in driving off another intruding upon his domain ${ }^{1}$. On such occasions. I have seen the victor rise spirally upwards to a height of from twenty to fifty feet, pouring forth its little song while on the wing, then suddenly darting down again to the concealment of the brush. Very rarely indeed I detected the same species feeding on the nectar of the lehua flowers, and shot them with the beak dripping therewith. O. mana of Hawaii generally frequented the tall koa trees, also coming down into the underbrush of bastard sandal; 0 . bairdi, of Kauai, was mostly seen in the lehuas; the other species largely frequented the low brush, being frequently seen amongst the fernfronds and even on the ground. They feed much on caterpillars and small moths, which they find on the trunks and branches, climbing along the undersides of the latter and up the largest of the former with equal ease. Large moths, when caught, they hold down with their claws, tearing off the wings before eating them. To Owls they have the greatest aversion, and when one flies overhead they become greatly excited, all those in the neighbourhood joining in the clamour. I have seen some twenty or thirty Oreomyza gathered around one of these birds, which was sleeping on a dead branch, but they kept at a respectful distance, and did not venture out of the brush. It is highly probable that in past times they were largely preyed on by the

\footnotetext{
1 "This refers more especially to Oreomyza montana. O. newtoni I heard sing more frequently."
} 
Owls, the favourite food of which they possibly were, as they lack the objectionable odour of the other green birds, and the latter never seemed similarly frightened. As to the Owl (Asio accipitrinus) itself, it now preys mostly on the introduced mice, which abound, especially on the lower slopes and plains, but at times it may be seen hawking for small birds in parts of the forest where mice are quite absent. Moreover, it was probably much more abundant in past times, as it was never destroyed by the natives, who considered it a most powerful god. The old navigators speak of its great abundance and tameness; but since the settling of the country by white men it has been largely destroyed (though still abundant), since it is given to carrying off the newly-hatched chickens. 'To this day few natives will shoot at one of these birds.

"To one species referred to this genus by Mr. Rothschild in his book ("The Birds of Laysan,' \&c.) I have not alluded. 'This is the Himatione parva, of Kauai, which has neither the habits nor appearance of Oreomyza, but belongs rightly to the genus in which it was first placed. It is to a great extent a honey-sucker, like its congeners. The slight difference between it and them in the wing-formula is quite insufficient to detach it from its allies. It also has the nasal opercula bare, as in the other members, not overhung with antrorse feathers, like Oreomyza. But, apart from this, the formation of the tongue at once shows its proper place. In Himatione and Loxops this is elongated, very narrow, and terminates in a brush. The lateral margins are bent upwards, to meet in the middle line above, and form a tubular canal, for about half the length of the horny part of the tongue. In Oreomyza the tongue is very short and comparatively broad, the sides but slightly raised, and not nearly meeting above; it is not terminated in a brush, but the apex is cleft in the middle for some considerable depth. Himatione and Loxops (including Chrysomitridops) are at once distinguished from each other by the longer, thinner, more or less curved bill of the former, the beak of Loxops being short and thick with the apex of the mandible more or less deflected (either to the right or left), tending to cross the maxilla."

Description.-Upper parts dark olive-green, with a band of yellow on the forehead and above the eyes, which varies in breadth, though usually the front portion of the head is mainly yellow, the cheeks and middle of the lower surface being similarly coloured. 'The sides of the body are greenish, the bill and feet dark brown. In life the latter are said to be silvery grey with a pinkish tinge ${ }^{1}$.

Dimensions. -Total length $4 \cdot 5$ inches, wing $2 \cdot 5$, tail 2 , tarsus $\cdot 8$, culmen $\cdot 4$.

The female is greyer above and lighter yellow below, but does not differ from the male so much as is the case in many other species of the genus.

'Rothschild, Avif. Laysau, p. 115. 


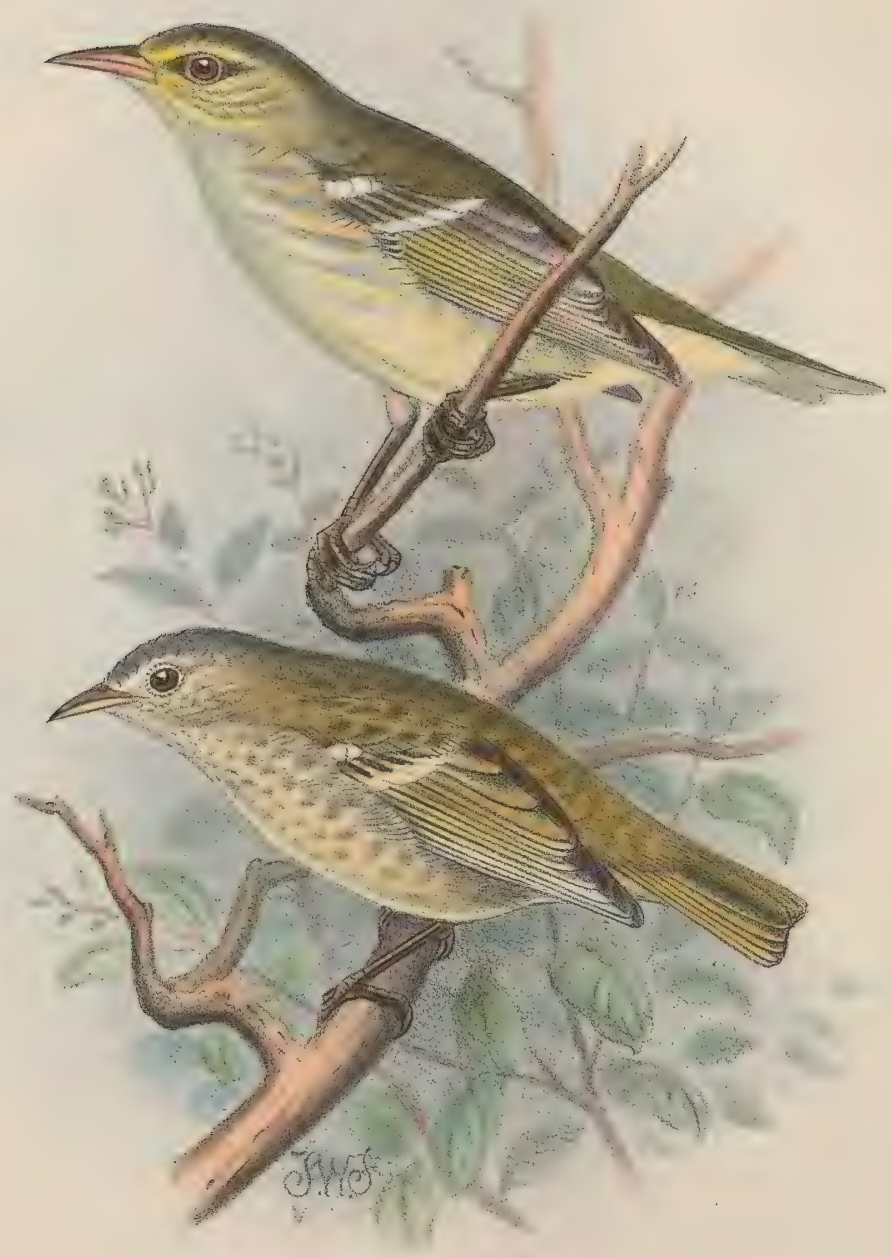

F.W.Frohawk del et lith. 


\section{HIM A TIONE MACULATA.}

AMAKIHI.

Himatione maculata, Cabanis, Mus. Hein. i. p. 100 (1850-51); Hartlaub, Arch. f. Naturgesch. 1852 , i. p. 110 ; Reichenbach, Handb. sp. Orn. p. 256 (1853) ; Bonaparte, Comptes Rendus, xxxviii. p. 264 (1854) ; Stejneger, Proc. U.S. Nat. Mus. 1887, p. 94; S. B. Wilson, Ibis, 1890, p. 186.

Drepanis (Himatione) sanguinea, juv., G. R. Gray, Cat. B. Trop. Isl. p. 9 (1859).

Himatione virens, Sharpe, Cat. B. Br. Mus. x. p. 9, partim (1885).

Viridonia maculata, Rothschild, Bull. Brit. Orn. Club, i. p. Ivii (1893).

Oreomyza maculata, Rothschild, Avif. Laysan, p. 113, pl. (1893).

THIS straight-billed bird, found only upon Oahu, was described by Prof. Cabanis, in the 'Museum Heineanum,' from a male and an immature female obtained in that island by Deppe when in company with Townsend in 1836-37. The validity of the new species seemed, however, more than doubtful to G. R. Gray, and afterwards to Dr. Sharpe when writing the tenth volume of the 'British Museum Catalogue of Birds'; for the first author considered it to be the young of Himatione sanguinea, while the last-named referred it to H. virens. Dr. Stejneger, nevertheless, reported it as certainly

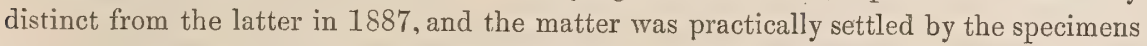
which I obtained in the same year, on my first visit to the Sandwich Islands. It is true that all of these examples were immature; but, owing to the kindness of the authorities of the Museum of the Academy of Natural Sciences of Philadelphia, I ras enabled to compare with them an adult male procured by Townsend, which is that described below. Mr. Rothschild, who at one time considered the bird to be a member of his new genus Viridonia, says: "Wilson remarks that Cabanis's name 'maculata' is inappropriate." This, however, was not the word that I used; I said that the name was " unfortunate"-which it certainly is, for the adult male exhibits no traces of spots,-and " unfortunate" has not the same meaning as "inappropriate."

Himatione maculata is fairly common in the district of Halemann, where there are still some remains of the former forest; and Palmer found it "not rare" in the upland region of Waialua at an altitude of 1500 feet and upwards, while Mr. Perkins obtained a considerable number of specimens at the same place and at Kawailoa in 1893, some of them at a rather lower elevation. Its habits resemble those of other members of the genus (Oreomyza) as limited in the Introduction. 
Description.-Adult male. Very similar to the adult male of H. chloris, but with the olive upper plumage darker, though tinged with yellow; forehead hardly brighter than the crown, but a distinct, though indefinitely marked, yellowish streak over the eye; lores brownish black; chin, cheeks, auriculars, and throat clear golden-yellow, which colour pervades the breast and belly, becoming very pale, almost white, on the abdomen; lower tail-coverts pale yellow. Wing-coverts with distinct whitish marks of considerable size.

Adult female. Very unlike the male above described. Streak over the eye and under parts white, tinged with yellow; sides of the body and flank-region greyish; upper parts olive-grey, showing whitish marks, which are much less distinct than in the male. Bill and feet rather dark brown. "Soles flesh colour and orange; iris dark brown "(Rothschild).

The male characterized above is not, however, the form usually found, even when the birds are breeding. No doubt its colour is such as would be expected, judging from the other species most nearly related to it; but the tints seem to be quite abnormal, as both sexes are usually coloured much alike, though the male has more distinct and rounder white wing-spots.

Dimensions.-Total length about 5 inches, culmen about $\cdot 6$, wing $2 \cdot 6-2 \cdot 8$, tail nearly 2 , tarsus 8 . 



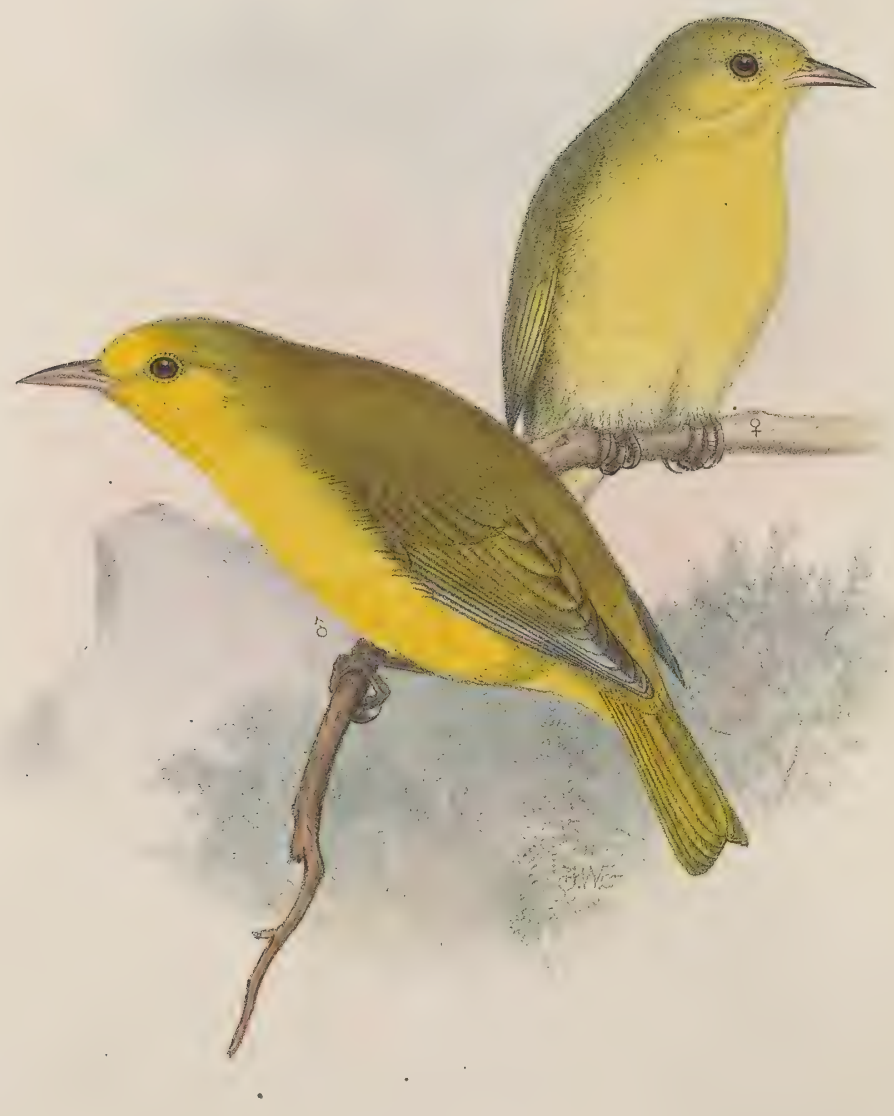

FW.Frohawk del.et7ith

West, Iewman imp

HIMATIONE MONTANA. 


\section{HIMATIONE MONTANA.}

Himatione montana, S. B. Wilson, Proc. Zool. Soc. 1889, p. 446.

I'HIs hitherto undescribed species I obtained in the mountain-region of Lanai, at a spot called Lanaihale (the house of Lanai), at a height of about 3000 feet, the brilliant yellow of the underparts in the freshly killed male and its nearly straight bill clearly showing it to be distinct from any other member of the genus. I only met with four specimens, of which I secured an adult male and female on the same day in the locality mentioned above, and subsequently two immature examples in a gulch at a much lower elevation. As, perhaps, an account of our mountain trip on the day on which I shot the former may be of interest, I here transcribe from my Journal some notes, taken on the spot:-

"Ist June, 1888.-To-day we took two natives, one of them armed with an axe with which to clear the path for us. The day was fine, and the trail by which one ascends to the plateau was consequently in good order, so we arrived there without accident. Here we tied up our horses, and then all of us started down a narrow forest-path, the same which we had followed the day before. For a few hundred yards it is thickly overhung with ferns (Gleichenia) and the climbing Ieie (Freycinetia arborea), and we had almost to take to our knees, which was intensely tiring work. After this thick bit it becomes more open, owing to the presence of wild pigs; and here F. and I, with one of the natives, waited, as it was at this spot that $\mathrm{Mr}$. Gibson had shot some birds the previous day. I was very unlucky in not finding several specimens which I killed; Mr. Gibson soon returned with a few birds, but of the same species that I had already obtained in Hawaii. From here we started about 12 o'clock, following the path, to try to make the summit of the mountain. Before long the path emerges from the thick scrub and comparatively tall trees on to a plateau, where the scrub only reaches to one's knees. From this open plateau we had a magnificent view of the west side of the island, with Molokai and Maui in the far distance, surrounded by a bright blue sea. The path then ascends gradually till we reach a point overlooking Palawai Valley, which looks a mere dot in the landscape, so far is it below us. We followed the path a little higher; here it becomes decidedly steep, and the rich light yellow soil is very slippery as far as the top of the mountain; the ohia and other trees are of considerable size, but we could neither hear nor see any birds. However, at a point called Lanaihale, on our return journey, I caught sight of a bright yellow bird in an ohia bush, a few yards down the side of the gulch; I put my gun instantly to my shoulder and fired, and down came the bird; F. and I scrambled down the gulch and fortunately found it. 
Its breast was of a brilliant yellow, far brighter in tint than the plumage of any other species I had previously obtained; its legs and bill were a light pink: in dissecting it I found some small larvæ."

No words of mine can convey an idea of the difficulty and danger of collecting in the mountains of Lanai; this is due to the almost impenetrable bush which covers the upland plateau, to the fogs which render riding extremely dangerous, and to the rains which make the nearly perpendicular mountain-trails treacherous even to a sure-footed Lanai horse; indeed, inured as I was to "steep bits" in my islaud travels, I must confess that the first trip we made into these solitudes surprised me. I must here mention that the discovery of this interesting species is due to the kindness of my friend Mr: Henry Gibson, in kindly acting as our guide on our explorations, and also to the late Mr. Jesse Morehead's invariable kindness to me during a stay of some weeks' duration under Mr. F. H. Hayselden's hospitable roof.

Description.-Adult male. Forehead, sides of the face, and throat deep lemon-yellow, shading into a lighter tint of yellow on the breast and abdomen, the lower part of which is white; under tail-coverts deep lemon-yellow; upper parts, with the exception of the rump, which is yellow, are dull greenish yellow; primaries (of which the second is much shorter than the fourth and fifth, which are equal) ashy brown; edged with dull yellow; wing-lining white, tinged with clear yellow ; tail-quills ashy brown edged with dull yellow; bill light pinkish; feet slender, of the same colour as the bill.

Adult female. Similar in general colour to the male, though the underparts are of a very light shade of lemon-yellow instead of the deep yellow of the male.

Dimensions. - Total length 4 inches, wing from carpal joint $2 \cdot 25$, culmen $\cdot 35$, tarsus $\cdot 70$, tail $2 \cdot 75$.

Obs.-The bill in curve approaches nearest to Oreomyza and in size to Himatione parva, Stejn. 



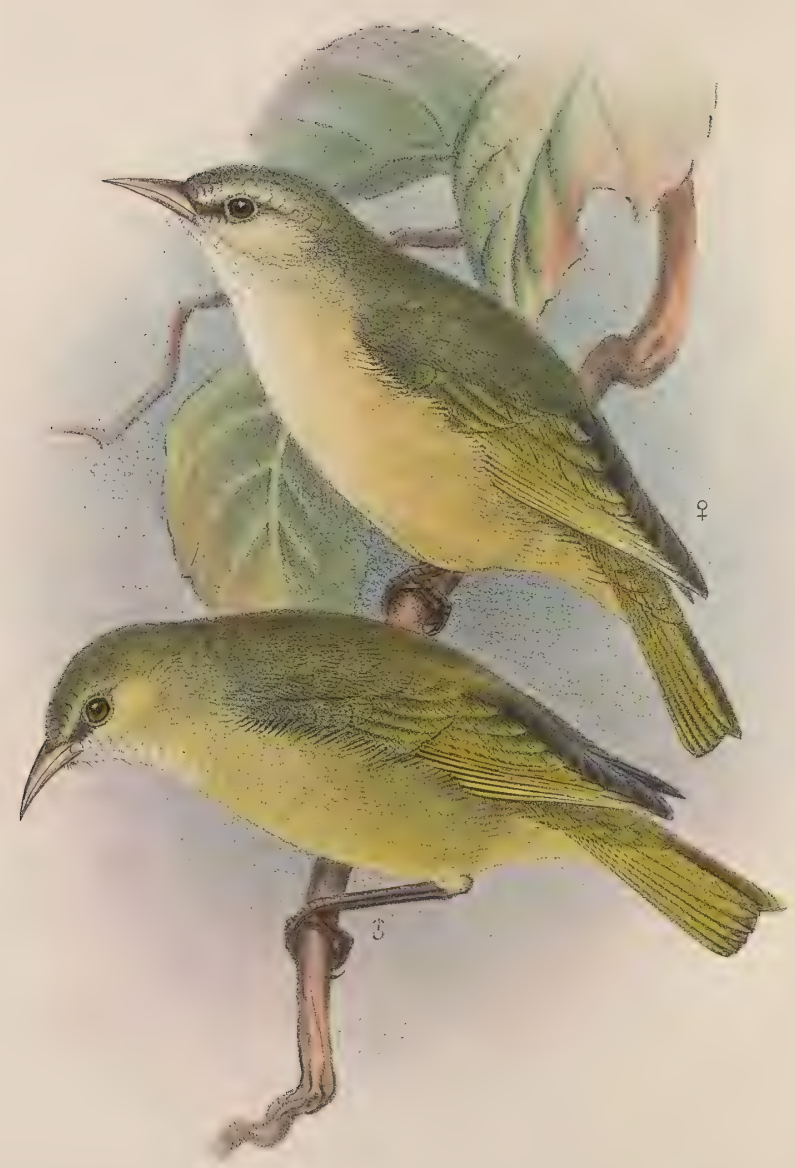




\section{HIMATIONE MANA.}

Himatione mana, S. B. Wilson, Ann. \& Mag. Nat. Hist. ser. 6, vii. p. 460 (1891).

OF this new species I only obtained three specimens; and I must confess that I did not recognize its distinctness from Himatione virens, inhabiting as it does the same localities in Hawaii, until I examined my examples with Professor Newton; while Count T. Salvadori, on looking over the birds in my collection, remarked its similarity to Oreomyza bairdi in the nearly straight bill and the plumage of the underparts, especially in the female.

Description.-Adult male. Head ashy olive, shading into dull olive-green on the back; beneath dull greenish buff, except the chin and throat, which are whitish; wings and tail brown, edged outwardly with olive-green.

Female. Duller on the upper parts, while the chin and throat beneath are nearly white, the rest of the underparts more buff than in the male.

Dimensions.-Total length $4 \cdot 45$ inches, wing $2 \cdot 50$, culmen $\cdot 45$, tarsus $\cdot 70$, tail $1 \cdot 40$. 



\section{LOXOPS COCCINEA.}

\section{AKEPEUIE.}

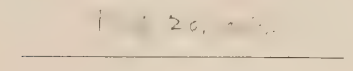

"Scarlet Finch," Latham, Gen. Synops. ii. p. 270 (1783).

Fringilla coccinea, Gmelin, Syst. Nat. i. p. 921 (1788); Latham, Ind. Orn. i. p. 444 (1790); Donndorff, Orn. Beytr. ii. p. 541 (1795) ; Tiedemann, Anat. Naturgesch. Vög. ii. p. 433 (1814) ; Stephens, Shaw's Zool. ix. p. 454 (1815) ; Cuvier, Règne Anim. i. p. 387 (1817); Vieillot, N. Dict. d'Hist. Nat. xii. p. 167 (1817) ; id. Encycl. Méthod., Ornithol. p. 983 (1823); J. E. Gray \& Griffith, An. Kingd. Aves, ii. p. 140 (1829); G. R. Gray, Gen. B. ii. p. 371 (1849).

"Le Moineau des Iles Sandwich," Sonnini, Hist. Nat. Buffon, Ois. xii. p. 251 (1802).

"Chardonneret écarlate," Vieill. Ois. Chant. pl. 31 * (1805).

Fringilla rufa, Bloxam, Voy. 'Blonde,' p. 250 (1826); J. E. Gray, Zool. Miscell. p. 11 (1831).

Carduelis coccinea, Lesson, Compl. Buffon, viii. p. 281 (1837).

Linaria? coccinea, Gould, Zool. Voy. 'Sulphur,' p. 41, Birds, pl. $22 *$ (1843).

Drepanis rufa, G. R. Gray, Gen. B. i. p. 96 (1847).

Loxops coccinea, Cabanis, Arch. f. Naturgesch. 1847, i. p. 330 ; G. R. Gray, Cat. B. Trop. Isl. p. 28 (1859); id. Hand-l. B.i. p. 114 (1869) ; Sclater, Ibis, 1871, p. 360, 1879, p. 92 ; Sharpe, Cat. B. Br. Mus. x. pp. 49, 50 (1885).

Hypoloxias coccinea, Bonaparte, Consp. Av. i. p. 518 (1850) ; Lichtenstein, Nomencl. Av. p. 48 (1854) ; Hartlaub, Arch. f. Naturgesch. 1852, i. p. 133; Dole, Proc. Bost. Soc. N. H. 1869, p. 301 ; id. Hawaiian Alman. 1879, p. 49.

Loxops coccineus, Von Pelzeln, Journ. f. Orn. 1872, p. 29.

"Byrseus coccineus, Reichenbach," Bonaparte ut suprà [Byrseus, Reichenbach, Natürl. Syst. Vög. tab. lxxv. (1850)].

Drepanis aurea, Dole, Hawaiian Alman. 1879, p. 45.

Loxops aurea, Sharpe, Cat. B. Br. Mus. x. p. 50, partim (1885).

* Figurae notabiles.

THis is one of the birds of which examples have always been so rare in museums that few persons have had opportunities of examining them, and in consequence we have an involved synonymy. Brought home by Cook's people, and originally described by Latham from the Leverian Museum, it was named Fringilla coccinea by Gmelin, but unfortunately received the new appellation of $F$. rufa from Bloxam; while G. R. Gray, having the 'Blonde' specimens before him, referred them in 1847 to the genus Drepanis, retaining also, in 1849 , the original $F$. coccinea as a distinct species; Gould, moreover, in the Zoology of the Voyage of H.M.S. 'Sulphur,' failed to perceive that the so-called.two species were identical. Further confusion has been caused by Judge Dole, who, while including $F$. coccinea in his list, redescribed it there as Drepanis aurea 
from an example in Mills's collection, which has been examined by myself. The curved and slender bill makes its reference to Drepanis, as that name has been sometimes used, excusable; but Dr. Finsch unfortunately referred (Ibis, 1880, p. 80) to the so-called " $D$. aurea" - the type of which came from Hawaii-the birds which he obtained in Maui, belonging to a wholly different species, as is elsewhere shown in the present work.

This bright-coloured species is confined to the Island of Hawaii, where it is so uncommon that during eight months' collecting I obtained but five specimens. It may be of interest to state the localities and give some details of the capture, as this is one of the rarest of Hawaiian birds, and cannot, I think, be far from extinct. The first example that I procured was on June 15th, 1887, at a ranche called Puulehua, in the district of Kona, at an elevation of 5000 feet, and, soon after, I got another in the same locality, while a third was shot by my friend Mr. Horswill in September, about three miles from the Volcano House, on the Keauhou road. I had seen this bird the day previous, sitting on an old stump of an ohia tree, and had fired at it but missed; yet the next day on our return to the spot we found it not thirty yards from where we had seen it before, and Mr. Horswill shot it. It is a curious fact that the natives at the house insisted it was the far-famed Mamo (Drepanis pacifica); and this ignorance tends to show that that species cannot have been seen of late years, as here were natives living within fifteen miles of Olaa-formerly a famous bird-catching resort, and supposed to be the home of the Mamo,-confounding it with a bird totally unlike it in form and colour. Again, in January 1888, when shooting in the forest on Puukapu near Waimea, in company with Mr. Frank Spencer, jun., I saw an example of this species in the flower-covered branches of an ohia tree, and called to my friend to fire; he killed it and brought down an Amakihi (Himatione virens) with the same barrel. My fifth bird was shot within a few miles of Mana, the Hon. Samuel Parker's residence. These five specimens were all obtained at altitudes ranging from 3000 to 5000 feet, so that the habitat may be said to be the middle and upper forest-zones; and there seems to have been less difficulty in obtaining them in former times, as more than one of the old explorers procured several during comparatively brief stays on the island. A good figure of the male was given by Gould in his account of the birds of the Voyage of the 'Sulphur.' That ship appears to have made Honolulu its headquarters, which the explorers reached on July the $17 \mathrm{th}, 1837$; there they remained till the $27 \mathrm{th}$, much of the interval, as the narrative tells us, being very agreeably spent among the lovely valleys of Oahu. It is probable, therefore, that most of their collecting was done on that island, but as they revisited the Islands in June 1839, they very possibly landed on and explored Hawaii, to which this species is, so far as I know, peculiar. Bloxam, Voy. 'Blonde,' App. p. 250, gives a brief description of it from specimens obtained by the expedition; he mentions Akepakepa as its Hawaiian name, which has some resemblance to its proper title of Akeperie. No reference to the island which is its home is made by any of the authors who have hitherto noticed it, except by Judge Dole (Hawaiian Almanack, p. 45, 1879), who, after describing an example belonging to the 
late Mr. Mills, goes on to say that M. Bailleu had observed a brown variety which might be the female. As I have elsewhere remarked, $\mathbf{M}$. Bailleu made his collections in Kona (the place where my first two specimens were obtained), while those in the Mills cabinets were probably procured in the vicinity of Olaa. I have examined the birds in the British Museum of Natural History, obtained by Bloxam, and that described by Gould in the Voyage of the 'Sulphur,' and find that they are identical with mine, though the brilliant orange has faded to a great extent.

Description.-Adult male. General colour of the whole of the upper surface scarletorange, inclining to a brownish tint on the back; lower surface also scarlet-orange but of brighter hue, especially towards the abdomen; wing-quills and tail dusky brown edged with brownish orange; wing-lining whitish washed with light scarletorange; irides dark hazel; bill bluish black; feet black.

Dimensions.-Adult male. 'Total length 4.5 inches, wing from carpal joint 2.45 , culmen $\cdot 35$, tarsus $\cdot 85$, tail $1 \cdot 65$.

Obs.-Of my five specimens none were females, so I am unable to say whether the sexes differ. 



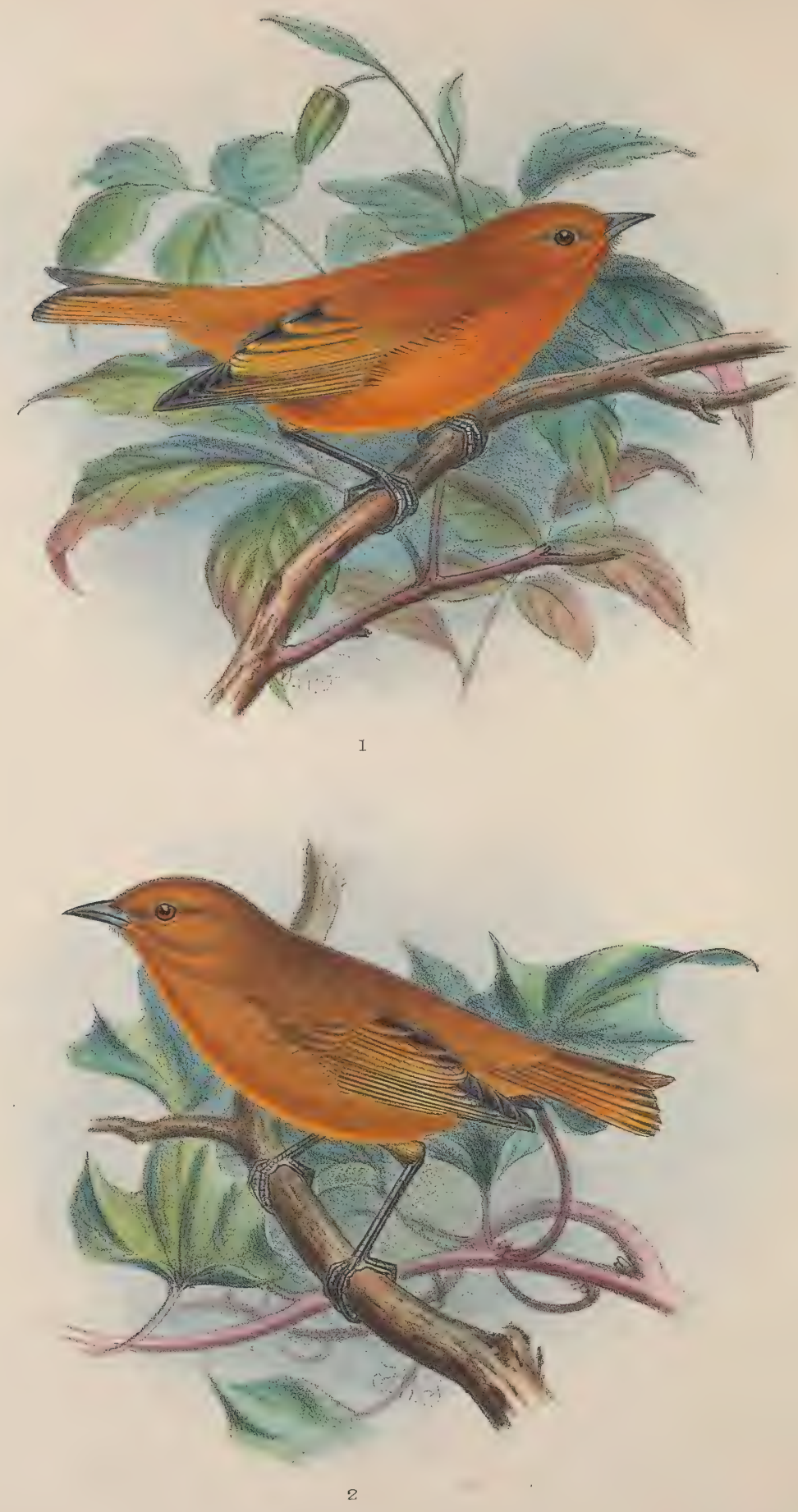

F.W.Frohavk del etlith. 


\section{LOXOPS RUFA.}

Fringilla rufa, Bloxam, Voy. 'Blonde,' p. 250 (1826); J. E. Gray, Zool. Miscell. p. 11 (1831).

Linaria ?coccinea, Gould, Voy. 'Sulphur,' p. 41, Birds, pl. 22 (1843) (see Fringilla coccinea, Gmel.). Drepanis rufa, G. R. Gray, Gen. B. i. p. 96 (1847).

Loxops coccinea (pt.), G. R. Gray, Cat. B. Trop. Isl. p. 28 (1859); id. Hand-l. B. i. p. 114 (1869);

Sharpe, Cat. B. Br. Mus. x. pp. 49, 50 (1885); Wilson, B. Sandw. Isl. pt. i. (1890).

Loxops wolstenholmei, Rothschild, Bull. Brit. Orn. Club, 21 June, 1893, p. lvi.

Following the example of the late Mr. G. R. Gray in 1859, of Dr. Sharpe in 1885, and others, I was led in my account of Loxops coccinea to suppose that the Fringilla rufa of Bloxam, the types of which (obtained during the visit of the 'Blonde' to the Sandwich Islands) still exist in the British Museum, was identical with the $F$. coccinea of Gmelin. This belief was strengthened by the fact that a specimen of the same species from Gould's collection (probably that figured in the 'Voyage of the Sulphur'), and also in the same museum, had also been referred by him to $F$. coccinea. It is true that these examples possessed little of the vivid colouring displayed by my own recently obtained examples of the latter; but this was attributed to the former having been for so many years exposed to the effects of the London atmosphere, which seemed sufficiently to account for their faded appearance, on which I duly remarked at the time. Knowing, however, that most of Bloxam's specimens must have been procured in Oahu, where I was not so fortunate as to meet with a Loxops, and finding that Mr. Rothschild had described a species of that genus from that island, I was induced to look again into the matter, and then it was evident that Bloxam's birds were perfectly distinct from the Hawaiian $L$. coccinea, and must be recognized under the name of L. rufa, of which Mr. Rothschild's $L$. wolstenholmei is a synonym, as he has since admitted.

Mr. Perkins, who was with Wolstenholme in Oahu when he shot an example for Mr. Rothschild, has also examined the specimens in the British Museum and agrees to their identity.

As J. E. Gray and Gould had the opportunity of examining the bird when the colours were comparatively fresh, I here subjoin their descriptions, in preference to re-describing it in the present faded condition.

The former says:- "Body red-foxy; lores blackish; wing and tail olive-brown; wing-coverts, quills, and tail red-edged, inner edge of quills and under wing-covert white; bill short, triangular, conic, tip straight, acute, whitish; feet brown; tarsus 
9 lines. Mr. Bloxam describes 'the tongue as short, tubular, and divided [into] filaments at the end!'”

Gould says:- "The whole of the plumage rich rusty-red, deepening into brownishred on the back; wings and tail brown, margined with rusty-red; bill horn colour; feet black.

"Total length 4 inches, bill $\frac{7}{15}$, wing $2 \frac{1}{4}$, tail $1 \frac{3}{4}$, tarsi $\frac{3}{4}$." 



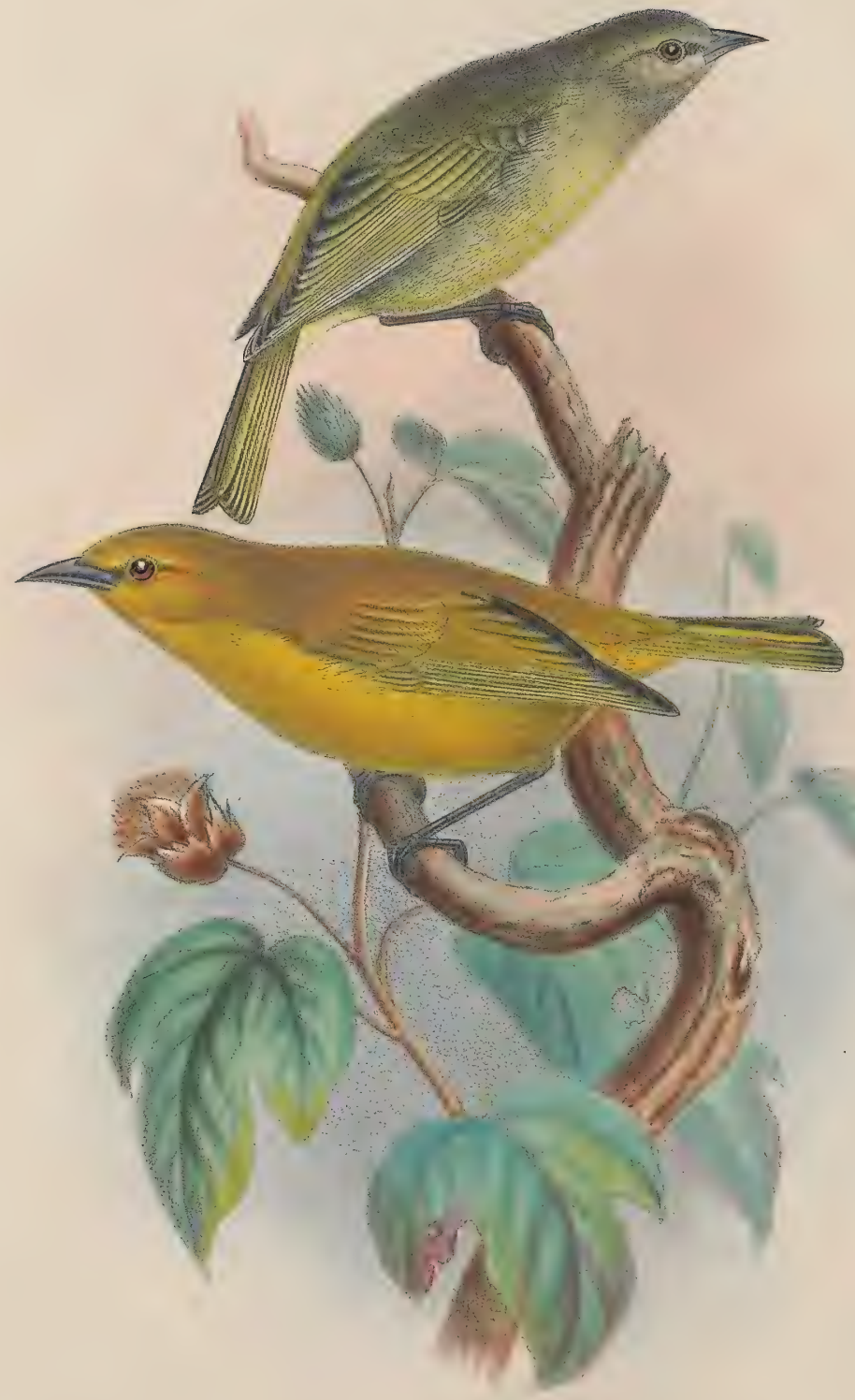

West, Newman imp.

FWW Frohawk del et lith.

HIMATIONE AUREA. 


\section{LOX OPS AUREA.}

Hypoloxias aurea, Finsch, Ibis, 1880, p. 80 (nec Drepanis aurea, Dole, 1879).

Loxops aurea, Sharpe, Cat. B. Br. Mus. x. p. 50 (1885) ; Perkins, Ibis, 1895, p. 121.

Loxops ochracea, Rothschild, Bull. Brit. Orn. Club, 21 Dec., 1892, p. xvi (descr. null.); id. Ibis, 1893, pp. 112, 281.

Himatione aurea, Wilson, B. Sandw. Isl. part iv. (1893) (cancelled).

I HAVE very much to regret that in a former part of the present work I erroneously referred this species to the genus Himatione, and in extenuation of my mistake can only urge that the type specimens obtained by Dr. Finsch, and obligingly forwarded by the authorities of the Berlin Museum for the use of this work, were unavoidably in my hands but for a very short time. I was of course unwilling to detain them any longer than was necessary, and the greater part of their brief sojourn in England was passed with Mr. Frohawk, who has carefully depicted them. One advantage has, however, followed from this mischance: I am now able to avail myself of the extremely interesting observations of Mr. Perkins, which show that this species, of which so little had been known before, is dimorphic-an uncertain number of the cock birds assuming a red plumage; and by favour of the Joint Committee of the Royal Society and the British Association I am allowed to figure one of the beautiful examples obtained by that gentleman, in addition to the types of Dr. Finsch's Hypoloxias aurea.

Mr. Perkins's remarks are:-

"In the genus Loxops, which contains the smallest of the native birds, the different species have much the same habits, and the song, which is short and simple, though sweet, is nearly the same in all. Their call is a plain 'keewit, uttered once or repeated, and is constantly to be heard. 'They seek their food amongst the leaves, especially at the ends of the branches, more rarely on the limbs themselves. It consists largely of caterpillars and the smaller spiders. They also suck the nectar of the ohia flowers (Metrosideros); this I saw them do but rarely, and only two of the species, $L$. aurea and $L$. [Chrysomitridops] caruleirostris. Most often, when seen amongst the blossoms, they were merely seeking insects, thereby attracted; but several times I shot specimens with the beak dripping, and on tasting the fluid found it to be, beyond doubt, the nectar of these flowers.

"From the other green birds, their green young and females are readily distin- 
guished, at any height, by their more forked tails, which, combined with their short thick beaks, give them a very Finch-like aspect.

"The young generally follow the parents (some going with the male, and some with the female), who feed them most assiduously even after they appear well able to shift for themselves.

"The difference in colour of the sexes is very marked, while the male of $L$. aurea is dimorphic (yellow or red), though with occasional intermediate forms. L. cceruleirostris of Kauai, so far as colour is concerned, has claim to be considered the primitive form, both sexes largely retaining the green plumage, which only appears in the female and young of the red species on the more southern islands.

"On one occasion I saw a pair of $L$. aurea building, high up in a tall ohia tree, toward the end of a branch. They came down to the ground for material, stripping off the brown down that covered the young fronds of some stunted 'pulu' ferns. On another occasion I watched a pair sporting on the wing, now ascending, now descending, but gradually rising upwards till they became mere specks in the sky. It must have been several minutes before they finally alighted at no great distance from their starting-point. Both were splendid males."

Dr. Finsch thus describes his types:-

"Uniform orange; quills blackish brown, margined externally with the same colour, but more sordid; covers of primaries and secondaries on the outer webs broadly margined with dull orange. Bill hornish-blue, tip blackish; iris dark brown. Stomach containing nests of insects (caterpillars). First and third primaries longest, first scarcely shorter.

"Young (just able to fly, and fed by the former).-Upper parts dull olive-green, the outer margin of the dark brown quills and tail-feathers more vivid, the same as the tips of the secondaries, which form a pale cross band on the wing; lower parts pale olive-yellow, chin passing into whitish; bill horn-blackish, tip darker; feet black; third and fourth primaries longest, second equal to fifth, somewhat shorter; first a little shorter; tail twelve feathers. Tongue ordinary, bifurcated at tip."

The red form, which is here figured on the same Plate as the orange, only differs in the brighter coloration; but it should be observed that the lower figure (from Dr. Finsch's type) shows a somewhat intermediate bird, not so yellow as in some cases.

The question of the trivial name which this species should bear is one that may interest those fond of nomenclatural puzzles. It is beyond all doubt the Hypoloxias aurea of Dr. Finsch, admirably described by him in 1880. But he, by a very pardonable mistake, wherein he was followed in 1885 by Dr. Sharpe, referred it to the Drepanis aurea of Judge Dole, which, as I have already mentioned, I had ascertained (from examining the type while I was in Honolulu) to have been founded on an immature specimen of the Hawaiian species, Loxops coccinea. It is therefore open for some to urge that the term aurea is precluded to any other species of Loxops; but, on the other hand, it is to be observed that this term originally appearing in connexion with Drepanis was a wholly inaccurate generic assignment, while as used by 


\section{HIMATIONE A UREA.}

Hypoloxias aurea, Finsch, Ibis, 1880, p. 80 (nec Drepanis aurea, Dole).

IN 'The Ibis' for 1880 Dr. Finsch described two examples of this species, which he procured at Olinda in Maui, and referred them to the genus Hypoloxias. On examination, however, I find that they undoubtedly belong to Himatione, while care must be taken not to confound the bird, as the above author has done, with Drepanis aurea of Dole (Hawaiian Alman., 1879, p. 45), by which may possibly be intended Loxops coccinea from Hawaii.

I regret that during a short stay on Maui I did not procure specimens, not having collected at Olinda or having met with the species when exploring at similar elevations; but I am enabled to give a figure, thanks to the kindness of the authorities of the Berlin Museum, who forwarded the two examples obtained by Dr. Finsch for my inspection.

The adult is very dull orange above and below-the colour somewhat that of the breast of the young in Vestiaria coccinea, but more dingy: it appeared, however, much faded, and would probably be a bright golden yellow in a freshly killed bird.

Dr. Finsch's description of the type specimens is as follows:-

"Uniform orange; quills blackish brown, margined externally with the same colour, but more sordid; covers of primaries and secondaries on the outer webs broadly margined with dull orange. Bill hornish-blue, tip blackish; iris dark brown. Stomach containing nests of insects (caterpillars). First and third primaries longest, first scarcely shorter.

"Young (just able to fly, and fed by the former). Upper parts dull olive-green, the outer margin of the dark brown quills and tail-feathers more vivid, the same as the tips of the secondaries, which form a pale cross band on the wing; lower parts pale oliveyellow, chin passing into whitish ; bill horn-blackish, tip darker; feet black; third and fourth primaries longest, second equal to fifth, somewhat shorter, first a little shorter ; tail twelve feathers. Tongue ordinary, bifurcated at tip." 
. 
Dr. Finsch it was correctly referred (Hypoloxias being merely an equivalent of Loxops), and, accordingly, it may be reasonably contended that justice to the perspicuity of this distinguished ornithologist demands that his name should not be set aside. So far as practice is concerned no confusion is likely to follow from maintaining the term aurea in Dr. Finsch's sense; and, as Mr. Rothschild was neither the discoverer nor the first describer of the species, and could not have known except from my work what the "Drepanis aurea" really was, there seems no need to treat his name for the Maui bird otherwise than according to the strictest law, which to me does not appear to require the adoption of his subsequently conferred designation of ochracea.

Dimensions. - Total length 4.5 inches, wing $2 \cdot 6$, tail $1 \cdot 9$, tarsus $\cdot 75$, culmen $\cdot 38$. 



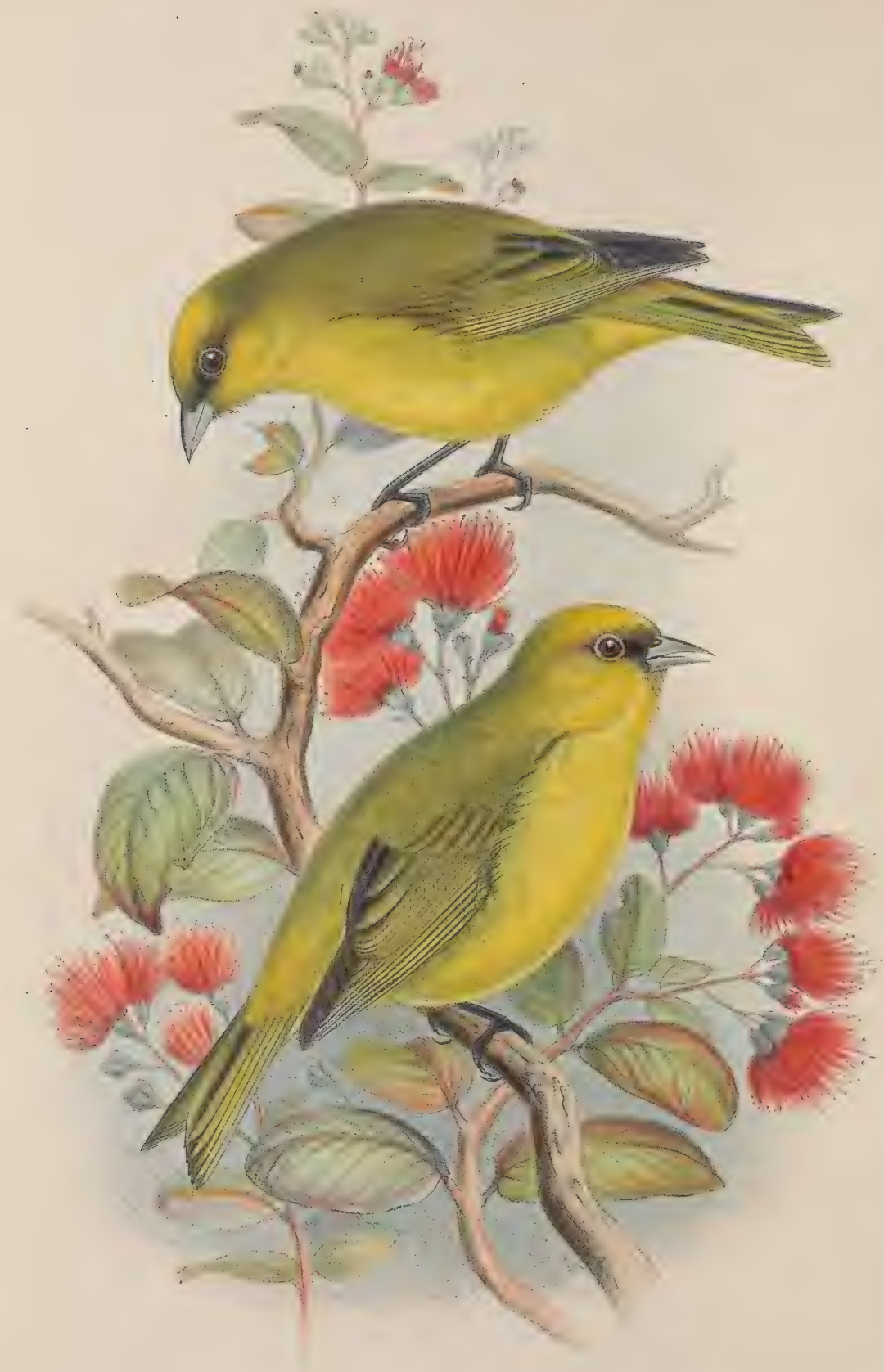




\section{CHRYSOMITRIDOPS CERULEIROSTRIS. \\ O-U HOLOWAI.}

Chrysomitridops caruleirostris, Scott Wilson, Proc. Zool. Soc. 1889, p. 445.

THIs interesting novelty $\mathbf{I}$ obtained in the district of Waimea, in Kauai, during October 1888, at an elevation of about 3000 feet, and, as far as can be determined, it is confined to that island. The Siskin-like song serves to distinguish it from Himatione parva, with its low plaintive "tweet," in company with which it is generally found, the two birds frequenting in common the lower branches of the ohia trees (Metrosideros polymorpha). The first specimen which I shot, whilst flitting about a flower-covered ohia at a considerable height from the ground, I took for $H$. parva; and great was my delight, on picking it up, to find I had secured a variety quite unknown to me. The general colour of the two species is much alike, but the bright prussian blue of the bill of Chrysomitridops is most striking in a freshly-killed example and has no other counterpart in the Sandwich Islands. Mr. Francis Gay-whose knowledge of the birds of the group is very considerable-had not previously met with it, nor, as far as I am aware, had Mr. Knudsen, whose labours in regard to the Hawaiian Avifauna are so well known to science; so that it seems that I was fortunate to come across it, with two such good observers already in the field. It cannot be common, as during a stay of some days in the mountains I seldom saw it, and never in the lower forestzone. On my return to Makaweli, Mr. Gay showed my new bird to a large number of natives in the employ of the Sinclair family, and but one, at the time, gave it a nameO-u holowai; subsequently another old native, who seemed to recognize it, applied to it the same name; $\mathrm{O}-\mathrm{u}$ is the local name of Psittirostra psittacea, holo means "to fetch" and wai "water" in the Hawaiian language.

At first it seemed doubtful whether this generic form should be assigned to the Finches or to the Honey-eaters; the slightly-covered nostrils indicated the latter, but the mucronate tips of the secondary quills appeared to point to a Fringilline affinity. The first part of the name "O-u holowai" tends to show that the islanders recognize a likeness to the $\mathrm{O}-\mathrm{u}$ (Psittirostra psittacea), which is undoubtedly allied to the Finches. I brought home specimens of Chrysomitridops in alcohol with the idea of settling this point, but unfortunately the box containing them and several other species was lost during my journey to England; however, I may mention here that since my return a specimen of this species has been sent to me in alcohol, which, as will be seen in another portion of this work, has enabled Dr. Gadow to determine its relations with the Drepanidida. 
Description.-Adult male. Bill light prussian blue, darker on maxilla. Lores black, meeting below the chin and in front, where the black passes into olive and is succeeded by an ill-defined coronal patch of gamboge-yellow, gradually shading into yellowish olive, which extends over the whole surface of the sides of the head, neck, mantle, back, and rump, but is rather brighter on the last; lower surface gamboge-yellow, brightest on the throat, and shading into olive on the flanks. Wing-lining primroseyellow, passing into white. Wing- and tail-quills blackish brown, margined outwardly by olive and the former inwardly by greyish white, while the middle pair of the latter have most of the inner web dusky olive; irides dark hazel; feet bluish black.

Dimensions. - Total length 4.5 inches, wing $2 \cdot 5$, tail 2 , culmen $\cdot 4$, tarsus $\cdot 75$. 



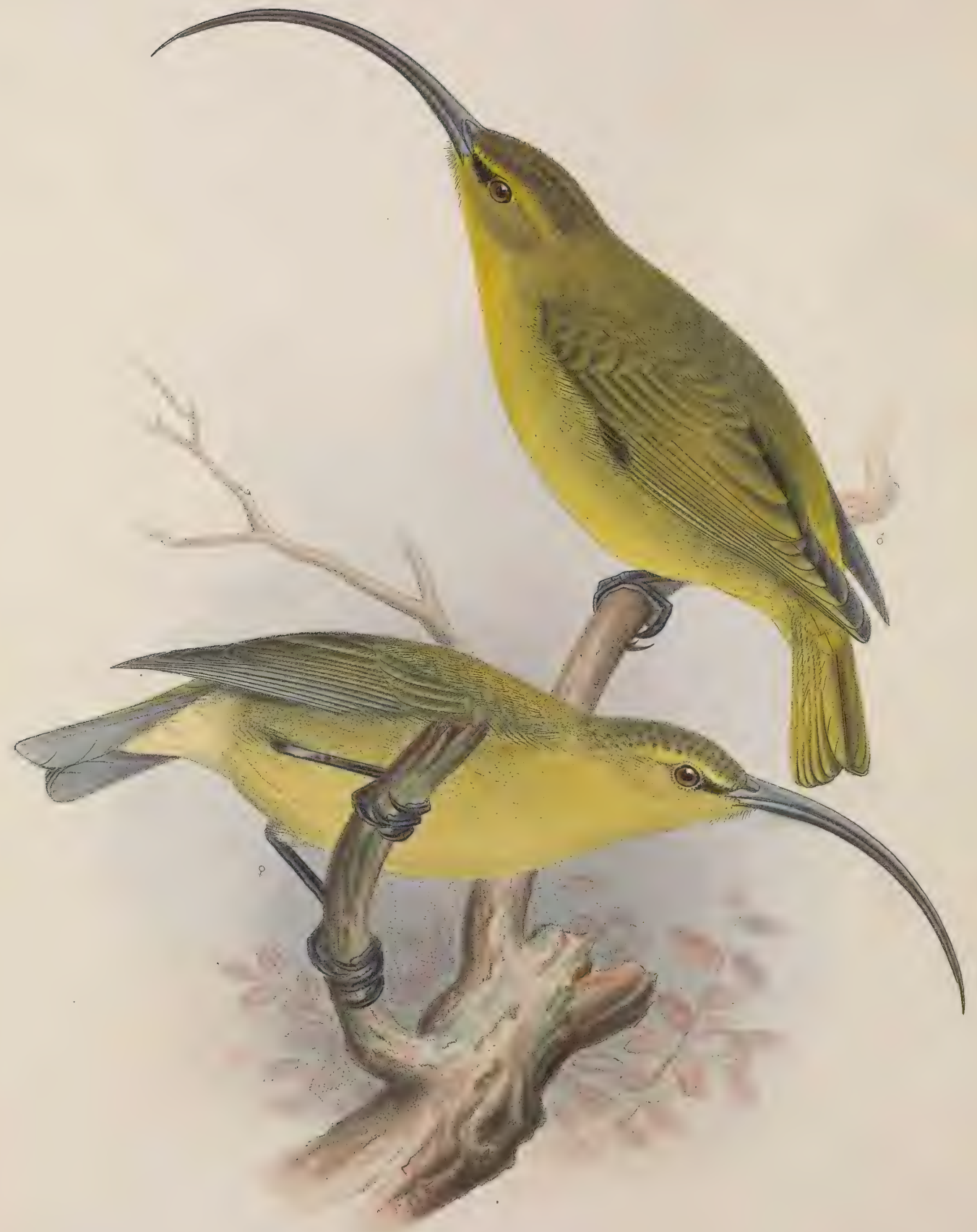




\title{
HEMIGNATHUS PROCERUS.
}

\author{
IIWI ${ }^{1}$.
}

Hewignathus oľscurus, Dole, Proc. Bost. Soc. N. H. xii. p. 298 (exx. ex Kauai) (1869) ; id. Hawaiian Alman. 1879, p. 45 (partim) ; Stejneger, Proc. U.S. Nat. Mus. 1887, p. 93 (nec Gmelin; nec Lichtenstein).

Hemignathus procerus, Cabanis, Journ. für Orn. 1889, p. $331^{2}$.

Hemignathus stejnegeri, S. B. Wilson, Ann. \& Mag. N. H. ser. 6, jv. p. 400 (1 November, 1889); id. Ibis, 1890, p. 190, pl. vi. fig. 2; Stejneger, Proc. U.S. Nat. Mus. xii. p. 384 (1889).

T'His bird, according to our present information, is peculiar to Kauai, and examples from that island had been examined-though not recognized as different from H. obscurusby Judge Dole, when he wrote his article on the Birds of the Hawaiian Islands in the 'Proceedings of the Boston Society of Natural History' for 1869; finding, however, that the birds from Kauai and Hawaii were perfectly distinct, I suggested, on my return to England in 1888, that the former should be separated as H. stejnegeri. As the result of inquiry regarding the various species of the genus in the Berlin Museum, information was received through Professor Möbius that Professor Cabanis had come to a similar conclusion on inspection of the specimens there, and had forestalled my proposed title by a few weeks; so that I must at once acknowledge his activity in securing priority for his name $H$. procerus.

Of this well-marked species, which I was enabled to figure for the first time in 'The Ibis' for April 1890, Mr. V. Knudsen sent specimens in 1887 to Dr. Stejneger, who showed them to me in Washington, and described them, though with some doubt, as belonging to H. obscurus. At the time of my visit to the Island of Kauai in the month of September it appeared to be rather scarce; hence I obtained but few examples, and was able to make but scanty notes on its habits; of these, however, I am fortunately in a position to give a good description, owing to the excellent observations made by Mr. G. C. Munro, assistant to Mr. Palmer, a collector in the interest of the Hon. Walter Rothschild, who, since my return, has spent many months on the Island of Kauai and has met with the bird in fair numbers. He has kindly sent me a most

1 Ir. Francis Gay has informed me that this species is known by the name of Tiwi on Kauai, and not by that of Akialoa, which name is applied to $H$. obscurus and, I think, also to $H$. olivaceus, the two species found on Hawaii.

${ }^{2}$ The species is said to have been described at the Ireoting of the Allgemeine Ornithologisehe Gesellschaft held on the 9 th September, 1889, of which a report was published in 'Vossische Zeitung, No. 429, of the 14th September. 
interesting account, which his long stay on the island has enabled him to make much more complete than my own. I subjoin it verbatim here:-

"This bird is much more common and enjoys a wider range than the Nukupuu, which bird it much resembles in habits. It seems to inhabit the whole forest-region of Kauai ; its food consists of insects, their eggs and larvæ, and we have also seen them sucking honey from the Lehua flowers. Above Makaweli in January and February we found it less common than at other places we visited: there they were mostly on the koa trees (being the most suitable hunting-ground for them in this locality). Usually there was a pair in the same vicinity, but not keeping very close together, so that when one was shot we would usually get another.

"At Kaholuamano in the latter end of February and beginning of March they were more common, generally, in company with the Akikiki, feeding on the Lehua trees, the pairs keeping more together. In one instance $I$ shot a female, and the male stopped in the top of the tree calling desperately. I fired at him without effect, and so intent was he in looking for his mate that he immediately returned and was brought down by another shot. At Halemanu towards the end of March we found them as plentiful as at the latter place, but the Akikiki not being so common the Akialoa were more often found apart from them; here we first heard the Akialoa sing, although it was some time before we knew for certain it was the bird whose sweet note we heard every day; once I heard one sing whilst flying from one tree to another. Near Hanalei in April we found these birds not uncommon, generally in pairs chasing each other about, or singing in the tops of the trees. Their chirp seemed different here; Mr. Palmer likens both the chirp and song to that of the canary. We watched a pair singing together one day; the smaller and duller bird (probably the female) seemed to have fewer notes than the other.

"Females that I dissected here had the ovaries enlarged, which with before-mentioned notes on the subject would denote the approach of the breeding-season. I have seen these birds from the branches in the tops to the roots of the trees, probing into holes and under the bark, where they find a harvest of cockroaches' eggs, beetles, and grubs; on one occasion I saw one alight on the ground and insert its bill amongst mats of dead leaves and bits of wood; have also seen them collecting insects from the bases of the leaves of the halapipi tree; have not often seen them feeding on honey. In feeding they do not seem to depend much on sight; have never noticed them to look into a crevice, as the A-A, before inserting their bill. I saw one send its bill at full length into a hole in a tree; have seen them work about one spot for some minutes, but have not noticed them break off any portions of bark or wood. Like the Nukupuu, it is an active bird but can be easily approached within gunshot with ordinary caution. Have also a strong smell when killed; and some, shot at Makaweli, had sores on their feet like the other birds in that locality at that time."

The range, as I stated in 'The Ibis,' is from the lowest forest-zone to 3000 feet or perhaps higher, the highest ground on Kauai (Waialeale) being but 4000 feet. This 
view seems to be borne out by Mr. Palmer's account; he also met with it at Hanalei, on the other side of the island, a district which I did not explore.

Description.-Adult male. Front and top of the head dark ashy olive, shading into olive on the back, which becomes brighter on the rump; sides of the face olive, with an indistinct olive line over the eye; body beneath sulphur-yellow, light primrose on abdomen, the flanks washed with olive; under tail-coverts olive-yellow; wing- and tail-quills ashy brown, edged outwardly with olive; secondaries and wing-coverts ashy brown, very broadly edged with olive; irides dark hazel; bill black; feet bluish black.

Adult female. Above dingy yellowish buff, the feathers on the head being yellowish olive with black centres; the yellow mark over the eye more distinct, owing to the blacker lores; beneath uniform olive-buff.

In both male and female the edge of wing and wing-lining is white, slightly tinged with primrose-yellow.

Dimensions. - Adult male. 'Total length' $7 \cdot 50$ inches, wing from carpal joint $3 \cdot 75$, tarsus 1 , tail 2 , hind toe with claw $\cdot 75$, middle toe with claw 95 , maxilla following the curve $2 \cdot 80$, chord subtending the curve $1 \cdot 75$, difference between maxilla and mandible $\cdot 30$.

Adult female. Maxilla following the curve 2.55 inches, difference between maxilla and mandible $\cdot 25$.

.Obs.-Generally resembling H.obscurus (Gm.), but much exceeding it in size and of brighter tint, especially beneath, the abdomen being of a light primrose-yellow. 




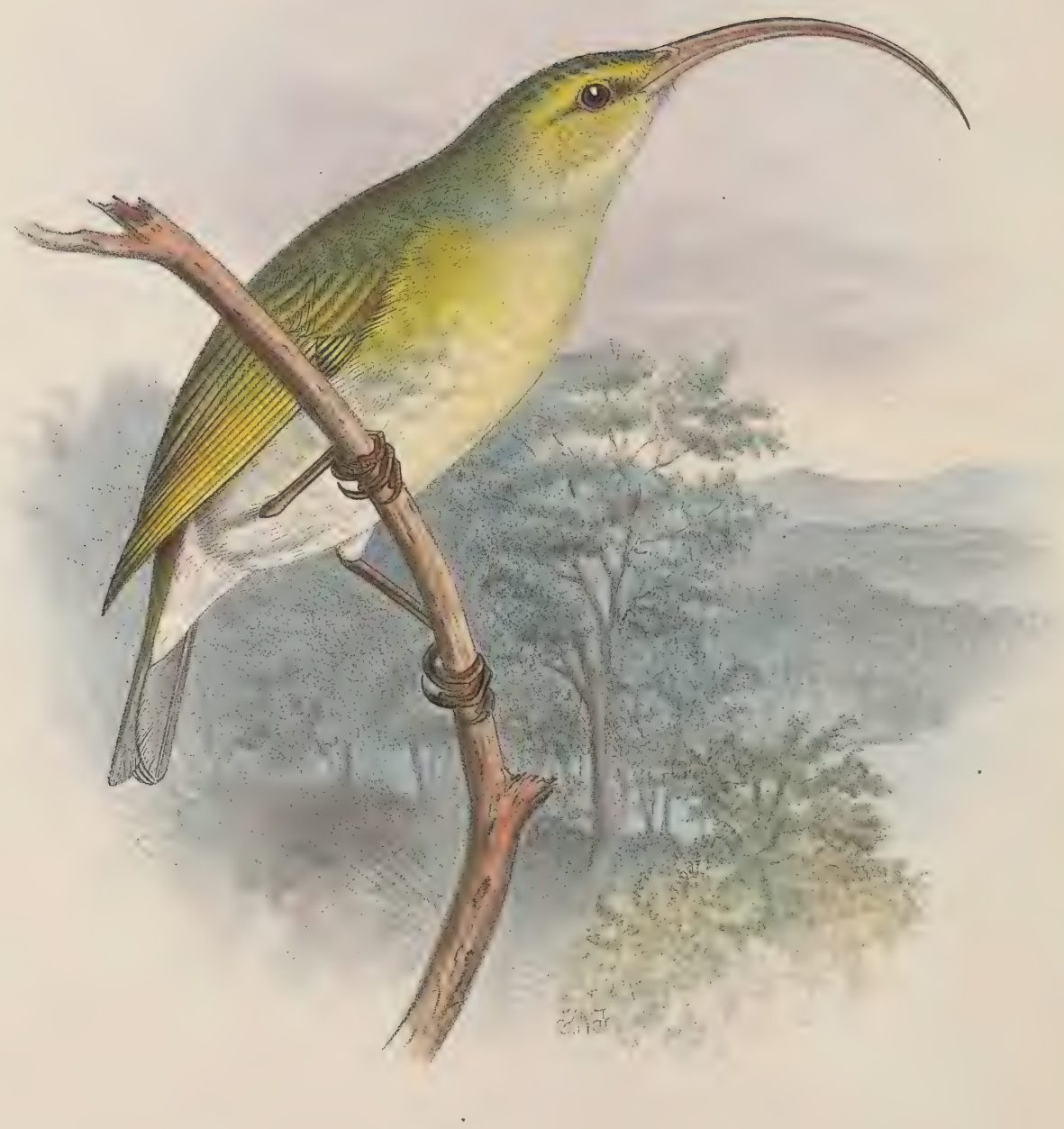

FW.Frohawk del.et lith.

West, Nerman imp.

HEMGNATHUS LICHTENSTEINI. 


\section{HEMIGNATHUS LICHTENSTEINI.}

JIBI.

Hemignathus obscurus, Lichtenstein, Abhandl. k. Akad. Berlin, 1838, p. 449, tab. v. fig. $1^{*}$ (nec Certhia obscura, Gmelin); id. Nomencl. Av. Mus. Berol. p. 55 (1854) ; Dole, Proc. Bost. Soc. N. H. xii. p. 298 (partim) (1869) ; id. Hawaiian Alman. 1875, p. 45 (partim).

Hemignathus lichtensteini, S. B. Wilson, Ann. \& Mag. N. H. (6) iv. p. 401 (Nov. 1889) ; id. Ibis, 1890, p. 190.

Hemignathus ellisianus, Rothschild, Avifaun. Laysan, p. 87 (1893) (nec Gray).

* Figura notabilis.

THrs very distinct species, peculiar, so far as we know, to Oahu, had, as I pointed out in the paper above cited, been hitherto confounded with its Hawaiian congener H. obscurus. Examples of the former were obtained in 1837 by Deppe, and one of them was figured in the following year by Lichtenstein, who doubtless had not seen a specimen of the latter or he could scarcely have failed to perceive the difference between them. On my return from the Sandwich Islands in 1889 , I was fortunately able, through the kindness of Prof. Möbius of Berlin, to compare the very subject of his illustrious predecessor's figure with my own specimens of $H$. obscurus, and thus to justify the suspicion of their distinctness that had been already aroused. I accordingly bestowed on the present species the name of the celebrated zoologist who first published an indication of its existence, and I have to thank my good fortune for being the first to elucidate this matter.

Mr. Rothschild (loc. cit.) has referred this species to the "Drepanis (Hemignathus) ellisiana" of Gray (Cat. B. Trop. Isl. Pacif. p. 9), which I have already correctly quoted as a synonym of $H$. obscurus. It is pretty clear that Mr. Gray never saw a specimen of either, and it is absolutely certain that three out of the four authorities cited by him refer to $H$. obscurus. Vieillot, the first of them, as I have already shown, figured (Ois. Dor. pl. 53) the very specimen, now at Liverpool, which was formerly in the Leverian Museum, and actually the type of Latham's description, on which was founded the Certhia obscura of Gmelin, and hence the H. obscurus of modern ornithologists. Similarly the bird figured in Ellis's unpublished drawings (no. 28), which from the name used by Gray is doubtless to be regarded as the type of his supposed species, is most unquestionably H.obscurus, as anyone who examines the drawing in the British Museum 
may satisfy himself ${ }^{1}$. The last of the authorities cited by Mr. Gray is Cassin, and he quotes Peale as saying that the species he speaks of was obtained in "Hawaii only," and that according to his observations it did "not inhabit Oahu ; " it was accordingly also $H$. obscurus; and the mere fact of Mr. Gray's mistakingly referring Lichtenstein's figure, and assigning Lichtenstein's locality, to the so-called "Drepanis (Hemignathus) ellisianc" cannot remove the incontestable objection that his other references show it to be but a synonym of $H$. obscurus. The error probably originated in his adopting the view of Lesson that this last was the female of Vestiaria coccinea; but even that error was pardonable, as so little was known of the ornithology of the Hawaiian Islands, and indeed when I arrived there I was, on the strength of the information then existing, quite prepared to find that the brilliant scarlet bird had a green partner.

Although I believe that the bird still exists in diminished numbers on one of the mountain-ranges which I was unable to explore-a belief strengthened by the accurate description of it given to me by a native of Oahu in 1888, who said that he had seen it during that year near Waialua,-I am bound to admit that my failure to meet with it in the course of my explorations there, and the similar issue of the careful examination of the heights by Mr. Perkins and Mr. Rothschild's collectors, point to its possible extinction. Though Deppe is said to have obtained several examples in the interior of Oahu, where it was called "Jibi," the only specimen I have seen is that so kindly placed at my disposal by the authorities of the Museum of Berlin, and the species must be regarded as one of the rarest in the world.

Description, condensed from Lichtenstein (ut suprà, p. 450).-_ Uniform olive-green above and on the wing-feathers, though the inner and concealed parts of the latter are dull brown. Beneath paler though as little brilliant. The chin, middle of the belly, and the lower tail-coverts pale cream-colour. A pale yellow stripe over the eye is enlivened by a dark brown streak running immediately beneath it from there to the bill. The lower mandible is 3 lines shorter than the upper. The whole length of the bird is 7 inches, of which the bill and tail measure each $1 \frac{3}{4}$; the tarsus 11 lines; the middle toe with its claw 9 lines; the outer toe one half and the inner a whole line shorter than the middle toe."

\footnotetext{
1 To any one acquainted with the movements of Cook's ships, on each of which Ellis in turn sorved, it is obvious that he never had an opportunity of collecting specimens in $0 \mathrm{ahu}$, at which island they touched but for one single day (27 February, 1779), when the captains only seem to have gone ashore. It is not very likely that they would bring off a live bird of this species for Ellis to draw, and we have the inscription on the sketch in his own writing: "W. W. Ellis delin. \& pinxt. ad viv. 1779."
} 



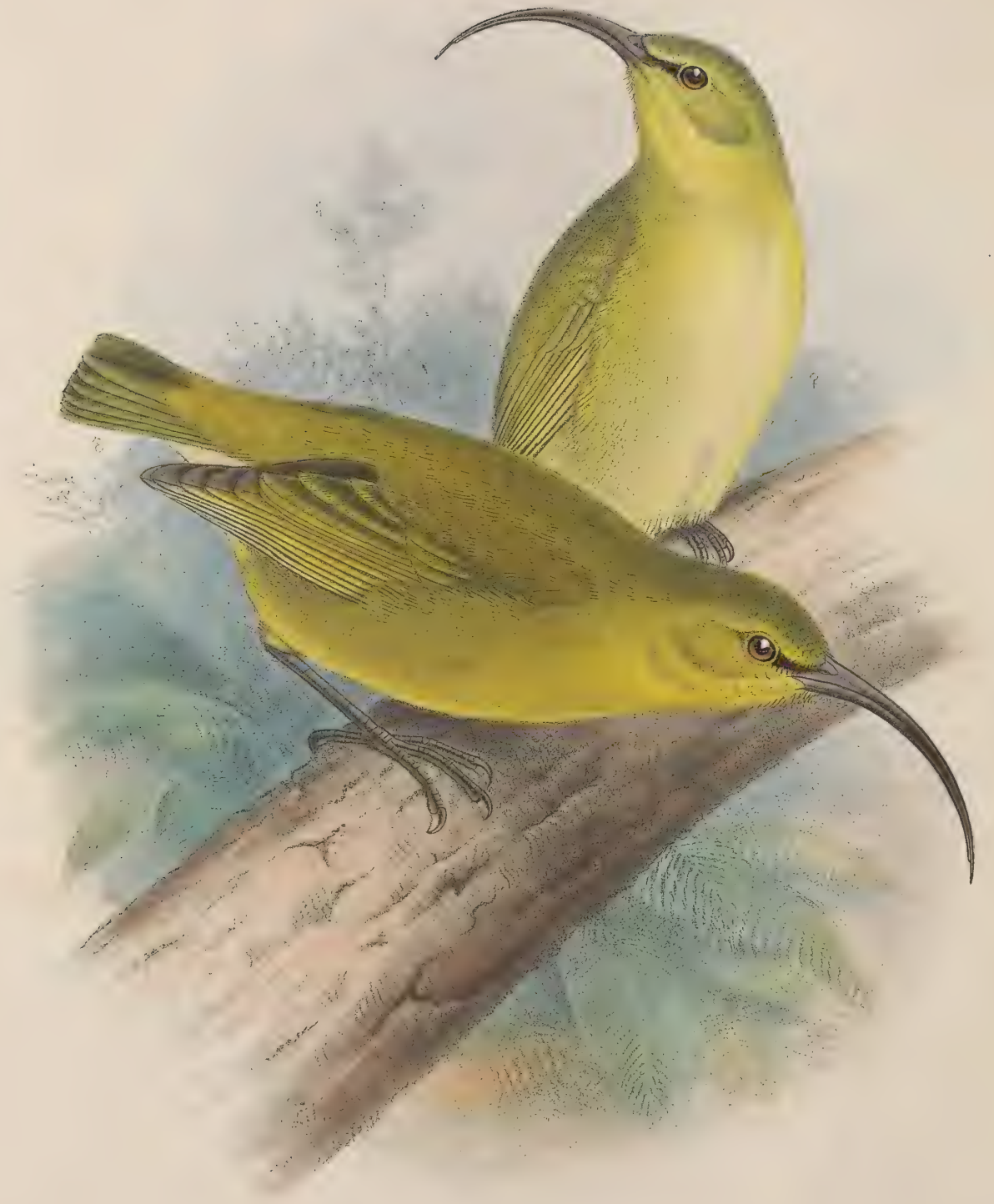

FW.Frohawk, del. et lith. 


\title{
HEMIGNATHUS OBSCUROS.
}

\author{
AKIALOA.
}

"Hook-billed Green Creeper," Latham, Gen. Synops. i. p. 703, pl. xxxiii. fig. 1 (1782); id. Suppl. p. 126 (1787).

? Akaiearooa," King, Voy. Pacif. Ocean, iii. p. 119 (1784).

Certhia obscura, Gmelin, Syst. Nat. i. p. 470 (1788); Latham, Ind. Orn. p. 281 (1790); Donndorff, Orn. Beytr. i. p. 621 (1794); Shaw, Zool. viii. p. 227 (1812); Tiedemann, Anat. Naturgesch. Vög. ii. p. 430 (1814) ; J. E. Gray \& Griffith, An. Kingd., Aves, vii. p. 358 (1829).

"L'Akaiearoa," Vieillot, Ois. Dorés, ii. p. 111, pl. liii. (1802) ; Lesson, Compl. Buffon, ix. p. 155 (1837).

"Grimpéreau à long bec des îles Sandwich," partim, Virey (Sonnini), Hist. Nat. Buffon, Ois. xrii. p. 98 (1804-5).

Melithreptus obscurus, Vieillot, N. Dict. d'Hist. Nat. xiv. p. 322 (1817) ; id. Encycl. Méth., Ornithol. p. 601 (1823) ; Cuvier, Règne Anim. ed. 2, i. p. 433 (1829).

Drepanis obscura, Temminck, Man. d’Orn. i. p. Ixxxvi (1820).

"Hook-billed Green Honey-Eater," Latham, Gen. Hist. B. iv. p. 192, pl. 71. fig. 1 (1822).

Melithreptus vestiarius, of Lesson, Tr. d’Orn. p. 300 (1831).

Vestiaria akaroa, Lesson, Rev. Zool. 1840, p. 268.

Drepanis coccinea (partim), G. R. Gray, Gen. B. p. 96 (1847).

Hemignathus obscurus, Peale, U.S. Expl. Exped., Birds, p. 153 (1848) ; Hartlaub, Arch. f. Naturgesch. 1852, ii. p. 110 ; Reichenbach, Handb. sp. Orn., Tenuirostres, p. 312, pl. 591. fig. 4009 (1853) ; Cassin, U.S. Expl. Exped., Mamm. \& Orn. p. 178 (1858); Dole, Proc. Bost. Soc. N. H. xii. p. 298 (partim) (1869) ; id. Hawaiian Alman. 1879, p. 45; Sclater, Ibis, 1871, p. 360 ; id. op. cit. 1879, p. 92 ; Sundevall, Tentam. p. 48 (1872) ; Sharpe, Cat. B. Br. Mus. x. p. 4 (1885) ; S. B. Wilson, Ann. \& Mag. Nat. Hist. ser. 6, iv. p. 400 (1889); id. Ibis, 1890, p. 189.

Drepanis (Vestiaria) coccinen, \&, G. R. Gray, Cat. B. Trop. Isl. p. 8 (1859); id. Hand-l. B. i. p. 114 (1869).

Drepanis (Hemignathus) ellisiana, G. R. Gray, Cat. B. Trop. Isl. p. 9 (1859); id. Hand-l. B. i. p. 114 (1869).

NATURE has shown great symmetry with regard to the species of this genus to be found in the Sandwich Archipelago, three of the main islands having each a long-billed and a short-billed form, in the latter of which, moreover, the mandible is only about half the length of the maxilla. The subject of our present notice is the long-billed form from Hawaii, which was called by Latham the "Hook-billed Green Creeper" in his 'General Synopsis' of 1782, and the "Hook-billed Green Honey-eater" in his later 
work, the 'General History of Birds,' being figured on both occasions; he should have had before him a specimen from the Museum of Sir Ashton Lever, procured during Cook's last voyage, and still preserved in the Derby Museum at Liverpool, which is unquestionably that delineated in Viellot's 'Oiseaux Dorés,' being copied from a drawing sent to the author by Parkinson, then owner of the Leverian Museum.

The specific title obscurus dates from Gmelin's Certhia obscura of 1788, and has only since been altered in error, as by G. R. Gray in the case mentioned below; while it will be seen that both Vieillot and Lesson identified King's "Akaiearooa" with our species. The generic appellation, on the other hand, has experienced similar vicissitudes to those of allied forms from the same region, alternating between Certhia, Melithreptus, Vestiaria, Drepanis, and Hemignathus; but when once it became evident that Temminck's Drepanis included within itself several distinctly separable genera, it followed that the only one of the above names applicable to the present group of birds was the last, originally bestowed by Lichtenstein on examples obtained by Deppe in Oahu, and considered by him to be identical with those from Hawaii, though they now prove to belong to a different species which I have named H. lichtensteini. G. R. Gray, who in more than one case erroneously considered the green birds to be the females of the red, referred $H$. obscurus partly to the female of Vestiaria coccinea, partly to his Drepanis ellisiana, which, therefore, must rank as a synonym.

This species-peculiar, so far as my observations go, to the Island of Hawaiioccupies the lower forest-zone from about 1100 to 2500 feet, and is most plentiful among the tall ohia trees. Like its larger relative-H. stejnegeri on Kauai,-it prefers decayed timber in which to search for its food, and invariably chooses a rotten or halfdead tree for its hunting-ground, no doubt on account of its slender bill; which requires soft material to work upon. It is also very partial to the great tree-ferns which in the forests of Hawaii reach a height of more than 30 feet, and, as the sombre colour of its plumage is very nearly that of their foliage, it is most difficult to observe, and is at the same time more quiet and unobtrusive in its habits than any other member of the genus; in fact, had it not been for its clear and characteristic call-note, I doubt whether I should have noticed it at all. It must-at least in the several localities I visited and at the time of year I saw them-be considered a scarce bird: and whilst I was at Olaa in the district of Puna-a place renowned in ancient times for its bird-catchersan old native, Hawelu, an excellent observer and well skilled in the almost forgotten art, told me that it was extremely rare. During a long stay in the higher forestregion in Kona, I did not notice it, and believe, as I remarked above, that it is confined to the lower forest-zone.

Description.-Adult male. Head and upper parts generally uniform dull greenish olive, rather brighter on the rump; lores dusky, with a yellow mark over the eye; throat, sides of face, and breast dull olive-green, lighter on abdomen and under tail- 
coverts; wing- and tail-quills ashy brown, edged with dull olive; irides dark hazel; bill and feet dark brown.

Adult female. Nearly similar to the male, but perhaps rather duller in plumage.

Dimensions.-Adult male. Total length 5.50 inches, wing from carpal joint 3.5 , maxilla following the curve 1.85 , chord subtending the curve 1.50 , difference between maxilla and mandible $\cdot 15$, tarsus $\cdot 85$, middle toe with claw $\cdot 80$, hind toe with claw $\cdot 75$, tail $1 \cdot 60$.

Adult female. Total length $5 \cdot 15$ inches, wing from carpal joint 3 , maxilla following the curve $1 \cdot 45$, chord subtending the curve $1 \cdot 30$. 



\section{HEMIGNATHUS LANAIENSIS.}

Hemignathus lanaiensis, Rothschild, Bull. Brit. Orn. Club, i. p. xxiv (1893) ; id. Avif. Laysan, p. 89, pl. (1893).

Ат the January meeting of the above Club in 1893, the following communication was read from Mr. Rothschild, on a new species from the island of Lanai in the Sandwich group, for which he proposed the name of

\section{"Hemignathus lanaiensis.}

" $H$. similis $H$. obscuro, sed rostro valdè longiore et crassiore, pileo cinerascente, notæo sordidiore olivascenti-viridi, pectore sordidè flavo, hypochondriis sordidè olivascentibus, et subcaudalibus albicantibus, distinguendus. Long. alæ $3 \cdot 1-3 \cdot 3$ poll., culm. $2 \cdot 9-3 \cdot 1$.

"Hab. in insulâ Sandwichensi 'Lanai ' dictâ.

"Mr. Rothschild's communication contained the following remarks on this new bird :-

" "This species belongs to the typical section of Hemignathus, which, in my opinion, includes two different species from the island of Kauai, one from Hawai, and one from Oahu, in addition to the new species. They all have the upper and lower mandible of about the same length, while the aberrant Heterorhynchus-section, which now contains four species, has the upper mandible nearly twice the length of the lower.

" The male differs from the same sex of $H$. obscurus (its nearest ally) from Hawai in its much longer and very stout bill, ashy-greyish tint of the crown, and much duller olivaceous green of the back, neck, and rump. Breast dirty yellow, gradually passing into dull olive on the flanks, instead of bright yellowish olive as in $H$. obscurus. Under tail-coverts creamy white, instead of olive green.

" Female. Everywhere dull greyish olive, becoming more yellowish on the abdomen and under tail-coverts. Throat and cheeks dull greyish.

"Young male. Similar to the adult male, but all the colours strongly suffused with an ochraceous tinge.

" "Iris dark brown; bill blackish brown, greyish at the base; feet and legs bright slaty blue, soles of the feet yellowish. Wing 3.1 to 3.3 inches, culmen 2.9 to 3.1 (much longer than that of H. obscurus)." ",

Mr. Perkins believes that he saw an adult male in Lanai, but he was unable to procure it. 



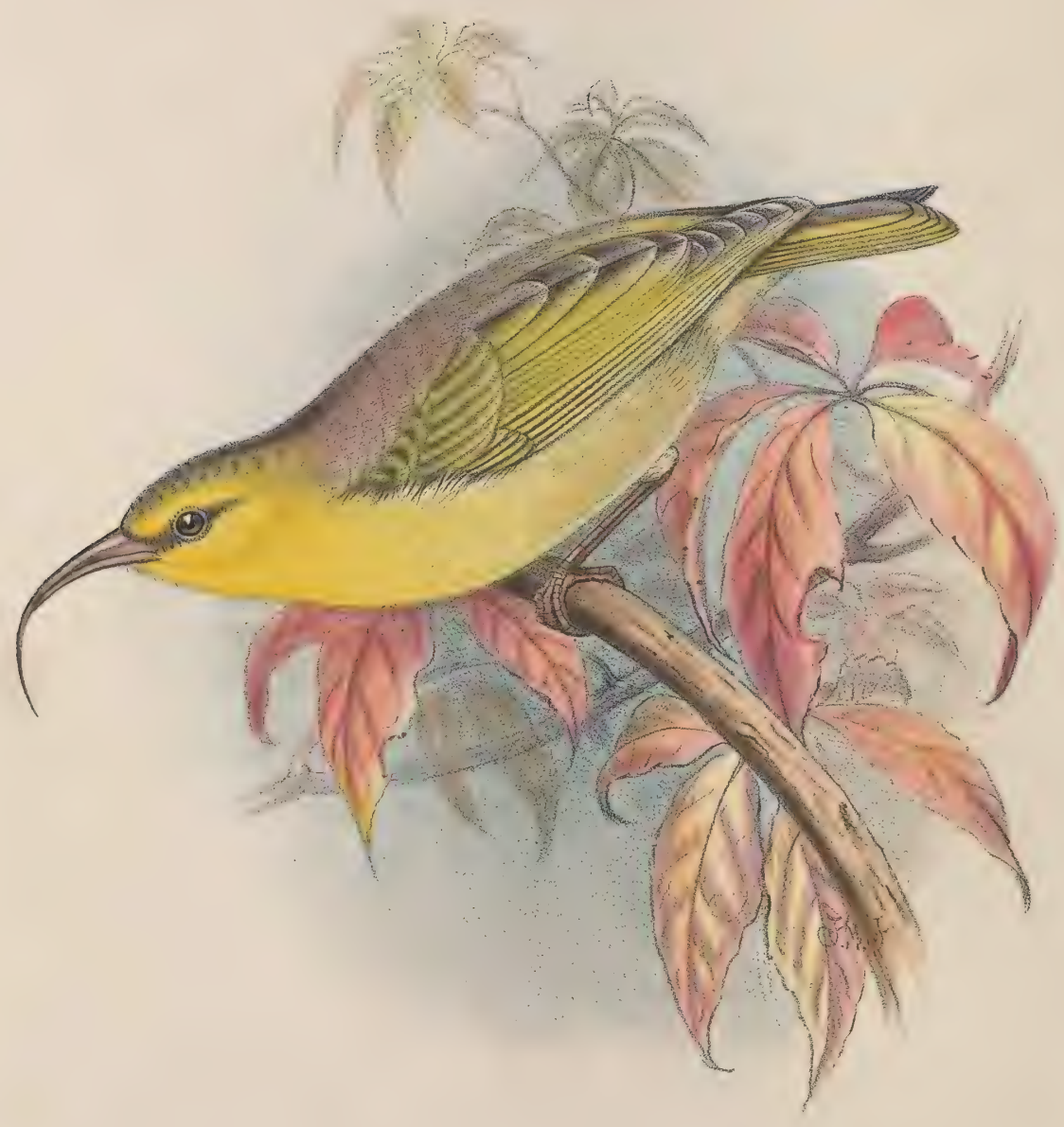

FWFrohawk del et lith.

West,Newman imp

HEMIGNATHUS LUCIDUS. 


\section{HEMIGNATHUS LUCIDUS.}

Hemignathus lucidus, Lichtenstein, Abhandl. k. Akad. Berlin, 1838, p. 451, t. v. figg. 2, $3 *$; id. Nomencl. Av. Mus. Berol. p. 55 (1854); Hartlaub, Arch. f. Naturgesch. 1852, i. p. 110 (partim) ; Reichenbach, Handb. sp. Orn., Tenuirostres, p. 313 (1853) ; Cassin, U.S. Expl. Exped., Mamm. \& Orn. p. 180 (1858) ; Dole, Proc. Boston Soc. N. H. xii. p. 298 (1869); id. Hawaiian Alman. 1879, p. 45 ; Sclater, Ibis, 1871, p. 360 ; id. op. cit. 1879, p. 92 ; Sharpe, Cat. B. Brit. Mus. x. p. 5 (1885) ; S. B. Wilson, Ann. \& Mag. N. H. ser. 6, iv. p. 401 (1889); id. Ibis, 1890, p. 192; Hartert, Katal. Vogelsamml. Mus. Senckenb. p. 28 (1891).

Heterorhynchus lucidus, Reichenbach, Handb. sp. Orn., Tenuirostres, p. 223 (1853), Taf. dxci. figg. 4012, 4.013** Rothschild, Avif. Laysan, p. 105 (1893).

Drepanis (Hemignattus) lucida, G. R. Gray, Gen. B. i. p. 96 (18t7) (partim); id. Cat. B. Trop. Isl. p. 9 (1859); id. Hand-l. B. i. p. 113 (1869).

* Figura notabiles.

Oun knowledge of this species, as of $H$. lichtensteini, is due to the Prussian collector Deppe, who sent specimens of it which he obtained in Oahu to the Museum of Berlin, where they were described and figured by its Director, the celebrated Lichtenstein, as above stated. While Deppe was in the Sandwich Islands he was joined by the still better-known American naturalist Townsend, who (with Nuttall) accompanied Captain Wyeth's expedition across the Rocky Mountains to the Columbia River, and thence proceeded to Honolulu. In his work ${ }^{1}$ Townsend states that he and Deppe, in January 1837, hired a house in the Nuano Valley, five miles from that town, with the object of collecting birds and plants, and we may well suppose that this species (and II. lichtensteini also) was found by them in that district. On Townsend's return he sent several specimens of birds collected by him to Audubon, then in this country, and among them two of the present species, which were acquired by the late Sir William Jardine, at the sale of whose collection, in 1886, they were bought for the Museum of the University of Cambridge. On one of them being submitted, at my request, to Professor Cabanis for comparison with the type at Berlin, that eminent authority declared the two to be specifically identical. This result was the more satisfactory since I myself was unable to meet with the species, and later explorers have been no more fortunate, so that there is reason to fear that it has become extinct. It was undoubtedly peculiar to the island of Oahu, where Deppe informed Lichtenstein that it frequented the plaintainblossoms in considerable numbers.

Mr. Rothschild holds me much to blame for having referred the short-billed

Narrative of a journey across the Rocky Mountains to the Columbia River, and a visit to the Sandwich Islands, Chili, \&c., with a Scientific Appendix. Philadelphia: 1839. 8vo.

It is much to be regretted that Townsend's 'Appendix' is limited to the Mammals and Birds of the Oregon Territory. The observations of a naturalist so well informed as he was on the zoology of the Hawaiian Islands at that time would be invaluable. 
Hawaiian species to the Heterorhynchus olivaceus of Lafresnaye, stating that he has carefully examined the type of the latter in the Paris Museum, and that it is no doubt identical with the Hemignathus lucidus of Lichtenstein from Oahu. This assertion I am unable to contradict, for I long ago expressly said that, not having seen Lafresnaye's type ${ }^{1}$, I could only judge of his species by the figure, which I still think that few persons will be able to reconcile with the figures given by Lichtenstein, not, however, for the reason assigned by Reichenbach, since the difference in the tail noticed by him, though admittedly shown in the plates, does not exist in the birds. The differences offered by actual comparison of specimens was unquestionably first mentioned by Cassin, who wrote in 1858 :- " It is probably very nearly impossible to determine or reconcile with each other the synonyms of these two species, or the instances in which they have been mistaken for each other; but we have given them as they appear to us, and as represented in the plates cited." This difference has been recognized by all subsequent writers (including Judge Dole and Mr. Sclater) except Mr. G. R. Gray in the following year, and he really had no materials on which to form an opinion, the genus being represented in the British Museum by only a single specimen (apparently a female) of H. lucidus, which was presented by Sir Edward Belcher, and was therefore probably obtained during the voyage of the 'Sulphur' between 1838 and 1842 .

If $\mathrm{Mr}$. Rothschild's views be correct, it would seem that it was my good fortune to be the first to meet with and make known the Hawaiian species, and it is therefore not without some sense of retributive justice, for which I thank him, that, as though to make amends for the severity of his remarks, he has proposed to honour me by calling it $H$. wilsoni, though he thereby commemorates the error with which he charges me.

Description (from a specimen at Cambridge, no doubt immature).-Upper parts dull olire-green with a brown tinge, the whole of the wing- and tail-feathers being brown with yellowish-green margins to the outer webs. A thin line of yellow nearly surrounds the eye, and may almost be called a streak above it. Lores brown; throat yellow; underparts generally buffish white, the decided buff tint being varied by a yellow tone in parts. Sides of the body brownish; under tail-coverts and flanks buff. A little bright yellow is present at the bend of the wing, the under surface of which is grey and buffish white. The curved bill is dusky, the feet of the same colour.

Dimensions. - Total length 5.62 inches, wing 3, tail 2, tarsus $\cdot 87$, culmen just over 1 , the mandible being almost exactly two-thirds of the maxilla.

Another specimen, also at Cambridge, entirely lacks the yellow tints, and is probably still younger than the last.

Mr. Rothschild says that the bill is longest in the male.

${ }^{1}$ How Lafresnaye's type (which is included as no. 5677, bis, in the lithographed catalogue of his collection, drawn up after his death by the late M. Jules Verreaux) found its way to Paris is not apparent. The collection is supposed to have been sold in its entirety to the Natural History Society of Boston, and there this specimen should be expected to exist; but I have learned through the courtesy of Professor Hyutt that it cannot be recognized there. This fact strengthens the assertion that it is at Paris, but still the authenticity of the specimen seems to need verification. 



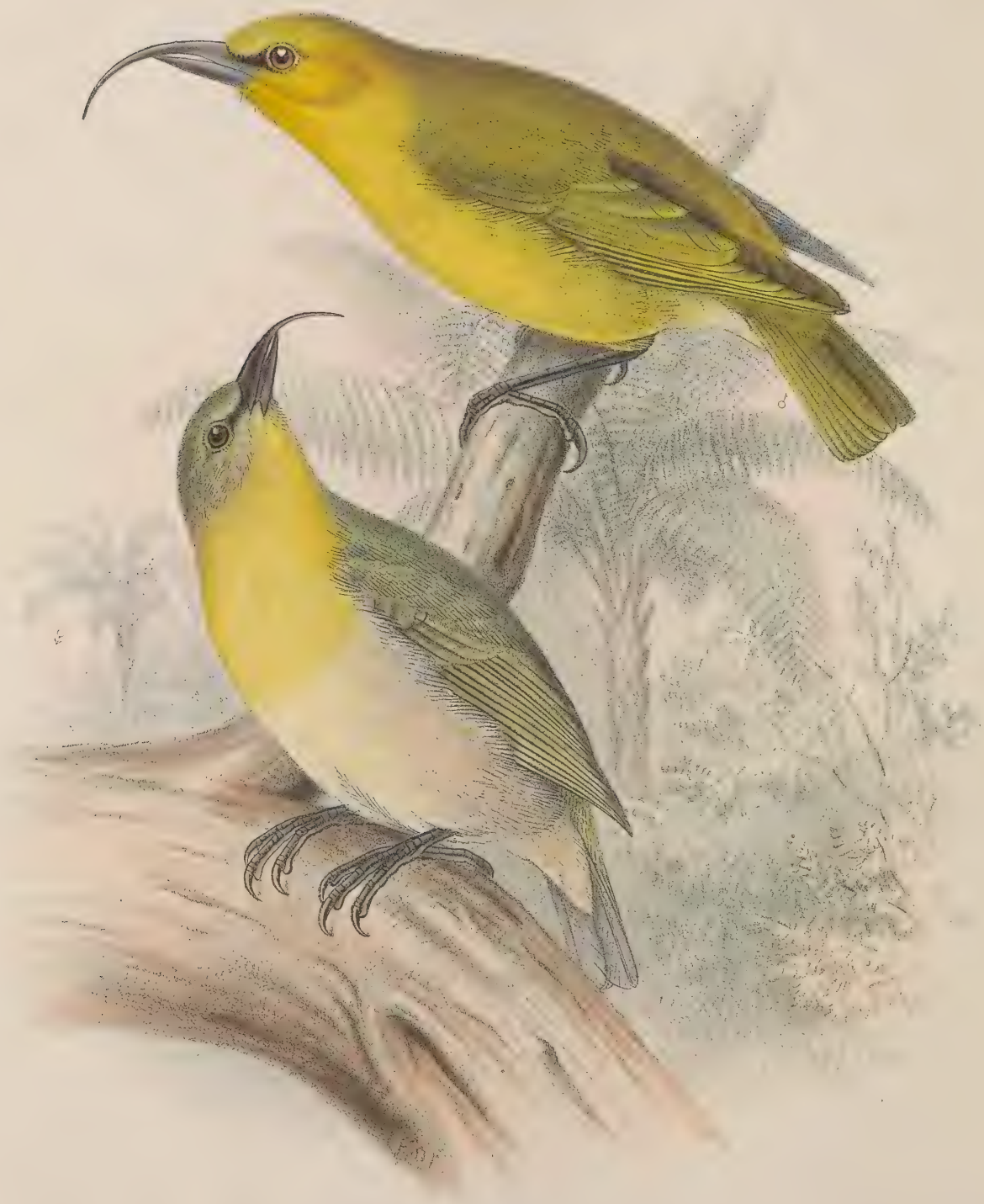

F.W.Frohawk, del et lith. 


\section{HEMIGNATHUS OLIV ACEUS.}

AKIALOA.

Heterorhynchus olivaceus, Lafresnaye, Mag. de Zool. 1839, Ois. pl. x.; id. Rev. Zool. 1840, p. 321 ; Florent-Prévost, Voy. Vénus, Ois. pl. i. figs. 1, 2 (18-?).

Vestiaria heterorhynchus, Lesson, Rev. Zool. 1840, p. 269 ; id. op. cit. 1842, p. 209.

Drepanis olivacea, G. R. Gray, Gen. B. p. 96 (1847).

Hemignathus lucidus, Peale, U.S. Expl. Exped., Birds, p. 153 (1848) ; Bonaparte, Consp. Av. i. p. 404 (1850); Hartlaub, Arch. f. Naturgesch. 1852, i. p. 110 (partim) ; Florent-Prévost \& O. DesMurs, Voy. Vénus, Zool. p. 191 (185-) (nec Lichtenstein).

Hemignathus olivaceus, Reichenbach, Handb. sp. Orn., Tenuirostres, pp. 223, 313 (1853), pl. 591. figg. 4010, 4011; Cassin, U.S. Expl. Exped., Mamm. \& Orn. p. 179 (1858); Dole, Proc. Bost. Soc. N. H. xii. p. 298 (1869) ; id. Hawaiian Alman. 1879, p. 45 ; Sclater, Ibis, 1871, p. 360 ; id. op. cit. 1879, p. 92 ; Sharpe, Cat. B. Br. Mus. x. p. 4 (1885) ; S. B. Wilson, Ann. \& Mag. N. H. ser. 6, iv. p. 400 (1889); id. Ibis, 1890, p. 191.

Drepanis (Hemignathus) lucida, G. R. Gray, Cat. B. Trop. Isl. p. 9 (1859); id. Hand-I. B. i. p. 112 (1869), partim.

THIS short-billed Hawaiian species was brought to the knowledge of ornithologists at a much later date than many others from the Sandwich Islands, having been unknown to the earliest writers on the group. Lafresnaye, who was the first to specify the bird, described and figured it as forming a subgenus of "Héorotaire" (i. e. Drepanis), under the name of Heterorhynchus olivaceus, in the 'Magasin de Zoologie' for 1839, from an example bought (for 25 francs) of Dupont, a dealer in Paris. In 1848, in his account of the United States Exploring Expedition, Peale mistook it for H. lucidus, the corresponding form of $\mathrm{Oahu}$, and thereby led astray various authors down to G. R. Gray in 1869, who combined the two species under one heading; the error, however, had no serious consequences, as Cassin, in his revision of Peale's work, put the matter on a proper footing, and has been followed by Judge Dole and more recent authorities. Meanwhile MM. Florent-Prévost and DesMurs had given another description and figure in the Zoology of the Voyage of the 'Vénus,' a French frigate sent round the world for purposes of exploration: they named the bird correctly on the plate, though assigning the specific name to "Lichtenstein"by many writers; but in the letterpress, having possibly seen Peale's book meanwhile, they referred it to $H$. lucidus. Lesson, considering it congeneric with Vestiaria, changed the appellation to $V$. heterorhynchus, and G. R. Gray placed it under Drepanis; but the distinctness of the genus Hemignathus of 1838 being finally settled, that term takes precedence over Heterorhynchus of 1839 ; moreover, it is clear that while in any case the latter can only be applied to the short-billed forms, the former will cover those 
with a long bill also, as Lichtenstein figured an example of each when founding his genus in the year first mentioned.

In the Island of Hawaii, to which, as far as we know at present, it is peculiar, this bird is decidedly rare, and I obtained only three specimens during a stay of some five weeks in June in Kona, where it frequents the koa trees alone, running up their great smooth trunks and along their limbs in search of insects. In the mamáne woods near Mana, I subsequently found it in considerable numbers in the month of January, when these trees are in full flower, resembling laburnums with their golden clusters. Its movements are very rapid, and the quickness with which it slips from one side of a limb to the other is surprising: I never could detect it in the act of sucking honey from flowers, nor, indeed, have $I$ seen any of its congeners so engaged; Mr. Palmer, however, has seen H. stejnegeri sucking the Lehua flowers. I noticed that many of the branches of the mamáne were dead, or sometimes half the tree, while the bark of large examples was easily detached and well suited to the penetrating bill of this bird; so that, although I was unable to approach near enough to watch the precise mode of procedure, the bill is probably thrust into cracks and crannies in the decayed wood, where grubs and insects are found, or it may loosen the bark and then capture the insects beneath with its long tongue.

Its vertical range seems to be from 3500 to 5000 feet, as I never met with it in the lower forest-zone.

Description.-Adult male. Head dull olive-yellow, passing into greenish olive, which covers the entire upper surface; throat and breast deep gamboge-yellow, shading into dull white on abdomen; under tail-coverts ashy olive; wing- and tail-quills greyish brown edged with olive; bill and feet slaty black.

Adult female. Head, sides of face, and entire upper surface ashy olive; throat and upper part of breast light gamboge-yellow, passing into dull ashy washed with lemonyellow; wing- and tail-quills greyish brown, edged with a duller shade of olive than in the male.

Immature. Upper surface uniform ashy, slightly tinged with olive on mantle and rump; chin and throat dull white, passing into ashy brown on flanks, while the breast and abdomen are ashy tinged with primrose-yellow.

Dimensions.-Male. Total length 5.75 inches, wing from carpal joint 3.35 , maxilla following the curve $1 \cdot 15$, chord subtending the curve $\cdot 85$, mandible $\cdot 65$, difference between maxilla and mandible $\cdot 40$, tarsus $\cdot 95$, tail $2 \cdot 15$.

Female. Total length $5 \cdot 10$ inches, wing from carpal joint 3 , maxilla following the curve $\cdot 95$, chord subtending the curve $\cdot 70$, mandible $\cdot 60$, tarsus $\cdot 85$, tail $1 \cdot 65$. 


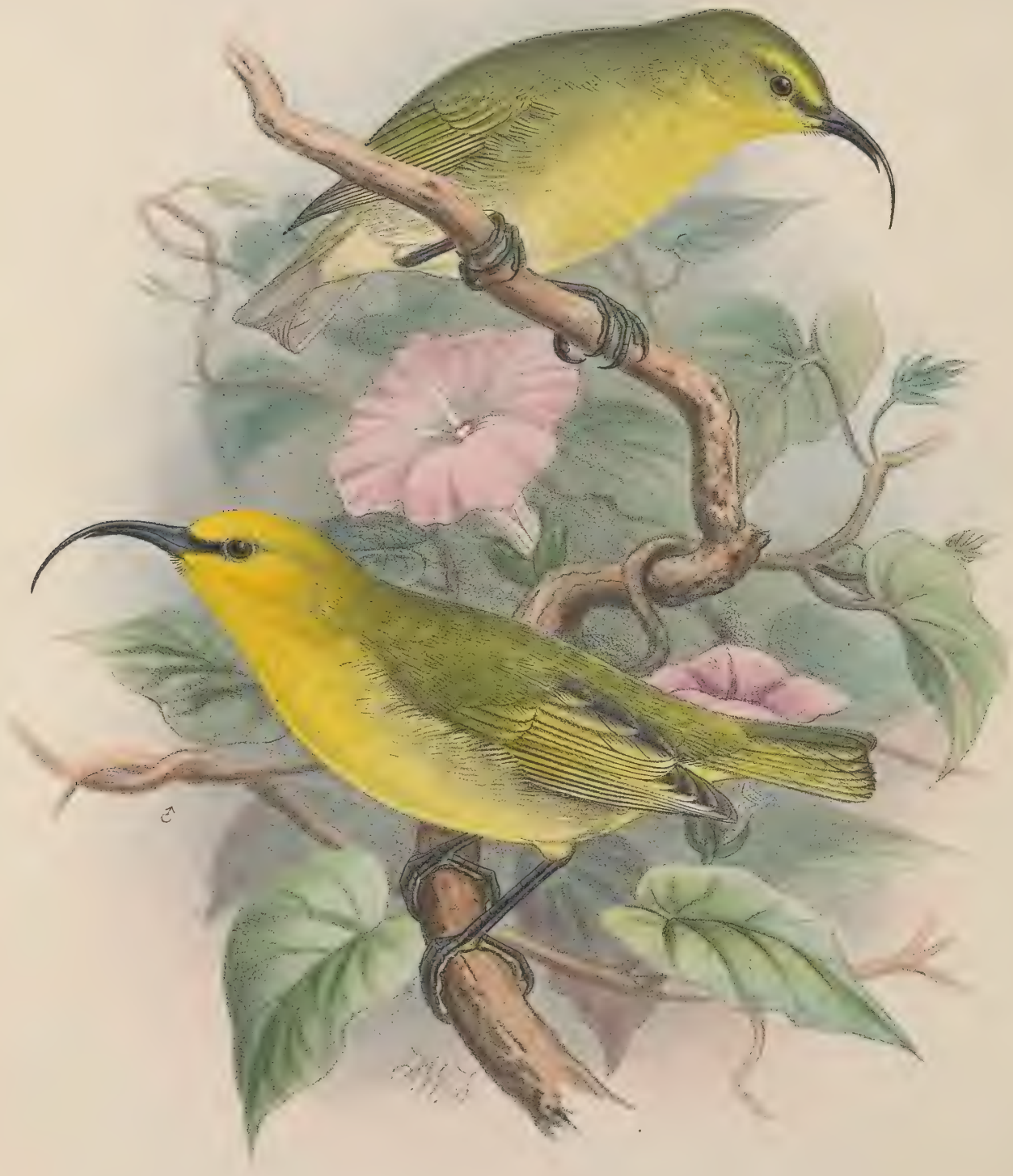

F.W. Frohawk del et lith

West, Newman 1 mp 


\section{HEMIGNATHUS AFFINIS.}

Hemignathus affinis, Rothschild, Ibis, 1893, p. 112.

Heterorhynchus affinis, Rothschild, Avif. Laysan, pp. 103, 104; Perkins, Ibis, 1895, p. 119.

Mr. Perkins's observations, recorded on the spot, give an excellent idea of the peculiarities of the genus as a whole. He says that since writing on the Hawaiian species he had had the opportunity of observing the habits of the present species on Maui, and $H$. hanapepe on Kauai :- "Both of them are found in the upper forest, though stragglers may occur at times at lower elevations. Their habits seem to" me quite identical; and going straight from the haunts of the one to those of the other, I failed to detect any difference in their songs. At the same time, besides the ordinary song (which resembles that of $H$. wilsoni, the Hawaii species, but is less loud), the Maui bird has a second distinct one, much like that of an introduced Carpodacus, which abounds in the same locality and nests there. This is no doubt imitated, as some of the native birds not infrequently sing like some other (native) species, the song of which is quite unlike their own proper one. Their call-note is a sharp 'keewit' once or twice repeated and louder than that of other birds in which it is very similar. This the sexes are repeatedly uttering, pausing in their feeding at short intervals for this purpose. Their food consists mainly of various insects, which they procure much in the same way as does $H$. wilsoni, but they are altogether quieter and less vigorous in their movements. In their stomachs I usually found spiders, wood-feeding larvæ of Tinæidæ and Geometridæ, and wood-boring beetles, especially the endemic brassy weevils of the genus Oodemas. Sometimes, too, they contained small pieces of lava, no doubt to aid in breaking up the hard shells of the beetles mentioned. That $H$. affinis also sucks honey I obtained decisive evidence, though I never saw it myself; probably all the species do so at times except $H$. wilsoni, which has become more entirely specialized for a Woodpecker's mode of life.

"In life, apart from their very distinct song and call-notes, these birds and the Hemignathi can readily be distinguished from all the other native species by the extremely short tail in proportion to their total length, - a distinction which the eye can apprecinte at distances at which neither the form of the beak nor the colour of the plumage is any longer to be made out. Moreover the Heterorhynchi differ in another respect from all the other green birds, for the latter, even in feeding on the limbs of trees, advance by more or less distinct hops, whereas the former regularly creep over the surface of the trunks and branches." 
To complete my account of the two species from Hawaii, already treated in this work, I here append Mr. Perkins's observations upon them, published in 'The Ibis' for 1893 (pp. 106-108):-

"But of all the birds of Kona the most interesting in habits is the shorter-billed Hemignathus [H.wilsoni]. The mere sight of so extraordinary a form could hardly fail to awaken in any one a keen desire to witness the manner of its feeding, and this I have many times been able to accomplish. It is a common bird from rather below 4000 feet to some hundreds of feet above that altitude, and most probably much higher still. It is most partial to the larger acacias, running up and down the limbs and trunks with equal ease, and also hoth on the upper and lower surfaces of the branches. It was on the 11th of July, soon after my arrival at a sufficient altitude for this bird, that I first saw one, a fine bright male, feeding. When I first canght sight of it it was some ten yards off; but I easily got closer without scaring it in the slightest. Being bare-footed and bare-legged at the time, and the ground being overgrown with a very prickly introduced thistle, after following it for half an hour I found my feet somewhat painful. Meanwhile the bird kept straying over the fallen trunks, turning its head, now right, now left, in its desire for food. In this manner it searched both sides of the tree in one journey without retracing its steps. And this is how it uses its bill:-The upper mandible it plunges into the small holes or cracks in the wood, while the lower presses on the surface of the bark. By this means, I imagine, it gets a considerable leverage to help it in opening out the burrows of the insects. In the same way it thrusts its upper bill under the loose bark, resting the lower one on the surface, and in this way strips the bark off. The upper mandible, though so thin, is very strong and somewhat flexible; while the curve of the bill follows the curve of the burrow, for insects nearly always burrow more or less in a curve. Should the curve of the burrow not agree with the curve of the bill, the difficulty is overcome both by the slight flexibility of the beak and by the wonderful flexibility of the bird's neck, which it twists round so as to bring the curve of the bill to follow that of the burrow. In this manner it gets out its prey, being largely aided by the long tongue, which is as long as the upper beak. Every now and then it gives several blows to the trunk, the sound of which may be heard at a considerable distance, sometimes, I think, to frighten out its prey to the entrance of the burrow, sumetimes for the purpose of actually breaking the wood.

"I had several other opportunities of observing this bird when feeding, afterwards; the blows that it gives to the trunk and branches are dealt with great vigour and with the beak wide agape, so that the points of both mandibles come in contact with the surface. One hot morning, shortly before I left Kona, I watched one of these birds for some time lying on a branch of the mamane and basking in the sun. Now and then it would lazily turn and peck at the bark without changing its position. Suddenly it started up and commenced to feed in earnest, dealing blows with savage energy. Into these blows it throws its whole weight, swinging backwards from the thighs to renew each stroke. In some cases at least these blows are for the purpose of driving out insects, or at any rate hare that result; for several times $I$ saw the bird after a stroke 
make a sudden dart, sometimes even taking an insect on the wing, and, after swallowing it with evident satisfaction, return again to its labour. Its song is short but rather pleasing, and, as one would expect from its habits, full of life and energy.

"The long-billed species [H. obscurus] is also an interesting bird, as in its habits it is intermediate between Himatione and its short-billed relative. Himatione mainly feeds on insects amongst the leaves and flowers of the forest trees, but not infrequently pecks at the bark in true Woodpecker style. In the long-billed Hemignathus this mode of feeding becomes much more usual, and its tapping may often be heard in acacia and other trees; still it feeds largely on insects amongst the leaves of the lehuas, \&c., while the short-billed species has almost entirely assumed a Woodpecker's habits. This bird is by no means confined to the lower forest, but extends its range right up into the haunts of the short-billed bird, where they may be seen even in the same tree. I rarely heard it sing. Its song reminded me somewhat of that of the yellow Himatione, but was distinct enough."

Mr. Rothschild's original description of this species is as follows:-

"This bird is very closely allied to $H$. hanapepe, of Kauai, but differs in having the head, throat, and upper breast more golden yellow, and the back, rump, and upper wing-coverts dull olive colour instead of greenish yellow. Moreover, in $H$. affinis the yellow of the head terminates abruptly at the occiput, while it gradually passes into the colour of the back in H. hanapepe. 'The anal region and under tail-coverts are yellowish green, whilst in $H$. hanapepe they are white. Total length about 5 inches, wing $3 \cdot 05$, tail 2 , tarsus $0 \cdot 85$, culmen $1 \cdot 2 . "$

The female is greyish above, with pale yellow lower parts and superciliary streak. 



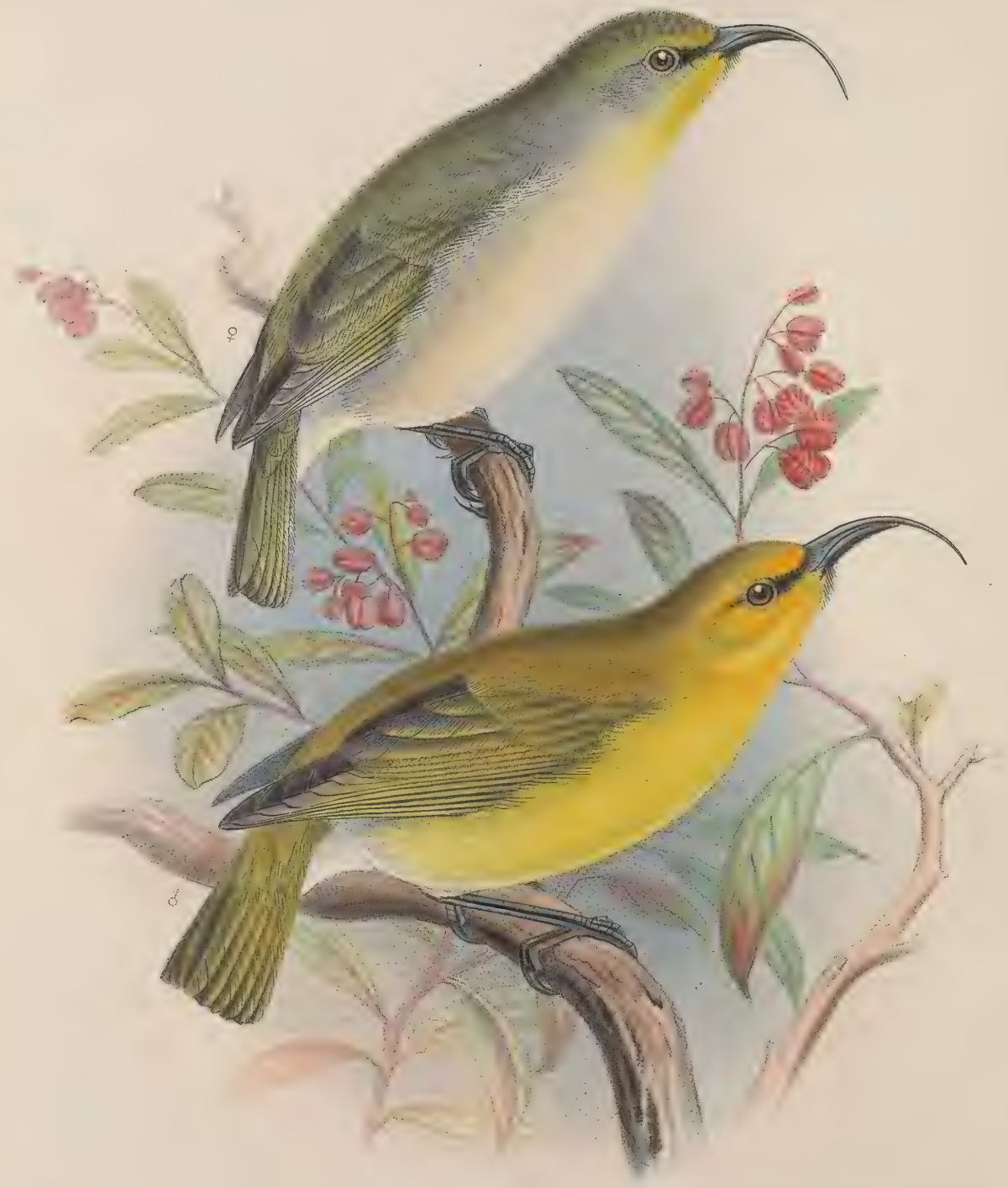




\section{HEMIGNATHUS HANAPEPE。}

\section{NUKUPUU.}

Hemignathus hanapepe, S. B. Wilson, Ann. \& Mag. Nat. Hist. ser. 6, iv. p. 401 (1 Nov. 1889); id. Ibis, 1890 , p. 192, pl. vi. fig. 1.

THIs interesting bird, which in colour and size much resembles $H$. olivaceus of Hawaii, I described as new in my paper on "Three undescribed Species of the Genus Hemignathus," in the 'Annals and Magazine of Natural History' for November 1889, while I subsequently figured it in 'The Ibis.'

I discovered the Nukupuu whilst staying at a little mountain-cottage belonging to the Sinclair family in the higher forest-region of Kauai, at an altitude of some 3000 feet, to which excellent collecting-ground Mr. Aubrey Robinson most kindly accompanied me. Here I stayed with my native-Keawe-for ten days, and as the cottage is some five hours' ride from any other habitation, and is completely surrounded by forest on three sides-the fourth having a fine outlook to the sea, across a stupendous and thickly-wooded ravine, which separates it from the next plateau-one could not well imagine a better camping-ground. That this bird is very scarce is pretty clear, for my friend Mr. Francis Gay, who for some years past has paid great attention to birds, had never seen any specimens, and, furthermore, I only obtained five during a stay of nine days. Mr. Palmer-the collector sent to the islands by the Hon. Walter Rothschild-only secured eight during a visit of some duration, and but two additional examples in seven weeks' collecting in the wooded mountain-slopes above Makaweli (2000 feet), the latter in different months. The fact of Mr. Palmer's procuring specimens near Makaweli is of interest, as showing that the bird is not entirely confined to the higher forest-zone. The first I shot, a fine male which was in a lofty ohia tree, I took to be Himatione parva, the briliant yellow of the breast in both species being very noticeable, and I was therefore greatly delighted to find, on picking it up, that I had secured a form quite new to me. Mr. Palmer says that he found difficulty in distinguishing the females and young males of the Nukupuu from the Amakihi (Himatione stejnegeri), as the two birds have so great a resemblance to each other. For my own part-as I remarked in my paper in 'The Ibis' for 1890-I found that the slaty colour of the upper surface of the former enabled me to determine them easily enough, even when engaged in hunting for insects at a great height from the ground. With regard to the exact manner in which the curiously formed bill is used, I regret that neither Mr. Palmer nor I have been able to throw any light on the subject, for the bird is so active in its movements, and the maxilla so slender, that it is most 
difficult to discern the latter at all, even at a short distance, while the extreme rarity of the species made me unwilling to risk the loss of a specimen by too close observation. I agree with $\mathrm{Mr}$. Palmer in believing that the bird merely inserts its long hooked beak into crevices and holes in decayed wood, extracting by that means the grubs and insects which abound under the bark; its habit of keeping along the upper surface of a branch and examining the sides within its reach we both noted. The food doubtless consists for the most part of insects, larvæ, small beetles, \&c., but I am assured by my native-Keawe-that the Nukupuu also feeds on bananas and oranges, and I have every confidence in the assertion. In the district of Waimea, especially near the renowned Hanapepe Falls, after which I named my discovery, orange-trees are numerous, and though I did not actually see the Nukupuu there, Mr. Palmer's specimens from the vicinity of Makaweli make it very probable that the bird may occur in that locality.

Description.-Adult male. Front and top of the head dull gamboge-yellow, passing into bright olive, which extends over all the upper surface of the back, wing-coverts, and tail; lores black, joined by a narrow black line just above the bill; throat, cheeks, and breast deep gamboge-yellow, passing into dusky white on abdomen and tail-coverts; wing- and tail-quills greyish brown, edged outwardly with olive; irides dark hazel; bill and feet slaty black.

Adult female. Tinged with olive on the forehead, an indistinct line passing over the eye; wing- and tail-quills margined with olive; breast primrose-yellow, changing into dull white on the abdomen; lower tail-coverts tinged with buff.

Dimensions.-Adult male. 'Total length 5.60 inches, wing from carpal joint 3.25, maxilla following the curve $1 \cdot 20$, chord subtending the curve 80 , difference between maxilla and mandible $\cdot 50$, tarsus $\cdot 90$, middle toe with claw $\cdot 70$, hind toe with claw $\cdot 75$, tail $1 \cdot 85$.

Obs.-Generally resembling $H$. olivaceus, but differing remarkably in the shape of the mandible, which follows the curve of the maxilla as in H. lucidus, and is not straight as in the former bird; the rather brighter tinge of yellow that perrades most of the plumage and the white abdomen are other distinguishing marks. 


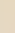




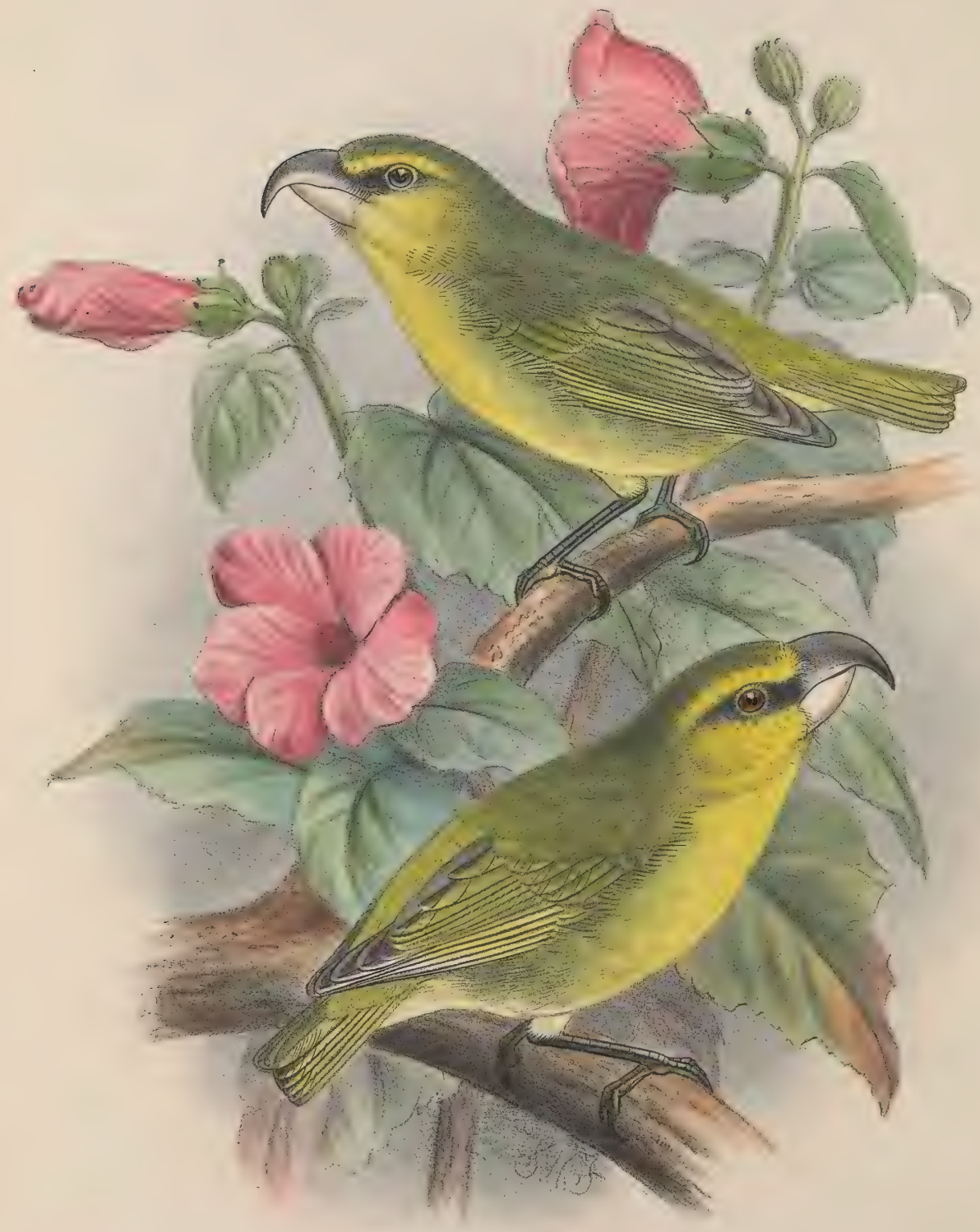




\section{PSEUDONESTOR XANTHOPHRYS.}

Pseudonestor xanthophrys, Rothschild, Bull. Brit. Orn. Clnb, i. p. xxxv (1893) ; Perkins, Ibis, 1895, p. 118.

OF this very curious stoutly-built form, peculiar to Maui, especially noticeable for its abnormally large hooked bill, Mr. Perkins writes as follows :-

"Of the Fringillidæ (nearly all of which are peculiar to the Island of Hawaii) I have already given some account of the habits; but there remains one,-Pseudonestor xanthophrys,-peculiar to the Island of Maui, which is perhaps the most remarkable form of all. It is local and rare, and seems to be confined to the highest forest on Haleakala, at an elevation of some 5000 feet above sea-level. Being very tame and apparently unwilling to fly far, I had on several occasions excellent opportunities to learn something of its habits, and especially of the use of its curiously formed and exceedingly powerful beak. The bird has an evident predilection for the koa trees (Acacia falcata), and it is from these that it mainly gets its food. This consists of the larvæ of a highly peculiar endemic genus of Longicorn beetles (Clytarlus), of which there are in the islands a considerable number of species, nearly all of them attached to the different species of native acacias. The larger ones usually burrow in the main trunks, the smaller in the limbs and twigs above. It is on the larvæ of the latter that Pseudonestor feeds and in procuring thern has developed the large hooked beak, the powerful jaw-muscles, and heavy skull, which constitute its chief peculiarities. It may be observed that the twigs in which the Clytarli have their burrows are not generally rotten, but dry, and of excessive hardness, often surpassing in this respect the still living and unaffected branches. The bird is sluggish, in its movements parrot-like in the extreme, especially in the varied hanging attitudes that it assumes, while the similarity is still further increased by the shape of its beak.

"Those that I saw in the act of feeding were generally clinging to the under sides of the thin branches or twigs, the head raised above the upper surface; the point of the curved maxilla was thrust into the burrow, the short mandible opposed thereto, and pressed against the side or under surface of the twig, and the burrow opened out by sheer strength. All that I shot contained larræ of these beetles, as many as 20 or 30 being found in the stomach of a single bird. No less than four species of Clytarlus were found on the acacias in the actual haunts of Pseudonestor; these too, like the bird, are all of species peculiar to the same island. When alarmed the bird gave frequent utterance to a short squeaking cry; it has besides a decided song, 
which reminded me much of that of the green Himatione. Once I heard it sing on the wing, as it crossed a gulch ${ }^{1}$.

"The unpleasant scent of Pseudonestor, like that of many Drepanididæ and other Hawaiian Finches, is very noticeable.

"Looking at the Hawaiian Finches as a whole, it may be noticed how wonderfully the structure of each of them has been specially developed according to the nature of its own particular and most important article of food. Thus, Pseudonestor, as above mentioned, has an enormous development of beak and skull and muscles attached thereto, for splitting the koa twigs; Chloridops has a huge beak and still heavier skull and muscles, which enable it to crack the hard nuts of the bastard sandal (Myoporum); then there is the strong cutting-beak of Rhodacanthis for dividing up the koa beans, and a large development of the ahdominal portion of the body, in accordance with the large fragments that it swallows; the shorter bill of Loxioides, which deftly cuts off the bean of the mamane acacia (Sophora), while the bird holding it in position with its foot opens the pod and devours the seeds; and, lastly, the hooked bill of Psittacirostra, with which it digs out the separate components of the fleshy inflorescence of the 'ieie' (Freycinetia), for this is certainly its natural food, though it has now come to feed largely on various introduced fruits-guavas, oranges, and the like. Besides their special foods, all the Finches vary their diet at times with the larvæ of Lepidoptera."

Description. - Upper parts greenish grey, greener towards the rump and head, a canary-yellow superciliary streak reaching nearly to the nape on each side; lower parts of the same yellow colour, which extends upwards to the bottom of the sides of the neck; wings and tail browner with greenish margins; maxilla blackish, mandible nearly white; feet slaty black.

Dimensions.-Total length $5 \cdot 5$ inches, wing 3 , tail $1 \cdot 9$, tarsus $\cdot 9$, culmen 1 .

The female is duller grey above, and less bright below, being smaller in all her dimensions. 


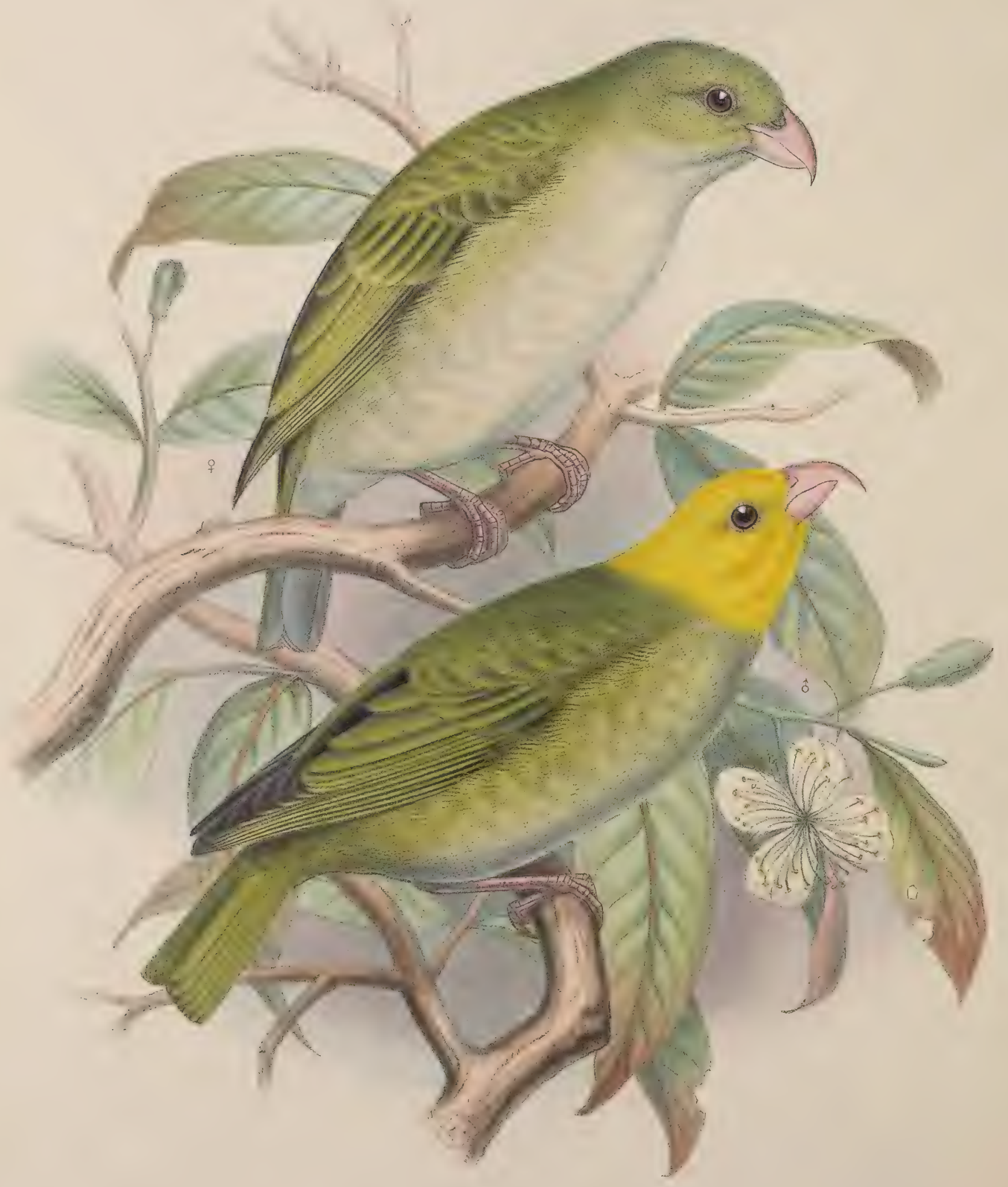




\title{
PSITTACIROSTRA PSITTACEA.
}

\author{
$\mathrm{OU}^{1}$.
}

"Parrot-billed Grosbeak," Latham, Gen. Synops. ii. p. 108, pl. xlii.* (1783).

"Bird with a yellow head," King, Voy. Pacif. Ocean, iii. p. 119 (1784).

Loxia psittacea, Gmelin, Syst. Nat. i. p. 844 (1788) ; Latham, Ind. Orn. i. p. 371 (1790) ; Donudorff, Orn. Beytr. ii. p. 343 (1795) ; Tiedemann, Anat. Naturgesch. Vög. ii. p. 433 (1814); Stephens, Shaw, Zool. ix. p. 268 (1816) ; Bloxam, Voy. 'Blonde,' p. 249 (1826).

"Le Gros-bec Perroquet," Virey (Sonnini), Hist. Nat. Buffon, Ois. xi. p. 81 (1803-4).

Strobilophaga psittacea, Vieillot, N. Dict. d'Hist. Nat. ix. p. 609 (1817); id. Encycl. Méth., Ornithol. p. 1021 (1823).

Psittirostra psittacea, Temminck, Man. d’Orn. i. p. Ixxi (1820); Swains. Classif. B. ii. p. 295 (1837) ; G. R. Gray, Gen. B. ii. p. 389, pl. 94. fig. $2 *$ (1845); Bonaparte, Consp. Av. i. p. 492 (1850) ; Hartlaub, Arch. f. Naturgesch. 1852, i. p. 133 ; Cassin, U.S. Expl. Exped., Mamm. \& Orn. p. 432 (1858); Dole, Proc. Bost. Soc. N. H. xii. p. 301 (1869); id. Hawaiian Alman. 1879, p. 49; Sclater, Ibis, 1871, p. 360 ; id. Proc. Zool. Soc. 1878, p. 347; id. Ibis, 1879, p. 92 ; Von Pelzeln, Journ. f. Orn. 1872, p. 30 ; id. Ibis, 1873, p. 21 ; Finsch, op. cit. 1880, p. 81 ; Sharpe, Cat. B. Br. Mus. x. p. 51 (1885) ; Stejneger, Proc. U.S. Nat. Mus. 1889, p. 386 ; S. B. Wilson, Ibis, 1890, p. 194.

"Raouhi," Quoy \& Gaimard, Voy. 'Uranie' et 'Physicienne,' Zool. ii. p. 36 (1824).

Psittirostra sandvicensis, Stephens, ut suprà, xiv. p. 91 (1826).

Psittacirostra icterocephala, Temminck \& Laugier, Nouv. Rec. Pl. Col. 457*, livr. 77 (1828); Cuvier, Règne Anim. éd. 2, i. p. 415 (1829).

Sittacodes, Gloger, Gemeinn. Hand- u. Hilfsbuch, p. 249 (1842).

Psittacopis psittacea, "Nitzsch," Cabanis (Ersch \& Gruber), Allgem. Encycl. sect. i. 1, p. 219 (1849); Sundevall, Tentam. p. 32 (1872).

Psittacina olivacea, Lichtenstein, Nomencl. Av. p. 48 (1854).

Psittirostra icterocephala, G. R. Gray, Cat. B. Trop. Isl. p. 28 (1859).

* Figura notabiles.

THIS is one of the birds originally made known by Latham, who described and figured as the "Parrot-billed Grosbeak" in the 'General Synopsis' an example of each sex from the collection of Sir Ashton Lever; of these the male is now in the Imperial Museum at Vienna, while both were doubtless obtained during Cook's last voyage, in the account of which King refers to this species as the "Bird with a yellow head." Cassin, by merely mentioning it as from the Sandwich Islands, in the "Catalogue of Birds' at the end of his account of the U.S. Exploring Expedition, would seem to

$1 \mathrm{Mr}$. F. Gay informs me that on Kauai the male is sometimes called "Ou poolapalapa" (Ou with the yellow head), while the female goes by the name of "Ou laevo" (the green $\mathrm{Ou}$ ). Bloxam also called the bird "Ohu," 
imply a wide and general range, while Peale omitted it entirely, though his party obtained the examples vouched for by Cassin. Gmelin called the bird Loxia psittacea, and, as will be seen from Dr. Gadow's 'Remarks' in this work, it is truly Fringilline and is near Loxioides, though belonging to a different genus, which Temminck rightly felt justified in separating in 1820 under the title of Psittirostra: I agree, however, with that author's later opinion that the more correct form is Psittacirostra, which was accepted at a subsequent date by Cuvier. In his 'Manuel,' Temminck made the mistake of considering the female, of which he had only a drawing, to be a distinct species; but when figuring it in the 'Planches Coloriées' he corrected the error ${ }^{1}$, Latham in his 'General History of Birds' having meanwhile drawn attention to it.

In the former author's own copy of the catalogue of the sale of the Bullock Collection (23rd day), a single specimen of this bird is marked " $£ 11$ s.-genre nouveau:" in another copy, with annotations supposed to be in Latham's handwriting, the same example is marked "Lichtenstein;" but this is probably a mistake, as the genus does not occur in Lichtenstein's "Verzeichniss," and therefore presumably was not in the Berlin Museum in 1823. Temminck, moreover, in the 'Planches Coloriées,' remarks : "Le Musée des Pays-Bas possède les sujets achetés à la vente du Bullockian Muséum, à Londres," where "sujets" is in the plural. This would indicate that the Museum of the Netherlands contained more examples than one, though whether they all came from Bullock's collection must remain somewhat doubtful. A male and female are also in the Derby Museum at Liverpool (marked 1829 and $1829 a$ in Lord Derby's old catalogue), while W. W. Ellis has a drawing of the bird among those preserved in the British Museum (No. 79, “1779”).

This well-known species is distributed throughout the Sandwich group, and I obtained specimens from every island save Oahu and Maui, on the former of which I have good reason to believe it has become extinct or else extremely scarce. I cannot detect any appreciable difference between examples from the various islands, although I think those I obtained on Lanai are brightest in plumage. The size and shape of the curiously formed bill varies considerably, especially in the males: the two woodcuts on the next page will serve to show the variation referred to.

Next to Vestiaria coccinea, it is perhaps the most noticeable of the forest-birds of the islands, the bright yellow head and neck of the adult males rendering them very conspicuous in their straight dashing flight from tree to tree. The immature males and females, which lack this distinctive feature, might easily be mistaken for the sombre-coloured Phoornis obscura; but the coinstant twittering which the Ou almost invariably makes while feeding at once betrays its identity. Freshly killed examples possess a peculiar scent, which I did not observe in any other forest-dwelling species; it is probably due to their extremely varied fruit-diet.

Though Psittacirostra, as remarked above, is generally distributed throughout the group, in no locality does it seem to be abundant; but I am told by Mr. Francis Gay

${ }^{1}$ The figure in the $\mathrm{Pl}$. Col, is absurdly overcoloured, being of a bright grass-green, whereas the true colour is decidedly tinged with olive. 
that at the time of year that the guava is ripe it may be seen in great numbers feeding on its yellow fruits. I think that I found it most plentiful among the trees which clothe the abrupt sides of the deep ravine running down to the leper settlement on the island of Molokai; and very lovely these little birds looked, flying continually to and fro, up and down this stupendous gorge-their yellow necks flashing in the bright sunlight, as they darted out from among the dark green ohias or from the silvery foliage of the kukui (Aleurites triloba). The food of Psittacirostra consists entirely of fruits, and chiefly of that of the ieie (Freycinetia arborea), the ripe seeds of which I found in most cases in the stomach when dissecting specimens; I noticed also, particularly in one place on the outskirts of a forest in the district of Kona, that a very large proportion of the fruits of the climber were eaten away at the apex, and here I shot a good number of examples. I killed others as they were busily engaged in feeding on the small crimson fruit of the wild mulberry (Morus papyrifera), the juice of which had dyed their throats a deep crimson.

Necklaces, "leis," used sometimes to be made from the bright green plumage of the back and underparts of this bird, but they were commonly used in combination with the black feathers of Acrulocercus nobilis and the scarlet feathers of Vestiaria coccinea. I saw a wreath thus made at Olaa in the district of Puna, which I attempted to purchase, but the native woman wanted a higher price than I was inclined to give.

Description.-Adult male. Head and neck gamboge-yellow, all the rest of the upper parts olive-green inclining to yellow on the rump; whole of the under surface greenish yellow with the exception of the breast, which is grey; remiges and rectrices dusky brown margined with olive-green; irides dark hazel; bill and feet pinkish.

Adult female. Head and neck olive-green above and grey beneath; the rest of the under surface greyish white; under tail-coverts pure white.

Dimensions.-Adult. Total length 6.30 inches, wing $3 \cdot 85$, culmen $\cdot 70$, tarsus $\cdot 95$, tail $2 \cdot 20$.

Woodcuts are here given of the heads of two examples to show the difference in size and shape of the bill; in the first figure it is of an abnormal size and extraordinarily decurved. Other specimens vary between the two extreme types figured.
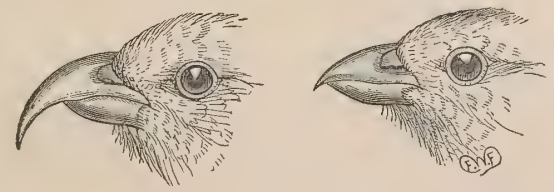

Obs.-An immature female from Kauai has the upper wing-coverts tipped with light olive-yellow. This specimen has also more yellow on the underparts than have others of that sex in my collection. Dr. Stejneger, in a paper entitled "Notes on Psittirostra psittacea from Kauai, Hawaiian Islands" (Proc. U.S. Nat. Mus. 1887, pp. 389, 390), 
discusses the possibility of there being two species, and in conclusion asks: "Are there two different species of Psittirostra on the Sandwich Islands, or are the differences pointed out above perhaps only due to age?" Since the publication of this paper Dr. Stejneger has been kind enough to send me one of the specimens described in itan adult male-for comparison. I have carefully compared it with others from Hawaii and cannot detect any marked difference, though it has the head rather brighter than the average from that island; while I imagine that the discrepancy which the author found between it and Latham's description may have been due to the latter having had only poor examples before him. I did not, however, obtain specimens from Oahu, and Herr von Pelzeln may be right when he remarks (Ibis, 1873, p. 22), with regard to two examples procured on Oahu as compared with Latham's type, "even the older one $\left[\sigma^{*}\right]$ differs from Latham's male bird [then before him], the middle of the breast and belly and the thighs being whitish;" the latter in all probability came from Hawaii. I may here remark that an immature male from Lanai has the under surface clear primrose-yellow, with bright olive-green flanks, while the olive-green of the upper parts is also brighter than in any other specimen which I possess. These variations are, I imagine, due to age, as a female from the same island does not differ from one from Hawaii. Examples from Molokai do not present any definite points of difference, though perhaps they are somewhat duller beneath. I did not, as already remarked, obtain a single bird from Maui ${ }^{1}$.

${ }^{1}$ Dr. Finsch (Ibis, 1880, p. 80) says "when collecting at Olinda, Maui, Psittirostra psittacea I saw repeatedly; but I lost those I shot, from their falling into the ferns." My friend Mr. Randal von Tempsky informs me that he saw several specimens of this bird during a visit made to the Ukumehame Gulch in 1890 . 



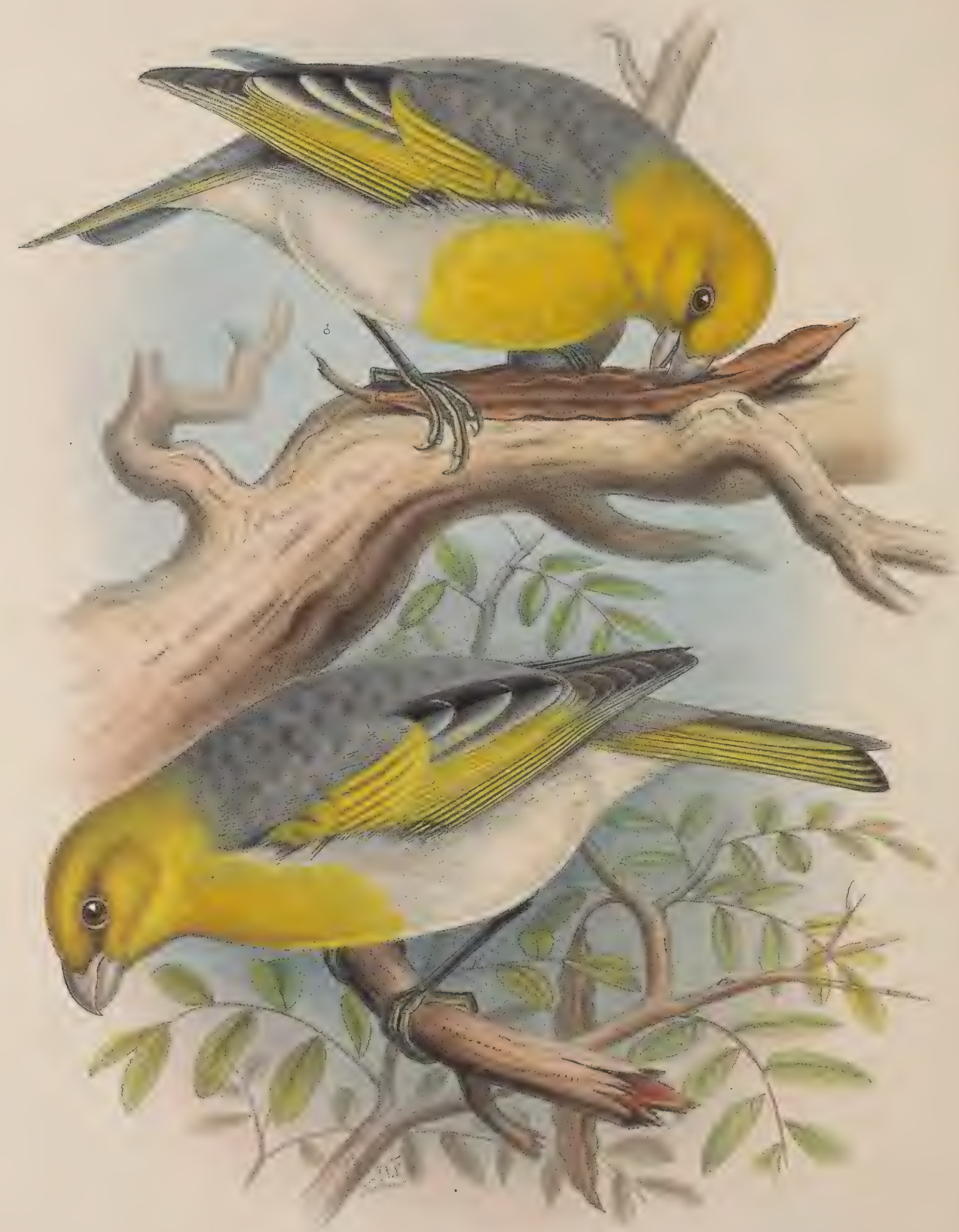




\section{LOXIOIDES BAILLEUI.}

PALILA.

Loxioides bailleui, Oustalet, Bull. Soc. Philomath. Paris, sér. 7, i. p. 100 (1877); Ibis, 1878, p. 376; Sharpe, Cat. B. Br. Mus. x. p. 49 (1885).

" bailleni (err.), Sclater, Ibis, 1879, pp. 90, 92, pl. ii.*

* Figura notabilis.

THE literary history of this bird is of the simplest nature. Described by M. Oustalet in 1877 , as a new species of a new genus, undoubtedly Fringilline, and similar to Psittirostra, while easily distinguishable from it, the only dissentients of authority seem to be Messrs. Sclater and Sharpe, who have considered both to belong to the Family Dicceidae, or at least to approach it very nearly. The two original examples were sent by M. Bailleu ${ }^{1}$ from the Sandwich Islands in 1876 ; and though M. Oustalet did not state the exact locality from which they came in the first instance, he afterwards informed Mr. Sclater that the habitat was Hawaii, where the author also obtained his specimens.

A good coloured figure is given in 'The Ibis,' as above, from the pencil of Mr. Keu- . lemans, to illustrate Dr. Sclater's paper "On recent Additions to our Knowledge of the Avifauna of the Sandwich Islands." In this paper the author makes some most valuable observations on this "very remarkable type" as he terms it, which I here transcribe:- "It will be at once observed that Loxioides in general appearance is closely allied to Psittirostra. The form, size, and distribution of colours are similar. When we come to a closer comparison of the skins, the result arrived at is the same. The wing-formula is nearly the same in each. There are nine fully formed primaries, of which the first is about equal to the fifth, and the intermediate ones are the longest in the wing. In Psittirostra these three primaries are nearly equal in length; in Loxioides the second is rather more elongated beyond its fellows. The structure of the feet in the two forms is also nearly similar, those of Psittirostra being, however, shorter and stouter. The tarsi in both cases are unmistakably Oscinine, and the divisions of the scutes are quite obsolete. In the shape of the bill only, as will be seen by the outlines ( $\alpha$ of the bill of Loxioides, and $b$ of that of Psittirostra) given on the plate, there is considerable divergence, that of the newly discovered form being considerably shorter and much more swollen laterally than that of Psitti-

\footnotetext{
1 The late M. Bailleu was an enthusiastic naturalist, and spent some months at Dr. Trousseau's mountaincottage in the district of Kona on Hawaii, engaged in forming a collection of birds which he forwarded to the Iruseum of the Jardin des Plantes, with a second collection consisting of fishes.
} 
rostra. This, and the differences in the feet, may justify the separation of the two forms into two genera; but there cannot be the slightest doubt that they are very nearly allied, and must be placed next to one another in the system. M. Oustalet places Loxioides near the Finches and Paradoxornis. But Paradoxornis has, I believe, no near relationship to the Finches. And I adhere to my previously expressed sentiment ${ }^{1}$, that in all probability Psittirostra, and with it Loxioides, are not really Fringilline genera, but merely abnormal forms of the same type as Drepanis and Hemignathus, either belonging to or closely allied to the Dicæidæ ${ }^{2}$. This question, however, can only be satisfactorily determined by an examination of the structure of the tongue and other soft parts." I am happy to say that the valuable investigations of Dr. Gadow, the result of which will be found in the present work, have pretty well decided this question.

That Loxioides is closely allied to Psittirostra there can be little doubt, and their striking general resemblance often causes the natives to mistake the former for the latter; the two species, however, are, to my knowledge, scarcely ever met with in the same forest-zone-Loxioides being confined to the middle and upper, while Psittirostra is seldom seen except in the lower region. The Palila-to call it by its liquid and euphonic native name-is, as far as I absolutely know, confined to the island of Hawaii, and even there is singularly local, being found, I believe, only in the upland districts of Kona and Hamakua. Few natives recognize it, but as I remarked above-deceived by its general resemblance to Psittirostra-confound the two species. Its chief food, according to my observations, consists of the seeds of the mamáne ${ }^{3}$ (Sophora chrysophylla), the golden laburnum-like racemes of which tree make such a striking feature of the upper forest-zone during the months of January and February. The upper figure in the Plate represents a bird which I watched at close quarters splitting a mamáne pod, as the following extract from my journal will show:- "I shot a Palila to-day, as it was in the act of extracting the seeds from a mamáne pod; the bird's method of procedure was to cut the pod off with its beak, and then to lay it on a horizontal branch, holding it firmly with its claws, and pecking out the seeds one after the other. I was a few yards off, partially concealed by a tree."

As the sandalwood (Santalum album) and the bastard sandalwood (Myoporum santalinum) occur in fair quantity in the region in which Loxioides is found, I think that it very probably feeds on them; however, I have generally observed it in

1 "Cf. Ibis, 1871, p. 360 "

" "Mrohoa seems to be a Meliphagine form; but Drepanis, Hemignattus, and the other genera (except perhaps (hatoptila) in the list given, Ibis, 1871, p. 360, having only nine primaries, should probably be referred to the Dicæidx."

${ }^{3}$ I observed the mamáne also on the island of Maui, and it is reported, perhaps erroneously, from Kauai; so I think that Loxioides may inhabit the former island; and I am the more inclined to this belief, from the fact that a man but lately arrived in Hawaii from the highlands of Maui seemed at once to recognize the bird, and told me it was abundant where he had been liring. 
the mamáne, and have found the seeds of that tree alone in its crop. My friend Mr. Francis Sinclair tells me that the Sophora of New Zealand (S. grandiflora, the Kowhai of the natives), which bears a strong resemblance to the Sandwich Island species, is a great favourite with the Tui (Prosthemadera nova-zealandice) and other birds; and Sir W. Buller, in his 'History of the Birds of New Zealand' (2nd ed.), informs us that the Kaka (Nestor meridionalis) feeds on the pollen of the same plant, and figures the Tui on a branch of it.

The Palila, as far as I know, has no song, but merely a very clear whistle-like note, which, when often repeated, is held by the natives to be a sign of approaching rain. While at Waimea, a specimen of Loxioides was brought to me alive though injured; it lived a few days, during which it constantly uttered the clear whistle without giving evidence of any further powers. On June 14th I found a nest from which I saw the bird fly; it was placed in the topmost branches of a Naio tree (Myoporum santalinum), about 35 feet from the ground, but contained no eggs, and when we subsequently revisited it we found it deserted. It may be briefly described as cupshaped, 4 inches in diameter, and very loosely constructed of dry grass, among which is interwoven a considerable quantity of grey lichen; the inside being composed of the same lichen, with a few slender rootlets added.

Description.-Adult male. Entire head and neck deep gamboge-yellow, the remainder of the upper surface ashy grey, slightly inclining to whitish on the rump; wing-coverts, wing-quills, and tail-feathers dusky black, edged externally with olive-yellow; throat and upper part of breast gamboge-yellow, the rest of the under surface dusky white; irides dark hazel; bill and feet slaty-purple.

Adult female. Differs from the male in having the yellow of the head and neck washed with brown, which gives it a very dusky appearance, while the yellow on the under surface has a distinctly greenish tinge.

Dimensions.-Total length 6.5 inches, wing from carpal joint 3.55 , culmen 5 , tarsus $\cdot 95$, tail $2 \cdot 65$. 


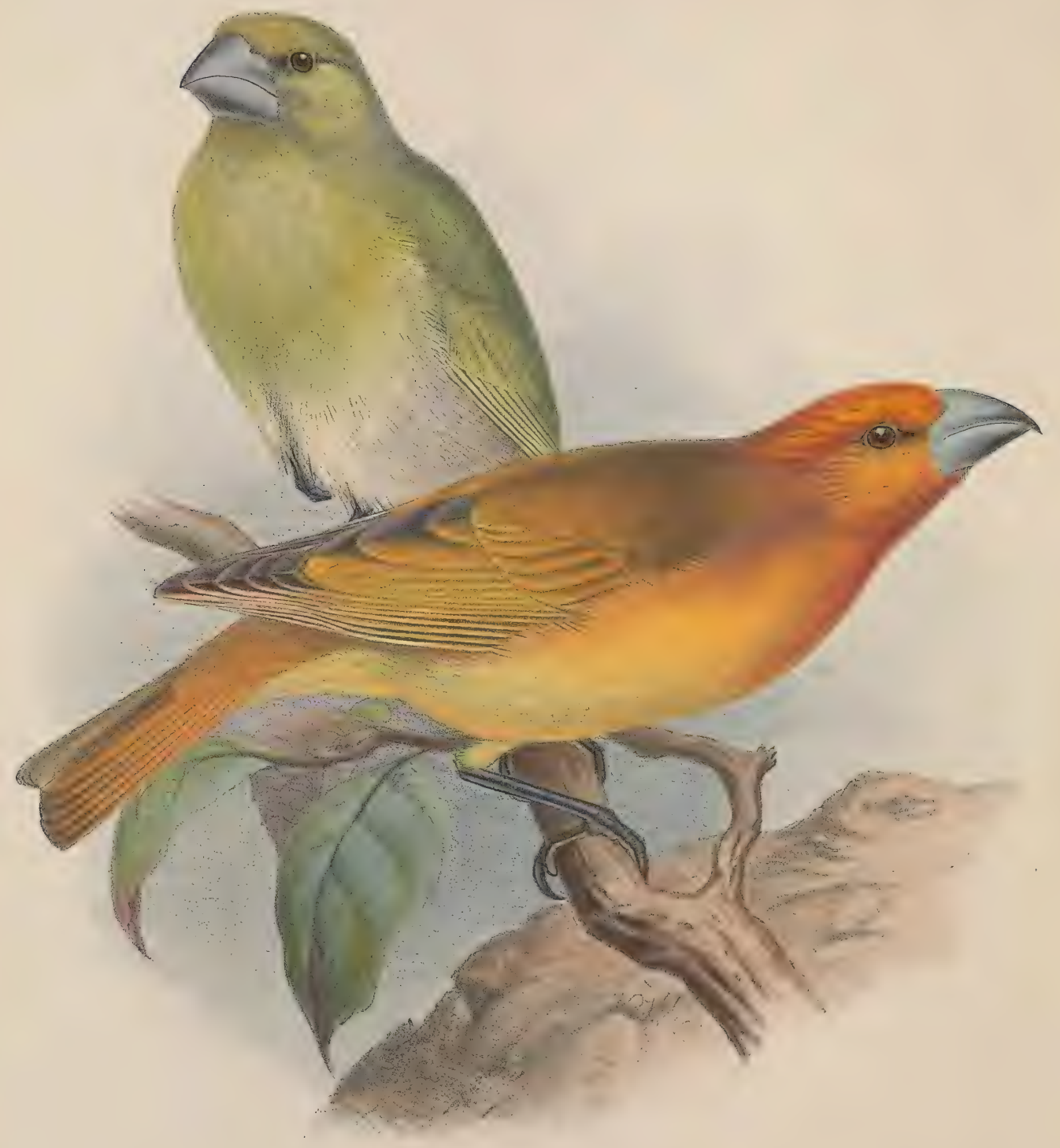

FWFrohawk del etlith. 


\section{RHOD ACA N TH IS ${ }^{1}$ P A L M ERI.}

Rhodacanthis palmeri, Rothschild, Ann. \& Mag. N. H. (6) x. p. 111 (July 1892) ; Perkins, Ibis, 1893, p. 103.

IN the paper here cited Mr. Rothschild describes the above as a species of a new genus from Kona in Hawaii, and in 1892 I received two examples from that district, while about the same time Mr. Perkins obtained many others from the forests at an altitude of 4000 feet.

He writes ('Ibis,' 1893, pp. 103-104) of them as follows :-

"The Koa Finch (Rhodacanthis palmeri) is the largest and most beautiful of all the Hawaian Finches. It frequents the tallest and most leafy acacias, both when growing on the roughest lava-flows and in the grassy openings in the forest. It belongs entirely to the upper forest, and is probably most numerous at about 4000 feet. Its peculiar whistle, though not very loud, is very clear, and can be heard for a considerable distance. If imitated closely it will readily answer, and sometimes, after fruitless hunting for hours without even hearing a sound from this bird, a whistle has been immediately responded to. At other times a distant bird has been drawn close by the imitation of its whistle and easily secured. It devours the beans of the acacia, and these it swallows in very large pieces. I think that the enormous development of the abdominal portion of the body must be connected with this habit. I have seen both male and female feeding the full-grown young, and as I could find nothing but the large pieces of koa bean in the latter, I conclude that the young are fed on pieces similar to those swallowed by the parents, without mastication. The young male soon acquires the peculiar whistle, for I have shot one in almost perfect song in quite immature plumage and with the skull still cartilaginous. It does not restrict itself to the koa bean, but varies its diet by feeding on lepidopterous larvæ, just as the Psittacirostra does; for this purpose it generally descends into the aaka or bastard sandal-wood trees, and, as was the case with that bird, I have found in the crop of Rhodacanthis larvæ with conspicuous 'warning' colours. When it has been feeding on the koa beans its bill is often much stained with their green juice and green fragments. The female I have heard to utter a rather deep single note when alarmed. On one occasion when I had shot a male I heard his mate repeatedly utter this note, and she continued to do so for some five minutes, but seemingly possessed some

1 To prevent misapprehension it should be noticed that the genus is not closely allied to the bird called Acanthis by classical writers, or to the supposed genus (see 'Ibis,' 1892, p. 556) of that name, nor is it rosecoloured. 
ventriloquial power - the sound seeming now in front, now behind, now near, now far; yet it was utterly impossible that the bird could have flown without my being aware of it. At last the bird became silent, and I never caught sight of it at all."

Description.-Adult male. Head, throat, and underparts rich scarlet-orange, becoming slightly more yellow on the chest and gradually merging into the mere orange of the abdomen and under tail-coverts; upper back and wing-coverts brown, washed with yellowish olive; remiges and rectrices blackish brown, with a narrow margin of dull orange on the outer web; lower back with rump and tail-coverts dull orange; under surface of wings and tail whitish grey, with a little orange on the axillaries. The outer wing-coverts and bend of wing are tinged with orange. Bill bluish grey, legs almost black.

Dimensions. - Total length $8 \cdot 87$ inches, wing $4 \cdot 62$, tail $2 \cdot 87$, tarsus 1 , culmen $\cdot 75$.

Adult female. Above brownish, washed with fairly bright olive-green, which is still brighter on the crown, forehead, sides of face, rump, and upper tail-coverts; throat and chest much as the rump, but more white-looking; rest of underparts greyish white with a slight green wash; axillaries tinged with green. The wings and tail are similarly coloured to those of the male, but with green margins instead of orange. The hook of the maxilla is less prolonged than in the male. The dimensions are smaller, except as regards the tarsus and culmen.

Young male, No. 1. The scarlet-orange is beginning to show on the forehead and, slightly, on the crown; the under surface is dull orange, with indications of green on the breast; the region of the rump is duller than in the adult; the maxilla is whitish at the sides.

Young male, No. 2. Entirely olive-green above; throat yellower; breast mottled with green and yellow, owing to the feathers having green centres and broad buffishyellow margins; abdomen pure buffish yellow; maxilla similar to that of the female.

Mr. Rothschild considers some examples from Kona to be specifically distinct, and calls them $R$. flaviceps (Ann. Mag. N. H. ser. 6, x. p. 111). In these the head, neck, and underparts are yellow, greener below; the upper parts are ashy-green, brighter towards the rump; the iris is brown. Only the forehead is yellow in the female. The dimensions are respectively smaller than in the last species. 


\section{RHODACANTHIS FLAVICEPS.}

Rhodacanthis flaviceps, Rothschild, Ann. \& Mag. Nat. Hist. ser. 6, x. p. 111 (July 1892).

WHEN treating of Mr. Rothschild's species Rhodacanthis palmeri, from Kona in Hawaii, we carefully abstained from expressing any decided opinion upon the exact status of $R$. flaviceps, of which we had not then examined a specimen, quoting nevertheless the describer's opinion as to its validity, and stating the main points of difference. Two birds, obtained by Palmer at the same locality as $R$. palmeri, have, however, now been submitted to us, with the result that we unhesitatingly agree to the perfect validity of the species, which is undoubtedly distinct from its larger and more orange congener. The original description is consequently given below, as it appeared in the 'Annals and Magazine of Natural History' :-

\section{"Rhodacanthis flaviceps, sp. n.}

"Adult male. Head, neck, and underparts generally apple-yellow, brighter and richer on the head and neck and greener on the underparts. Upper parts ashy green, becoming bright green on the lower back, rump, and upper tail-coverts; wings and tail dull blackish brown, the feathers externally margined with green. Bill blue-brown; legs grey; iris brown.

"Total length about $7 \cdot 5$ inches, culmen $0 \cdot 72$, wing $3 \cdot 8$, tail $2 \cdot 5$, tarsus $1 \cdot 0$.

"Adult female. Differs from the male in being much greener and duller in colour, only the forehead being yellow; the crown similarly coloured to the back. Underparts dull yellowish green." 



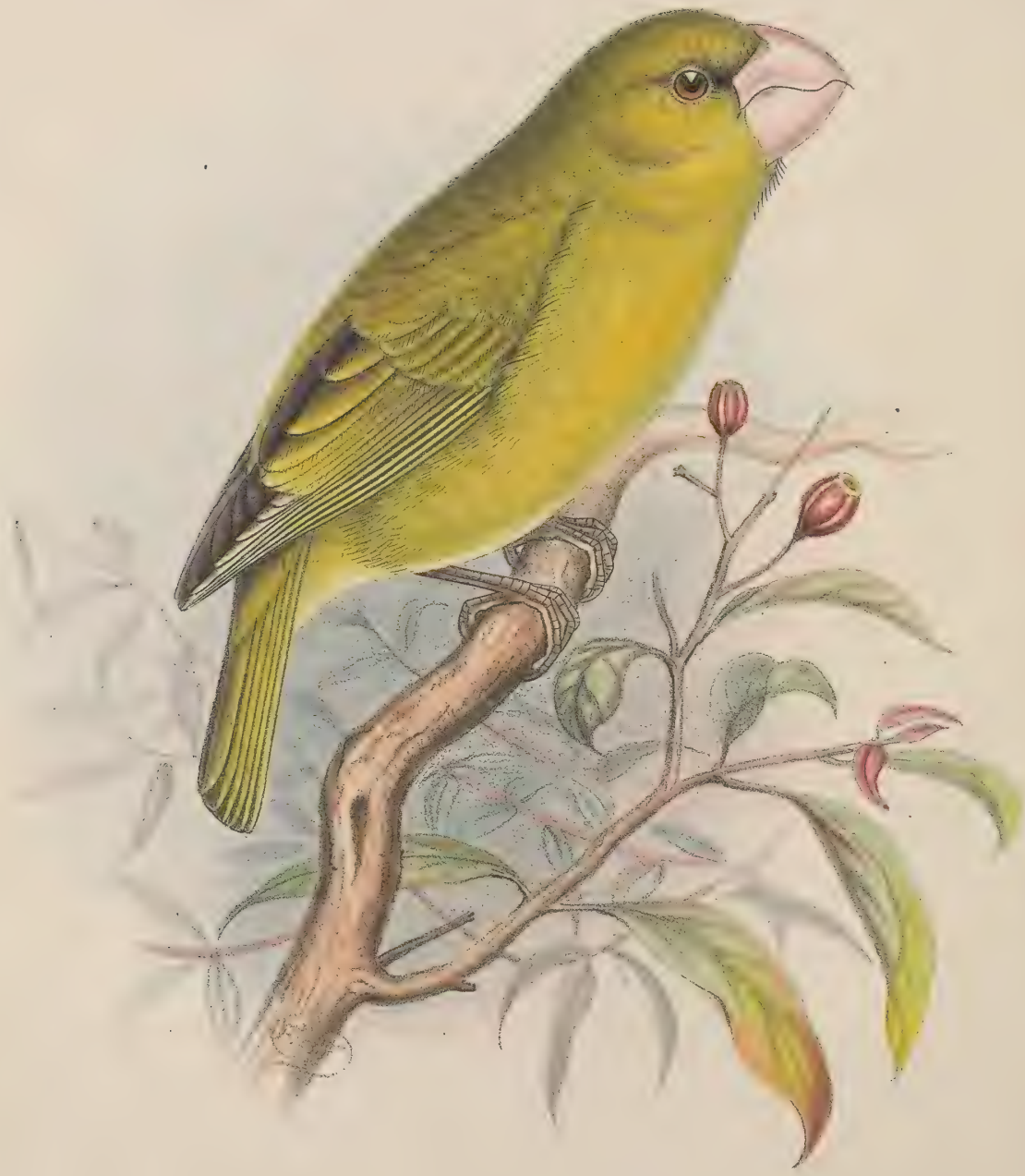

F.W. Frohawik del. et lith 


\title{
CHLORIDOPS KONA.
}

\author{
PALILA.
}

Chloridops kona, S. B. Wilson, Proc. Zool. Soc. 1888, p. 218; Perkins, Ibis, 1893, p. 104.

I sнот a single example of this species on June 21st, 1887, when collecting at an elevation of about 5000 feet in the district of Kona on the west coast of Hawaii, in a great tract of forest, consisting principally of koa-trees (Acacia koa); but there were also the mamane (Sophora chrysophylla), the alii (Dodoncea viscosa), the sandalwood (Santalum album), and the bastard sandalwood (Myoporum santalinum). I think that as Loxioides bailleui, so far as I know, feeds only on the seeds of the Sophora, it is most probable that this big Finch eats them also. During my stay of four weeks I only saw three examples of it. The specimen shot was on a tall Myoporum. The bird must be extremely rare, as I have since collected at almost similar elevations, where there are the same species of trees, but failed to obtain either of these Finches again, nor do the natives know them, whence I conclude that they are peculiar to the Kona district.

The general appearance of this bird is that of an exaggerated Greenfinch (Fringilla chloris, Linn.).

Description.-Adult female. Bill dull flesh-colour; lores dusky black. General colour above bright olive-green, passing into golden-green on the throat and belly; abdomen whitish; quill-feathers dusky black, edged outwardly with olive-green.

Dimensions. - Total length 5.75 inches; wing from carpal joint 3.25 ; tail 2 ; billfrom gape to tip $\cdot 8$, height from chin to forehead $\cdot 73$; maxilla, width at base $\cdot 52$; mandible, width at base $\cdot 59$.

Mr. Robert Perkins has recently published the following notes on the habits of this species in 'The Ibis':-

"The Palila (Chloridops kona), though an interesting bird on account of its peculiar structure, is a singularly uninteresting one in its habits. It is a dull, sluggish, solitary bird, and very silent-its whole existence may be summed up in the words 'to eat.' Its food consists of the seeds of the fruit of the aaka (bastard sandal-tree, and probably at other seasons of those of the sandal-wood tree), and as these are very minute, its whole time seems to be taken up in cracking the extremely hard shells of this fruit, 
for which its extraordinarily powerful beak and heavy head have been developed. I think there must have been hundreds of the small white kernels in those that I examined. The incessant cracking of the fruits when one of these birds is feeding, the noise of which can be heard for a considerable distance, renders the bird much easier to get than it otherwise would be. It is mostly found on the roughest lava, but also wanders into the open spaces in the forest. I never heard it sing ( $\mathrm{I}$ once mistook the young Rhodacanthis' song for that of the Chloridops), but my boy informed me that he had heard it once, and that its song was not like that of Rhodacanthis. Only once did I see it display any real activity, when a male and female were in active pursuit of one another amongst the sandal-trees. Its beak is nearly always very dirty, with a brown substance adherent to it, which must be derived from the sandal-nuts." 


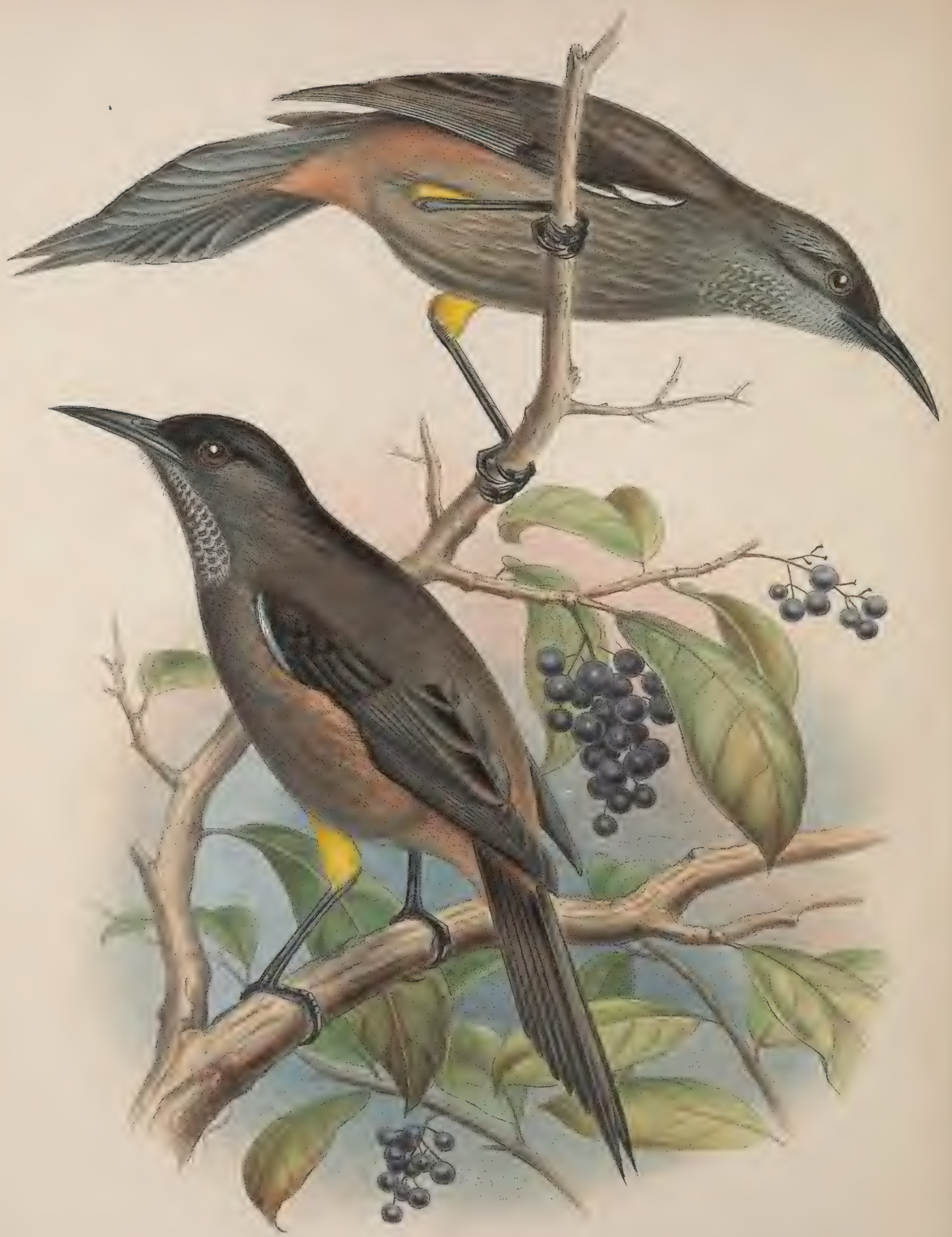




\title{
ACRULOCERCUS BRACCATUS.
}

\author{
O.O A-A.
}

"Yellow-tufted Bee-eater, var. B.," Latham, Geu. Synops. Suppl. 2, p. 149 (1802).

"Certhia pacifica, Latham," Peale, U.S. Expl. Exped., Birds, p. 149 (1848) (nec Gmelin, Latham). Mohoa fasciculata o, Reichenbach, Handb. sp. Orn. p. 333 (1853), tab. 614. fig. 4.099 * (nec Lath.).

„ braccata, Cassin, Proc. Acad. N. S. Philad. 1855, p. 440; id. U.S. Expl. Exped., Mamm. \& Orn. p. 172 (1858) ; Sclater, Ibis, 1871, pp. 358, 360, 1879, p. 92; Von Pelzeln, Journ. f. Orn. 1872 , p. 26.

Moho braccata, Cassin, U.S. Expl. Exped., Mamm. \& Orn. p. 172 (1858); G. R. Gray, Cat. B. Trop. Isl. p. 9 (1859); id. Hand-I. i. p. 114 (1869) ; Dole, Proc. Bost. Soc. N. H. 1869, p. 296; id. Hawaiian Alman. 1879, p. 46 ; Stejneger, Proc. U.S. Nat. Mus. 1887, p. 100.

Moho nobilis, Gadow, Cat. B. Br. Mus. ix. p. 284, partim (1884).

* Figura notabilis.

AT least one example of this undoubtedly good species was received in England in comparatively early days, but was regarded by Latham as a variety of $A$. nobitis; and that it should have been obtained even by Cook's people is only natural, since his ships more than once visited Kauai (then known by the name of A-tooi), to which island it is peculiar. But the real merit of its discovery is due to Cassin, who in 1855 first defined it, as above, from a single specimen-marked as a male-previously brought by Townsend to the Museum of the Academy of Philadelphia, where it had been ascriber in error to Certhia pacifica. The same mistake was made by Peale, who writes that " another bird is called $\mathrm{Oo}_{0}$ by the natives; it is Certhia pacifica of Latham, and is found on the island of Kauai, one of the same group. It also has tufts of yellow feathers which have been collected for the same purpose in former days; theirs are on the thighs, not on the sides as in the genuine $\mathrm{O}_{0}$; the feathers are smaller, much inferior in beautiful texture, and are no longer collected; both species are black. We killed specimens at Hanalei, a department of the Island of Kauai, where they are found in the woody districts on the mountains." The United States Exploring Expedition, however, does not appear to have brought back any examples; but Cassin, as we have seen, clearly perceived the error and, in pointing it out, properly described the present bird as a distinct, but allied, member of the genus Mohoa, as he called it: he moreover observed that Reichenbach figured it as the female of $M$. físciculata $[=A$. nobilis], whereas Judge Dole has since stated that the subject of that figure must have been a male. The original of the drawing is at Dresden, but otherwise no specimens are known to have reached Europe except those brought by myself; while I have 
had the great advantage of comparing my examples with Townsend's, through the kindness of the authorities of the Museum at Philadelphia, who with great courtesy forwarded it, together with examples of other varieties procured by the same traveller, for my inspection. Except for the fact that Dr. Gadow, in the Catalogue of the Birds in the collection of the British Museum, combined this species with A. notilis, little more need be added to its history.

This bird is confined to the island of Kauai, where it seems to be found at all elevations throughout the forests, and is called O-O A-A-the dwarf O-O-by the natives, who therefore recognize its resemblance to the $\mathrm{O}-\mathrm{O}$ of Hawaii (Acrulocercus nobilis), while distinguishing it by its inferiority in size. The general appearance of the two species, especially at a distance, is black, so that it is hardly a matter for astonishment that mistakes occur even among the islanders; but in that under discussion the yellow axillary tufts are wanting, being replaced by others of a pale buffish grey which are far less developed; the colour, however, which is absent from the wing, is here found on the lower part of the tibiæ.

Dr. Stejneger (Proc. U.S. Nat. Mus. 1887, pp. 100-103) has tabulated very fully the differences between Acrulocercus nobilis and $A$. braccatus, while he gives a key by which the three members of the genus may be very easily distinguished, which I here reproduce:-

" $a^{2}$. Tail-feathers uniform blackish, without any trace of white $\ldots \ldots \ldots \ldots \ldots \ldots . . . . . M$. braccata.

$a^{2}$. Tail-feathers blackish, four or more tipped with white.

$b^{1}$. Only two outer tail-feathers on each side tipped with white ............ M. nobilis.

$b^{2}$. All the tail-feathers, except the middle pair, tipped with white........ M. apicalis."

So far back as 1871, Dr. Sclater also (Ibis, 1871, p. 358) recognized these three as undoubtedly good species; and I trust that the coloured figures to be found in the present volume will prevent the possibility of any further confusion. With regard to the call-note-a kind of chuck-it is noteworthy that it is somewhat similar to that of the larger $\mathrm{O}-\mathrm{O}$, though in a higher key; the bird has also a sweet song, some of its notes possessing a bell-like clearness. It is common in the woods by which Makaweli, the lovely mountain residence of the Sinclair family, is surrounded, where in the early morning its dulcet tones may be heard to perfection, blended with those of its forest companions; here its home is a natural plateau open towards the west, with a magnificent view of the Pacific - the island of Niihau alone breaking the broad expanse of ocean. Mr. V. Knudsen says that in districts of Kauai where the banana ${ }^{1}$ grows wild the dwarf $\mathrm{O}-\mathrm{O}$ feeds on the fruit, hollowing it out before it is ripe. Its chief food, however, appears to consist of nectar, which it extracts from the ohia, the arborescent Lobeliaceo, and other plants, in the same way as its large relative the O-O of Hawaii;

\footnotetext{
I This information seems to be corroborated by the following extract from Townsend's 'Narrative of a Journey across the Rocky Mountains and a Visit to the Sandwich Islands' (Pbiladelphia, 1839, p. 207) :-

"The Birds are the same here (Kauai) as we found and collected on Oahu, but are not so numerous. They are principally Creepers (Certhia) and Honey-suckers (Nectarinia): feed chiefly upon flowers and the sweet juice of the Banana, and some species are very abundant."
} 
at all events, the specimens of $A$. braccatus which $I$ obtained were invariably feeding in flower-covered ohia trees. This bird is not nearly so wary as $A$. nobilis, but is very clever in concealing itself among the thick foliage, thereby rendering observation difficult. I did not succeed in finding its nest, my visit to Kauai being made in October.

Description.-Adult male. Head black, streaked with a few longitudinal lines of white; rest of the upper surface slaty brown, brightening into russet on the rump and flanks; throat and breast black, each feather barred with white; rest of the under surface dull slaty brown, while the centres of the feathers being grey give it a streaked appearance; wings and tail black, the central pair of feathers of the latter much exceeding the rest in length; axillary tufts (little developed) of a pale greyish buff; edge of the wing pure white; tibiæ rich golden yellow; irides light yellow; bill and feet black.

Adult female. Similar to the male, but with the feathers on the throat much more extensively barred with white, which gives the bird the appearance of having a welldefined whitish patch on the throat and upper part of the breast.

Dimensions. -Total length $7 \cdot 75$ inches, wing from carpal joint $3 \cdot 90$, culmen $1 \cdot 5$, tarsus $1 \cdot 5$, tail $3 \cdot 5$. 



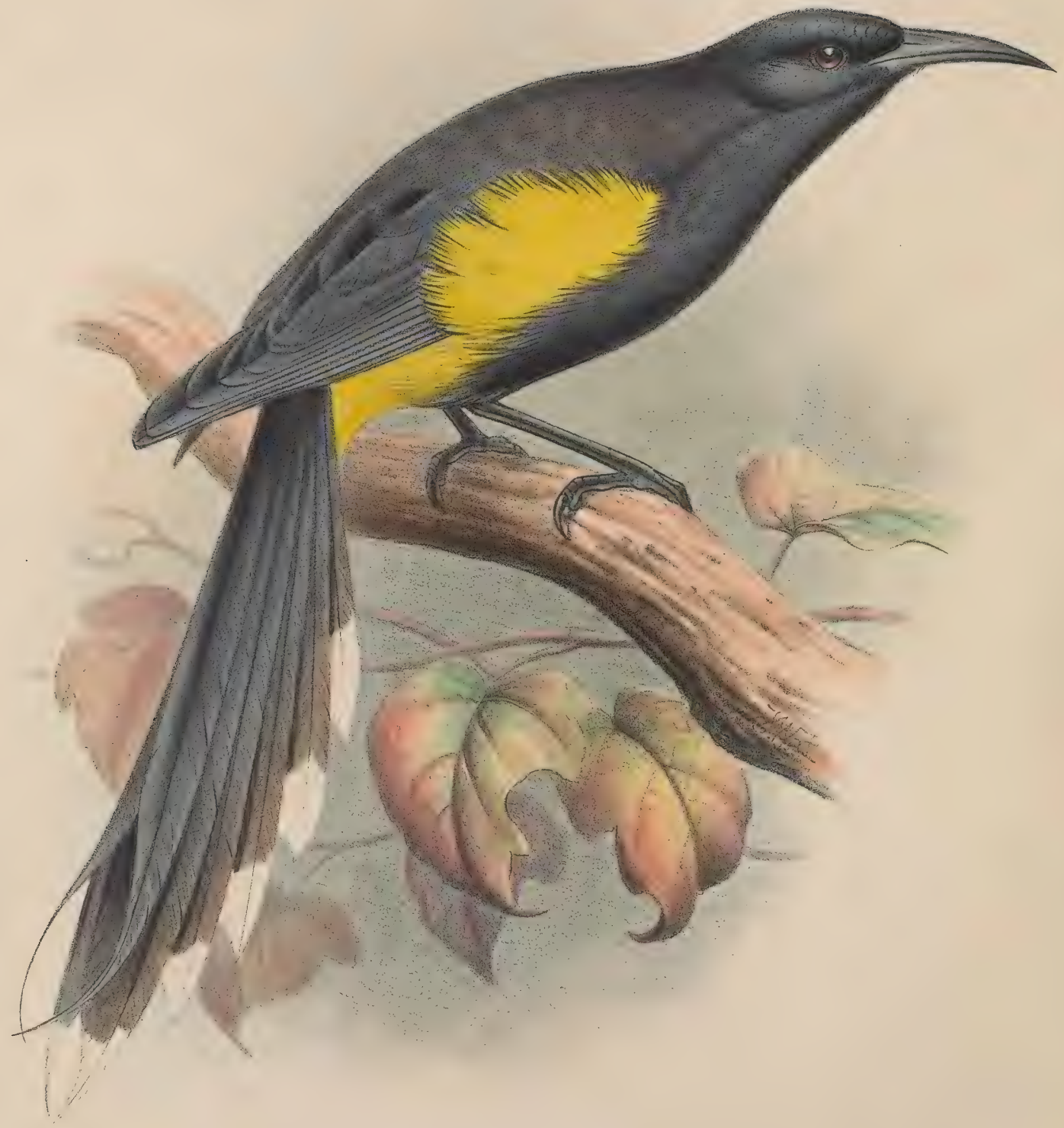




\section{ACRULOCERCUS APICALIS.}

"Yellow-tufted Bee-eater," Dixon, Voy.pl. to face p. 381 * (figure only) (1798) (nec Latham, Gen. Synops. i. p. 683).

"Yellow-tufted Bee-eater, var. A," Latham, Gen. Synops. Suppl. 2, p. 149 (1802).

Moho nobilis, var., G. R. Gray, Cat. B. Trop. Isl. Pacific Ocean, p. 9 (1859).

Moho upicalis, Gould, Proc. Zool. Soc. 1860, p. 381 ; Dole, Proc. Bost. Soc. N. H. 1869, p. 297 (nec Hawaiian Alman. p. 46, quæ=Drepanis pacifica!); G. R. Gray, Hand-l. B. i. p. 114 (1869); Gadow, Cat. B. Br. Mus. ix. p. 285.

Mohoa apicalis, Sclater, Ibis, 1871, p. 360, 1879, p. 92 ; Von Pelzeln, Journ. f. Orn. 1872, p. 26.

* Figura notabilis.

THis species, figured as the "Yellow-tufted Bee-eater" in Captain George Dixon's "Voyage round the World,' was described as "Variety A" of the same by Latham (loc. cit.), and was properly distinguished specifically from Acrulocercus nobitis by Gould in 1860, on the strength of two examples-supposed to be one of either sexwhich are now in the British Museum.

Gould stated that "Dixon's bird was obtained at Owhyhee," and believed that his own "two specimens were brought from the same island," but produced no evidence in support either of his statement or of his belief, while we are now in a position to show that each was almost certainly unfounded; and there cannot be a doubt that the present species inhabited Oahu, where, in January 1837, a male and female were procured by Deppe, now preserved at Vienna, as recorded by Von Pelzeln (ut suprà). An examination of Dixon's work shows that his ship, the 'Queen Charlotte,' anchored but once, and then for little more than twenty-four hours, off Owhyhee (Hawaii), and that in the historic bay of Karakakooa ${ }^{1}$, the very district at that time and still inhabited by the kindred species $A$. nobilis, alongside of which the present is hardly likely to have

1 There is a discrepancy (which should be noticed) between the account of Dixon's voyage (pp. 50, 52), as told by William Beresford the narrator ( $c f$. Portlock's 'Voyage,' p. 6, note), and the ship's log, as printed by her Commander (Dixon, Voyage, App. ii. p. 10), in regard to the precise day (whether the 26th or 27th May; 1786) on which the 'Queen Charlotte' and her consort the 'King George' (under Capt. Portlock) anchored in this bay; but that is of no importance, and there is none as to the duration of the ships' stay, confirmed as it is by Portlock (op. cit. pp. 62, 65). The crews were in want, among other things, of water, which their commanders (both of whom, it may be observed, had served on Cook's voyage and knew the place) expected to get there, but to their disappointment the sources were "tabooed," and the ships had to be off as soon as they could. Though on two occasions subsequently coasting along the shores of Hawaii, near enough to communicate with and receive supplies from the natives, but more than once interrupted by bad weather, the ships never brought up, and it can hardly bo supposed that, when fresh meat and vegetables were the sole object of the intercourse, anything so unimportant as a small bird would be thought of in the way of traffic. 
existed. On the other hand, we know that Dixon's ship anchored on three occasions, and for a considerable time, in King George's Bay, on the south side of Oahu (Woahoo or Whahoo as it is spelt in his book). The 'Queen Charlotte' lay there from the 1st to the 5 th of June, and from the 30 th of November to the 20th December, 1786, and again from the 10 th to the 13 th of September, 1787 , so that the chance is greatly in favour of that being the locality where this species was procured. He could hardly have got it in Attoui (Kauai) or Oneehow (Niihau), for the former is the home of the allied $A$. braccatus; nor in Ranai (Lanai) or Morotai (Molokai), for there the species would in all probability be A. bishopi. Accordingly the inference that Oahu was the real habitat of $A$. apicalis is so strong as, accompanied by the positive evidence of Deppe, to be irresistible; and since it is known that the 'Blonde' also made a long stay at Honolulu, the specimen brought home by Byron, and now in the British Museum-being the third now there,-may well have been obtained thence.

Though no success attended the indefatigable explorations of Mr. Rothschild's collectors, and $\mathrm{Mr}$. Perkins has not yet been more fortunate, I am of opinion that the bird still exists, and will be rediscovered hereafter; but the disappearance of several other species from Oahu tells, I confess, against this hopeful view. If the bird be extinct, the cause is probably the destruction of so much of the ancient forest on that island. According to Judge Dole, the subject of the present notice shares with the other members of the genus the name $\mathrm{O}-\mathrm{o}$, and the habits and food are similar; but the "Moho apicalis" of his last paper is not this bird, but Drepanis pacifica, and should have been cited in the synonymy of that species.

Description (from Gould)._- "General plumage sooty-black; tail brown, all but the two middle feathers largely tipped with white; the two central feathers somewhat narrower than the others, and gradually diminishing in the apical third of their length into fine hair-like or filamentous upturned points; axillæ or under surface of the shoulder white; flanks and under tail-coverts bright yellow; bill and legs black.

"Total length 12 inches, bill $1 \frac{1}{2}$, wing $4 \frac{3}{4}$, tail $6 \frac{3}{4}$, tarsi $1 \frac{1}{2}$.

"The plumage of the female is in every respect similar to that of the male; but, as in the Honey-eaters of Australia generally, particularly amongst the members of the genus Ptilotis, the body is fully a fourth less in size."

The striated appearance of the breast of $A$. apicalis, a character found in so many of the Meliphagido, though hardly perceptible in its congener $A$. nobilis, is especially noticeable.

Von Pelzeln remarked that the edges of the mandibles in both male and female were partially serrated, as Reichenbach stated to be the case in $M$. nobilis; and that the end of the tongue was clearly brush-shaped in the female.

The figure is from one of the specimens in the British Museum.

The species of Acrolocercus, if one there was, inbabiting Maui has yet to be ascertained (Feb. 1894). 
. 


\section{ACRULOCERCUS NOBILIS.}

O-O.

“Yellow-tufted Bee-eater," Latham, Gen. Synops. i. p. 683 (1782); Suppl. p. 120 (1787); Suppl. 2, p. 149 (1802).

? "Mohò," Ellis, Narrat. Voy. Cook \& Clerke, ii. p. 156 (1782).

? "Hoohoo," King, Voy. Pacif. Ocean, iii. p. 119, partim (1784).

Gracula nobilis, Merrem, Beytr. besond. Gesch. Vögel, Heft i. p. 8, pl. ii.* (1784).

" longirostra, var. $\beta$, Gmelin, Syst. Nat. i. p. 398 (1788).

Merops niger, Gmelin, tom. cit. p. 465 (1788); Tiedemann, Anat. und Naturgesch. Vög. ii. p. 431

(1814).

" fasciculatus, Latham, Ind. Orn. i. p. 275 (1790).

"Le Moho," Sonnini, Hist. Nat. Buffon, Ois. xviii. p. 286 (1802).

Philemon fasciculatus, Vieillot, Encycl. Méthod., Ornithol. p. 613 (1823).

?Nectarina [sic] niger, Bloxam, Voy. 'Blonde,' p. 249 (1826).

Meliphaga fasciculata, Temminck \& Laugier, Rec. d’Ois. livr. 79, Pl. Col. $471 *$ (1829).

"Philédon moho, Merops fasciculatus, Lath.," Lesson, Tr. d’Orn. p. 302 (1831) ; id. Compl. Buffon, ix. p. 149 (1837).

Acrulocercus niger, Cabanis, Arch. f. Naturgesch. xiii. p. 327 (1847); Sundevall, Tentam. p. 50 (1872).

Moho niger, G. R. Gray, Gen. B. i. p. 96 (1847) ; Bonaparte, Consp. Av. i. p. 394 (1850) ; Hartlaub, Arch. f. Naturgesch. 1852, i. p. 131; Dole, Proc. Boston Soc. N. H. 1869, p. 296.

Ptiloturus fasciculatus, Peale, U.S. Expl. Exped., Birds, p. 148 (1848).

Mohoa fasciculata, Reichenbach, Handb. sp. Orn. p. 333, partim (1853), tab. 614. fig. 4098*.

" nobilis, Cassin, Proc. Acad. N. S. Philad. 1855, p. 439 ; Sclater, Ibis, 1871, pp. 358, 360;

id. Proc. Zool. Soc. 1878, p. 347; Von Pelzeln, Journ. f. Orn. 1872, p. 25.

Moho nobilis, Cassin, U.S. Expl. Exped., Mamm. \& Orn. p. 170 (1858); G. R. Gray, Cat. B. Trop.

Isl. p. 9 (1859); Dole, Hawaiian Alman. 1879, p. 46; Gadow, Cat. B. Br. Mus. ix. p. 284, partim (1884); Stejneger, Proc. U.S. Nat. Mus. 1887, p. 101.

Acrulocercus nobilis, Scott Wilson, Ibis, 1890, p. 177.

* Figurce notabiles.

THIs bird, with its decidedly Meliphagine affinities, was first described by Latham from the Leverian Museum, under the nane of the "Yellow-tufted Bee-eater," which led to its inclusion by Gmelin in the genus Merops. The original specimens were received from the companions of Cook on his third voyage, when the Sandwich Islands were discovered and twice visited; but the number of these and the circumstances of their capture are quite unknown. From the outset the native name was entirely misapprehended by the unrefined ears of the early travellers, who wrote it variously Mo-hò, 
Hoohoo, Uho, and so forth, according to their fancy, a mistake ${ }^{1}$ which has been perpetuated by later writers, not only in the specific, but even in the generic designation; Lesson, however, did not, as is often supposed, employ Moho as a strictly generic term, George Robert Gray being the first to do so.

But though Latham was the original describer of the species, Blasius Merrem two years later had the good fortune to bestow upon it the earliest scientific appellation, Gracula nobilis, and to figure it without reference to that author's work-while placing it in an entirely distinct genus-in his 'Beyträge zur besondern Geschichte der Vögel,' published in $\mathbf{1 7 8 4}$ at Göttingen, where he was at the time a Professor. He states that an example had been sent to the museum there by King George III., who, as Elector of Hanover, seems to have taken great interest in the University founded by his predecessor: but, in referring it to the genus Gracula, he was misled by its apparent resemblance to the G. longirostra of Pallas; while Gmelin, with the usual perspicacity of a compiler, failed to see that Merrem's bird was identical with that of Latham, and so made two species out of one: later writers, again, bestowed upon it various names, which were set aside for several reasons by Professor Cabanis in favour of Acrulocercus ${ }^{2}$ in 1847, the same year that Gray adopted Lesson's barbarous Moho.

It does not appear that after the days of Cook any additional information concerning the subject of our notice reached the scientific world for many years. It is briefly mentioned in the meagre list by Bloxam appended to the narrative of Lord Byron's voyage in H.M.S. 'Blonde,'-the vessel which, in 1825, conveyed home the corpses of the King and Queen of the Sandwich Islands, who had died in England,-but merely as "the bird whose yellow feathers are so highly prized," showing that the writer did not discriminate between it and Drepanis pacifica. Very different is the case with the naturalists attached to the celebrated United States Exploring Expedition under Commodore Wilkes in the 'Vincennes' and 'Peacock'; for its ornithologist, Titian R. Peale, in a work of which nearly all the copies were unfortunately destroyed, gives a very good description of the bird from Hawaii, mentioning not only its note, its love of the loftiest forest-trees, and its habits in general, but also the use of its feathers and the method of capture-all agreeing well with my own experience; as does the fact of his writing the native name O-O. Cassin, in the 'Proceedings' of the Academy of Philadelphia for 1855, compared the specimens then obtained, which he considered to represent examples of both sexes, with those presented to its Museum by the well-known

1 The mistake (for such it undoubtedly was) in regard to Mohò originated with W. Ellis, describing himself as "assistant-surgeon to both vessels" in Cook's Expedition, who also executed the series of drawings now in the British Museum (Natural History). In a passage in his 'Narrative' of the royage (vol. ii. p. 156), he writes:- "They have also a kind of fly-flap made of a bunch of feathers fixed to the end of a thin piece of smooth and polished wood: they are generally made of the tail-feathers of the cock, but the better sort of people have them of the tropick birds feathers, or those belonging to a black and yellow bird called mo-hò." O-O is the correct name of this species, Mo-hò is that of Rallus ecaudatus, King.

3. Acrulocercus, signifying a tail that is curly at the tip, though apt enough for the present species, is unfortunate as regards its two congeners, where the tail presents no such peculiarity. 
traveller Townsend, who, after crossing the Rocky Mountains, made more than one visit to the Sandwich Islands.

Additional examples have since occasionally found their way to Europe or America. The Liverpool Museum contains two specimens, a male and female, obtained by the late Mr. J. Heywood; and the Hepburn collection, presented in 1870 to the Museum of the University of Cambridge, included another: but the distinction between the different members of the genus having been made sufficiently clear, there is no necessity for further details.

This is, perhaps, the best known species both to natives and denizens of the Sandwich Islands; for it was principally from the yellow feathers that grow beneath its wings, together with the still more beautiful and similarly coloured upper tail-coverts of the now extinct Drepanis pacifica, that the state robes of the princes ${ }^{1}$ were fabricated. It was the privilege of those classes alone to wear them; nor can it be denied that they formed a becoming and magnificent garb, as beautiful as anything that the triumphs of civilized art can now produce. The fine statue of Kamehameha I., which stands in front of the Government House in Honolulu, represents the great conqueror who first consolidated his sovereignty over the various islands, draped in his Mamo, as this feather cloak is called in the Hawaiian language, the texture of which is wonderfully represented by the sculptor's chisel. Gazing on this and recalling the fact that the princes of Hawaii-Nei were a race of giants, most of them being over six feet in height, we can well understand what an imposing effect must have been produced. The great yellow war-cloak of Kamehameha I. had been gradually growing in size through the reigns of eight preceding monarchs. The groundwork is of coarse netting, to which, with skill now impossible to emulate, are attached the delicate feathers, those on the border being reversed: the length is four feet, while there is a spread of eleven feet and a half at the bottom, the whole having the appearance of a mantle of gold. The cloaks and eapes which I examined in Honolulu were all of the lighter shade of yellow, which belongs to the feathers of the present species; but on carefully going through those in the Ethnological Collection of the British Museum, I find that in most of the robes made of the wing-tufts of Acrulocercus the more beautiful plumage of Drepanis pacifica is introduced, though in small quantities only. The ancient kings had a regular staff of bird-catchers, who were very expert in their vocation, and made use of the sticky juice of the bread-fruit (called in Hawaiian "Pilali"), or of the tenacious gum of the fragrant olapa (Cheirodendron gaudichaudii), smearing it over the branches of a ohia tree, and often fastening there an example of the scarlet liwi (Vestiaria coccinea), of which more in another place, as an additional attraction to the Royal bird, well known for his pugnacity, who, in his eagerness to attack his

\footnotetext{
${ }^{1}$ It appears from the following extract from the Hon. R. M. Dagget's able Introduction to 'The Legends and Myths of Hawaii' by his Hawaiian Majesty Kalakaua (p. 32), that in olden times certain classes were privileged to wear robes made of feathers of certain colours:- "Yellow was the 'tabu' colour of royalty, and red that of the priesthood, and mantles of feathers of the $O_{0}$ and Mamo could be worn only by kings and princes. Feather capes of mingled red and yellow distinguished the lesser nobility."
} 
brilliant rival, would fall an unsuspicious victim to this ingenious device. That large numbers of the $\mathrm{O}-\mathrm{O}$ must have been taken in former days is clear from the quantities of "leis" or wreaths of feathers that now remain in the possession of the natives, who still set so great store by them that it is but rarely that a traveller is able to purchase so interesting a relic of a past age; but I was fortunate enough to obtain a small example, for the construction of which it is reckoned that two hundred ${ }^{1}$ birds must have been sacrificed. The Hon. C. R. Bishop possesses some very fine specimens, and the contents of a small tin box of them I estimated as being worth ten thousand dollars. What the value of a cloak or cape may be it is impossible to say. At the ceremony of opening the Hawaiian Legislature in 1888 capes were donned by two of the native officials, and very imposing they looked, though the effect could not be compared with that produced by the flowing war-cloak.

This bird is preeminently a honey-sucker, extracting the nectar with its long tubular tongue from the flowers of the ohia or from those of the great tree-lobelia, the hollow curving corolla of which is perfectly adapted in shape to the O-O's bill; and though I have on several occasions observed it feeding on the fruit of the banana, I believe this to be only a secondary article of diet: in a state of captivity it has been kept with success on the juice of the sugar-cane.

It has a very peculiar call, whence its native name is derived; and here I may insert some extracts from notes taken in the district of Kona, where it is still fairly common:-

"We shot two O-Os to-day, but these birds are extremely difficult to obtain, as they are constantly on the move from tree to tree, hardly ever at a less height than 90 feet from the ground. Their cry is somewhat harsh, and resembles the sound of the letter $\mathrm{O}$ repeated twice, with a well-marked pause between; it is, however, extremely difficult of imitation by the human voice. The yellow axillary tufts are very conspicuous when this bird is on the wing, and its dipping mode of flight somewhat resembles that of the Magpie, while its long tail still further suggests a resemblance to that bird. The O-O exhibits a decided preference for the extreme top of any tree, on which it alights, and when thus perched may be seen continually jerking its long plume-like tail up and down at a right angle to its body, all the while uttering its harsh cry." As mentioned above, it is an extremely wary bird and most difficult of approach when met with

\footnotetext{
${ }^{1}$ It may be interesting to compare with the above the numbers of the Kaka (Nestor meridionalis) still annually captured by the Maories; I therefore quote the following paragraph from Sir Walter Buller's 'History of the Birds of New Zealand,' (2nd ed. vol. i. p. 163):- “The Kaka is particularly abundant in the Urewera country, and during the short season the rata is in bloom the whole Maori population, old and young, are out Kaka-hunting. An expert bird-catcher will sometimes bag as many as 300 in the course of a day; and at Ruatahuna and Mangopohatu alone it is said that from 10,000 to 12,000 of these birds are killed during a good rata season, which occurs about every three years."

I may mention that the rata of Now Zealand, of which an excellent representation is given in Sir Walter's plate, is Metrosideros robusta, the crimson flowers of which are doubtless as attractive to the Kaka as are to the Q-O the larger but very similar blossoms of the ohia (Metrosideros polymorpha), of which a branch, though not the flower, is shown in my Plate.
} 
in the ohia-forest, so that the only occasions on which I was enabled to watch it at close quarters were amongst the foliage of the lobelias.

The $\mathrm{O}-\mathrm{O}$ is esteemed a great delicacy by the natives, and used formerly to be eaten by them, fried in its own fat. I can vouch personally for its excellence, as one day, after bringing in a fine specimen from a collecting-expedition, I placed it carefully on a shelf to await my convenience; but at dinner the Chinese cook, $\mathrm{Ah}$ Lung, set down in front of me a small dish, containing my lovely prize! On remonstrances being addressed to him in no measured terms, he only smiled and said "Me thinkee all same Kolea (Plover)." However my host, Mr. Spencer, and I tasted it, and found it excellent.

I never obtained a specimen in immature plumage, nor did I find a nest, but from the bird's evident preference in the breeding-season (May and June) for the topmost branches of the lofty ohia-trees, 90 to 100 feet from the ground, I conclude that it chooses a site amongst them, and venture to say that it will be long before its eggs are taken, as not even a Hawaiian-bold, skilful, and withal utterly reckless climber as he is-would be able to span that giant girth. The ordinary vertical range of this bird, which I only observed on the island of Hawaii, is from 1200 to 4000 feet; but I am told by my friend Mr. Ashford Spencer that he has observed it, at certain seasons of the year, in the forest around the sheep-station of Kalaieha, of which the altitude is above 6000 feet. It is probable that the O-O, like other Hawaiian birds, follows its food, migrating to this high mountain-region as soon as the ohia-tree is out of flower in the lower forest-zone.

Peale, quoted by Cassin (U.S. Expl. Exp. p. 171), says:- "The Oo is found in most of the woody districts of the Island of Hawaii; it frequents the thick foliage of the loftiest trees; in voice and manners it has some resemblance to the Oriole of North America (Icterus Baltimore). The natives capture it by means of bird-lime, and after plucking out the yellow feathers from beneath the wings, restore it to liberty, until again wanted to assist in paying the royal tax." I never could ascertain with certainty whether the natives really set the bird at liberty after plucking out its yellow tufts; but doubtless at the time of Peale's visit in 1840 many of the old bird-catchers were alive, from whom he could get the information; yet $I$ hardly fancy these birds were taken as late as $\mathbf{1 8 4 0}$ for the purpose of paying the poll-tax.

Dr. Pickering, also attached to the Expedition, states that the flight was high, somewhat after the manner of the Boat-tailed Grakle of the United States. The note was a loud chuck, repeated two or three times, and the habits reminded him of the Poibird of New Zealand. Cassin goes out of his way to warn us that native names are not entitled to much consideration - a warning which, in the case of the Hawaiians (a people with a most accurate ear for sounds), is utterly uncalled for. He then proceeds to observe that the name of this bird must sound quite different to different persons, and certainly-Mo-hò, Hoohoo, Uho-are strangely at variance; however we must ascribe this to the defects of ear of the individual explorers, since the Hawaiian gives to it but one name, $\mathrm{O}-\mathrm{O}$. 
Description.-Adult male. General colour black, inclining to dull umber on the abdomen; axillary tufts bright yellow; terminal half of the two outer pairs of tailquills white; middle pair of tail-quills greatly elongated and spirally twisted; irides dark hazel; bill and feet black.

Adult female. Similar in colour to the male, but with the middle pair of tail-feathers not nearly so much elongated or twisted.

Dimensions.-Adult male. Total length 12.5 inches, wing from carpal joint 5.95, culmen $1 \cdot 25$, tarsus $1 \cdot 5$, tail $7 \cdot 5$.

Adult female. Total length $9 \cdot 5$, wing from carpal joint 4, culmen $\cdot 95$, tarsus 1.25 , tail $5 \cdot 95$. 


\section{.}




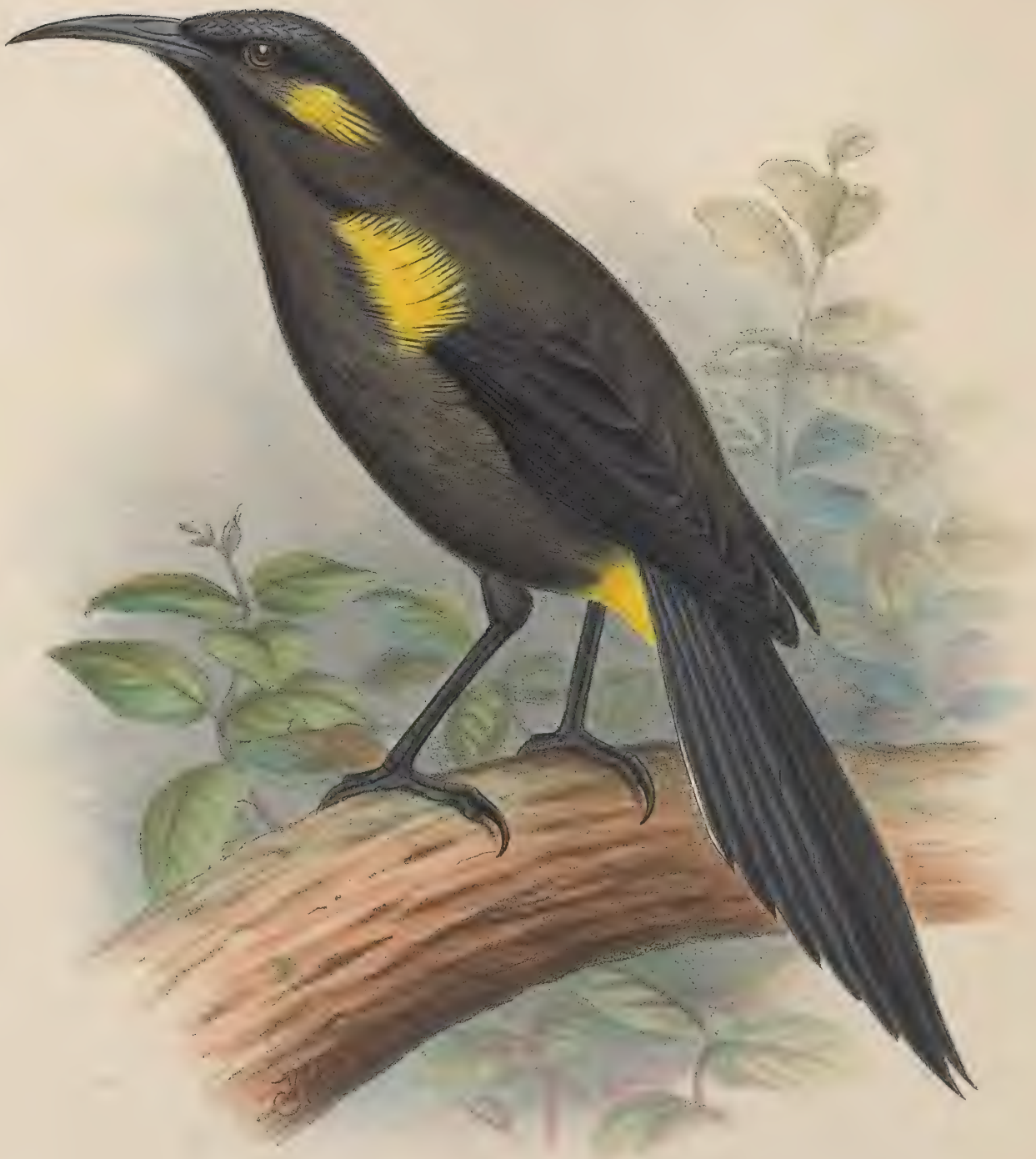

F.W.Frohawrk del,et lith. 


\section{ACRULOCERCUS BISHOPI.}

Acrulocercus bishopi, Rothschild, Bull. Br. Orn. Club, no. viii. p. xli (1893).

Specimens of this lately-described species were obtained in Molokai by Mr. Perkins in the summer of 1893, and I am indebted to the Joint Committee appointed by the Royal Society and the British Association for the opportunity of figuring one of them; but as yet nothing has been published respecting its habits, though these may be presumed to resemble those of its allies which I have already described. So far as I am aware, the bird is peculiar to the Island of Molokai, though I should not be surprised to learn that it also inhabited Maui.

Description.-Adult male. Upper parts black, with a brownish tinge on the back; underparts brownish black, the feathers of the latter and of the hind neck being lanceolate and having whitish shaft-streaks. A tuft of feathers with long golden-yellow tips springs from near the ear-coverts and is directed backwards; the under tail-coverts are of the same colour, as are the axillary tufts, which are similar to those of $A$.nobilis, but smaller. A little white shows itself on the lower surface of the wing near the bend, while the plumage of the crown is slightly curled. The beak is slighter than that of A. nobilis, but is a little longer; while the shape of the tail, which Mr. Rothschild describes as more pointed, seems much the same. Bill and feet black.

The above author states that the female is similar to the male, but considerably smaller.

Dimensions (of the specimen figured).-Total length 8.62 inches, wing about 4, tail $4 \cdot 25$, tarsus $1 \cdot 37$, culmen $1 \cdot 12$. 




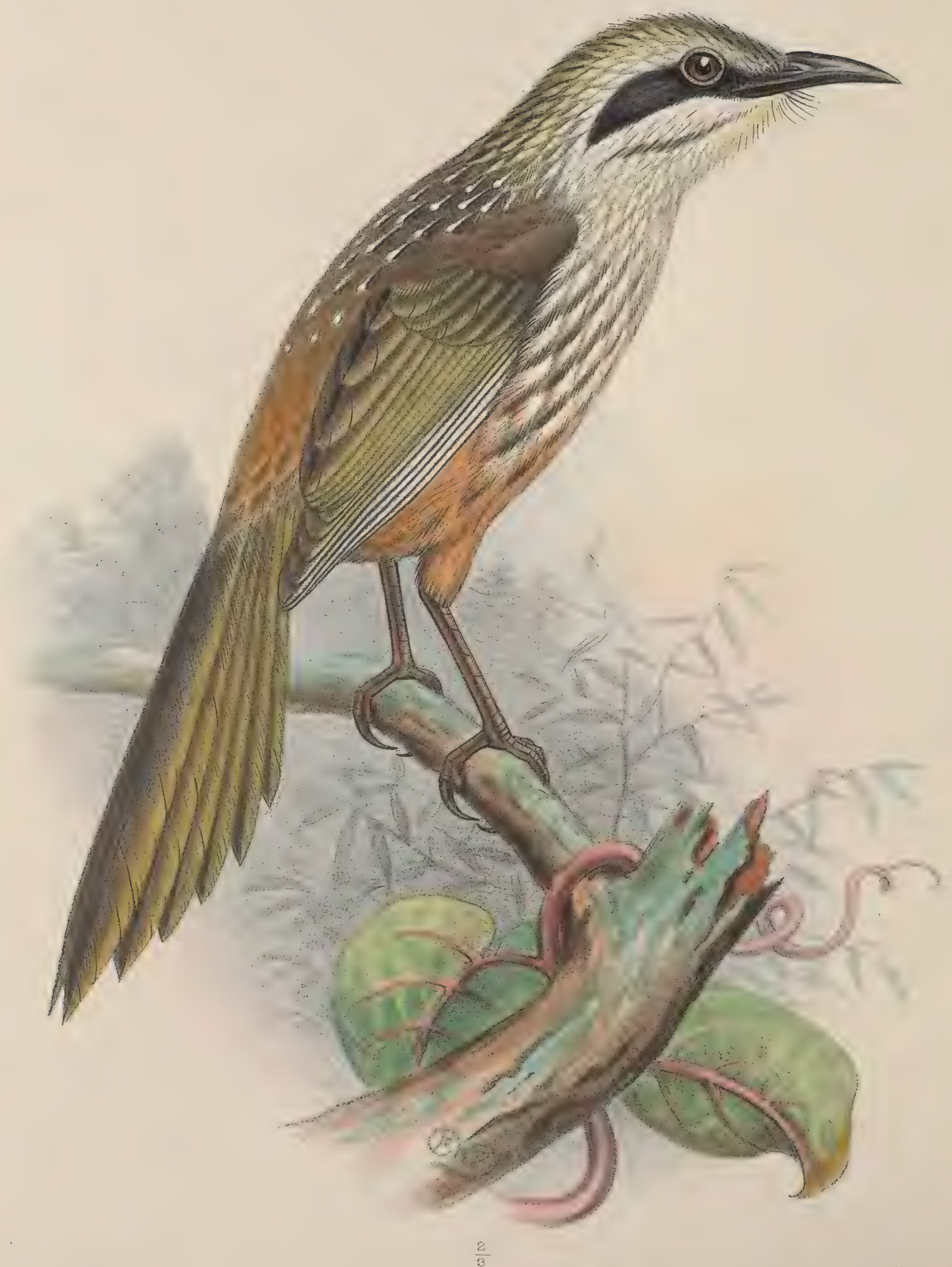




\section{CHETOPTILA ANGUSTIPLUMA.}

Entomiza? angustiphuma, Peale, U.S. Expl. Exped., Birds, p. 147, pl. xl. fig. $2^{*}$ (1848).

Anthochara? angustipluma, Hartlaub, Arch. f. Naturgesch. 1852, i. p. 131; G. R. Gray, Cat. B. Trop. Isl. p. 13 (1859).

Mohoa angustipluma, Cassin, Proc. Acad. Sc. Philad. 1855, p. 440.

Moho angustipluma, Cassin, U.S. Expl. Exped., Mamm. \& Orn. p. 168, pl. xi. fig. $1 *$ (1858) ; Dole, Proc. Bost. Soc. N. H. 1869, p. 296 ; id. Hawaiian Alman. 1879, p. 47.

Chœetoptila angustipluma, "Sclater, 1868," G. R. Gray, Hand-list, i. p. 159 (1869); Sclater, Ibis, 1871, pp. 358, 360 ; id. op. cit. 1879, p. 92.

\section{* Figurce notabiles.}

IN his 'Catalogue of the Birds of the Tropical Islands,' Gray doubtfully cites Moho atriceps of Lesson [Traité d'Orn. p. 646 (1831)] as identical with this species, but the description shows that this is unlikely, for the flanks are not "vert-olive," nor is the breast black. However this may be, Peale during the Exploring Expedition in the 'Vincennes' and 'Peacock' certainly met with the bird; and, failing Lesson, to him all credit is due for the original description as well as for the discovery. Peale found it in the wooded districts of the island of Hawaii, where he obtained a single specimen, and, while premising that its habits were those of a Meliphaga, he included it doubtfully in Swainson's genus Entomiza, pending further investigation; moreover, he bestowed upon it the specific name of angustipluma, derived from the peculiar nature of the feathers, and gave a figure in his account of the above expedition. Cassin transferred it to the genus Mohoa or Moho, where it remained until 1869, when the name Choetoptila, suggested by Mr. Sclater, was accepted by G. R. Gray in his 'Hand-list'; and now Dr. Gadow's examination of my specimen-the first brought to Europeindicates that the accepted view of its relationship to the Meliphagidoe is perfectly correct. Judge Dole gives Molokai as an additional habitat of this species, a statement which I am unable to corroborate at present. It may be of interest to quote here Peale's original remarks, as follows:- "This rare species was obtained at the Island of Hawaii. It is very active and graceful in its motions, frequents the woody districts, and is disposed to be musical, having most of the habits of a Meliphaga; they are generally found about those trees which are in flower."

"We have placed this . . . species in Mr. Swainson's genus Entomiza, with a doubt 
of the propriety of doing so, but trusting that our figure will prove sufficiently correct to supply the means of a more systematic arrangement."

Cassin, in his edition of the account of the Exploring Expedition, says of it:-

"Hab. Island of Hawaii. Specimen in Nat. Mus. Washington.

"Though we suspect that the bird above described is not in mature plumage, it appears to be a distinct species of the genus Moho, Lesson, of which the only species heretofore known are Moho nobilis (Merrem), and probably the bird described as Certhia pacifica, Gmelin, Syst. Nat. i. p. 470 (Vieill. and Aud. Ois. Bor. pl. lxiii.), and Moho braccata, Cassin. It does not appear to belong to the genus Strigiceps, Less. Rev. Zool. 1840, p. 266, though evidently related to it.

"The feathers on the head and breast in this bird present a remarkable character on account of the filaments composing the webs of the feathers being unusually few in number, and at such a distance from each other as not to touch, or become adherent. This structure of the feathers gives to the plumage of the parts mentioned a somewhat hairy appearance, and prevails also, in some measure, on the abdomen and other underparts of the body. Many of the feathers on the throat and neck in front terminate in bristles curved outwardly, and readily discernible on viewing the specimen in profile."

After quoting part of Peale's remarks, already given above, Cassin continues:"Dr. Pickering mentions having seen this species 'alighting in the tops of the trees and uttering a loud chuck.'

"We regard this bird as one of the most interesting of the ornithological discoveries of the Expedition, and much regret to find a single specimen only in the collection. It is represented in our plate above cited of the size of life."

I obtained an example of this curious-looking bird from the collection of the late Mr. Mills, through the generosity of the present owner, the Hon. C. R. Bishop, of Honolulu, and it is now in the Museum of the University of Cambridge. It was probably procured by Mr. Mills in the district of Hilo near Olaa, that having been his favourite hunting-ground. Why this bird should have become extinct seems inexplicable, as its feathers were not used for ornaments; yet the natives of the present day do not know it even by tradition, moreover the local name Kiowea given to it by Judge Dole is certainly that applied to the Whimbrel (Numenius femoralis). The specimen obtained by Peale during his visit I had the advantage of examining while at Washington on my way to the Islands.

Description.-Top of the head and neck blackish brown, each feather with a greyishwhite shaft-streak, which is strongly tinged with yellow on the nape and sides of the neck. A greyish-white stripe over the eyes. Wing-coverts and back hair-brown, tinged with ochreous on the rump, the feathers of the mantle with a white shaft-streak widening into a tear-shaped spot towards the tip. Remiges and rectrices deep brown, their outer margin yellow, giving a greenish effect to the whole. A greyish-white 
stripe over the eye. Lores, sides of the head, and ear-coverts dull black, the feathers immediately under the eye mottled with greyish white. Chin and throat dull white, tinged with yellow, the shafts and the hairs with which this part is beset black. Breast and abdomen dull white, striped longitudinally with darkish brown, flanks strongly tinged with ochreous. Bill and legs very dark brown, almost black.

Dimensions.-Total length about 13 inches, wing 5.5, tail 6, bill (allowing for a slight injury at the tip) from forehead $1 \cdot 31$, from gape $1 \cdot 5$, tarsus $1 \cdot 75$, middle toe without claw $\cdot 93$, hind toe $\cdot 56$. 



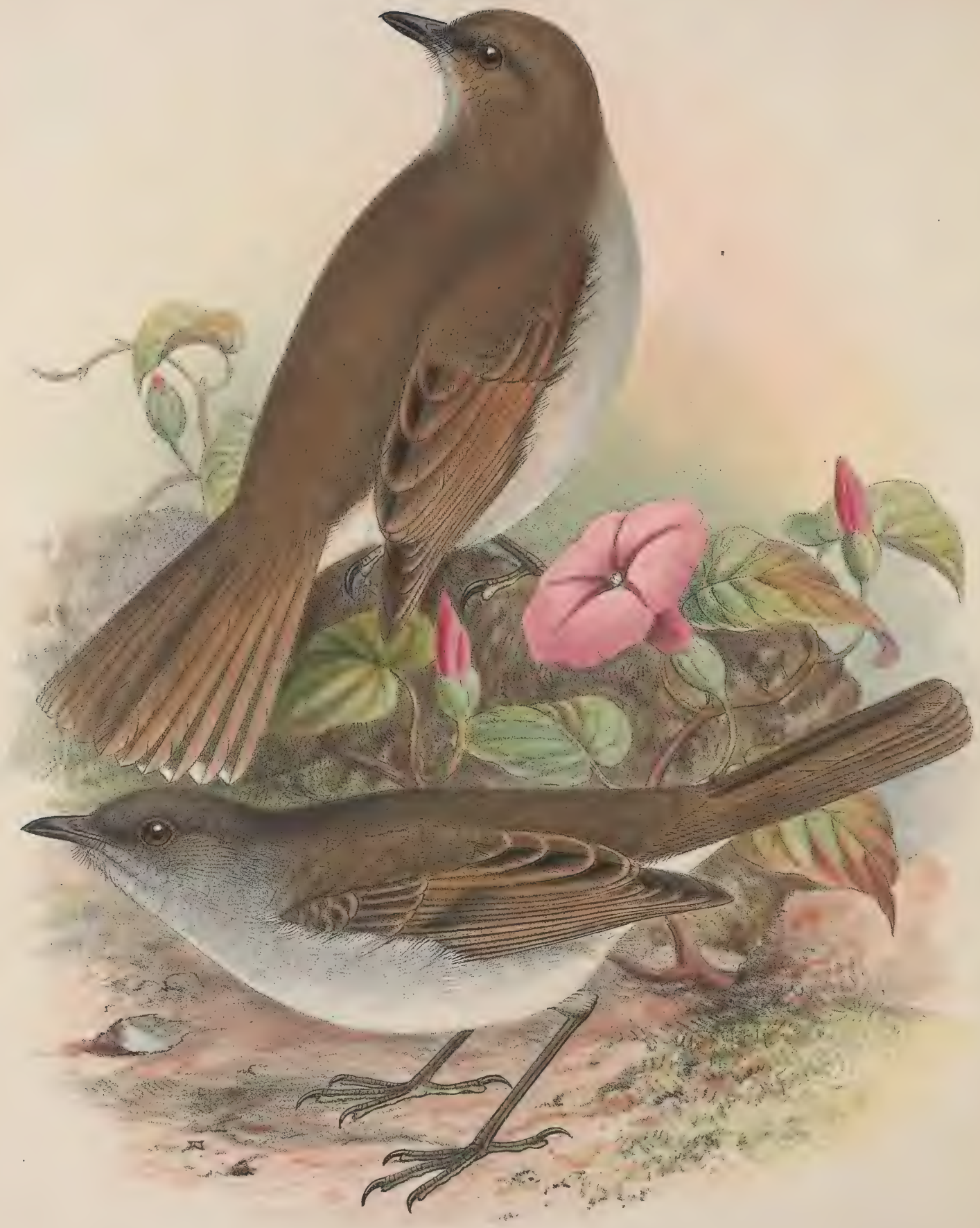




\section{PHEORNIS MYIADESTINA.}

KAMAO.

? Tenioptera obscura, o, Cassin, U.S. Expl. Exped., Mamm. \& Orn. p. 155 (1858).

Phreornis myadestina [sic], Stejneger, Proc. U.S. Nat. Mus. 1887, p. 90 ; id. op. cit. 1889, p. 383 ;

S. B. Wilson, Ibis, 1890, p. 195.

" myiadestina, Sclater, Ibis, 1888, p. 143.

TuIs species, which inhabits Kauai, has been lately described as new by Dr. Stejneger (as above cited). I obtained specimens on that island from nearly the same locality as he did, several being in immature plumage. Dr. Stejneger gives as native names Ou or Uapauau, neither of which is, as far as I know, applied to this bird, Kamao being that by which it is generally known.

In a letter received lately from my friend Mr. F. Gay, he raises the question of there being another species of Phocornis found on Kauai, and his remarks on a skin recently obtained by a collector are as follows:- "It appeared to me to be a species of Kamao, the only difference being a narrower bill, lighter coloured feet, and a smaller body, and, according to the collector, lighter coloured feathers about the head. Our natives always said there was a different variety called the Puaiohi, which they said had a different note from the common Kamao. I never believed much in what the natives said about it, as the Kamao varies so much in colour and spots. This bird may be more common on the windward side of the island, as the name of Puaiohi is more commonly used there than here." Mr. Gay adds : "the single skin I saw was a poor one, having been partly eaten by rats." 



\section{PHE $\mathbb{E} 0$ RNIS LANAIENSIS.}

OLOMAO.

Phcornis lanaiensis, S. B. Wilson, Ann. \& Mag. Nat. Hist. ser. 6, vol. vii. p. 460 (1891).

I OBTAINED several specimens of this bird on the island of Lanai, which from its much smaller size and the whiteness of the underparts is deserving of separation from either Phaoornis obscura of Hawaii or P. myiadestina of Kauai. It appears to be identical with the species inhabiting Molokai,-as was to be expected, seeing that the two islands are separated only by a narrow channel, some ten miles in width-and is known by the name of Olomao there : on Lanai, where I first obtained it, and after which island it is named, I met with no natives who knew the names of birds ; indeed, in a few years there will not be many natives remaining.

It closely resembles $P$. obscura and $P$. myiadestina, but is smaller in dimensions than either; while the bill is distinctly intermediate in size between those of the two species. The outer pair of tail-feathers alone have very slight white markings at the tip, while the abdomen and under tail-coverts are nearly pure white.

The length of the wing from the carpal joint is only 3.65 inches, as against 4 in P. obscura. 



$$
\text { . }
$$




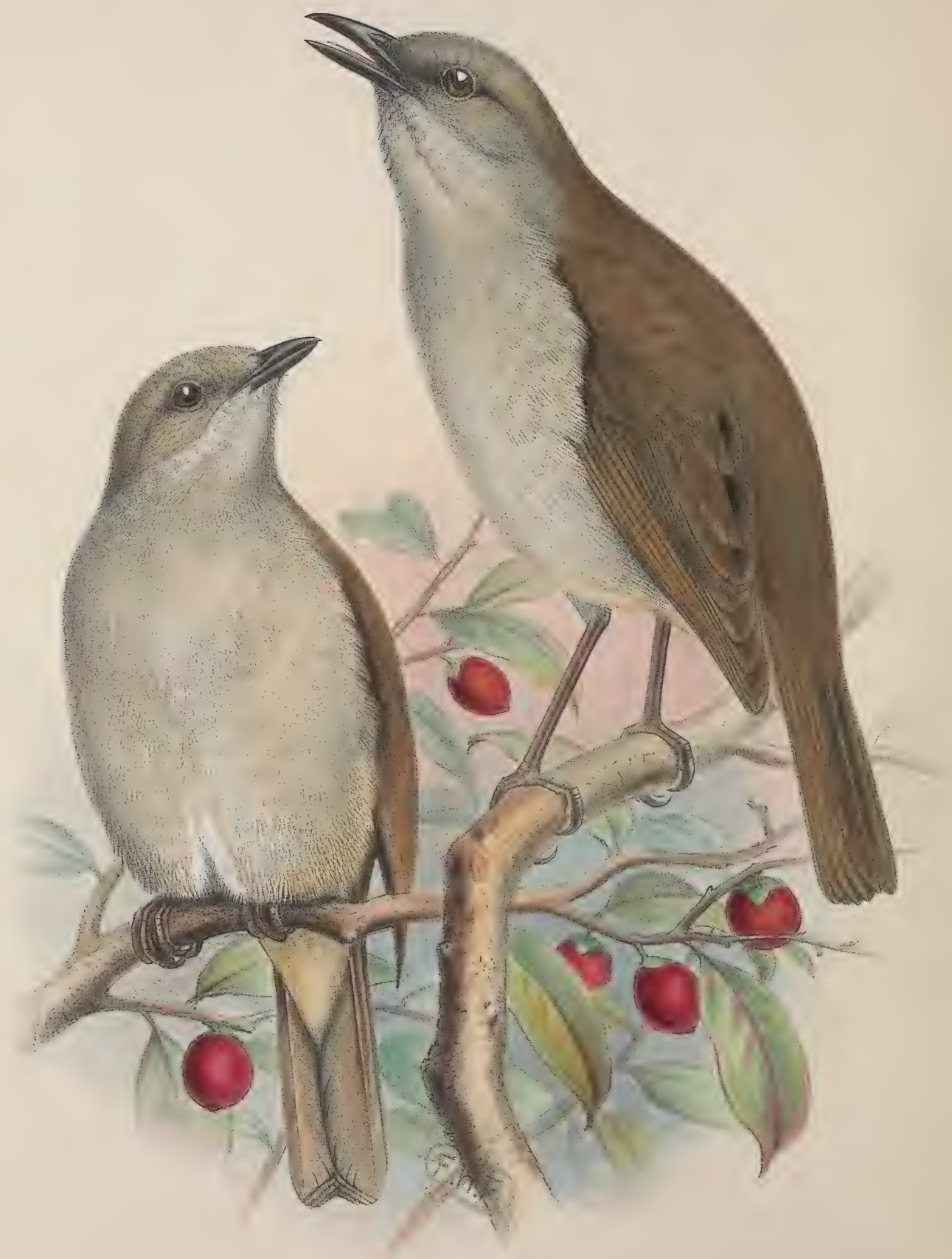




\section{PHEORNIS OBSCURA. \\ OMAU, OLOMAU, KAMAU.}

"Dusky Flycatcher," Latham, Gen. Synops. ii. p. 344 (1783).

Muscicapa obscura, Gmelin, Syst. Nat. i. p. 945 (1788); Latham, Ind. Orn. p. 479 (1790); Stephens, Shaw's Zool. x. p. 405 (1817); Vieillot, N. Dict. d’Hist. nat. xxi. p. 465 (1818); id. Encycl. Méthod., Ornithol. p. 809 (1823).

"Gobe-mouche brun des îles Sandwich" (sp. 2), Virey (Sonnini), Hist. Nat. Buffon, Ois. xiv. p. 172 (1802).

Tyrannula obscura, Peale, U.S. Expl. Exped., Birds, p. 310 (1848).

Chasiempsis obscura, Hartlaub, Arch. f. Naturgesch. 1852, i. p. 133.

Tonioptera obscura, Cassin, U.S. Expl. Exped., Mamm. \& Orn. p. 155, pl. ix. fig. 3 * (1858); Dole, Proc. Bost. Soc. N. H. 1869, p. 300 ; id. Hawaiian Alman. 1879, p. 48.

Pheornis obscura, Sclater, Ibis, 1859, p.327, 1871, p. 360; id. Proc. Zool. Soc. 1878, p. 347; Von Pelzeln, Ibis, 1874, p. 462 ; Sharpe, Cat. B. Br. Mus. iv. p. 5 (1879); Scott Wilson, Ibis, 1890, p. 195.

Eopsaltria (Chasiempsis) obscura, G. R. Gray, Cat. B. Trop. Isl. p. 22 (1859).

" (Pheornis) obscura, G. R. Gray, Hand-l. i. p. 390 (1869).

* Figura notabilis.

As was the case with so many other Sandwich-Island species, this was first described by Latham from examples in the Leverian Museum, brought home by Cook's companions on his third and fatal voyage; and, from Herr von Pelzeln's note in 'The Ibis' for 1874, it appears that the type specimen still exists in the Museum of Vienna ${ }^{1}$. Gmelin, in 1788, gave it the name of Muscicapa obscura, nor has it since received a different specific title; but Peale, who obtained additional specimens during the United States Exploring Expedition in the 'Vincennes' and 'Peacock', placed it in the genus Tyrannula, the remarkable distinctness of the Family to which that belongs not being then fully appreciated. Cassin, in his account of this Expedition, redescribed and figured it under the designation of Tanioptera obscura, with notes taken mainly from Peale; while, unless the variety of Turdus sandwichensis, from $\mathrm{Oahu}$, be meant for the same bird in Bloxam's list in the narrative of the voyage of the 'Blonde' (p. 250), it does not seem to have been observed by the naturalists on board that ship. No later visitors to the Islands appear to have procured examples until I did so in 1887, but the dingy

1. The difficulty as to its habitat, noticed by Herr von Pelzeln, seems explicable on the supposition that "Christian's Isle under the Line" is a transcriber's mistake for Christmas Island, which was discovered and so named by Cook a few days before he found the Sandwich Islands; but even then another mistake has probably been made, for there is no evidence that the species inhabits that lonely spot, which is also called Turtle Island. 
appearance of the bird is of itself almost sufficient explanation of the slight interest taken in it, except by ornithologists such as Mr. Sclater, with whom considerations of science outweigh those of beauty of plumage. That distinguished naturalist was the first to propose for it the new generic name of Phoornis in 1859.

This sombre-coloured bird is still fairly common in most districts of Hawaii, and in some is perhaps the species most frequently met with; yet this may be due to its familiar habits, for the Omau, to use its most common native name, is a very tame bird, and while not absolutely courting man's society, shows little fear of his presence. Indeed, it was no uncommon occurrence for one of them to alight within a few yards of me and begin its melodious strain, which somewhat resembles that of our Common Thrush, though inferior in volume, and is so varied and sweet that the bird is fairly entitled to be called the Hawaiian Nightingale. Mr. D. H. Hitchcock, of Hilo, told me that many years ago the people used to bring him the young, which he caged for the sake of their song; and this is the only instance I know of a native forest-bird being successfully kept for any length of time in captivity. The Lark-like habit of singing on the wing, characteristic of $P$. myiadestina of Kauai, mentioned by Dr. Stejneger on Mr. Knudsen's authority, I observed also in this species. The call-note of $P$. obscura is a particularly clear tweet, easily recognized; but it utters a very remarkable hissing sound when approached closely. Its flight is slow, and it may be shot without difficulty while flying from tree to tree; while it possesses a very peculiar habit (not noticed by Mr. Knudsen with regard to $P$. myiadestina) of quivering with its wings when perched on a branch, as if shivering with cold or seized with an attack of ague. The chief food consists of berries, particularly those of the kopiko (Straussia hawaiiensis), a tree which is very common in forests throughout the group. The vertical range extends from the lowest forest-zone up to 5000 feet, and probably higher. The branch shown in the Plate is that of the lama (Maba sandvicensis), a very conspicuous shrub in some districts of Hawaii, particularly between Waimea and Puuanahulu; its shining red berries have a slight resemblance to those of the coffee, and are habitually eaten by the inhabitants.

Description.-Adult male. Entire upper surface dull hair-brown, except the forehead, which is grey; lower parts ashy grey, shading into white on the abdomen; under tail-coverts buff; flanks dull russet; wing-quills dull brown, russet at the base, and edged on the outer web with the same colour; tail brown; irides dark hazel; bill and feet dark brown, the soles yellow.

Adult female. Differs from the male in having the ashy grey of the underparts somewhat lighter and more uniform in tint.

Dimensions.-Total length 6.75 inches, wing from carpal joint 4 , culmen 62 , tarsus $1 \cdot 35$, tail 3. 


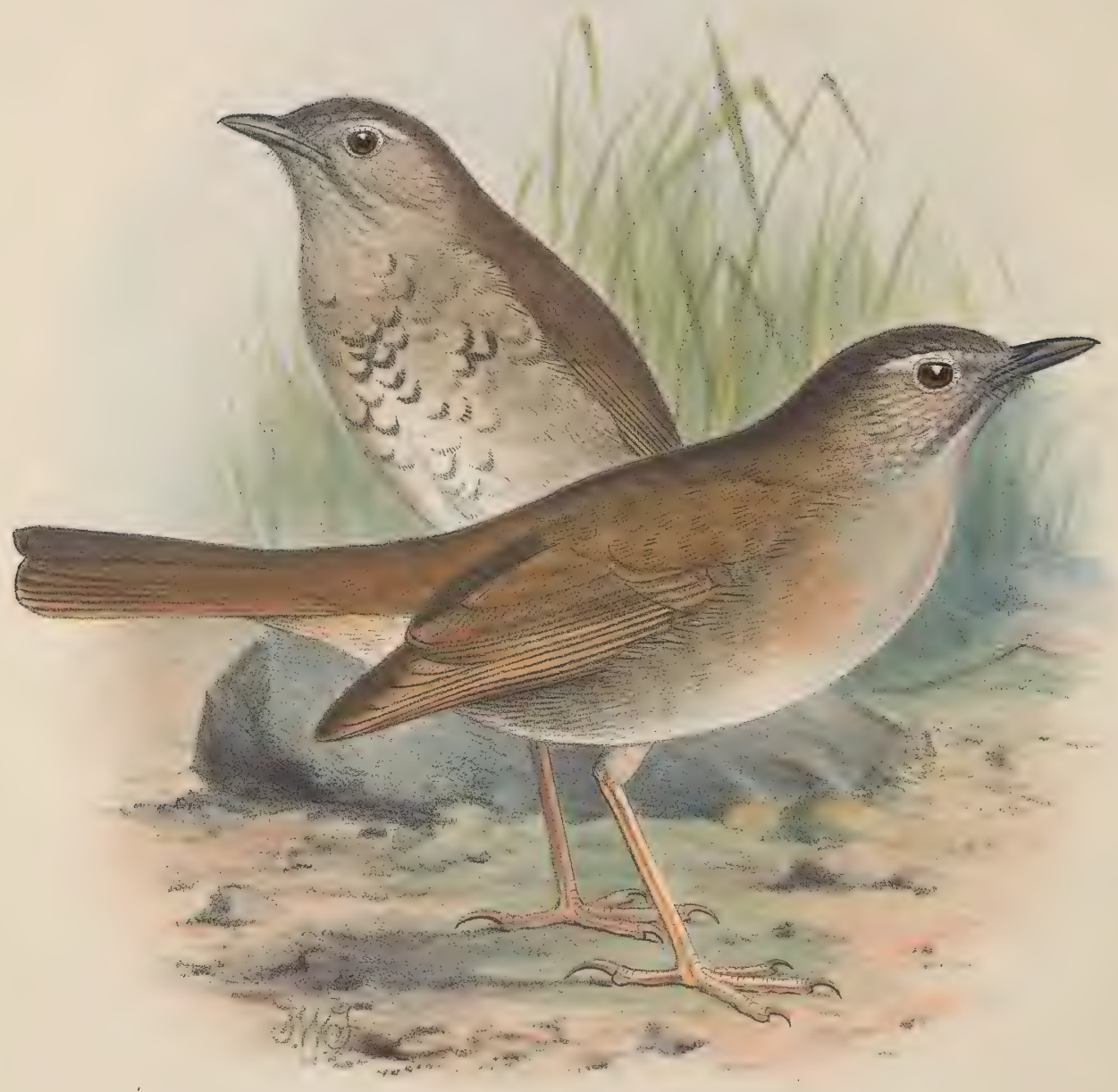




\section{PHEORNIS PALMERI.}

PUAIOHI.

Pheornis palmeri, Rothschild, Avif. Laysan, p. 67.

UNDER the heading of Phoornis myiadestina, I have already mentioned in this work that Mr. Gay believed that a second species of the present genus existed in Kauai, of which he had seen a skin, subsequently destroyed by rats. That gentleman stated that it was smaller than its congener, with lighter-tinted feet, light colour about the head, and narrower bill, thereby giving a very good idea of the points wherein P.palmeri differs from P. myiadestina. This species Mr. Rothschild's collectors, from one of whom it takes its specific title, thereafter procured. For a knowledge of the habits I am indebted to Mr. Perkins, the following being an epitome of his notes taken from a letter to Mr. Evans.

It has the appearance of a diminutive Kamao ( $P$. myiadestina), but it is difficult to obtain a good view of the bird on account of its excessive shyness. The favourite spots are those where koas grow amongst the brushwood, and the ground is covered with dead leaves and fallen twigs; here it flits about the lower branches in a restless manner, and at times descends to the ground in search of food, consisting of lepidopterous larvæ, beetles, spider's, and, exceptionally, of small molluscs. The flight is generally low, rapid, and direct, recalling that of the Kingfisher, while the song is usually uttered from the top of a tree, though occasionally when on the wing, as is the case with its congeners. The notes, which are very strong and constantly repeated, resemble those of the Nukupuu (Heterorhynchus hanapepe), but are louder and shorter; a squeaking noise is also produced when in company with the female, and the alarm-note is of a grating nature. This species is found up to an altitude of at least 4000 feet.

Description.-Adult male. Above dull brown, with darker head and almost uniform wings and tail, the latter when expanded showing buff on the inner web of the external pair of feathers and in the centre of the next pair. A white ring surrounds the eye. Beneath greyish, becoming nearly white on the abdomen and buff on the lower tailcoverts, while a distinct whitish patch marks the under surface of the wing-quills. Iris brown, bill blackish, feet pearly white.

Dimensions. - Total length $6 \cdot 75$ inches, wing $3 \cdot 87$, tail $2 \cdot 5$, tarsus $1 \cdot 37$, culmen 62 . 
Adult female. Apparently similar to the male.

Young male. Some spots of buff on the upper parts; lower parts with blackishbrown crescentic markings, caused by the dark margins of the feathers.

As compared with the present species, $P$. myiadestina is somewhat more rufous above, and has whitish tips to a few of the lateral tail-feathers, the patches under the wings are buff rather than white, and the white feathers of the lower parts show slight grey margins. The young have similar dark crescentic markings, but the feathers incline to buff in the central portion, and the plumage generally is more plentifully marked than in P. palmeri. 


$$
\text { . }
$$




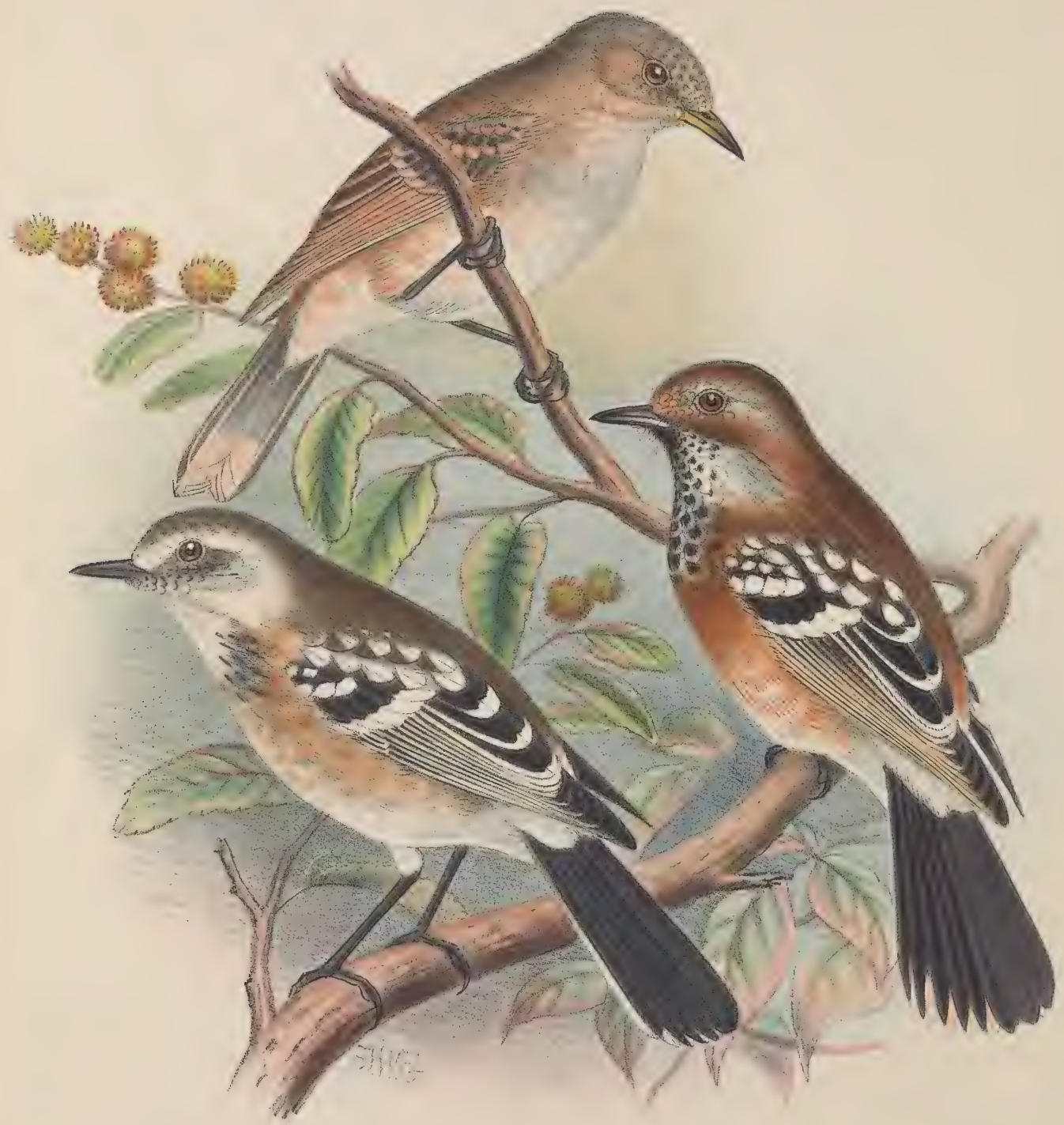




\title{
CHASIEMPIS SANDVICENSIS.
}

\author{
ELEPAIO.
}

"Sandwich Flycatcher," Latham, Gen. Synops. iii. p. 344 (1783).

? "A small bird of the flycatcher kind," King, Voy. Pacif. Ocean, iii. p. 119 (1781).

Muscicapa sandwichensis, Gmelin, Syst. Nat. i. p. 945 (1788) ; Donndorff, Orn. Beytr. ii. p. 591

(1795) ; Tiedemann, Anat. und Naturgesch. Vög. ii. p. 429 (1814) ; Vieillot, N. Dict. d'Hist.

Nat. xxi. p. 472 (1818) ; id. Encycl. Méthod. p. 814 (1823); G. R. Gray, Gen. B. i. p. 263 (1846).

Muscicapa sanduicensis, Latham, Ind. Orn. ii. p. 479 (1790).

"Gobe-mouche brun des îles Sandwich" (sp. 1), Virey (Sonnini), Hist. Nat. Buffon, Ois. xiv. p. 171 (1802).

Muscicapa sandvicensis, Stephens, Shaw's Zool. x. p. 394 (1817).

Chasiempis sandvicensis, Cabanis, Arch. f. Naturgesch. xiii. p. 208 (1847); Sclater, Ibis, 1871, p. 360 ; id. Proc. Zool. Soc. 1878, p. 346 ; id. Voy. 'Challenger,' p. 94 (1881) ; Sharpe, Cat. B. Brit. Mus. iv. p. 232 (1879).

Chasiempsis sandwichensis, Bonaparte, Consp. Av. i. p. 327 (1850) ; Finsch \& Hartlaub, Faun, Centralpolyn. p. xxxv (1867).

Chasiempsis sandvicensis, Hartlaub, Arch. f. Naturgesch. 1852, i. p. 133 ; id. Journ. f. Orn. 1854, p. 170 .

Cnipolegus, sp.?, Sclater, Cat. Am. B. p. 203 (1862) (cf. Proc. Zool. Soc. 1873, p. 555).

Eopsaltria sandvicensis, Dole, Proc. Bost. Soc. N. H. 1869, p. 300; id. Hawaiian Alman. 1879, p. 48.

Chasiempis sandwichensis, Sclater, Ibis, 1885, p. 18 (partim), pl. i.; Rothschild, Avif. Laysan, p. 71, pl. - - figs. 1, 2, 3, and pl. - fig. 1 (1893) ; Perkins, Ibis, 1893, p. 109.

Chasiempis ridgwayi, Stejneger, Proc. U.S. Nat. Mus. 1887, p. 89; S. B. Wilson, Proc. Zool. Soc. 1891, p. 166; Rothschild, Bull. Brit. Orn. Club, i. p. livi (1893).

Chasiempis ibidis, Stejneger, Proc. U.S. Nat. Mus. 1887, p. 89 ; S. B. Wilson, Proc. Zool. Soc. 1891, p. 166.

Soon after my return to England at the end of the year 1888 I proceeded to sort out and examine the large series of specimens of birds of the genus Chasiempis that I had procured from each of the three islands of the group on which it occurs, namely, Hawaii, Oahu, and Kauai. Owing to the change of plumage which its members undergo in their progress to maturity, and also to the fact that they occasionally pair and, to all appearance, breed before assuming the fully adult dress, this was no easy task; but I presently arrived at the conclusion that there were three species, each of them peculiar to one or the other of the three islands named, and then the difficulty was to assign to them proper names out of the many that had been conferred, for I hardly rentured to suppose that I had to bestow a new one. My conclusion I now find to have been right; but, unfortunately, I was induced subsequently to abandon that opinion, to which I now recur. 
Before doing anything else it was necessary to ascertain, if possible, which was the species originally described by Latham as the "Sandwich Flycatcher," from a specimen in the collection of Sir Joseph Banks. Though this specimen had, of course, long ago perished, it must have been obtained during Cook's voyage, and therefore either on Kauai or Hawaii-but the latter preferably, since his ships made the longest stay there, and we know that most of the birds they brought home were procured there, while Latham's description, on which was founded the Muscicapa sandwichensis of Gmelin, does not ill accord with the younger stage of the Hawaiian bird. But Latham also described, as belonging to a second species, which he called the "Spotted-winged Flycatcher," a specimen in the Leverian Museum "Supposed to inhabit the Sandwich Islands," and now wholly lost to sight, for I have failed to find any mention of it, by which it could be traced, in the sale-catalogue of that collection. This, being the foundation of Gmelin's Muscicapa maculata, has been generally regarded as specifically identical with the other, and I am certainly not in a position to urge a contrary view; but since it may possibly have been a Kauaian example, I think it better to exclude from the already complicated synonymy of Chasiempis sandvicensis any reference to this second species, which after all may have been something very different, since its having come from the Sandwich Islands was only a matter of supposition; and, even if its locality could be proved, the name given to it by Gmelin is forestalled.

Pursuing my investigation I found little help obtainable from collections or books. The meagre list of Bloxam included Muscicapa sandwichensis, the specific name being wrongly assigned, as was the fashion in those days, to Linnæus instead of Gmelin, but rightly identified with the "Elepaio" (or Erepeio as the word was then written) of the natives. Nothing more, however, was said of it, though Bloxam obtained specimens of at least one of the species, which were in the British Museum so lately as 1868; but none seem to have been procured by the naturalists of the French or the United States' expeditions, and evidence is wanting that any ornithological author, the late Mr. G. R. Gray excepted, had examined an example until, in 1847, Prof. Cabanis founded upon Latham's species the genus Chasiempis, though he, as has since been shown by Mr. Sclater, had not specimens of the true sandvicensis to examine, but only those, collected by Deppe, of the species which inhabits Oahu. In 1850 Reichenbach (Natürl. System der Vögel, p. lxvii) gave an outline of the head, wing, and foot of the new genus, but these figures are not particularly discriminative. 'The rarity of this form in collections and the little that was known of it is shown by the fact that, in 1862, so skilful an ornithologist as Mr. Sclater referred (though with doubt) a specimen of it which had passed under the practised eye of Verreaux to a genus of a wholly different family. In $1882 \mathrm{Mr}$. Ridgway, on receiving specimens of Chasiempis from Kauai, rightly described them as belonging to a distinct species, C. sclateri; but three years after $\mathrm{Mr}$. Sclater was loth to admit its validity. He, however, in 'The Ibis' for 1885 , rendered the great service of giving, for the first time, two coloured figures of the true C. sandvicensis, though it must be said that these figures were temporarily the cause of confusion, for on one of them Dr. Stejneger in 1887 founded his C. ridgwayi, and on the other his $C$. ibidis. Moreover, the remarks of the latter were the means of 
leading me astray, as I saw in them what appeared to be a solution of my difficulties, which had been rather increased by the contribution to the subject of $\mathrm{HH}$. von Berlepsch and Leverkühn in 1890 ; but I found that the Oahu bird was without a name, and in $1891 \mathrm{I}$ gave it one, C.gayi. So matters remained until the following year, when Mr. Perkins was despatched by the Joint Committee of the Royal Society and the British Association, and his attention was particularly drawn to the desirability of clearing up the question. This he has most effectually done, with the result, to me satisfactory, of confirming my original conclusion as to the existence in the islands of three species, neither more nor fewer. It is also gratifying to find that in this point Mr. Rothschild agrees with me.

This small Flycatcher is extremely common on Hawaii, and by far the tamest and most familiar bird of any I met with in the islands. Its call very much resembles a man's sharp whistle, which may be expressed almost exactly as "twee-ou," and is uttered repeatedly and with piercing shrillness; besides this, its general note, it has a great variety of others-at times giving vent to a gurgling sound like that of our Whitethroat, while at others its note may be readily mistaken for that of the Quail.

We found a nest in an alii tree (Dodonaca viscosa) in Kona on the 11th of June, the two old birds being close by ; unfortunately it contained no eggs, but from the anxious way in which the birds were hopping about and watching us, there could be no doubt of the ownership. A few days later I found another nest, composed almost entirely of the bleached seed-vessels of the cape gooseberry-in Hawaiian parlance poha or pahina-an introduced plant which has taken firm hold in many upland regions of Hawaii ; it was attached on three sides to the slender branches of a small sandalwood tree (Santalum album), somewhat after the manner in which the Sedge-Warbler attaches its nest to the stems of plants: unfortunately this nest, too, was empty.

Mr. Perkins remarks:- "Of Chasiempis I have several times found the nest (without eggs, unfortunately). It is small, very neat and compact, placed from 10 to 30 feet from the ground, and generally well concealed."

On the 31st of May, 1887, in the ohia forests above Kaáwaloa in Kona, we met with an entire family of this species: the young were being fed by the parents, and I was loth to shoot them; but as young birds had, so far as I knew, never before been obtained, I secured two, which show no trace whatever of the white on the smaller wing-coverts seen in the mature birds. One very charming habit, possessed by the Elepaio, is that of spreading its tail in the shape of a fan on alighting on a branch, reminding one much of the Fan-tailed Warbler.

I have often seen this species catch small moths on the wing, and, as $\mathrm{Mr}$. Perkins remarks in his notes (Ibis, 1893, p. 110):- "These birds live chiefly on insects and their larvæ. The insects they often take on the wing, their beaks closing with a very audible snap, often nearly as loud as the 'cracking' of Chloridops. They frequently descend to the ground or on to fallen trees, where they get wood-boring larvæ or small myriapods." The writer then goes on to relate the following anecdote which he had from a native woman in Kona, and which was told me several times while living on Hawaii :-" "Of all the birds the most celebrated in ancient times was the Elepaio, 
and for this reason: When the old natives used to go up into the forest to get wood for their canoes, when they had felled their tree the Elepaio would come down to it. If it began to peck it was a bad sign, as the wood was no good, being unsound; if, on the contrary, without pecking, it called out 'Ono ka ia,' 'Sweet the tish,' the timber was sound.' The names Elepaio and Ono ka ia (pronounced onōkäiă) are both creditable word-imitations of the cry of Chasiempis under various emotions, here presumably of disgust."

The range of the Chasiempis found on Hawaii is from the lower forest-region at about 1400 feet to over 5000, and probably a good deal higher, as Mr. Perkins says " to the limits of proper forest on Mauna Loa and also high up Hualalai."

The members of this genus occasionally breed before assuming the adult plumage.

Description.-Adult male. Above brown with a tinge of rufous, the forehead and superciliary streak decidedly redder. A few of the inner secondaries have white inner margins, the lateral rectrices have broad white tips; the rump is white, as are the tips of many of the wing-coverts, giving an appearance of spots. The throat is black, with white tips to the feathers of the lower portion, which extend to the sides of the neck; the breast is rich yellowish-brown, the middle of the abdomen white. The bill, which is much larger than in the other species, is black, as are the feet.

Adult female. 'The forehead, superciliary stripe, and throat are nearly white. with very little black on the latter, below which is a brown crescent. The whole plumage is browner than in the male.

'The young, which vary considerably, have rufous rump and wing-spots, being almost uniform dingy white below.

Dimensions. - Total length $5 \cdot 5$ inches, wing 3 , tail $2 \cdot 75$, tarsus 1 , culmen $\cdot 44$.

The synonyms of the supposed species Chasiempis maculata are as follows:-

"Spotted-winged Flycatcher," Latham, Gen. Synops. iii. p. 345 (1783).

Muscicapa maculata, Gmelin, Syst. Nat. i. p. 945 (1788) ${ }^{1}$; Latham, Ind. Orn. ii. p. 480 (1790);

Donndorff, Orn. Beytr. ii. p. 593 (1795) ; Tiedemann, Anat. und Naturgesch. Vög. ii. p. 429

(1814) : Stephens, Shaw's Gen. Zool. x. p. 390 (1817); Vieillot, N. Dict. d’Hist. Nat. xxi. p. 473 (1818) ; id. Encycl. Méthod. p. 815 (1823) ; G. R. Gray, Gen. B. i. p. 263 (1846); Dole, Proc. Bost. Soc. N. H. 1869, p. 299 ; id. Hawaiian Alman. 1879, p. 48; Sclater, Ibis, 1871, p. 359.

"Gobe-mouche brun des îles Sandwich" (sp. 3), Virey (Sonnini), Hist. Nat. Buffon, Ois. xiv. p. 173 (1802).

? Eopsaltria (Chasiempsis) maculata, G. R. Gray, Cat. B. Trop. Isl. p. $22(1859)^{2}$.

? Eopsaltria (Chasiempis) maculata, G. R. Gray, Hand-l. B. i. p. 390 (1869) ².

1 Nec Muscicapa maculata, P. L. S. Müller, Natursyst. Anhang, p. 169 (1776).

$=$ For the reasons assigned under the heading of $C$. gayi these references must be considered doubtful. 


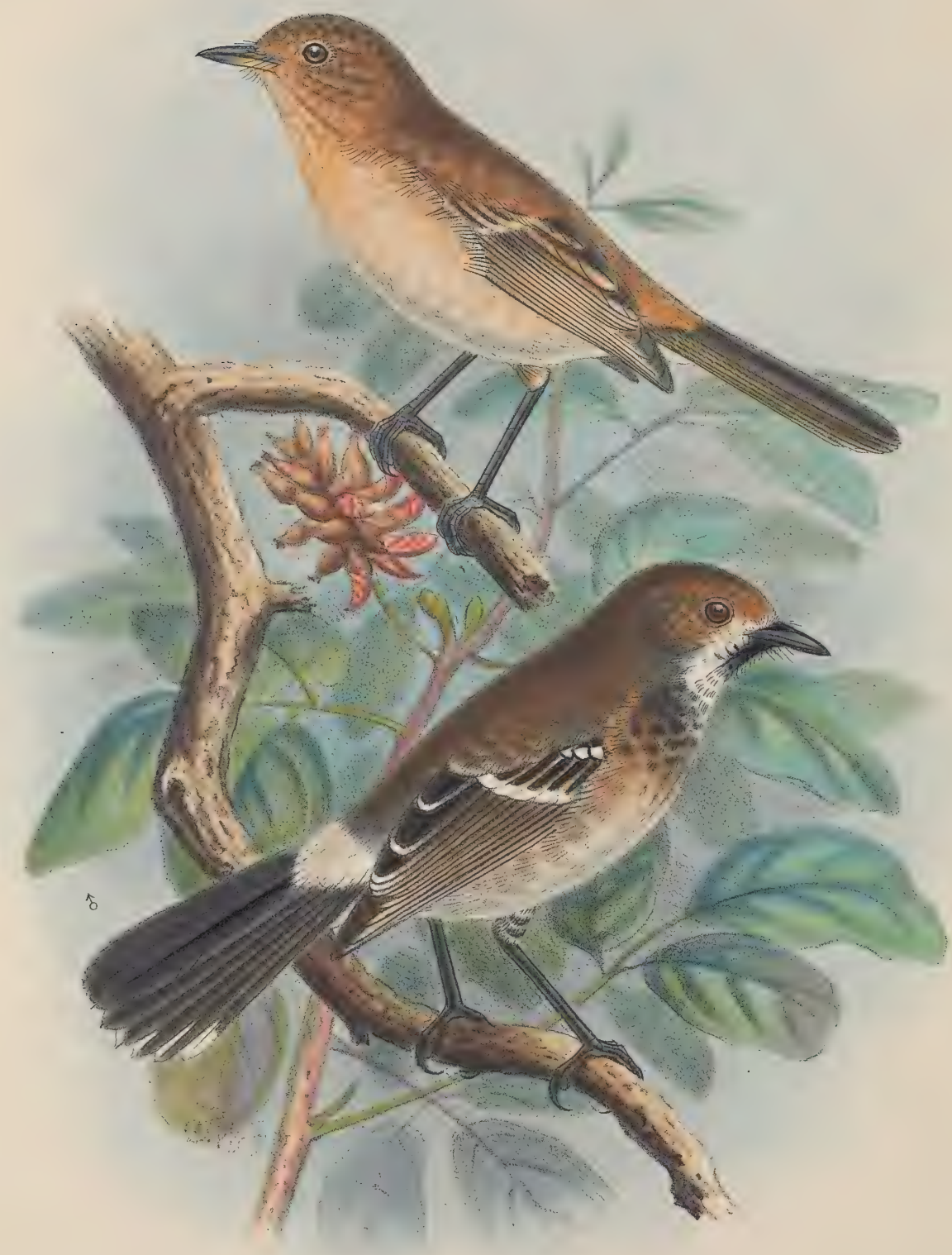

F.W.Frohawk del et lith. 


\title{
CHASIEMPIS GAYI.
}

\author{
ELEPAIO.
}

? Muscicapa sandwichensis, Bloxam, Voy. 'Blonde,' p. 250 (1826) '.

Chasiempis sandvicensis, Cabanis in Lichtenstein's Nomencl. Av. Mus. Berol. p. 19 (1854) (nec Cabanis, 1847).

? Eopsaltria (Chasiempsis) sandwichensis, G. R. Gray, Cat. B. Trop. Isl. p. 21 (1859) '.

? Eopsaltria (Chasiempis) sandwichensis, G. R. Gray, Hand-l. B. i. p. 390 (1869) ${ }^{1}$.

Chasiempis sandwichensis, Sclater, Ibis, 1885, p. 18 (partim); Von Pelzeln, Ibis, 1874, p. 462 ; Von Berlepsch \& Leverkühn, Ornis, 1890, p. 2 (partim), tab. i. fig. 3 ; Rothschild, Bull. Brit. Orn. Club, i. p. lvi (1893).

Chasiempis gayi, S. B. Wilson, Proc. Zool. Soc. 1891, p. 165 ; Rothschild, Avif. Laysan, p. 75, pl. -. figs. 2, 3 (1893).

THIS species, confined to the island of Oahu, had long been confounded with $C$. sandvicensis of Hawaii, until my paper in the 'Proceedings of the Zoological Society' for 1891 appeared; but the whole matter may now be considered finally settled, owing to the exertions of Mr. R. C. L. Perkins, who obtained both young and old of all the three members of the genus, and proved conclusively that the former had the rump tawny and the latter white.

The habits of this bird are apparently identical with those of the forms from the other islands. The nest, according to Mr. Rothschild, is placed in a fork about ten to thirty feet high, and is composed of fine roots and moss, with a lining of the former and herbage, being decorated externally with lichens. The eggs are white, with small spots and blotches of brick-red.

Description.-Adult male. Above much as in C. sandvicensis, but the spots on the wing-coverts have the appearance of bars. The throat is more conspicuously marked with white, and the breast is almost entirely white.

Adult female and young differ from the male as do those of $C$. sclateri.

Dimensions._-'Total length $5 \cdot 4$ inches, wing $2 \cdot 75$, tail $2 \cdot 76$, tarsus 1 , culmen $\cdot 4$.

1 These references must be regarded with doubt, though Bloxam's specimens were most likely obtained in Oahu. Two of them were in the British Museum so lately as 1868, as stated by Mr. G. R. Gray in a letter written by him in that year, and shown to me by Prof. Newton. They are not, however, included by Dr. Sharpe in his 'Catalogue' (iv. p. 232) as existing in 1879, any more than is a specimen of the "Muscicapa maculata" of Gmelin, which Mr. Gray in the same letter mentions as being in the Museum, and then thought to be the young of $C$. sandvicensis. 




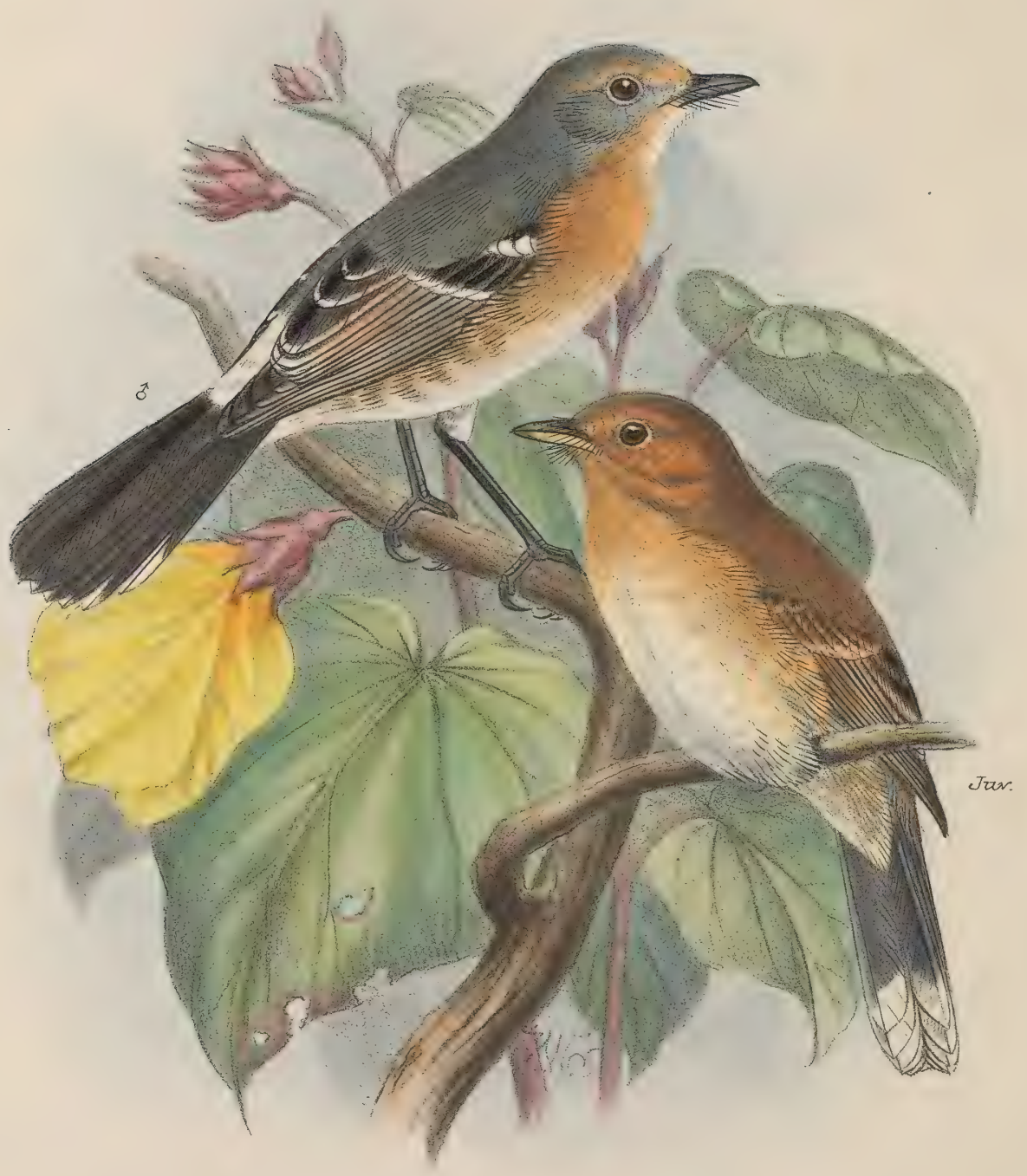




\section{CHASIEMPIS SCLATERI.}

Chasiempis sclateri, Ridgway, Proc. U.S. Nat. Mus. iv. p. 337 (1882); S. B. Wilson, Proc. Zool. Soc. 1891, p. 166; Rothschild, Bull Brit. Orn. Club, i. p. lvi (1893) ; id. Avif. Laysan, p. 77, pl. - . figs. 1, 2 (1893).

Chasiempis sandwichensis, Sclater, Ibis, 1885, p. 19 (partim) ; Von Berlepsch \& Leverkühn, Ornis, 1890 , p. 2 (partim).

Chasiempis dolei, Stejneger, Proc. U.S. Nat. Mus. 1887, p. 90 ; S. B. Wilson, Proc. Zool. Soc. 1891, p. 166.

Mr. Ridgway was perfectly justified when, in 1882, he differentiated this form (found only in Kauai) from those of the neighbouring islands; but, unfortunately, Mr. Sclater, in his article on the genus in the 'Ibis' for 1885, suggested that it was the female of C. sandvicensis, at the same time rightly determining the latter, of which he figured the male and female. Dr. Stejneger, in 1887, separated the birds from Kauai as two species, giving the name of $C$. dolei to that which he considered undescribed; but Mr. Perkins, to whom we owe the elucidation of so many knotty questions, has now been able to ascertain that one form only inhabits the above-mentioned island. 'The habits cannot be said to differ from those of the other members of the genus, the nest and eggs resembling those of $C$. gayi.

Description.-Adult male. Nearly uniform greyish above, with white rump and an indistinct rufous nuchal collar. The wing and tail much as in C. sandvicensis. The throat is orange-rufous, with no black markings, the colour gradually merging into the white of the central abdomen. The chin is whitish, and there is very little rufous on the forehead or above the eye.

Adult female. The throat and forehead are much whiter.

The young are very rufous above and chiefly orange-rufous below.

Dimensions. -Total length $5 \cdot 5$ inches, wing $2 \cdot 75$, tail $2 \cdot 78$, tarsus 1 , culmen $\cdot 38$. 



\title{
ASTO ACCIPITRINUS.
}

\author{
PUEO.
}

Stryx accipitrina, Pallas, Reise d. versch. Prov. d. Russischen Reichs, i. p. 455 (1771).

Strix brachyotus, J. R. Forster, Phil. Trans. lxii. p. 384 (1772).

"Owl," Cook, [Last] Voy. Pacif. Ocean, ii. p. 227 (1784).

"Short-eared Owl," Latham, Gen. Synops. Suppl. ii. p. 56 (1802).

Strix sandwichensis, Bloxam, Voy. 'Blonde,' p. 250 (1826).

Otus galapagoensis, Gould, Proc. Zool. Soc. 1837, p. 10 ; Darwin, Zool. Voy. 'Beagle,' Birds, p. 32, pl. iii. (1841) ; Cassin, Cat. Strigidæ Coll. Acad. N. S. Philad. subfam. 1, gen. 3, sp. 6 (1851 ?).

Otus brachyotus, Nuttall, Man. Orn. i. ed. 2, p. 141 (1840); D’Orbigny, Voy. Amér. Mérid. iv. pt. 3, Oiseaux, p. 134 (1835-44) ; Peale, U.S. Expl. Exped., Birds, p. 75 (1848) ; Sclater, Proc. Zool. Soc. 1878, p. 348.

Otus palustris, Darwin, Zool. Voy. 'Beagle,' Birds, p. 33 (1841).

Asio brachyotus, Strickland, Orn. Synon. i. p. 209 (1855) ; Sclater, Voy. 'Challenger,' Birds, p. 96 (1881).

Brachyotus galapagoensis, Cassin, U.S. Expl. Exped., Mamm. \& Orn. p. 107 (1858); Dole, Proc. Bost. Soc. N. H. 1869, p. 296 ; id. Hawaiian Alman. 1879, p. 43.

Otus brachyotus, var., G. R. Gray, Cat. B. Trop. Isl. p. 3 (1859).

Asio sandvicensis, Blyth, Ibis, 1863, p. 27.

Asin accipitrinus, Gurney, in Yarrell's Br. B. ed. 4, i. p. 167 (1872) ; Dresser, B. Eur. v. p. 257, pl. 304 (1876) ; Stejneger, Proc. U.S. Nat. Mus. 1887, p. 85.

[Except as regards the first two citations the above refer to this widely-ranging species only in relation to the Sandwich Islands or other localities in the Pacific Ocean.]

THE modern view that the Sandwich Island species is identical with the widely-distributed Short-eared Owl of the Old and New Worlds, of which the races are usually deemed barely separable, coincides with that of the earlier writers. It is mentioned by the author of the account of Cook's last voyage as the "Orwl," by Latham as the "Shorteared Owl," and by Peale as Otus brachyotus; Bloxam, however, preferred to call it Strix sandwichensis, and Cassin, considering it to be identical with the bird from the Galapagos Islands, included it under the heading of Otus galapagoensis, instead of giving both these names as synonyms of the common species. Messrs. Strickland, G. R. Gray, Sclater, and the late J. H. Gurney, on the other hand, have at various times given it as their opinion that the original view is correct. Peale states that examples were observed on all the islands of the Sandwich group, as well as in Oregon and California, while as Cassin includes the name in his list of the collection of the Expedition, some of these were doubtless procured at that time. 
Dr. Stejneger (Proc. U.S. Nat. Mus. 1887, p. 85) remarks:- "The four specimens of Short-eared Owls from the Hawaiian Islands before me do not justify the retention of Asio sandwichensis as a separable race;" while the late Mr. J. H. Gurney, who examined a specimen in my collection, was of the same opinion. Dr. Stejneger also suggests that Owls on the Hawaiian Islands are in part migratory, but I do not think they are so.

The subject of this article was held in great awe by the ancient Sandwich Islanders, as it was believed by them to be an "Akua" or Spirit; and to this day it is considered that death will be the fate in the course of the same year of any one who is rash enough to kill a Pueo. It was a bird held sacred to the gods, and therefore the natives believed that if one were killed, not only would its slayer die within the year, but some great calamity would fall on the nation. In a most interesting legend entitled "The Sacred Spear-point" ('Legends and Myths of Hawaii,' pp. 219-225), the Pueo plays a prominent part; but in this story an evil spirit seems to have taken its form and to hare for many years visited different districts of Oahu, killing children, pigs, and fowls ; the priests, moreover, declared it to be a Pueo, sacred to the gods, and therefore not to be molested with safety, even if harm were possible from human hands.

The following abbreviation of the latter part of the legend may be of interest to my readers :-

At last a prince bearing the name of Kaulalaau, who suspected it was an evil spirit, followed the bird and was by supernatural agency impelled to hurl his javelin in its direction. In twenty paces the point did not droop; in forty it did not fall to the ground; in a hundred a new energy seized it, and like a flash of light it sped out of sight. A moment later the prince saw the bird sink and disappear down a precipice. He and his companion hastened to the base, where they found it dead with the javelin buried in its breast. They carried it to the temple, but the high priest declared that they should be sacrificed to the gods to avert their wrath. An appeal was made to the king, and on the bird being examined in the presence of the Court, it was found that its head was not that of a Pueo; nor did it bear a resemblance in form to that of any bird known. It was narrow between the eyes, which in colour were like those of a shark, and its long pointed mandibles, both of the upper and under jaws, turned sharply upward. The priests were severely reprimanded by the king for their mistake, and the prince-the slayer of the monster-was asked to explain what he knew about it. To this appeal he replied: "If I may rely upon what seemed to be a dream last night, the bird was possessed by the spirit of Hilo-a-Lakapu, one of the chiefs of Hawaii who invaded Oahu-during the reign of your royal father. He was slain at Waimano, and his head was placed upon a pole near Honouliuli for the birds to feed upon. He was of "Akua" blood, and through a bird-god relative his spirit was given possession of the monster which the gods enabled me to slay." The spirit of Hilo had come in with the head of the dead bird, and with the utterance of these words by the prince the eyes rolled, the ponderous jaws opened and closed, and with a noise like the scream of an "Alae" the malignant spirit took its departure. 
The shark-god was another "Akua," which, together with the Owl, was held in great reverence by the ancient Hawaiians, and even now the natives will sometimes tell you their "Akua" or "protecting spirit" is the Mano (shark).

I did not succeed in obtaining the eggs, but while on the island of Lanai in 1888, my young companion, Mr. Frederick Bickerton, found two half-fledged birds and took one alive to Honolulu with him, where it lived for some time in confinement. On the Waimea plains in Hawaii one often sees these Owls wheeling about in the daytime in search of mice, and on the waste land round the great extinct crater, Diamond Head, near Honolulu, they are also very common, while they are generally distributed over the islands of the whole group. One point more must be noticed with regard to them, and that is the presence of a large black parasite, about the size of a small blue-bottle fly, which swarms among the feathers. I noticed this particularly in the case of a specimen shot in Kona, and my friend Mr. F. Burchardt, who is well acquainted with these birds in Kohala, assures me they are seldom free from them. I secured specimens at the time, but unfortunately the glass tube in which they were preserved has been lost. 



\section{STERNA FULIGINOSA.}

Sterna fuliginosa, Gmelin, S. N. i. p. 605 (1788) ; G. R. Gray, List B. Br. Mus. iii. p. 177 (1844); Stejneger, Proc. U.S. Nat. Mus. xii. p. 379 (1889) ; Saunders, Cat. B. Br. Mus. xxv. p. 106 (1896).

Sterna oahuensis, Bloxam, Voy. 'Blonde,' p. 251 (1826).

Sterna (Onychoprion) serrata, G. R. Gray, Cat. B. Trop. Is. p. 59 (1859).

? Sterna panaya, Dole, Proc. Boston Soc. N. H. 1869, p. 306 ; id. Haw. Alman. 1879, p. 56.

Onychoprion fuliginosus, Wiglesworth, Aves Polyn. p. 75 (1891).

Haliplana fuliginosa, Rothschild, Avif. Laysan, p. 39 (1893).

[Except in a few cases the above citations refer to the Sandwich Islands and some other localities in the Pacific Ocean. The list could be easily extended.]

THIs bird was noticed in the Sandwich Islands by Bloxam, who recorded it in his Voyage of the 'Blonde' by the name of Sterna oahuensis, under the impression that he had discovered a new species. Two specimens from Oahu, an adult and a young bird presented by Sir Edward Belcher, are still in the British Museum, as may be seen from Mr. H. Saunders's Catalogue of the Gulls and Terns. Mr. Dole apparently included this species in his lists under the name of Sterna panaya, while Dr. Stejneger received an adult from Mr. Knudsen, procured on Kauai, where it appears to be common; others were contained in the collection which I made in 1887, and Palmer found large breeding colonies in the Laysan group in 1891. The bird is very widely distributed throughout the tropical and subtropical seas, while it is even found outside these limits.

Description.-Adult male and female. Sooty black, with white forehead, superciliary stripes, sides of the neck, and under surface; the lores, crown, and nape still blacker, while the two lateral tail-feathers shew white on their outer webs. Bill and feet black.

Dimensions._- "Total length about 17 inches, culmen $2 \cdot 1$, wing $11 \cdot 75$, tail about $7 \cdot 5$, tarsus $\cdot 9$, middle toe with claw $1 \cdot 1 "$ (Saunders). 


\section{STERNA LUNATA.}

Sterna lunata, Peale, U.S. Expl. Exped. p. 277 (1848) ; Cassin, U.S. Expl. Exped. p. 382 (1858); G. R. Gray, Cat. B. Trop. Is. p. 59 (1859) ; Stejneger, Proc. U.S. Nat. Mus. xii. p. 379 (1889) ; Saunders, Cat. B. Br. Mus. xxv. p. 100 (1896). Onychoprion lunatus, Wiglesworth, Aves Polyn. p. 76 (1891). Haliplana lunata, Rothschild, Avif. Laysan, p. 37, pl. (1893).

IT is quite possible that this Pacific species passed through the hands of $\mathrm{Mr}$. Dole before 1879, though he does not include it in either of his lists; but, if so, he did not distinguish it from the much more widely spread S. fuliginosa. In $1887 \mathrm{I}$ obtained specimens when in the Sandwich Islands, and in 1889 Dr. Stejneger received others from Kauai (sent by Mr. Knudsen). Palmer afterwards met with the bird in the Laysan group in abundance.

This bird is smaller than S. fuliginosa, and has the mantle dark grey, the nearly allied $S$. ancestheta having it brownish slate-coloured. 



\section{ANOUS STOLIDUS.}

Sterna stolida, Linnæus, Syst. Nat. ed. 12, i. p. 227 (1766).

Anous niger, Stephens, Gen. Zool. xiii. p. 140 (1825).

Anous stolidus, Cassin, U.S. Expl. Exped. p. 391 (1858) ; G. R. Gray, Cat. B. Trop. Is. p. 59

(1859); Finsch \& Hartlaub, Faun. Centralpolyn. p. 234 (1867); Dole ${ }^{1}$, Proc. Boston Soc.

N. H. 1869, p. 307 ; id. Haw. Alman. 1879, p. 57 ; Wiglesworth, Aves Polyn. p. 76 (1892);

Rothschild, Avif. Laysan, p. 41, pl. (1893) ; Saunders, Cat. B. Br. Mus. xxv. p. 136 (1896).

[All the above citations, except the first two and the last (in part), refer to the Sandwich Islands and some other localities in the Pacific Ocean. The list could be easily extended.]

THE Noddy Tern, widely distributed as it is in many parts of the world, is not to be found in such abundance in the neighbourhood of the Sandwich Islands as it is elsewhere. It is true that Palmer found it breeding on Laysan and on French Frigate Island, to the north-west of the above group, but its numbers were considerably less than those of Anous hawaiiensis, which was met with at the same time, while it must for the present remain doubtful whether it ever visits the main archipelago, though it probably does so. Mr. Dole quotes from Dr. Elliott Coues a tabulated form of the differences existing between specimens from the Pacific and from America; and, although he refers his specimen to $A$. stolidus, it seems that he intended to describe the bird now known as $A$. hawaiiensis. No certain record, therefore, exists of the occurrence of the typical Noddy in the Sandwich Islands.

Description.-Adult male and female. Sooty brown with whitish forehead, grey crown, and often black lores and throat; wings and tail blacker. Bill black; feet reddish brown with yellowish webs.

Dimensions.— "Total length about 16 inches, culmen $2 \cdot 1$, wing $10 \cdot 25-11$, tail $6-7$, tarsus 1 , middle toe with claw $1.55 "$ (Saunders).

${ }^{1}$ The two citations from Mr. Dole very possibly refer in part, if not entirely, to Anous hawaiiensis. 




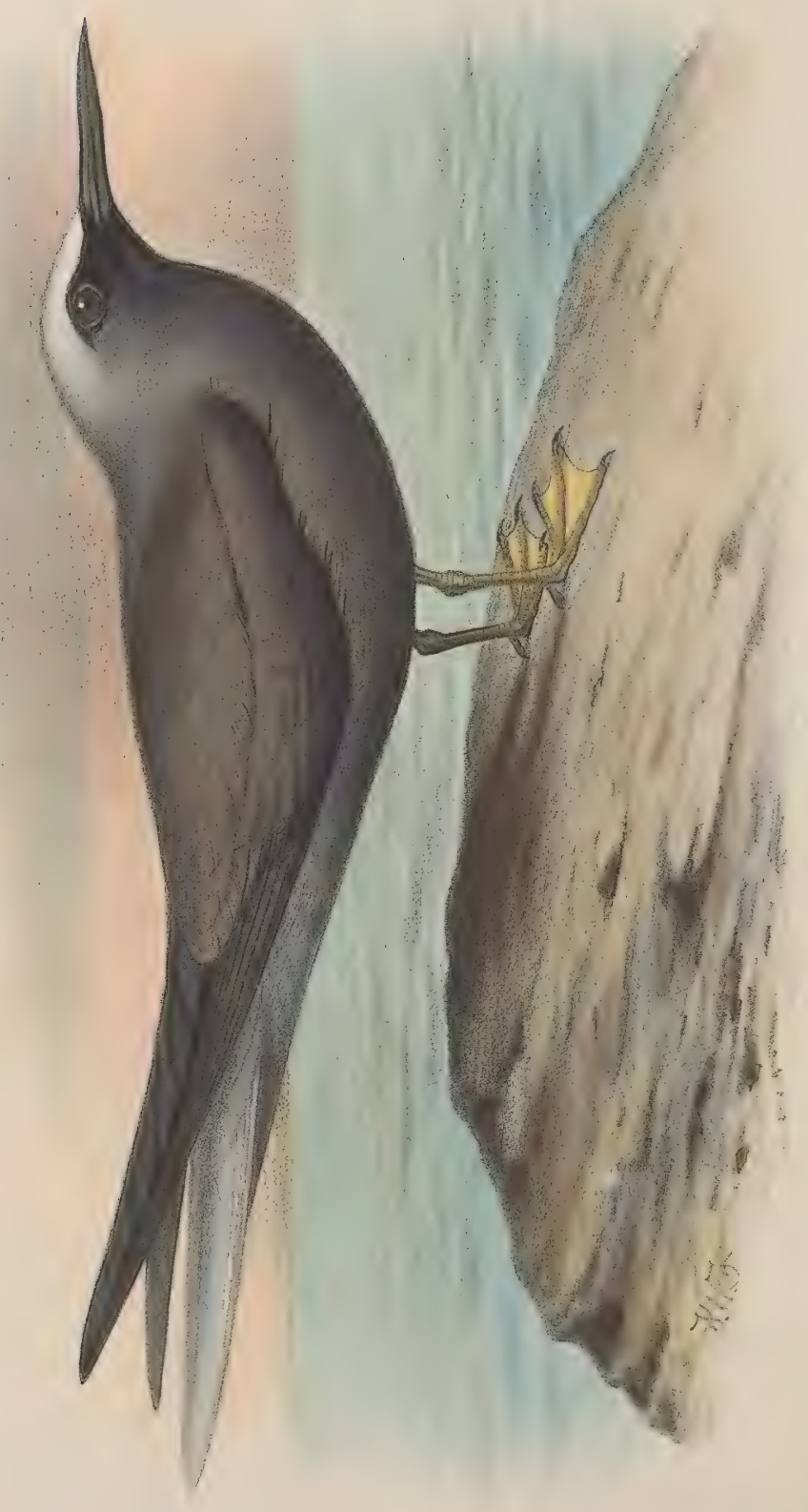

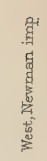

$$
\text { is }
$$

ठैं

$+$

Uर

Z

기

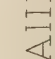

3

出

${ }_{1}$
$Z$
4
$[-1$
$E$
on

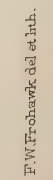




\section{ANOUS HAWAIIENSIS.}

NOIO.

"Sterna owhyhaensis," Bloxam, MS. (1825) (specimen in Br. Mus. from Owhyhee).

Anous tenuirostris, G. R. Gray, List B. Br. Mus. iii. p. 180 (1844), partim (nec Temminck); Lichtenstein, Nomencl. Avium, p. 97 (1854).

Anous melanogenys, Stejneger, Proc. U.S. Nat. Mus. xi. p. 94 (1888) (nec Gray, Gen. B. iii. pl. 182, fide Saunders, Cat. B. Brit. Mus. xxv. p. 148).

Anous hawaiiensis, Rothschild, Bull. Brit. Orn. Club. i. p. lvii (1893) ; id. Avif. Laysan, p. 43, pl. (1893).

Micranous hawaiiensis, Saunders, Cat. B. Br. Mus. xxv. p. 148 (1896).

THIs northern form of the smaller Noddy, A. melanogenys, was recognized as distinct from its larger congener by Bloxam, the naturalist of H.M.S. 'Blonde,' so long ago as 1825. It was described in his manuscripts, which, by favour of his son, Mr. A. Roby Bloxam, of Christ Church, New Zealand, have recently been examined by the writers, under the name of "Sterna owhyhaensis"; but, through the mischance or mismanagement which attended their publication, the name has never found its way into print. There can be no doubt of the identity of Bloxam's examples, for one which was obtained by the 'Blonde' expedition under Lord Byron has escaped destruction and still exists in the British Museum, as testified by Mr. H. Saunders.

Dr. Stejneger, however, who received four specimens from Mr. Knudsen of Kauai, which had been obtained in Niihau, did not in 1888 distinguish this species from A. melanogenys; and it was therefore left to Mr. Rothschild to give it the above specific name, which luckily agrees, except in spelling, with that originally proposed by Bloxam.

Mr. Dole asserts that in the Sandwich Islands this Noddy breeds on cliffs, but such seems very unlikely to be the case; and Palmer, who met with colonies in Laysan, Lisiansky, and Midway Islands, tells us that its habits are in general those of the typical form, and that it lays its eggs upon the sand. He also observed the bird on Kauai, whence Knudsen reported it to Dr. Stejneger as living "on the rocks about the coast." Mr. Perkins says that it is quite common throughout the group.

Description.-Adult male and female. Forehead and crown greyish white; lores black; cheeks and throat dark lead-grey; nape, shoulders, mantle, and tail lavendergrey; lower parts black : bill black; feet brown, with yellowish webs.

Dimensions._" Total length 13.5 inches, culmen $1 \cdot 8$, wing $8 \cdot 65$, tail 5 , tarsus $\cdot 75$, middle toe with claw 1.25 " (Saunders). 



\section{GYGIS ALBA.}

"White Tern," Latham, Gen. Synops. iii. p. 363 (1785); Portlock, Voyage round the World, p. 312, pl. (1789).

Sterna alba, Sparrman, Mus. Carlsonianum, no. 11 (1786); Gmelin, Syst. Nat. i. p. 607 (1788).

Sterna candida, Gmelin, Syst. Nat. i. p. 607 (1788).

Gygis candida, Wagler, Isis, 1832, p. 1223; Saunders, Cat. B. Br. Mus, xxv. p. 149 (1896).

Gygis alba, Lichtenstein, Nomencl. Av. p. 97 (1854) ; Cassin, U.S. Expl. Exped. p. 389 (1858)

(fig. of egg, p. 390); Dole, Proc. Boston Soc. N. H. 1869, p. 306; id. Haw. Alman. 1879, p. 56 ; Wiglesworth, Aves Polyn. p. 78 (1891); Rothschild, Avif. Laysan, p. 35, pls. (bird and eggs) (1893).

[Several of the above citations refer to the Sandwich Islands and some other localities in the

Pacific Ocean. The list could easily be extended.]

As will be seen from the synonymy, Mr. Dole included this species in both of his lists of the birds of the Sandwich Islands, but in 1879 he was still uncertain as to whether it was really found there. Since, however, Palmer subsequently met with it in abundance on Laysan and Lisiansky Islands, where it was breeding on the rocks and among the scrub, there can be little doubt that it visits the group first mentioned, at least occasionally. The habits recorded by Palmer differ considerably, as Mr. Rothschild tells us in his 'Avifauna of Laysan,' from those commonly observed in more southern climes, where the bird habitually lays its egg on the branch of a tree.

It should be mentioned that King (Voy. iii. p. 120, 1784) says that he observed a "large White Pigeon"; and this statement may possibly refer to the present species, as what he saw certainly could not have been a Pigeon.

Description.-Adult male and female. White, with a black ring round the eye; bill black; feet dark brown, with yellow webs.

Dimensions.- "Total length about 12 inches, culmen $1 \cdot 8$, wing $9 \cdot 5$, tail $4 \cdot 25$ to 5 , tarsus $\cdot 6$, middle toe with claw $1 \cdot 1 "$ (Saunders). 



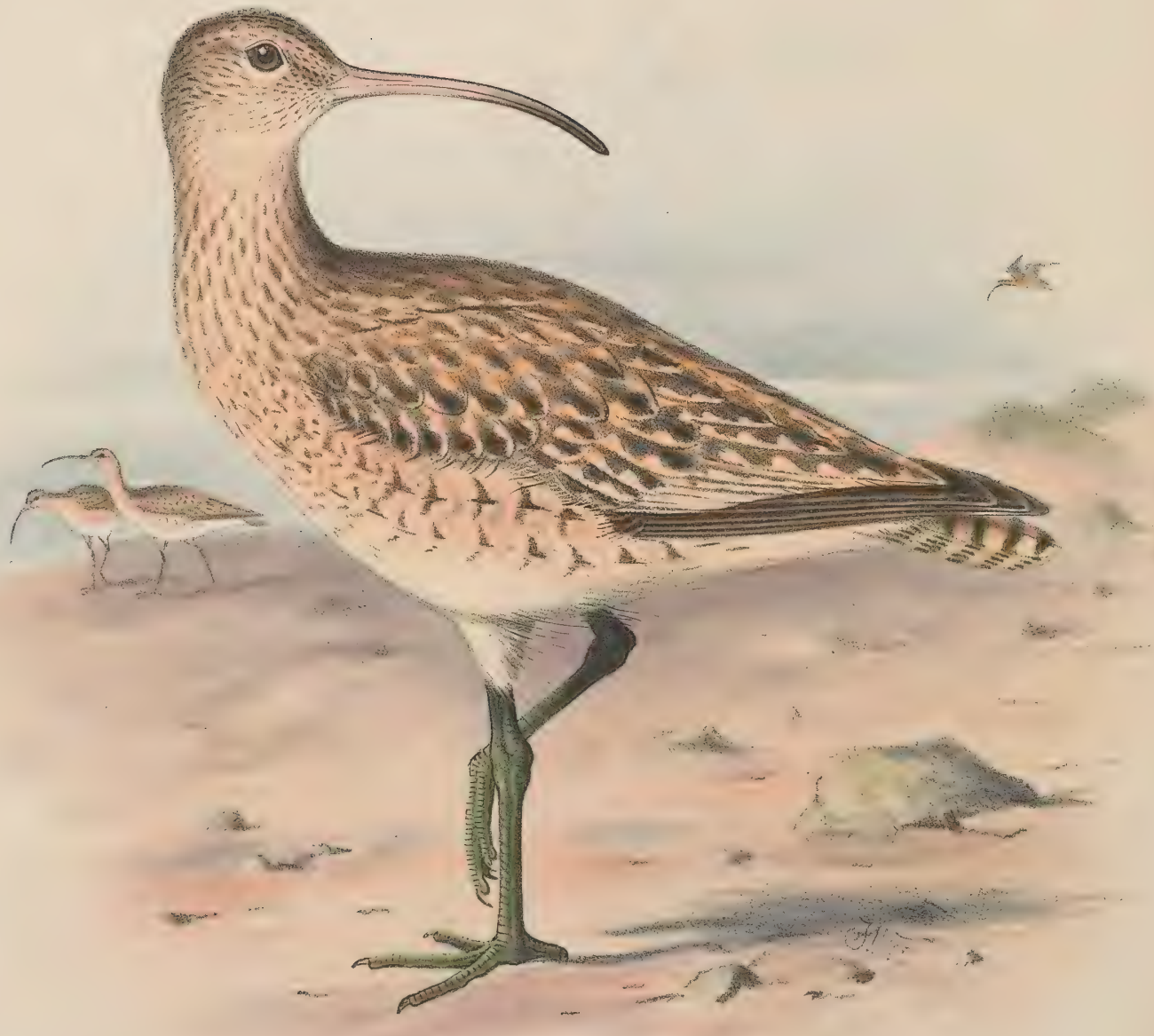




\title{
NUMENIUS TAHITIENSIS.
}

\author{
KIOEA.
}

"Otaheite Curlew," Latham, Gen. Synops. iii. p. 122 (1785).

Scolopax tahitiensis, Gmelin, Syst. Nat. i. p. 656 (1788).

Numenius tahitiensis, Latham, Ind. Orn. ii. p. 711 (1790) ; Vieillot, N. Dict. d'Hist. Nat. viii. p. 308 (1817); id. Encycl. Méth. p. 1157 (1823) ; Stephens, Shaw's Zool. xii. pt. 1, p. 32 (1824) ; G. R. Gray, Gen. B. iii. p. 569 (1847) ; id. Cat. B. Trop. Isl. p. 49 (1859) ; Ridgway, Proc. U.S. Nat. Mus. 1880, p. 201 ; Baird, Brewer, \& Ridgway, Water-B. N. Am. i. p. 324 (1884) ; Turner, Contr. N. H. Alaska, p. 190 (1886) ; Seebohm, Geogr. Distr. Charadriidæ, p. 333 (1887) ; Nelson (\& Henshaw), Rep. N. H. Coll. Alaska, p. 121, pl. (1887); Wiglesworth, Aves Polynesiæ, p. 66 (1891).

"Le Tevrea," Sonnini, Hist. Nat. Buffon, Ois. xxii. p. 280 (1803-4).

Scolopax phropus? ?, Forster, Descr. Anim. (Lichtenstein), pp. 156, 242 (1844).

Numenius femoralis, Peale, U.S. Expl. Exped. Birds, p. 233, pl. 64. fig. 1 (1848) ; Hartlaub, Arch. f. Naturgesch. 1852, i. p. 120 ; id. Journ. f. Orn. 1854, p. 170 ; Cassin, U.S. Expl. Exped., Mamm. \& Orn. p. 316, pl. xxxvii. (1858) ; G. R. Gray, Cat. B. Trop. Isl. p. 50 (1859) ; Finsch \& Hartlaub, Beitr. Fauna Centralpolyn. p. 175 (1867) ; Ridgway, Am. Nat. 1874, p. 435 ; Finsch, Ibis, 1880, pp. 220, 432 ; Tristram, Ibis, 1881, p. 251 ; id.op.cit. 1883, p. 47 ; Layard, Ibis, 1882, p. $533^{2}$.

Numenius phcoopus (partim), Schlegel, Mus. Pays-Bas, Scolopaces, p. 93 (1864).

Numenius australis, Dole, Proc. Bost. Soc. N. H. xii. p. 303 (1869); id. Hawaïan Alman. 1879, p. 51 (nec Gould).

Numenius taitensis, Coues, Check-List, ed. 2, p. 105 (1882); id. Key N. Am. B. ed. 2, p. 646 (1884).

Great credit is due to Peale, the chief ornithologist of the United States Exploring Expedition under Commander Wilkes, for detecting what is unquestionably the most remarkable character of the present species, namely, that afforded by the shafts of some of the flank-feathers, which are elongated and devoid of barbs near the tip. At the same time he seems to have been mistaken in supposing that the bird had not been described before, even though this peculiarity escaped the observation of Forster and of Latham, as it may well have done. There can be scarcely any doubt that it was the bird found on Otaheiti and the adjacent islands, and taken by the former authority to be the Scolopax phoopus of Linnæus, while the latter more properly recognized it as a new species of Curlew. The specimen he described from Sir Joseph Banks's collection has of course long since perished, and it is certainly true that no other is known to have been since brought from Tahiti, where it ras called by the natives "Tevrea" or

\footnotetext{
1 By an error in a second passage on this page, and also in a footnote of the page following, the epithet
} femoralis appears as tibialis. 
"Tewèh," and where it inhabited marshy places, being sometimes found also on the hills; but there is nothing in Lathain's description of his "Otaheite Curlew" inconsistent with its being specifically identical with that subsequently described by Peale from Vincennes Island, one of the Paumotu archipelago; while the latter, according to Drs. Finsch and Hartlaub, was obtained also by Dr. Gräffe on the Phœnix group, as well as by Dr. Finsch himself on the Marshall and Kingsmill Islands, and Canon Tristram's collection contains specimens from the Marquesas and from Fanning Island. Moreover, the claims of no other species to the title of Numenius tahitiensis have been established, for that described and figured by Cassin under the name in the Ornithological Appendix to Commodore Perry's Expedition to Japan (p. 228, plate) is assuredly a very different bird, not at all agreeing with Latham's diagnosis. It is probable that Schlegel in assigning the Numenius femoralis of Peale and Cassin to $N$. phoopus had no specimens of the former before him, or he would hardly have declared them to be merely "individus à plumes des jambes usées et depourvus de barbules." Indeed there is no evidence to show that the present species, whatever be the trivial name assigned to it, frequents the western part of the Pacific Ocean. Its first appearance in North America was recorded by Mr. Ridgway in 1874, an example having been taken by Mr. Bischoff at Fort Kenai on Kadiak Island in May 1869. 'The authors of 'The Water-Birds of North America' were, in 1884, under the impression that the occurrence of this specimen at a distance of some 5000 miles from its presumed habitat, "in a locality so remote and so unlike its natural haunt, can only be regarded as being something purely accidental." 'They did not then know that four years before Mr. Nelson had procured one of a pair of "Bristle-thighed Curlews" (as the species has now been called) in Alaska. That gentleman writes (op. cit. p. 121):- "On May 24, 1880, while I was shooting Black Brant, a pair of these birds settled near by on a rising stretch of land covered with large tussocks. They uttered a loud whistling call-note very much like that of hudsonicus, but something in their general appearance led me to stalk and secure one of the birds. To my gratification it was a Bristle-thighed Curlew, and I made great efforts to secure the mate, which had stopped a hundred yards or so beyond. As she raised on my approach I fired at long range and the bird fell mortally hurt on a distant hill-side, where it was lost amid a host of large tussocks.

"The specimen secured was a male in fine plumage, and this is the second known instance of the bird's occurrence on our shores, the former record resting on the capture of a specimen at Kadiak Island by Bischoff, as announced by Mr. Ridgway in the 'American Naturalist' for July 1874, under the name of Numenius femoralis, Peale. Nothing is known of its habits in America, but the presence of the pair at the date mentioned in the vicinity of St. Michael's would indicate that it nests, at least occasionally, in Alaska. . . . . Dr. Streets also found them very abundant on Palmyra Island, but only a few were seen on the other islands of the Fanning group."

That Mr. Nelson's opinion will be proved correct there can scarcely be a doubt. Numenius tahitiensis may be regarded as having its home in Alaska, and migrating 
southward in autumn to the Sandwich Islands and other groups in the Eastern half of the Pacific Ocean. As a species it is probably not very numerous, though Peale writes that the birds were abundant on Vincennes Island "in the month of September, when they had become exceedingly fat by feeding on the berries of a species of Canthium (?), then very plenty. The birds were rather tame, and uttered a clear plaintive whistle when flushed."

Judge Dole, in his Catalogue, only remarks of this species, referring it to $N$. austratis: "Curlew. Not very common." Dr. Stejneger (Proc. U.S. Nat. Mus. 1887, pp. 83, 84) gives a short account of some specimens sent him by Mr. Knudsen from Kauai, in which he says :-

"The bristly thigh-feathers of $N$. femoralis are quite characteristic, and are not due to abrasion, as has been supposed by some authors, for they are certainly present in a quite young bird collected by Mr. Charles H. Townsend in Alaska during the summer of 1885."

Dr. Stejneger also states, in another contribution (Proc. U.S. Nat. Mus. 1888, p. 97):- “Four additional specimens from Niihau show that this bird, originally added to the Hawaiian avifauna by Mr. Knudsen, was by no means an accidental stranger to the islands. In his letter to me he remarks, however, that the "Kioea" is a rare bird there, though almost always to be found in the localities affected by it, but he does not believe it to nest in the islands."

"The bristly elongation of the shafts of thigh-feathers are well developed in all four specimens. I may add that all four specimens are molting their inner primaries."

The Kioea ${ }^{1}$ is, I believe, generally distributed throughout the Hawaiian group, but in no locality is it plentiful. I myself obtained specimens on Molokai and Oahu, and heard of it on Hawaii and Maui, while Dr. Stejneger, as will be seen above, received others from Kauai and Niihau. Near Kaunakakai, on Molokai, I obtained examples out of a flock of a dozen birds, my kind host Mr. R. W. Meyer having driven me down to the beach at a spot which he knew to be frequented by them. I could not ascertain that the Kioea nests in the Islands; some natives, however, assured me that it does.

Description.-Adult. The crown is clear brown, with a pale streak down the centre and another over the eye. The upper parts are dark brown, mottled with cinnamonbrown and ochreous; upper tail-coverts cinnamon; tail slightly darker, inclining to tawny and barred with dark brown; neck, breast, and abdomen pale buff ; fore part of breast and flanks tinged with cinnamon and finely streaked and barred with brown; under tail-coverts pale cinnamon; primaries brown, shafts white.

The feathers on the flanks have the shafts (which are white) much elongated, in some cases projecting fully an inch beyond the barbs.

\footnotetext{
${ }^{1}$ Judge Dole applies the name spelt Kiowea to Chcetoptila angustipluma, whereas Mr. Knudsen gives Kioea as the name of this bird-this latter being, I believe, the correct orthography.
} 
Dimensions. - Total length 16.50 inches, wing from carpal joint 9, culmen 3.25, tarsus $2 \cdot 25$, middle toe with claw $1 \cdot 75$, tail $3 \cdot 50$.

Another example measures $17 \cdot 75$ and has the bill 0.40 inch longer, wing and tarsus also slightly longer; primaries black, shafts white. In other respects the specimens are similar. 



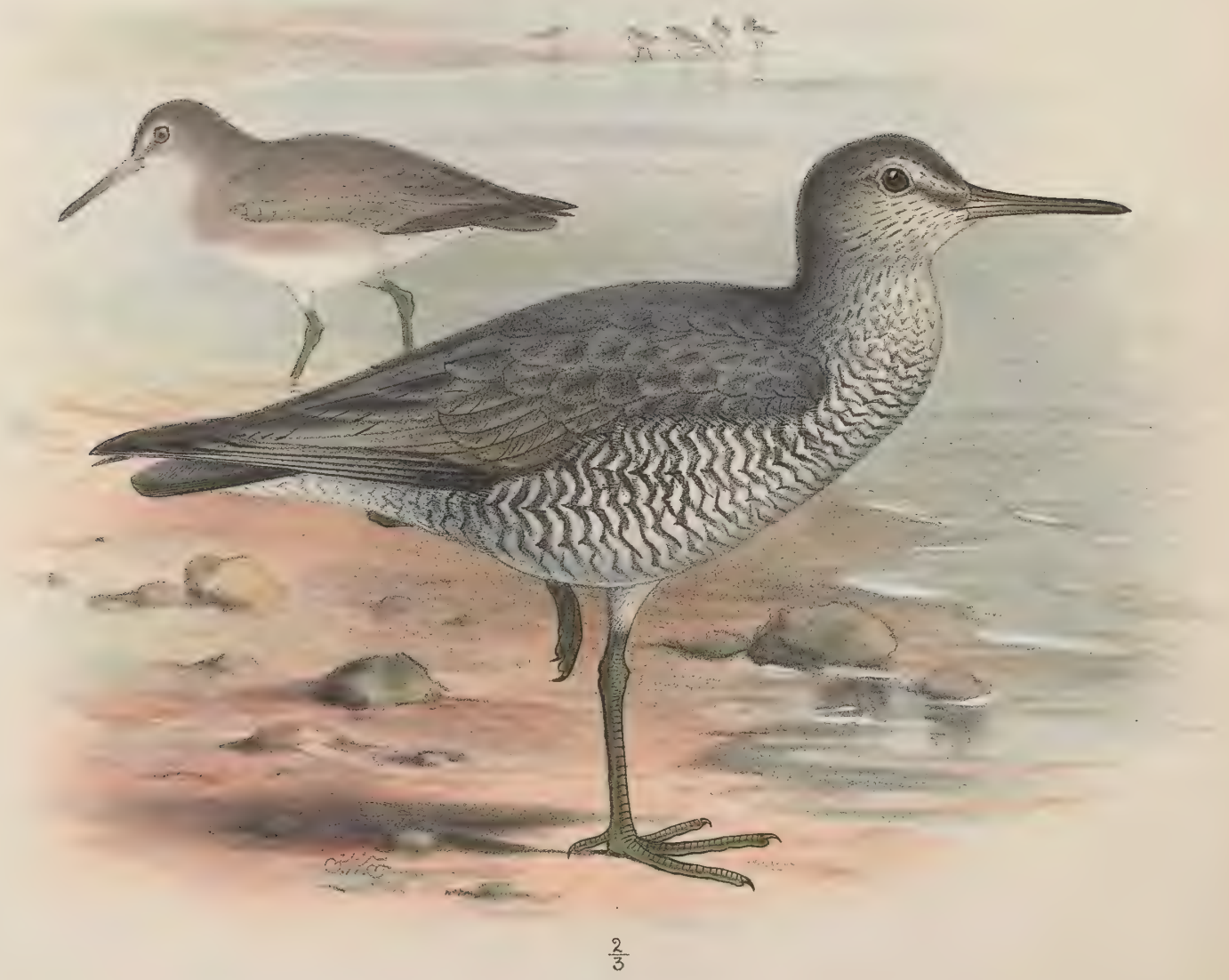




\section{TOTANUS INCANUS.}

\section{ULILI.}

"Ash-coloured Snipe," Latham, Gen. Synops. iii. p. 154 (1785).

Scolopax incana, Gmelin, Syst. Nat. i. p. 658 (1788); Latham, Ind. Orn. ii. p. 724 (1790).

"Le Chevalier cindré," Sonnini, Hist. Nat. Buffon, Ois. xxii. p. 101 (1803-4).

Totanus incanus, Vieillot, N. Dict. d'Hist. Nat. vi. p. 400 (1816) ; id. Encycl. Méth. p. 1098 (1823) ; Stephens, Shaw, Zool. xii. pt. I, p. 156 (1824) ; Schlegel, Mus. Pays-Bas, Scolopaces, p. 74 (partim) (1864) ; Sclater, Proc. Zool. Soc. 1878, p. 351 ; id. Rep. Voy. 'Challenger,' Birds, p. 99 (1881) ; Seebohm, Geogr. Distr. Charadriidæ, p. 360 (1887) ; Ramsay, Tab. List Austral. B. ed. 2, p. 20 (1888).

Scolopax solitaris, Bloxam, Voy. 'Blonde,' p. 252 (1826).

Totanus pedestris, Lesson, Traité d’Orn. p. 552, partim (1831).

Totanus fuliginosus, Gould, Voy. 'Beagle,' Birds, p. 130 (1841) ; Gray \& Mitchell, Gen. B. p. 573, pl. 154, partim (1846).

Scolopax undulata, Forster, Descr. Anim. (ed. Lichtenstein), p. 173 (1844).

Totanus polynesia, Peale, U.S. Expl. Exped., Birds, p. 237, pl. 65. fig. 1 ; Hartlaub, Arch. f. Naturgesch. 1852, i. p. 120 ; id. Journ. f. Orn. 1854, p. 169.

Totanus oceanicus, Lesson, Compl. Buffon, p. 244. (1847) ; Cassin, U.S. Expl. Exped., Mamm. \& Orn. p. 318 (1858).

Totanus solitarius, Hartlaub, Journ. f. Orn. 1854, p. 170.

Gambetta fuliginosa and G. oceanica, Bonaparte, Comptes Rendus, xliii. p. 597 (1856).

Heteroscelus brevipes, Baird, Expl. \& Surv. R. R. Route Pacif. ix. pt. ii. pp. 728 and 734 (1858); id. B. 'N. Am. pl. 88 (1860) ; Dall \& Bannister, Tr. Chicago Acad. 1869, p. 293 (nec Vieillot).

Totanus (Gambetta) incanus, G. R. Gray, Cat. B. Trop. Isl. p. 50 (1859).

Totanus undulatus, Verreaux, Rev. et Mag. Zool. 1860, p. 437.

Totanus brevipes, Sclater \& Salvin, Proc. Zool. Soc. 1870, p. 323 (nec Vieillot).

Heteroscelus incanus, Salvin, Trans. Zool. Soc. ix. p. 503 (1876); Elliott, Monogr. Seal Isl. Alaska, p. 130 (1882); Baird, Brewer, \& Ridgway, Water-B. N. Am. i. p. 290 (partim) (1884).

Heteractitis incanus, Stejneger, Auk, 1884, p. 236 ; id. Bull. U.S. Nat. Mus. no. 29, p. 132 (1885) ; id. Proc. U.S. Nat. Mus. 1887, p. 133; Turner, Auk, 1885, p. 157; id. Contr. N. H. Alaska, p. 148 (1886); Nelson (\& Henshaw), Rep. N. H. Coll. Alaska, p. 118 (1887).

[N.B.-The above list of synonyms and references is based on that given by Dr. Stejneger in his 'Results of Ornithological Explorations in the Commander Islands and in Kamtschatka' (Bull. U.S. Nat. Mus, no. 29), as he seems to be the first author who clearly shewed the distinction between this species and the nearly allied Totanus brevipes of Vieillot. It might yet be extended.]

THIs species, first made known by Latham from specimens in the Banksian collection obtained at Eimeo and Palmerston Island, has been the cause of much perplexity to ornithologists, as the above long list of synonyms will show. According to Forster it 
was also met with at Otaheite, Uliatea, and Tonga Tabu, and he seems to have discriminated between it and the ally with which it has often been confounded, as both are said by him to have occurred at the island last named. It has, however, been made pretty clear, chiefly by the labours of Dr. Stejneger, that the present species prevails over the eastern part of the Pacific Ocean, breeding in Alaska; while the true Totanus brevipes has its home in Asia, and during the winter months overruns the more westerly shores and islands of the same ocean. There is no doubt that T. incanus visits the Sandwich Islands, and as yet there is no authority for believing that $T$. brevipes occurs there. I met with the former on several parts of the Kona coast on Hawaii, where it is usually seen in pairs.

The main points of distinction, according to Dr. Stejneger, are as follows:-In the larger $H$. incana the nasal groove extends to one third of the exposed part of the culmen, in H. brevipes only to half. In the barred stage of the former (presumably the breeding-plumage) the back is greyish, the middle of the abdomen and the under tail-coverts distinctly and uniformly barred with blackish grey; in the same state of the latter the back is browner and the other parts mentioned pure white. In the unbarred stage the grey and brown tints similarly prevail.

A new genus, Heteroscelus, was proposed by Baird for these forms; but this being preoccupied in entomology, Dr. Stejneger suggested in its place Heteractitis. I prefér, however, still to include them under Totanus.

Judge Dole's note on T. incanus is :- "Frequent the shores singly or in pairs. Are called Ulili by the natives, from their note, which is a clear utterance of that word." Mr. Nelson, who gives a good account of it in his "Report upon Natural History Collections made in Alaska' (p. 118), describes it as an unsuspicious bird with a flutelike note, found solitary or three or four together on rocky parts of the coast; in fact its habits appear to be very much what those of the Common Redshank would be in an equally desolate region.

The figure in the background is that of a bird which has not completed the first year and shews signs of immaturity: the wings are not fully grown. 


\title{
CALIDRIS ARENARIA.
}

\author{
HUNAKAI.
}

Tringa arenaria, Linnæus, Syst. Nat. ed. 12, i. p. 251 (1766); Gay, Hist. Chile, Zoologia, i. p. 425 (1847) ; Schlegel, Mus. Pays-Bas, Scolopaces, p. 57 (1865); Philippi, An. Univ. Chile, xxxi. p. 276 (1868); Wiglesworth, Aves Polynesiæ, p. 64 (1891).

Calidris arenaria, Cassin, U.S. Nav. Astron. Exped. S. Hemisph. ii. p. 194 (1855) ; Baird, Proc. Acad. N. S. Philad. 1859, p. 306 ; Suckley, Rep. Expl. Railr. Mississ, xii. Bk. ii. p. 741 (1860) ; Sclater \& Salvin, Proc. Zool. Soc. 1868, p. 176; iid. op. cit. 1870, p. 323 ; Dall \& Bannister, Trans. Chicago Acad. Sc. i. p. 292 (1869) ; Finseh, Abh. Naturw. Ver. Bremen, iii. p. 65 (1872) ; Lawrence, Mem. Bost. Soc. N. H. ii. p. 308 (1874) ; Salvin, Trans. Zool. Soc. ix. p. 503 (1876) ; Finsch, Ibis, 1880, p. 331 ; id. Mitth. Orn. Ver. Wien, 1884, p. 127; Sharpe, Proc. Zool. Soc. 1881, p. 16; Nelson, Cruise 'Corwin,' p. 88 (1883) ; id. (\& Henshaw), Rep. N. H. Coll. Alaska, p. 115 (1887); James, List Chil. Birds, p. 13 (1885); Turner, Contr. N. H. Alaska, p. 189 (1886); Taczanowski, Orn. Pérou, iii. p. 353 (1886) ; Stejneger, Proc. U.S. Nat. Mus. 1887, p. 82 ; Oustalet, Miss. Sc. du Cap Horn, Oiseaux, p. B. 296 (1891).

[Except the first, the above citations refer mainly to the West Coast of America, the Sandwich Islands, and the Galapagos.]

To Mr. Knudsen we are indebted for the transmission of the first specimens of the Sanderling from the Hawaiian Islands. They were taken, as recorded by Dr. Stejneger (loc. suprà cit.), on the island of Kauai, probably in the winter months. It does not seem to be a common bird in that region, and I was only able to procure one example, for which I am indebted to Mr. Francis Gay, who shot it on the island of Niihau. It is worthy of notice that though met with on the coasts of Japan and China, and occasionally on the Commander Islands and at Sitka, whence it becomes more common to the eastward, this species did not come under the observation of Mr. Nelson in the southern part of Alaska during his stay there between 1877 and 1881 . It was, however, observed in numbers by Mr. Dall at the mouth of the Yukon, both in spring and autumn. It passes down the whole western coast of America to Cape Horn, and has been found in the Galapagos, but the only unquestionable record of its occurrence in Polynesia seems to be that of Dr. Finsch. The statement of Temminck (Man. d'Orn. iv. p. 349) that it had been found in the Sunda Islands and in New Guinea, though widely copied by authors, and by some extended generally to "the islands of the Malay Archipelago" (Seebohm, Geogr. Distr. Charadriidæ, p. 432), is not borne out 
by recent experience. Specimens exist in the Leyden Museum from Java, but there is no proper evidence that the species appears on other islands in the Indo-Malay or Papuan areas. Two examples, however, from New South Wales, a locality hitherto unrecorded, are contained in the Derby Museum at Liverpool. 


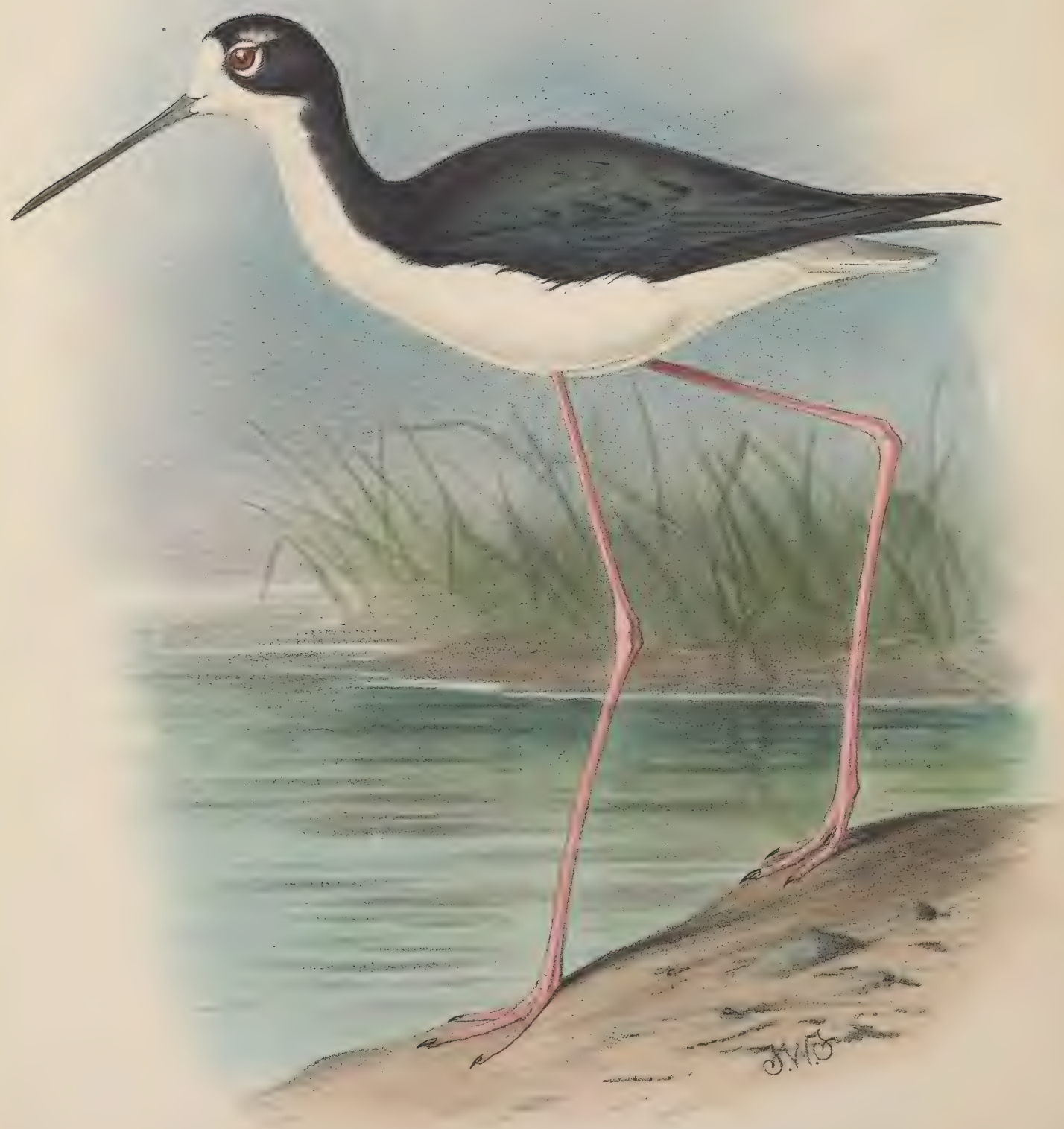




\section{HIM ANTOPUS KNUDSENI.}

$\mathrm{AEO}^{2}$.

Himantopus nigricollis?, Pelzeln, Verh. z.-b. Gesellsch. Wien, 1873, p. 159 (nec Vieillot).

Himantopus candidus, Dole, Hawaiian Alman. 1879, p. 52 (nec Bonnaterre).

Himantopus knudseni, Stejneger, Proc. U.S. Nat. Mus. 1887, p. 8I, pl. vi. fig. 2 (errore kandseni in plate); id. op. cit. 1888 , p. 96 ; id. op. cit. 1889 , p. 381.

As cited above, Dr. Stejneger, to whom Mr. Knudsen sent specimens from Kauai, described this bird as new in 1887 , giving woodcuts by which it may be easily separated from $H$. mexicanus; his remarks, diagnosis, and table of relative measurements I here quote, giving a figure from an example in my collection. He says :-

"This species is most nearly related to the two American species, $H$. brasiliensis and H. mexicanus, and differs from the last one in about the same degree as do the species mentioned inter se, $H$. mexicanus being in a measure intermediate as far as the relative amount of black and white in the coloration of the plumage is concerned.

"H. knudseni, which I take great pleasure of naming in honor of Mr. Valdemar Knudsen, who made the interesting collections upon which the present paper is based, needs only comparison with H. mexicanus, and the most salient differences have already been pointed out in the diagnosis ${ }^{2}$. I may add that $I$ have before me 17 specimens of the latter species, representing very fairly the individual and seasonal variation, as well as that due to age and sex. The type of $H$. knudseni is evidently an old male.

"The accompanying cuts (see Plate vi.) explain at a glance the different distribution of black and white in the two species, and make a more detailed comparison superfluous. Suffice it to say, that in the whole series of $H$. mexicanus $I$ have not found a single individual that even approaches $H$. knudseni, and in none of them, old or young, is the black mottling on the fore neck even indicated, the border-line between the black of the hind neck and the white of the sides being quite abrupt.

"The coloration of the tail is very peculiar, as already described in the diagnosis. Only in a single specimen of $H$. mexicanus (No. 84669, from Florida) is there any approach to the pattern exhibited by the type of $H$. knudseni, but the dusky markings are not so large, nor so dark and well-defined. It may be, therefore, that these marks have no diagnostic value.

\footnotetext{
1. The natives on Molokai and Oahu gave me the name as "Kukuluaia," but I expect that "Aeo," given by Mr. Knudsen, is more correct.

2 Infra, p. 4.
} 
"In regard to the dimensions, it will be seen from the subjoined table of measurements of adult $H$. mexicanus compared with those of $H$. knudseni, as given above, that in the latter the bill is $4 \mathrm{~mm}$. longer than maximum of the former, the tarsus $7 \mathrm{~mm}$. longer, and the tail-feathers $13 \mathrm{~mm}$. longer, while the wing is slightly shorter than that of the largest $H$. mexicanus. The extraordinary length of the tail in the Hawaiian bird is especially remarkable, it being more than 25 per centum longer than the average of five adult males of the North American species.

"The occurrence of a Stilt in the Hawaiian Islands was first recorded by Dr. A. v. Pelzeln (l.c.), who named the bird H. nigricollis, with a query. The specimen was a female, collected at Honolulu, February 21, 1870, by Mr. H. Kraus, who noted the colour of the iris as 'red.' Dr. O. Finsch (l.c.), during his recent visit to the islands, observed the Stilt on Maui, and now we have it, thanks to the liberality of Mr. Knudsen, from Kauai. This gentleman states that the name by which it is known to the natives is 'Aeo.'

"Measurements of Himantopus mexicanus.

\begin{tabular}{|c|c|c|c|c|c|c|c|c|c|}
\hline $\begin{array}{l}\text { U. S. Nat. } \\
\text { Mus., No. }\end{array}$ & Collector. & $\begin{array}{l}\text { Sex } \\
\text { and } \\
\text { age. }\end{array}$ & Locality. & Date. & $\stackrel{+0}{\Xi}$ & 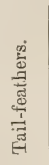 & 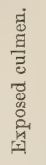 & 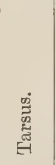 & 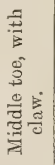 \\
\hline $84669 \ldots$ & Maynard. & o ad. & Florida. & & 222 & 68 & 66 & . & $\ldots$ \\
\hline $30332 \ldots$ & Marsh. & ơ ad. & Jamaica. & Apr. 一, 1863. & 200 & 64 & 66 & 114 & 45 \\
\hline $59754 \ldots$. & Sumichr. & $\delta^{*}$ ad. & Tehuantepec, Mexico. & Aug. 4, 1869 . & 227 & 69 & 68 & 114 & 46 \\
\hline $17274 \ldots$ & Xantus. & ô ad. & Sierra de Santiago, & $\operatorname{Jan} .-1860$ & 228 & 74 & 66 & 112 & 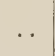 \\
\hline $79839 \ldots$ & Henshaw. & o ad. & Colorado. & June $21, \ldots$ & 234 & 70 & 71 & 113 & 46 \\
\hline $17272 .$. & Xantus. & $q$ ad. & Sierra de Santiago, & Jan. - 1860. & 220 & 74 & 63 & 102 & 42 \\
\hline $80998 \ldots$ & Ober. & 우 ad. & $\begin{array}{l}\text { St. Thomas, West } \\
\text { Indies. }\end{array}$ & 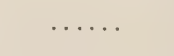 & 214 & 70 & 66 & 107 & 43 \\
\hline $1154 .$. & Baird. & 우 ad. & Cape May, N. J. & July 21, 1843. & 215 & 68 & 65 & 107 & $43^{\prime \prime}$ \\
\hline
\end{tabular}

The same author, in a second paper, refers to this bird as follows :-

"Two specimens from Niihau confirm the validity of this species. The peculiar coloration of the tail alluded to in the original description is also found in these, though less pronounced in No. 113463. The additional specimens, however, present another very strongly marked character which I did not mention in describing the type specimen, because most of the feathers in question were wanting, viz., that the longest upper tail-coverts have the inner webs entirely black, and that the down surrounding the uropygial gland is blackish. In some of the specimens of $\pi$. mexicanus the upper 
tail-coverts are more or less suffused with light grey, but I have found nothing like the broad median black stripe covering the base of the tail in $H$. knudseni.

"The type specimen, having a greenish black back, is undoubtedly a male, while the two Niihau birds appear to be females, having the back brownish.

"The appended table of dimensions corroborates the deduction previously made as to the relative proportions of the two species. Their wings and toes are of the same length, but $H$. knudseni has longer bill, tarsus, and tail.

"Measurements.

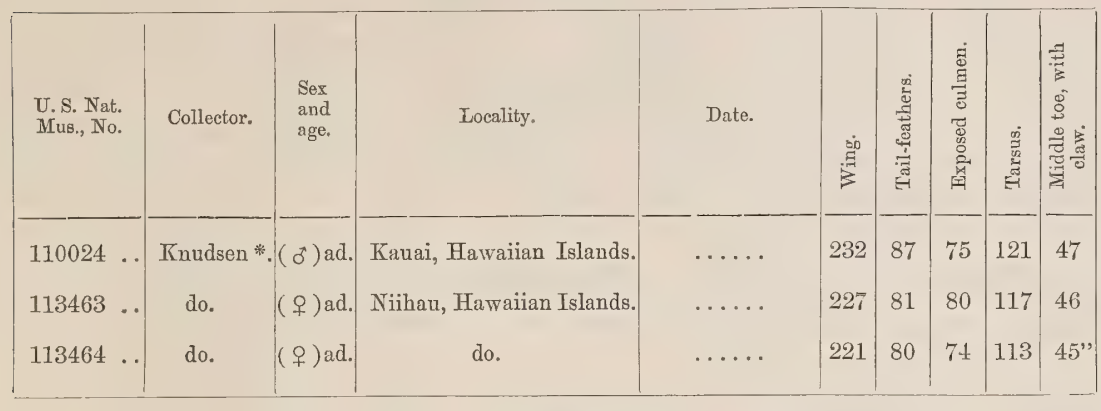

* Type.

Dr. Stejneger, to whom I sent all my specimens for inspection, has recently written to me as follows:- "I have carefully compared them with the type, with which they agree in all essential points. The coloration seems to be most reliable, especially the relative amount of black and white on head and neck, clearly shown in the figure accompanying my first paper. 'The dimensions of bill and feet give less definite results, as might be expected in birds of this kind, since the individual variation in these exaggerated parts is so enormous; but you will find that the length of the tail (middle tailfeathers to base between them) is constantly larger in the Hawaiian birds. Although most of the specimens of the latter are females, the measurements of the tail-feathers average considerably over $80 \mathrm{~mm}$., while in the American birds the average of about an equal number of $\delta$ and $q$ is about $66 \mathrm{~mm}$, with a maximum in the $\sigma$ not reaching the minimum of the $q$ of $H$. knudseni. There is therefore not the slightest doubt in my mind as to the specific distinctness of the latter."

Judge Dole says :- "Legs very long, and bright pink in colour. Common in ponds and swamps all over the group. Generally wades, but is able to swim. Is not very shy, and often troubles sportsmen by keeping just out of gunshot, and warning other birds away by its peculiar cry of defiance. It carries its legs straight out behind when it flies."

I obtained specimens near Koko Head, some few miles from Honolulu, also near Kaunakakai on Molokai; at the latter place in June I found young in the down, of 
whose presence I was made aware by the noisy cries and behaviour of the parent birds, who swept to and fro quite near me in their anxiety. I heard that it was fairly abundant at some lagoons. near Kekaha on Kauai, and as Dr. Finsch observed it on Maui ${ }^{1}$, it is doubtless distributed throughout the entire group, as might have been expected.

"Diagnosis.-Similar to Himantopus mexicanus (MüLL.), from North America, but with the black of the head extending further down on the forehead and occupying the proximal half of the lores; black on neck extending to the sides and the front of the neck, except the middle line, mottled with black, the feathers being narrowly tipped with black; tail-feathers broadly and abruptly tipped with greenish black, nearly the entire outer web of the outer pair being of the same colour; tail-feathers, with the outer webs, light smoky gray, and the inner ones white, except the middle pair, which has both webs light smoky gray; bill, tarsus, and tail considerably longer than in $H$. mexicanus.

"Dimensions of type specimen.-Wing $232 \mathrm{~mm}$., tail-feathers $87 \mathrm{~mm}$., exposed culmen $75 \mathrm{~mm}$. ; tarsus $121 \mathrm{~mm}$., middle toe with claw, $47 \mathrm{~mm}$."

${ }^{1}$ Dr. O. Finsch ('Ibis,' 1880, p. 79) says:-- "Here [at the lagoon of Kahalui on Maui] I also observed Actitis incana, a Charadrius (like C. hiaticula), a Himantopus, which Mr. Dole designates H. candidus, but which seems to be identical with the American species, and a Snipe like our Gallinago scolopacina." 


\title{
STREPSILAS INTERPRES.
}

\author{
AKEKEKE.
}

Tringa interpres, Linnæus, Syst. Nat. ed. 12, i. p. 248 (1766).

Strepsilas interpres, Illiger, Prodr. p. 263 (1811) ; Darwin, Voy. 'Beagle,' Birds, p. 132 (1841); Peale, U.S. Expl. Exped., Birds, p. 238 (1848); Hartlaub, Arch. f. Naturgesch. 1852, i. p. 135 ; id. Journ. f. Orn. 1854, p. 170 ; Schlegel, Mus. Pays-Bas, Cursores, p. 44 (1865); Von Pelzeln, Reise 'Novara,' Vögel, p. 117 (1865); Finsch \& Hartlaub, Beitr. Orn. Centralpolyn. p. 197 (1867) ; Dole, Proc. Bost. Soc. N. H. xii. p. 304 (1869) ; id. Hawaiian Alman. 1879, p. 51 ; Salvin, Tr. Zool. Soc. ix. p. 502 (1876); W'iglesworth, Aves Polynesiæ, p. 63 (1891).

Tringa oahuensis, Bloxam, Voy. 'Blonde,' p. 251 (1826).

Cinclus interpres, G. R. Gray, Cat. B. Trop. Isl. p. 48 (1859).

Arenaria interpres, Stejneger, Proc. U.S. Nat. Mus. xii. p. 380 (1889).

[Except as regards the first two citations the above refer to this widely-ranging species only in relation to the Sandwich Islands and some other localities in the Pacific Ocean. The list could be easily extended.]

THE first occurrence of this well-known and almost cosmopolitan species in the Sandwich Islands is that noted by Mr. Bloxam, to whom, however, it must have been unfamiliar, for he described and named it, as if new, Tringa oahuensis-no doubt from having met with it on the island on which Honolulu stands. Yet, beyond stating that the natives called the birds "Korea," and that they are "gregarious," he added nothing. Judge Dole described an example shot at Kapaa on the island of Kauai, and says:"They frequent the shores, but are often found on grass-lands." From the same island Mr. Kuudsen sent two specimens to Dr. Stejneger with the native name of "Akekeke"; but in a former paper (Proc. U. S. Nat. Mus. 1887, p. 82) that name is also applied to the Sanderling (Calidris arenaria), which rejoices in the more poetical and yet very apposite name of Hunakai, signifying "Sea-foam."

I shot three examples when in the Sandwich Islands-two on the island of Oahu, one on Molokai. The dates varied from April to June. 



\title{
CHARADRIUS FULVUS.
}

\author{
KOLEA.
}

"Plover, nearly the same as our whistling plover," Ellis, Narrat. Voy. Cook \& Clerke, ii. p. 143 (1782).

"Plover . . v very like the whistling plover of Europe," King, Voy. Pacif. Ocean, iii. p. 120 (1784).

"Fulvous Plover," Latham, Gen. Synops. iii. p. 211 (1785).

"Golden Plover," Latham, Gen. Synops. iii. p. 194. (partim) (1785).

Charadrius fulvus, Gmelin, Syst. Nat. i. p. 687 (1788); Latham, Ind. Orn. p. 747 (1790); Donndorff, Orn. Beytr. i. p. 1092 (1794); Tiedemann, Anat. Naturgesch. Vög. ii. p. 434 (1814) ; Wagler, Syst. Av. (Charadrius, sp. 37) (1827); G. R. Gray, Cat. B. Trop. Isl. p. 47 (1859) ; id. Hand-1. iii. p. 14 (1869); Dole, Proc. Bost. Soc. N. H. xii. p. 304 (1869); id. Hawaiian Alman. 1879, p. 50 ; Streets, Contr. Nat. Hist. Hawaiian and Fanning Isl. p. 16 (1877) ; Seebohm, Geogr. Distr. Charadriidæ, p. 99 (1887); Wiglesworth, Ares Polynesiæ, p. 63 (1891).

Charadrius pluvialis (partim), Gmel. Syst. Nat. i. p. 688 (1788); Latham, Ind. Orn. p. 740 (1790); Peale, U.S. Expl. Exped., Birds, p. 239 (1848); Von Kittlitz, Denkwürd. Reise, ii. pp. 141, 187 (1858) ; Coinde, Rev. Zool. 1860, p. 400 ; Von Pelzeln, Reise 'Novara,' Vögel, p. 115 (1865).

Charadrius xanthocheilus, Cassin, U.S. Expl. Exped., Mamm. \& Orn. p. 325 (1858) (qu. Wagler?).

Charadrius taitensis, Lesson, Man. d'Orn. ii. p. 321 (1828).

Charadrius glaucopus, J. R. Forster, Descr. Anim. p. 176 (1844).

Charadrius auratus orientalis, Temminck \& Schlegel, Faun. Jap., Aves, p. 104, pl. lxii. (18 ?).

Charadrius virginianus, Hartlaub, Arch. f. Naturgesch. 1852, i. p. 121 (partim).

Pluvialis longipes, "Temm.", P.xanthocheilos, et P. fulvus, Bonaparte, Comptes Rendus, xliii. p. 417 (1856).

Pluvialis fulvus, Schlegel, Mus. Pays-Bas, Cursores, p. 50 (1865).

Charadrius dominicus fulvus, Ridgway, Proc. U.S. Nat. Mus. 1880, p. 198; Nelson, Cruise 'Corwin,' 1881, p. 84 (1883) ; Stejneger, Bull. U.S. Nat. Mus. no. 29, p. 104 (1885); id. Proc. U.S. Nat. Mus. 1887 , pp. 80, 126; id. op. cit. xii. p. 380 (1889).

[The foregoing references chiefly relate to localities in the North Pacific Ocean.]

Since the Sandwich Islands were first discovered it has been well known to ornithologists that one of the forms of the Golden Plover frequented their shores at certain seasons. Ellis and King both mention having met with the bird, and most subsequent voyagers in that part of the Pacific have also observed it; while of late years the exact species has been ascertained, and proves to be not the ordinary American C. virginicus, but the Asiatic form ( $C$. fulvus), the breeding-range of which just crosses the American boundary-line into Alaska. Specimens sent by Mr. Knudsen from Kauai, and those in the United States National Museum, agree with Asiatic and Alaskan examples, as do mine. 
Judge Dole states that the plovers appear at the end of August and leave again early in May, and that the flocks "always assemble at the eastern or north-eastern shore of the Islands preparatory to starting." These flocks have often been encountered on the high seas, and considerable interest attaches to Professor Forbes's account of one such instance recorded by Professor Newton in a communication to 'Nature' for 1879 (vol. xix. p. 580). The latter says, speaking of the Sandwich Islands:- "Prof. George Forbes .... informs me that when there, on the occasion of the transit of Venus, he shot scores of these birds, and that his friend Capt. Cator, R.N., of H.M.S. Scout, having sailed thence, was overtaken in mid-ocean by them, flying in a direct line for Vancouver's Island, on arriving at which he found they had already reached it." This would imply that these migrants are birds which breed in or near Alaska, and have nothing in common with the bands that pour down by another route from Asia to the South Pacific, reaching far within the confines of Australasia.

In April, shortly before their departure, plovers are in the best condition, and indeed become so fat that they frequently burst on falling to the ground when shot: I met with them, however, in the greatest numbers in December on the plains of Waimea, where they may be seen in thousands, and their clear musical note may be heard on every side. During a tour along the sea-coast of Hawaii-from Kawaihae to Kiholo-made in the same month with my friend Mr. F. Spencer we had excellent plover-shooting, waiting for the birds as evening fell and shooting them as they came down to the shore to feed. I think the Golden Plover is the finest bird for the table of all those found in the Hawaiian Islands, and resident sportsmen there agree with me: in December, when the plains are covered with large grubs called by the natives "poko," the birds feed largely on them and fatten amain.

In olden times the islanders were very expert in snaring them, but like other of their former arts the method has been forgotten, or the present generation is too lazy to practice it. I am indebted to Mr. F. Spencer for one of the "Kolea stones" used for the capture, which is a piece of smooth lava, grooved to receive a hair-noose. 'The natives used to set many hundreds of these snares, and on the authority of Mr. Spencer enormous numbers were caught, the women and girls being quite as expert as the men at the practice-a remark which also applies to the capture of the various forest-birds described in this work. 


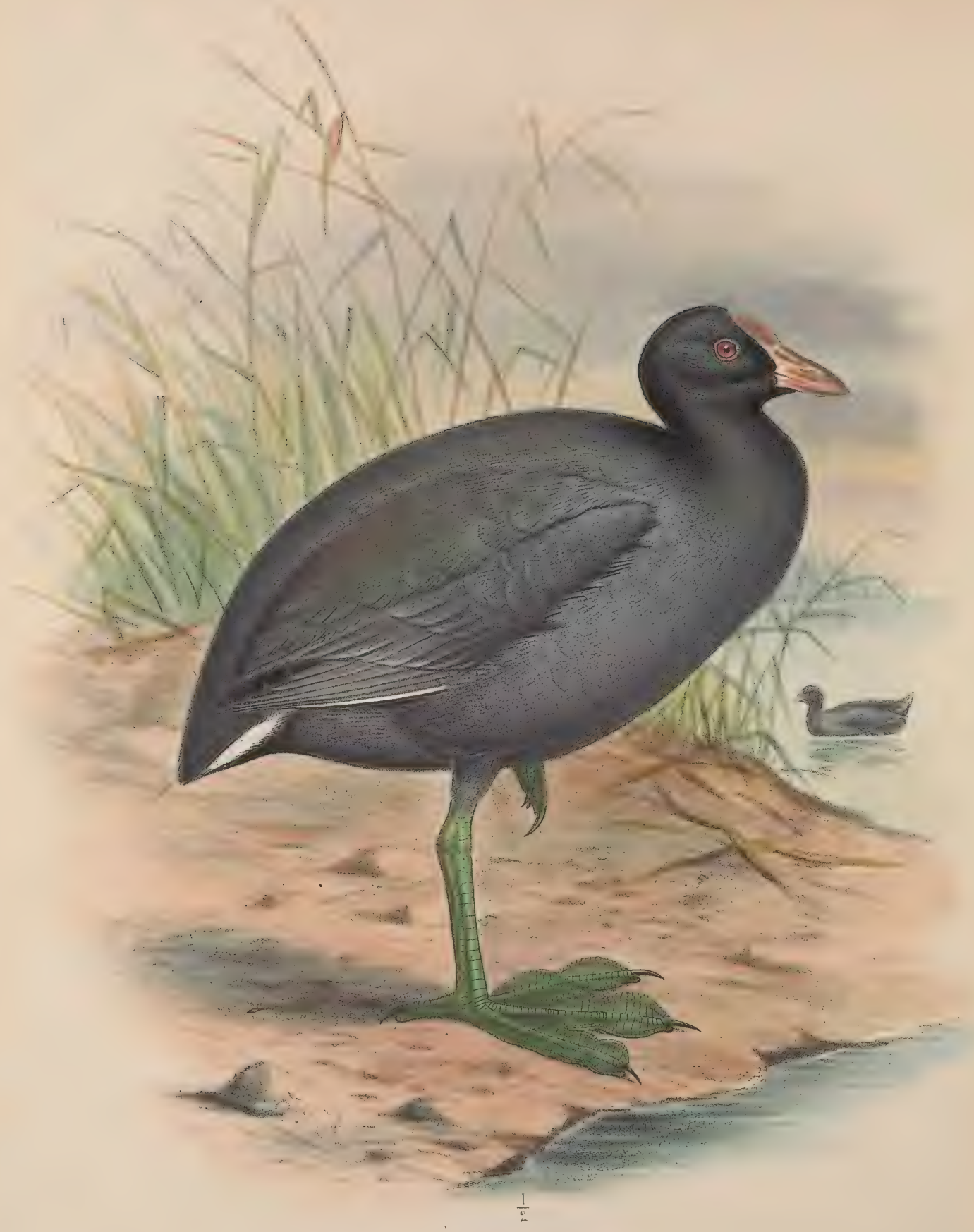




\title{
FULICA ALAI.
}

\author{
ALAI KEOKEO.
}

Fulica atra, Bloxam, Voy. 'Blonde,' p. 251 (1826) (nec Linnæus).

Fulica alai, Peale, U.S. Expl. Exped., Birds, p. 224, pl. lxiii. fig. $2 *$ (1848) ; Hartlaub, Arch. f. Naturgesch. 1852, i. pp. 119, 137; id. J.f. O. 1853, Ber. vii. Jahresversamml. deutsch. Orn. Ges. pp. 75, 89 ; Cassin, U.S. Expl. Exped., Mamm. \& Orn. p. 306, pl. xxxvi.* (1858) ; id. Proc. Acad. Philad. 1862, p. 322 ; G. R. Gray, Cat. B. Trop. Isl. p. 54 (1859) ; Sclater, Tbis, 1871, p. 361 ; id. P. Z. S. 1878, p. 351 ; id. Rep. Voy. 'Challenger,' Birds, p. 99 ; Pelzeln, Verh. z.-b. Gesellsch. Wien, 1873, p. 159; Streets, Contr. N. H. Haw. \& Fanning Isl. p. 21 (1877); Finsch, Ibis, 1880, p. 78 ; Stcjneger, Proc. U.S. Nat. IMus. 1887, p. 80 ; id. op. cit. 1888, p. 95. Fulica alae, Dole, Proc. Boston Soc. N. H. xii. p. 302 (1869) ; id. Hawaiian Alman. 1879, p. 54.

* Figurce notabiles.

Bloxam appears to have been the first ornithologist to notice a Coot on the Sandwich Islands, though he imagined it to belong to the common European species. The credit of distinguishing it from the other members of the genus belongs to Peale, who, while he was somewhat doubtful of his own correctness, named it Fulica alai, from the native appellation of "Alai" or "Alae," which is also applied to the Hawaiian Water-Hen, and is evidently used indiscriminately for birds of this description. The chief points of distinction relied on are the smaller size and more slender beak; but Dr. Finsch, who observed both Coots and Water-Hens at Waike, Kahalui in Maui, and Waimanalo in Oahu, states that the pale greyish colour of the feet, without any greenish band on the joint of the knee, constitutes a further mark of differentiation; adding that the cry is not so loud or harsh as in the European bird, nor are the eggs so large.

Peale found this species not uncommon on marshy creeks and in the taro patches, Dr. Finsch on the lagoons. The latter author and Judge Dole agree in saying that the habits are similar to those of its congeners; while the Judge further states that " the frontal knob" is "ivory-white, instead of pale blue, as Peale gives it."

It was also obtained by Stimpson, of the N. Pacific Surveying and Exploring Expedition of the United States, at Hilo, in Hawaii, in 1856, and by H. Kraus during the Austrian Mission to E. Asia and America in 1870.

I regret to say that I did not obtain examples when in the Sandwich Islands; Dr. Stejneger, however, received two from Mr. Knudsen, procured in Kauai, and was thus able to corroborate his statement already made in 1887 , that the bird, which is 
abundant on the southern islands, occurs also on the northernmost. With regard to it being a distinct species, Dr. Stejneger wrote to me quite recently:- "In regard to Fulica alai I would say that the difference between it and the American species is very much greater than between the Gallinules. I consider it an offspring of the American, of course, but now quite specifically distinct."

Peale describes the bird as follows:-

"Closely allied to Fulica americana, but smaller, and having a more slender bill; head and neck black; body dark cinereous, tinged with brown on the back: wings brown, margined with white; second primary longest, third nearly equal to the second, first and sixth equal; shafts brown: tail very short, brown, the lower coverts white: bill reddish white; the frontal knob pale blue: legs bluish green.

"Total length, $14 \frac{1}{10}$ inches; wing, from the carpal joint, $7 \frac{3}{10}$ inches; bill to the frontal knob $1_{10} \frac{2}{10}$ inch, including the knob, $2 \frac{1}{10}$ inches; to the corner of the mouth, $1_{10} \frac{4}{10}$ inch; tarsi, 2 inches; middle toe, including the nail, $3 \frac{6}{10}$ inches, nail, $\frac{6}{10}$ inch; hind toe, $1_{1}^{\frac{3}{6}}$ inch; nail, $\frac{9}{20}$ inch." 



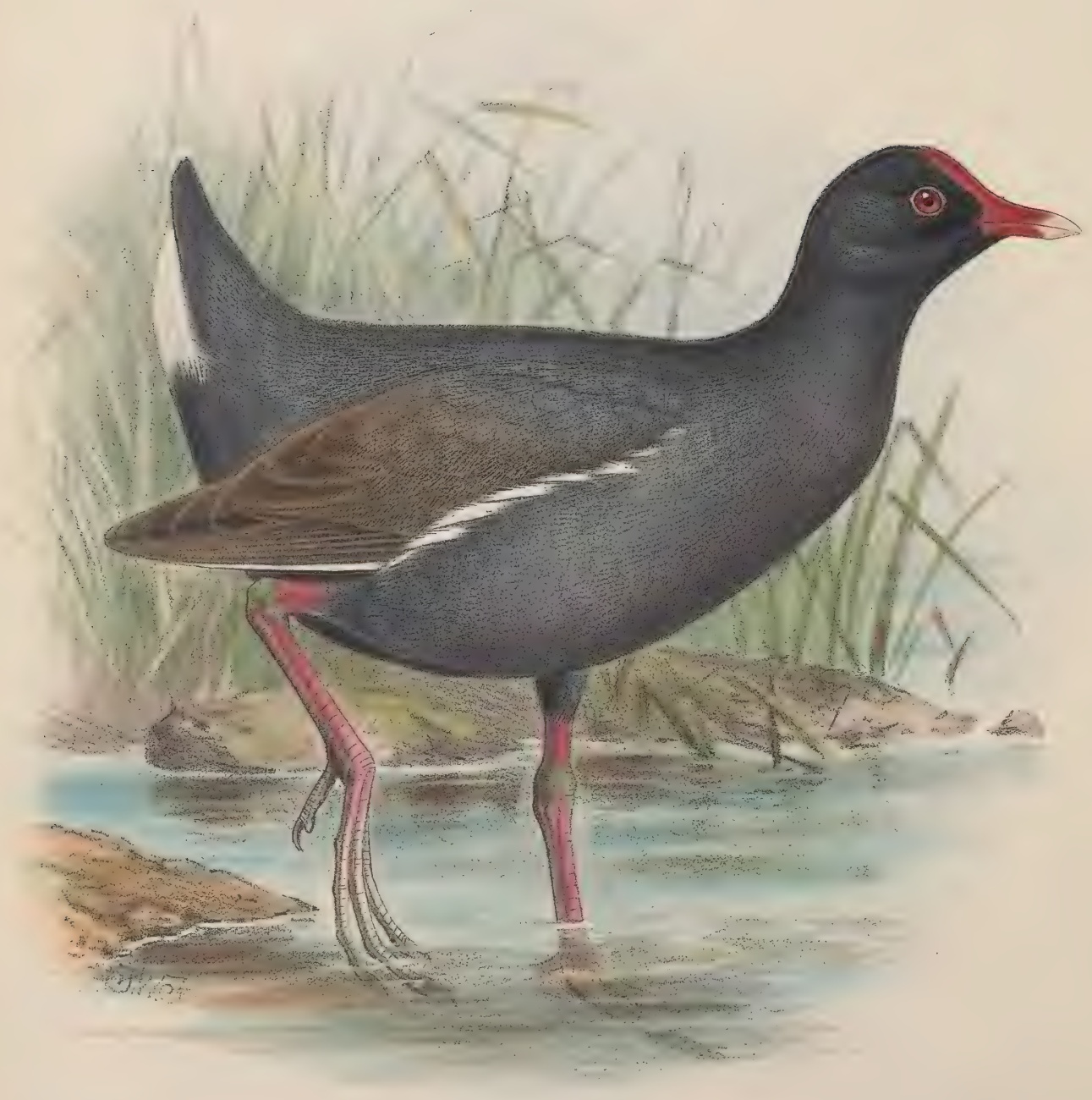

F.W Frohawk del.etlith. 


\section{GALLINULA SANDVICENSIS.}

ALAE or ALAI.

"Common Water or darker [qu. daker?] hen," King, Voy. Pacif. Ocean, iii. p. 120 (1784).

Fulica chloropus, Bloxam, Voy. 'Blonde,' p. 250 (1826) (nec Linn.).

Gallinula chloropus, Peale, U.S. Expl. Exped., Birds, p. 220 (1848); Hartlaub, Arch. f. Naturgesch. 1852 , i. pp. 118, 137 ; Dole, Proc. Boston Soc. N. H. xii. p. 302 (1869); id. Hawaiian Alman. 1879 , p. 53.

Gallinula —— G. R. Gray, Cat. B. Trop. Isì. p. 53 (1859).

Gallinula galeata, G. R. Gray, Hand-1. B. iii. p. 66 (partim) (1871).

Gallinula sandvicensis, Streets, Ibis, 1877, p. 25 (fig. of forehead); id. Contr. N. H. Haw. \& Fanning Isl. p. 19 (1877); Finsch, Ibis, 1880, p. 78.

"Gallinula galeata sandvicensis," Stejneger, Proc. U.S. Nat. Mus. 1887, p. 78; id. op. cit. xii. p. 380 (1889).

Althougr King, Bloxam, and Peale all met with this Water-Hen, they did not distinguish it from the American form of G. chloropus, since called G. galeata; but in $1877 \mathrm{Dr}$. Streets endeavoured to show, by means of a full description and figure of the forehead in 'The Ibis,' that it should be separated as G. sandvicensis. The points of distinction, however, on which he relied are by no means constant, and, if it were not for the colour of the front of the tarsi, the bird could hardly claim even subspecific rank. 'This colouring is said by Peale to be "pale crimson blush;" by Dr. Streets to be "decided crimson blush;" and though Dr. Stejneger was at first inclined to doubt whether such was invariably the case, Judge Dole has informed me that in the freshly-killed bird the legs are "salmon-colour;" while a specimen in my collection shows unmistakable signs of red coloration on the same parts. In 1890 Dr. Stejneger received further examples with decidedly red tarsi. Whether, however, the bird is to be considered a species or subspecies, I have thought it best to figure it under the above title as an island form of considerable interest, leaving it to those who prefer doing so to denominate it G. galeata sandvicensis. The habits do not seem to differ from those of the American or the European Water-Hen.

Dr. Stejneger's full account is here reproduced; while I may add that there is an unfinished sketch by W. Ellis among his drawings preserved in the British Museum, evidently meant to represent this species. The former says (P. U.S. Nat. Mus. 1887, p. 78):-

"Mr. Knudsen sends two specimens of this representative form of the American G. galeata, LicHT., which, compared with Streets' type and typical specimens of 
G. galeata, show that the differences between the alleged two species are much smaller than supposed by the original describer of $G$. sandvicensis.

"Dr. Streets $(l l . c c$.$) sums up the distinctive characters as follows:- [ [1] The greater$ extent of the frontal plate, [2] the shorter wing, [3] the absence of white on the abdomen and [4] on the under surface of the wing, as well as its reduction to a mere trace on the margin of the latter, [5] the more robust and different form of the tarsus, being broader and more rounded in front, [6] as well as the great difference in the colour of the tarsus, are characters which separate it immediately from G. galeata, and render its identification easy.'

"(1) There are numerous American specimens in the collection before me which have just as large frontal shields as the Hawaiian birds, and some have it even larger.

"(2) It will be seen from the table of measurements given below that there is no difference whatsoever in regard to dimensions or proportions, No. 84683 , from Florida, being, in fact, nearly identical with the type of $G$. sandvicensis in these respects. I should remark that the American specimens were picked up at random for measuring, except the last one, a young male, which was selected as being the largest of the whole series before me, and the only one with the wing longer than the second Hawaiian specimen.

"(3) The absence or presence of white on the abdomen is simply due to season, the type of $G$. sandvicensis being without white markings, while both the birds collected by $\mathrm{Mr}$. Knudsen have them. Both styles are well matched by American birds.

"(4) Also in regard to the scarcity of white on the lining of the wing the Hawaiian specimens are completely matched.

" $(5)$ The tarsus is of the same length in both forms, as shown by the table below. As to robustness and different form, I can only state that I am unable to discover any tangible difference.

"(6) 'There remains only the difference in the colour of the tarsus, which is said to be, in the Hawaiian bird, of 'a decided crimson blush on the front;' while in the American form the tarsus is uniformly 'yellowish green.' I am, however, somewhat doubtful as to the stability and value of this character; for in No. 110026 there is every indication of the tarsus having been green like the toes, and not red like the lower end of the tibia.

"A very careful comparison with numerous American specimens fails to reveal any other differences, except, possibly, a somewhat deeper shade of plumbeous on the lower parts.

"It seems, therefore, that there are no characters upon which to base a specific separation; and were it not that the difference in regard to the color of the tarsus may hold good in the majority of specimens, I should be disinclined to regard the Hawaiian bird as even subspecifically distinct.

"The Gallinule is probably a comparatively recent immigrant to the islands from the American continent, as shown by the very small amount of differentiation, for the 
close resemblance to the original stock can hardly be accounted for by any other supposition.

"Bloxham, in 1826, mentions 'Fulica chloropus' as a Hawaiian bird; but he apparently obtained no specimen. Peale, during the United States Exploring Expedition, obtained a specimen from Oahu, but lost it, and Streets' specimen was from the same island. Dr. Finsch (l.c.), during the summer of 1879 , observed the Gallinule in the lagoons near Waike and Kahalui, Maui, and near Waimanalo (Oahu). Knudsen's specimens show that it also occurs on. Kauai. This completes, so far as I know, the published record of this bird on the islands.

" Mr. Knudsen writes that this species is called by the natives 'Alai ula,' Red Alai, as distinguished from 'Alai keokeo, the coot with the white frontal shield (Fulica alai). He says that the latter also occurs in Kauai.

\section{"Comparative Table of Measurements.}

a. Gallinula sandvicensis.

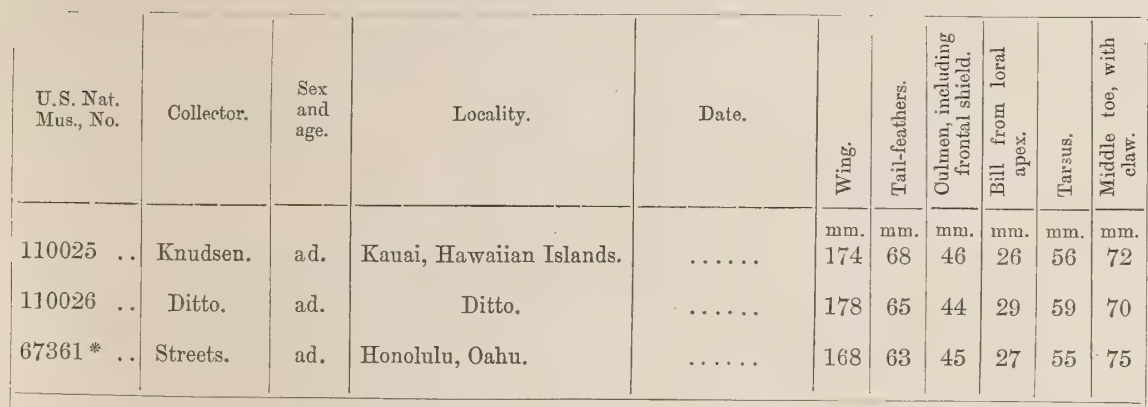

* Type.

\section{b. Gallinula galeata.}

\begin{tabular}{|c|c|c|c|c|c|c|c|c|c|c|}
\hline $80912 \ldots$. & Ober. & o ad. & Montserrat, W. I. & $\ldots \ldots \ldots$ & 169 & 63 & 48 & 27 & 58 & 78 \\
\hline $84683 \ldots$ & Maynard. & $q \mathrm{ad}$. & Florida. & Jan. 3, 1872. & 174 & 70 & 43 & 26 & 55 & 79 \\
\hline 60317 & Latimer. & ad. & Porto Rico, W.I. & & 165 & 63 & 44 & 27 & 53 & 71 \\
\hline 84684 & Nelson. & o jun. & Illinois. & Aug. 25, 1874. & 195 & 83 & 40 & 28 & 56 & $81^{\prime \prime}$ \\
\hline
\end{tabular}

I regret to say that I obtained but a single specimen, shot near Kiholo, on the Island of Hawaii ; while I failed to note the colour of the tarsus, upon which so much stress is laid in the foregoing account. The Alae is common in the swampy taro patches throughout Hawaii, Oahu, Maui, and Kauai, on all of which islands I personally observed it, though I neglected to secure more examples. Mr. Dole, in his 'List,' briefly refers to the derivation of its native name a-lae-burnt foreheadfrom a tradition of the Hawaiians of its being the discoverer of fire. This legend is 
so quaint that I quote a translation of it (I believe from the able pen of the Hon. F. D. Alexander, F.R.G.S.) which appeared some few years back in the "Hawaiian Almanack':-

"Origin of Fire.-Maui and Hina dwelt together, and to them were born four sons, whose names were Maui-mua, Maui-hope, Mani-kiikii, and Maui-o-kalana. These four were fishermen. One morning, just as the edge of the dawn lifted itself up, Maui-mua roused his brethren to go fishing. So they launched their canoe from the beach at Kaupo, on the Island of Maui, where they were dwelling, and proceeded to the fishingground. Having arrived there, they were beginning to fish, when Maui-o-kalana saw the light of a fire on the shore they had left, and said to his elder brethren: 'Behold, there is a fire burning; whose can this fire be'? And they answered, 'Whose indeed! Let us return to the shore that we may get our food cooked; but first let us get some fish.' So, after they had obtained some fish, they turned toward the shore, and when the canoes touched the beach Maui-mua leaped ashore and ran toward the spot where the fire was burning. Now, the curly-tailed Alae (mud-hen) were the keepers of the fire, and when they saw him coming, they scratched the fire out and flew away. Maui-mua was defeated, and returned to the house to his brethren. Then said they to him, 'How about the fire '? 'How, indeed,' he answered; 'when I got there, behold there was no fire, it was out. I supposed some man had the fire, and behold it was not so ; the Alae are the proprietors of the fire, and our bananas are all stolen.'

"When they heard this they were filled with wrath, and decided not to go fishing again, but to wait for the next appearance of the fire. But after many days had passed without their seeing the fire, they went fishing again, and behold, there was the fire! And so they were continually tantalized. Only when they were out fishing would the fire appear, and when they returned they could not find it.

"This was the way of it: The curly-tailed Alae knew that Maui and Hina had only these four sons, and if any of them staid on shore to watch the fire while the others were out in the canoes, the Alae knew it by counting those in the canoes, and would not light the fire. Only when they could count the four men in the canoes would they light the fire. So Maui-mua thought it over, and said to his brethren, 'To-morrow morning do you go fishing, and I will stay ashore. But do you take the tall calabash and dress it in kapa, and put it in my place in the canoe, and then go out to fish.'

"They did so, and when they went out to fish the next morning, the Alae counted and saw the four figures in the canoe, and then they lit the fire and put the bananas on to roast. Before they were fully cooked, one of the Alae cried out, "Our dish is cooked! Behold, Hina has a smart son.' And with that Maui-mua, who had stolen close to them unperceived, leaped forward, seized the curly-tailed Alae, and exclaimed, 'Now I will kill you, you scamp of an Alae! Behold it is you who are keeping the fire from us. I'll be your death for this!' Then answered the Alae, 'If you kill me the secret dies with me, you won't get the fire.' Then Maui-mua began to wring its neck. But the Alae again spoke and said, 'Let me live and you shall have the fire.' 
So Maui-mua said, 'Tell me, where is the fire'? 'The Alae replied, 'It is in the leafstalk of the ape plant.' So, by the direction of the Alae, Maui-mua began to rub the leaf-stalk of the ape with a piece of stick, but the fire would not come. Again he asked, 'Where is the fire '? And the Alae said, 'In the leaf-stalk of the kalo.' And he tried that also without success. And that is the reason why there is a long hollow on the leaf-stalk of the ape and kalo to this day. Again he asked, 'Where is the fire that you are hiding from me'? The Alae answered, 'In a green stick.' And he rubbed a green stick, but got no fire. So it went on, until finally the Alae told him he would find it in a dry stick. And so indeed he did. But Maui-mua, in revenge for the conduct of the Alae, after he had got the fire from the dry stick, said ' Now there is one more thing to try:' and he rubbed the top of the Alae's head till it was red with blood, and the red spot remains there to this day."

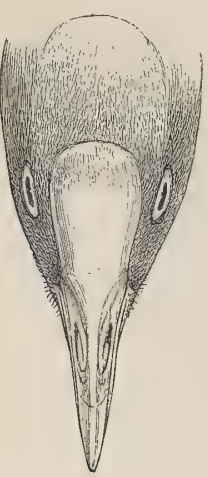

Frontal shield of Gallinula sandvicensis. ('Ibis,' 1877, p. 25.) 




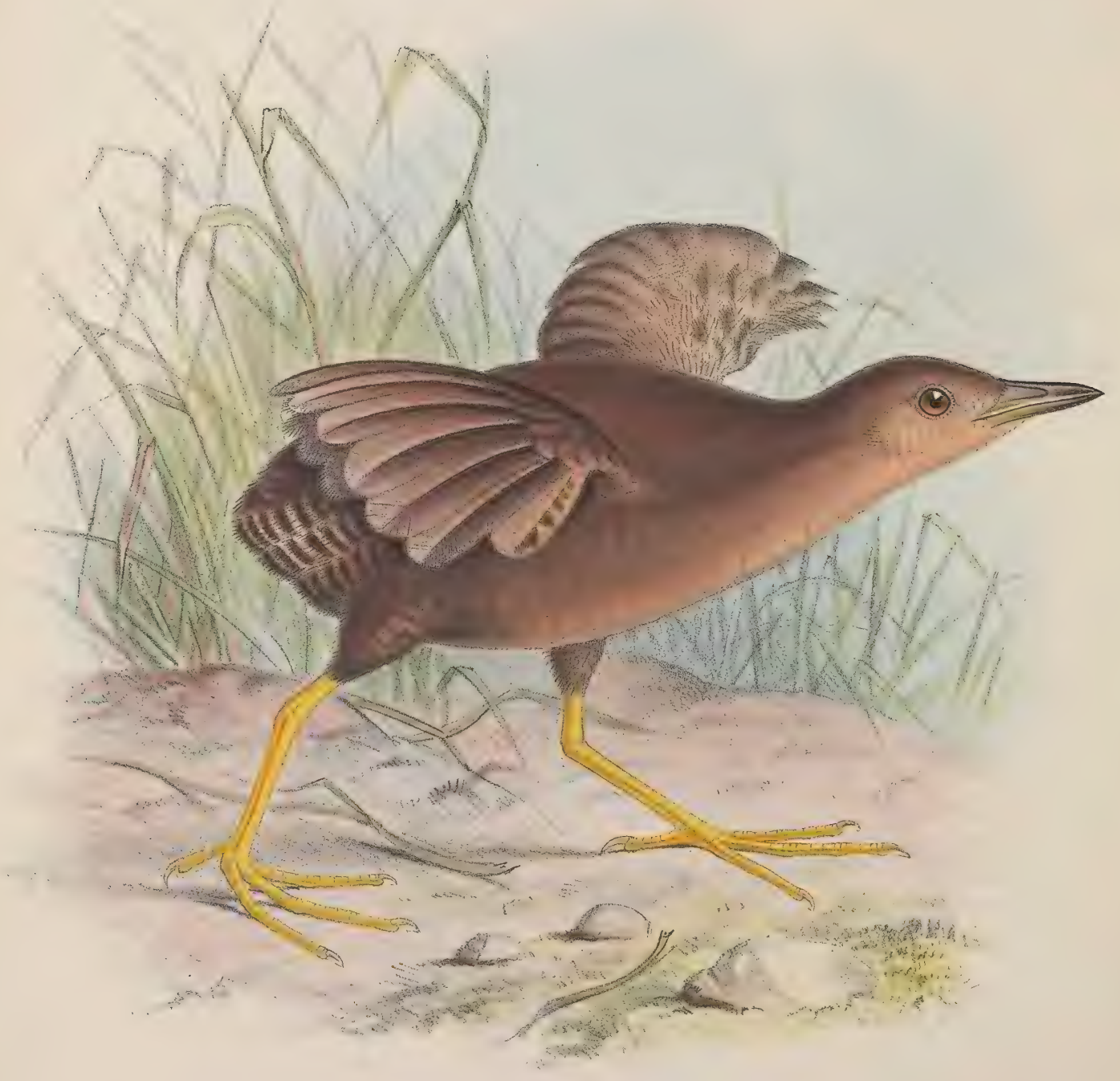




\section{PENNUIFA ECAUDATA.}

\section{MOHO.}

Rallis ecaudatus, James King, Voy. Pacif. Ocean, iii. p. 119 (1784) ; S. B. Wilson, hujus operis, pt. i. art. Acrulocercus nobilis, p. 2, note (December, 1890).

"Dusky Rail," Latham, Synops. iii. p. 237 (1785).

Rallus obscurus, Gmelin, Syst. Nat. i. p. 718 (1788); Latham, Ind. Orn. p. 759 (1790); Donndorff, Orn. Beitr. i. p. 1151 (1794); A. Newton, Proc. Zool. Soc. 1889, p. 5.

Rallus obscurus et R. acaudatus, Tiedemann, Anat. und Naturgesch. Vög. ii. p. 434 (1814).

Corethrura obscura, G. R. Gray, Gen. B. iii. p. 5 (1846).

Porzana obscura, Hartlaub, Arch. f. Naturgesch. 1852, pt. i. p. 137; id. Journ. für Orn. 1854, p. 170.

Ortygometra obscura, G. R. Gray, Cat. B. Trop. Isl. p. 53 (1859).

Ortygometra? sandwichensis (partim), id. tom. cit. p. 52 (1859).

"Wingless bird . . . which the natives call 'Moho," " Pease ( fide J. E. Gray), Proc. Zool. Soc. 1862, p. 145 ( $c f$. Sclater, Ibis, 1880, p. 241).

Ortygometra obscura, Dole, Proc. Boston Soc. N. H. xii. p. 302 (1869); id. Hawaiian Alman. 1879, p. 53.

Pennula millsi (errore typogr. "millei"), Dole, Hawaiian Alman. 1879, p. 54; (reprint) Ibis, 1880, p. 241 ; A. Newton, Proc. Zool. Soc. 1889, p. 5.

Pennula ecaudata, Hartlaub, Abhandl. naturwissensch. Vereins Bremen, xii. p. 396 (1892).

Pennula sandwichensis, Sharpe, Bull. Br. Orn. Club, no. iv. p. xx (21 Dec. 1892) (nec Rallus sandvichensis, Gmel.; cf. Hartlaub, op. cit. no. v. p. xxiv ; Sharpe, op. cit. no. viii. p. xlii).

I тHIN there can be no doubt that the species of which a figure is here for the first time published is that mentioned by Captain James King ${ }^{1}$ (loc. cit.) among the birds met with on Cook's expedition, to the command of which he ultimately succeeded, as a "a rail, with very short wings and no tail, which on that account we named rallus ecaudatus." It seems to be just as certain that this species is also the "Dusky Rail" of Latham (ut suprà), described by him from a specimen in the Leverian Museum, the fate of which I have been unable to trace. On this last was founded, as shown by the synonymy above given, the Rallus obscurus of Gmelin, while the R. ecaudatus of King was wrongly referred by Mr. G. R. Gray to the "Sandwich Rail " of Latham (Synops. iii. p. 236), a wholly different bird. Since the disappearance of Latham's type of the former, it is probable that no example of it had been seen in Europe until the specimen here figured was brought home by me in 1888 . This was exhibited at a meeting of

${ }^{1}$ Of course not to he confounded with the Captain Philip Parker King, who some fifty years later surveyed the coasts of Australia and South America. 
the Zoological Society on the 15th January, 1889 by Professor Newton (ut suprà), who then referred it to Latham's "Dusky Rail," which had not since been recognized, but soon after informed me that he believed it to be identical with the previously designated Rallus ecaudatus of King. I obtained the specimen, which I subsequently presented to the Museum of my University, through the kindness of Mr. Bishop, it being one of five, procured nearly thirty years before by the late Mr. Mills and preserved in his collection, where they were described by Judge Dole (locc. citt.) as belonging to a new species, which in his second paper on Hawaiian ornithology he ascribed to a new genus in the following terms:-

"Pennola millei ". Moho. Not previously described. $6 \frac{1}{2}$ in. long. Bill $\frac{3}{4}$ in. long, black, straight, sides compressed, curved at tip. Tail not visible. Wings rudimentary, hidden in the long, loose, hairy feathers. Plumage dark, dull brown, ashy under the throat; feathers loose, hairy, long. Lower part of tibia naked. Legs long, set far back. Toes 3 front, 1 back. Habitat, uplands of Hawaii. Nearly extinct. Specimen in Mills' Coll.

"I feel confident that this remarkable bird belongs to the Rallido, but am unable to fix its place more definitely. It is the only bird which the natives call Moho, which word is nearly synonymous with the New Zealand word Moa, which is their name for the gigantic wingless bird of that country. Regarding it as a new genus I have taken the liberty of naming as above, gladly thereby recognizing $\mathrm{Mr}$. Mills' valuable services in preserving specimens of this bird, and giving others opportunities of studying it."

Mr. Sclater (loc. cit.), in remarking on the above passages, pointed out that this was the bird "with rudimentary wings" mentioned in a letter from Mr. W. H. Pease, the well-known authority on the conchology of the Hawaiian and other Pacific-Island groups, an extract from which the late Dr. J. E. Gray had communicated to the Zoological Society in 1862 (ut suprà) as follows :- "There is a wingless bird of small size living in the Island of Hawaii, which the natives call 'Moho,' which is now nearly extinct, having been killed off by the wild cats and dogs within late years; I have seen but a single specimen."

Though the bird is not "wingless," Mr. Sclater's identification is doubtless correct, and it is quite likely that Mr. Pease's information may have been based upon one of Mr. Mills's specimens. If so, it may indicate the time about which they were procured, and that, should the species be (as is supposed) really extinct, would be a matter of some interest. The inference would seem to be that at the date of Mr. Pease's letter (20th November, 1861) Mr. Mills possessed only one specimen, and that the other four which I myself saw were obtained subsequently. Two of them have since passed into Mr. Rothschild's collection, and the remaining two are still in that of Mr. Bishop. No further examples have been secured, though it is doubtful whether any extended search has been made. In the month of November 1887 I visited Olaa, where I resided some ten days at 'The Halfway House,' Mr. L. Severance (an old resident

\footnotetext{
${ }^{1}$ A printer's error for millsi.
} 
in Hilo) having told me that in that neighbourhood Mr. Mills had procured the birds. Mr. Severance, moreover, had kindly given me a letter to Hawelu, the landlord of 'The Halfway House'-the man who actually shot the original specimens; this house is halfway between Hilo and the Volcano of Kilauea, and is very finely situated on the outskirts of the forest, commanding a splendid outlook over the sea, while a fine clump of tall Eucalyptus trees close at hand adds greatly to its picturesqueness.

The weather was very wet at the time of my visit; nevertheless I went out shooting every day, and when I visited the forest, Hawelu and other natives, encouraged by the promise of a large reward, scoured the country round for the Moho, but to no purpose. However, owing to the fact of my having no dog, and Hawelu but a poor one, our chances of success were not great; and in my opinion the bird may, nay probably does, still exist on the scrub-covered plains between Olaa and Kilauea. Moreover, Hawelu told me that the mail-carrier had seen the bird cross his path within the last three years; on the same authority, the Moho outruns any dog possessed by the natives, and it is possible to track it by its cry-a whirring sound resembling the rising of a bevy of Quail, while its nest is made on the ground.

The five specimens were all procured by Hawelu in the scrub-covered lava-flats about five miles south of the Volcano House, but more information than this I could not obtain, and my intelligent informant is now a leper on Molokai. The aspect of the region where the Moho was found much resembles a Scotch moor, with a short densely-growing Vaccinium in the place of heather; this is intermingled with a species of Carex and the Ukiuki ${ }^{1}$ (Dianella ensifolia), a bright silver-leaved plant bearing a blue berry-the whole forming the thickest of cover. The only trees in this region are scrubby stunted Ohias, though here and there are thickets of fern interspersed with small bushes.

I may add that the late King Kalakaua was most anxious to procure specimens of the subject of the present notice, and had for some years before my visit offered the natives a large reward for them. Olaa used to be a noted locality in olden times for bird-catching, and his late Majesty, through his Chamberlain, Mr. C. P. Jaukea, gave me a written permission to shoot specimens of the Mamo (Drepanis pacifica) and $\mathrm{O}-\mathrm{o}$ (Acrulocercus nobitis) there, believing that I should meet with both of them as well as the Moho; he afterwards expressed great disappointment at my failing in my object.

Description (taken from the specimen at Cambridge).-Upper parts rufous brown, somewhat lighter upon the forehead, the outer primary being marked with reddish buff on the outer web; sides of the face, chin, and throat whitish; the rest of the underparts rufous or ruddy buff, becoming much browner around the thighs; the feathers, near the vent, which meet beneath the place where the tail should be, with subterminal buff cross-bars. Beak brown; feet now almost white.

${ }^{1}$ MS father has flowered this (since my return) from sceds I brought home. 
The wings have a very thin appearance and are short and rounded, each feather being also rounded at the tip and rather broad; tail absent, its place supplied by the coverts; all the feathers soft and lax.

Dimensions.-Total length about 13 inches, wing 6, tarsus $3 \frac{1}{4}$, middle toe with claw just under 3 , culmen $\cdot 75$. 



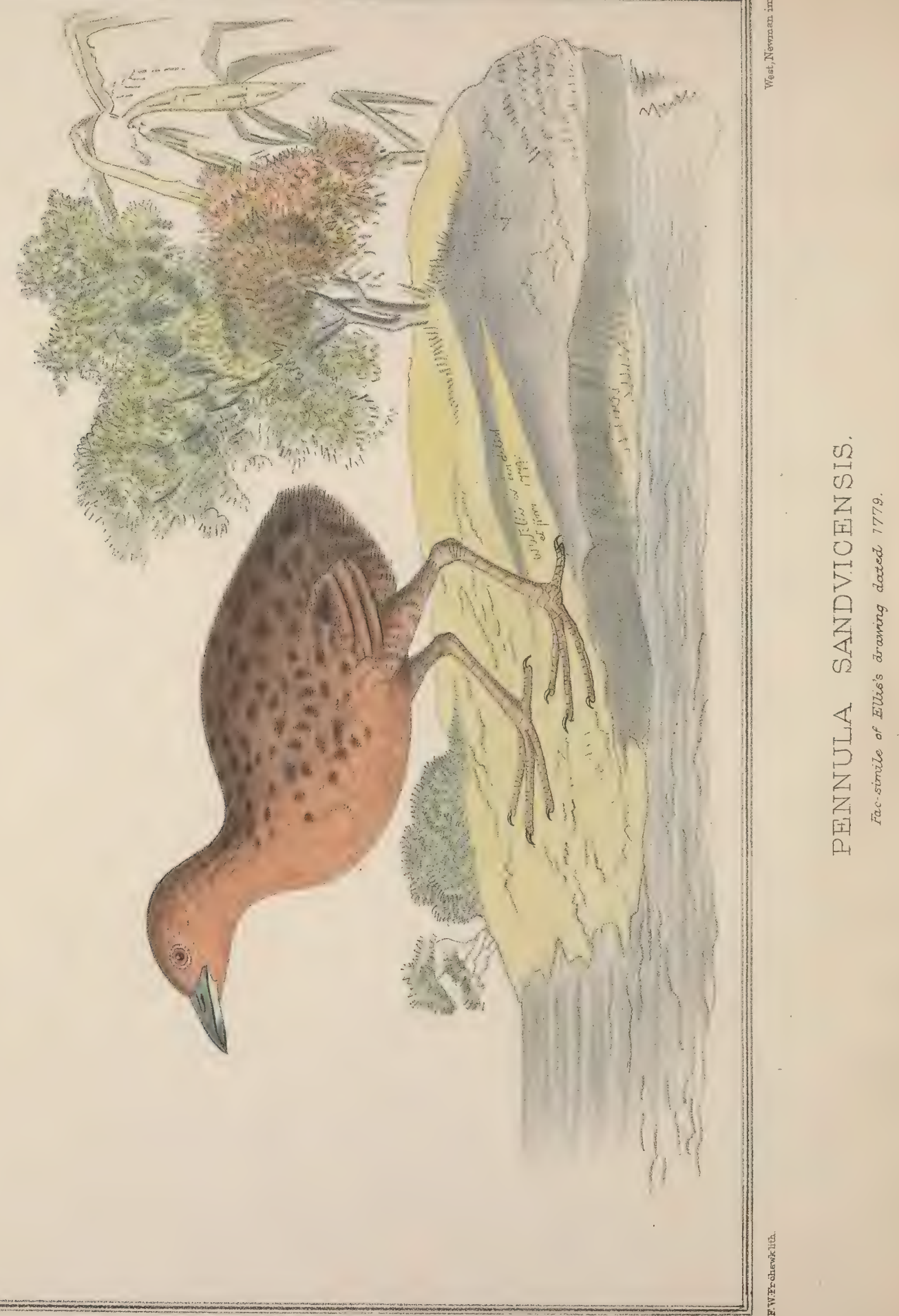





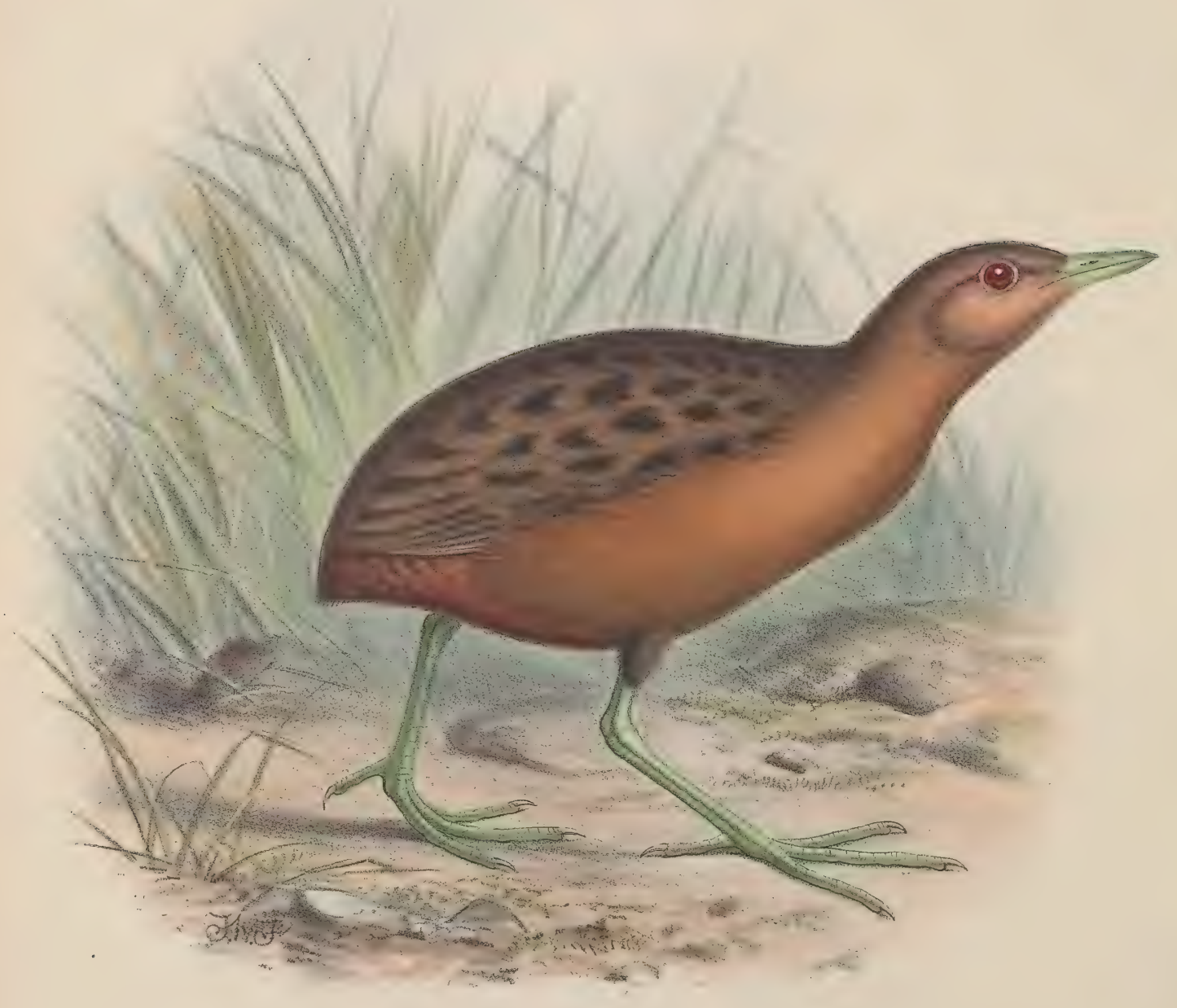

F.W.Frohawh del. et hith

PENNULA WILSONI. 


\section{PENNULA SANDVICENSIS.}

"Sandwich Rail," Latham, Syn. iii. p. 236 (1785).

Rallus sandwichensis, Gmelin, Syst. Nat. i. p. 717 (1788); Tiedemann, Anat. und Naturgesch. Vög. ii. p. 434 (1814); Vieillot, N. Dict. d’Hist. Nat. éd. 2, xxii. p. 564 (1817); id. Tabl. Encyclop., Orn. p. 1069 (1823).

Rallus sanduicensis, Latham, Ind. Orn. p. 759 (1790).

Zapornia sandwichensis, Reichenbach, Handb. sp. Orn., Rasores, tab. cix. figg. 1184, 1185 (1846).

Corethrura sandwichensis, G. R. Gray, Gen. B. iii. p. 595 (1846).

Porzana sandvicensis, Hartlaub, Arch. für Naturgesch. 1852, i. p. 137.

Ortygometra? sandwichensis, G. R. Gray, Cat. B. Trop. Isl. p. 52 (1859) (partim).

Ortygometra sandvicensis, Dole, Proc. Boston Soc. N. H. xii. p. 302 (1869); id. Hawaiian Alman. 1879 , p. 53 (partim) ${ }^{1}$.

Rallus sandvichensis, Hartlaub, Abhandl. naturw. Vereins zu Bremen, xii. p. 397 (1892) (partim).

Pennula ecaudata, Sharpe, Cat. B. Br. Mus. xxiii. p. 114 (partim, sed minime P. sandwichensis, ejusd. tom. cit. p. 336) (1894).

Pennula sandwichensis, Stone, Proc. Acad. N. S. Philad. 1894, p. 147.

ReLing on the statement of Schlegel (Muséum des Pays-Bas, Ralli, pp. 25, 26) that the Leyden Museum possessed a specimen of the Rallus sandwichensis of Gmelin, which had been procured on Cook's voyage, I went to Holland, being anxious to examine the alleged unique example of an extinct species, and to obtain a drawing of it by Mr. Frohawk, who accompanied me for that purpose. Arrived at Leyden we were most kindly received by Dr. Finsch; but it immediately became evident that the specimen did not correspond with the "Sandwich Rail" of Latham, on which Gmelin's name was based, and Dr. Finsch, considering it to belong to an undescribed species, gave shortly after an account of it (Notes from the Leyden Museum, xx. pp. 77-80), and did me the honour of calling it Pennula wilsoni.

No living example of the Sandwich Rail has apparently been met with within human inemory, and it may be safely asserted that no specimen exists in any Museum. I have therefore thought it advisable to give a facsimile copy by Mr. Frohawk of the drawing of it (no. 70) by W. W. Ellis in the British Museum (Natural History). This drawing, it will be seen, is signed by the artist and dated 1779, besides having the words "Sandwich Isles" written on the back, apparently by him. The bird is

1 The description of the species given by Mr. Dole is that of 0 . quadristrigata, copied from Finsch and Hartlaub (Orn. Centralpolynesiens, p. 165). 
obviously a Penmula, and its colouring fairly corresponds with Latham's description of it, which is as follows:-

"Size small. Bill dusky ash-colour; general colour of the plumage pale ferruginous; the feathers on the upper parts darkest in the middle; tail short, hid by the upper coverts; legs dusky flesh-colour.

"Inhabits Sandwich Isles. Was also found on the island of Tanna; but the plumage is darker on the upper parts; and the bill and legs yellorvish.-Sir Joseph Banks."

Latham was no doubt in error when he imagined that a bird like this could also inhabit 'Tanna, which is one of the New Hebrides, and, indeed, Mr. Wiglesworth (Aves Polyn. p. 61) identifies the latter with Ortygometra cinerea (Vieillot).

Where Reichenbach saw the specimens which he professes to figure it is impossible to say. They do not now exist in the Dresden Museum, as we are obligingly informed by Professor A. B. Meyer. Indeed, the whole ornithological collection there was burnt in the disturbances of 1849 .

\section{PENNULA WILSONI.}

Mr. Frohark having executed a plate from Schlegel's wrongly-called "Crex sandwichensis," I here present an impression of it to my readers, together with extracts from Dr. Finsch's remarks upon the species, which they will perceive has no claim as yet to be included in the 'Aves Hawaiienses,' nor can the Leyden specimen possibly be the type of Latham's species as asserted by Dr. Sharpe.

"On the so-called 'Sandwich Rail' in the Leyden Museum. By Dr. O. Finscrr.

"Crex sandwichensis, Schleg. (nec Rallus sandwichensis, Gml.), Mus. P.-B., Ralli, 1865, p. 25.

"Rallus sandwichensis, Hartl. (nec Gml.), Abhandl. naturw. Vereins in Bremen, xii. (1892), p. 397 (syn. part.) ; Sharpe, Ibis, 1893, p. 443.

"Pennula sandwichensis, Sharpe, Cat. B. Brit. Mus. xxiii. (1894), p. 336 (syn. part.).

\section{"Pennula wilsoni, Finsch.}

"Schlegel's type in the Leyden Museum:

"Upper parts dark ruddy brown with blackish centres to the feathers of the back and wings, producing on these parts well marked blackish longitudinal stripes; head and neck somewhat lighter and uniform ruddy brown, like the sides of head and neck; underparts uniform rusty brown, shading into vinous red, a little darker on the flanks; middle of chin somewhat lighter; anal region and lower tail-coverts dark vinous-red, forming a well marked darker patch; primaries blackish, very narrowly margined with brown on the outer web; broad and lax upper tail-coverts with very narrow light rusty-brown apical margins, showing as lighter undulations.--Bill and feet light hornybrown (as far as can be judged greenish in life).-Sex and Habitat unknown. 


\section{"Measurements taken from the above type:}

\begin{tabular}{|c|c|c|c|c|c|c|c|}
\hline & $\begin{array}{l}\text { Total length. } \\
150 \mathrm{~mm} .\end{array}$ & $\begin{array}{l}\text { Wing. } \\
73 \mathrm{~mm} \text {. }\end{array}$ & $\begin{array}{l}\text { Culmen. } \\
19 \mathrm{~mm} \text {. }\end{array}$ & $\begin{array}{l}\text { Tarsus. } \\
30 \mathrm{~mm} .\end{array}$ & $\begin{array}{l}\text { Tibia. } \\
7 \mathrm{~mm} .\end{array}$ & $\begin{array}{l}\text { Middle toe with claw. } \\
\qquad 35 \mathrm{~mm} .\end{array}$ & Finsch. \\
\hline $\begin{array}{c}\text { (French) } \\
=\end{array}$ & in mill. & $\begin{array}{l}3.2 \text { inch. } \\
85 \mathrm{~mm} .\end{array}$ & $\begin{array}{l}10 \text { lin. } \\
23 \mathrm{~mm} .\end{array}$ & $\begin{array}{l}12 \mathrm{lin} . \\
27 \mathrm{~mm} .\end{array}$ & $\begin{array}{l}4 \mathrm{lin} . \\
11 \mathrm{~mm} .\end{array}$ & $\begin{array}{l}13 \text { lin. } \\
30 \mathrm{~mm} .\end{array}$ & Schlegel ${ }^{1}$. \\
\hline $\begin{array}{c}\text { (English) } \\
=\end{array}$ & $\begin{array}{l}150 \mathrm{~mm} . \\
5.3 \mathrm{inch} . \\
135 \mathrm{~mm} .\end{array}$ & $\begin{array}{l}73 \mathrm{~mm} \text {. } \\
2.8 \mathrm{inch} \text {. } \\
68 \mathrm{~mm} .\end{array}$ & $\begin{array}{l}20 \mathrm{~mm} . \\
08 \mathrm{lin} . \\
19 \mathrm{~mm} .\end{array}$ & $\begin{array}{l}29 \mathrm{~mm} \text {. } \\
1.3 \text { inch. } \\
34 \mathrm{~mm} \text {. }\end{array}$ & & $\begin{array}{l}34 \mathrm{~mm} . \\
1.35 \mathrm{inch} \text {. } \\
37 \mathrm{~mm} .\end{array}$ & $\begin{array}{l}\text { Hartlaub. } \\
\text { Sharpe. }\end{array}$ \\
\hline
\end{tabular}

"The wing is round; the primaries nearly hidden under the long and soft coverts; the first primary is $40 \mathrm{~mm}$. long and $15 \mathrm{~mm}$. shorter than the $3 \mathrm{rd}$ and 4 th, which are the longest, though only a little longer: than the $2 \mathrm{nd}$ and 5 th; the exact number of primaries is difficult to ascertain without injuring the specimen. For the same reason I am able to find only two tail-feathers (dark-coloured, soft, narrow, and $20 \mathrm{~mm}$. long), as they are hidden under the extremely thick, long, and soft upper tail-coverts, and are difficult to distinguish from the latter. So this species may be called 'ecaudatus' as truly as Pennula ecaudata, King, and, as seen by the structure of the wings, is no doubt a flightless form. The feet are feeble; the nails short and small.

"'The type specimen in the Leyden Museum is stuffed and not too well; the stuffing, however, is apparently not of very old date, as may be judged from the artificial eyes (with red irides), which seem to be of enamelled glass, or-at any rate-of a kind which was unknown in the beginning of this century. The wire used for stuffing is of brass, as commonly used by the taxidermists of the Leyden Museum.

"On the underside of the stand of the specimen is written, undoubtedly by the hand of Temminck, 'Rallus-Latham,' and perhaps also by Temminck 'Rall. obscura'; to this is added 'Crex sandwichensis, Cat. No. 1,' no doubt written by Schlegel, as possibly also are the words 'Sandwich. Cook.' In the 'Catalogue of the Ralli' Schlegel says unhesitatingly 'observé dans les îles Sandwich; voyage de Cook,' but this statement does not seem to rest on any reliable foundation, for there does not exist any notice when and from whom Temminck acquired the specimen! This fact must be mentioned, as Dr. Hartlaub assures us that Temminck bought this Rail at the auction of Bullock's collection ( 3 June, 1819) for $£ 115 s$, which may have been the case; but it cannot be proved that it was the specimen in question.

"Latham's 'Dusky Rail' (Rallus obscurus, Gml.), said to come also from the Sandwich Islands, is, according to his description, a quite different and much larger bird ('legs two inches' $=50 \mathrm{~mm}$.; 'legs red-brown'; 'bill scarcely one inch '-our specimen has the bill only $7 \frac{1}{2}$ lines long!), and is most likely not a 'Pennula' at all. Evidently Latham would have mentioned the rudimentary tail ${ }^{2}$, as he did not overlook this prominent character in the description of his 'Sandwich Rail.' The type of

\footnotetext{
1 "The measurements of the wings and culmen given here are not exact."

2 "The identity with Pennula ecaudata (King) seems therefore rather doubtful, as already mentioned by Dr. Hartlaub."
} 
Latham's 'Dusky Rail' was in the Leverian Museum, but unfortunately appears to have been also lost.

"Schlegel's 'Crex sandwichensis' is only known from the specimen in the Leyden Museum and is no doubt one of the rarest of birds, being most certainly not the same as 'Rallus sandwichensis' or 'Rallus obscurus' of Gmelin; it must therefore be renamed. I have the pleasure to name it after Mr. Scott B. Wilson ${ }^{1}$, to whom science is so highly indebted, and whom we have to thank for figuring this rare type through the skill of Mr. Frohawk.

"Although not referable at present to the Avifauna of the Hawaiian Islands, and probably one of the species 'nearly or quite extinct,' perhaps we still may hope for the rediscovery of Pennula wilsoni in one of the neighbouring small islands as yet unsatisfactorily explored."

"Leyden Museum, February 1898."

1 "This gentleman, in company of the artist, came over from England only for describing and figuring the bird in question." 



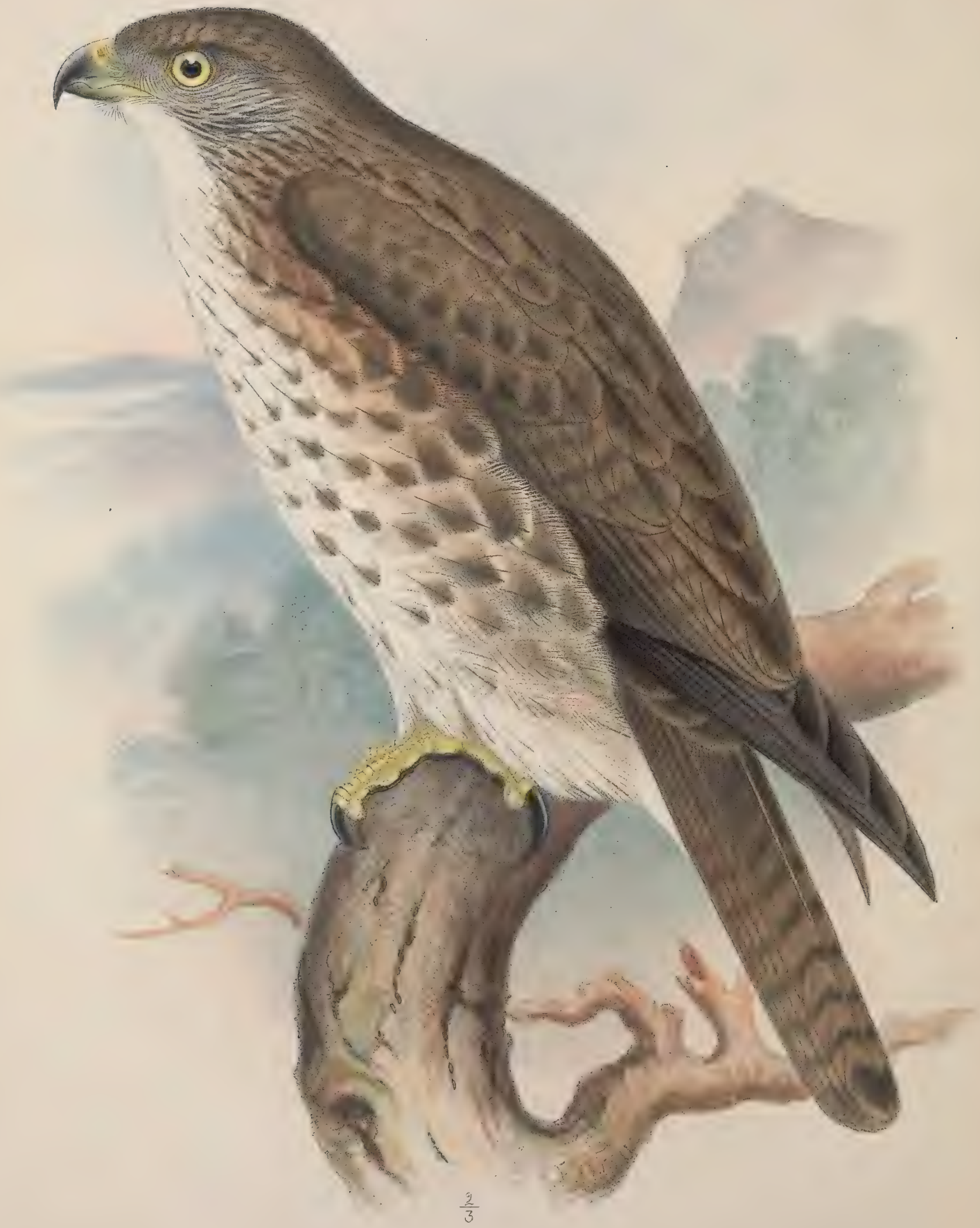





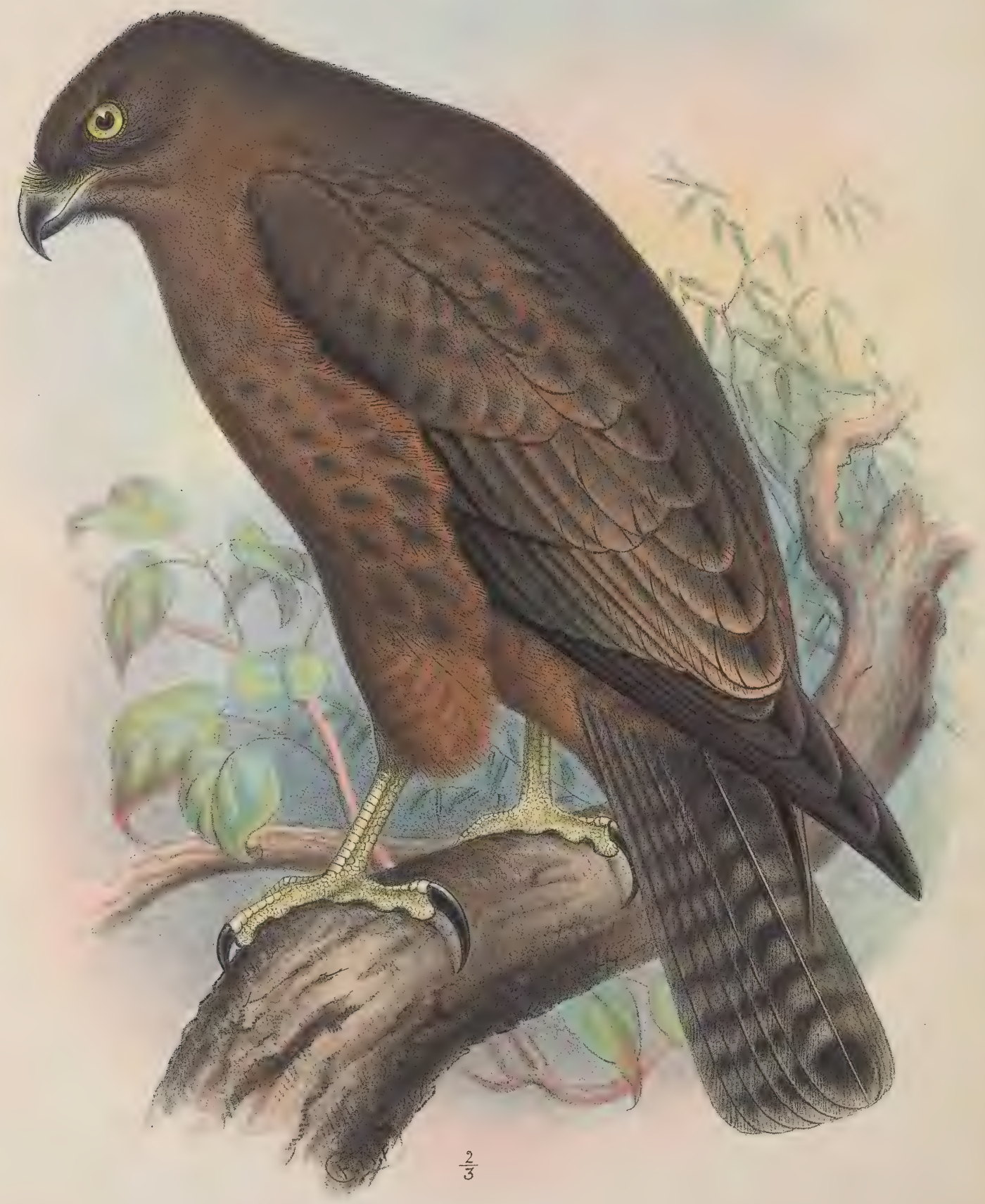





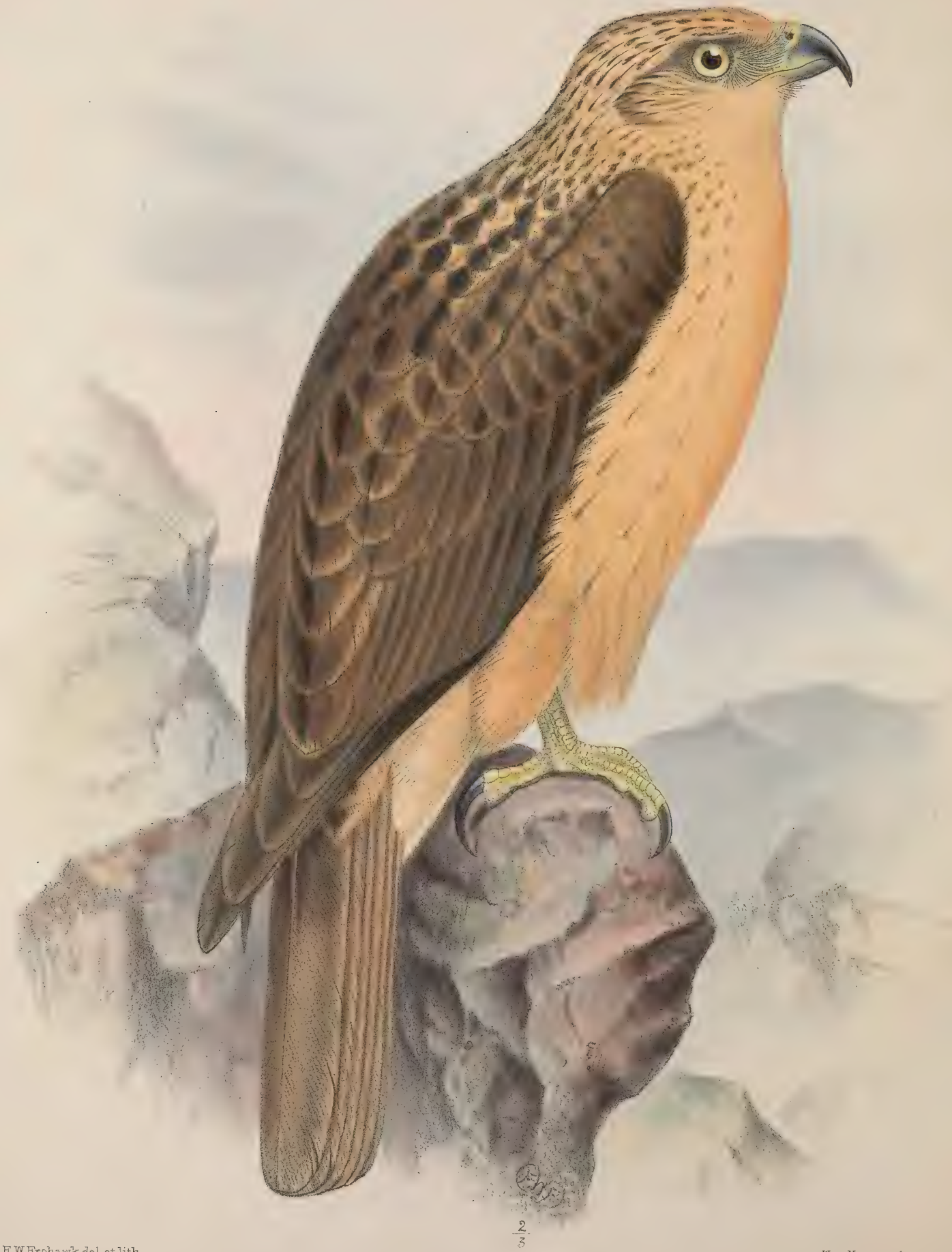




\section{BUTEO SOLITARIUS。}

IO.

"Brown Hawks or Kites," Cook, [Last] Voy. Pacif. Ocean, ii. p. 227 (1784).

Buteo solitarius, Peale, U.S. Expl. Exped., Birds, p. 62, pl. xvi.* (1848); Hartlaub, Arch. f. Naturgesch. 1852, i. p. 131 ; Sclater, Proc. Zool. Soc. 1878, p. 348; id. Ibis, 1879, p. 92 ; id. Rep. Voy. 'Challenger,' Birds, p. 96, pl. xxi.* (1881); Gurney, List Diurn. B. Prey, p. 64. (1884). Pandion solitarius, Cassin, U.S. Expl. Exped., Mamm. \& Orn. p. 97, pl. iv.* (1858); Dole, Proc. Bost. Soc. N. H. 1869, p. 295 ; id. Hawaiian Alman. 1879; p. 42.

Pandion (Polioaetus) solitarius, G. R. Gray, Cat. B. Trop. Isl. p. 1 (1859) ; id. Hand-list, i. p. 15 (1869).

Onychotes gruberi, Ridgway, Proc. Acad. N. S. Philad. 1870, p. 149; id. Rep. U.S. Geol. \& Geogr. Surv. 1876, p. 135; Baird, Brewer, \& Ridgway, Hist. N. Amer. B. iii. p. 254 (1874) ; Sharpe, Cat. B. Br. Mus. i. p. 158 (1874); Gurney, Ibis, 1876, p. 476 ; id. op. cit. 1881, p. 396 pl. xii.*; id. List Diurn. B. Prey, p. 71 (1884).

Polioaetus solitarius, Sharpe, Cat. B. Br. Mus. i. p. 452 (1874).

Onychotes solitnrius, Ridgway, Proc. U.S. Nat. Mus. 1885, p. 38.

Buteo (Onychotes) solitarius, Gurney, Ibis, 1891, p. 21 (posthum.).

* Figura notabiles.

WHEN Captain Cook discovered the Sandwich Islands on his last voyage, "Brown Hawks or Kites" are said to have been observed, though apparently no specimen of them was then procured; they were therefore not brought to the notice of scientific men until Peale returned from the U.S. Exploring Expedition in the 'Vincennes' and 'Peacock.' He only observed the bird on the island of Hawaii, but he gives a brief account of its habit of sitting " solitary on dead trees patiently watching small birds, which constitute its principal food." No examples were contained in the collection of the Expedition, most of the birds from Hawaii being lost in the wreck of the 'Peacock'; but Peale described and figured as Buteo solitarius a specimen of which he says it was "obtained near Karakakoa Bay by the Rev. Mr. Forbes, Presbyterian missionary on that station; he transmitted it to Mr. J. K. Townsend, who kindly loaned it to be drawn." Judge Dole, however, in the 'Proceedings of the Boston Society' for 1869, states that this species is not confined to Hawaii, but is found also on Niihau and Molokai. Though Cassin, in 1858, by some misconception referred it to the genus Pandion, and as late as $1870 \mathrm{Mr}$. Ridgway redescribed it in one of its phases under the title of Onychotes gruberi, these errors were not allowed to remain long uncorrected; while the late Mr. Gurney's notes written for this work effectually settle the whole question. 
This is the only member of the Hawk tribe peculiar to the Hawaiian group, and, so far as I absolutely know, it is confined to the large island of Hawaii. The first example I obtained in the forest of Kona, at an elevation of about 5000 feet, in June 1887. The bird was perched motionless in a mamáne tree (Sophora chrysophylla) and seemed to be on the watch for its prey-consisting of the brilliant-plumaged Iiwi (Vestiaria coccinea) or some other small forest bird. I have found in the stomach, in two instances, remains of Vestiaria, so the fact that this Buzzard feeds at least occasionally on small birds is clearly proved. On the $23 \mathrm{rd}$ of June, 1888, I was so fortunate as to find in the same locality a nest of this species, containing a single young bird in the down; it was placed in a koa tree (Acacia koa) about 50 feet from the ground, in a fork between two thick branches, and was a large structure of nearly circular form, being a foot and a half deep, and a foot in diameter, composed of dead koa branches and twigs. I subsequently obtained several more specimens in Kona, and others in the hills above Puuiki near Waimea. The bird does not seem to be confined to a single district of the island as is the case with the Crow (Corvus hawaiiensis), but it must at the same time be considered rare, as during a long stay on Hawaii I procured but seven examples. The naturalists of the 'Challenger' Expedition in 1875 secured two near Hilo; while there are two others in the Mills collection from the same neighbourhood. All the specimens preserved have therefore been obtained on the island of Hawaii, though certainly the koa forests in the district of Kula, on the island of Maui, seem eminently suited to this species; but I did not make a stay of sufficient duration on that island to be able to say whether it is found there, though I heard reports from natives of a large Hawk to be found " in the mountains," which was probably this bird. Judge Dole, as above cited, narrates an incident which occurred to his brother, Mr. G. H. Dole, on the island of Kauai, relating to a Hawk which I imagine to have been of this species, which surmise, if correct, proves that it is to be found on Kauai. It is true that Judge Dole puts the story under the heading of Accipiter hawaii, which is Circus hudsonius, but I do not think it is likely that it was that bird. The incident was as follows :- "Mr. G. H. Dole while riding one day in Koloa, Island of Kauai, accompanied by a Scotch terrier, noticed one of these birds and was led by his peculiar movements to watch him carefully. The bird appeared much disturbed by the presence of the dog, and after circling about him a few times flew to a pile of stones and took one in his claws and flew back with it to his old position over the dog and balanced himself in the air as if intending to drop it on to the dog's back, but after some apparent hesitation he gave up whatever he was intending to accomplish with the stone, and carrying it back, he placed it on the pile whence he had taken it."

There are three distinct phases of this species, differing strikingly from one another in regard to coloration, as my series of specimens shows, and therefore $I$ have thought it well to have a figure drawn of each. Three of my examples, which were acquired by the late Mr. Gurney, are now to be seen in the Norwich Museum, and four others in that of the University of Cambridge; and Mr. Gurney, in response to a 
rcquest of mine that he would send me some notes upon them, was kind enough to furnish me with the following for publication in this work ${ }^{1}$.

\section{"Notes on Buteo (Onychotes) solitarius.}

"Buteo solitarius of Peale was originally described under that name in the first edition of the Zoology of the United States Exploring Expedition (Birds, p. 62), published in 1848, from a specimen obtained near Karakakua Bay, in the island of Hawaii, by the Rev. Mr. Forbes, and sent by him to Dr. J. K. Townsend, who presented it to the collection of the Academy of Natural Sciences of Philadelphia.

"In the second edition of the above work, edited by the late Mr. Cassin, and published in 1858 , this specimen was described at p. 97 , and figured on pl. 4 of the accompanying atlas. In the letterpress of this article the specimen is stated to be 'adult,' but the accompanying plate shows it to be in the paler stage of plumage, which appears to me to be indicative of immaturity.

"Mr. Cassin inserted this specimen in his work under the title of 'Pandion solitarius," but in $187 \pm$ it was again (and certainly more correctly) referred to the genus Buteo in Messrs. Baird, Brewer, and Ridgway's 'History of North-A merican Land-Birds,' vol. iii. p. 255; and Mr. Ridgway's views as to the Buteonine character of the species were quoted by me in 'I'he Ibis,' 1876, p. 231. 'The preceding page of the same volume of the 'North-American Birds' contained a description and woodcut of a melanistic specimen of the same species under the name of 'Onychotes gruberi,' by which it had previously been described by $\mathrm{Mr}_{\mathrm{r}}$. Ridgway in the 'Proceedings' of the Philadelphia Academy of Sciences for December 1870, p. 149.

"It was only at a later period that, through the acute discrimination of $\mathrm{Mr}$. Ridgway, the identity of Onychotes gruberi with Buteo solitarius was demonstrated, the specimen originally described under the former name having been sent to the Smithsonian Institution from San Francisco, and having been supposed (as it is now thought, erroneously) to have been obtained in California.

"The Smithsonian Institution subsequently obtained an additional specimen in the plumage which I now consider to be the normal adult dress, but without any reliable information as to the locality where it was originally obtained. Both the above specimens were described by Mr. Ridgway under the name of Onychotes gruberi in his 'Studies of American Falconidæ,' published in 1876, p. 13j, and they were referred to by myself under the same title in 'The Ibis' for 1876 , p. 476 , and for 1881 , p. 396, the latter notice being accompanied by coloured figures (on pl. 12) of both the specimens in question.

"H.M.S. 'Challenger' visited the island of Hawaii in August 1875, and brought home amongst other specimens two examples of Buteo solitarius. One of these was for a time accidentally mislaid, but the other, a normal adult female, was recorded in

\footnotetext{
1 The younger Mr. Gurney finding the draught of this treatise among his father's papers, and not knowing the purpose for which it had been intended, forwarded it for publication to the Editor of 'The Ibis,' in which journal it was accordingly printed (Ibis, 1891, pp. 21 et seqq.).
} 
a paper on the collection of birds brought home by the 'Challenger,' contributed by Mr. P. L. Sclater to the 'Proceedings' of the Zool. Soc. for 1878, which included a description of this specimen drawn up by myself, and subsequently reprinted in the Official Scientific Report of the Voyage of the 'Challenger,' Zoology, vol. ii. pt. 8, p. 96. ' This description was in both cases rendered inaccurate by an unfortunate printer's error, owing to which the occiput and hinder part of the neck were misprinted as being 'white-coloured' instead of 'whole-coloured;' this error was, however, rendered less important by an accurate coloured figure of the specimen, which formed plate 21 of the ornithological volume of the 'Challenger's' Report. The missing specimen subsequently came to light, and proved not to be very different in plumage to the female which had been figured, though probably a somewhat younger bird. This specimen was described by me at p. 141 of my ' List of Diurnal Birds of Prey,' published in 1884.

"Both the specimens brought home by the 'Challenger' are now preserved in the British Museum.

"The figure of Buteo solitarius published in the Report of the 'Challenger' Expedition struck Mr. Ridgway as so closely resembling the second example of Onychotes gruberi which had been acquired by the Smithsonian Institution that he was led to a further investigation of the subject, which resulted in his being convinced that these two names had in fact been assigned to one and the same species.

"Mr. Ridgway published the conclusion at which he arrived, and the data which led to it, in the 'Proceedings' of the United States National Museum for 1885, p. 36.

"'The Editors of 'The Ibis,' at p. 450 of the volume for 1885, announced and accepted the conclusion at which Mr. Ridgway had arrived, and as to the correctness of which there can, I think, be no possible doubt.

"Mr. Ridgway, in his paper above referred to, expresses the opinion that " the genus or subge:us Onychotes . . . . is tenable' for the present species, and gives a diagnosis in support of that view; but my own feeling is that the Hawaiian Buzzard does not differ sufficiently from other members of the genus Buteo to make it needful to refer it to a distinct subgenus. It is of very similar dimensions to Buteo pennsylvanicus, and their proportions, though different, do not differ very greatly, as may be seen by the annexed comparative measurenents (in inches and decimals) of an adult of each of these two species; but I ought to add that I believe the sexes of the specimens measured are different, $B$. solitarius being probably a male, and $B$. pennsylvanicus a female.

\begin{tabular}{|c|c|c|c|c|c|c|c|c|c|}
\hline & Cere. & $\begin{array}{c}\text { Culmen } \\
\text { without } \\
\text { cere. }\end{array}$ & Wing. & Tail. & Tarsus. & $\begin{array}{c}\text { Middle toe } \\
\text { without } \\
\text { claw. }\end{array}$ & $\begin{array}{c}\text { Claw of } \\
\text { middle } \\
\text { toe. }\end{array}$ & $\begin{array}{c}\text { Hind toe } \\
\text { without } \\
\text { claw. }\end{array}$ & $\begin{array}{c}\text { Claw o } \\
\text { hind } \\
\text { toe. }\end{array}$ \\
\hline & $\cdot 3$ & $\cdot 95$ & 10.75 & 6.20 & $2 \cdot \varepsilon$ & $1 \cdot 70$ & $\cdot 80$ & $\cdot 70$ & $1 \cdot 30$ \\
\hline & .25 & .75 & $11 \cdot 30$ & 6.40 & 2.50 & $1 * 35$ & .65 & .70 & $1 \cdot 10$ \\
\hline
\end{tabular}

"If I am correct in my view as to the normal immature and adult plumages of Buteo solitarius, the following list will enumerate the specimens now existing in different English and American collections so far as I am acquainted with them:- 
"Nestling in down.

"One specimen collected by and in the possession of Mr. Scott B. Wilson "

"First year's plwmage (normal).

"Type specimen of Buteo solitarius in the collection of the Academy of Natural Sciences of Philadelphia, figured in the second edition of the Zoology of the United States Exploring Expedition, Ornithology, pl. 4.

"One obtained by Mr. Wilson, and placed in the Norwich Museum.

"One retained in Mr. Wilson's collection" ${ }^{\text {. }}$

"Adult or nearly adult plumage (normal).

"One in the United States National Museum, Washington, figured in 'The Ibis,' 1881 , p. 396 (right-hand figure), under the name of Onychotes gruberi.

"'Two in the British Museum, brought home by the 'Challenger,' one of which is figured in the Zoology of the Voyage of H.M.S. 'Challenger,' Birds, pl. 21.

"One obtained by Mr. Wilson, and placed in the Norwich Museum.

"One retained in Mr. Wilson's collection ".

"Melanistic specimens.

"Type of Onychotes gruberi in the United States National Museum, Washington, figured at p. 254 of vol. iii. of Baird, Brewer, and Ridgway's 'North-American LandBirds,' also in 'The Ibis,' 1881, p. 396 (left-hand figure).

"One obtained by Mr. Wilson, and placed in the Norwich Museum.

"One retained in Mr. Wilson's collection ".

"Summary of specimens referred to.

In Philadelphian Museum ................. 1

In Washington Museum ..................... 2

In British Museum ........................ 2

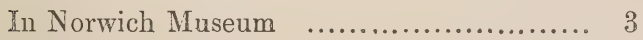

In Mr. Wilson's collection ${ }^{1}$.................. 4

Total ................. 12"

Description.-(Fig. 1.) Adult male. Above dark brownish black, the feathers all more or less edged with rusty brown; wing-quills darker, with white on inner webs of primaries; tail bluish black above, narrowly but very distinctly barred with dark brown; beneath, throat white, rest of the under surface white variously mottled with brown. Legs light yellow, bill black.

Dimensions.-(Fig. 1.) Total length $15 \cdot 70$ inches, wing 11 , culmen $1 \cdot 30$, tarsus 3 , tail $6: 60$.

Obs. This bird was shot at the nest.

${ }^{2}$ Now in the Museum of the University of Cambridge. 
(Fig. 2.) This specimen is of nearly the same colour above as fig. 1, but has no white on the under surface, which is brown edged with dark rusty brown, approaching rusty red on tibiæ and abdomen.

Total length 15 inches, wing $10 \cdot 90$, tarsus 3 , tail $6 \cdot 25$.

(Fig. 3.) This very light variety has the head buff with a few dark streaks of brown, while the rest of the under surface is also buff with a few faint streaks of brown on the sides. The tail is light brownish white, very indistinctly barred.

Total length $15 \cdot 50$ inches, wing $11 \cdot 20$, tarsus 3 , tail $6 \cdot 30$. 


\section{CIRCUS HUDSONIUS.}

Falco hudsonius, Linnæus, Syst. Nat. ed. 12, i. p. 128 (1766).

? Strix delicatula, Dole, Proc. Bost. Soc. N. H. 1869, p. 295 ; Sclater, Ibis, 1871, p. 358 (nec Gould).

Accipiter hawaii, Dole, Hawaiian Alman. 1879, p. 43 ; Ibis, 1880, p. 241.

Circus cyaneus hudsonius, auctt. American. recentiorr.

THIs Harrier, possibly a mere straggler to the Sandwich Islands, is undoubtedly identical with that so abundant in North America, and had it not been that Judge Dole in the 'Hawaiian Almanack' renamed it Accipiter hawaii, no certain synonyms would exist so far as our group is concerned. The mistake is the more important as it was reproduced in 'The Ibis' for 1880 .

Of the subject of our notice I obtained a single specimen in November 1888-on the morning of my final departure from the Islands-which had been shot near Honolulu, while Judge Dole was also kind enough to present me with a skin obtained by a friend of his some years since during a shooting expedition to one of the mountain ranges of Oahu. Though I made several excursions on that island and camped out for a considerable time in a particularly favourable locality, I did not meet with the bird. The natives have no name for it-Io (Buteo solitarius) being the only species of Hawk recognized by them; and such being the case, I am of opinion that it is confined, as far as the Sandwich Islands are concerned, to $\mathrm{Oahu}$, an island which has never been famed for its bird-catchers, and where, therefore, it would be more likely to have been overlooked by the residents. Even there it may be of comparatively recent introduction and so may not as yet have spread to the other islands of the group.

The habits of this species, so well known in North America as the "Marsh Hawk," require no notice here. It is recorded as occurring all over that continent to the Isthmus of Panama, as well as in Cuba and in the Bahamas; but the present is the first publication of the fact that its range extends to the Sandwich Islands. 



\section{,}




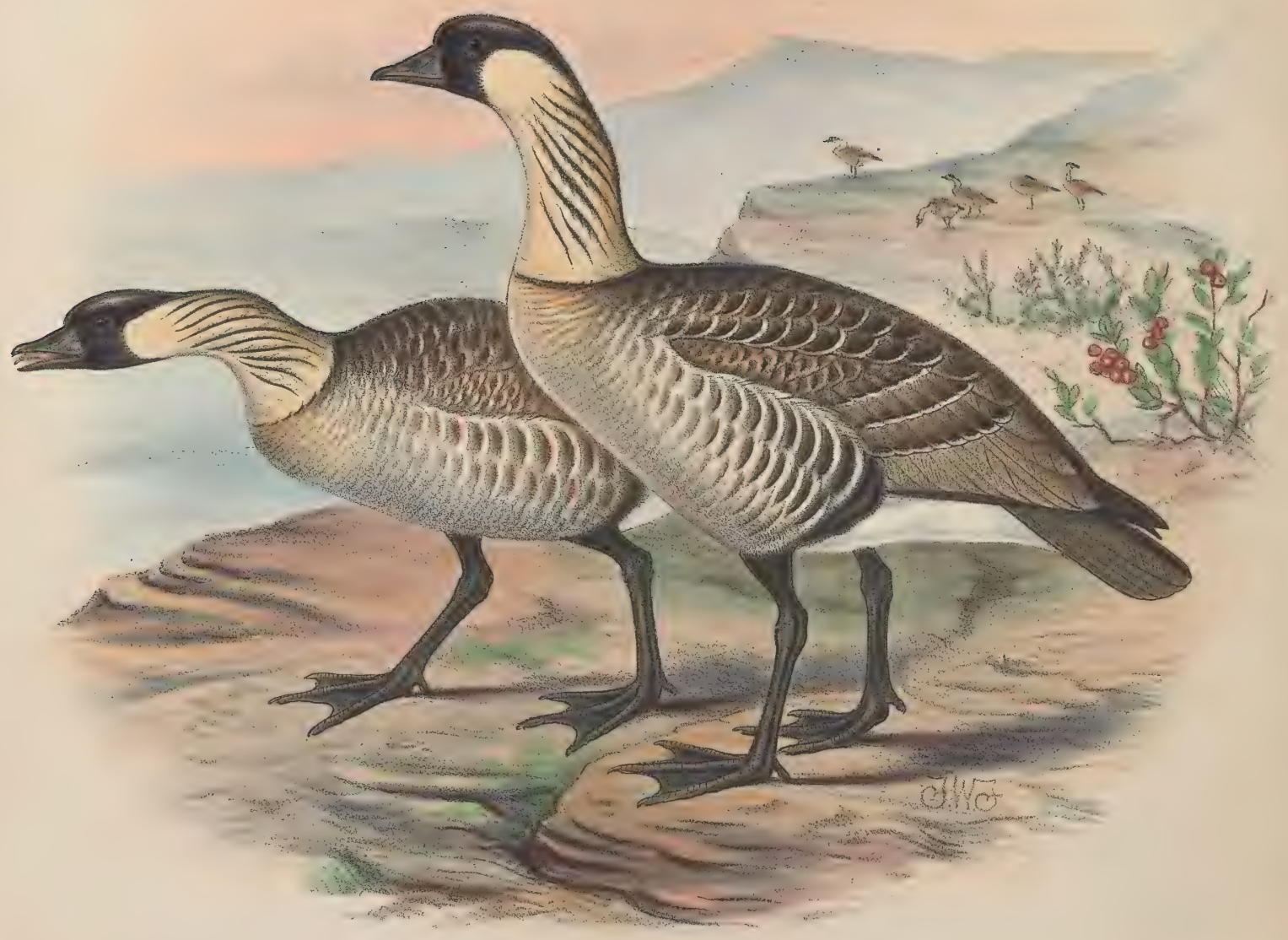




\title{
B ERNICLA SANDVICENSIS.
}

\author{
NENE.
}

" Geese . . . not unlike the Chinese Geese," Ellis, Narrat. Voy. ii. p. 143 (1782).

Anser sandvicensis, Vigors, Iist of Anim. in the Gardens of the Zool. Soc. ed. 11, p. 4 (for June 1833).

Bernicla sandvicensis, Vigors, Proc. Zool. Soc. 1833, p. 65; id. op. cit. 1834, p. 43; Stanley, tom. cit. p. 4]; Jardine and Selby, Illust. Orn. ser. 2, pl. viii.* [no pagination]; Hartlaub, Arch. f. Naturgesch. 1852, i. p. 137 ; Dole, Proc. Bost. Soc. N. H. xii. p. 305 (1869); id. Hawaiian Alman. 1879, p. 54; Pelzeln, Verh. z.-b. Gesellsch. Wien, 1873, p. 159.

Anser hawaiiensis, Eydoux \& Souleyet, Voy. 'Bonite,' Zool, i. p. 104, pl. 10 * (1841).

Anser hauaïnsis, Peale, U.S. Expl. Exped., Birds, p. 249, pl. lix.* (1848).

Anser hawaiensis, Hartlaub, Arch. f. Naturgesch. 1852, i. p. 122.

Bernicla sandwichensis, Cassin, U.S. Expl. Exped., Mamm. \& Orn. p. 338 (1858) ; G. R. Gray, Cat. B. Trop. Isl. p. 54 (1859).

Branta (Leucopareia) sandwichensis, G. R. Gray, Hand-1. B. iii. p. 76 (1871).

* Figurce notabiles.

VIGors, as cited above, was apparently the first author to give a specific name to the Sandwich Island Goose, a pair of which were presented to the Zoological Society of London by Lady Glengall in 1833 ; but the birds had been noticed before that time both by Ellis and Bloxam. The former author writes:- "Upon our first arrival at Karacacooah Bay, the natives brought off several Geese, which were quite tame; they were not unlike the Chinese Geese ; they called them Na-na." To this account Latham also refers, as noted below ${ }^{1}$, under the account of Anser cygnoides. Bloxam merely mentions "wild geese and ducks of a small size" during the voyage of the "Blonde," and did not apparently obtain specimens; but Eydoux and Souleyet, while cruising in the 'Bonite,' were more successful, and, thinking that they had made a new discovery, figured it and named it Anser hawaiiensis. Peale, who repeatedly observed the bird, also called it after the island on which he found it, in ignorance of the previous accounts; but Cassin, when editing that author's work, seems to have been aware of the prior claims of $A$. sandvicensis. Herr Kraus, as stated by von Pelzeln, also noticed it during the Austrian Mission to Eastern Asia and America in 1870.

An interesting account is given by the then Lord Stanley, in the 'Proceedings' of the Zoological Society of London for 1834, of the breeding of some of these birds at

1 Cf. Latham, Gen. Syn. iii. p. 448 ; id. Gen. Hist. B. x. p. 238. 
Knowsley, which were received at about the same time as Lady Glengali's, four eggs being laid and three young birds hatched.

The figure given by Jardine and Selby was taken from an example in Lord Derby's possession.

This Goose shows extreme docility in captivity, instances of which I adduce below. Judge Dole states that it builds its nest in grass on the high lava-fields (5000-7000 feet), and lays two or three white eggs, about the size of those of the Common Goose.

This interesting species, almost entirely confined as it is to one district of the island of Hawaii, is clearly doomed to extinction before many years are past. At present, however, it exists in fair numbers in Kona on Hawaii, where its favourite breedinghaunts are, strangely enough, the old lava-flows, than which nothing more unsuited to a goose can be imagined. I heard that it nested in the crater of Haleakala, on Maui, but I did not visit that place. A pair bred near Kiholo, and a native who saw the place assured me there was little or no nest. Dr. O. Finsch (Ibis, 1880, p. 81) says :"Just as unsuccessful was our trip to the spot where Bernicla sandvicensis breeds in the gigantic crater of Haleakala, as, on account of the exhausted condition of our horses, we could not get into the crater, but were forced to be satisfied with a look into it - a sight never to be forgotten." It has been observed occasionally on Kauai and Niihau, on neither of which, however, does it breed.

In July 1887 I forwarded a pair to England, where they were deposited in the Gardens of the Zoological Society, and were kept for some three years in perfect health in company with another of the same species. My birds did not breed, to my great disappointment; but Mr. A. D. Bartlett assures me that some years ago he was successful in rearing a considerable number, while my friend Judge R. F. Bickerton was equally fortunate in Honolulu. The Nene, in June and July, is to be found at an elevation of some 5000 feet, showing a preference for the clinker-beds of the old lava-flows, and its food consists principally of fruits of plants, such as the ohelo ${ }^{1}$

\footnotetext{
${ }^{1}$ Peale, as quoted by Cassin, says :- " We observed them on the voleanie mountains of the Island of Hawaii; they were generally in pairs at the season of our visit in the month of Norember, rarely four or five were seen together feeding on the berries of a very abundant species of Vaccinium growing on the old beds of lava; on these they became very fat, and were delicious eating; grass appeared, however, to be their ordinary food. We never saw them near water, which is scarce in those regions, our party being obliged to carry the necessary supply for the journey in calabashes; but they are said to breed near shallow ponds, some few such occurring between the mountains. What is most remarkable is the story related to us by natives, and which we have every reason to believe is a fact, that this Goose, which has the powers of flight which would cnable it to move to as great distances as any others of the genus, is limited to the single Island of Hawaii; rarely visiting any other islands of the group, although several are in sight. It bears confinement well, is hardy, and soon becomes domesticated. Its voice resembles that of the Snow Goose, Anser hyperboreus."

Cassin (U.S. Expl. Exped., Mamm. \& Orn. p. 339) says that "Dr. Pickering, in his Journal, now in our possession, mentions having seen this Goose in the mountains, especially numerous at a height which he estimates as having been about seven thousand feet above the level of the sea. He states that it appeared to be much less suspicious than other species with which he was aequainted, and when disturbed, flies off, near the surface of the ground, without rising in the air, like the species of North America. Dr. Pickering mentions having seen this bird feeding on berries."
} 
(Vaccinium reticulatum), the strawberry (Fragaria chiliensis), and a black berry called by the natives "popolo": possibly Sonchus asper, as given by $\mathrm{Mr}$. Dole, may be also a food-plant of this goose. The weird cry of the Nene, according to Peale resembling that of the Snow Goose (A. hyperboreus), is very distinct from that of any other species that I know; and in olden times the bird was kept in captivity by the natives, acting as a sentinel by giving loud warning of the advent of a stranger. It is easy of approach, and $I$ am told that when one of a flock is wounded the remainder will not leave their companion, so that the collector, if heartless enough, may kill the entire number.

As an instance of its tameness and attachment, I may mention a bird which would follow its mistress for a distance of fifteen miles; and this not once, but on many occasions-indeed, it was in the habit of accompanying her on her rides as a dog would do.

The flesh of this goose is good eating ', and from it may be made the most excellent soup, which I remember to have formed the most delicious item amongst many other delicacies-as roasted goat, golden plover on toast, quail, bananas, bread-fruit, pineapples, custard apples, mangos - of my Christmas dinner at Kiholo on Hawaii.

One point remaining to be noticed is the peculiar sweet musky scent found in the neck of the Nene-a fact well known to Hawaiians, but not, I believe, recorded in print hitherto. My birds in the Zoological Society's Gardens were caught one day for my friend Captain F. H. Salvin's inspection ; and that gentleman confirms the statement made above.

Description.-Adult male. Head, neck, and throat black, which colour extends a little below the eye and for about two inches down the back of the neck; sides of neck tawny buff, becoming lighter towards the lower part, the feathers blackish at their bases, giving the neck a peculiarly mottled appearance ; breast and belly pale greyish brown, feathers darker on flanks, barred with umber, and almost white at the tips; abdomen and under tail-coverts pure white; upper surface dark umber, the feathers variously barred with brown; rump and tail dusky black. Irides dark hazel; bill and feet black.

Adult female. The black extending further down the throat and occupying a greater space below the eye; feathers on flanks paler than in the adult male; lower breast not so pale, but uniform in colour with the flanks.

The young male is similar in colour to the adult fernale.

Dimensions.-Total length $22 \cdot 50$ inches, wing from carpal joint $16 \cdot 30$, culmen $1 \cdot 6$, tarsus $2 \cdot 80$, tail $6 \cdot 75$.

${ }^{1}$ In 'Pearls of the Pacific,' the author, Mr. J. W. Boddam-Whetham, agrees with me; for he says (p. 100):- "On returning to the house I found a very tempting repast ready, and amongst other luxuries was a strawberry-fed goose, which had been enveloped in leaves and baked in a hole in the earth." This was during his stay at the Yolcano House at Kilauea on Hawaii. 



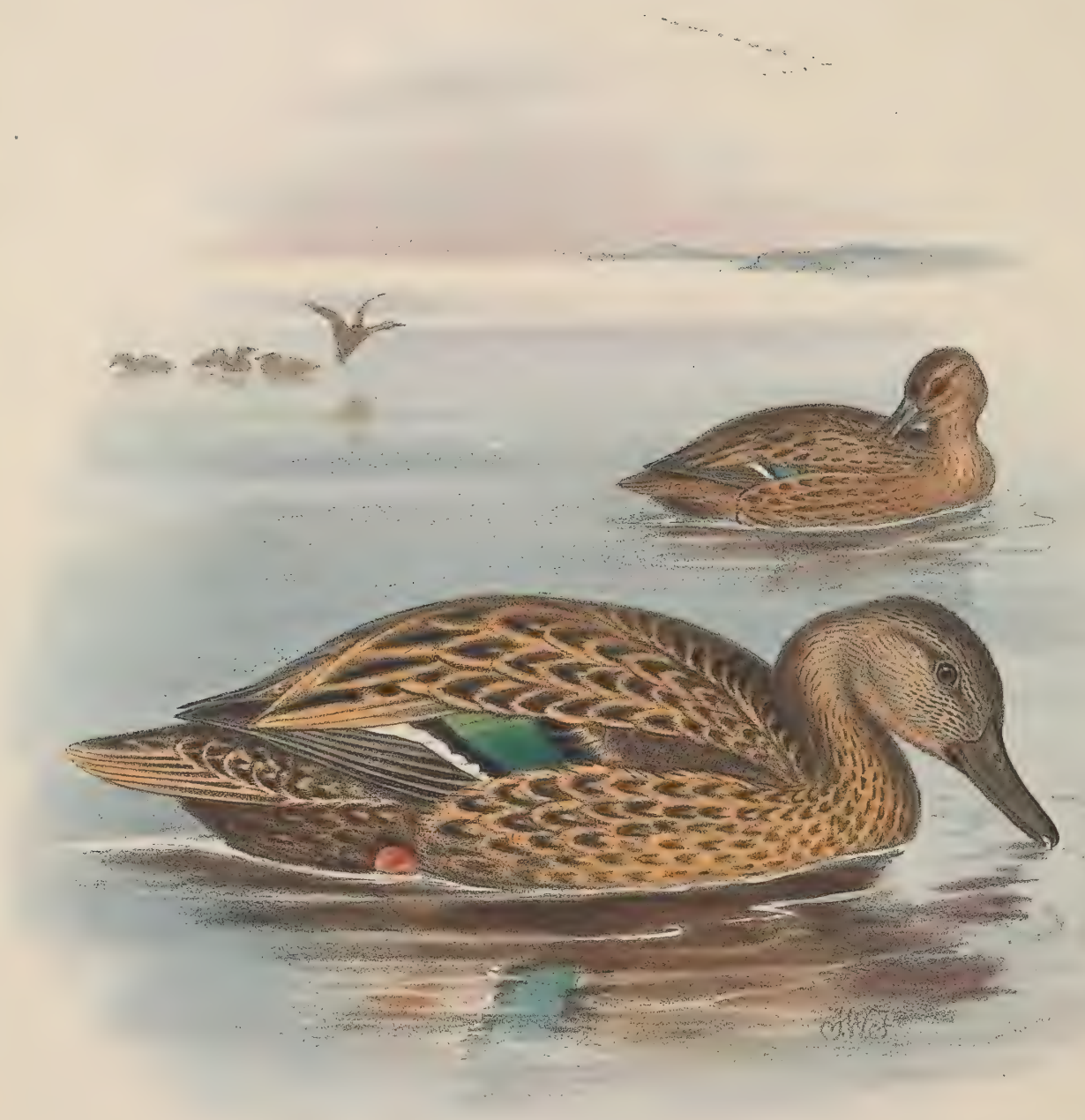


\title{
ANAS WYVILLIANA.
}

\author{
KOLOA MAOLI.
}

Anas superciliosa, var. a, sandwichensis, Bonaparte, Comptes Rendus, xliii. p. 649 (1856).

Anas superciliosa, var., G. R. Gray, Cat. B. Trop. Isl. p. 54 (pariim) (1859).

Anas boschas?" (Mus. Berol.) Oahu," Hartlaub, Arch. f. Naturgesch. 1852, i. p. 137 ; Cassin, Proc. Acad. Philad. 1862, p. 322.

Anas superciliosa, Dole, Proc. Bost. Soc. N. H. xii. p. 305 (1869); id. Hawaiian Alman. 1879, p. 55 (nec Gmelin).

Anas wyvilliana, Sclater, Proc. Zool. Soc. 1878, p. 350 ; id. Voy. 'Challenger,' Birds, p. 98

pl. xxii.* (1881) ; Ridgway, Proc. U.S. Nat. Mus. 1878, p. 251 ; Finsch, Tbis, 1880, p. 79 ;

Stejneger, Proc. U.S. Nat. Mus. 1888, p. 98.

? Anas superciliosa et boschas, Hartlaub \& Finsch, Beitr. Faun. Polynes. p. xxxix (1867).

* Figura notabilis.

DoubTLESS it will be the opinion of some ornithologists that this bird should be denominated Anas sandvicensis, in accordance with the subspecific name bestowed in 1856 by Bonaparte; but as that author seems to have considered it a mere variety of A. superciliosa, and gives no description, I follow Dr. Sclater in calling it A. wyvilliana, a name based upon two examples obtained in 1875 at Hilo, in Hawaii, during the voyage of the 'Challenger.' There is no longer any doubt of its specific distinctness from either $A$. superciliosa or $A$. boscas, though its superficial resemblance to the former and to the female of the latter has no doubt been the cause of its being often passed over. It will be seen, however, in the article on Bernicla sandvicensis, that Bloxam noticed "ducks" when at the Sandwich Islands ; while the specimens from "Oahu" mentioned by Hartlaub were no doubt obtained by Deppe, and Cassin records the fact that Stimpson noticed " $A$. boschas" during the United States North Pacific Surveying and Exploring Expedition in 1856. Dr. Stejneger, as above cited, considers our species very closely related to $A$. aberti, Ridgw., of N.W. Mexico; but it rather resembles $A$. obscura.

I shot specimens in November near Waialua, on the island of Oahu, and observed others on the island of Hawaii near Hilo; while Mr. W. H. Purvis told me he used to kill them at small ponds which occur in the forest near Kukuihaele, in the district of Hamakua. Dr. O. Finsch remarks ("Ibis,' 1880, p. 79):-_Of the latter (Anas wyvilliana, Sclater) I saw flocks in the swamps near Waimanalo (Oahu)." Dr. Stejneger also received four specimens, obtained by Mr. Knudsen on Kauai, of which he gives an exhaustive account (Proc. U.S. Nat. Mus. 1888, p. 99). Judge Dole's statement that it inhabits the whole group is therefore probably correct. 
My specimens agree in measurements with those of Dr. Sclater, except that the total length is about $2 \frac{1}{2}$ inches more and the wing rather shorter.

Diagnosis of the male (translated from that of Dr. Sclater).-Above black, the feathers bordered with dusky; crown black, minutely dotted with dusky; beneath pale dusky, ratker redder on throat and breast, more ochraceous on belly, feathers dotted and blotched with black; wings exteriorly brownish grey; speculum broad, purple, enhanced by a white edge above and below, followed by black; axillaries white; beak black above, flesh-coloured below; feet orange. Total length 15.0 inches, of wing 9.3 , of tail $3 \cdot 0$, of beak from gape $2 \cdot 0$, its breadth under the nostril $0 \cdot 7$, length of tarsus $1 \cdot 5$.

Mr. Ridgway describes the female at length in the 'Proceedings of the United States National Museum" for 1878; but as he considers it "to differ but little in coloration" from the male, it is not necessary to reproduce his account here. It may be added that the " $A$. freycineti, Bp.", of Gray's 'Hand-list,' which Mr. Ridgway thought might possibly be $A$. wyvilliana, is, according to the original describer, an European species. 


\section{DAFILA ACUTA.}

KOLOA MAPU.

Anas acuta, Linnæus, Syst. Nat. ed. 12, i. p. 202 (1766); Schlegel, Cat. Mus. P.-B. Anseres, p. 38 (1866).

Dafila caudacuta, Stephens (Shaw), Zool. xii. pt. 1, p. 127 (1824).

Dafila acuta, Cassin, U.S. Expl. Exped., Mamm. \& Orn. p. 341 (1858) ; Sclater \& Salvin, Ibis, 1859, p. 231 ; iid. Proc. Zool. Soc. 1876, p. 391 ; Baird, Brewer, \& Ridgway, Water-B. N. Am. i. p. 511 (1884); Stejneger, Bull. U.S. Nat. Mus. no. 29, p. 153 (1885); id. Proc. U.S. Nat. Mus. 1887, p. 136.

[The above references are almost limited to the appearance of this well-known Holarctic species in the countries bordering on the North-Pacific Ocean.]

THe well-known Pintail Duck is only a winter visitor to the Sandwich Islands, in this respect resembling the Shoveller. The first record of its occurrence there is that by Dr. Stejneger, in the 'Proceedings of the United States National Museum' for 1888, a male having been procured for him in Kauai by Mr. Knudsen, who gave its native name as "Koloa mapu." I also observed several on the sea-coast near Kiholo, in Hawaii, in the month of December. Drs. Townsend and Pickering are stated by Cassin to have noticed it in Oregon; but no specimens were brought home by the United States Exploring Expedition.

According to Messrs. Sclater and Salvin, the furthest locality to the southward in which the bird has been observed is the Isthmus of Panama, where McLeannan found it. Northwards its distribution is, of course, general throughout the Arctic Regions; while it has been found in California, and commonly during winter in Guatemala, Cuba, and Jamaica. As regards the other side of the Pacific, Messrs. Dresser and Sharpe, in their 'Birds of Europe,' record it from the whole of Siberia to Japan and China. 



\title{
SPATULA CLYPEATA.
}

\author{
KOLOA MOHA ${ }^{1}$.
}

Anas clypeata, Linnæus, Syst. Nat. ed. 12, i. p. 200 (1766) ; Schlegel, Cat. Mus. P.-B. Anseres, p. 34 (1866) ; Dole, Proc. Bost. Soc. N. H. xii. p. 305 (1869) ; id. Haw. Alman. 1879, p. 55. Spatula clypeata, Boie, Isis, 1822, p. 564; Sclater \& Salvin, Ibis, 1859, p. 231; iid. Proc. Zool. Soc. 1876, p. 396 ; Lawrence, Mem. Bost. Scc. N. H. ii. p. 314 (1874); Peale, U.S. Exp]. Exped., Birds, p. 251 (1818) ; Cassin, U.S. Expl. Exped., Mamm. \& Orn. p. 343 (1858) ; G. R. Gray, Cat. B. Trop. Isl. p. 55 (1859); Gould, Handb. B. Austral. ii. p. 370 (1865); Baird, Brewer, \& Ridgway, Water-B. N. Am. p. 526 (1884) ; Stejneger, Bull. U.S. Nat. Mus. no. 29, p. 159 (1885) ; id. Proc. U.S. Nat. Mus. 1887, p. 137.

Rhynchaspis clypeata, Hartlaub, Arch. f. Naturgesch. xviii. Heft 1, p. 136 (1852).

[Nearly all the above references indicate the occurrence of this widely-ranging Holarctic species on the shores or islands of the Pacific Ocean only.]

I OBSERVED this species in some brackish lagoons on the sea-coast near Kiawaiiki, in Hawaii, during December 1887, but failed to procure specimens. Peale, in his account of the United States Exploring Expedition, says:- "Good specimens of this beautiful Duck were obtained at the islands of Hawaii and Oahu; they appear to be identical with the Americans, and in this respect are worthy of attention, as but few of the birds found on that group of islands have analogues on either of the shores of the Pacific Ocean opposite to them."

Dr. Stejneger, in the 'Proceedings of the United States National Museum' for 1888, records a male specimen received through Mr. Knudsen from Kauai in winter plumage, apparently a bird of the year; and on the authority of that gentleman gives the native name as "Koloa moha." He remarks that at that season it seems a comparatively common bird.

The Shoveller ranges throughout the Arctic Regions, and thence to Australia; and Mr. Gould's account in his 'Handbook' of the birds of that country may be found interesting. He says:- "When I visited New South Wales during the rainy season of 1839 , all the depressed parts of the land were filled with water, and the lagoons here, there, and everywhere were tenanted by hundreds of Ducks of various species, and every now and then one, two, or more beautifully plumaged Shovellers were seen among them; but I did not succeed in shooting one of them, and must have left the

1 Mr. Dole gives the native name as "Moha," and proceeds to say:- " They spend the winter months at the Islands, and migrate in the spring to the North-west coast of America, returning late in the fall. Frequent fresh water." 
matter in doubt as to the particular species, if the late Mr. Coxen, of Yarrundi, had not had the skin of a splendid old male in his possession, which he had himself shot, and which, after a careful examination, I found to be identical with the Spatula clypeata of Britain and the European continent."

Messrs. Sclater and Salvin, as cited above, state that the bird is common in winter on the Lake of Dueñas, in Guatemala, occurring also in Cuba, Jamaica, and Mexico; while Messrs. Dresser and Sharpe, in their 'Birds of Europe,' trace it from the northwest of Asia to Ceylon, China, and Japan. 


\section{PLEGADIS GUARAUNA.}

Scolopax guarauna, Linnæus, S. N. ed. 12, i. p. 242 (1766).

Plegadis guarauna, Ridgway, Proc. U.S. Nat. Mus. i. p. 163 (1878) ; id. Water-B. N. Am. i. p. 97 (1884); Stejneger, Proc. U.S. Nat. Mus. 1887, p. 84.

[The list of references to this American species might, of course, be easily extended.]

A single immature bird was sent by Mr. Knudsen from Kauai in 1872, which Mr. Ridgway referred somewhat doubtfully to this species of Glossy Ibis. It appears to be a mere straggler to the Sandwich Islands, as it does not appear to have been observed by anyone else. 


\section{ARDEA SACRA.}

\section{AUKU,}

"Sacred Heron," Latham, Gen. Synops. iii. p. 92 ; "Blue Heron," var. B, id. tom. cit. p. 78.

? Ardea cerulea, var. $\gamma$, Gmelin, Syst. Nat. i. p. 631 (1788).

Ardea sacra, Gmelin, Syst. Nat. i. p. 640 (1788) ; Finsch \& Hartlaub, Orn. Centralpolyn. p. 201

(1867) ; Dole, Proc. Boston Soc. N. H. 1869, p. 303 (partim); id. Hawaiian Alman. 1879, p. 52 (partim) ; Finsch, Ibis, 1880, p. 79 (partim).

Ardea (Herodias) sacra, G. R. Gray, Cat. B. Trop. Isl. p. 48 (1859).

Demiegretta sacra, Wiglesworth, Aves Polyn, p. 67 (1891); Sharpe, Cat. B. Br. Mus. xxvi. p. 137 (1898).

[This list of references could, of course, easily be extended.]

EvIDENCE as to the occurrence in the Sandwich Islands of this widely ranging species rests only on the observations of $\mathrm{Mr}$. Dole and Dr. Finsch ${ }^{1}$, each of whom records the appearance of a white Heron, which may very likely have been an example of the white form of Ardea sacra, though neither of them obtained a specimen, and it is pretty clear that the others named by them were Night-Herons (Nycticorax)-the only species of the family Ardeidce there commonly met with. None of the more recent ornithological explorers (not even Mr. Perkins, who passed so long a time in the islands) observed or much less procured an example which could have belonged to either the blue or the white form of Ardea sacra, and we know from specimens which that gentleman obtained that the young of Nycticorax griseus are not white, but have the same plumage there as elsewhere.

That Ardea sacra should occasionally stray to the Sandwich group is quite probable, since it appears on almost every cluster of islands in the Pacific Ocean; but it is certain that Mr. Dole's information as to its being "common all over the group," and laying "two eggs, which are mottled," must be incorrect, while the fine specimen shot near Honolulu, and described by him from memory, was doubtless an adult Nycticorax. Dr. Finsch's evidence is simply: "The white form I observed once at Kahalui."

Description.-Adult male and female. "Saturate cinereo-cærulescens, abdomine subfuscescente, linea a mento per mediam gulam decurrente lata nivea; cristæ, tergi et

1 It is true that Mr. G. R. Gray (loc. cit.) assigned the Sandwich Islands as a locality for this species, and even gave "Otoo" (probably an old way of writing $A u k u$ ) as the native name it there bore, but on what authority he made either statement is unknown. 
pectoris plumis elongatis, apice ligulatis; rostro supra fusco, infra et apice flavescente; pedibu flavidis; iride flavo.

"Jun. Tota alba." (Finsish \& Hartlaub.)

Dimensions.—“Long. c. $17 \frac{11}{2}$; rostr. $3^{\prime \prime} 2^{\prime \prime \prime}$; al. $10 \frac{11}{2}$; caud. $4 \frac{11}{2}$; tars. $2^{\prime \prime} 5^{\prime \prime \prime "}$ (Finsch \& Hartlaub). 


\title{
NYCTICORAX GRISEUS.
}

\author{
AUKU KOHILI.
}

Arden nycticorax, Linn. Syst. Nat. ed. 12, i. p. 235 (1766) ; A. grisea, id. tom. cit. p. 239.

Ardea nœvia, Boddaert, Tabl. Pl. Enl. p. 56.

Ardea exilis, Peale, U.S. Expl. Exped. p. 216 (1848) ; Dole, Proc. Boston Soc. N. H. 1869, p. 303;

id. Haw. Alman. 1879, p. 53 (nec Gmelin).

Botaurus exilis, Cassin, U.S. Expl. Exped. p. 300 (1858) (ex Peale, nec Gmelin).

Ardea sacra, Dole, Proc. Boston Soc. N. H. 1869, p. 303 (partim) ; id. Haw. Alman. 1879, p. 52

(partim); Finsch, Ibis, 1880 , p. 79 (partim) (nec Gmel.).

Nycticorax nycticorax navius, Stejneger, Proc. U.S. Nat. Mus. 1887, p. 84; 1888, p. 102.

Nycticorax griseus, Wiglesworth, Aves Polyn. p. 69 (1891).

Nycticorax nycticorax, Sharpe, Cat. B. Br. Mus. xxvi. p. 146 (1898).

[Except with regard to a few cases, the above citations refer to the Sandwich Islands, or at least to the Pacific Ocean.]

Dr. Stejneger was the first to determine the Night-Heron as a bird of these islands, though it had doubtless been seen there previously by Mr. Dole and Dr. Finsch-the former of whom described what must have been an adult of this species under the name of Ardea sacra, while he referred other specimens (as the above synonymy will shew) to $A$. exilis - a species which there is no reason to believe occurs in the group ${ }^{1}$. Dr. Stejneger was at first troubled with doubts as to whether the specimens sent to him by Mr. Knudsen from Kauai belonged to the New or Old World form of Nycticorax, and finally came to the conclusion that they agreed in every respect with American examples. Fortunately these doubts need not trouble us, since it is now generally allowed that no specific distinction between the two alleged forms can be maintained.

I observed many individuals in the neighbourhood of Waikiki, in Oahu, during my visit to the islands in 1887, while I obtained some immature specimens on Kauai; but I never met with an instance of this species breeding. Mr. Perkins, however, says that the bird is very abundant throughout the islands, at fish-ponds near the sea, on mud-flats, and on mountain streams. It breeds together in numbers at low elevations on the mountains, generally on kukui trees.

Description.-Adult male and female. Crown, nape, and back glossy greenish black,

I Mr. G. R. Gray, however (Cat. B. Trop. Isl. p. 49), has under the name of A. exilis "Society Islands (Oahu)" : 
with two long, narrow, white nuchal feathers; wings, lower scapulars, tail, and back of the neck puce-grey, as are the sides of the body, rump, and upper tail-coverts. Base of the forehead, sides of the head, and entire lower parts white; under wing-coverts and axillaries very pale grey; bill black, lighter below; feet yellowish.

Juv. Upper parts with buff spots on the wing-coverts and longer rufous lines elsewhere; tips of wing- and tail-feathers whitish. Lower parts streaked with dark brown, light brown, and creamy white; throat whiter.

Dimensions._- "Total length 18 inches, culmen 3, wing 10.5, tail 4, tarsus $2 \cdot 8$ " (Sharpe). 


\section{FREGATA A QUILA.}

IWA.

Pelecanus aquilus, Linnæus, Syst. Nat. ed. 12, i. p. 216 (1766).

Tachypetes aquila, Vieill. N. Dict. d'Hist. Nat. xii. p. 143 (1817).

Tachypetes aquilus, Kittlitz, Kupfertafeln zur Naturgesch. der Vögel, p. 15, pl. xx. (1833); id. Mus. Senckenb. i. p. 121 (1834 ?); Cassin, U.S. Expl. Exped. p. 358 (1858); Dole, Proc.

Boston Soc. N. H. 1869, p. 308.

Attagen aquilus, G. R. Gray, Cat. B. Trop. Isl. p. 61 (1859).

Tachypeies palmerstoni, Dole, Haw. Alman, 1879, p. 58.

Fregata aquila, Stejneger, Proc. U.S. Nat. Mus. 1888, p. 102; Wiglesworth, Aves Polyn. p. 71 (1891); Rothschild, Avif. Laysan, p. 21 (1893); Grant, Cat. B. Br. Mus. xxvi. p. 443 (1898).

[The above citations refer chiefly to the Sandwich Islands and some other localities in the Pacific Ocean. This list could easily be extended.]

As there was at one time some misunderstanding with regard to the species of FrigateBird found in the Sandwich Islands, it may be of interest to our readers to peruse the remarks of Dr. Stejneger, which are quoted below. Palmer met with large colonies nesting on bushes both in Laysan and the neighbouring islands from May to July; Mr. Perkins observed it on Oahu; and Mr. Dole quotes from Kittlitz the statement that it "breeds on Nihoa," while the last-named also found it in the Laysan group.

Dr. Stejneger says :-

"In his first edition of his 'Synopsis' (Proc. Boston Soc. Nat. Hist. xii.) Mr. Dole enumerated the Frigate-Bird under the above specific name [Tachypetes aquilus], but in 1879 ('Hawaiian Almanac') he corrected the identification as erroneous, and substituted for it the name Tachypetes palmerstoni, without stating his reasons for so doing. It seems, however, as if he made the change under the impression that 'Tachypetes aguila, a similar but much larger bird of the Atlantic Ocean,' is confined to the latter, and that no other species than the small one (the correct name of which is Fregato minor) occurs in the 'tropical belt of the Pacific and Indian Oceans.' This is not quite exact, for while $F$. minor is restricted to the Pacific, and particularly its southern part, F. aquila is found in both oceans, especially north of the Equator, and the specimen from Kauai, sent by Mr. Knudsen, belongs to the large form. As Dr. Streets has found $F$. minor on the Fanning Islands (Bull. U.S. Nat. Mus. no. 7, p. 25), it is quite likely that it may also occur, at least occasionally, in the Hawaiian Archipelago. Knudsen's specimen is a female, with the head, neck, lower breast, and belly 
blackish; upper fore neck grayish; chest whitish, strongly suffused in the middle with ochraceous buff; smaller upper wing-coverts grayish brown with darker centers and paler margins.

"The measurements of this specimen are as follows:-

\begin{tabular}{|c|c|c|c|c|c|c|c|c|c|}
\hline $\begin{array}{l}\text { U.S. Nat. } \\
\text { Mus. No. }\end{array}$ & Collector. & Sex. & Locality. & Date. & Wing. & $\begin{array}{c}\text { Tail- } \\
\text { feathers. }\end{array}$ & $\begin{array}{l}\text { Exposed } \\
\text { culmen. }\end{array}$ & Tarsus. & $\begin{array}{c}\text { Middile } \\
\text { toe with } \\
\text { claw. }\end{array}$ \\
\hline 113446 & Knudsen. & 우 & Kauai, Hawaiian Islands. & $\ldots$ & 595 & 345 & 120 & 25 & $73 "$ \\
\hline
\end{tabular}

Description.-Adult male. Blackish brown with reflexions of green and purple. Bill bluish white in the middle; feet more or less red; orbits, lores, and pouch scarlet.

Adult female. Browner, with white underparts and pinkish feet. Little or no pouch.

Dimensions.- "Total length about 40 inches, culmen from feathers on forehead $3 \cdot 6-5 \cdot 2$, wing $20 \cdot 5-26 \cdot 7$, tail 14-19, tarsus $\cdot 7-1$ " (Ogilvie Grant). 


\section{PHAETHON RUBRICAODA.}

Phaeton rubricauda, Boddaert, Tabl. Pl. Enl. p. 57 (1783); Cassin, U.S. Expl. Exped. p. 395 (1858); G. R. Gray, Cat. B. Trop. Isl. p. 60 (1859) ; Dole, Proc. Boston Soc. N. H. 1869, p. 308 ; id. Haw. Alman. 1879, p. 58; Wiglesworth, Aves Polyn. p. 73 (1891) ; Rothschild, Avif. Laysan, p. 33 (1893) ; Grant, Cat. B. Br. Mus. xxvi. p. 451 (1898).

Phaeton phøenicurus, Gmel. Syst. Nat. i. p. 583 (1788).

Phaeton cethereus, Bloxam, Voy. 'Blonde,' p. 251 (1826) (nec Linn.).

Phaethon phonicurus, Brandt, Mém. Acad. Sc. St. Pétersb. sér. 6, p. 2ð̃2, tab. i. (1839).

[The above citations refer chiefly to the Sandwich Islands and some localities in the

Pacific Ocean. The list could easily be extended.]

OWING to Bloxam's error, noticed by Mr. Rothschild, of recording this Tropic-Bird under the name of $P$. athereus, no writer previous to $\mathrm{Mr}$. Dole appears to have mentioned it as an inhabitant of the Sandwich Islands. The first-named remarked, however, upon the great value that the red tail-feathers possessed in the eyes of the natives, and thereby made it clear that $P$. rubricauda was the species which he intended. It breeds in several places in the group, especially on Kauai and Niihau, and chooses holes in almost inaccessible cliffs wherein to deposit its eggs, though in Laysan they are laid in hollows scraped in the soil under bushes. When in the Sandwich Islands I shot several specimens from the bigh rock-walls surrounding the caldera of Kilauea, which are in most parts particularly steep. Mr. Perkins considers this species much more uncommon in the group than $P$. athereus.

Description.-Adult male and female. Satiny white, often tinged with pink; the upper parts marked with blackish bars or patches, and shewing black marks near the eyes. Bill red; feet yellowish, with black toes. The long median tail-feather's dull red, with black shafts and very narrow webs.

Dimensions.- "Total length about 36 inches, culmen from feathers on forehead 2.55-2.65, wing 12.3-13.4, tail 17-18.5, tarsus 1.2" (Ogilvie Grant). 



\section{PHA ETH ON ・ ETHEREUS.}

Phaeton athereus, Linn. Syst. Nat, ed. 12, p. 219 (1766).

? Phaëton (an candidus ?), Kittlitz, Mus. Senckenb. i. p. 123 (1834 ?).

Phaethon athereus, Brandt, Mém. Acad. Sc. St. Pétersb. sér. 6, v. p. 257, tab. ii. (1839) ; Cassin, U.S. Expl. Exped. p. 394 (1858) ; G. R. Gray, Cat. B. Trop. Is. p. 60 (1859); Dole, Proc. Boston Soc. N. H. 1869, p. 308; id. Haw. Alman. 1879, p. 58; Wiglesworth, Aves Polyn. p. 73 (1891); Grant, Cat. B. Br. Mus. xxvi. p. 457 (1898).

[The above citations refer chiefly to the Sandwich Islands and some other localities in the Pacific Ocean. The list could easily be extended.]

LITTLE need be said of this well-known inhabitant of the tropics, which appears to be common on all the Sandwich Islands. Mr. Dole records it in both of his lists, though he furnishes no information as to where it was noticed, while Cassin does not give it as occurring in the group in his account of the U.S. Exploring Expedition; but Mr. Rothschild has kindly sent a note in which he says that it was obtained by Palmer, and Mr. Perkins states that he met with it on the cliffs round Honolulu and elsewhere, breeding not uncommonly on the rocky ledges. It may also be found on one or more of the outlying islands to the north-west.

Description.-Adult male and female. Similar to $P$. mubricauda, but with white median tail-feathers.

Dimensions. - "Total length about 40 inches, culmen from feathers on forehead $2 \cdot 4-2 \cdot 6$, wing $11 \cdot 5-13$, tail about 26, tarsus 1·15-1.2" (Ogilvie Grant). 



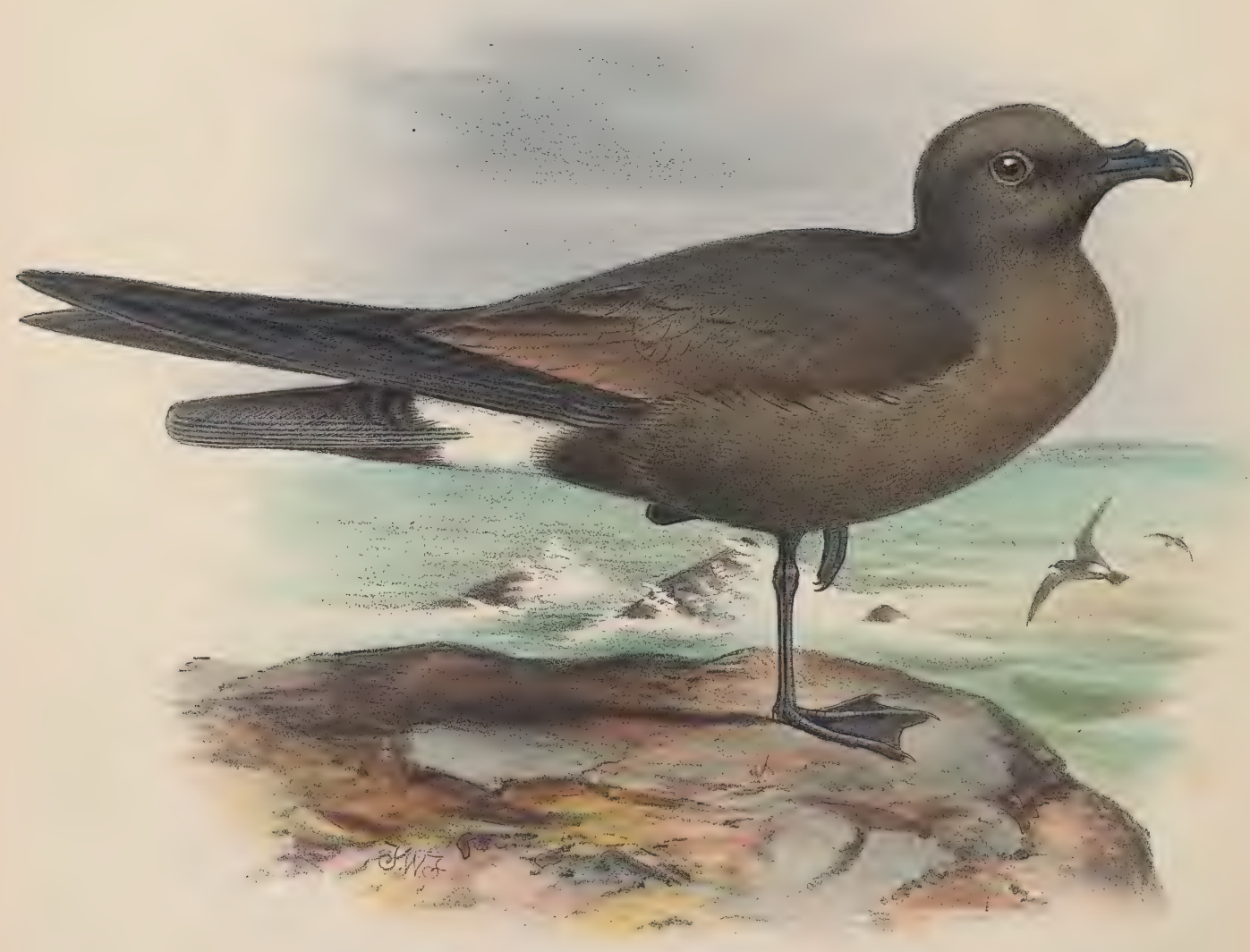




\section{OCEANODROMA CRYPTOLEUCURA.}

? Thalassidroma —, Dole, Proc. Bost. Soc. N. H. xii. p. 308 (1869) ; id. Hawaiian Alman. 1879, p. 55 .

Cymochorea cryptoleucura, Ridgway, Proc. U.S. Nat. Mus. iv. p. 337 (1882); Baird, Brewer, \& Ridgway, Water-B. N. Am. p. 406 (1884).

Oceanodroma cryptoleucura, Stejneger, Proc. U.S. Nat. Mus. 1887, p. 78.

OF this Petrel I was fortunate enough to procure examples from my friend Mr. Francis Gay, procured on the Island of Niihau.

Dr. Stejneger, Proc. U.S. Nat. Mus. 1887, p. 78, thus refers to it:-"Mr. R. Ridgway in 1882 described this species as new, from two specimens collected by Mr. Knudsen (Nos. 41949 and 41950). It is easily distinguished from all its allies by having the upper tail-coverts white, the larger ones broadly tipped with black, and by having the concealed bases of the tail-feathers, except middle pair, white.

"This is probably the unnamed 'Thalassidroma' to which Mr. Dole refers (Proc. Boston Soc. N. H. xii. 1869, p. 308, Extr. p. 15; and 'Hawaiian Almanac,' 1879, p. 55)."

Mr. Ridgway's description is as follows:-

"Description.-Uniform fuliginous, the head and upper surface more slaty, the greater wing-coverts and outer webs of tertials paler, inclining to dull ash-grey; remiges and rectrices dull black, the latter (except middle pair) white at the base; upper tailcoverts white, the longer feathers broadly tipped with blackish (as in Procellaria pelagica); anal region mixed with white, and white of the upper coverts extending laterally to the sides of the crissum. Tail only slightly forked or emarginated, the outer feathers being only about $\cdot 20$ to $\cdot 30$ of an inch longer than the middle pair. Bill, legs, and feet (including webs) deep black. Wing 5.80-6.30 inches; tail $3 \cdot 0-3 \cdot 15$; bill (measured in straight line from base of culmen to point of the maxilla) 60 ; tarsus -85-90 ; middle toe, with claw, $85-90$."

Nothing certain is known respecting the range of this species. 



\section{BULWERIA ANJINHO.}

Procellaria anjinlio, Heineken, (Brewster's) Edinb. Journ. Sc. n. ser. i. p. 231 (1829).

Procellaria bulweri, Jardine \& Selby, Ill. Orn. ii. pl. 65; Jardine, Edinb. Journ. Nat. \& Geogr.

Sc. i. p. 245 (1830).

Thalassidroma bulweri, Gould, B. Eur. v. pl. 449 (1837).

Puffinus columbinus, Webb \& Berthelot, Hist. Nat. Iles Canariennes, ii. p. 44, pl. iv. fig. 2 (1841).

Bulweria buhweri, Bonaparte, Catal. Metod. Uccelli Eur. p. 81 (1842) ; Stejneger, Proc. U.S. Nat.

Mus. xii. p. 378 (1889); id. op. cit. xvi. p. 620 (1893) ; Rothschild, Avif. Laysan, p. 51

(1893) ; Salvin, Cat. B. Br. Mus. xxv. p. 420 (1896).

Bulweria columbina, C. L. Brehm, Naumannia, 1855, p. 296.

Procellaria macgillivrayi, Tristram, Ibis, 1881, p. 252 (nec G. R. Gray).

Eistrelata bulweri, Coues, Check List N. Am. B. 1882, p. 126.

[This list of citations could obviously be much extended.]

Тношян Mr. Rothschild's collector Palmer found this species breeding commonly under some old turtle-shells on French Frigate Islands, and also met with it on Laysan, the only evidence of its occurrence in the Sandwich Islands is that furnished by Dr. Stejneger in 1889, whose information is as follows:-

"I have but little doubt that the two birds received from Mr. Knudsen since the rest of this paper was submitted to the printer really belong to this species. They make a very unexpected addition to the Hawaiian fauna.

"As far as coloration is concerned they agree minutely with B. bulweri, the greater wing-coverts being lighter than the rest of the wing, in this respect differing from the original description ${ }^{1}$, and, so far as I know, the only one, of $B$. macgillivrayi. Nor are the bills larger; on the contrary, they are somewhat slenderer; nor do the dimensions or proportions differ, as the appended measurements show. The only doubt is caused by the difference in shape of the nasal tube, which in the single specimen of undoubted B. bulweri at my command is swollen almost to the base, while in Knudsen's two specimens it is compressed from about the middle backwards. This difference may be entirely unessential, however.

"The occurrence at the Hawaiian Islands of this species, which has hitherto been

1 " 'Tike T. butweri, but with the bill rather larger; and it is without the sooty brown on the wings,' Gray, Cat. Birds Trop. Isl. Pac. Oc. p. 56 (1859). This diagnosis, with slight additions and measurements, is reproduced in Finsch \& Hartlaub, Beitr. Faun. Centralpolynes. p. 242 (1867)." 
recorded only from the Eastern Atlantic, and as occasionally occurring in Greenland and the Bermudas, is very interesting, especially as we might have expected to find $B$. macgillivrayi there, and raises the question whether the latter, of which $I$ think only one specimen is known, may not simply be an abnormal individual of $B$. bulweri.

"Measurements.

\begin{tabular}{|c|c|c|c|c|c|c|c|c|c|}
\hline $\begin{array}{c}\text { U.S. Nat. } \\
\text { Mus. No. }\end{array}$ & Collector. & $\begin{array}{c}\text { Sex and } \\
\text { age. }\end{array}$ & Locality. & Wing. & $\begin{array}{c}\text { Tail- } \\
\text { feathers. }\end{array}$ & $\begin{array}{c}\text { Exp. } \\
\text { eulmen. }\end{array}$ & Tarsus. & $\begin{array}{c}\text { Middle } \\
\text { toe with } \\
\text { claw. }\end{array}$ & $\begin{array}{c}\text { Graduation } \\
\text { of tail. }\end{array}$ \\
\hline 116945 & Knudsen. & Ad. & Kauai, Hawaiian Islands. & 199 & 110 & 21 & 27 & 30 & 47 \\
116946 & do. & Ad. & do. & 196 & 113 & 21 & 28 & 28 & 42 \\
32519 & $\ldots$. & Ad. & Canary Islands. & 199 & 109 & 22 & 25 & 28 & $43 "$ \\
\hline
\end{tabular}

Description.-Adult male and female. Almost uniform sooty brown, rather lighter below and on the greater wing-coverts; bill black; feet yellow, with darker webs.

Dimensions._"Total length about 11 inches; wing $7 \cdot 7$; tail, central feathers $4 \cdot 1$, lateral 3 ; culmen about $1 \cdot 2$; tarsus $1 \cdot 05$, middle toe $1.2 \%$ (Salvin). 



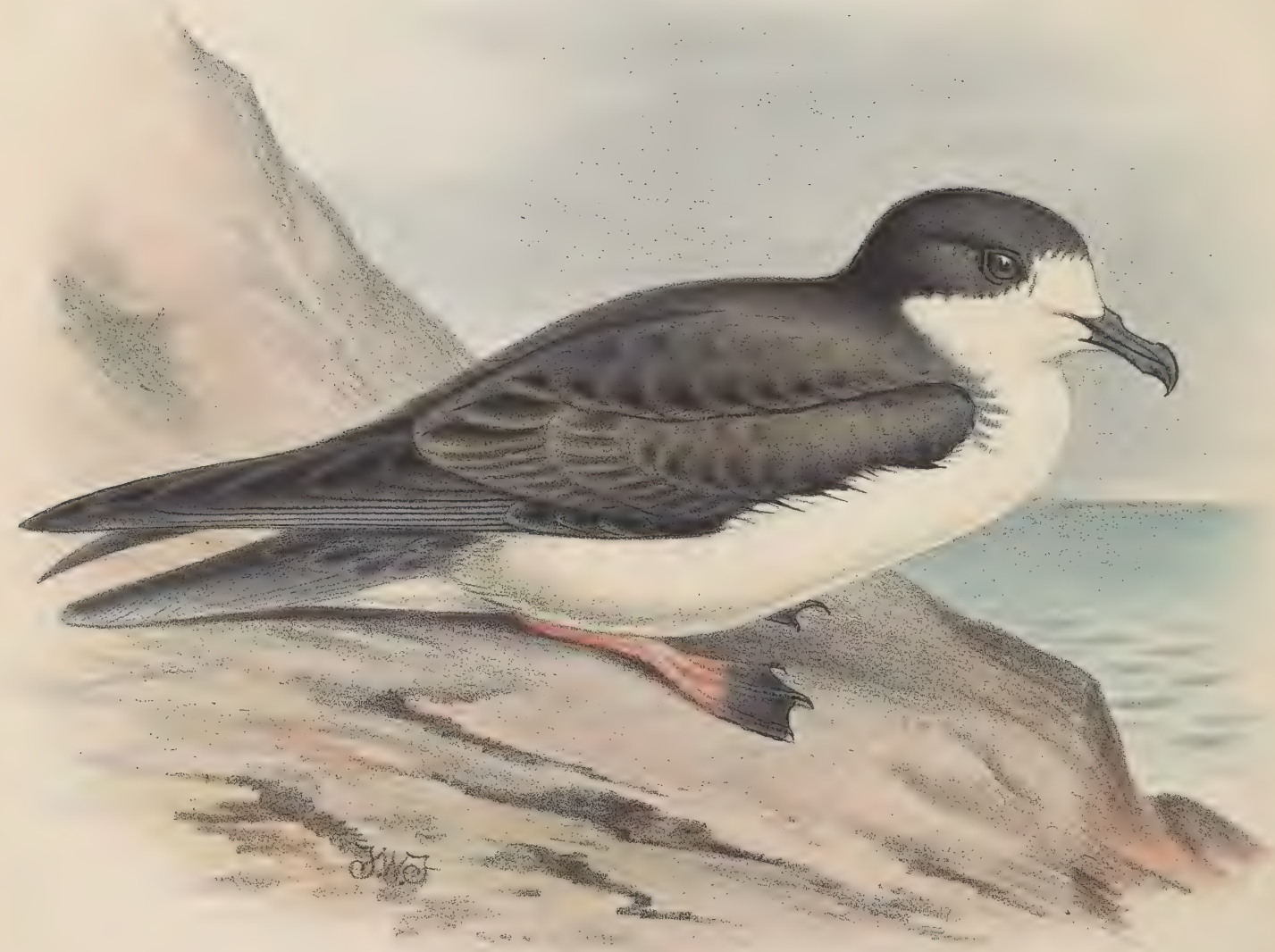




\section{CSTRELATA PHEOPYGIA.}

UUAU.

? Procellaria alba, Dole, Proc. Bost. Soc. N. H. xii. p. 308 (1869) ; id. Hawaiian Alman. 1879, p. 55 (nec Gmelin).

Estrelata phceopygia, Salvin, Trans. Zool. Soc. ix. p. 507, pl. 88. fig. 1 (1876); Ridgway, Manual N.-A. Birds, p. 65 (1887).

EEstrelata sandwichensis, Ridgway, Water-B. N. Am. ii. p. 395 (1884).

Estrelata sandwichensis, Ridgway, Proc. U.S. Nat. Mus. ix. p. 95 (1886); id. op. cit. xi. p. 104 (1888) ; Stejneger, op. cit. x. p. 77 (1887).

IN the 'Proceedings of the U.S. National Museum' for 1587 Dr. Stejneger writes as follows :-

"In the great work on, the.Water-Birds of North America Mr. R. Ridgway writes as follows (ii. pp. 394-395):- 'A specimen from the Sandwich Islands (No. 61259, V. Knudsen coll.), labelled "Puffinus meridionalis," differs from the above diagnosis [of EE. hoesitata] in several particulars, and may possibly be distinct. The entire upper parts, except forehead, are continuously uniform dusky, nearly black on the head, the nape, the back, and scapulars more greyish brown; this dark colour even covers uniformly the entire side of the head and neck, except that portion of the former before the eye, and thence downward and backward across the malar region. The feathers of the nape and side of the neck, however, are white immediately beneath the surface, this colour showing conspicuously wherever the feathers may be disturbed. There is, likewise, no exposed white on the upper tail-coverts or base of the tail ; the former are, however, very abruptly, white beneath the surface, but the latter is white only at the extreme base, and the outer rectrices have a considerable amount of white on their inner webs. The lower parts are almast entirely white, there being merely a few plumbeous irregular bars on the flanks. The measurements are as follows:wing 11.80 inches (less than the average of $E$. hoesitata as given by Dr. Coues); tail $5 \cdot 75$, its graduation $2 \cdot 40$; culmen 1.22 ; depth of bill at base 0.99 ; tarsus $1 \cdot 40$, middle toe (without claw) $1 \cdot 55$. In view of the differences of coloration, much more graduated tail, and smaller dimensions-and especially in view of its different habitat, no specimens of $E$. hositata having to our knowledge been reported from any part of the Pacific Ocean-the specimen in question may be really distinct. Should such prove to be the case, the name $E$. sandwichensis is proposed as a suitable designation.' And in a footnote he adds:- 'In pattern of coloration this specimen agrees exactly with an example of $E$. cookii, but has the back, scapulars, rump, and tail decidedly less ashy.' After having had an opportunity to compare Knudsen's bird with examples of true 
QE. hoesitata, and also with the type of Lawrence's $\mathbb{E}$. meridionalis, the same author afterwards (Pr. U.S. Nat. Mus. ix. 1886, p. 96) pronounces the opinion that they are entirely distinct from $E$. sandwichensis, but has ' a suspicion that the latter is the same as EE. phreopygia, Salv. (Trans. Zool. Soc. Lond. vol. ix. pt. ix. May 1876, p. 507, pl. 88. fig. 1), from the Galapagos.'

"This point, however, can only be determined by direct comparison of the types, and until then we prefer to retain the name which belongs strictly to the Hawaiian specimens. Latham's 'White-breasted Petrel' (Gen. Syn. iii. 2, p. 400), 'from Turtle and Christmas Islands,' upon which Gmelin based his Procellaria alba, scarcely belongs here, as from the description of the former it seems to have the whole head and neck blackish with a white patch on the throat ("the head, neck, and upper parts of the body dusky brown, nearly black; on the throat a whitish patch ; breast, belly, and vent white'). I do not know Mr. Dole's reasons for including $P$. alba in the list, unless it be Bloxham's very uncertain statement (Voy. 'Blonde,' p. 252), and I think it most probable that $E$. sandwichensis is the bird he intended by that name."

Mr. Ridgway afterwards wrote (Proc. U.S. Nat. Mus. xi. p. 104):-“In volume ix. of these 'Proceedings' [1888], p. 96, in an additional note to an article on this bird, I expressed a suspicion that it might be the same as $E$. phcoopygia, Salv. ('Trans. Zool. Soc. Lond. vol. ix. pt. ix. May 1876, p. 507, pl. 88. fig. 1), and in my more recently published 'Manual of North-American Birds' (p. 65) relinquished any doubt to the question by giving the Sandwich Island bird as $\mathbb{E}$. phoopygia. In the meantime the type had been sent to Mr. Salvin for comparison with the types of his species, and his letter, dated December 11, 1887, confirms the views which I had adopted, as the following quotation from his letter will show:- 'I have compared it $[i . e$. the type of E. sandwichensis] with the two types in the British Museum of $\mathbb{E}$. phoopygia, and done my best to make them different, but they are as like as any three specimens of the same species of Petrel that I ever examined. The bill is a trifle small in all its dimensions, and outer rectrices a little more freely mottled with white, but the Galapagos birds vary just as much inter se."

I obtained a young bird-said to be of this species-in the down from a native, whilst staying at Kilauea in the month of September 1887, and was told that a considerable number had their nests in holes in the ground in the vicinity, more particularly on the slopes of Mauna Loa. At Kilauea we used to hear at evening-time the peculiarly harsh cry of a bird flying over our heads, and the natives told me it was the Uuau. 'The flesh is esteemed a great delicacy by the Hawaiians. 


\section{.}




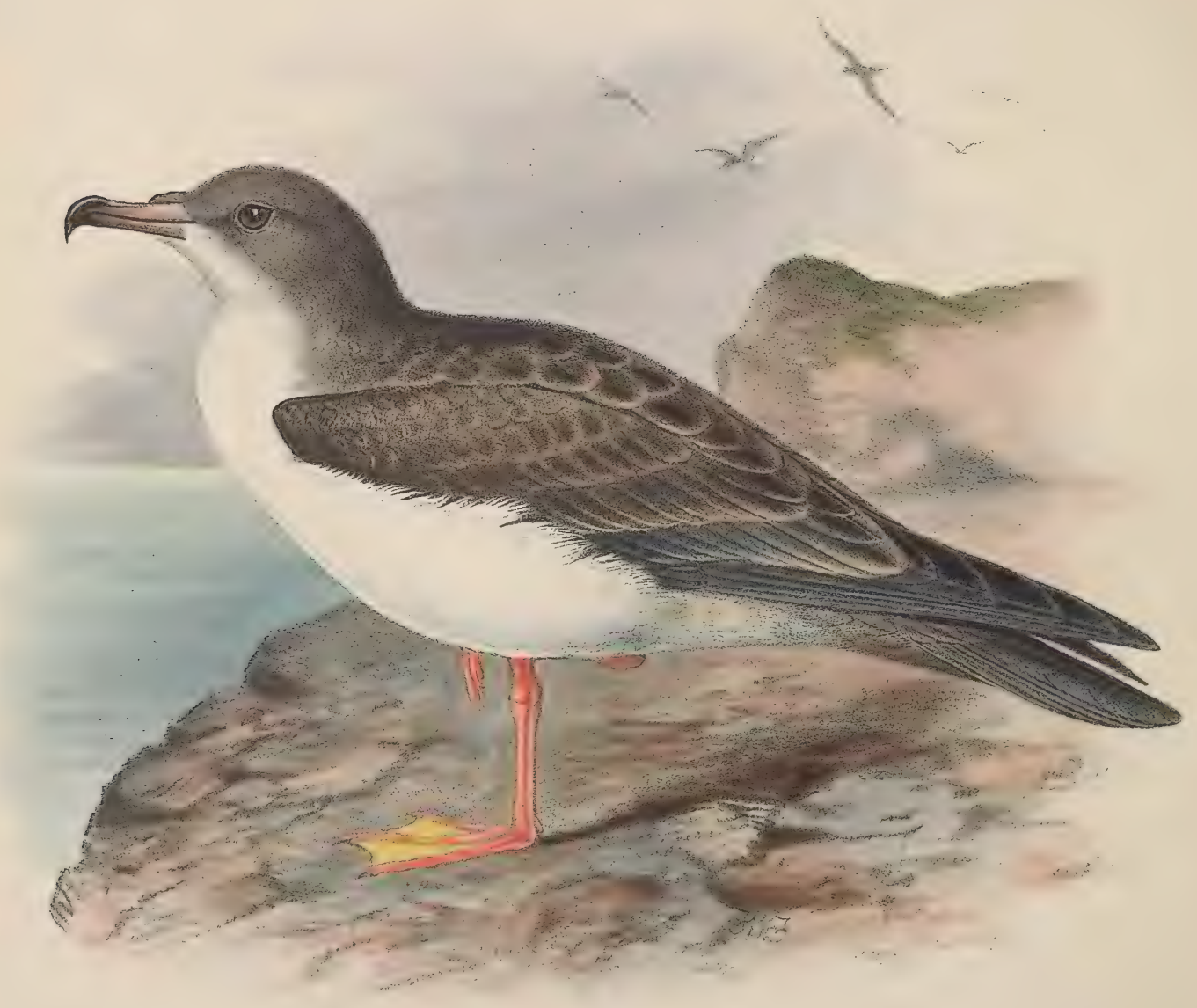




\title{
PUFFINUS CUNEATUS.
}

\author{
UAU KANE.
}

Puffinus cuneatus, Salvin, Ibis, 1888, p. 353; Stejneger, Proc. U.S. Nat. Mus. xii. p. 377 (1890). Puffinus knudseni, Stejneger, Proc. U.S. Nat. Mus. 1888, p. 93.

IN 'The Ibis' for July $1888 \mathrm{Mr}$. Salvin described this bird from the Krusenstern Islands (Marshall group) as Puffinus cuneatus, while in November of the same year Dr. Stejneger redescribed it as $P$. knudseni from Kauai, Sandwich Islands; the latter author, however, on comparison of further specimens, readily admitted that the first name took precedence.

$\mathrm{Mr}$. Salvin writes as follows:-

"In general coloration this species resembles $P$. creatopus, Cones, but it may be readily distinguished by its smaller darker bill, smaller feet, and especially by its longer more cuneate tail, the latter character placing it along with $P$. chlororhynchus and $P$. bulleri, described below, in Gloger's supposed genus or section 'Thiellus' (see Coues, Pr. Ac. Nat. Sci. Phil. 1864, p. 122) ${ }^{1}$.

"I have two specimens of this bird before me, both obtained in the spring of 1883 by $\mathrm{Mr}$. H. J. Snow, of Yokohama ${ }^{2}$.

"In several respects this bird conforms to Latham's description of his White-breasted Petrel ${ }^{3}$, said to inhabit Turtle and Christmas Islands; but there are differences which make it undesirable to make another, and probably fruitless, attempt to identify this name, which has already been applied to Estrelata neglecta of the Kermadec Islands. Turtle Island is probably Vatoa or Turtle I., one of the Fiji group; and Christmas I. the island of that name south of the Sandwich Islands."

Dr. Stejneger, after giving a diagnosis and discussing the bird's affinities, says :-

"Mr. Knudsen writes me in regard to the present species, which according to his label is called 'Uau kane' by the natives, that it was formerly found plentiful every

1 "The name 'Thyellus' was proposed by Gloger in Froriep's 'Notizen,' xvi. (1827) p. 279, simply as a substitute for Puffinus. Bonaparte (Consp. Av. ii. p. 200) altered the spelling, and restricted it to this section of Puffinus, and in so doing he was followed by Coues."

2 "The Krusenstern Islands here referred to are apparently the small cluster of islands so named by Kotzebue, which form part of the Marshall Group, and are situated in about lat. $10^{\circ} 17^{\prime} \mathrm{N}$., long. $190^{\circ} \mathrm{W}$. The islands extend over an area of 15 miles long by 5 wide. The native name of the largest is Ailuk. There is a Krusenstern Rock lying to the westward of the Sandwich Islands; but this can hardly be the place whence these Petrels were obtained, as the sea is described as only breaking in one spot."

3 "White-Breasted Petrie, Lath. Gen. Syn. vi. p. 400.

Procellaria alba, Gm. Syst. Nat. i. p. 565 ; Lath. Ind. Orn. ii. p. 822." 
summer at the top of the mountains as high up as 5000 feet, where they had their nests in long burrows, but that in the last ten years they have become rare, as the foreign rats kill them in their nests."

If Dr. Finsch is correct as to the genus, the subjoined account ('Ibis,' 1880, p. 81) may also refer to this species; but only future investigations can determine this with certainty. He says:- "I also got information of a very curious bird, which the natives call ' $U-a u$.' According to the description it breeds in holes underground on the mountains, resorting to its nesting-place only at night. I do not doubt that the bird is a species of Puffinus, as similar habits are known of allied species in the Fijis, Navigators' Islands, Tahiti, \&c. To obtain information of this species, which Mr. Dole enumerates as 'Procellaria alba, Gm.,' I made a day's trip to a part of the Northern Haleakala ranges [in Maui], where the birds were said to be breeding. Although I took the best guide I could get, we found nothing but a few old holes under the ferns and an old dried-up white egg. The species remains, therefore, still uncertain; but I have no doubt that it is the same which I saw soaring in evening-time on the rocky coast near Lahama. The bird looked black, white below, and reminded me of Puffinus obscurus."

Description (translated from that of Mr. Salvin).-Above sooty ; crown, lower back, lesser wing-coverts, and remiges darker, feathers of the upper back bordered with sooty colour of a pale tint, greater wing-coverts tinged with grey at the tips: beneathwhitish in the middle part; sides of the throat and neck grey, breast and flanks also of this colour, entire lower belly and vent darker; under wing-coverts whitish, very slightly marked with grey; tail wedge-shaped, black: beak dull lead-colour; feet yellow, darker on the outer part. Total length $17 \cdot 0$ inches, of wing $11 \cdot 8$, of middle tailfeathers $5 \cdot 3$, of lateral $3 \cdot 65$, of beak from gape $2 \cdot 2$, from nostrils $1 \cdot 2$, of exposed culmen $1 \cdot 6$, of tarsus $1 \cdot 85$, of middle toe with claw $2 \cdot 32$. 


\section{DIOMEDEA IMMUTABILIS.}

Diomedea (an exulans?), Kittlitz, Mus. Senckenb. i. p. 120 (1834,?) (nec Linn.).

Diomedea brachyura, Peale, U.S. Expl. Exped. pp. 290, 337 (1848) ; Cassin (partim), U.S. Expl. Exped. p. 398 (1858); Dole, Haw. Alman. 1879, p. 57 (nec Temminck).

Diomedea melanophrys, Bean, Proc. U.S. Nat. Mus. v. pp. 170, 173 (1882)? (nec Boie, apud Temminck).

Diomedea immutabilis, Rothschild, Bull. Br. Orn. Club, i. p. xlviii (1893) ; id. Tbis, 1893, p. 448, and 1894, p. 548; id. Avif. Laysan, p. 57, pls. (1893); Salvin, Cat. B. Br. Mus. xxv. p. 446.

As will be seen from the synonymy, Mr. Rothschild was the first author to distinguish this species from Diomedea exulans and D. brachyura. He received specimens from his collector Palmer, who found it in immense numbers on Laysan, and in fair quantity on Lisiansky, while he observed a few individuals on French Frigate Shoals and near Niihau. Mr. Dole had previously recorded it, under the name of $D$. brachyura, as "common about the Hawaiian Islands," and a specimen killed by Bailleu on Hawaii is, according to Mr. Rothschild, in the Paris Museum. No evidence of its breeding in the group is as yet forthcoming. Numerous specimens were collected by the United States Exploring Expedition, and in the accounts of that voyage the bird was stated to be "particularly abundant at sea north of the Sandwich Islands."

Description.-Adult male and female. "Head, neck, lower rump, and entire under surface pure white; space in front of the eye sooty black; wings and wing-coverts blackish brown; interscapular region, back, and upper part of rump paler and more smoky brown; tail black, fading into white at base ; under wing-coverts mixed blackish brown and white."

"The first plumage of the young (which is dark in most Albatrosses) is similar to that of the adult bird; the breast and entire underparts pure white."

"The nestling is covered with brown down; its bill is blackish brown, and its iris brown also." (Rothschild.)

Dimensions. - "Total length about 32 inches, wing $18 \cdot 6-19$, bill 4, tarsus $3 \cdot 2$, middle toe with claw $4 \cdot 3$ " (Rothschild). 


Birds of the Sandwich Jstands

Plate I.

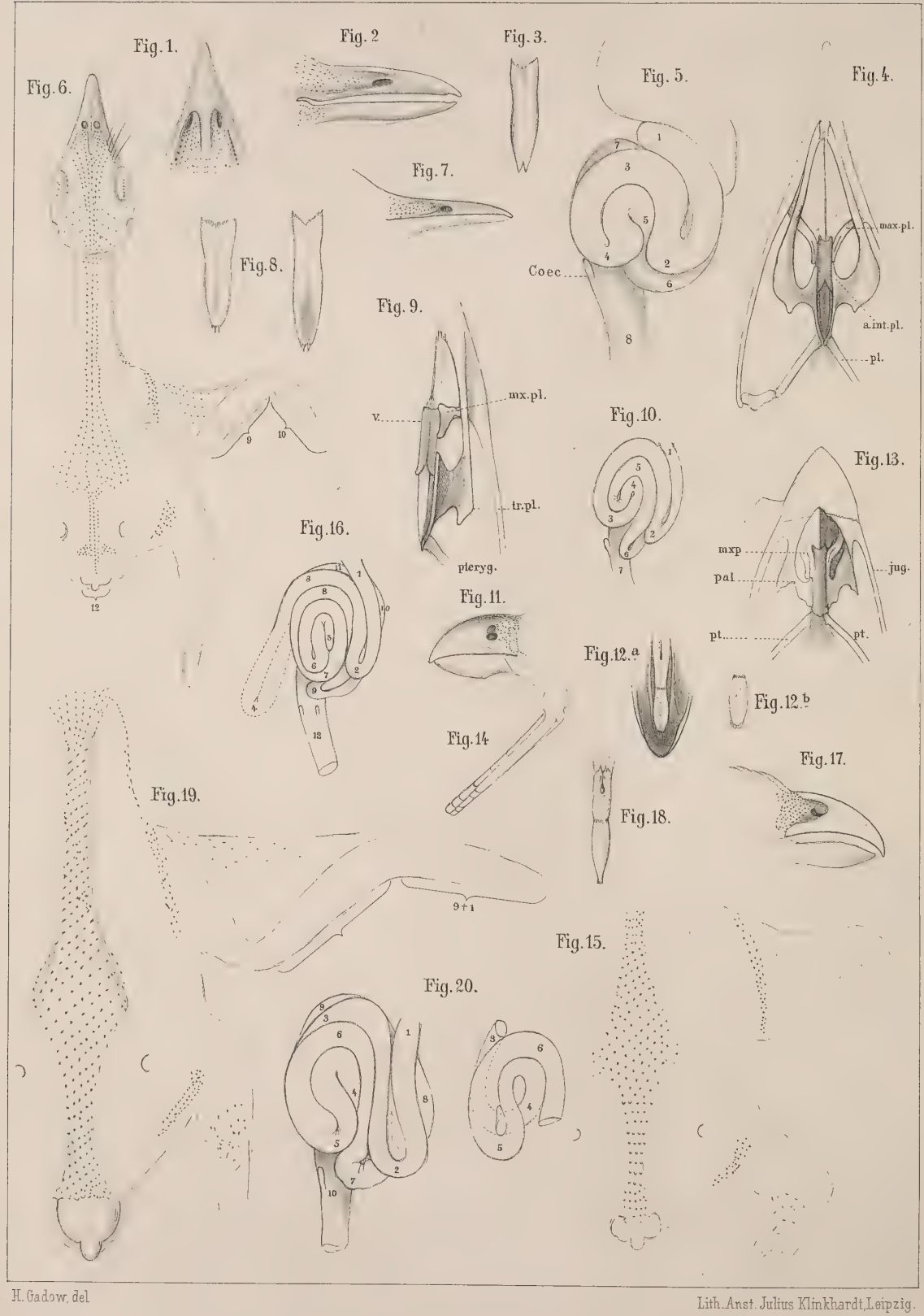



Birds of the Sandwich Jslands.

Plale II.

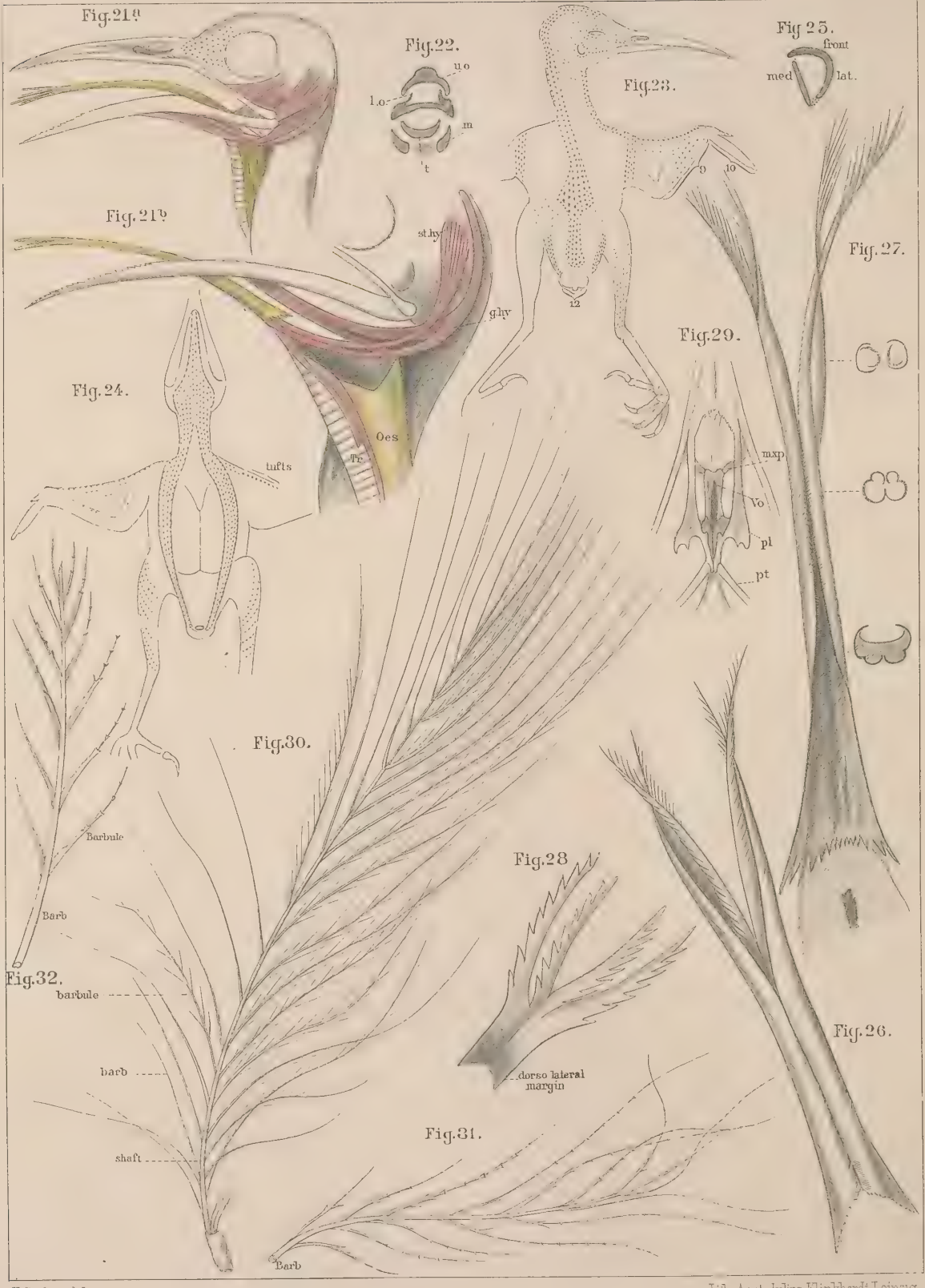



Birds of the Sandwich Jslands.

Plate III.

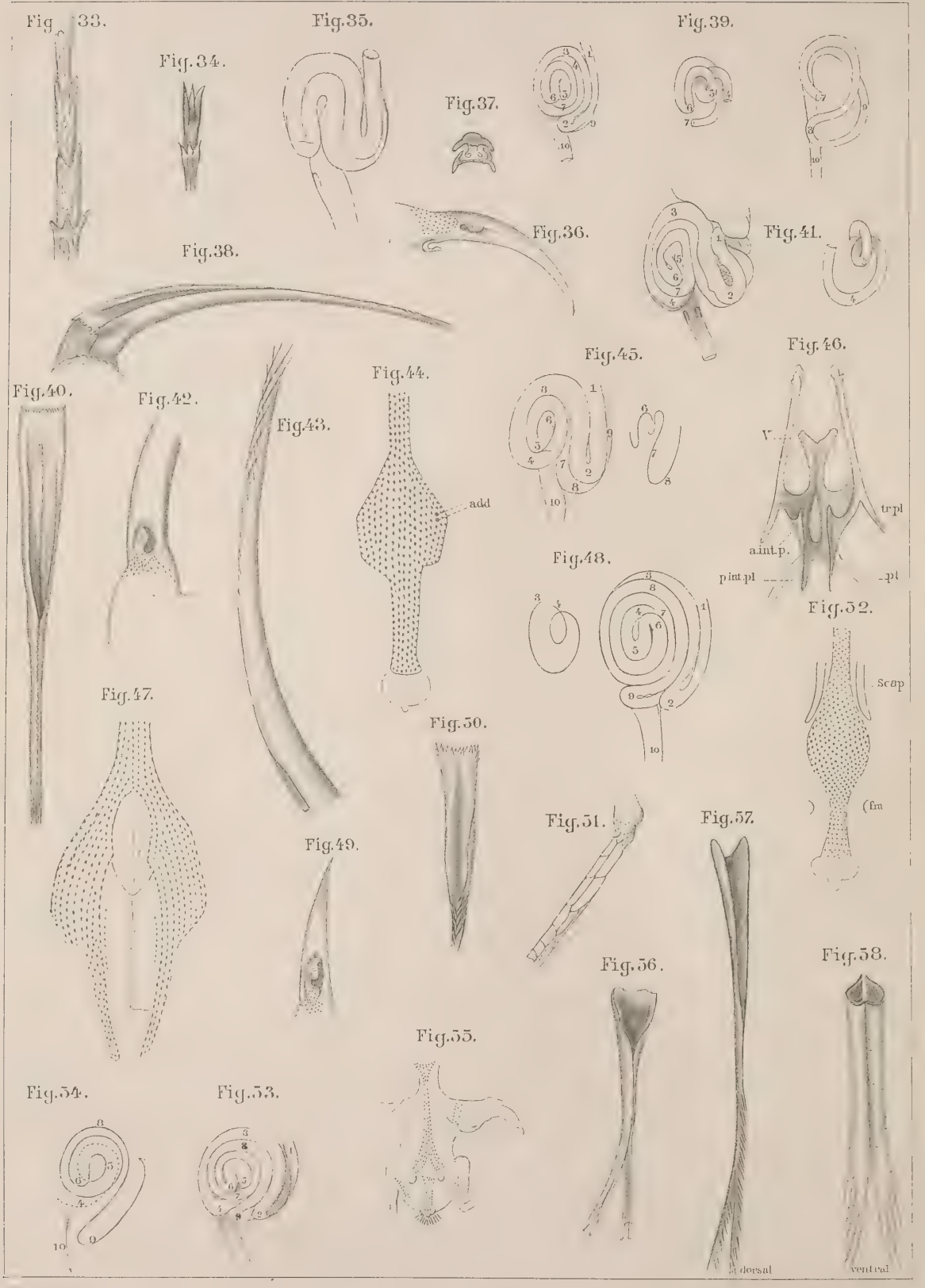

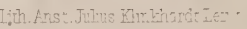


R E M A K S

ON THE

\section{STROCTURE OF CERTAIN HAWAIIAN BIRDS,}

WITH REFERENCE TO THEIR SYSTEMATIC POSITION.

$\mathrm{BY}$

HANS GADOW, M.A., Рн.D.,

STRICRLAND CURATOR AND LECTURER ON THE ADVANCED MORPHOLOGY OF VERTEBRATES IN THE

UNIVERSITY OF CAMBRIDGE.

Mr. WiLSON has handed over to me for examination a considerable number of wellpreserved spirit-specimens of Hawaiian birds ${ }^{1}$, requesting me to ascertain their systematic position and to give an account of the more important parts of the structure of the species constituting this almost unique material. All these birds are Oscines, truly acro- and polymyodean. I have not described their skeletons because these are now preserved in the Cambridge Museum, and consequently will be accessible at any future time, should they be considered worth the trouble of describing and figuring. In the following pages I have restricted myself to the description of those parts which are either more perishable than the bones, or which $\mathrm{I}$ found to be of greater taxonomic value. In order to investigate the affinities of the birds in question, it was necessary to compare them with many other forms, of which, however, the selection was sadly restricted and determined by the scanty material at my disposal.

To complete this account, the stuffed specimens of Drepanis pacifica and of Choetoptilo, angustipluma have likewise been examined.

1. Phæornis obscura.

Chasiempis sandricensis.

Loxioides bailleui.

Psittacirostra psittacea.

Acrulocereus braccatus

$$
\text { , nobilis, }
$$

Vestiaris coccinẹ,
Himatione sanguinea.

" virens.

Loxops coccinea.

Oreomyza bairdi.

Chrysomitridops cæruleirostris.

Hemignathus procerus.

, olivaceus. 


\section{Pheornis obscura. (Pl. I. figs. 1-5.)}

Bill with a tooth-like notch near the tip of the premaxilla, and with a corresponding emargination near the tip of the mandible; the rest of the cutting-edge sharp and unbroken. The bill is considerably flattened, being much broader than it is high at the base, with a prominent culmen. The nostrils are oval and open, situated at the anterior ventral corner of a large and soft coriaceous groove, nearer the tip of the bill than the base. The neighbourhood of the nostrils is bare of feathers; the rest of the coriaceous groove is covered with feathers, and there are a few upper rictal bristles.

The bones of the palate exhibit distinctly Turdine features, and differ considerably in their arrangement from that which exists either in Muscicapidæ (e. g. Muscicapa, Petroca) or in Pachycephalinæ. The vomer is forked anteriorly and posteriorly, and is, as in the Thrushes, not accompanied laterally by septo-maxillary splints, which are well developed in Flycatchers and in Pachycephalinæ. The palatine bones articulate posteriorly with the pterygoids and are well separated from each other, so that the sphenoid remains visible between them. The interpalatine spurs are long and almost touch the long and uniformly slender maxillo-palatines, while the ends of the latter are widely separated from the interpalatine spurs in Shrikes, Flycatchers, and Pachycephalinæ, but not in Thrushes. Moreover, the slender distal halves of the maxillopalatines of Phocornis are scooped out ventrally for the reception of certain air-sacs, while these bones in the Flycatchers are distally swollen to a considerable extent, and in Pachycephala are triangular, broadest at the base.

Tongue thin, smooth, much shorter than the bill, elongated, slightly arrow-shaped, and slightly bifurcated at the tip.

Pterylosis.-There are ten primary remiges, of which the tenth or terminal is functional and well developed, being nearly half the size of the ninth; and two and a half times larger than its covert. 'The tip of the wing is formed by the seventh, sixth, and fifth quills. The number of secondaries is nine, that of the rectrices twelve, of which the outer pairs are slightly shorter than the rest. The feather-tracts are much generalized (resembling, for instance, those of Psittacirostra), but numerous hair-like feathers are interspersed between the contour-feathers of all the tracts, and the spaces between the dorsal and ventral cervical tracts are sprinkled with small downy contour-feathers. The shape of the saddle differs much from that of the Pachycephalinæ, but in the Muscicapidæ and Turdidæ this varies too much to permit of safe comparisons.

The metatarsus is covered by three long and unbroken laminæ-one in front, one on the median, and one on the lateral side. The possession of three long laminæ is rather a Turdine feature, while the metatarsus of the Pachycephalinæ, except in the subgenus Pachycephalopsis, is entirely covered with transverse scales; the same transverse scutellation exists still more markedly in the Muscicapidx.

Alimentary canal.-The œsophagus showed no trace of a crop. The stomach was 
round, strongly muscular, lined internally with dark cuticle, and contained no insects whatever, but only hard seeds and pulpy masses. This indicates that Phooornis lives on stony fruit and soft berries, especially since the stones or hard kernels are also found in the gut, and are consequently passed out through the vent, a habit common among Thrushes. The whole gut is correspondingly wide, especially the sacculated duodenum and the rectum, which again is characteristic of frugivorous birds. The cæca are narrow non-functional tubes 0.8 centim. long. The total length of the gut is only 21 centim., the relative length only 3.5 . This shortness, again, indicates soft and easily digestible food. The intestinal convolutions are very simple, as in most Oscines with short guts. The right lobe of the liver is three times as large as the left.

Summary.-Phoornis has no resemblance either to the Muscicapidæ or with the Pachycephalinæ, as these groups are limited in the Catalogue of Birds in the British Museum; its supposed affinity with Eopsaltria can be disregarded, because that genus is intermediate between the two groups. There remains the question of its being related to the Prionopidæ, as suggested by Mr. Sharpe. Of the genera which he (Cat. Birds Brit. Mus. vols. iii. and iv.) has made to constitute the Prionopidæ, only those of Australian and Malayan origin can be taken into consideration for comparison. Of these Grallina is out of the question; there remain consequently Rectes, Collyriocincla, and Pinarolestes. According to the key (vol. iii. pp. 270, 271), Phaornis would coincide with Collyriocincla, a genus which Gray associated with the Pachycephalinæ, and of which the questionable species "sandwichensis" (Hand-list of Birds, no. 5832) is probably our Phœornis obscura. Unfortunately only skins and skeletons of Collyriocincla, with none of the soft parts, could be examined owing to want of material. However, Collyriocincla is not a Pachycephaline bird, and it also differs considerably from Phoornis in its strong transverse scales on the front of the metatarsus, in shape of bill, formation of the tip of the wing, and above all in the bones of the palate, which bear no resemblance to those of that species. Moreover, the three Prionopine genera in question agree with each other and differ from Phcoornis in the much more basal, round, and almost concealed nostrils. Lastly, according to Gould, Collyriocincla "feeds upon insects of various kinds, caterpillars and their larvæ," while Phocornis is essentially a vegetable eater, a frugivorous bird.

Which of the still-existing birds form the link between Turdidæ, Muscicapidæ, and the ill-defined Prionopidæ we do not know, owing to the want of well-preserved spiritspecimens. Phcoornis agrees fully with none of these families, but it differs least from the Turdidæ. Its frugivorous habits are much in favour of its affinity to the Thrushes, although many of these birds vary their diet with snails and other soft-bodied invertebrates. There are many instances known in which birds that originally fed on vegetables have changed into insect eaters; but the reverse, the change from essentially animal to vegetable food, implies much more serious changes of the alimentary system. The apparent scarcity of Hawaiian insects, or rather the extremely hidden life which many of them seem to lead, has forced the more indigenous insectivorous birds, the Drepanididæ, 
to develop the most specialized features. Other insectivorous birds, especially those which are much larger than most of the Drepanididæ, would, as more recent arrivals, find competition very difficult under the prevailing circumstances. However, the small Chasiempis does manage to coexist with the Drepanididæ. A berry-eating bird, such as a generalized or rather primitive Thrush, would, on the other hand, find the field free, and would therefore not be forced to become so intensely Turdine as the members of the genera Geocichla, Turdus, and Merula are now. Lastly, if in the future far more extensive and really exhaustive investigations should after all reveal the Prionopine ancestry of Phoornis, we should have one more instance of the affinities of the Hawaiian to the Australian fauna.

\section{Chasiempis sandvicensis. (Pl. I. figs. 6-10.)}

Bill like that of Muscicapine birds, broadened and flattened towards the base, with a distinct notch near the tip of the premaxilla.

Nostrils with round openings, situated near the middle of the bill and in front of a coriaceous groove which is covered with feathers. Posterior margin of this groove soft, anterior margin hard, without any opercular flap, but partly concealed by feathers. Long and strong upper rictal bristles are present.

Tongue flat, slightly bifid and broken up near the tip.

Pterylosis.-Primary remiges ten in number, the tenth or distal feather being two thirds the length of the ninth. Tip of wing formed by the seventh to fifth primaries, the ninth being shorter than the rest. Secondaries nine in number. Tail square and long, consisting of twelve feathers. The spinal feather-tract forms a rhombic saddle, in the middle of which is a faint indication of a featherless space. The posterior continuation of the saddle is narrow, but broadens out again towards the oil-gland. The pectoral tract has a distinct lateral hook.

The metatarsus is covered in front by about five scales, which are distinct in front only, but fused with each other towards the sides. The lateral and the median sides of the metatarsus are each protected by one long scute, and on the posterior or plantar side the scutes are separated by soft skin and do not form prominent ridges.

Alimentary canal. - Esophagus without crop. Stomach large and round, of moderate strength; it contained a large smooth caterpillar, together with the eggs, legs, and other remains of moths. The eggs were probably not swallowed separately, but together with the female insect. The gut is wide throughout; it is short, and stowed away in simple typically Oscine convolutions; the middle loop is the longest and is slightly spirally twisted; the last loop, partly overlapped by the first or duodenal loop, is almost closed. Two very small, non-functional cæca are inserted $2 \cdot 3$ centim. from the anus. The total length of the gut is 18 centim., the relative length about $4 \cdot 5$.

Summary.-Chasiempis is an insectivorous Oscine bird, which in some of its essential points agrees with the Muscicapidæ, while it differs considerably from the Pachycephalinæ, and therefore from the Laniidæ. I cannot find any resemblance between Chasiempis and Miro, which have been placed near each other (Cat. Birds Brit. Mus. 
vol. iv.). Of the last I have been able to examine specimens owing to the kindness of Sir Walter Buller. Lastly, the supposed affinity of Chasiempsis to Phocornis cannot be supported, because of the different nostrils, metatarsal scales, spinal and pectoral feather-tracts, food, and bones of the palate.

LoXioIdes BaILleui. (Pl. I. figs. 11-16.)

Bill like that of typical Conirostres and clearly Fringilline, without notches.

Nostrils almost round, open, impervious; dorsal and posterior margins soft, not forming a protecting flap or operculum; the ventral or outer margin almost entirely formed by the horny sheath of the bill.

Tongue thick and fleshy, much shorter than the bill, very slightly protractile; tip rounded off and ending in a neat horny scoop, which is formed by the lower horny covering of the tongue projecting a little; the brim of this scoop is slightly frayed out, as is the case in many Fringillidæ. Each side of the tongue is accompanied by a high longitudinal fold of soft tissue, which arises sidewards from the epiglottal region, extends forwards, and ultimately meets its fellow from the other side below the free end of the tongue, passing into the frenum lingur. Such guiding folds or projections of the lingual floor are frequently met with in birds which eat uncrushed seeds, and likewise in the Drepanididæ.

Pterylosis.-Spinal tract with an unbroken rhombic saddle, which is continued to the oil-gland. Pectoral tracts uniformly broad, without distinct lateral corners. Primary quills ten in number, the last of which is very slender and short, not functional, completely hidden by the upper covert. The tip of the wing is formed by the eighth and seventh primaries, the ninth being equal in length to the sixth, while the fifth is still shorter. The number of secondaries is nine, as in most Passerine birds. The twelve tail-feathers are nearly equal in length, but the median are slightly shorter.

The metatarsus is covered in front by six transverse scales, which decrease in length from the ankle-joint downwards. The median and the lateral side are each covered by one long scute, which is followed near the toes by several small scales.

Alimentary canal.-The œsophagus forms a capacious elongated dilatation, without, however, assuming the shape of a distinct crop. The stomach is square in shape and strongly muscular: that of one specimen contained, besides two soft hairless caterpillars, several hard seeds and some large unbusked seeds of another kind of plant; that of the second specimen contained small, very hard seeds, and small bits of rough red lava, which, of course, had been swallowed to assist in the trituration of the hard food. The gut is very narrow and long, and shows somewhat complicated convolutions, there being present an extra, closed, and rather long loop (3, 4, in fig. 16), which is stowed away dorsally from the usual central coil $(5,6,7,8)$. Both the absolute and the relative lengths of the gut vary individually; the female, the smaller specimen, possessing the longer gut:-

\&, absolute length of gut 49 centim., relative length 9 .

o, $\quad 46 \quad$ " $46 \quad 8$. 
Such a considerable relative length of gut occurs also in Loxia and Coccothranstes, and is even surpassed by Pinicola. About 2 centim. from the anus are two very small rudimentary cæca. 'The proportion of the right to the left lobe of the liver is $2: 1$.

The palatine region of the skull exhibits the features usual in the Fringillidæ; the various subfamilies and even genera of these birds show, however, so many considerable differences from each other, that the examination of a given type cannot reveal any binding characters. According to the late Professor W. K. Parker, who is the authority "on the skull of the ægithognathous birds," the palatine bones are not united with each other in the medio-ventral line in the Emberizine section of the Fringillidæ (e. g. Emberiza, Phrygilus, Plectrophanes lapponious) nor in Icterus. On the other hand, in the true Fringillinæ (e. g. Linaria, Estrilda, Coccothraustes) the two palatine bones are broadened above the sphenoid bone into one continuous bony plate, which being also fused with the posterior end of the vomer, forms a single interpalatine plate. This is the case in Psittacirostra and in Loxioides, the latter of which much resembles Pyrrhula in the configuration of its palatine region; anteriorly the jugal bones are quite fused with the palatines; the maxillo-palatines are hollow, as in many Fringillidæ, and (as a special feature) posteriorly almost touch the interpalatine spurs.

Summary.-Loxioides bailleui is a member of the Fringillidæ, and approaches the genera Loxia, Coccothraustes, and Pyrrhula.

Psittacirostra psittacea. (PI. I. figs. 1T-20.)

Bill like that of Loxioides.

Nostrils oval or kidney-shaped, surrounded by soft coriaceous tissue, which is naked and forms a small swollen flap, partly overhanging them from above. The internasal septum is complete, although cartilaginous only, as in Loxioides. This character, however, is of no importance owing to the variable condition of the septum in different genera; in Coccothraustes, for instance, the septum is thick and completely ossified. Considerable variations occur also in the lacrymal region, rendering futile in this respect any attempt to compare $P$ sittacirostra with other birds which are not Fringilline.

Tongue shorter than the bill, very slightly protractile, rather thick, hard, and horny, tapering out towards the tip, and while differing considerably from the tongue of Loxioides, nevertheless truly Fringilline.

Pterylosis almost entirely like that of Loxioides. Primary remiges ten in number; the tenth or terminal quill is, however, very slender and short, and completely covered by the upper covert. 'The tip of the wing is formed by the eighth and seventh quills, the ninth equals the sixth in length. The secondaries and the tail-feathers are like those of Loxioides.

Metatarsus covered in front by six or seven transverse scales, laterally and medially with one long scute. 
Alimentary canal.-The œsophagus forms a very distinct pouch-like crop, which rests on the right side between the two clavicles. Such a typical crop occurs in many truly granivorous Fringillidæ - for instance, in Pyrrhula, Loxia, and Vidua, less developed in Fringilla, Loxioides (q. v.), Emberiza, also in Ampelis and Panurus. The stomach is square, strongly muscular, internally lined with a strong corrugated brown cuticle; it contained seeds and particles of flowers. The whole gut is rather wide, consequently shorter and more regularly convoluted than that of Loxioides; its absolute length is 30.5 centim., its relative length 5.5 , agreeing in this respect with Fringilla colebs, Passer domesticus, and many other Passerine birds. The two cæca are inserted about 2 centim. from the anus, and are comparatively long ( 0.8 centim. and 1 centim. in length) and functional, which is a very exceptional feature among Passeres. The right lobe of the liver is in bulk about double that of the left.

Summary.-There are no features in Psittacirostra which disagree with its being placed among the Fringillidæ; on the other hand, its nostrils, crop, and intestinal convolutions show clearly that it well deserves generic distinction from Loxioides. Lastly, no characters remove these birds from the Fringillidæ and connect them with either the Dicæidæ or the Meliphagidæ.

Acrdlocercus braccatus. (Pls. II. and III. figs. 21-35.)

Bill.-The distal third of the edges of the upper and lower jaws is finely serrated, the points of the indentations being very sharp and directed forwards. There is no notch near the tip.

Nostrils large, somewhat removed fiom the base of the bill, with a large coriaceous upper operculum, and with a somewhat smaller lower one which is partly overlapped by the upper. The nostrils are bare, not covered by feathers, but there are a few soft rictal bristles.

Tongue as long as the bill, considerably protractile. The yellowish horny sheath of the tongue constitutes its greater portion. The lateral margins of the horny sheath are sharp and quite thin; they curve upwards and inwards, and, by approaching each other in the dorsal middle line, form two nearly closed tubes, each of which breaks up into two, and is frayed out on its lateral margin. The distal third of the tongue presents, therefore, the aspect of a quadruple brush. The hyoid bones extend backwards and upwards round the occiput, and end at the level of the middle of the orbit. The principal protractor muscle of the tongue is the M. genio-hyoideus. This consists of two parts, each of which arises as a narrow band from the inner margin of the middle of the mandible. This band passes backwards and splits into two. The median portion attaches itself to the upper half of the cerato-branchial or "hyoid horn," by surrounding or enveloping this bone in a slightly spiral direction, while only loosely fastened to it by connective tissue. The outer portion accompanies the cerato-branchial throughout its length on the anterior or dorsal surface and is attached to its tip. Both these portions, which form the genio-hyoid muscle, are surrounded by a common slippery sheath which compels them to act exclusively in the 
direction of the hyoid horn. The muscle has its punctum fixum at its origin at the mandible, and consequently by its contraction protrudes the tongue. The right and left horns of the tongue, each surrounded by its genio-hyoid muscle, may be compared to a flexible rod surrounded by an elastic steel spiral, which is fastened to one end of the rod; it will then be understood that the force with which, and the extent to which, the tongue can be propelled depends directly upon the length of the hyoid horns. Thus we see that in Woodpeckers and in Humming-birds, which can protrude their tongues very far, the hyoid horns are so long that they are carried quite round the skull, and with their tips reach the neighbourhood of the nostrils. The retractors of the tongue are the right and left stylo-hyoid muscles, each of which arises as a broad band from the lateral and posterior surface of the occiput, a little in front of and sidewards from the hyoid horn, crossing the two bands of the genio-hyoid of its side, and being inserted on the sides of the base of the tongue, laterally and dorsally from the base of the hyoid horn. These muscles, each having its punctum fixum at the occiput, act as the chief retractors of the tongue. Various other muscles move the tongue sidewards, lift it up towards the palate, or depress it in order to assist in the act of swallowing food. Two such depressor muscles are figured in Nectarinia, where they are seen to extend from the base of the tongue down the side of the trachea.

Remiges.-There are nine cubital quills or secondaries and ten primaries. The terminal distal or tenth quill is well developed, being nearly two thirds the length of the ninth; its upper covert is only 1 centim. long. As is frequently the case in birds in which the tenth primary is distinctly functional or of fair size, there is present an extremely small eleventh primary quill, together with an equally tiny upper covert. The tip of the wing is formed by the eighth to sixth primaries; the ninth equals the fourth in length.

The rectrices are twelve in number and soft-the middle pair being the longest, the outermost pair the shortest.

The spinal tract forms a distinct rhombic saddle, and is continued as an unbroker tract down to the base of the oil-gland, where it is slightly broader than at the hinder corner of the saddle. The feathers of the latter are fluffy. Between the contourfeathers of the spinal tract are interspersed numerous filoplumes or hair-like feathers, together with little black downs, some of which also occur on the apteria or bare spaces, especially sidewards from the saddle.

The well-d efined pectoral tracts exhibit nothing remarkable. The so-called pectoral or axillary yellow tufts consist of about twelve very thin soft feathers on each side, which are about 4 centim. in length, are black at the basal quarter, and arise in one row from the anterior margin of the wing-membrane near the shoulder. According to this position they belong to the inferior marginal contour-feathers, but they are modified into downs. Each feather consists of one long and feeble shaft with numerous almost equally long, but still feebler, rami or barbs. Each ramus, again, carries an anterior and a posterior series of radii or barbules. These barbules are at their basal 
portion flattened out into thin blades, but further towards the tip they become extremely thin and flexible. None of these barbules carry barbicels like those which in typical contour-feathers are transformed into cilia and hamuli or hooklets, but these barbules show at regular intervals a great number of peculiarly shaped and pointed nodules. The absence of such hooks prevents the barbules from forming a coherent vane, and renders the whole feather extremely soft and fluffy. The barbules of the more distal or marginal parts of the long barbs are shorter and thicker, and their nodules are less prominent.

The metatarsus is covered in front with five or six irregularly shaped transverse scales, which have a tendency to fuse with each other. All these scales overlap the lateral side of the metatarsus, and by complete fusion form one long continuous scute. The median side is covered by one similar scute, which is separated from the front row by a soft furrow. On the back of the metatarsus the median scales project as a prominent but somewhat soft ridge, which is connected with the lateral sheathing by soft skin.

Alimentary canal.-The esophagus has no crop. The stomach is comparatively small, oval, and furnished with strong muscles : in the specimens examined it contained Lepidopterous larvæ, hard pupa-cases, and other remnants of insects. The gut is of uniform width and soft; 1.5 centim. from the anus are two rudimentary cæca of 0.4 centim. in length. The total length of the gut from the stomach to the anus is 14.5 centim., its relative length only 3.5 ; in accordance with this very short relative length, the intestinal convolutions are very simple, forming only three short alternating loops, of which the second or middle loop shows no indication of a spiral twist. The proportions of the right and left lobes of the liver are $3: 2$.

Summary.-Acrulocercus nobilis and $A$. braccatus belong to the group Cinnyrimorphæ, judging from the serrated bill, the strongly developed nasal operculum, the principal features of the pterylosis (especially the functional tenth primary and the presence of axillary tufts), the scutellation of the tarsus, and the simplicity of the intestinal canal. They further belong to the family Meliphagidæ, owing to the quadruple brush-like tongue; they approach the subfamilies Myzomelinæ and Meliphaginæ proper, and of the latter the genera Meliphaga, Meliornis, Acanthorhynchus, and Acanthochora; in other words, they are more nearly related to the Australian than to either the Malayan or to the Pacific members of the group. Acrulocercus differs from them all, however, in its pattern of colour (bearing in this respect a striking resemblance to Drepanis pacifica), although black, yellow, and white are favourite colours among the Meliphaginæ (e. g. Meliphaga, Meliornis, and above all Pogonornis). The long and much graduated tail of Acrulocercus can scarcely be looked upon as an important deviation from the generally square or only slightly rounded tail of the Meliphaginæ, since it occurs also in the genus Acanthochcera of South Australia. 'The peculiarly pointed tail-feathers of Acrulocercus occur again in Drepanis pacifica, and in the New Zealand genus Pogonornis. 


\section{Chetoptila angustipluma.}

The following remarks refer to the stuffed specimen, which, owing to the liberality of $\mathrm{Mr}$. Wilson, now forms one of the treasures of the Cambridge Museum of Zoology. Unfortunately the horny sheath of the tip of the bill, perhaps to the extent of 0.5 centim., is broken off. The mandibular sheath is, however, nearly intact. The edges of the mandible are slightly overlapped by those of the premaxilla and appear to be quite smooth and not at all serrated. The premaxillary edges seem likewise to be smooth. Whether there was a notch near the tip, can no longer be made out. The nostrils are basal, situated within a large and bare coriaceous groove, and have a large upper operculum; they agree in every respect with those of other strong-billed Meliphaginæ.

Pterylosis. - The tenth primary is 5 centim. long and slightly curved inwards. The tip of the wing is formed by the seventh to fourth primaries; the eighth equals the third in length, the ninth is, with the exception of the tenth, the shortest of all. The feathers of the lower back are fluffy, those of the axillary region only slightly so. The twelve rectrices form a long and much graduated tail; the single feathers are obliquely 'pointed at their tips. Most of the feathers on the upper throat, near the base of the nostrils-and even those of the forehead-end in hair-like bristles.

Metararsus covered in front with six to seven transverse scales, of which those in the middle are the longest; all these front scales are partly fused with each other and with the long scute which covers the lateral side. On the median side is one long scute, with a few small scales near the toes. The latter closely resemble those of Acanthochoera; especially in the length of the hallux and its very strong and large claw.

Choetoptila angustipluma is certainly a member of the Meliphagidæ, and probably belongs to those Meliphaginæ which possess a multiple brush-tongue. In many of these birds the fine serration of the cutting-edges of the bill is replaced by larger and irregular dents, which are sometimes almost obsolete; and are then frequently associated with or rather supplanted by a tooth-like notch near the tip of the premaxilla. This is, for instance, the case in several species of Ptilotis and in Acanthochcera. With the latter South Australian and Tasmanian genus Chcetoptila agrees in most of the particulars mentioned above. The pattern and coloration of the plumage, with the light striated marks on the feathers, the shape of the tail, the feet, and even the hair-like curved tips of the feathers of the upper throat, closely resemble those of Acanthochora carunculata; but there is no trace of those peculiar wattles which are so conspicuous in many Meliphagine genera.

\section{DREPANiS PACIFICA.}

The following observations refer to the stuffed specimen of this now extinct bird, which Mr. Wilson was fortunate enough to procure. The structure of its tongue, the distribution of the feather-tracts, and the whole of its internal anatomical features 
remain therefore unknnwn, and can only be supposed to have resembled those of other Drepanididæ. The external features, except the coloration of the plumage, are entirely like those of the other Drepanididæ. The shape of the non-serrated bill, the operculated nostrils, their shape and size, agree in every detail with the corresponding parts of Hemignathus procerus and Vestiaria. The tenth primary is occult; the tip of the wing is formed by the eighth, seventh, and sixth primaries, the ninth equals the fifth in length. Some of the marginal axillary feathers are fluffy and elongated. The rich yellow feathers of the lower back are extremely fluffy and long. The twelve tailfeathers have obliquely pointed tips, but the tail, when spread out, is slightly rounded. The metatarsus is covered in front with a row of five or six transverse scales, which are partly fused with each other; the lateral side is protected by one long scute, and distally by several small scales, and the same applies to the median side. Whether there was a prominent ridge on the posterior side of the metatarsus cannot be determined with certainty. The second toe is the shortest, the middle one the longest, the hallux the strongest. The claw of the hallux is by far the longest and strongest.

There remains the question, whether the resemblance in shape and coloration of the whole bird to Acrulocercus is accidental or a case of mimicry; and if it is mimicry, which of the two birds is the original and which is the copy? The fundamental difference, at first sight almost imperceptible, between the serrated bill of the Meliphagine Acrulocercus and the smooth bill of Drepanis adds to the interest of the case. Of course the question cannot be settled conclusively, but the following arguments may help to a solution.

Both birds are aberrantly coloured, differing from their respective relations. All the Drepanididæ, except $D$. pacifica, are either of a uniform dull green, or a beautiful red, or red mottled with black, or, lastly, indifferently grey and brown like Oreomyza. Vivid yellow, combined with black and varied by a few white patches, which is the colour of Drepanis pacifica, appears abnormal in this family. D. pacifica differs likewise from its allies in being by far the largest and strongest.

Acrulocercus, a truly Meliphagine bird, on the other hand exhibits colours which occur also in many other Meliphagidæ, although none of these, except Pogonornis, are chiefly black with yellow and white ornaments. Moreover, yellow tufts in the axillary region are a favourite ornament among the Nectariniidæ, which are undoubtedly allied to the Meliphagidæ. Lastly, there are three species of Acrulocercus, all greatly resembling each other and distributed over most of the Hawaiian Islands, while there was apparently only one black-and-yellow Drepanis.

These arguments seem to vouch for the probability of Acrulocercus being the original, Drepanis pacifica the imitating form. However, it must not be forgotten that the Meliphagidæ are, in the Hawaiian Islands, represented only by Acrulocercus and Chotoptila, and that consequently the four species may be looked upon as strangers and intruders, while the Drepanididæ are present in considerable numbers as species and genera, and may therefore be regarded as.more indigenous. 
Certainly the curious resemblance between the two forms proved equally fatal to both, since both attracted their greatest enemy, Man, by their beautiful yellow plumes.

Vestiaria COCCINEA. (Pl. III. figs. 36-39.)

Bill.-The sharp cutting-edges of the bill are smooth, without the slightest indication of any serration. The edges of the premaxillary sheath fit closely over those of the mandible; the tip of the premaxilla projects a little, less than 5 millim., over those of the mandibles.

Nostrits bare, basal, only the posterior corner bordered by short feathers; bristles entirely absent. Nostrils shut by a complete upper operculum, which itself overlaps a similar but smaller flap arising from the ventral margin of the nasal opening.

Tongue.-The sharp dorso-lateral margins of the horny sheath of the tongue are raised upwards, and gradually meet each other in the middle line, without fusing with each other, but transforming the dorsal surface of the tapering tongue into a single semicanal. The distal halves of these raised margins are frayed out into numerous horny bristles or laciniæ, which become longer towards the tip of the tongue, cross each other, or are even interlaced, and thus turn the end of the tongue into a brush. The whole tongue is as long as the bill, and, when the latter is shut, completely fills the space between the two mandibles. The tongue cannot be protruded far, because the hyoid horns do not project above or beyond the level of the eye: they are shorter than in Nectarinia, but resemble those of Acrulocercus.

Pterylosis.-The spinal feather-tracts form a broad unbroken saddle, the sides of which are not sharply marked, while it is continued as a wide band to the base of the oil-gland. The feathers of the saddle, especially those of its anterior and lateral portions, are fluffy. The pectoral tracts resemble those of Hemignathus in their breadth and lateral expansion. There are elongated, fluffy axillary feather-tufts, which, however, are not conspicuously coloured. The tenth or most distal primary is very slender and short, and is concealed by its larger covert. The tip of the wing is formed by the eighth, seventh, and sixth quills, the ninth being equal to the fifth in length. Of the nine secondary or cubital remiges, the ninth or most proximal is by far the shortest, and in the male is entirely white, thus differing from the rest in colour as well as in size. The twelve rectrices are all obliquely pointed and form a nearly square tail, which resembles that of Loxops, and is slightly forked when closed.

Metatarsus covered in front with four or five transverse scales, which are partly fused with each other. The lateral side is covered by one long scute, which is followed by two or three smaller scales; the median side is protected by one long scute, which forms posteriorly a sharp projecting ridge. Of the toes, the first, second, and fourth are about equal in length, the second, which at its base is closely joined to the third, is perhaps the shortest. The first or hallux is, however, the strongest, and carries the thickest and longest claw.

Alimentary canal. - The œsophagus forms a distinct ventral crop, which is lodged 
between the arms of the furcula; its width is nearly 1 centim., its length 1.5 centim.; while its walls are thin and smooth internally. The stomach is decidedly small, of oval, almost globular shape, and rather weak: contents, chitinous remains of insects and a smooth caterpillar in one specimen, smooth caterpillars and small spiders in another. The gut is short, as in most strictly insectivorous birds. The duodenum is by far the widest portion; the rest of the canal is much narrower, especially that portion which forms the spiral. The convolutions of the gut are peculiar and rather unlike those of most other Passeres, owing to the irregular way in which the second principal or middle of the three loops is twisted into a spiral. The cæca are inserted only 1 centim. from the anus, and are very small, quite rudimentary sacs without function. Both the absolute and the relative length of the intestinal canal, from the stomach to the anus, varied somewhat in the adult specimens examined:

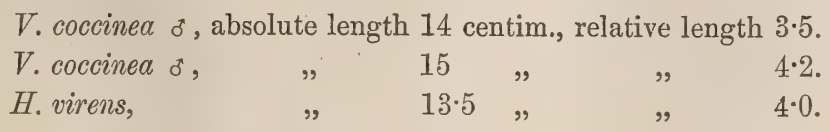

The proportion of the right to the left lobe of the liver is $3: 2$.

Bill not serrated.

\section{Himatione sanguinea. (Pl. III. figs. 40-41.)}

Nostrils basal, posterior lower corner partly concealed by short and somewhat bristly feathers; with a distinct dorsal operculum, which again overlaps a smaller lower flap near the basal and posterior corner of the nasal opening.

Tongue almost exactly like that of Vestiaria coccinea.

Pterylosis.-Tenth primary very small and slender, but stiff, hidden by the stiffer and longer upper covert. The tip of the wing is formed by the eighth and seventh primaries, the ninth equals the sixth. Tail and feet like those of Vestiaria. The feather-tracts also much resemble those of Vestiaria, and there are likewise present axillary tufts, which, however, are not yellow or otherwise conspicuously coloured.

Alimentary canal.-The œsophagus forms a very distinct ventral crop. The rest of the canal and its convolutions closely resemble those of Vestiaria: but the stomach is comparatively larger and stronger; in the specimens examined it was full of comminuted parts of soft insect larvæ. Absolute length of gut 13 centim., relative length 4 .

\section{LOXOPS COCCINEA.}

Bill short, almost straight, conical and pointed, not serrated.

Nostrits basal, small, oval, open, with a dorsal coriaceous opercular flap, which resembles that of Hemignathus, but is bulged out laterally and does not close the nostril, which is partly concealed by short and bristly postnarial feathers.

Tongue short, in conformity with the bill, but ending in a frayed-out single brush, which, like the whole organ, is formed exactly like that of the other Drepanididæ. 
The pterylosis presents the same features as in Hemignathus. The feathers of the sides of the saddle are long and fluffy. The axillaries, or rather one row of the marginal feathers near the shoulder, are elongated and somewhat fluffy. The tenth primary is only 0.5 centim. long, and is concealed by its slightly larger and stiffer covert. The tip of the wing is formed by the eighth and seventh quills, the ninth equals the sixth in length. The tail is very Fringilline in appearance, the middle pair of the soft rectrices being the shortest, the outer pair the longest.

The metatarsus is covered laterally by one scute and by four or five transverse scales in its distal half; the front is protected by four or five scales, which are partly fused with each other; the median side is covered by one long scute, which forms a prominent ridge behind.

Alimentary canal.-The œsophagus formed no crop, but a distinctly marked long oval dilatation, which was full of small soft insects. The stomach was small, oval, and muscular, full of the remains of soft insects. The total length of the gut is 12 centim., its relative length $4 \cdot 3$. The convolutions were torn by shot.

\section{Oreomyza BATRDi. (Pl. III. figs. 49-54.)}

Bill short, slightly curved, not serrated, pointed. Mandible slightly overlapped by, and a little shorter than, the premaxilla.

Nostrils resembling those of Himatione, Loxops, and Hemignathus. They are protected, but only partly closed, by an upper operculum, and at the posterior ventral corner by a smaller, internal flap like that of Vestiaria described and figured.

Tongue a little shorter than the bill, thin and horny, but at first sight apparently different from that of the Drepanididæ. However, the lateral horny margins are raised up dorsally and frayed out. The distal fourth of the horny part of the tongue is slightly split into a right and a left half, but far less than in Coereba. This broader, shorter, and less decidedly tubular tongue is in conformity with the slightly broader bill.

Pterylosis like that of Loxops, but the feathers on the central portion of the saddle and on its continuation towards the oil-gland are a little more scanty and weaker. The axillaries are elongated and fluffy.

Metatarsus covered in front with five or six strongly marked scales, and laterally with five or six scales which decrease in size towards the toes; the median side is covered with one scute near the ankle-joint, distally with three small scales.

Alimentary canal.-The œesophagus has, as in Loxops, an oval dilatation, which contained the same sort of soft yellow caterpillar speckled with brown as seems to be the food of so many Hawaiian birds. The stomach was oval and comparatively large, but not strong, 1 centim. broad and 1.5 long, and contained caterpillars. The gut is long for a bird which lives on soft larvæ, namely 19 centim., with a relative length of 5 . The convolutions of the gut much resemble those of other Drepanididæ. 


\section{Chrysomitridops CARULEIROSTRIS.}

This little bird agrees in most of its important features either with Loxops or with Oreomyza.

\section{Hemignathus Procerus. (Pl. III. figs. 42-46.)}

Bill enormously elongated and curved, not serrated. The cutting margins of the mandibles are sharply curved inwards and are therefore partly overlapped by those of the premaxilla, which projects nearly 1 centim. beyond the tip of the mandibles.

Tongue as long as the mandible; forming nearly throughout its length an almost complete tubular brush. Otherwise the tongue is formed exactly like that of the other Drepanididæ.

Pterylosis also like that of the other Drepanididæ: The tenth primary is very slender and 0.7 centim. long, like its covert. The tip of the wing is formed by the eighth, seventh, and sixth primaries; but the ninth is slightly shorter than the sixth and a little longer than the fifth. The tail is soft, nearly square, and short.

The scutellation of the metatarsus is intermediate between those of Oreomyza and Acrulocercus, owing to the tendency of the four anterior scales to fuse with each other and with the lateral row, which, however, is composed of one long proximal scute and several very small distal scales. The median side is protected by one long unbroken scute; which forms a rounded-off and not a prominent ridge.

Alimentary canal.-The cesophagus is thin-walled and has an elongated but not pouch-like dilatation, which internally is furnished with nearly twenty longitudinal ridges, apparently permanent; it contained one smooth caterpillar. The stomach is quadrangular and extremely muscular; it was crammed full of comminuted remains of caterpillars and spiders. Digestion was assisted by several angular bits of lava. In another specimen it contained, besides insects and bits of lava, several peculiarly shaped seeds, very hard and smooth. Whether these seeds were likewise swallowed in order to help in the trituration of the food appears doubtful, because of their smooth surfaces. The absolute length of the gut, which forms a typical central spiral, though with a peculiarly twisted returning branch (marked 6, 7 in fig. 45 ), is 20.5 centim., giving the relative length of $4 \cdot 5$.

\section{Hemignathus olivaceus: (Pl. III. figs. 47, 48.)}

This species differs from the long-billed form chiefly in the formation of its short mandible. The tongue is consequently short and less tubular, being intermediate in structure and appearance between those of Himatione and Vestiaria. The stomach is, as in $H$. procerus, quadrangular and strong; it contained, however, only spiders and a huge caterpillar, with no stones or other triturating matter. The convolutions of the intestinal canal are like those of the other species; but the central spiral has one twist more, owing to the greater length of the gut, the total length being as much as $25 \cdot 5$ centim., giving the relative length: of 6 : 


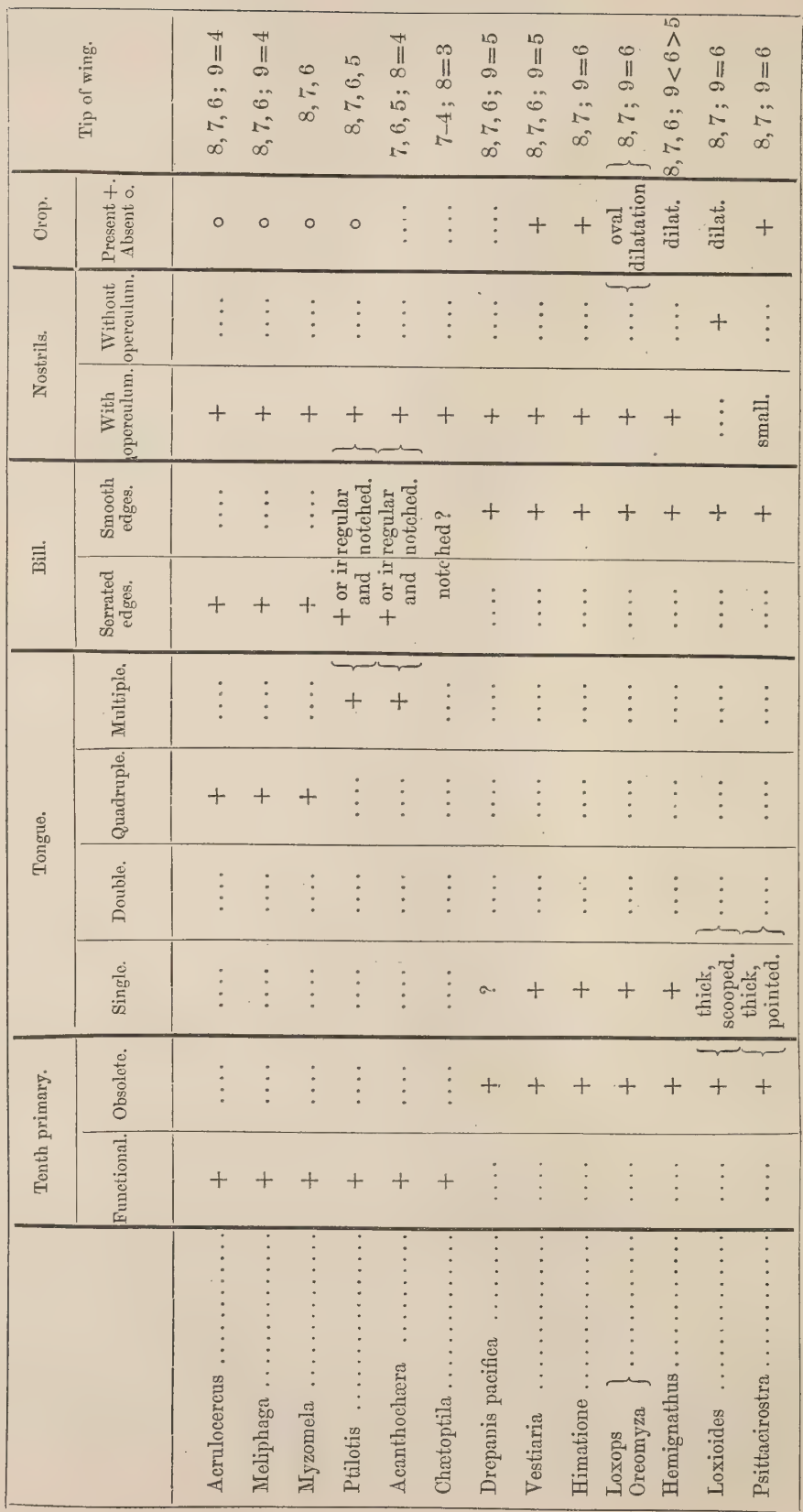




\section{THE AFFINITIES OF THE DREPANIDIDA.}

The genera Drepanis, Vestiaria, Himatione, Loxops, Chrysomitridops, Oreomyza, and Hemignathus resemble each other so much, and differ at the same time so considerably from other birds, that they may well be distinguished as Drepanididæ. There remains the question to which other groups or families these Drepanididæ are most nearly allied. Certainly not to the Dicæidæ, because these can at once be distinguished, first by the tongue, which ends in four equally-sized semitubular projections without the slightest indication of laciniated or frayed-out margins, secondly by the distally forked spinal saddle, both being characters which occur in no Cinnyrimorphæ. The shape of the tongue of Dicarm is unique, and the forked saddle bears the closest resemblance to that of the Hirundinidæ. Nor are the Drepanididæ allied to the Zosteropidæ, birds of which the deeply forked and smooth tongues, the pterylosis, and various other characters make it very doubtful whether they are rightly included among the Meliphagidæ.

If we assume that all the Oscines with tubular or with brush-shaped tongues are comparatively more nearly allied to each other than to the rest of the Oscines, we can arrange them as follows, using the condition of the edges of the bill and the length of the tenth or terminal primary as further differentiating characters:-

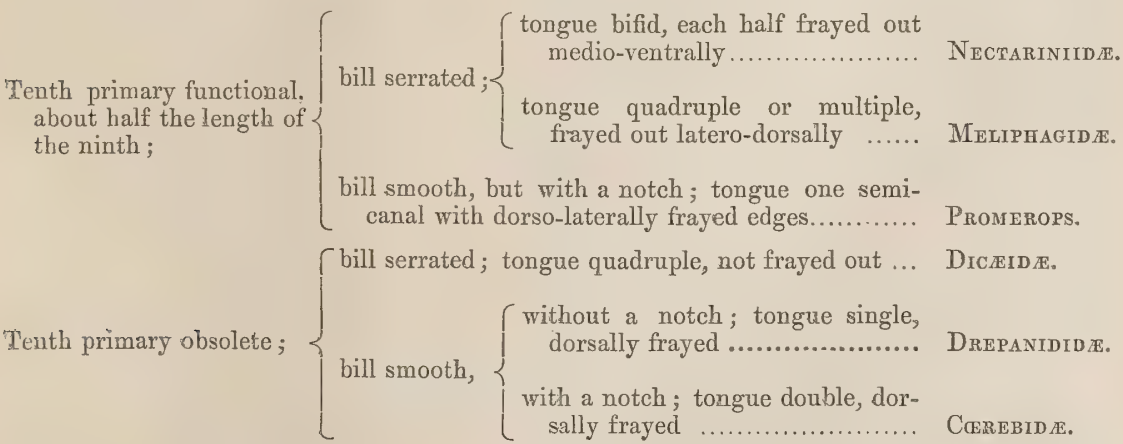

It is to be observed that if split in the middle line the tongue of the Drepanididæ would assume the characters of that of the Cœrebidæ, while the multiple brush-tongue of many of the Meliphagidæ can be derived directly from the quadruple brush. It is also probable that the absence or presence of serrated edges stands in correlation to the structure of the tongue. The following arrangement may therefore be preferable:-

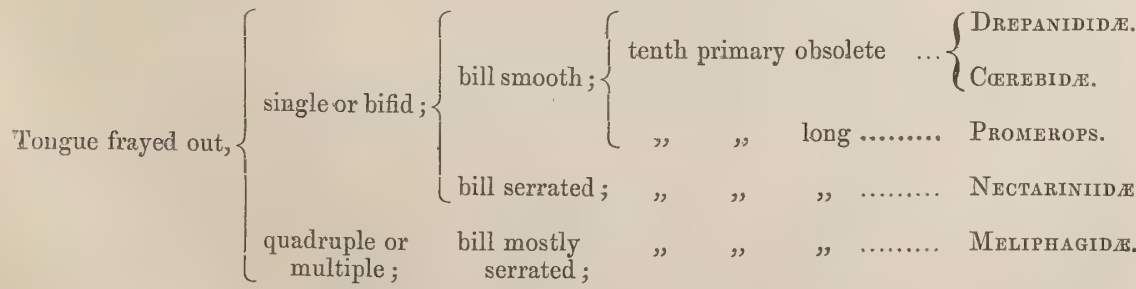

Tongue not frayed, quadruple; bill serrated; tenth primary obsolete ........... DicঞIDx. 
While the Dicæidæ will always assume a separate position, to whichever characters we give preference, the Drepanididæ can, on the other hand, be separated from the Cœrebidæ only by the notch in the premaxilla.

The whole assembly of birds with tubular or brush-shaped tongues appears rather heterogeneous, but not so hopelessly divergent as the so-called Oscines novem-pennatæ, which correspond with the Tanagroid Passeres of Wallace, and with the section Fringilliformes of the Catalogue of the Birds in the British Museum. 'The families of nine-quilled Passeres are ${ }^{1}$ :-

1. Dісдірж (excl. Drepanididæ).

6. Drepanidida.

2. HirUNDiNide.

7. Cerebide.

3. Амpelidas.

8. Tanagride.

4. MNiotiLtide.

9. ICTERIDF.

5. Motacillidde.

10. Fringithide.

To these should be added Zosteropidæ, on account of their terminal or tenth primary, which is extremely short and sometimes even suppressed altogether; these birds certainly are more deserving of being called nine-quilled than many Hirundinidæ and Icteridæ.

Now we see that if we attribute more taxonomic value to the tenth primary than to the tongue, the Drepanididæ are completely removed from the Cinnyrimorphæ, with the Meliphagine family of which they have undoubtedly many important features in common, besides the structure of their tongues. I have already (p. 11) given some of the principal reasons why the Dicæidæ (exclusive of the Drepanididæ) cannot be nearly related to the Drepanididæ, while on the other hand their associations with the Hirundinidæ are strong. If we want to retain the section Fringilliformes, then the Dicæidæ, together with the Hirundinidæ, should form one, let us say, Hirundinine subsection; while the third, fourth, and fifth families enumerated above are likewise widely different from the rest, to which the appellation Fringilliformes might advantageously be restricted. Whether the Drepanidida are to be included in this Fringilliform assembly or in that of the Meliphagidæ cannot be settled until we have examined the taxonomic value of their characters with reference to the Cinnyrimorphæ, or rather Meliphagida, and to the Fringilliformes.

The formation of the tongue agrees with that of the Cœrebidæ (Fringilliformes) and with that of the Australian Myzomeline genus Acanthorhynchus. The possession of such a latero-dorsally frayed-out semitubular tongue does not consequently settle the question, and, if anything, indicates that the Drepanididæ, through the Cœrebidæ, form a link between Fringilliformes and Meliphagidæ, unless we assume that such tongues have been developed independently in the groups in question. Such an assumption is perfectly possible. On a former occasion ${ }^{2} \mathrm{I}$ have shown that the

${ }^{1}$ In a paper entitled "Remarks on the Numbers and on the Phylogenetic Development of the Remiges of Birds," Proc. Zool. Soc. 1888, pp. 655-667, I have drawn attention to the variability in length of this tenth primary, which is supposed to be absent, but nevertheless occasionally 3 centim. long, in the Fringilliformes.

2 "On the Suctorial Apparatus of the Tenuirostres," Proc. Zool. Soc. 1883, pp. 62-69, pl. xvi. 
tubular and brush-like portions of such tongues are formed entirely by the elongation, enlargement, and splitting of the ventral half of the horny sheath, while the dorsal half or covering does not partake of this formation, but tapers out and gradually disappears where the body or fleshy portion of the tongue ends. Indications of an elongation, with a frayed-out margin, of the ventral sheath occur in the tongues of many Fringillidæ, e. $g$. in Loxioides. Morphologically, we can derive a brush-tongue from a Fringilline, but not from either a Sylviine, Laniinæ, or Turdine tongue.

The smooth, not serrated, edges of the bill are a feature of the Cœrebidæ, while those Meliphagidæ which like them possess no serrated edges also differ in the formation of their whole bill from others of their family. It is therefore not advisable to compare the Drepanididæ with the smooth-billed Meliphagidæ. The general shape of the bill differs so greatly in the various Drepanididæ, and is subject to such alterations in the numerous Fringilliformes, that no valid conclusions can be drawn from it. We know for certain that the bill is a most adaptive organ, and the arguments concerning the tongue apply still more forcibly to the bill.

The nostrils, with their strongly developed opercula, seem to be decidedly Cinnyrimorphous, and in the special description of the various Drepanididæ this feature has been laid stress upon in order to differentiate them from Loxioides and Psittacirostra, which are Fringillidæ. But here again the Drepanididæ are intermediate, their nostrils possessing both the upper and the lower flap, although the upper one is never so complete as in most Meliphagidæ. 'The completeness of the operculum is correlated to the length and shape of the bill and to the use of the latter: hence the variability.

The condition of the primary quills of the Dicæidæ strongly favours their Fringilliform affinity, not merely because of the obsolete nature of the tenth quill, but also on account of the entire absence of an eleventh quill. An eleventh quill does not seem to occur in the Fringilliformes, although some of them have the tenth quill not more reduced than many Alaudidx and Ploceidæ. In many species of the latter two families, and even in some Icteridæ, the tenth primary is distinctly functional, and comparatively of the same size as it is in many Meliphagidæ and Nectariniidæ; but these latter two groups have an extra quill, the eleventh. Hence it is not so much the mere size of the tenth quill as its non-association with an eleventh quill that gives it its taxonomic value in the Drepanididx.

The rest of the pterylosis, the feather-tracts, affords us no help, because the Meliphagidæ and the Fringilliformes seem to differ less from each other in these respects than do the Cinnyrimorphæ among themselves, notably Arachnothera and Promerops. However, the fluffy nature of the feathers of the back, flanks, and axillaries in the Drepanididæ reminds us of the Meliphagidæ and not of the Fringilliformes. The pattern of colour affords no clue at all, because the red of Vestiaria and of Himatione, although remarkable for its absence in all the Meliphaginæ, is a favourite colour of the Myzomelinæ, and the Fringilliformes, like the Psittaci, exhibit all conceivabie colours. 
The shape of the tail can scarcely be considered in earnest, although its Fringilliform appearance in the Drepanididæ is obvious.

The scutellation of the tarsus likewise permits of no safe generalization applicable to families and not to genera only.

Concerning the alimentary canal, the possession of a distinct ventral crop, or at least an obvious dilatation of the œsophagus, by the Drepanididæ is unquestionably a Fringilliform character, because of all the Oscines only some Fringillidæ have hitherto been known to possess a crop. The crop of the apparently strictly-insectivorous Drepanididæ is therefore all the more remarkable, although the Trochilidæ have it likewise welldeveloped.

The peculiar intestinal convolutions of the Drepanididæ cannot unfortunately be brought into comparison, owing to want of material in other groups, notably Cœrebidæ. The latter are insectivorous, to judge from their tongues strictly so ; many Fringillidx are granivorous or have a mixed diet: hence the resemblance between several of the Drepanididæ and Meliphagidæ is not decisive. The bones of the palate of the Drepanididæ, especially of Hemignathus, and in a less degree of Vestiaria, are most peculiar. The vomer is posteriorly completely fused with the palatines, and the lanceolate space between the two halves of the basal or dorsal parts of the palatines is closed by a transparent plate of bone, which covers, and rests upon, the sphenoid. Such a truly interpalatine plate occurs in many Fringillidæ. The ventral palatine spurs (Parker's interpalatine spurs) are very high and slender, and posteriorly extended to such an extent that they project far beyond the level of the articulation of the pterygoids. The latter articulate with the palatines, and not with the sphenoid at all, by distinct cartilaginous feet, resembling in this respect again certain Fringillidæ, e.g. Coccothraustes, although in the latter these feet are bony and liable to fuse with the palatines. The transpalatine or posterior lateral spurs are long and very slender. The maxillo-palatines are long and slender, passing ventrally over and past the anterior fork of the vomer and touching with their tips the anterior interpalatine spur; they rather resemble the same parts of Loxioides and of Coccothraustes: we must, however, bear in mind how much these little bones vary in shape, size, and position even in the various Fringillidæ, as a glance at the numerous illustrations in Parker's work on the Egithognathous skull will show. The whole arrangement of the bones of the palate of the Drepanididæ is totally different from that of the Meliphagidæ and other Cinnyrimorphr, and can only be compared with that which is indicated to a small extent in some Fringillidæ (Coccothraustes, Cardinalis, Estrilda). The configuration of these bones in the Drepanididæ looks as if it were derived from Fringilline conditions by reduction of the width (not length) of the palatine expansions, not vice versâ. This may well be the case considering the lesser strength of the masticatory muscles in the Drepanididæ in comparison with that of typical Conirostres, and considering that the elongated bill of the Drepanididæ is undoubtedly not a primary feature but a secondary specialization. That Loxioides and Psittecirostra differ so much in the configuration of 
their palatines from the Drepanididx is another weighty argument against their affinity to that family.

Now to sum up: although these remarks are scanty, necessarily incomplete, and consequently premature, on account of the want of anything like a sufficient amount of suitable material, I consider that the Drepanididx form a separate family of the Fringilliformes rather than of Meliphagine birds or even of the Cinnyrimorphæ, and that of the Fringilliformes they are nearest allied to the Cœrebidæ, $i$. e. to the Neotropical and Central-American families. Thence to the Fringillidæ is a long way, but we can imagine the intermediate stages. Loxioides and Psittacirostra I judge to be Fringillidæ, while I consider that there is no direct connection between these two genera and the Drepanididæ. None of these forms can be included among the Dicæidæ, which are an essentially Old-World family.

If the numerous resemblances between the Drepanididæ and the Meliphagidæ are not all merely coincidental-and they cannot be explained away at all satisfactorilythen the large group of the Cinnyrimorphæ (through the Meliphagidæ and possibly through the genus Zosterops, unless these birds connect the Nectariniidre in another direction) and that of the Fringilliformes (through the Drepanididæ and Cœrebidæ) converge to form a still larger group. How many other families will ultimately be found to gravitate towards the same centre must be left to him who may be favoured with an exhaustive supply of spirit-specimens, and will not shrink from devoting much time and labour to their examination. Whenever we endeavour to study seriously even a few different Oscines, the attempt is apt to assume enormous dimensions. The examination of a small twig of the Passerine branch of the Avine tree shakes and disturbs the whole branch, if not the whole top of the famous ideal tree. At any rate we seem in our case to get a glimpse of one of the bigger ramifications of the Oscine portion; and although, at first sight, the idea of a Fringilli-Cinnyrimorphous branch appears rather appalling, it is after all not more diversified than another branch, which is composed of the Corvidæ, Lauiidæ, and Muscicapidæ. A Raven and a Flycutcher do not seem to have much in common, but with the help of the Austrocoraces and other tropical forms the differences fade away and vanish.

\section{LIST OF ILLUSTRA'TIONS (PLATES I.-III.).}

Figs. 1-5. 1'HжоRNis овscura.

1. Dorsal, 2. Lateral view of nostrils and bill. Nat, size.

3. Tongue, dorsal view. Nat. size.

4. Ventral view of the bones of the palate; enlarged. $p t .=$ pterygoids ; $m a x . p l$. = maxillopalatines; a.int.pl.=anterior or interpalatine spur or process.

5. Right-sided view of the intestinal convolutions, beginning with one near the pylorus and ending with eight at the anus. 
Figs. 6-10. Chasiemíts sandvicensis.

6. Dorsal view of the bill, nostrils, and feather-tracts. Nat. size.

7. Side view of bill and nostrils. Nat. size.

8. Dorsal view of tongue. Nat. size.

9. Ventral view of bones of palate; enlarged. $v .=$ vomer; $\max . p l$. =left maxillo-palatine; $t r . p l .=$ transpalatine portion of left palatine.

10. Right-sided view of the intestinal convolutions.

liigs. 11-16. Loxioides bailleut.

11. Side view of bill and nostrils. Nat. size.

12 $a$. Dorsal view of the tongue, situated within the under jaw. Nat. size.

$12 b$. Dorsal view of the tongue proper. Nat. size.

13. Bones of the palate.

14. Scutellation of metatarsus, seen from the lateral side. Nat. size.

15. Dorsal feather-tracts. Nat, size.

16. Convolutions of the intestinal canal.

Higs. 17-20. Psittacirostra Psitracea. Nat. size.

Figs. 21-35. Acrulocercus braccatus.

$21 a$. Bill, nostrils, and principal muscles of the tongue, after removal of the skin. Nat. size. For comparison, in order to understand the mechanism, see fig. $21 b$, Nectarinia splendida. g.hy.=geniohyoid muscle; st.hy.= stylohyoid muscle; $t r .=$ trachea.

22. Transverse section through the bill, across the nostrils, to show position of upper and lower opercula (u.o. and l.o.) : $t=$ tongue; $m=$ mandible.

23, 24. Dorsal and ventral views of pterylosis.

25. Transverse section through metatarsus, to show position of scales; enlarged.

26,27 . Ventral and dorsal views of the tongue; enlarged.

28. Diagrammatic representation of mode of splitting and fraying out of the sheath of the tongue.

29. Ventral view of the bones of the palate; enlarged.

30. One entire feather of the axillary tufts; enlarged and diagrammatic.

31. One barb of the same feather, from its basal half; considerably magnified, to show absence of hooklets.

32. The same, from the tip of the feather; seen under the same power as fig. 31.

33. The tip of a barbule of the barb represented by fig. 32 ; strongly magnified.

34. The tip of a barbule of the more fluffy or basal barbs; strongly magnified.

35. Diagram of the intestinal convolutions.

Figs. 36-39. Vestiaria coccinea.

36. Side view of bill and nostrils. Nat. size.

37. Transverse section across the nostrils. Same as fig. 22 .

38. Side view of the tongue; enlarged.

39. Intestinal convolutions.

Fig. 40. Himatione sanguinea. Dorsal view of the tongue; enlarged.

Iig. 41. Hrmatione virens. The intestinal convolutions, seen from the right side. 
Wigs. 42-46. Hemignathus procerus.

42. Right nostril and base of bill; enlarged.

43. Right view of tongue; enlarged.

44. The dorsal or spinal feather-tract.

45. The intestinal convolutions.

46. Ventral view of the bones of the palate; enlarged. $v=$ vomer; $t r \cdot p l .=$ transpalatine expansion of palatine; $p . i n t . p l_{.}=$posterior interpalatine spur of palatine; $p t_{.}=$pterygoid.

Figs. 47, 48. Hemignathes olivaceus.

47. The pectoral feather-tracts.

48. The intestinal convolutions.

Figs. 49-54. OReomyza batrdi.

49. Side view of bill and nostril ; enlarged.

50. Dorsal view of tongue; enlarged.

51. Lateral view of left metatarsus.

52. The spinal feather-tract.

53. The intestinal convolutions in situ, seen from the right side.

54. Diagram of the convolutions.

Mig. 55. Diczun pectorale. Dorsal feather-tracts, after Nitzsch.

Fig. 56. Drcmum trigonostigma. Dorsal view of the tongue; enlarged.

Higs. 57, 58. Carreba longirostris.

57. Dorsal view of the tongue; enlarged.

58. Ventral view of the tip of the same tongue; still more enlarged. 

FURTHER REMARKS

ON THE

RELATIONSHIPS OF THE DREPANIDIDE.

BY

HANS GADOW, M.A., PH.D., F.R.S.

In my first paper on the anatomy of the Birds of the Sandwich Islands ("Aves Hawaiienses,' Pt. II. pp. 1-23, Pls. I.-III.) I had come to the conclusion that the genera Psittacirostra and Loxioüdes were Fringillidæ, and not to be included among the Drepanididæ. This view has never met with favour from Mr. Perkins, who has persistently and consistently maintained, first, that the two genera in question are not "Finches"; secondly, that they belong to the same group as do the Drepanididx, whatever the relationship of the latter may be. The same applies to the more recently discovered genera Chloridops, Rhodacanthis, and Pseudonestor. Mr. Perkins has arrived at this notion from the study of the habits, the voice, and the peculiarly strong and disagreeable scent of the birds.

I promised Mr. Perkins to reconsider the whole question on the strength of more extensive anatomical material ${ }^{1}$, and I now have much pleasure in declaring that most likely his view is the right one. By using the words "most likely," I do not want to hedge, but once for all draw attention to the fact that such questions as the present one cannot be proved, although they may be reasoned out.

1 The material submitted to anatomical examination is numerous enough (Drepanis, Viridonia, Palmeria, Himatione, Loxops, Oreomyza, Pseudonestor, Psittacirostra, some of them in several specimens either complete or in parts), but it is sadly deficient in so far that as regards Rhodacanthis and Chloridops there is only one single tongue of the former! Of course this whole investigation is thereby rendered incomplete. Rhodacanthis and Chloridops are both extreme forms. It seems reasonable to connect them with Loxiö̈des, Psittacirostrci, and Pseudonestor. Nothing would be gained by trying to exclude the first two genera from the Drepanididx after once the other three have been admitted. The same applies to Ciridops anna, of which hearsay report tells that it has or had a split and somewhat frayed-out tongue. 
Although it is, as a rule, not an agreeable task to acknowledge one's self in the wrong, I have in this case derived a good deal of pleasure from my renewed and more extensive investigations, since-if our conjoint conclusions are correct-they have revealed one of the most remarkable instances of convergent analogies between what are generally called Fringillidæ and some of the Drepanididæ.

Nobody has as yet been able to diagnose any family of the Fringilliformes. Certainly the Drepanididæ, after the addition of the thick-billed genera, defy any real diagnosis, except perhaps that they are nine-quilled Oscines, which are confined to the Sandwich Islands. This is perhaps a step in advance.

I firmly believe that in time to come we shall more and more frequently have to admit geographical distribution as a diagnostic character not only of species and genera but even of larger groups.

I am inclined to accept the central portion of Dr. Sharpe's scheme of nine-quilled Passeres ( $c f$. Cat. Birds, x. p. 2), but modify it slightly as follows:-

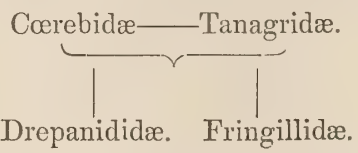

Which, translated into the apparently very exact, but really mystical and still all-in-theclouds parlance of the phylogenist, means that there was once an undefined stock of generalized Cœrebine and Tanagrine birds, whence have sprung as two independent offshoots the Drepanididæ and Fringillidæ. The more numerous of these "families" has specialized more in the direction of seed-eaters, while the other very small family underwent the necessity of adapting itself to peculiar insular conditions, and either specialized as insect-eaters (probing the insects out of cracks, not catching them on the wing), or in a roundabout way became as much graminivorous and thick-billed as many of the Fringillidæ and Tanagridæ.

In talking of these "families" we are apt to forget, or rather we never appreciate, the solemn fact that, strictly speaking, all the Oscines together are of the rank of one family only! The greatest differences between the so-called families of Oscines are in reality of very small value; and when we are discussing, as in the present case, the morphological difference between what should be termed subsections of subfamilies, we have about arrived at the end of our tether, or rather perceptive insight. Of course there are differences between them, larger and more stable than those between, for instance, various species of Paroaria, which are "striking" enough, but we do not know them! In fact we have to be grateful for small mercies.

We cannot, as said before, define either Drepanididæ or Fringillidæ, Cœrebidæ or Tanagridæ-that means to say, we have no single character, nor a combination of features, which apply to all the species of each family. This concerns the pterylosis, namely distribution of feathers, fluffy nature of the feathers of the lower back, relative length and shape of the primaries and of the tail, the pattern of colour; it applies 
also to the feet, the shape of the bill, and the structure of the tongue, the modifications of the palatal framework, and to the intestinal tract inclusive of its convolutions. The smell of the Drepanididx is different from anything else I know; but are we prepared to admit this as a diagnostic character, until we know that it does not depend upon the food, although Acrulocercus is devoid of that sort of scent?

\section{Additional Data concerning the Relationship of the thick-tilled Hawaiian Birds.}

In my former paper, p. 6, and fig. 18, I described the tongue of Psittacirostra as "rather thick, hard, and horny, tapering out towards the tip, and while differing considerably from the tongue of Loxiö̈des, nevertheless truly Fringilline." Several well-preserved specimens of Psittacirostra, brought home by $\mathrm{Mr}$. Perkins, show a different condition. The tongue is Heshy in its basal three-quarters, while the distal quarter is thin and horny, slightly split in the middle, and with the thin lateral edges turned up and inwards, forming a very imperfect half-tube, and slightly frayed out distally, $i . e$. at the anterior free end. It is consequently far less "Fringilline" than the tongue of Loxioïdes. On the other hand it resembles, or approaches, that of Pseudonestor, which is far less fleshy, more slender, more deeply split in the middle; the distal third of the horny sheath becomes gradually transparent towards the tip, is very slightly frayed out towards the tip and on the lateral edges, but shows no indication of curling up of the free margins.

The tongue of Rhodacanthis, of which Mr. Perkins has brought home one single specimen but well preserved, is the most compact of all. Its upper surface is slightly scooped out, while the whole under surface is covered with the usual thick and hard horny sheath, the thin lateral edges of which curl over upon the dorso-lateral sides, and are very slightly frayed out at the distal sixth only, where alone they form slightly sharp edges of the tongue, the tip of which is scarcely split at all.

The shape and structure of the tongue is primarily referable not so much to the nature of the food itself (if soft insects, as spiders, larvæ, or hard seeds) as to the way in which these various kinds of food are to be procured. The long- and slender-billed birds probe flowers, or cracks of bark or lava, for insects, which they then coax and brush out with their slender and flexible tongue; the thick-billed birds break open the pods or worm-eaten trees, and then scoop out or simply nip the insects or seeds.

When arranged according to the tongue, Oreomyza and Psittacirostra assume a somewhat central position, leading on the one side to Pseudonestor and ending with Loxioides as an extreme; while on the other side Oreomyza leads to the more complete tubular brush-tongue of Chrysomitridops, Loxops, Himatione, and Palmeria, to the extreme as represented by Vestiaria, Drepanis, Viridonia, and Hemignathus.

A similar divergent development is traceable in the modifications of the operculum and the nostrils. Himatione, Loxops, and Oreomyza assume a central, more indifferent 
position, whence the most perfectly operculated Palmeria, Vestiaria, Drepanis, and Hemignathus can be traced. On the other hand, Psittacirostra has still a small but distinct opercular flap, then follows Loxiödes', and lastly Pseudonestor, with no operculum whatever and with round nostrils embedded in soft surroundings. Rhodacanthis and Chloridops make a side departure from the last two genera; there is no operculum, but the nostrils are long-oval, embedded in soft surroundings; the soft portion bordering the lower margin of the nostrils lies in a deeper level than the dorsal border of the nostril, and seems to be the remnant of the inner lower flap which is so common in many of the Drepanididæ, see Part II., Pl. III. fig. 37. Anyhow there is no detailed resemblance of the narial arrangement of other birds with any of the Fringillidæ, while Rhodacanthis and Chloridops run surprisingly close to the Tanagrine Pitylus (not to the Fringilline Pheuctious, Paroaria, or Chloris), and still greater is the resemblance between Psittacirostra and Tanagra, e. g. bonariensis. An absolute distinction between any of the thick-billed Hawaiian birds and the Fringillidæ seems to be that in the latter the generally open and roundish nostril is blocked, so to speak, from the inside by the anterior little concha naris, which projects into the fundus of the nostril.

We have here remarkable cases of collateral or convergent development, as exhibited by the numerous members of the Drepanididæ. The long- and slender-billed forms have developed features which make them very similar to certain Meliphagidæ (cf. Arachnothera and Hemignathus), and in the case of Drepanis pacifica and Acrulocercus the resemblance has become startling. Equally near or puzzling has become the approach to various Fringillidæ and Tanagridæ by the thick-billed Hawaiian birds.

The analogies with Fringillidæ extend even to some unexpected details of structure as well as habits. Mr. Perkins says ('Aves Hawaiienses,' Part VI.) that Pseudonestor is "in its movements Parrot-like in the extreme, especially in the varied hanging attitudes that it assumes, while the similarity is still further increased by the shape of its beak ..... generally clinging to the under sides of the thin branches or twigs, the head raised above the upper surface." Does all this not remind us at once of Loxia pityopsittacus?

Curiously enough, there exists another still more striking analogy between the Crossbills and some Hawaiian birds, namely with Loxops incl. Chrysomitridops. As already known to Cabanis, when he established the genus Loxops, the under jaws of these little birds are not symmetrical - the distal half of the under jaw is twisted either to the right or to the left. It is interesting to note that the amount of twisting varies individually, right- and left-billed specimens occurring in equal numbers, and that it is smallest in young birds. There is not the slightest doubt that this asymmetry is acquired individually by their twisting open husks or seeds, or cracks of bark, in search of their food.

It would be a case of great rashness to look upon the twisted bills of Loxops and the pendulous attitudes of Pseudonestor as confirmatory indications of their Fringilline affinities. Now it so happens that Loxops and Chrysomitridops combine with their 
Finch- or rather Siskin-like appearance other characters which reveal these birds as typical Drepanididx:-(1) The tongue, which, of the length of the bill, forms a typical brush-tube; it is as typically developed as in the most intensified Drepanididæ. (2) The arrangement of the bones of the palate conforms with that of the more slenderbilled forms, namely, the maxillo-palatines are rather long and slender, the interpalatine spurs form a pair of narrow vertical plates, the transpalatines are very little broadened, but the right and left halves are fused in the middle into one plate, together with the vomer. (3) The nostrils have a small but distinct soft operculum, which, however, does not close the narial opening, which is long-oval; the general configuration closely resembles that of Oreomyza, while the differences from Fringillidæ, if examined side by side, are obvious.

We have to consider the following hypotheses :-

I. All the Sandwich Island birds in question are Drepanididæ. The most central, or least modified, are the small-sized genera Oreomyza, Loxops and Chrysomitridops, and Himatione. Thence have sprung in two divergent lines-

1. The long- and slender-billed ultra-Drepanine forms with long tubular brush-tongues: Hemignathus, Viridonia, Vestiaria, Drepanis.

2. The thick-billed Fringilloid genera with short, more fleshy, reduced tongues: Psittacirostra, Pseudonestor, Loxioïdes, Rhodacanthis, Chloridops.

II. The majority of the birds are Drepanididæ, while the thick-billed forms without tubular tongues are Fringillidæ. The relationship of these thick-billed genera does, however, not lie with the palæarctic Chloris, e. g. Kawarahiba, nor with any of the Coccothraustinæ, least so with the genus Geospiza from the Galapagos Islands. The very thick-billed Fringillidæ indicate a terminal, not an indifferent, stage of development. Such forms as Geospiza, Loxigilla, Coccothraustes, and Pyrrhula are undoubtedly instances of convergent analogies.

III. All the Drepanididæ have started from Fringillidæ, some of which have developed further in essentially Fringilloid lines, leading to Chloridops and Rhodacanthis as extremes. We should have to assume that Loxops and Chrysomitridops are least removed from the hypothetical starting-point; but it so happens that these two genera are closely allied to Oreomyza, while by their tongue, nostrils, and palatal arrangement they are far removed from moderate, not exaggerated, true Fringillidæ, e. g. Chrysomitris. We should further have to assume that, by the development of a more slender bill-in fact, by departing from typical Fringilline features,-some of the birds in the Sandwich Islands have produced the tubular brush-tongue, have weakened and lengthened the palatal arrangement (although retaining the fused palatines), have elongated the trans- and interpalatine portions, and last, but not least, have developed operculated nostrils. Anatomically, at least, the development of the nasal 
operculum of the typical Drepanididæ from Fringillid conditions is absolutely impossible.

IV. All the birds in question are related to each other as one group, Drepanididæ; but out of them have sprung the Fringillidæ. Morphologically this assumption is possible from a general point of view, but it does not at all work satisfactorily in detail. First, we cannot assume that a family like the Fringillidæ has spread from a volcanic group of oceanic islands all over the world, with the very exception of the bulk of the Pacific islands and of the Australian region. Secondly, Pseudonestor, Chloridops, Loxiödes, and Rhodacanthis have by their bills, reached a stage more exaggerated than that of most of the typical thickbilled true Fringillidæ, while they differ from the geographically nearest rather thick-billed Chloris in the pattern of colour, general moulding of the beak, and, above all, in the configuration of the narial region. It is equally futile, as said before, to connect them with Coccothraustina.

Lastly, the remarks concerning Chrysomitridops and Loxops militate against this assumption (No. IV.).

Consequently there remains only assumption No. I., namely, that the thick-billed birds of the Sandwich Islands are modified Drepanididæ, which by convergence, by adaptation to similar habits, have developed features which we are accustomed to associate with typical Fringillidæ.

Although we have now disposed of the Fringillidx, the whole question of the affinities of the thick-billed genera cannot be considered as threshed out until we have substituted the Tanagridæ for Fringillidæ in the four hypotheses examined above.

Terminal forms of the Tanagridæ are Orchesticus, Saltator, Tanagra. Comparison between them and the Sandwich Island genera is rather favourable. The resemblance in the whole narial configuration and the build of the bill is striking. The stout-billed Tanagridæ have, in fact, modified their bills and nostrils in exactly such a way as, anatomically speaking, we expect these parts to be modified when starting from a condition like that which is represented by Cœrebidæ and the slender and short-billed Drepanididx. This is one of the very points which excludes any direct relationship of the thick-billed islanders with Fringillidæ.

In the general build and in the pattern of colour Loxioides and Rhodacanthis resemble certain Tanagridæ-say, for instance, Saltator, Orchesticus, and Pitylus-much more than they do any of the Fringillidæ. The Tanagridæ seem to be devoid of a pronounced crop, they possess only a slight dilatation; but the same applies also to Embernagra among the Fringillidæ, and thus this once cherished character is weakened. On the other hand, the Tanagridæ differ strongly from the Sandwich Island birds in the structure of the palate (especially their broad maxillo-palatine processes and the partly separated palatines) and the tongue, which is fleshy, rather bifid, and ends in two cone-shaped horny caps.

However, the Tanagridæ are in all probability related to the Cærebidæ, the latter 
representing the lower, older stage, but having specialized in bill and tongue. In my former paper I pointed to these same Cœrebidæ as the possible ancestral relations of the typical Drepanididæ. It is, I think, significant that I should now, in a roundabout way, again be led towards this same family of birds. It was my fault that I did not take the Tanagridæ into our confidence; it would have been a small step only from the Corebidæ, but I was biased by the watchword "Finches" or not Finches.

Let us now sum up. Concerning the Tanagridæ, they are neither the descendants nor are they the direct ancestors of the thick-billed Sandwich Island birds, but they come very near them. The origin of the Drepanididæ we do not know; in my former paper I hinted at the Ccrebidæ. I still fail to see any valid reasons against such a descent: on the contrary, it seems now a little more probable.

The Sandwich Islands have received their characteristic bird population from the south-east, as an offshoot of the Columbian fauna (Drepanididæ sensu latiore), and from the south-west-Australian Meliphagidæ, namely, Acrulocercus and Chcetoptila, whose near relation, Leptornis, lives in the Fiji Islands; the Flycatcher (Chasiempis sandvicensis) has its nearest relation, Ch. dimidiata, in Rarotonga, and the Thrush-like Phoornis points also towards the south-west. 



\section{N D E X.}

Acanthis, 93.

Acanthochcora, 227, 228, 234.

$$
\text { carunculats, } 228 .
$$

Acanthorhynchus, 227, 236.

Accipiter hawaii, xix, 180, 185.

Accipiares, xxiii.

Acridotheres tristis?, $\mathrm{xx \nabla}$.

Acrocephalus familiaris, xxv.

Acrulocercus, xvii, sviii, xxiii, 5, 16, 104, 106, 107, $229,230,233,234,245,246,249$.

apicalis, xxii, xxiv, xxvii, 103, 104.

bishopi, xxii, xxiv, 104, 111.

- braccatus, хxir, 4, 99, 100, 101, 104, 219, $225,227,240$.

- niger, 105.

nobilis, xxiv, xxvii, 4, 5, 11, 87, 99, 100, 101, 103-105, 111, 171, 173, 219, 227.

Actitis incana, 158.

Aistrelata sandwichensis, 213.

Alaudid 237.

AMPELID 236.

Ampelis, 225.

Anas aberti, 191.

- acuta, 193.

- boscas, 191.

- boschas ?, 191.

- clypeata, 195.

- freycineti, 192.

- laysanensis, $\mathrm{xxv}$.

- obscura, 191.

- sandvicensis, 191.

superciliosa, 191.

-_ superciliosa, var., 191.

- superciliosa, var. a, sandwichensis, 191.

- wyvilliana, xvi, 191, 192.

Anous hawaiiensis, 141, 143. melanogenys, 143. niger, 141.
Anous stolidus, 141.

- tenuirostris, 143.

Anser cygnoïdes, 187.

- hanaiënsis, 187.

- havaiensis, 187.

- hawciiiensis, 187.

- hyperboreus, 188, 189.

— sandvicensis, 187.

Anseres, xxiii.

Anthochara? angustipluma, 113.

Arachnothera, 237, 246.

Ardea ? carulea, var. $\gamma, 199$.

- exilis, 201.

- grisea, 201.

- navia, 201.

- nycticorax, 201.

- sacra, 199, 201.

- (Herodias) sacra, 199.

Ardeid 199.

Arenaria interpres, 159.

Asio accipitrinus, xix, xxiii, 42, 133.

— brachyotus, 133.

_- sandvicensis, 133.

- sandwichensis, 134.

Attagen aquilus, 203.

A dotrocoraces, 239.

Bernicla minima, xxv.

- munroi, xxv.

nigricans, $\mathrm{xx \nabla}$.

sandvicensis, 187, 188, 191.

sandwichensis, 187.

Botaums exitis, 201.

Brachyotus galapagoensis, 133.

Branta (Leucopareia) sandwichensis, 187.

Bulweria anjinho, 211. bulweri, 211. 
Butweria columbina, 211.

- macgilliurayi, 211, 212.

Buteo, xviii.

-_ pennsylvanicus, 182. solitarius, 179, 181-183, 185.

- (Onychotes) solitarius, 179, 181.

Byrseus coccineus, 49.

Catidris arenaria, 153, 159.

Cardinalis, 238.

Carduetis coccinea, 49.

Carpodacus, xix, 77.

frontalis, $\mathrm{xxv}$.

Certhia, xiv, 4, 10, 68, 100.

- coccinea, 9, 10.

- obscura, $65,67,68$.

— pacifica, 3, 4, 99, 114.

- sanguinea, 19.

- vestiaria, 9 .

-virens, 29.

Chactoptita, xvii, xviii, xxiii, 15, 90, 113, 229, 234, 249.

- angustipluma, xxii, xxiv, 113, 149, 219, 228.

Chavadrius auratus orientalis, 161.

- dominicus fulvus, 161.

- fulvus, 161.

_- glaucopus, 161.

—_ "like C. hiaticula," хxv, 158.

- pluvialis, 161.

- taitensis, 161.

- virginianus, 161. xanthocheilus, 161.

Chasiempis, xviii, xxiii, 125-128, 222, 249.

— dimidiata, 249.

- dolei, 131.

- gayj, xxii, xxiv, 127, 129, 131.

- ibidis, 125, 126.

— ridgwayi, 125, 126.

- sandvicensis, ix, xxiv, 21, 125, 126, 129, 131, $219,222,240,249$.

_- sandwichensis, 125, 129, 131.

- sclateri, xxii, xxiv, 126, 129, 131.

Chasiempsis, 223.

- obscura, 121.

- sandvicensis, 125.

___ sandwichensis, 125.

Chen Typerboreus, xxv.

Chloridops, xvii, xxi, 84, 98, 127, 243, 246-248.

_tona, xviii, хxii, хxir, 97.
Chloris, 246, 248.

- kawaratiba, xviii, 247.

Tcittlitzi, xriii.

Chlorodrepanis, $\mathrm{xxi}, 35$.

— chloridoüdes, xxi, xxii, xxiv.

chloris, $\mathrm{xxi}, \mathrm{xxir}$.

- Kalaana, xxi, xxii, xxiv.

-stejnegeri, xxi, xxii, xxir.

-virens, $\mathrm{xxi}, \mathrm{xxiv}$.

—vilsoni, xxi, xxii, xxiv.

Chrysomitridops xxi, 42, 59, 235, 245-248.

- ccenteirostris, хxii, хxiv, хxvii, 33, 59, 219, 233.

Chrysomitris, 247 .

Cinclus interpres, 159.

Cinntrimorpirs, 227, 235-239.

Circus cyaneus hudsonius, 185.

-_hudsonius, xix, 180, 185.

Ciridops, xix, xxi, xxii, 23, 243.

- anna, xxir, 23.

_- sp., 23.

Cnipolegus, sp. ?, 125.

Coccothraustes, 224, 238, 247.

Coccothriustina, 247, 248.

Coreba, 232.

- Tongirostris, 241.

Cerrebid 2 , xviii, 235-239, 244, 248, 249.

Collyriocincla, 221.

- sandwichensis, 221.

Conirostres, 238.

Corethrura obscura, 171. sandwichensis, 175.

Corvide, xxiv, 239.

Corvus, xviii.

- hawaïensis, 1, 21, 180.

- ossifragus, 2.

- tropicus, xxiv, 1.

(Physocorax) hawaiiensis et tropicus, 1.

? Cracticus ater, 1.

Crex sandwichensis, 176-178.

Cymochorea cryptoteucura, 209.

Dafila acuta, 193.

- caudacuta, 193.

Demiegretta sacra, 199.

Diс_еID.x, xтiii, 33, 37, 38, 89, 90, 225, 235239.

Dicceum, 235.

- pectorate, 241.

- trigonostigma, 241. 
Diomedea albatrus (chinensis), $\mathrm{x} \times \mathrm{v}$.

- brachyura, 217.

-

- immutabilis, 217.

- melanophrys, 217.

- nigripes, $\mathrm{x} \times \mathrm{v}$.

Drepanxid 223, 229-239, 241-249.

Drepanis, xxi, xxii, 4, 5, 7, 16, 20, 49, 56, 68, 90, $229,235,243,245-247$.

- aurea, $49,50,55-57$.

- byronensis, 19.

- coccinea, 9, 12, 67 .

- ellisiana, 68.

?- flava, 29, 30.

funereu, $\mathrm{xx}, \mathrm{xxii}, \mathrm{xxiv}, 7$.

obscura, 67 .

- olivacea, 75 .

- pacifica, xxir, 3-8, 50, 103, 104, 106, 107, $173,219,227-229,23 \pm, 246$.

- rosea, 10, 11 .

- rufa, 49, 53.

sanguinea, 12, 19, 29.

vestiaria, 9 .

(Hemignathus) ellisiana, 65-67.

- (-) lucida, 73, 75 .

- (Himutione) sanguinea, 19, 27, 29, 43.

(Vestiaria) coccinea, 10, 67.

Emberiza, 224, 225.

- ciris, xix.

Eimbernagra, 248.

Entomiza, 113.

? angustipluma, 113.

Eopsaltria sandvicensis, 125.

- (Chasiempis) maculata, 128.

?- (Chasiempis) sandwichensis, 129.

- (Chasiempsis) maculata, 128. (Chasiempsis) obscura, 121.

?_- (Chasiempsis) sandwichensis, 129. - (Phocornis) obscura, 121.

Estrilda, 22t, 238.

Falco hudsonius, 185.

Fregata aquila, 203 . minor, 203.

Fringilla, xix, 225.

- anna, xix, 23. chloris, 97.

coccinea, 49, 53.
Fringilla coelebs, 225.

- rufa, 49, 53 .

Frivaminds, xvii, xтiii, xxi, 223-225, 236-239, 243-248.

Frixgilliformes, 236, 237, 239, 244.

Futice alae, 163.

- alai, 163, 164, 167.

- atra, 163.

- chloropus, $165,167$.

Gallinago "like G. scolopacina," xxr, 158.

Gallinula chloropus, 165.

- galeata, 165-167.

- galeatc sandvicensis, 165.

- sandvicensis, 165-167, 169.

- sp.?, 165.

Gambetta fuliginosa, 151.

- oceanica, 151.

Geocichla, 222.

Geospiza, 247.

Gracula longirostra, 105; 106.

- nobilis, 105, 106.

Grallina, 221.

Gygis alba, 145 .

- candida, 145.

Haliplana fuliginosa, 137.

Lunata, 139.

Hemignathus, xir, xv, xxi, xxii, 7, 16, 37, 68, 71, $75,77,79,81,90,230-232,234,235,238$, 245-247.

affinis, 77,79

ellisianus, 65.

- hanapepe, $77,79,81$.

- lanaiensis, xxii, xxir, 71 .

_- lichtensteini, xxii, xxiv, 65, 68, 73.

- lucidus, 73-75, 82.

-_obscurus, xxiv, 61, 63, 65-68, 71, 79.

olivaceus, $61,75,81,82,219,233,241$.

- procerns, xxii, xxiv, 61, 219, 229, 233, 241. stejnegeri, $61,68,76$.

vilsoni, $74,77,78$.

Heteractitis, 152.

- brevipes, 152.

incana, 152.

incinus, 151.

Heterorhynchus, xxi, xxiv, 37, 71, 75, 77. affinis, xxii, xxir, 77.

hanapepe, xxii, xxiv, 123.

lucidus, xxii, хxiv, 37, 73. 
Heterorhynchus olivaceus, $\mathbf{x i i ,} 74,75$.

- wilsoni, xxii, xxir.

Heteroscelus, 152.

- brevipes, 151.

incanus, 151.

Himantopus brasiliensis, 155.

- candidus, $155,158$.

kandseni, 155.

7nudseni, xxii, 155-157.

mexicanus, 155, 156, 158.

nigricollis ?, 155, 156.

Himatione, xxi, xxii, 15, 16, 20, 21, 37, 42, 55, $79,84,232-235,237,243,245,247$.

- aurea, 55 .

chloridoüles, 28.

- chloris, xxii, 25, 27, 28, 30, 31, 33, 34, 44.

- dolei, 15.

dolii, xxii, 15.

? flava, 29, 30, 33 .

freethi, xxiv, $\mathrm{xx \nabla}$.

_-_ kalaana, 28.

- maculata, xxi, 34, 43.

- mana, xxi, 47 .

- montana, xxi, 41, 45.

- newtoni, xxi, 41.

- parva, xxi, xxii, 33, 34, 42, 46, 59, 81.

- sanguinea, ix, xxi, хxir, 12, 15, 16, 19-21, $29,30,33,43,219,231,240$.

- stejnegeri, 25, 31, 81 .

- virens, ix, $21,27,29,31,33,34,43,47,50$, $219,231,240$.

- witsoni, 31 .

HiRUNDINIDAs, 236.

Hypoloxias, 57.

- aurea, 55, 56. coccinea, 49.

ICTERIDAE, 236.

Icterus, 224.

-_Baltimore, 109.

LANIID 239.

LANIIN 237.

Larus sp. indet., xxv.

Leptornis, 249.

LraricolAs, xxiii.

Iinaria, 224.

_. ? coccinea, 49,53 .

Loxia, 224, 225.

— pityopsittacus, 246.
Loxia psittacea, 85.

Loxigilla, 247.

Loxioïdes, xvii, xxi, 84, 89-91, 224, 225, 234, 237$239,243,245-248$.

bailleni, 89.

bailleui, xxiv, 89, 97, 219, 223, 224, 240.

Loxops, xxi, xxii, 33, 37-39, 42, 53, 55, 56, 230, $232-235,243,245-248$.

- aurea, xxiv, 49, 55, 56.

- coruleirostris, 56.

—_occinea, xxiv, 33, 37, 40, 49, 53, 56, 219, 231.

coccineus, 49.

- flammea, xxi, 39.

- ochracea, 55, 57.

roseá, 10.

rufa, xxiv, 53.

wolstenholmei, 53.

(Chrysomitridops) caruleirostris, 55.

Meliornis, 227.

Meliphaga, 113, 227, 234.

- fasciculata, 105.

MeliphagID无, xvii, xxiv, 15, 16, 35, 36, 104, 113, 225-229, 235-239.

Meliphagin五, 237.

Melithreptes vestiaria, 9 .

Melithreptus, 68.

- obscurus, 67.

- pacificus, 3 .

- vestiarius, 9, 67 . virens, 29.

Mellisuga coccinea, 9.

Merops, 105.

- fasciculatus, 105. niger, 105. sp.?, 9 .

Merula, 222.

Micranous havaiiiensis, 143.

Miro, 222.

Mvioxiltid $2,236$.

Moho, 106, 113, 114.

—_angustipluma, 113.

- apicalis, 103, 104.

- atriceps, 113.

- braccata, 99, 114.

niger, 105.

__ nobilis, 99, 103-105, 114.

Mohoa, 99, 113.

- angustipluma, 113. 
Mohoa apicalis, 100, 103.

-_braccata, 99, 100. fasciculata, 99, 105. nobitis, 100, 105.

Motacilutid 236.

Muscicapa maculata, 126, 128, 129.

- obscura, 121.

- sanduicensis, 125.

sandvicensis, 125 .

sandwichensis, $125,126,129$.

Muscicapidx, xix, xxiv, 220-224, 239.

Myzomela, 234.

? sanguinea, 19 .

MrZoMreunes, 237.

Nectarinia, xiv, 100, 226, 230.

byronensis, 19, 20.

coccinea, 9.

?- flava, 29, 30 .

?- niger, 105.

- sanguinea, 19.

NeCtarinim E, xviii, 235, 237.

Nestor meridionalis, 91, 108.

Numenius austratis, 147, 149.

- femoratis, 114, 147-149.

- hudsonius, 148.

- phceopus, 147, 148.

_ tahitiensis, 147, 148.

- taitensis, 147.

Nycticorax griseus, xxiii, 199, 201.

- nyeticorux, 201.

nycticorax nevius, 201.

Oceanodroma castro, xxii. cryptoleucura, 209.

Estrelata bulweri, 211.

—_ cookii, 213.

hoesitata, 213.

hypoleuca, $\mathrm{xxv}$.

meridionalis, 214.

neglecta, 215.

- phceopygia, xxii, 213, 214.

__ sandwichensis, 213, 214.

Onychoprion fuliginosus, 137.

lunatus, 139.

Onychotes gruberi, 179, 181-183.

- solitarius, 179.

Orchesticus, 248.

Oreomyza, xxi, 36, 37, 42, 43, 46, 233-235, 243, $245,247$.
Orcomyza bairdi, xiii, xxi, xxii, xxiv, 33, 37, 38, $41,47,219,232,241$.

- flammea, xxi, xxii, xxiv.

- maculata, xxi, xxiv, 43.

- mana, xxi, xxii, xxiv, 41.

montana, xxi, xxii, xxiv, 41.

newtoni, xxi, xxii, xxiv, 41.

wilsoni, 37.

(Rothschildia) parva, xxii.

Ortygometra cinerea, 176.

_- obscure, 171.

sandvicensis, 175.

? sandwichensis, 171, 175.

Oscines, 235, 238, 239, 244.

Otus brachyotus, 133.

— brachyotus, var., 133.

- galapagoensis, 133.

— palustris, 133.

Pachycephala, 220.

Pachycephatinda, 220, 221.

Pachyeephalopsis, 220.

Palmeria, xxi, xxii, 15, 16, 243, 245, 246.

- dntei, 15.

- dolii, xxiv, 15.

- mirabitis, 15.

Pandion solitarius, 179, 181.

- (Polioaetus) solitarius, 179.

Panurus, 225.

Paradoxornis, 90.

Paroaria, 244, 246.

Passer domesticus, xxv, 225.

Passeres, xv, xvii, xx-xxiii, 231, 238, 244.

Pelecanus aquitus, 203.

Pennula ecaudata, 171, 175, 177.

- millei, 171, 172.

- millsi, 171.

- sandvicensis, 175 .

- sandwichensis, 171, 175, 176.

— wilsoni, 175, 176-178.

Petrodroma sanguinea, 19.

Phcoornis, xix, 117, 122, 220, 221, 223, 249.

-lanaiensis, xxii, xxir, 119.

- myadestina, 117.

myiadestina, xxii, xxiv, 117, 119, 122-124.

- oahensis, xiii.

oahuensis, xxiv.

obscura, xiii, xxiv, xxvii, 86, 119, 121, 122, 219-221, 239.

— palmeri, xxii, xxiv, 123, 124. 


\section{INDEX.}

Phathon cethereus, 205, 207.

- phoenicurus, 207.

- rubriceseda, 205, 207.

Phaeton cethereus, 205, 207.

- , an cardidus?, 205.

- phonicurus, 207.

- rubricauda, 207.

Pheucticus, 246.

Phitemon fasciculatus, 105.

Phrygitus, 224.

Phyllornis tonganensis, 29.

- virens, 29.

Pinarolestes, 221.

Pinaroloxias, 37.

Pinicola, 224.

Pitylus, 246, 248.

Plectrophanes lapponicus, 221.

Plegadis grarauna, 197.

Ploceidde, 237.

Pluvialis fulvus, 161.

- longipes, 161.

— xanthocheilos, 161.

Pogonornis, 227.

- cincta, 5 .

Polioaetus solitarius, 179.

Porzana sandvicensis, 175.

Porzanula palmeri, xxr.

Prionopidx, xviii, 221.

Procellaria alba, 21, 213-216.

- anjinho, 211.

bulweri, 211.

- macrillivrayi, 211.

Promerops, 235.

Prosthemadera novo-zealandice, 91.

Psendonestor, xxi, 83, 84, 243, 245-248.

-xanthophrys, xxii, xxiv, 83.

Psittaci, 237.

Psittacina olivacea, 85.

Psittacirostra, xvii, xxii, 37, 38, 84, 86, 87, 93, 220, $224,225,234,237-239,243,245-247$. icterocephala, 85 .

— psittacea, xxiv, xxvii, 59, \$5, 219, 224, 240.

Psittacopis psittacea, 85 .

Psittirostra, 86, 88-90.

- icterocephala, 85 .

- psittacea, $85,87,88$.

- sandvicensis, 85 .

Ptilotis, 228, 234.

Ptiloturus fasciculatus, 105.

Puffinus, 215, 216.
Puffinus bulleri, 215.

- chlororhynchus, 215.

columbinus, 211.

creatopus, 215.

cuneatus, xxii, 215.

knudseni, 215.

meridionalis, 213.

nativitatis, $\mathrm{xxv}$.

obscurus, 216.

Pyrrhala, 224, 225, 247.

Ratwde, xxiii, 172.

IRallus acaudatus, 171.

- ecauclatus, 106, 171, 172.

- obscura, 177.

- obscurus, $171,177,178$

- sanduicensis, 175 .

- sandvichensis, 171, 175.

- sandwichensis, 175,176 .

Rectes, 221.

Rhipidura, xviii.

Rhodacanthis, xxi, 84, 93, 98, 243, 245-248.

- faviceps, xxii, xxiv, 94, 95.

- palmeri, xxii, xxiv, 93, 95.

Rhynchaspis clypeata, 195.

Rothschildia, xxi.

parva, xxi, xxir.

Saltator, 248.

Scolopax guurauna, 197.

- incana, 151.

- phooopus?, 147.

- solitaris, 151.

—_tahitiensis, 147.

- undulata, 151.

Sittacodes, 85.

Spatula elypeata, 195, 196.

Sterna alba, 145.

- uncestheta, 139.

bergii, xxv.

- candida, 145.

_- fuliginosa, 137, 139.

- Iunata, 139.

oahuensis, 137.

owhyhaensis, 143.

?- panayana, 137.

stotida, 141.

(Onychoprion) serrata, 137.

Strepsilas interpres, 159.

Strigiceps, 114. 
Strix brachyotus, 133.

?-_ delicatula, 185.

__ sandwichensis, 133.

Strobilophaga psittacea, 85.

Stryx accipitrina, 133.

Sturnopastor, 16.

Sula cyanops, xxv.

__ leucogaster (sula), xxv. piscator, $\mathrm{xxv}$.

SYLVIINA, 237.

Tachypetes aquita, 203. aquilus, 203.

palmerstoni, 203.

? Tonioptera obscura, 117, 121.

Tanagra, 248.

bonariensis, 246.

TANAGRIDE, 236, 244, 248, 249.

T'elespiza, xxi.

cantans, xviii, xxii, xxiv, xxv. flavissima, xxii, xxiv, $x \times v$.

Tenuirostres, 236.

Thalassidroma bulweri, 211.

- sp. ?, 209.

Thyellus, 215.

Totanus, $15 \%$.

- brevipes, 151, 152.

- fuliginosus, 151.

- incanus, 151, 152.

- oceanicus, 151.

pedestris, 151.

- polynesice, 151.
Totamus solitarius, 151.

- unclulatus, 151.

(Gambetta) incanus, 151.

Tringa arenaria, 153.

— interpres, 159.

oahuensis, 159.

Trochildie, 238.

TURDIDE, xix, xxiv, 220, 221.

Turdus, 222.

_- sandwichensis, xiii, 121.

woahensis, xiii.

T'urnagra, xix.

Turtur chinensis, $\mathrm{xx \nabla}$.

Tyrannula, 121.

- obscura, 121.

Testiaria, xxi, xxii, 11, 20, 37, 68, 75, 229, 231, 233-235, 237, 238, 245-247.

- akaroa, 67 .

- coccinea, ix, xxiv, 5, 9, 21, 66, 68, 86, 87, 107 , $180,219,230,231,240$.

- evi, 9 .

- heterorhynchus, 75 .

holıo, 3.

Vidua, 225.

Viridonia, xxi, xxii, 35, 43, 243, 245, 247.

- maculata, 43 .

_ sagittirostris, xxii, xxiv, 35 .

Zapornia sandwichensis, 175.

Zosteropide, 235, 236.

Zosterops, 239. 
258 


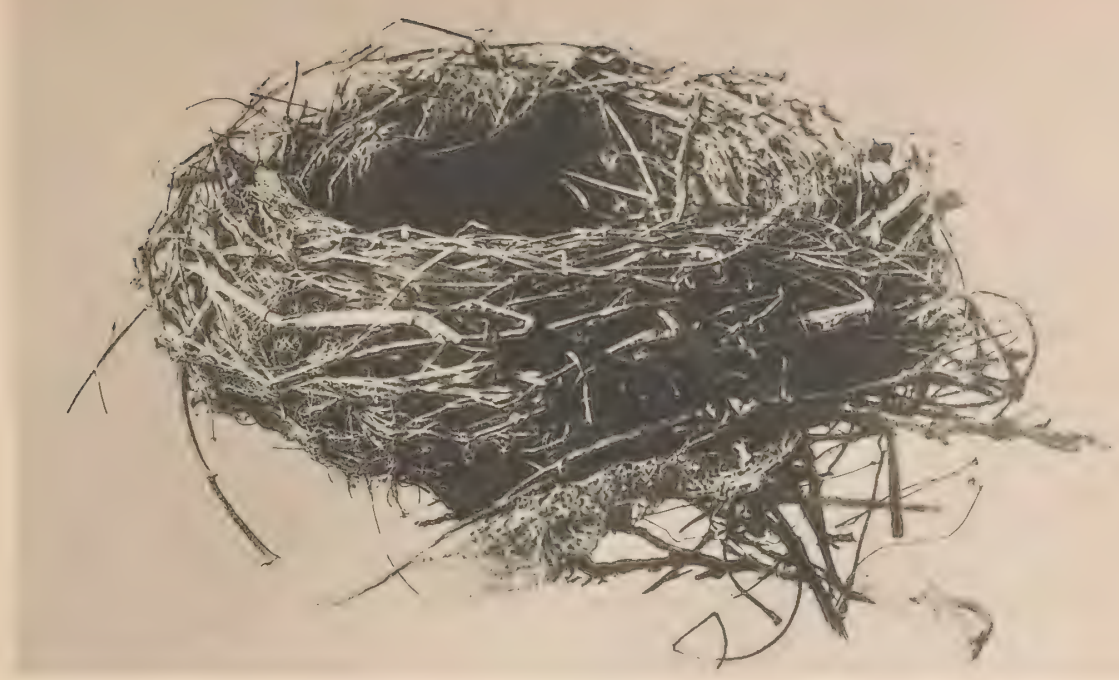

FIG. I.

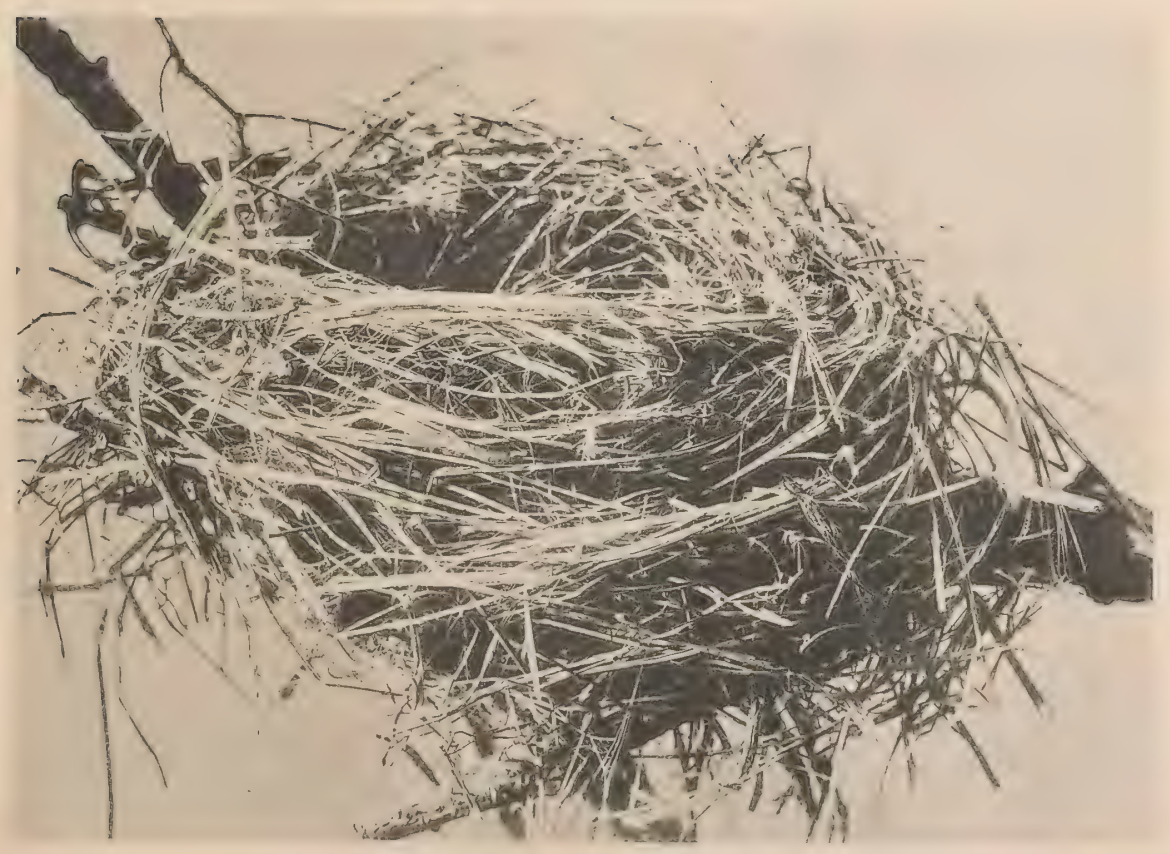

FIri. II.

Fic. I. Himatione sanguinea.

Fig. il. Himatione Virens 


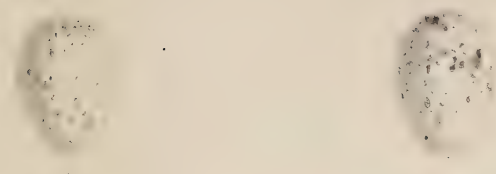

i.

:
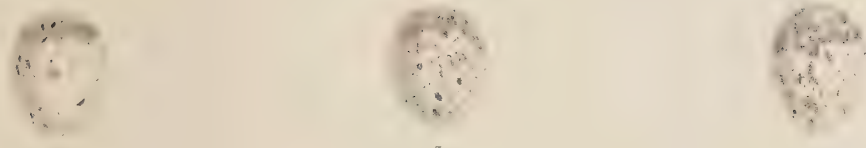

6
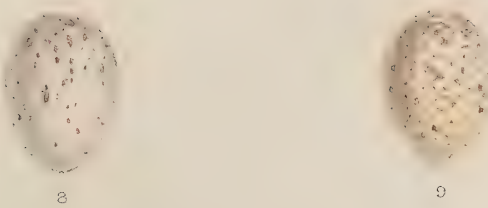

GW krowen aेel et lnt?

$$
\begin{aligned}
& \text { i-6. HTMATIONF, sp. } \\
& \text { 7-9. CHASIENPIS, sp. }
\end{aligned}
$$





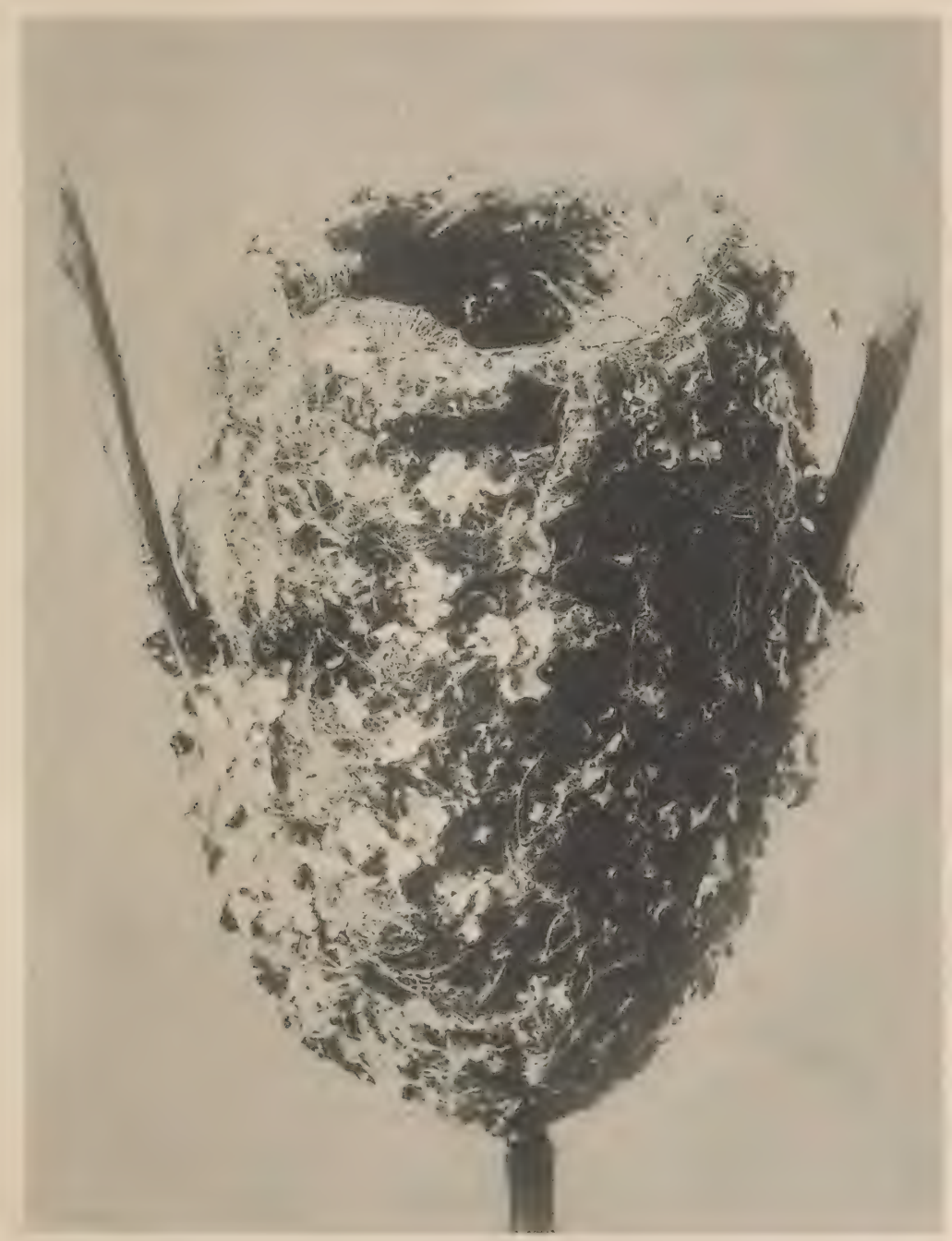

Chasiempis SAndVICEnsis. 



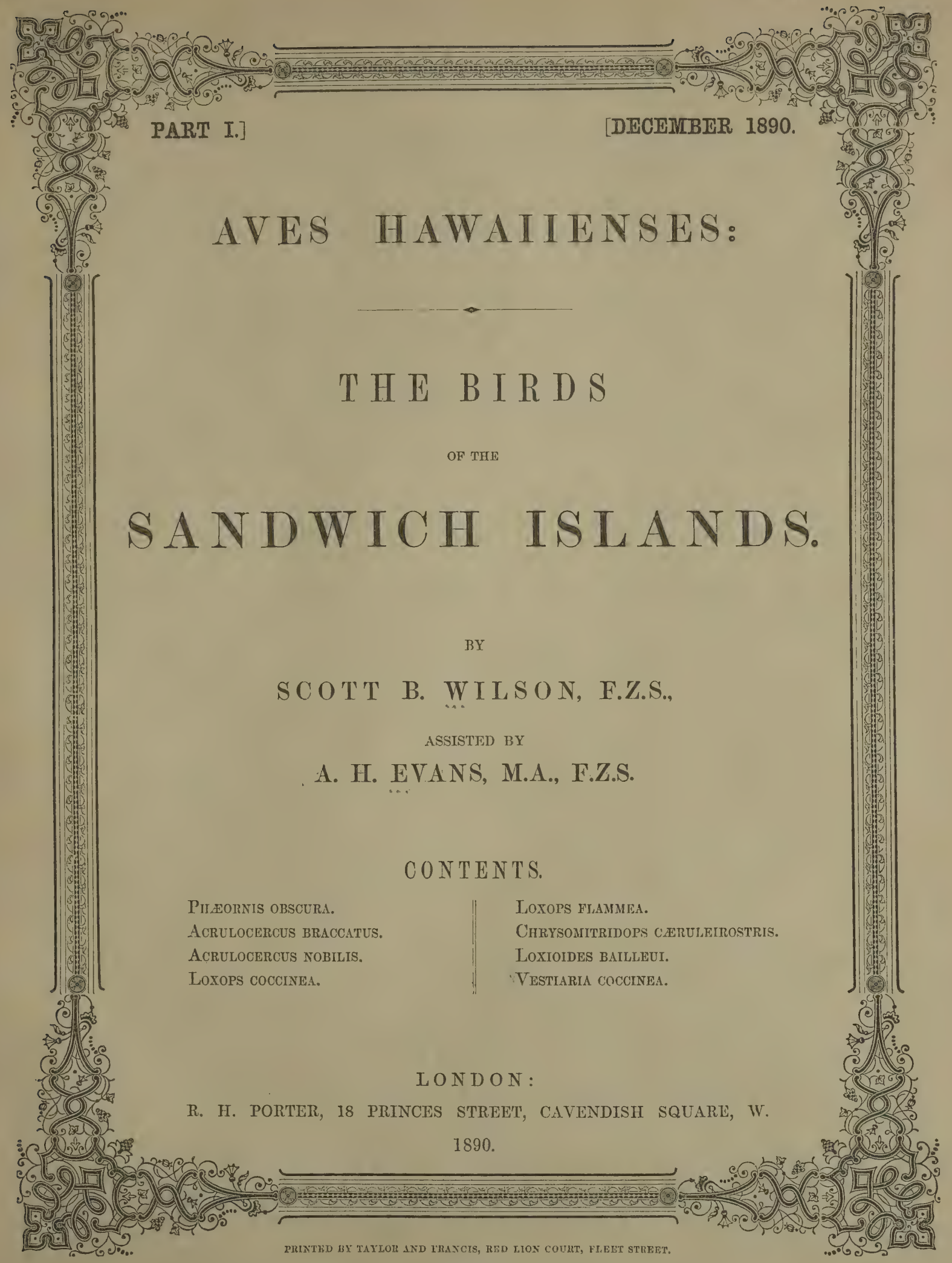


** Part II. will contain an Illustrated Dissertation on the

S T R U C T U E

OF SOME

\section{BIRDS OF THE HAWAIIAN ISLANDS}

IN REFEREYOE TO THEIR SYSTEMATIC POSITION.

BY

- Dr. HANS GADOW, M.A., Ph.D.,

STRICKLAND CURATOR AND LECTURER ON THE ADVAKCED MORPHOLOGY OF VERTEBRATES IN THK UNIVERSITY OF CAMBRIDGE. 



\section{The Birds of the Sandwich Islands.}

\section{SUBSCRIBERS' NAMES ALREADY RECEIVED.}

ASHER \& Co., Messrs. (3 copies.)

BAIN, Mr. J. (2 copies.)

BALSTON, R. J., Esq., F.Z.S.

BEALE, Lionel S., Prof., M.B., F.R.S.

CHAMBERLAIN, Walter, Esq.

CHASE, R. W., Esq.

CLARKE, W. Eagle, Esq., F.L.S.

CORY, C. B, Esq., F.Z.S.

CROWLEY, P., Esq., F.Z.S.

DIXON, Abraham, Esq.

DOGGETT, Mr. F.

DOWSON, Edward Morris, Esq.

DULAU \& Co., Messrs.

EITIOTT, Ernest A., Esq.

GAY, Francis, Esq.

GODMAN, F. Ju Cane, Esq., F.R.S.

GREVEL \& Co., Messrs, H.

HARCOURT, E. W., Esq., M.P.

HARRISON, Mrs. W, F.

HARVARD College.

HOPE, T., Esq.

HORNE, Edward, Esq., J.P.

JAMES, H. Berkeley, Esq., F.Z.S.

KEMPEN, Prof. Ch. van. KIRBERGER \& Kesper, Messrs.

KNUDSEN, Mrs. V.

LEES, Edward B., Essq.

IILFORD, The Rt. Hon. Lord, F.Z.S.

LUCAS, F. W., Esq.

MaCINTOSH, James, Esq.
MANGER, W. T., Esq.

MILTAIS, J. G., Esq., F.Z.S.

MILNER, Edward, Esq.

MORTLOCK, W., Esq.

NETVTON, Sir Edward, M.A., K.C.M.G., F.L.S.

NEWTON, Prof., M.A., F.R.S.

NOBLE, W., Esq.

OXLEY, Mrs. E.

PARKER, Captain R. Townley.

PURVIS, Herbert, Esq.

ROBINSON, Aubrey, Esq.

ROOKE, P. H., Esq.

ROTHSCHILD, The Hon. Walter, F.Z.S.

ROYA工 College of Surgeons.

RUSSELL, S. G. C., Esq.

SALVADORI, Count $\mathrm{T}$.

SALVIN, Capt. F. H.

SALVIN, Osbert, Esq., M.A., F.R.S.

SCLATER, P. L., Esq., M.A., Ph.D., F.R.S.

SEEBOHM, H., Esq., F.Z.S.

SINCLAIR, Francis, Esq.

SMITH, Armstrong, Esq., F.R.G.S.

SOTHERAN \& Co., Messrs. H.

SPENCER, Erancis, Esq.

TRLSTRAM, The Rer. Canon, D.D., F.R.S.

TURRILL, F., Esq.

WESLEY \& Son, Messrs. (2 copies.)

WILSON, G. F., Ksq., F.I.S.

WILSON, Herman G., lisq.

ZOOLOGICAL Society of London. 


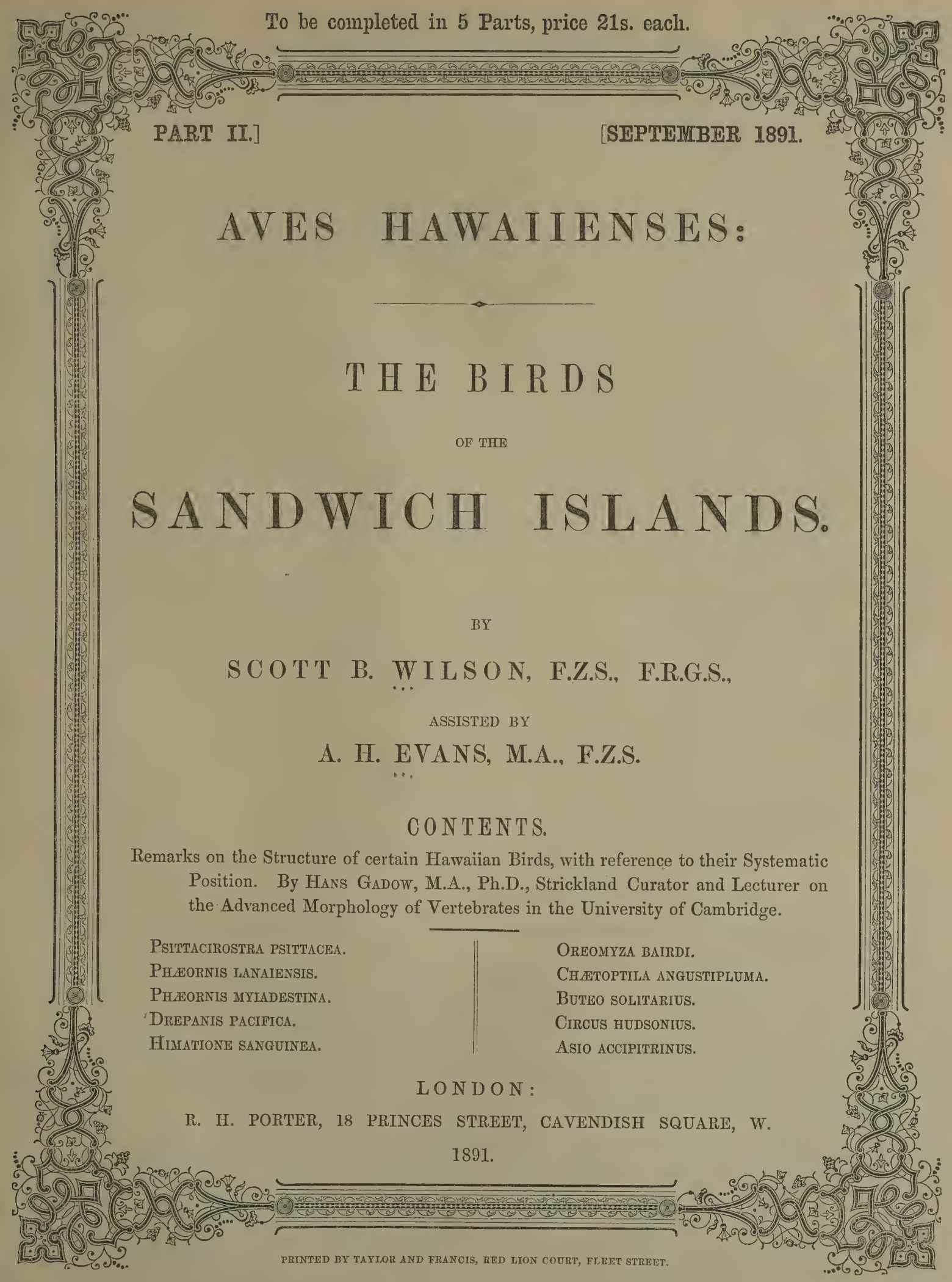






\title{
The Birds of the Sandwich Islands.
}

\section{SUBSCRIBERS' NAMES ALREADY RECEIVED.}

\section{RESIDENTS IN THE HAWAIIAN ISLANDS.}

\author{
H.R.H. THE PRINCESS VICTORIA KAIULANI.
}

BISHOP, Charles R., The Hon. (2 copies.)

CLEGHORN, A. S., The Hon.

GAY, Francis, Esq.

HAWAITAN News Co., The.

KNUDSEN, Mrs. V.

ROBINSON, Aubrey, Esq.
SINCLAIR, Francis, Esq. SMITH, Armstrong, Esq., F.R.G.S. SPENCER, Francis, Esq. TURRILL, F., Esq. VON TEMPSKY, Randal, Esq.
ARGYLI, His Grace the Duke of, K.G. ASHER \& Co., Messrs. (3 copies.)

\section{BAIN, Mr. J.}

BALSTON, R. J., Esq., F.Z.S.

BEALE, Lionel S., Prof., M.B., F.R.S.

BREWSTER, William, Esq.

BUCKLEY, T. E., Esq.

BURTON, Mr. H. T.

CAMIPBELL, Lord Archibald.

CARPENTER, J. H., Esq.

CHAMBERLAIN, Walter, Esq:

CHASE, R. W., Esq.

CLARKE, W. Eagle, Esq., F.L.S.

COBBETT, A., Esq.

COOPER, E. H., Colonel, F.Z.S.

CORY, C. B., Esq., F.Z.S.

CROWLEY, P., Esq., F.Z.S.

DEACON, W. S., Esq.

DIXON, Abraham, Esq.

DOGGETT, Mr. F.

DOWSETT, A., Esq.

DOWSON, Edward Morris, Esq.

DRESDEN, Royal Zoological Museum of.

DULAU \& Co., Messrs. (4 copies.)

ELIIOTT, Ernest A., Esq.

FRIEDL ÄNDER u. Sohn.

FROHAWK, F. W., Esq., F.E.S.

GAGE GARDINER, Mrs.

GODMAN, F. Du Cane, Esq., F.R.S.

GREVEL \& Co., Messrs. H.

HARCOURT, E. W., Esq., M.P.

HARRISON, Mrs. W. F.

HARVARD College.

HARVIE BROWN, J. A., Esq.

HOFFNUNG, A., Esq.

HOPE, T., Esq.

HORNE, Edward, Esq., J.P.

JAMTS, H. Berkeley, Esq., F.Z.S.
- KEGAN PAUL, TRENCH, \& Co., Messrs.

KEMPEN, Prof. Ch. van.

KIRBERGER \& KESPER, Messrs.

LEES, Edward B., Esq.

LILFORD, The Rt. Hon. Lord, F.Z.S.

LORENT, J. R., Esq.

LOTHIAN, The Marquess of, F.L.S.

LUCAS, F. W., Esq.

MACTNTOSH, James, Esq.

MANGER, W. T., Esq.

-MEYER, A. B., M.D., C.M.Z.S.

- MIDLAND Educational Co., The.

MILLAIS, J. G., Esq., F.Z.S.

MILNER, Edward, Esq.

NEWTON, Sir Edward, M.A., K.C.M.G., F.L.S.

NEWTON, Prof., M.A., F.R.S.

NOBLE, W., Esq.

OXLEY, Mrs. E.

PARKER, Captain R. Townley.

-PLUES, Miss.

PURVIS, Herbert, Esq.

ROOKE, P. H., Esq.

ROTHSCHILD, The Hon, Walter, F.Z.S.

ROYAL College of Surgeons.

-RÜCKER, H., Esq.

RUSSELI, S. G. C., Esq.

SALVADORI, Count T.

SALVIN, Capt. F. H.

SALVIN, Osbert, Esq., M.A., F.R.S.

SCLATER, P. L., Esq., M.A., Ph.D., F.R.S.

SEEBOHM, H., Esq., F.Z.S.

SOTHERAN \& Co., Messrs. H.

TRISTRAM, The Rev. Canon, D.D., F.R.S.

WESLEY \& Son, Messrs. (2 copies.)

WILSON, Bernard, Esq.

WILSON, G.F., Esq.,F.R.S., F.L.S.,F.C.S. (2 copies.)

WILSON, Herman G., Esq.

ZOOLOGICAL Society of London. 


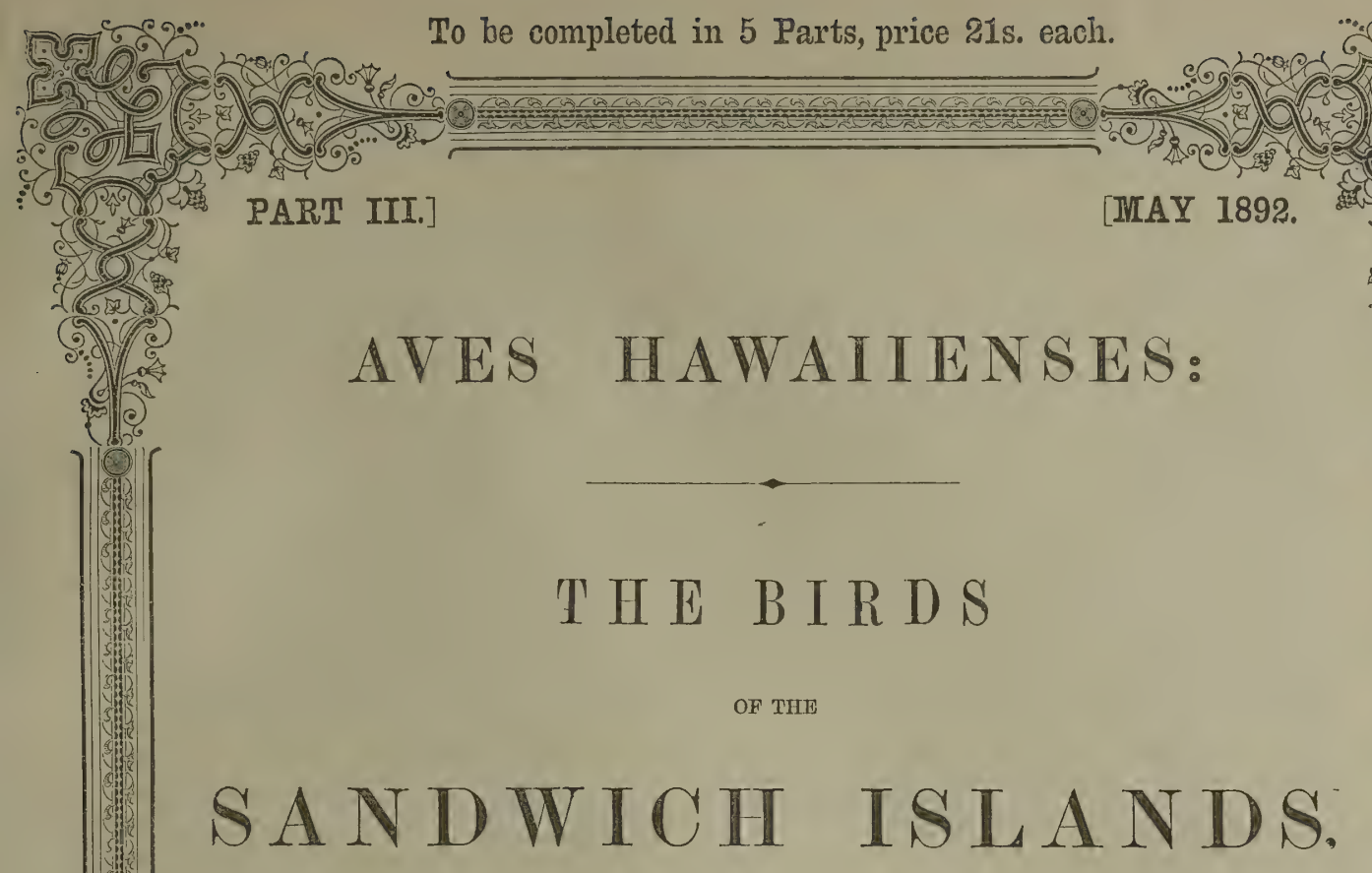

BY
S C O T T B. W I L S O N, F.Z.S., F.R.G.S., ASSISTED BY

A. II. EVANS, M.A., F.Z.S.

C O NTENTS.

Hemignathus obscurus,

' Hemignathus olivaceus.

Hemignathus PROCERUS.

HemignatiIUS HaNAPEPE.

HiMATIONE PARVA.

Himatione montana.

LON DON :

R. H. PORTER, 18 PRINCES STREET, CAVENDISH SQUARE, W.
Himatione STEJNEGERI.

ChaRADRIUS FULVUS.

STREPSILAS INTERPRES.

NUMENiUS TAHITIENSIS.

Totanus incanus.

Calidris arenaria.
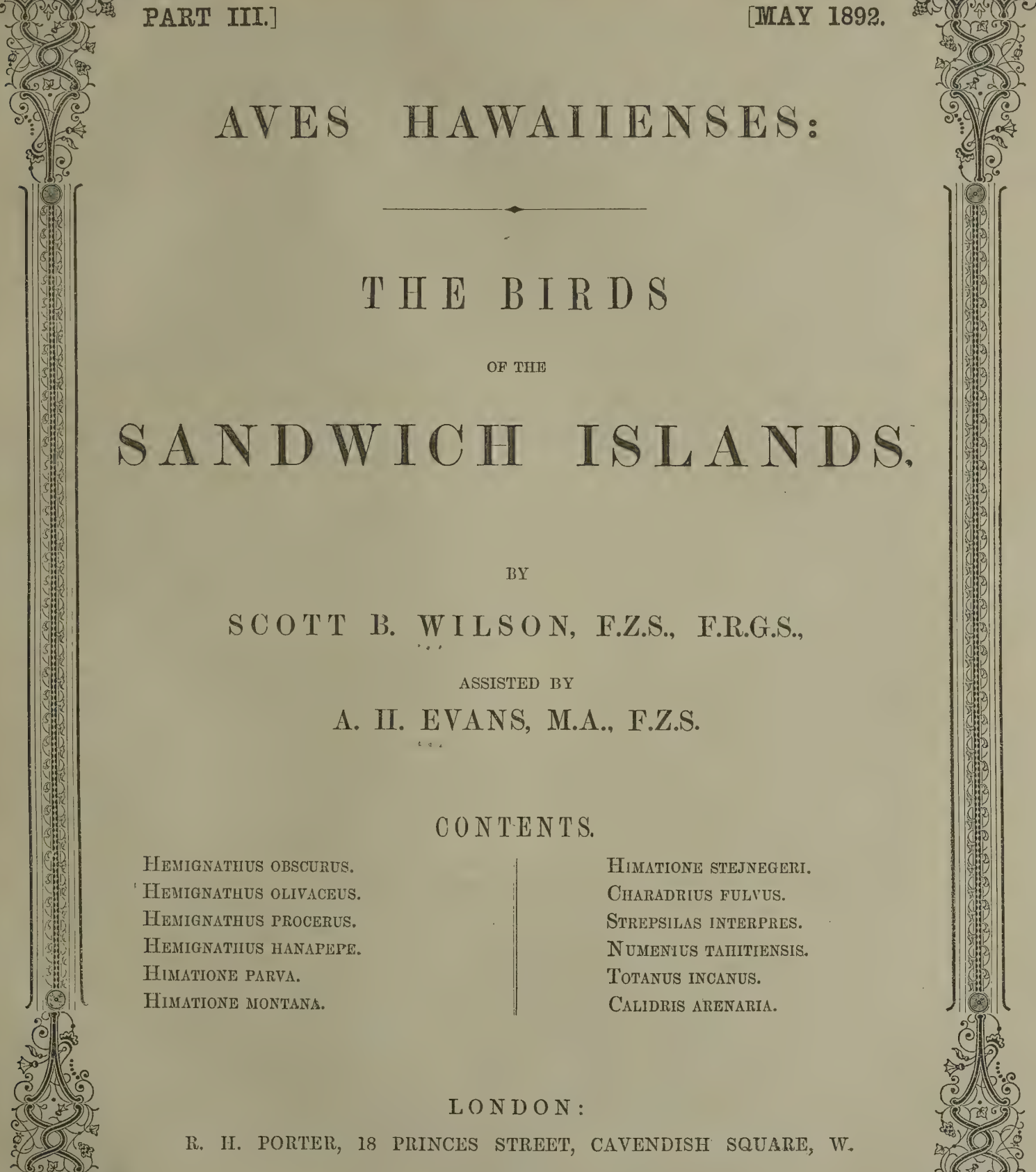

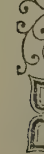




\section{The Birds of the Sandwich Islands.}

SUBSCRIBERS' NAMES ALREADY RECEIVED.

\section{RESIDENTS IN THE HAWAIIAN ISLANDS.}

\section{H.R.H. THE PRINCESS VICTORIA KAIULANI.}

\author{
BISHOP, Charles R., The Hon. (2 copies.) \\ CAR'TER, Mrs. Sybil A. (2 copies.) \\ CLEGHORN, A. S., The Hon. \\ GAY, Francis, Esq. \\ HAWAIIAN News Co., The. \\ KNUDSEN, Mrs. $\nabla$.
}

ROBINSON, Aubrey, Esq.

SINCLAIR, Francis, Esq.

SMITH, Armstrong, Esq., F.R.G.S.

SPENCER, Francis, Esq.

TURRILL, F., Esq.

VON TEMPSKY, Randal, Esq.
ARGYLT, His Grace the Duke of, K.G. ASHER \& Co., Messrs. (3 copies.)

BAIN, Mr. J.

BALSTON, R. J., Esq., F.Z.S.

BEATE, Lionel S., Prof., M.B., F.R.S.

BREWSTER, William, Esq.

BUCKLEY, T. E., Esq.

BURTON, Mr. H. T.

CAMPBELL, Lord Archibald.

CARPENTER, J. H., Esq.

CARSON, John, Esq.

CHAMBERLAIN, Walter, Esq.

CHASE, R. W., Esq.

CLARKE, W. Eagle, Esq., F.L.S.

COBBETT, A., Esq.

COOPER, E. H., Colonel, F.Z.S.

CORY, C. B., Esq., F.L.S.

CROWLEY, P., Esq., F.Z.S.

DAVIES, T. H., Esq.

DEACON, W. S., Esq.

DIXON, Abraham, E'sq.

DOGGE'TT, Mr. F.

DOWSETT, A., Esq.

DOWSON, Edward Morris, Esq.

DULAU \& Co., Messrs. (4 copies.)

ELLIOTT, Ernest A., Esq.

FRIEDLÄNDER u. Sohn. (3 eopies.)

FROHAWK, F. W., Esq., F.E.S.

GAGE GARDINER, Mrs.

GODMAN, F. Du Cane, Esq., F.R.S.

GREVEL \& Co., Messrs. H.

HARCOURT, E. W., Esc., M.P.

HARRISON, Mrs. W. F.

HARVARD College.

HARVIE BROWN, J. A., Esq.

HOFFNUNG, A., Esq.

HOPE, T., Esq.

HORNE, Edward, Esq., J.P.

JAJIES, H. Berkeley, Esq., F.Z.S.
KEGAN PAUL, TRENCH, \& Co., Messrs.

KEMLPEN, Prof. Ch. van.

KIRBERGER \& KESPER, Messrs.

LEES, Edward B., Esq.

LILFORD, The Rt. Hon. Lord, F.Z.S.

LORENT, J. R., Esq.

LOTHIAN, The Marquess of, F.L.S.

LUCAS, F. W., Esq.

MACINTOSH, James, Esq.

MANGER, W. T., Esq.

MIDLAND Educational Co., The.

MILLAIS, J. G., Esq., F.Z.S.

MILNER, Edward, Esq.

NEWTON, Sir Edward, M.A., K.C.M.G., F.L.S.

NEWTON, Prof., MI.A., F.R.S.

NOBLE, W., Esq.

OXLEY, Mrs. E.

PARKER, Captain R. Townley.

PLUES, Miss.

PURVIS, Herbert, Esq.

HOOKE, P. H., Esq.

ROTHSOHILD, The Hon. Walter, F.Z.S. (2 copies.)

ROYAL College of Surgeons.

RÜCKER, H., Esq.

RUSSELL, S. G. C., Esq.

SALVADORI, Count T.

SALVIN, Capt. F. H.

SALVIN, Osbert, Esq., MI.A., F.R.S.

SCLATER, P. L., Esq., M.A., Ph.D., F.R.S.

SEEBOHM, H., Esq., F.Z.S.

SOTHERAN \& Co., Messrs. H.

TRISTRAM, The Rev. Canon, D.D., F.R.S.

WESLEY \& Son, Messrs. (2 copies.)

WIISON, Bernard, Esq.

WILSON, G.F., Esq.,F.R.S., F.L.S.,F.C.S. (3 copies.)

WILSON, Herman G., Esq.

WILSON, Robert, Esq.

ZOOLOGICAL Society of London. 


\section{'THE BIRDS OF THE SANDWICH ISLANDS.'}

\section{THE IBIS.}

"We are much pleased to welcome the first part of Mr. Scott Wilson's promised volume on the avifuna of the Jawaiin Islands, and trust he will be able, with the assistance of Mr. Evans, to bring it to a satisfactory conclusion. It will be very convenient to have the great advances which Mr. Wilson has undoubtedly made in our knowledge of this most interesting subject incorporated with all that was proviously known of it

"Mr. Frohawls's plates will give pleasure to all who study them."

\section{THE A U K.}

"The progress of Ornithology of late years is well exemplified by the work before us. Twenty years ago a small octovo pamphlet held all we knew about the birds of one of the most interesting and peculiar zoogeographical provinces; while to-day it requires a landsome quarto volume with numerous coloured plates to fully represent our knowledge of the subject. Twenty years ago the number of species known to inhabit the Hawaiian Islands was considered to be about forty by the best authority, Sclater ('Ibis,' 1871, p. 361). To-day the number is scarcely less than seventy; and the most astonishing fact is that this increase of our lknowledge of one of the most accessible and most civilized archipelagoes in the Pacilic Ocean has taken place during the last five years. To Mr. Scott B. Wilson, who spent eighteen months on the islands in order to study their ormithology, much credit is due for this increase, and it is with great pleasure that we extend our welcome to the work which he is now publishing; and we wish especinlly to call the attention of our American Ornithologists to it, as, from the situation of the Hawaiian Archipelago in relation to our own continent, we ought to tale more interest in its avifauna than has been done hitherto.

"The work is uniform in appearance with most of the more ambitious ornithological monographs which hnve been published in England of late years, and is issued in Five Parts, two of which have adready been published. These two Parts treat of eighteen species, and are accompanied by twenty Plates, some of them representing species now extinct or nearly so. The second Part contains a very valuable and interesting trestise by Dr. Hans Gadow, 'On the Strueture of certain Hawaiian Birds, with reference to their Systematic Position,' to the illustration of which three of the Plates are devoted. Nany unexpected conclusions are the result of his investigation, and the ornithological public is under great obligations to $\mathrm{Mr}$. Scott B. Wilson for not having spared any expense in order to have this side of the ornithology of the group as well taken care of as that devoted to the outside of the birds alone. For details and information we refer the reider to the book itself, and we advise all who can afford it to subscribe for it.

"The author has had heary expenses in order to bring it out, and the work is well worth encourngement.-L. S."

\section{THE FIELD.}

"The avi-fanna of the Sandwich Islands lias been but imperfectly investigated by the various naturalists and exploring expeditions that have visited those islands, and, consaquently, our knowledge of it has been imperfect. The 'Challenger,' in its historic voyag'e (which, however, was chiefly to explore the deptlis of the sea), stayed in Hawaiian waters for some three weeks in 1875, but the collection of birds made by the officers included only one new species. Some of the birds of these islands have been exterminated since the time of Capt. Cook, and others are likely to follow in their course. Under these circumstances, Professur Newton induced Mr. S. B. Wilson to visit the islands, and to investigate their ornithology thornughly. Nrr. Wilson remained in the islands for nearly two years, and brought back a mucli more complete cullection than had been previously made. According to Professor Newton, Mr. Wilsou has done a great deal more than anyone before him ; for he has not only brought back a considerable number of new species, but, in addition, several specinens of birds that are now extinct. One of the most beautiful of the lalter is tho mamo, whase rich yellow feathers were formerly used to decorate the state robas of the chiefs. Of this biatutiful bird not half-a-dozen skins exist in the whole world; two are known at Vienna, and $\mathrm{M}_{1}$. Wilsun succeeded in obtaining two other specimens from the collection of an ornithologist long resident in the islands. These are now the only ones known in England. One Mr. Wilson has presented to the MLuseun at Odmbridge, and the other is in the possession of Mr. Walter Rothschild. In the Ethnological collection of the British Museum is a cape formed entirely of the plumage of the mamo. Its dimensions are 3 feet 6 inches wide at the lower margin. Such a cape must have required the plumage of some thousands of these birds.

"The inevitable extinction of many birds from the destruction of the forests in the tropical islands is deeply to be rogretted, and ornithologists are greatly indebted to $\mathrm{Mr}$. Wilson for publishing the results of his investigations in the very beautiful monograph under notice. It contains representations, admirably drawn and coloured by Frohawk, of the species described, several of which have already been exterminated. The text accompanying these plates is most interesting, not only from an ornithological, but from an ethnological point of view. Two parts of the fivo of whisch the volumio is to consist have already been publishod, and the third, which will shortly appear, will contain an account of the wingless bird of Hawiii, which has now also become extinet,"

\section{DAILY PACIFIC COMMERCIAL ADVERTISER. (IIONOLULU.)}

"The first two numbers of the 'Aves IIawaiienses' have reached Hunolulı, It will be remembored that Mrr. Scott 13, Wilson, F.Z.S., came out here five years agro and spent a couple of years maling a thorough investigation into Hawaiian birds, and collecting specimens of all the varieties on the different islands. The results of his labours are now taking shape in 'The Birds of the Sandwich [it should be Hawaiian.] Islands,' $a$ truly magnificent work, to be completed in Tive Parts and published by $\mathbf{R}$. H. Porter, 18 Princes Streot, Cavendish Square, London. The two first numbers contain eighteen very handsome full-page coloured plates representing eash species describad, and the work, when completed, will thus present a finished representation of each kind of bird known to these islands. MIost persons will be surprised to learn that there are so many handsome birds found here.

"Tho letterpress accompanying the plates gives, basides the scientific name and classification, a concise description of the bird and its lrabits, and other matter of a popular kind, which will make the book inteliirible and valuable to the genetal public as well as to those whose interests aro specifically scientific. This work, while possessingr a general ccientific value, will naturally bo of especial value to residents of this lingrioun. 


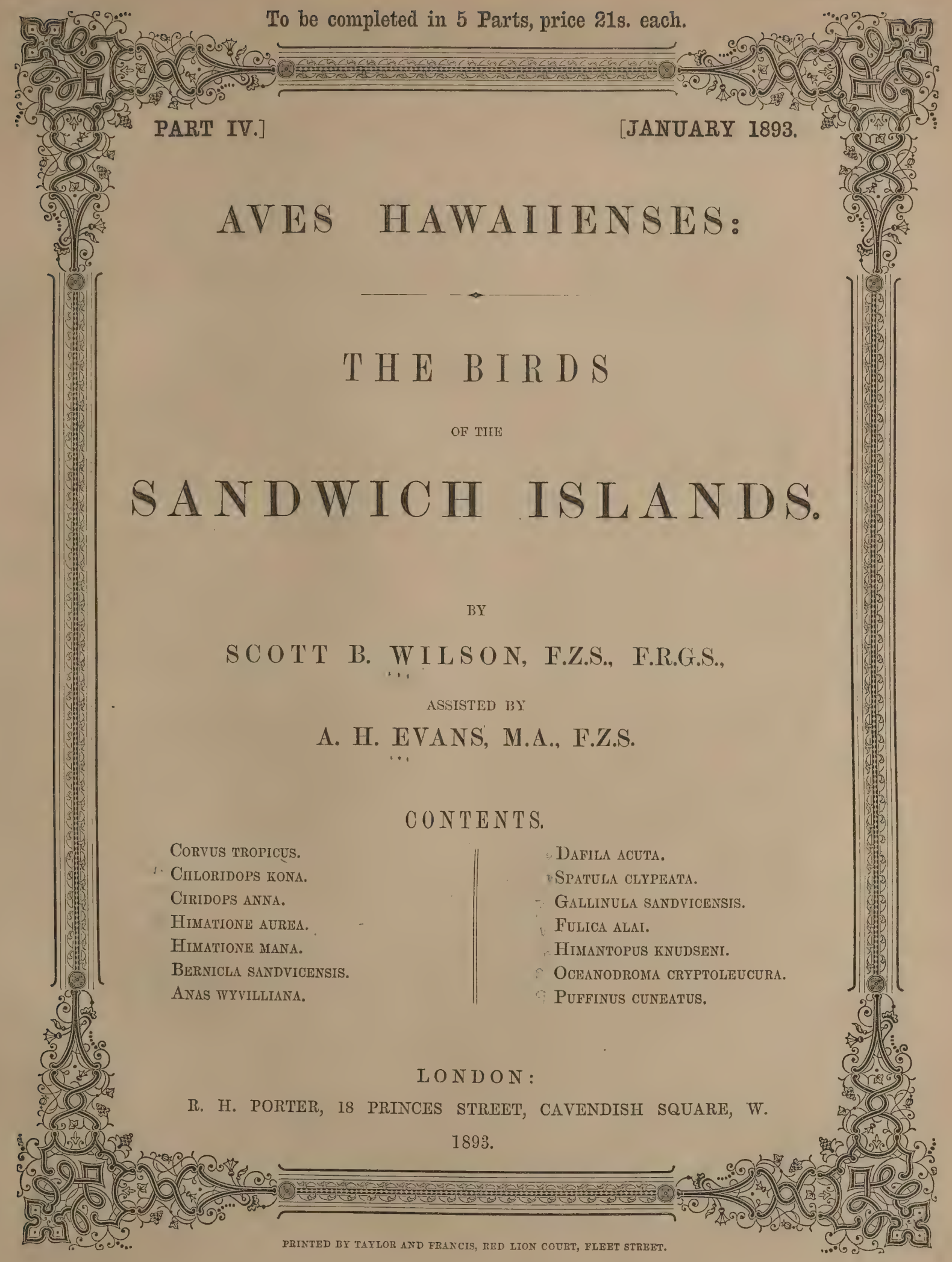




\section{The Birds of the Sandwich Islands.}

SUBSCRIBERS' NAMES ALREADY RECEIVED,

\section{RESIDENTS IN THE HAWAIIAN ISLANDS.}

\section{H.R.H.'THE PRINCESS VIOTORIA KAIULANI.}

BISHOP, Charles R, The Hon. (2 copies.) CAR'TER, Mrs. Sybil A. (2 copies.) CLEGHORN, A. S., The Hon. GAY, Francis, Esq. HAWATIAN News Co., The. KNUDSEN, Mrs. V.
ROBINSON, Aubrey, Esq. SINCLAIR, Francis, Esq. SMTTH, Armstrong, Esq., F.R.G.S. SPENCER, Francis, Esq. TURRILL, F., Esq. VAN TEMPSKY, Randal, Esq.
ARGYLI, His Grace the Duke of, K.G. ASHER \& Co., Messrs. (3 copies.)

\section{BAIN, Mr. J.}

BALSTON, R. J., Esq., F.Z.S.

BEALE, Lionel S., Prof., M.B., F.R.S.

BICKERTON, Mr. R. T.

BREWSTER, William, Esq.

BROWN, J., Esq.

BUCKLEY, T. E., Esq.

BURTON, Mr. H. T.

CAMPBELL, Iord Archibald.

CARPENTER, J. H., Esq.

CARSON, John, Esq.

CHAMBERLAIN, Walter, Esq.

CHASE, R. W., Esq.

CLARKE, W. Eagle, Esq., F.L.S.

COBBETT, A., Esy.

COOPER, E. H., Colonel, F.Z.S.

CORY, C. B., Esq., F.L.S.

OROWLEY, P., L'sq., F.Z.S.

DAVIES, T. H.; Eisq.

DEACON, W. S., Esq.

DIXON, Abraham, Esq.

DOGGETT, Mr. F.

DOWSETT, A., Esq.

DOW SON, Edward Morris, Esq.

DRESSER, H. E., Esq.

DULAU \& Co., Miessrs. (4 eopies.)

EDINBURGH Museum of Science and Art.

ELLIOTT, Ernest A.; Esq.

FRIEDLÄNDER 11. Solnn. (3 copies.)

FROHAWK; F. W., Esi., F.E.S.

GAGE GARDINER, Mrs:

GODMAN, F. Du Cane, Esq., F.R.S.

GREVEL \& Co., Messrs: H.

HARCOURT, E. W., Esq., M.P.

HARRISON, MIrs. W. F.

HARVARD College.

HARVIE BROWN, J. A., Esq.

HOFFNUNG, A., Esq.

HOPE, 'T., E'sq.

HORNE, Edward, Esq., J.P.

JAMES, H. Berkeley, Esq., F.Z.S. (the late). JENTINK, Dr. F. A.
KEGAN PAUL, TRENCH, \& Co, Messrs.

KEMPEN, Prof. Ch. van.

KIRBERGER \& KESPER, Messrs.

LEES, Edward B., Esq.

LEVERKÜHN, Herr Paul.

LILFORD, The Rt. Hon. Lord, F.Z.S.

LORENT, J. R., Esq.

LO'THIAN, The Marquess of, F.L.S.

LUCAS, F. W., Esq.

MACINTOSH, James, Esq.

MANGER, W. T., Esq.

IIIDLAND Educational Co., The.

MILLAIS, J. G., Esq., F.Z.S.

MILNER, Edward, Esq.

NEWTON, Sir Edward, M.A., K.C.M.G., F.L.S. NEWTON, Prof., M.A., F.R.S.

NOBLE, W., Esq.

OGILVIE, Menteith. Esq.

OXLEY, Mrs. E.

PARKER, Captain R. Townley.

PLUES, Miss.

PURVIS, Herbert, Esq.

REGEL, Dr. E.

ROOKE, P. H., Esq.

ROTHSCHLD, The Hon. Walter, F.Z.S. (2 copies.)

ROYAL College of Surgeons.

RÜCKER, H., Esq.

RUSSELL, S. G. C., Esq.

SALVADORI, Count T.

SALVIN, Capt. F. H.

SALVIN, Osbert, Esq., M.A., F.R.S.

SCLATER, P. L., Esq., M.A., Ph.D., F.R.S.

SEEBOHM, H., Esq., F.Z.S.

SHARPE, Dr. R. Bowdler.

SMITH, Armstrong, Esq., F.R.G.S.

SOTHERAN \& Co., Messrs. H.

STEJNEGER, Dr. L.

TRISTRAM, The Rev. Canon, D.D., F.R.S.

TULK, J. A., Esq.

WESLEY \& Son, Messrs. (2 copies.)

WILSON, Bernard, Esq.

WILSON, G.F., Esq.,F.R.S., F.L.S.,F.C.S. (3 copies.)

WILSON, Herman G., Esq.

WILSON, Robert, Esq.

ZOOLOGICAL Society of London. 



\section{'THE BIRDS OF THE SANDWICH ISLANDS.'}

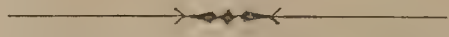

\section{THE IBIS.}

"We are much pleased to welcome the first part of Mr. Scott Wilson's promised volume on the avifauna of the Hawaiian Islands, and trust he will be able, with the assistance of Mr. Evans, to bring it to a satisfactory conclusion. It will be very convenient to have the great advances which Mr. Wilson has undoubtedly made in our knowledge of this most interesting subject incorporated with all that was previously known of it.

"Mr. Frohawl's plates will give pleasure to all who study them."

\section{THE A U K.}

"The progress of Ornithology of late years is well exemplified by the work before us. Twenty years ago a small octavo pamphlet held all we knew about the birds of one of the most interesting and peculiar zoogeographical provinces; while to-day it requires a handsome quarto volume with numerous coloured plates to fully represent our knowledge of the subject. Twenty years ago the number of species known to inhabit the Hawaiian Islands was considered to be about forty by the best authority, Sclater ('Ibis,' 1871, p. 361). To-day the number is scarcely less than seventy; and the most astonishing fact is that this increase of our knowledge of one of the most accessible and most civilized archipelagoes in the Pacific Ocean has taken place during the last five years. To Mr. Scott B. Wilson, who spent eighteen months on the islands in order to study their ornithology, much credit is due for this increase, and it is with great pleasure that we extend our welcome to the work which he is now publishing; and we wish especially to call the attention of our American Ornithologists to it, as, from the situation of the Hawaiian Archipelago in relation to our own continent, we ought to take more interest in its avifauna than has been done hitherto.

"The work is uniform in appearance with most of the more ambitious ornithological monographs which have been published in England of late years, and is issued in Five Parts, two of which have already been published. These two Parts treat of eighteen species, and are accompanied by twenty Plates, some of them representing species now extinct or nearly so. The second Part contains a very valuable and interesting treatise by Dr. Hans Gadow, 'On the Structure of certain Hawaiian Birds, with reference to their Systematic Position,' to the illustration of which three of the Plates are devoted. Many unexpected conclusions are the result of his investigation, and the ornithological public is under great obligations to Mr. Scott B. Wilson for not having spared any expense in order to have this side of the ornithology of the group as well taken care of as that devoted to the outside of the birds alone. For details and information we refer the reader to the book itself, and we advise all who can afford it to subscribe for it.

"The author has had heavy expenses in order to bring it out, and the work is well worth encouragement.-L. S."

\section{THE FIELD.}

"The avi-fauna of the Sandwich Islands has been but imperfectly inrestigated by the various naturalists and exploring expeditions that have visited those islands, and, consequently, our knowledge of it has been imperfect. The 'Challenger,', in its historic voyage (which, however, was chiefly to explore the depths of the sea), stayed in Hawaiian waters for some three weels in 1875 , but the collection of birds made by the officers included only one new species. Some of the birds of these islands have been exterminated since the time of Capt. Couk, and others are likely to follow in their course. Under these circumstances, Professor Newton induced $\mathrm{Mr}$. S. B. Wilson to visit the islands, and to investigat their ornithology thoroughly. Mr. Wilson remained in the islands for nearly two years, and brought back a much more complete collection than had been previously made. According to Professor Newton, $\mathrm{Mr}$. Wilson has done a great deal more than anyone before him ; for he has not only brought back a considerable number of new species, but, in addition, several specimens of birds that are now extinct. One of the most beautiful of the latter is the mamo, whose rich yellow feathers were formerly used to decorate the state robes of the chiefs. Of this beautiful bird not half-a-dozen skins exist in the whole world; two are known at Vienna, and Mr. Wilsun succeeded in obtrining two other specimens from the collection of an ornithologist long resident in the islands. These are now the only ones known in England. One Mr. Wilson has presented to the Museum at Cambridge, and the other is in the possession of Mr. Walter Rothschild. In the Ethnological collection of the British Museum is a cape formed entirely of the plumage of the mamo. Its dimensions are 3 feet 6 inches wide at the lower margin. Such a cape must have required the plumage of some thousands of these birds.

"The inevitable extinction of many birds from the destruction of the forests in the tropical islands is deeply to be regretted, and ornithologists are greatly indebted to Mr. Wilson for publishing the results of his investigations in the very beautiful monograph under notice. It contains representations, admirably drawn and coloured by Frohawl, of the species described, several of which have already been exterminated. The text accompanying these plates is most interesting; not only from an ornithological, but from an ethuological point of view. Two parts of the five of which the volume is to consist have already been published, and the third, which will shortly appear, will contain an account of the wingless bird of Hawaii, which has now also become extinct."

\section{DAILY PACIFIC COMMERCIAL ADVERTISER. (HONOLULU.)}

"The first two numbers of the 'Ares Hawaiienses' have reached Honolulu. It will be remembered that Mr. Scott B. Wilson, F.Z.S., came out here five years ago and spent a couple of years making a thorough investigation into Hawaiian birds, and collecting specimens of all the varieties on the different islands. 'L'he results of his labours are now taking shape in 'The Birds of the Sandwich [it should be Hawaiian] Islands,' a truly magnificent work, to be completed in Five Parts and publishod by K. H. Porter, 18 Princes Street, Uavendish Square, London. The two first numbers contain eighteen very handsome full-page coloured plates representing eash species described, and the work, when completed, will thus present a finished xepresentation of each kind of bird known to these islands. Most persons will be surprised to learn that there are so many handsome birds found here.

"The letterpress accompanying the plates gives, besides the scientitic name and classification, a concise description of the bird and its labits, and other matter of a popular lind, which will mako the book intelligible and valuable to the general public as well as to those whose interests are specifically scientitic. This work, while possessing a general scientific value, will naturally be of especial value to residents of this kingdom." 


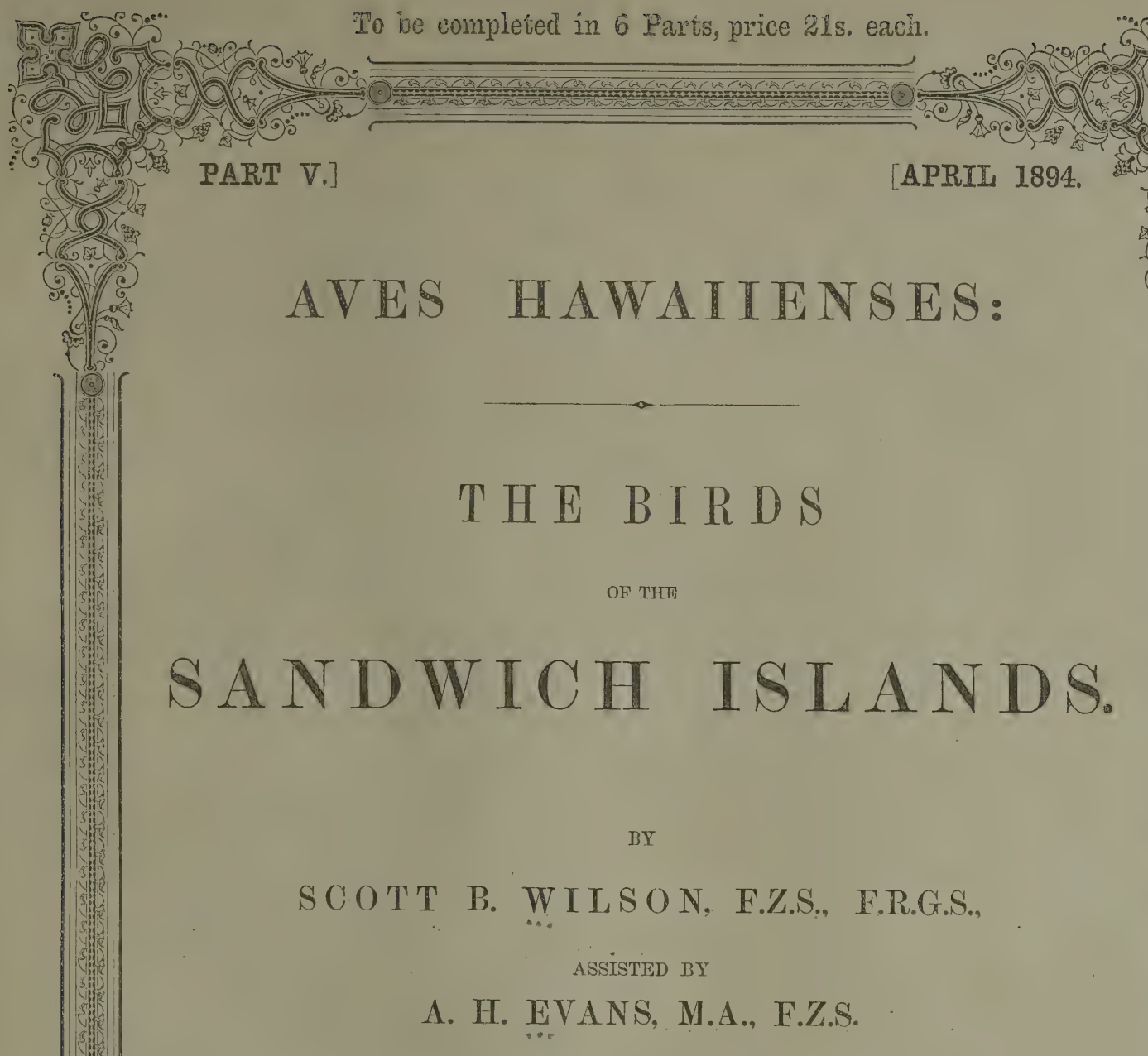




\section{The Birds of the Sandwich Islands.}

SUBSCRIBERS' NAMES ALREADY RECEIVED.

\section{RESIDENTS IN THE HAWAIIAN ISLANDS.}

\section{H.R.H. THE PRINCESS VICTORIA KAIULANI.}

BISHOP, Charles R., The Hon. (2 copies.) CAR'CER, Mrs. Sybil A. (2 copies.) CLEGHORN, A. S., The Hon.

GAY, Francis, Esq.

HAWATIAN News Co., The.

KNUDSEN, Mrs. V.
ROBINSON, Aubrey, Esq. SINCLAIR, Francis, Esq. SMITH, Armstrong, Esq., F.R.G.S. SPENCER, Francis, Esq. TURRILL, F., Esq.

VAN TEMPSKY, Randal, Esq.
ARGYLL, His Grace the Duke of, K.G.

ASHER \& Co., Messrs. (3 copies.)

BAIN, Mr. J.

BALSTON, R. J., Esq., F.Z.S.

BEALE, Lionel S., Prof., M.B., F.R.S.

BICKERTON, Mr. R. T.

BREWSTER, William, Esq.

BROWN, J., Esq.

BUCKLEY, T. E., Esq.

BURTON, Mr. H. T.

CAMPBELL, Lord Archibald.

CARPENTER, J. H., Esq.

CARSON, John, Esq.

CHAMBERLAIN, Walter, Esq.

CHASE, R. W., Esq.

CLARKE, W. Eagle, Esq., F.L.S.

COBBETT, A., Es\%.

COOPER, E. H., Colonel, F.Z.S.

CORY, C. B., Esq., F.L.S.

CROMPTON, Sidney, Esq.

CROWLEY, P., Esq., F.Z.S.

DAVIES, T. H., Esq.

DEACON, W. S., Esq.

DIXON, Abraham, Esq.

DOGGETT, Mr. F.

DOWSETT, A., Esq.

DOWSON, Edward Iorris, Esq.

DRESSER, H. E., Esq.

DULAU \& Co., Messrs. (4 copies.)

EDINBURGH Museum of Science and Art.

ELLIOTT, Ernest A., Esq.

FRIEDLÄNDER u. Sohn. (3 copies.)

FROHAWK, F. W., Esq., F.E.S.

GAGE GARDINER, Mrs.

GODMAN, F. Du Came, Esq., F.R.S.

GIREVEL \& Co., Messrs. $H$.

HARCOURT, E. W., Esq., M.P.

HARRISON, Mrs. W. F.

HARVARD College.

HARVIE BROWN, J. A., Esq.

HOFFNUNG, A., Esq.

HOPE, T., Esq.

HORNE, Edward, Esq., J.P.

INDTAN Museum, Calcutta.

JAMTES, H. Berkeley, Esq., F.Z.S. (the late).

JENTINK, Dr. F. A.
KEGAN PAUL, TRENCH, \& Co., Messrs. (2 copies.)

KEMPEN, Prof. Ch. van.

KIRBERGER \& KESPER, Messrs.

LEES, Edward B., Esq.

IEVERKÜHN, Herr Paul.

LILFORD, The Rt. Hon. Lord, F.Z.S.

LORENT, J. R., Esq.

LOTHIAN, The Marquess of, F.L.S.

LUCAS, F. W., Esq.

MACINTOSH, James, Esq.

MANGER, W. T., Esq.

MIDLAND Educational Co., The.

MILLAIS, J. G., Esq., F.Z.S.

MLNER, Edward; Esq.

NEWTON, Sir Edward, M.A., K.C.M.G., F.L.S.

NEWTON, Prof., MI.A., F.R.S.

NOBLE, W., Esq.

OGILVIE, Menteith, Esq.

OXIEY, Mrs. E.

PARKER, Captain R. Townley.

PLUES, Miss.

PURVIS, Herbert, Esq.

REGEL, Dr. E.

ROBB, Mrs.

ROOKE, P. H., Esq.

ROTHSCHILD, The Hon. Walter, F.Z.S. (2 copies.)

ROYAL College of Surgeons.

RÜCKER, H., Esq.

RUSSELL, S. G. C., Esq.

SALVADORI, Count T.

SALVIN, Capt. F. H.

SALVIN, Osbert, Esq., M.A., F.R.S.

SCLATER, P. L., Esq., M.A., Ph.D., F.R.S.

SEEBOHM, H., Esq., F.Z.S.

SHARPE, Dr. R. Bowdler.

SMITH, Armstrong, Esq., F.R.G.S.

SOTHERAN \& Co., Messrs. H.

STECHERT, Mr. G. E.

STEJNEGER, Dr. L.

TRISTRAM, The Rer. Canon, D.D., F.R.S.

TULK, J. A., Esq.

WESLEY \& Son, Messrs. (2 copies.)

WILSON, Bernard, Esq.

WILSON, G.F., Esq.,F.R.S., F.L.S., F.C.S. (3 copies.)

WIISON, Herman G., Esq.

WILSON, Robert, Esq.

ZOOLOGICAL Society of London. 


\section{'THE BIRDS OF THE SANDWICH ISLANDS'}

\section{THE IBIS.}

"We are much pleased to weleome the first part of Mr. Scott Wilson's promised volume on the arifauna of the Hawriian Islands, and trust he will be able, with the assistance of NIr. Evans, to briog it to a satisfactory conclusion. It will be very convenient to have the great advances which Mr. Wilson has undoubtedly made in our knowledge of this most interesting subject incorporated with all that was previously known of it.

"Mr. Frobawk's plates will give pleasure to all who study them."

\section{T H E A UK.}

"The progress of Ornithology of late years is wrell exemplified by the work before us. Twenty years ago a small octnyo pamphlet held all we knew about the birds of one of the most interesting and peculiar zoogeographical provinces; while to-day it requires a handsome quarto volume with numerous coloured plates to fully represent nur knowledge of the subject. Twenty years ago the number of species known to inhabit the Hawailan Islands was considered to be about forty by the best authority, Sclater ('Ibis,' 1871, p. 361). 'To-day the number is scarcely less than seventy; and the most astonishing fact is that this increase of our knowledge of one of the most accessible and most civilized archipelagoes in the Pacific Ocean has talken place during the last five years. To Mr. Scott B. Wilson, who spent eighteen months on the islands in order to study their ornithology, much credit is due for this increase, and it is with great pleasure that we extend our welcome to the work which he is now publishing; and we wish especially to call the attention of our American Ornithologists to it, as, from the situation of the Hawaiin Archipelago in relation to our own continent, we ought to take more interest in its avifauna than has been done hitherto.

"The work is uniform in appearance with most of the more ambitious ornithological monographs which have been published in England of late years, and is issued in Five Parts, two of which have already been published. These two Parts treat of eighteen species, and are accompanied by trventy Plates, some of them representing species now extinct or nearly so. The second Part contains a very valuable and interesting treatise by Dr. Hans Gadow, 'On the Structure of certain Hawaiian Birds, with reference to their Systematic Position,' to the illustration of which three of the Plates are devoted. Many unexpected conclusions are the result of his investigation, and the ornithological public is under great obligations to Mrr. Scott B. Wilson for not having spared any exponse in order to have this side of the ornithology of the group as well taken care of as that devoted to the outside of the birds alone. For details and information we refer the reader to the book itself, and we advise all who can afford it to subscribe for it.

"The author has had heavy expenses in ordcr to bring it out, and the work is well worth encouragement.-L. S."

\section{THE FIELD.}

"The avi-fauna of the Sandwich Islands has been but imperfectly investigated by the various naturalists and exploring expeditions that have visited those islands, and, consequently, our knowledge of it has been imperfect. The 'Challenger,' in its historic voyage (which, however, was chietly to explore the depths of the sea), stayed in Hawaiian waters for some three weelss in 1875 , bat the collection of birds made by the officers included only one new species. Some of the birds of these islands have been exterminated since the time of Capt. Couls, and others are likely to follow in their course. Under these circumstances, Professor Newton induced Mr. S. B. Wilson to visit the islands, and to investigate their ornithology thoroughly. Mr. Wilson remained in the islands for nearly two years, and brought brak al much nore complete collection than had been previously made. According to Professor Newton, Mr. Wilson has done a great deal more than anyone before him ; for he has not only brought back a considerable number of new species, but, in addition, several specimens of birds that are now extinct. One of the most beautiful of the latter is the mamo, whose rich yellow featbers were formerly used to decorate the state robes of the chiefs. Of this beautiful bird not half-a-dozen slins exist in the whole world; two are lsuown at Vienna, and Mr. TVilsun succeeded in obtaining two other specimens from the collection of an ornithologist long resident in the islands. These are now the only ones linown in Eugland. One Mr. Wilson has presented to the Miseum at Cambridge, and the other is in the possession of Mr. Walter Rothschiid. In the Ethnological collection of the British Museum is a cape formed entirely of the plumage of the mamo. Its dimensions are 3 fuet 6 inches wide at the lower margin. Such a cape must have required the plumnge of sume thousands of these birds.

"'The inevitable extinction of many birds from the destruction of the forests in the tropical islands is deeply to be regretted, and orvithologists are greatly indebted to MIr. Wilson for publishing the results of his investigations in the very beautiful monograph under notice. It contains representations, admirably drawn and coloured by Frohawk, of the species described, several of which have already been exterminated. The text accompanying these plates is most interesting, nut only from an ornithological, but from an ethnologieal point of viow. Two parts of the five of which the volume is to consist have already been published, and the third, which will shortly appear, will contain an account of the wingless bird of Hawaii, which lias now also become extinct."

\section{DAILY PACIFIC COMMERCIAL ADVERTISER. (HONOLULU.)}

"The first two numbers of the 'Aves Hawaiienses' bave reached Honolulu. It will be remembered that Mr. Scott B. Wilsun, F.L.S., came out here five years ago and spent a couple of years makingr a thorougn investigation into Hawaiian birds, and collecting specimens of all the varieties on the different islands. I'he results of his liburs are now taking shape in 'The Birds of the Sandwich [it should be Hawaiian] Islands,' a truly maynilicent twork, to be completed in five Parts and published by R. H. Porter, 1o Princes street, Cavendish Square, London. 'L'he two tirst numbers contain eighteen very handsome full-page coloured plates representing each species described, and tho work, when completed, will thus present a finished representation of each kind of bird known to these islands. Most persuris will be surprised to learn that there are so many haudsone birds found here.

"The letterpress accompanying the plates gires, besides the scientilic name and classification, a concise description of the bird and its habits, and other matter of a popular lind, which will male the book inteligible and valuable we the general public as well as to those whose interests are specifically scientinc. This work, wiule possessing a genterul scientitic value, will naturally be of especial value to residents of uis kingrolun." 


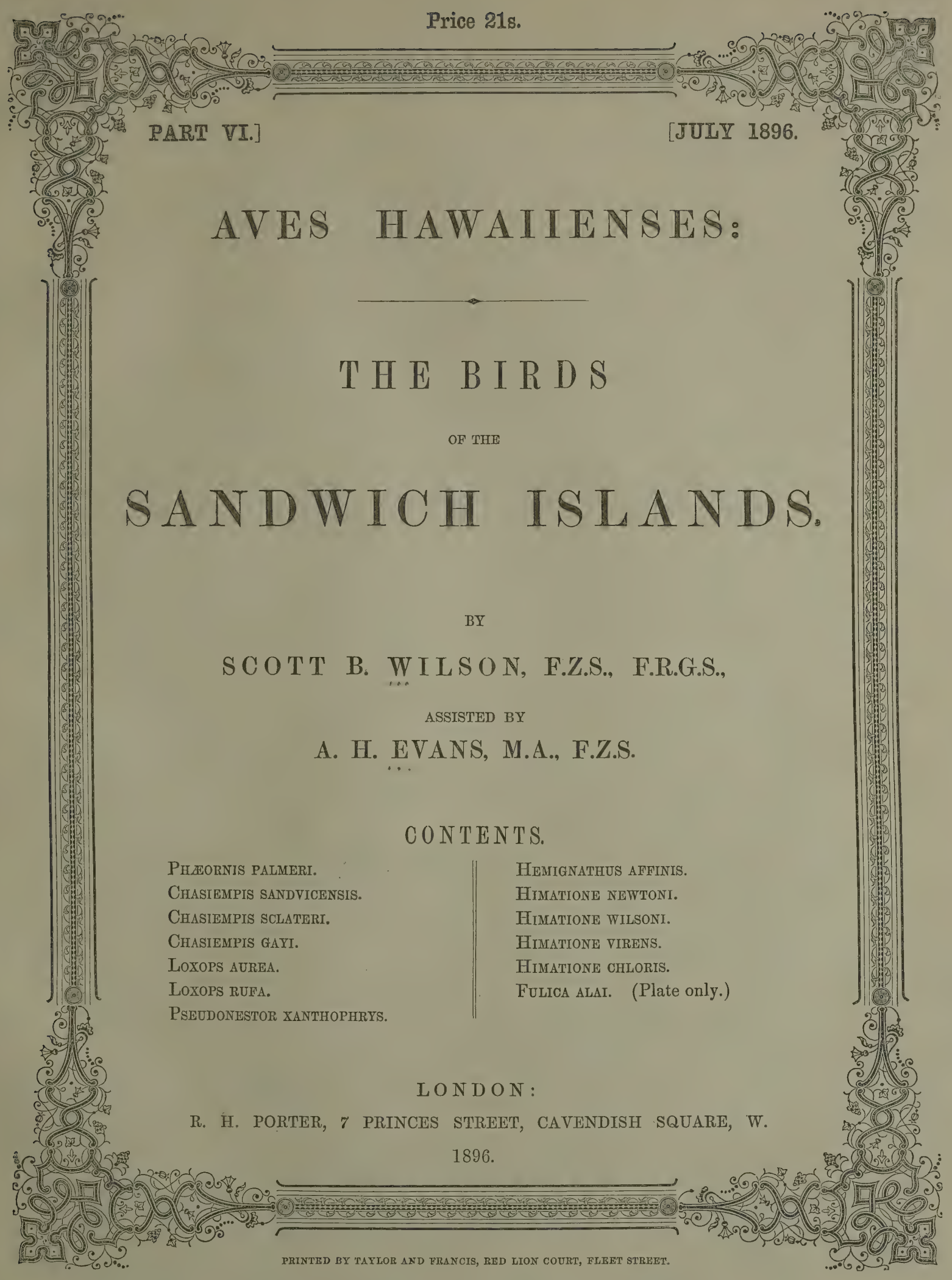






\section{'THE BIRDS OF THE SANDWICH ISLANDS.'}

\section{THE IBIS.}

"We are much pleased to welcome the first part of Mr. Scott Wilson's promised volume on the arifauna of the Hawaiian Islands, and trust he will be able, with the assistance of Mr. Evans, to bring it to a satisfactory conelusion. It will be very convenient to have the great advances which Mr. Wilson has undoubtedly mado in our lmowledge of this most interesting subject incorporated with all that was previously known of it.

"Mr. Frohawk"s plates will give pleasure to all who study them."

\section{TH E A UK.}

"The progress of Ornithology of late years is well exemplified by the work before us. Twenty years ago a small octavo pamphlet held all we linew about the birds of one of the most interesting and peculiar zoogeographical provinces; while to-day it requires a handsome quarto volume with numerous coloured plates to fully represent our knowledge of the subject. Twenty years ago the number of species known to inhabit the Hawaiian Islands was considered to be about forty by the best authority, Sclater ('Ibis,' 1871, p. 361). To-day the number is scarcely less than seventy ; and the most astonishing fact is that this increase of our lnowledge of one of the most accessible and most civilized archipelagoes in the Pacific Ocean has taken place during the last five years. To Mr. Scott B. Wilson, who spent eighteen months on the islands in order to study their ornithology, much credit is due for this increase, and it is with great pleasure that we extend our welcome to the work which he is now publishing; and wo wish especially to call the attention of our American Ornithologists to it, as, from the situation of the Hawaiian Archipelago in relation to our own continent, we ought to take more interest in its avifauna than has been done hitherto.

"The work is uniform in appearance with most of the more ambitious ornithological monographs which have been published in England of late years, and is issued in Five Parts, two of which have already been published. These two Parts treat of eighteen species, and are accompanied by twenty Plates, some of them representing species now extinct or nearly so. The second Part contrins a very valuable and interesting treatise by Dr. IIans Gadow, 'On the Structure of certain Hawaiian Birds, with reference to their Systematic Position,' to the illustration of which three of the Plates are devoted. Many unexpected conclusions are the result of his investigation, and the ornithological public is under great obligations to Mrr. Scott B. Wilson for not having spared any expense in order to have this side of the ornithology of the group as well taken care of as that devoted to the outside of the birds alone. For details and information we refer the reader to the book itself, and we advise all who can afford it to subscribe for it.

"The author has had heavy expenses in order to bring it out, and the work is well worth encouragement.-L. S."

\section{THE FIELD.}

"The avi-fauna of the Sandwich Islands has been but imperfectly investigated by the various maturalists and exploring expeditions that have visited those islands, and, consequently, our knowledge of it has been imperfect. The 'Challenger,' in its historic voyage (which, however, was chiefly to explore the depths of the sea), stayed in Hawaiian waters for some three weeks in 1875 , but the collection of birds made by the officers included only one new species. Some of the birds of these islands have been exterminated since the time of Capt. Cook, and others are likely to follow in their course. Under these circumstances, Professor Newton induced Mr. S. B. Wilson to visit the islands, and to investigate their ornithology thoroughly. Mr. Wilson remained in the islands for nearly two years, and brought back a much more complete collection than had been previously made. According to Professor Newton, Nr. Wilson has done a great deal more than anyone before him; for he has not only brought back a considerable number of new species, but, in addition, several specimens of 'birds that are now extinct. One of the most beautiful of the latter is the mamo, whose rich yellow feathers were formerly used to decorate the state robes of the chiefs. Of this beautiful bird not half-a-dozen skins exist in the whole world; two are known at Vienna, and Mr. Wilsun succeeded in obtaining two other specimens from the collection of an ornithologist long resident in the islands. These are now the only ones known in England. One Mr. Wilson has presented to the Museum at Cambridge, and the other is in the possession of Mr. Walter Rothschild. In the Ethnological collection of the British Museum is a cape formed entirely of the plumage of the mamo. Its dimensions are 3 feet 6 inches wide at the lower margin. Such a cape must have required the plumage of some thousands of these birds.

"The inevitable extinction of many birds from the destruction of the forests in the tropical islands is deeply to be regretted, and ornithologists are greatly indebted to $\mathrm{Mr}$. Wilson for publishing the results of his investigations in the very benutiful monograph under notice. It contains representations, admirably drawn and coloured by Frohawls, of the species described, several of which have already been exterminated. The text accompanying these plates is most interesting, not only from an ornithological, but from an ethnological point of view. Two parts of the five of which the volume is to consist have already been published, and the third, which will shortly appear, will contain an account of the wingless bird of IIawaii, which has now also become extinct."

\section{DAILY PACIFIC COMMERCIAL ADVERTISER. (HONOLULU.)}

"The first two numbers of the 'Ares Hawaiienses' have reached Honolulu. It will be remembered that Mr. Scott B. Wilson, F.Z.S., came out here five years ag'o and spent a couple of years making a thorough investigation into Hawaiian birds, and collecting specimens of all the varieties on the different islands. The results of lis labours are now taking shape in 'The Birds of the Sandwich [it should be Hawaiian] Islands,' a truly magnificent work, to be completed in Hive Parts and published by K. H. Porter, 18 Prinees Street, Cavendish Square, London. The two first numbers contain eighteen very handsome full-page coloured plates representing each species described, and the work, when completed, will thus present a finished representation of each kind of bird known to these islands. MIost persons will be surprised to learn that there are so many handsome birds found here.

"The letterpress accompanying the plates gives, besides the scientific name and classification, a concise description of the bird and its habits, and other matter of a popular kind, which will malre the book intelligible and valuable to the general public as well as to those whose interests are specifically scientific. This work, while possessing a general scientific value, will naturally be of especial value to residents of this kingdom." 


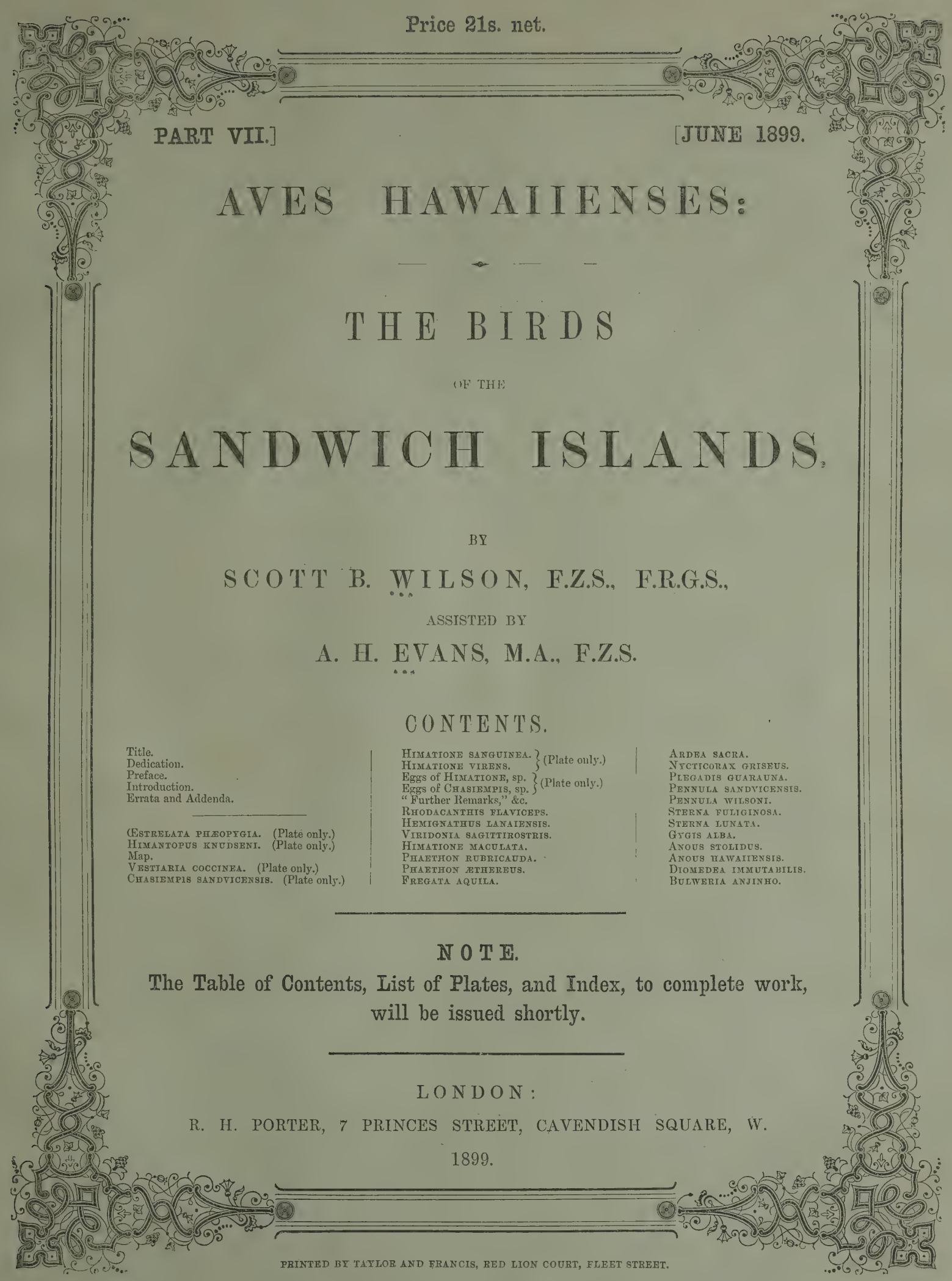







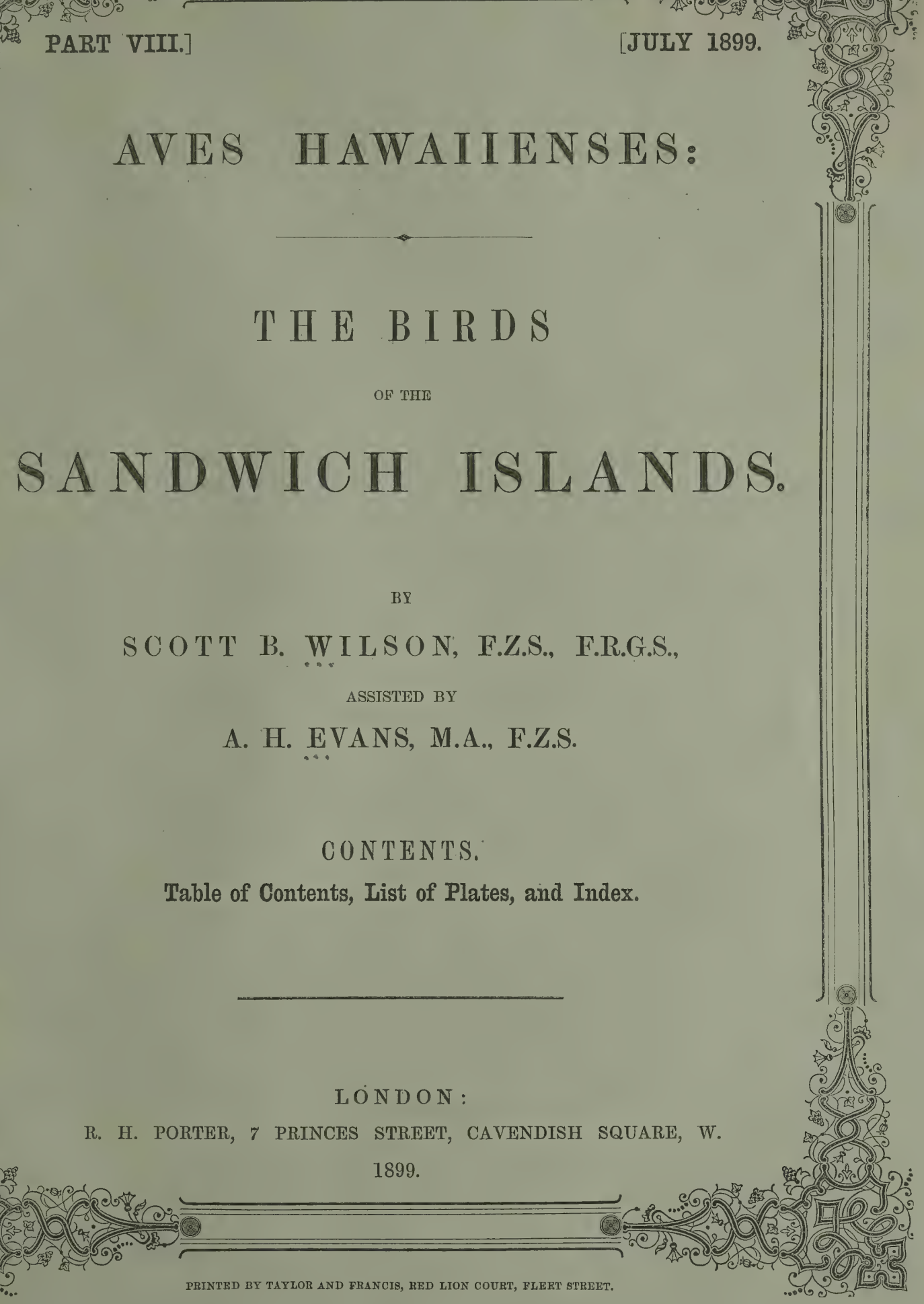






In Preparation. Royal 4to. Price to Subscribers, $£ 4$ 4s.

\section{AVES HAWAII ENSES:}

\section{T H E B I R D S}

OF THE

\section{SANDWICH ISLANDS.}

$\mathrm{BY}$

SCOTT B. WILSON, F.Z.S.

ILLUSTRATED WITH ABOUT 40 COLOURED PLATES.

L O N D O N :

R. H. PORTER, 18 PRINCES STREET, CAVENDISH SQUARE, W. 1890. 


\section{P ROSPECTUS.}

THE Author was induced to visit the Sandwich Islands in the belief that he would be able to throw some light on the Geographical Distribution of the species which constitute the very peculiar Avifauna of this Archipelago. In the course of the eighteen months that he passed on the beautiful islands which compose it, he was so fortunate as to find that his success had been beyond his most sanguine expectation, and that he was not only in a position to solve several problems which had hitherto puzzled ornithologists, but that he had added largely to the list of the indigenous species-of which all the land-birds and several of the water-birds are absolutely peculiar to the Hawaiian group.

Another consideration which prompted the Author was the opinion expressed by many competent judges that several of the native species of birds were in process of extirpation, through the destruction of the forests and the introduction of foreign rivalsif, indeed, this process had not in some instances been completed. His subsequerit investigations have shown that this opinion was only too well-founded, and that a few species had certainly become extinct, while the fate of a good many more is to all appearance decided. Most fortunately there existed in Honolulu an ornithological collection begun many years ago, and from that he was enabled to acquire specimens of several species which by all report have not been seen alive for more than a quarter of a century.

Though the Sandwich Islands were discovered in January, 1778, by Captain Coor, who, it will be remembered, met his death on one of them in the following year, and specimens of about a dozen species of their birds were soon after described by Latham in his ' General Synopsis,' examples of even the most common species have always been rare in collections, and there are now some important Museums which seem not to possess a single specimen from the Hawaiian group. Moreover, the descriptions and figures of those which have since been published have been scattered throughout many works, most of them not easy of access, whether in the accounts of Voyages performed by private adventurers or by the ships of various Governments-as, for instance, that of the French frigate Venus, the Vincennes and the Peacock of the United States' Exploring Expedition, and of H.M.SS. Blonde and Challenger-or, again, in the publications of various learned Societies.

In 1869, a most laudable and in some respects successful attempt to compile a List of the Birds of the Hawaiian Islands was made by Mr. Sanford B. Dole-now 


\section{( iii )}

His Honour, Mr. Justice Dole-in the 'Proceedings' of the Boston Society of Natural History; but, owing to the want of opportunity of comparing specimens and consulting original descriptions, this otherwise useful list contains several errors, while considered at its best it is little more than a catalngue. Some years after its appearance, Mr. Sclater, who had long taken an interest in the Avifauna of the Sandwich Islands, endeavoured to compile from it an improved list, but, for want of sufficient materials, combined with the fact that the habitat of some of the originally described species was unknown or overlooked, this list, accurate at the time, is now misleading, while the Author believes that his own investigations have added nearly a dozen new species to it. Mr. Sclater, however, made more evident than it had before appeared the great peculiarity of the Hawaiian Avifauna, and all that has been done since tends to prove that the peculiarity is even greater than he had thought. Comparisons of this kind are not easily made, but the peculiarity would really seem to be in its way as great as that of Madagascar or New Zealand; while as an expiring population it must be regarded as of equal interest with that of the latter country.

The beauty of many of the birds of the Sandwich Islands has long been known, chiefly from the marvellous helmets and robes of feather-work, some of which are still to be seen, though too often moth-eaten and disfigured, in various Museums. To form one of these mantles thousands of birds must have been sacrificed, and it is apparently in consequence of this that one of the finest species-Drepanis pacifica-has become extinct. Of this beautiful bird a single specimen, brought back by the Author, and now in the Museum of the University of Cambridge, seems to be the only one now in Great Britain; while the number of examples on the continent of Europe must be very limited. This, moreover, is by no means a singular instance. The Author succeeded in obtaining specimens of two other species, wholly unrepresented in European Museums, though one was met with by Cook's companions, and the other--for a long time believed to be unique-was obtained by the United States' Expedition.

Thus the Author hopes that a work on the Birds of the SANDwich IsLands will, for some or all of the reasons above stated, be acceptable to the Ornithological public, and he proposes to issue it of the size and on the plan of the first edition of Sir Walter Buller's 'Birds of New Zealand,' with plates giving a figure or figures of each of the species peculiar to the group, which cannot be fewer than forty in number. The plates will be executed by Mr. FroHawk and carefully coloured by hand. The Subscription price will be $£ 44 s$. for the complete work.

Intending Subscribers will please send their names direct to the Publisher,

R. H. PORTER,

18 Princes Street, Cavendish Square, London, W. 


\section{Specimen Page.]}

\section{ACRULOCERCUS NOBILIS.}

O-O.

“Yellow-tufted Bee-eater," Latham, Gen. Synops. i. p. 683 (1782); Suppl. p. 120 (1787); Suppl. 2, p. 149 (1802).

? "Mohó," Ellis, Narrat. Voy. Cook \& Clerke, ii. p. 156 (1782).

?"Hoohoo," King, Voy. Pacif. Ocean, iii. p. 119, partim (1784).

Gracula nobilis, Merrem, Beytr. besond. Gesch. Vögel, Heft i. p. 8, pl. ii. (1784).

" longirostra, var. $\beta$, Gmelin, Syst. Nat. i. p. 398 (1788).

Merops niger, Gmelin, tom. cit. p. 465 (1788).

", fasciculatus, Latham, Ind. Orn. i. p. 275 (1790).

"Le Moho," Sonnini, Hist. Nat. Buffon, Ois. xviii. p. 286 (1802).

Philemon fasciculatus, Vieillot, Encycl. Méthod. Ornithol. p. 613 (1823).

?Nectarina [sic] niger, Bloxam, Voy. 'Blonde,' p. 249 (1826).

Meliphaga fasciculata, Temminck \& Laugier, Rec. d’Ois. Livr. 79, PI. Col. 471 (1829).

"Philédon moho, Merops fasciculatus, Lath."; Lesson, Tr. d’Orn. p. 302 (1831); Compl. Buff., Ois. iii. p. 49 (1837).

Acrulocercus niger, Cabanis, Arch. f. Naturgesch. xiii. p. 327 (1847) ; Sundevall, Tentam. p. 50 (1872).

Moho niger, G. R. Gray, Gen. B. i. p. 96 (1847) ; Bonaparte, Consp. Av. i. p. 394 (1850).

Ptiloturus fasciculatus, Peale, U.S. Expl. Exped., Birds, p. 148 (1848).

Mohoa fasciculata, Reichenbach, Handb. sp. Orn. p. 333, partim (1853), tab. 614. fig. 4098.

" nobilis, Cassin, Proc. Acad. N. S. Philad. 1855, p. 439; Sclater, Ibis, 1871, pp. 358, 360 ;

Proc. Zool. Soc. 1878, p. 347; Von Pelzeln, Journ. f. Orn. 1872, p. 25.

Moho nobilis, Cassin, U.S. Expl. Exped., Mamm. \& Orn. p. 170 (1858) ; G. R. Gray, Cat. B. Trop.

Isl. p. 9 (1859) ; Dole, Proc. Boston N. H. Soc. 1869, p. 296 ; Hawaiian Alman. 1879, p. 46;

Gadow, Cat. B. Br. Mus. ix. p. 284, partim (1884); Stejneger, Proc. U.S. Nat. Mus. 1887, p. 101.

Acrulocercus nobilis, Scott Wilson, Ibis, 1890, p. 177.

THIs, the Royal Bird of modern times, is perhaps the best known of any species to both the natives and foreign resideuts in the islands. It is doubtful whether in ancient days it was from the yellow feathers that grow beneath its wings, or from the still more beautiful yellow upper tail-coverts of the now extinct Drepanis pacifica, that the state robes of kings and chiefs were wrought. It was the privilege of those classes alone to wear them; and it cannot be denied that they formed a becoming apparel, as magnificent and beautiful as anything that the triumphs of civilized art can now produce. The fine statue of King Kamehameha I., which stands in front of the Government House in Honolulu, represents the great conqueror who first consolidated 




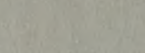



